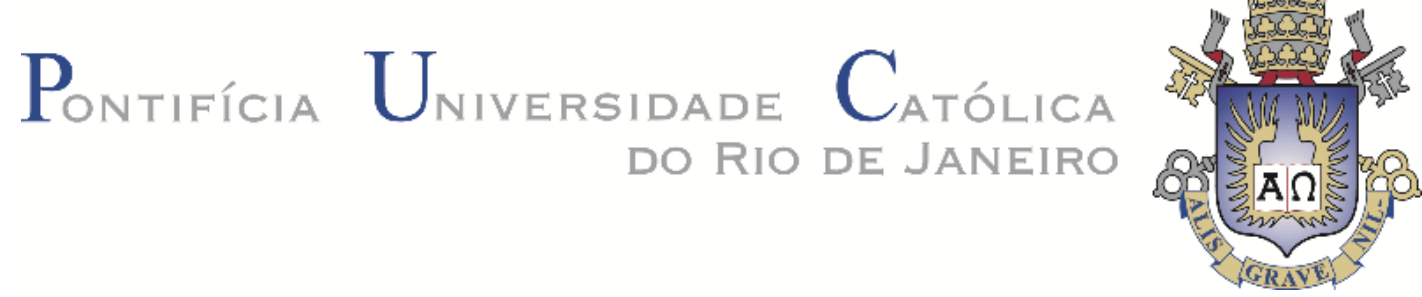

Thiago Rodrigues Nascimento

\title{
O ENSINO DE ESTUDOS SOCIAIS NO BRASIL: das "connexões naturaes" à integração pela via do autoritarismo (1930-1970)
}

Tese de Doutorado

Tese apresentada ao Programa de Pós-graduação em Educação da PUC-Rio como requisito parcial para obtenção do grau de Doutor em Educação.

Orientador: Prof. Jefferson da Costa Soares 
Todos os direitos reservados. É proibida a reprodução total ou parcial do trabalho sem autorização do autor, do orientador e da universidade.

\section{Thiago Rodrigues Nascimento}

Licenciado em História (2010) e Mestre em História Social (2012) pela Universidade do Estado do Rio de Janeiro (UERJ). Atuou como professor concursado na Secretaria de Estado de Educação do Rio de Janeiro (SEEDUC/RJ) e como professor substituto da área de Ensino de História e Estágio Supervisionado na Faculdade de Formação de Professores da UERJ. Pesquisa os seguintes temas: História da Educação, Estudos Sociais, Conselho Federal de Educação e Ensino de História.

Ficha Catalográfica

Nascimento, Thiago Rodrigues

O ensino de Estudos Sociais no Brasil: das "connexões naturaes" à integração pela via do autoritarismo (1930-1970) / Thiago Rodrigues Nascimento; orientador: Jefferson da Costa Soares. 2019.

397 f.: il. color.; $30 \mathrm{~cm}$

Tese (doutorado) - Pontifícia Universidade Católica do Rio de Janeiro, Departamento de Educação, 2019.

Inclui bibliografia 


\section{Agradecimentos}

O presente trabalho foi realizado com apoio da Coordenação de Aperfeiçoamento de pessoal de Nível Superior - Brasil (CAPES) - código de financiamento 001.

À PUC-Rio, pela bolsa de isenção concedida, sem a qual este trabalho não poderia ter sido realizado.

Ao orientador Jefferson Soares, pela disponibilidade e confiança, que me permitiram vencer algumas das inseguranças que atravessam a escrita acadêmica.

À professora Ana Waleska Mendonça (in memoriam), orientadora inicial deste trabalho, por compartilhar muito da alegria em pesquisar e escrever sobre a História da Educação.

Às professoras Beatriz B. Marques dos Santos, Juçara da Silva Barbosa de Mello, Marieta de Moraes Ferreira, Patrícia Coelho da Costa e ao professor Luís Reznik, pelas sugestões e contribuições nas diferentes fases de apresentação desta tese. Cada interlocução enriqueceu e aprimorou as argumentações aqui desenvolvidas.

À professora Alicia Bonamino, pela generosidade com que sempre me tratou.

À professora Helenice Rocha, orientadora na graduação e no mestrado, por apresentar a um jovem estudante de licenciatura as possibilidades da pesquisa em ensino de História.

Ao professor Luís Reznik, pelos ensinamentos proporcionados durante os anos em que atuei no "Centro de Memória da Imigração da Ilha das Flores".

Ao "Centro de Memória da Educação Brasileira do Instituto de Educação do Rio de Janeiro", na pessoa da sua coordenadora professora Marlúcia Neri, pela dedicação com que preservam um importante patrimônio brasileiro e pela presteza com que atendem os pesquisadores que acessam seus acervos.

À professora Vera Cabana de Queiroz, pela atenção em organizar o Acervo de Delgado de Carvalho (IHGB), composto por inúmeras latas de documentos, e pela permissão para que eu os acessasse em meio ao processo de catalogação.

À Aldaíres Souto França, pela leitura atenta dos originais desta tese e pelas trocas constantes na discussão sobre "a questão de Estudos Sociais".

Ao lado B da turma 2015 do doutorado em Educação da PUC-Rio, pelos debates sobre vida e educação (não necessariamente nesta ordem). Em especial:

À Liliane Balonecker Daluz, por diminuir a distância entre São Gonçalo e Gávea e por todo carinho a mim dedicado nos momentos mais difíceis desta travessia. Foi um apoio essencial para que o doutorado fosse concluído.

À Mirna Juliana S. Fonseca, pela revisão e formatação desta tese.

À Sandra Marcelino, pelos encontros, discussões, palavras e demonstração de força na adversidade. Grato por me ensinar outros sentidos de educação e luta. Como sempre digo: tudo aconteceu para que pudéssemos nos conhecer. 
À Vanessa Weber, pela atenção e apoio em diferentes momentos do doutorado e pelas discussões sobre a História da Educação.

A todos os amigos e familiares que de uma forma ou de outra me estimularam ou me ajudaram. Em especial à Camila Bógea e Adauto Tavares, amigos que acompanharam um pouco do longo processo de escrita.

À minha irmã, Fabiana Rodrigues, pelos auxílios a uma criança que teimava em não gostar de estudar.

À minha avó, Maria da Conceição Soares, pelas constantes orações para que o meu caminhar fosse sempre menos dificultoso.

À minha mãe, Rosilane Soares Rodrigues, por todas as renúncias e esforços para que eu cursasse a licenciatura em História e chegasse ao doutorado. Não haveria formação e tese sem a sua perseverança e doação. 


\section{Resumo}

Nascimento, Thiago Rodrigues; Soares, Jeferson da Costa (Orientador). O ensino de Estudos Sociais no Brasil: das "connexões naturaes" à integração pela via do autoritarismo (1930-1970). Rio de Janeiro, 2019. 397p. Tese de Doutorado - Departamento de Educação, Pontifícia Universidade Católica do Rio de Janeiro.

Esta tese se insere no conjunto de pesquisas que têm como temática principal a constituição histórica das disciplinas escolares. O seu objeto é a configuração do ensino de Estudos Sociais no Brasil, entre as décadas de 1930 e 1970, considerando dois contextos principais em que este foi discutido e/ou implantado. São privilegiadas as perspectivas defendidas por Carlos Miguel Delgado de Carvalho, entre as décadas de 1930 e 1960, e por Raimundo Valnir Cavalcante Chagas, um dos formuladores da política educacional dos anos da ditadura militar (1964-1985). Tencionamos compreender as continuidades e rupturas entre essas duas vertentes. A proposta se justifica pelo predomínio de trabalhos que analisam os Estudos Sociais isoladamente ou como criação de determinado período histórico - sobretudo, durante a ditadura militar - sem uma preocupação em considerar os diferentes momentos pelos quais passou essa disciplina escolar. Os Estudos Sociais foram introduzidos no Brasil nos anos de 1930 a partir de sua inclusão como "matéria de ensino" na Escola de Professores do Instituto de Educação do Distrito Federal e da publicação do "Programa de Ciências Sociais" (1934) pelo Instituto de Pesquisas Educacionais, dirigido por Delgado de Carvalho. Ambas as ações se inspiram no movimento escolanovista, na educação progressiva estadunidense, principalmente na filosofia educacional de John Dewey, e foram desenvolvidas sob a liderança de Anísio Teixeira à frente do Departamento de Educação do Distrito Federal. Nas décadas seguintes, diferentes experiências de ensino de Estudos Sociais se concretizaram, como as dos Ginásios Vocacionais e a indicação do Conselho Federal de Educação, de que fosse uma disciplina optativa a partir de 1962. Em 1971, no processo de reforma de ensino de $1^{\circ}$ e $2^{\circ}$ graus, pelas mãos do conselheiro Valnir Chagas, operou-se uma mudança radical, pois de proposta indicativa e experimental passou a disciplina obrigatória, substituindo História e Geografia no $1^{\circ}$ grau. Assim, esta tese concentra-se em compreender: por quais continuidades e rupturas passou a 
disciplina de Estudos Sociais em sua implantação e manutenção na educação brasileira? A hipótese é a de que, apesar das distintas interpretações, a apropriação feita a partir da perspectiva estadunidense influenciou ambos os educadores, mudando seus contextos e intenções. Dialoga-se com os referenciais teóricos da história das disciplinas escolares e história do ensino de História. Trata-se de uma pesquisa histórico-documental, cujas principais fontes são artigos, livros e pareceres escritos por Delgado de Carvalho e Valnir Chagas. A metodologia adotada é a "análise de texto", que propõe compreender a obra dos autores em relação ao seu contexto histórico, educacional, político e social, bem como os paradigmas intelectuais que os guiaram (Ciro Cardoso \& Ronaldo Vainfas). A análise documental indica que até a década de 1960 a função de cada uma das disciplinas escolares, sobretudo, História e Geografia, era importante na definição dos Estudos Sociais, algo que deixou de ocorrer a partir das reformas da ditadura militar. Naquele momento, os Estudos Sociais tornaram-se simples fusão de disciplinas e reunião de conteúdos histórico-geográficos sob uma mesma disciplina. As suas intenções também foram modificadas: da formação do aluno crítico e cidadão passou-se à formação do aluno como fator de segurança e estabilidade para si, para a sociedade e para o Estado.

\section{Palavras-chave}

História das disciplinas escolares; Ensino de História; Estudos Sociais; Delgado de Carvalho; Valnir Chagas. 


\section{Abstract}

Nascimento, Thiago Rodrigues; Soares, Jefferson da Costa (Advisor). Teaching Social Studies in Brazil: from natural connections to integration through authoritarism (1930-1970). Rio de Janeiro, 2019. 397p. Tese de Doutorado - Departamento de Educação, Pontifícia Universidade Católica do Rio de Janeiro.

This thesis is part of a set of researches focusing on the historical constitution of school subjects. The object of study is the setting of teaching Social Studies in Brazil, between the decades of 1930 and 1970, considering two main contexts in which it was discussed and/or deployed. Inside are the perspectives defended by Carlos Miguel Delgado de Carvalho, between the decades of 1930 and 1960, and Raimundo Valnir Cavalcante Chagas, one of the formulators of the educational policy along the years of military dictatorship (1964-1985). The intention is to comprehend the continuities and ruptures between these two approaches. The proposal is justified through a predominance of works that analyze Social Studies separately or as the creation of a given historical period - especially during the military dictatorship - without a care in considering the different occasions by which this school discipline went through. Social Studies were introduced in Brazil in 1930 from its integration as "school discipline" at the school of "Escola de Professores do Instituto de Educação do Distrito Federal" and the publication of "Programa de Ciências Sociais" (1934) by the "Instituto de Pesquisas Educacionais", directed by Delgado de Carvalho. Both actions are inspired by the Progressive Education movement, especially in the educational philosophy of John Dewey, and were developed under the leadership of Anísio Teixeira, to the head of the Department of education of Federal District. In the following decades, different experiences of Social Studies teaching are implemented, like "Ginásios Vocacionais" and the Federal Council of Education suggestion for it to be considered a minor discipline from 1962 on. In 1971, during the process of reforming the teaching in Primary and Secondary Education, by Advisor Valnir Chagas, a radical change was undertaken, as from an indicative and experimental proposal, it has become a compulsory subject, replacing History and Geography in Primary Education. Therefore, this thesis focuses on understanding: by which continuities and ruptures the Social Studies passed in its 
deployment and maintenance in Brazilian education? The hypothesis is that, in spite of the different interpretations, the appropriation made from the American perspective influenced both educators, changing contexts and intentions. It is a merge of theoretical references in the history of the school subjects and the history of History teaching. It is a historical documentary research, whose primary sources are articles, books and opinions written by Delgado de Carvalho and Valnir Chagas. The methodology adopted is the "text analysis", which proposes to understand the work of authors in relation to their historical, educational, political and social context, as well as the intellectual paradigms that have guided them (Ciro Cardoso \& Ronaldo Vainfas). The documentary analysis indicates, among other aspects, that until the 1960 `s, the function of each school subject, especially History and Geography, was important in the definition of Social Studies, something that ceased to occur from the reforms of military dictatorship. Currently, Social Studies have become a simple fusion of disciplines and the compilation of geographical-historical contents, meeting under the same discipline. The intentions have also changed: the formation of a critical student and citizen turned to a student's training as a factor of stability and security for his own self, to society and the State.

\section{Keywords}

History of school subjects; Teaching of History; Social Studies; Delgado de Carvalho; Valnir Chagas. 


\section{Sumário}

1 Introdução 14

$\begin{array}{ll}1.1 \text { Sem partida, não há viagem! } & 14\end{array}$

1.2 Construção do objeto e as problemáticas de pesquisa: por que analisar os Estudos Sociais? 19

1.3 Abordagem teórico-metodológica e fontes 26

1.3.1 Fontes $\quad 34$

$\begin{array}{ll}1.4 \text { Estrutura da tese } & 37\end{array}$

2 Literatura sobre o ensino de Estudos Sociais no Brasil: da denúncia à historicidade $\quad 41$

2.1 História do ensino de História: Estudos Sociais como apêndice 43

2.2 Estudos Sociais e ensino de História: articulações e especificidades $\quad 53$

$2.3 \mathrm{O}$ ensino de História no Brasil: da constituição aos indícios da crise do código disciplinar $\quad 65$

2.3.1 A construção do código disciplinar da História no Brasil (1838-1930) 66

2.3.2 Disciplinarização da História na escola primária e no curso secundário 72

2.3.3 Indícios da crise do código disciplinar da História e os Estudos Sociais 77

3 Bases conceituais para uma escola progressiva: a escola americana, John Dewey e a educação como vida $\quad 81$

3.1 Alguns sentidos de educação em John Dewey e Anísio Teixeira 83

3.1.1 Experiência e educação: "educação é vida"! 88

3.1.2 Educação como necessidade da vida e como função social 89

3.1.3 A escola, a sociedade e a vida 93

3.1.4 Ensino de História em John Dewey: a necessária contribuição para o presente e as inter-relações com a Geografia 96

3.2 Os educadores brasileiros e as "viagens pedagógicas": a "ambiência americana" e o contato com a obra de Dewey

4 Os Estudos Sociais e a vertente americana (1916-1934): documentos e definições 122

4.1 Consolidação de um termo: a definição de Estudos Sociais 128

4.2 Matriz de referência: os Estudos Sociais nos Estados Unidos da década de 1930

4.3 O professor e o ensino de Estudos Sociais: do conhecimento da realidade social à liberdade de ensino

4.4 Os Estudos Sociais para além das fronteiras americanas: das intenções da comissão ao elogio de Delgado de Carvalho

5 Introdução do ensino de Estudos Sociais no Brasil: da discussão metodológica à constituição de uma disciplina escolar 169

5.1 Reforma Anísio Teixeira (1931-1934): a criação dos “dois institutos" 170

5.2 PCS: fundamentação, organização e estrutura 178 
5.2.1 "Organização psicológica das matérias escolares": a crítica à disciplinarização como fundamento do programa escolar anisiano

5.2.2 Delgado de Carvalho na década de 1930: um professor a serviço da renovação educacional

5.2.3 Delgado e as apresentações do programa: uma abordagem teórica

5.2.4 PCS: entre projetos e conteúdos tradicionais

5.3 Instituto de Educação do Distrito Federal: formação de professores e ensino de Estudos Sociais

5.4 Ocaso de um projeto, persistência de uma ideia: seriam vitoriosos os Estudos Sociais?

6 Propostas de Delgado de Carvalho para o ensino de Estudos Sociais na escola secundária (1930-1960): integração, disciplinarização e fusão de disciplinas

6.1 "Meu cavalo de batalha": Delgado de Carvalho e os Estudos Sociais no curso secundário

6.2 Ensino de Ciências Sociais na escola secundária entre as décadas de 1930 e 1940: o papel das disciplinas e a Sociologia como elo

6.3 "Didática das Ciências Sociais" (1949): o primado da Geografia e o ensino como uma questão de método

6.4 Para além dos métodos: a definição de um programa escolar de Estudos

Sociais para a escola secundária

6.4.1 Programa de Estudos Sociais para a escola secundária

6.4.2 "Do conjunto dos Estudos Sociais, separemos, em primeiro lugar, a História": a propósito da crítica à Delgado na década de 1950

6.5 Formação para a cidadania: uma proposta na raiz dos Estudos Sociais

7 Da intenção à obrigatoriedade: Estudos Sociais, núcleo comum e marcas do autoritarismo

7.1 Década de 1960 e os Estudos Sociais: a proposta indicativa e os Ginásios Vocacionais

7.2 O golpe militar e as reformas educacionais: o papel de Valnir Chagas

7.3 Núcleo comum: os Estudos Sociais como "matéria"

7.4 Organização curricular: Estudos Sociais como atividade, área de estudo e disciplina

7.5 O que ensinar em Estudos Sociais? Da ausência de um programa oficial à formulação de um "exemplo"

7.6 A formação do professor de Estudos Sociais: da licenciatura curta

à proposta de extinção da licenciatura em História

8 Considerações finais

9 Referências bibliográficas 


\section{Lista de ilustrações}

* Quadros

Quadro 1 - Componentes dos Estudos Sociais 30

Quadro 2 - Produção acadêmica sobre os Estudos Sociais (1971-2016) 57

Quadro 3 - Principais temáticas presentes na produção sobre os

Estudos Sociais

Quadro 4 - Prescrição de conteúdos de História para a escola primária nas reformas educacionais de 1854,1879 e 1890

Quadro 5 - Elementos da institucionalização dos Estudos Sociais nos Estados Unidos (1892-1934)

Quadro 6 - Estudos Sociais: documentos, definições e componentes

Quadro 7 - Plano geral dos Estudos Sociais no curso secundário

Quadro 8-Os Estudos Sociais nos $7^{\circ}, 8^{\circ}$ e $9^{\circ}$ anos do ensino secundário 134

Quadro 9-Estudos Sociais nos $10^{\circ}, 11^{\circ}$ e $12^{\circ}$ anos da escola secundária 135

Quadro 10 - Temas em Estudos Sociais e sua distribuição na escola primária 198

Quadro 11 - Problemas principais a serem discutidos pelas Ciências Sociais na Escola Primária

Quadro 12 - Programa Mínimo de História para o $4^{\circ}$ ano da escola primária 209

Quadro 13 - Matriz Curricular da Escola de Professores entre 1933 e 1935215

Quadro 14 - Métodos de ensino em Ciências Sociais

Quadro 15 - Programa de História e Geografia, enquanto disciplinas autônomas $-4^{\mathrm{a}}$ série do ciclo ginasial da escola secundária

Quadro 16 - Conhecimentos e atividades indicados para a matéria Estudos Sociais na escola de $1^{\circ}$ grau

Quadro 17 - Matérias do Curso de Estudos Sociais, habilitação em EMC 348

Quadro 18 - Licenciaturas de Educação Geral e suas habilitações 350

\section{* Figuras}

Figura 1 - Programa de John Dewey para o ensino de História (1906)

Figura 2 - Caderno de Metodologia das Ciências Sociais. O indivíduo, a escola, a educação em trechos de John Dewey (p. 35)

Figura 3 - Notícia sobre professoras que fizeram intercâmbio nos EUA 
Figura 4 - Capa do relatório The Social Studies in Secondary School (1916)

Figura 5 - Capa da "Carta", relatório preliminar da "Investigation of the Social Studies in the schools"

Figura 6 - Capa do relatório final da "Investigation of the Social Studies in the schools"

Figura 7 - PCS para a escola primária do Distrito Federal, volume 1 $\left(1^{\circ}, 2^{\circ}\right.$ e $3^{\circ}$ anos $)$ e volume $2\left(4^{\circ}\right.$ e $5^{\circ}$ anos $)$

Figura 8 - "Fachada principal do INSTITUTO DE EDUCAÇÃO, Rio de Janeiro"

Figura 9 - Álbum de professores homenageados. Escola Normal do Distrito Federal, década de 1940

Figura 10 - Delgado de Carvalho em sua biblioteca particular (década de 1970)

Figura 11 - Delgado de Carvalho e a sua esposa, Vera Roxo de Carvalho, em viagem aos Estados Unidos (década de 1930)

Figura 12 - Publicação aulas ministradas por Delgado de Carvalho em Minas Gerais (década de 1940)

Figura 13 - Fragmento 1 de História Contemporânea, III série, Teste de Revisão

Figura 14 - Fragmento 2 de História Contemporânea, III série, Teste de Revisão, Dissertação Histórica

Figura 15 - Esboço de "Introdução metodológica aos Estudos Sociais" (1957)

Figura 16 - "Divisão e integração do conhecimento"

Figura 17 - Núcleo comum 
[...] a enormidade da tarefa e a complexidade dos problemas não devem desanimar os homens, porque a nossa obra não é a de nenhum de nós, mas a lenta acumulação dos esforços de todos.

Anísio Teixeira

Educar é possibilitar que a pessoa se descubra, se situe, se realize e tome consciência de seu papel de agente social, construtor da sociedade e da história. Educação é libertação.

Joana Neves 


\section{Introdução}

1.1

Sem partida, não há viagem!

O mínimo que se exige de um historiador é que seja capaz de refletir sobre a história da sua disciplina, de interrogar os sentidos vários do trabalho histórico, de compreender as razões que conduziram a profissionalização do seu campo acadêmico. O mínimo que se exige de um educador é que seja capaz de sentir os desafios do tempo presente, de pensar a sua ação nas continuidades e mudanças do trabalho pedagógico, de participar criticamente na construção de uma escola mais atenta às realidades dos diversos grupos sociais. (Antônio Nóvoa, 1996, p. 417).

Começo essa introdução refletindo sobre os pontos de partida que conduziram as inúmeras viagens - algumas delas no sentido literal da palavra realizadas durante o doutorado em educação cursado na Pontifícia Universidade Católica do Rio de Janeiro (PUC-Rio). "Sem partida, não há viagem" e "sem viagem não há conhecimento", declara Antonio Nóvoa (2015) em sua "Carta a um jovem historiador da educação". Os temas de investigação, conforme ele adverte, não são escolhidos ao acaso ou através de catálogos, mas a partir daquilo que queremos compreender e das perguntas que, por vezes muito sonhadoramente, penso eu, tencionamos responder: "é por isso que cada um tem de fazer um trabalho sobre si mesmo, até encontrar aquilo que o define e que o distingue como investigador." (Nóvoa, 2015, p. 25). Toda pesquisa tem uma história, com um ou vários pontos de partida; a desta começou em algum momento entre 2006 e 2010, quando cursei a graduação e iniciei os primeiros passos na pesquisa histórica.

Há alguns anos, situo-me, academicamente, na fronteira entre História e Educação. A pesquisa em ensino de História - e em História da Educação, conforme a indicação de Nóvoa (1996) - se constitui a partir da articulação teórica dos referenciais e das contribuições advindas dos campos da História e da Educação. Esse "lugar de fronteira", usando uma expressão difundida por Ana Maria Monteiro \& Fernando Penna (2011), caracteriza-se pelos encontros e diálogos, essenciais para a problematização dos objetos de pesquisa. Isso significa levar em consideração tanto a prática pedagógica quanto as especificidades da 
História (suas finalidades, sua constituição, sua profissionalização e as formas com que ela é ensinada). Não é uma tarefa simples. Desde meados da licenciatura em História, cursada na Faculdade de Formação de Professores da Universidade do Estado do Rio de Janeiro (FFP-Uerj), algumas inquietações têm atravessado minha trajetória acadêmico-profissional como pesquisador e, posteriormente, como professor de História em escolas da rede pública estadual do Rio de Janeiro.

A primeira delas se relaciona a um questionamento que todo historiador faz em algum momento de sua formação e vida profissional: para que serve a História? Junto a essa questão, preocupava-me em compreender quais são os saberes mobilizados pelo professor durante as suas aulas. $\mathrm{O}$ que o professor de História precisa saber para ensinar? As respostas para essas indagações estão inter-relacionadas. Inspirado nas reflexões de Maurice Tardif (2002), explorei, no trabalho de final de curso da licenciatura, as memórias dos professores de História da escola básica e a constituição dos saberes docentes, com a intenção de entender a prática pedagógica. Um professor, independente de sua disciplina, é resultado de seus saberes sociais, de sua experiência, situações de trabalho e mobiliza saberes provenientes de diferentes fontes e construídos ao longo do tempo. Por sua vez, o seu papel, ao ensinar a História, é promover o desenvolvimento de habilidades e a capacidade de leituras da realidade e de diferentes discursos.

Durante esse primeiro exercício de pesquisa, a partir das leituras e inflexões possibilitadas pela empiria, os Estudos Sociais surgiram como um possível tema para trabalhos posteriores. Uma das professoras entrevistadas era formada em licenciatura curta em Estudos Sociais, mas lecionava História. Portanto, nem sempre a formação e as exigências para lecionar a disciplina haviam sido as mesmas. Conhecia pouco a história do ensino de História no Brasil. Dos Estudos Sociais eu só trazia as lembranças de aluno da escola fundamental de finais da década de 1990: uma professora ensinando uma miscelânea de conteúdos de História e de Geografia sob o título de Estudos Sociais. A segunda inquietação surgiu nesse momento. Ora, os sentidos da História, os seus usos, a formação dos responsáveis por seu ensino e os saberes mobilizados pelos professores têm uma historicidade. Carlos Brandão (1995, p. 7) adverte que "ninguém escapa da educação". Entretanto, em grande parte das licenciaturas, não estudamos - ou o fazemos pouco - a história da educação brasileira. Conforme argumentam Cynthia Veiga \& Thais Nivia de Lima e Fonseca $(2008$, p. 8), seguindo a trilha de 
Brandão (1995): “podemos dizer que também ninguém escapa de uma história da educação". Ainda segundo as autoras,

[...] uma constatação evidente é a de que investigar os processos do aprender é fundamental para ampliarmos a compreensão das formas de como em tempos e espaços distintos, homens e mulheres organizaram sua vida, seus afazeres e suas ideias, enfim, seu modo de ser e estar no mundo. (p. 8).

Para o historiador da educação, parece ser uma "constatação evidente", mas não o era para um aluno de graduação, cujo acesso a essas questões fora limitado até então. Apesar de cursar uma graduação em História, não havia nenhuma disciplina, obrigatória ou eletiva, que tratasse da História da Educação. Os professores das disciplinas específicas, ao priorizarem o político e o econômico, não abordavam a questão, que ficou restrita a um pequeno tópico do último Laboratório de Ensino de História - disciplina da qual fui monitor ${ }^{1}$. A própria elaboração do projeto que deu origem a minha monografia causou certo estranhamento ao professor responsável pela disciplina Laboratório de Pesquisa em História, já que eram poucos os trabalhos que se debruçavam sobre uma "pedagogia da História". Não se trata de uma lacuna restrita à minha formação. Thais Nivia de Lima e Fonseca (2011, p. 7) salienta que:

Dos historiadores espera-se que conheçam bem a historiografia, os pressupostos teórico-metodológicos que orientam seu trabalho, as técnicas de investigação, os procedimentos para o tratamento das fontes de pesquisa. Além de tudo isso, daqueles que são também professores de História, espera-se que conheçam os conteúdos, as práticas pedagógicas e os procedimentos didáticos. No entanto, não é usual esperar que eles conheçam, também, a história da disciplina que pesquisam ou que ensinam. Seria, porém, desejável que isso ocorresse.

O cenário se modificou muito na última década, com um fortalecimento do estudo da história do ensino de História na formação tanto de pesquisadores quanto de professores. A partir da leitura do livro organizado por Veiga \& Lima e Fonseca (2008), passei a visualizar mais claramente a educação como um dos objetos da História e uni dois interesses: História e formação de professores. O objeto da pesquisa de mestrado foi o curso de licenciatura curta em Estudos Sociais da Faculdade de Formação de Professores (FFP) de São Gonçalo. Analisei a trajetória de criação, institucionalização e crise dessa modalidade de formação de professores no Brasil, entre os anos de 1970 e 1980, tendo por base a

\footnotetext{
${ }^{1}$ Disciplina ministrada pela professora $\mathrm{Dr}^{\mathrm{a}}$. Helenice Rocha, a quem agradeço pelos ensinamentos e apresentação do campo.
} 
experiência vivenciada pela FFP. Dialogando com uma bibliografia tradicional sobre a temática, e a partir da perspectiva da microanálise, proposta por Jacques Revel (1998), busquei romper com as generalizações que caracterizam a produção sobre a licenciatura curta e os Estudos Sociais (Nascimento, 2012) ${ }^{2}$, com achados de pesquisa particularmente importantes para a discussão sobre o tema.

A literatura tende, desde os anos de 1980, a analisar, com raras exceções, a licenciatura de curta duração em Estudos Sociais a partir do macro, com foco sobre o conjunto de cursos oferecidos, desconsiderando as peculiaridades de realidades diversas. A criação da FFP fazia parte de um projeto de ensino superior do último governo do estado do Rio de Janeiro (1971-1975), antes do processo de fusão dos antigos estados do Rio de Janeiro e da Guanabara. Portanto, nem toda licenciatura curta foi instituída em entidades privadas, como enfatiza a maior parte da bibliografia sobre o tema. A licenciatura curta em Estudos Sociais foi considerada por muito tempo apenas como uma descaracterização das licenciaturas plenas. Argumentei, por exemplo, que em seu momento de criação, em 1964, havia uma carência crônica de professores habilitados em cursos superiores. Contudo, de uma "solução emergencial" passou-se para uma "solução definitiva”. Nas faculdades que se estruturaram a partir do espírito da lei $n^{\circ}$ 5.692/71, a luta contra as licenciaturas curtas em Estudos Sociais se processou de forma diferente. No que concerne à FFP, é possível dizer que os professores formuladores dos currículos da sua licenciatura curta incorporaram o discurso de reforma educacional proposto nos anos de 1970 pelo Conselho Federal de Educação (CFE) e se inspiraram nos ideais dos Estudos Sociais difundidos no Brasil desde os anos de 1930 (Nascimento, 2012).

Não há como estudar a formação de professores sem uma compreensão da disciplina escolar e vice-versa. As leituras de John Dewey, Delgado de Carvalho e Valnir Chagas, e os referenciais da história das disciplinas escolares me estimularam a refletir sobre a constituição do ensino de Estudos Sociais no Brasil. Em 2011, pouco antes do exame de qualificação da dissertação, fui apresentado à tese de doutorado da professora Beatriz Boclin Marques dos Santos (2011). Este trabalho, bem como o pioneiro texto de Elza Nadai (1988), tornaram-se importantes referenciais, pois expuseram diferentes Estudos Sociais, e me levaram

\footnotetext{
${ }^{2}$ Retomaremos a análise desta bibliografia mais detidamente no capítulo 2, quando apresentamos outra abordagem para a análise dos Estudos Sociais na escola brasileira.
} 
a ver o tema de outro modo. De que forma uma "inovação", frente ao modelo de ensino francês vigente no país desde a criação do Imperial Colégio de Pedro II, no século XIX, tornou-se autoritário e alvo de tantas críticas? É uma pergunta que tenho feito desde então. As inquietações - ainda acadêmicas - cresceram a partir do contato com a difícil realidade de ensino e o desinteresse crescente dos alunos da escola básica pelo ensino de História, percebido como algo distante de sua realidade, que simplesmente passou e não precisa ser estudado. A prática docente intensificou o desejo por conhecer e compreender outras formas de se ensinar História para além do modelo que se consolidou no Brasil.

Sentia, apesar das incursões pelo campo da História da Educação, que esta ainda era uma lacuna em minha formação. Outro conselho de Antonio Nóvoa (2015, p. 25) relaciona-se justamente a esse aspecto: "conhece bem as regras da sua disciplina", "conhece bem aquilo que fazes". Com esse objetivo, decidida a hora de tentar um doutorado, optei por seleções em Programas de Pós-graduação em Educação. Aprovado em dois programas, ingressei na PUC-Rio. Dos três membros da banca de seleção, a professora Ana Waleska P. C. Mendonça, mostrou-se mais solícita e entusiasmada, tornando-se a orientadora inicial deste trabalho. Se a História não tivesse nenhuma outra serventia, advertia Marc Bloch (2001), ela ao menos nos entretém. Que prazer, um dos poucos entre tantas tarefas árduas, foi assistir às suas aulas em História da Educação, História da Profissão Docente e A universidade na História! ${ }^{3}$ Mas não somente isso! Com paciência, elegância e sabedoria, a professora Ana Waleska soube nos apresentar (as suas sucessivas turmas) as normas, metodologias e preceitos de um campo de pesquisa.

“O ensino de Estudos Sociais no Brasil: das 'connexões naturaes' à integração pela via do autoritarismo (1930-1970)" é fruto de uma série de “viagens" (algumas entre São Gonçalo e Gávea!), formações, dúvidas e inquietações e se inspira nas propostas de Nóvoa (1996). Trata-se de um duplo desafio: refletir sobre a história de minha disciplina (onde os Estudos Sociais, conforme apresento, exerceram um papel relevante), entender suas continuidades e rupturas, sem me afastar dos desafios impostos pelo presente. Compreender o papel social da disciplina escolar História nos dias atuais passa, necessariamente, por uma compreensão de seu passado. Um esforço em conhecer um pouco mais

\footnotetext{
${ }^{3}$ As disciplinas contaram com a colaboração do professor Jefferson Soares, orientador desta tese, que à época desenvolvia seu pós-doutorado supervisionado pela professora Ana Waleska.
} 
sobre o meu próprio campo de trabalho. Contudo, a pesquisa não pode e nem deve fazer sentido apenas para o seu autor. Deve fazer sentido para o outro, aquele que irá ler, avaliar, criticar. É isso que busco, a partir da próxima seção ${ }^{4}$.

\title{
1.2
}

\section{Construção do objeto e as problemáticas de pesquisa: por que analisar os Estudos Sociais?}

\begin{abstract}
A vida em sociedade é una, complexa e formada de elementos interdependentes. A sua essência sociológica é "interação" e "inter-relação"; isto é, a vida social, em momento nenhum, é exclusivamente geográfica, exclusivamente histórica ou exclusivamente econômica. A sua variedade resulta, em grande parte, da dosagem destes elementos em cada caso, um só deles não é suficiente para explicá-la. (Delgado de Carvalho, 1953).

A integração da História com as demais disciplinas que compõem as denominadas Ciências Humanas permite sedimentar e aprofundar temas. (Brasil, 2000, p. 20).
\end{abstract}

Esta tese se insere no conjunto crescente de trabalhos que têm como temática principal a constituição histórica das disciplinas escolares. Dialoga, particularmente, com as pesquisas que tematizam a História como disciplina constituinte do currículo escolar. Toma-se como objeto de estudo a configuração do ensino de Estudos Sociais no Brasil, entre os anos de 1930 e de 1970, considerando os contextos em que foi discutido e/ou implementado, com o objetivo de analisar o processo de apropriação ${ }^{5}$ das ideias pedagógicas - advindas do movimento da Escola Nova e da influência da filosofia educacional de John Dewey - a partir da década de 1930, sobre o ensino de Estudos Sociais, e as interpretações desse discurso no pensamento educacional brasileiro.

Duas concepções ganham relevo: aquela formulada por Delgado de Carvalho, entre os anos de 1930 e 1950, e a produzida por Valnir Chagas, no

\footnotetext{
${ }^{4}$ Até este ponto do texto, utilizei a primeira pessoa do singular, uma vez que reflito sobre aspectos da minha trajetória acadêmica. A partir da próxima seção, os debates serão pontuados na primeira pessoa do plural: "nós", pois esta tese é uma construção coletiva e envolve o diálogo com múltiplas vozes e leituras.

5 Apropriação no sentido defendido por Roger Chartier (1990), como a construção de sentidos que determinado grupo, neste caso os intelectuais, fazem dos objetos culturais que recebem. A abordagem "põe em relevo a pluralidade dos modos de emprego e a diversidade de leituras" ( $p$. 26).
} 
âmbito do CFE e no contexto da ditadura na década de $1970^{6}$. A análise da obra desses dois autores é privilegiada por três fatores principais:

1) Sua importância no cenário educacional brasileiro do século $X X$, sobretudo em momentos de reformas educacionais e/ou reformulações curriculares;

2) Seus autores foram os principais defensores da inclusão dos Estudos Sociais nos currículos brasileiros;

3) Ausência de estudos que aprofundem a discussão sobre as continuidades e rupturas nas propostas de Estudos Sociais desenvolvidas no Brasil.

A proposta de “integração de conteúdos” está em pauta no cenário educacional contemporâneo, mas essa discussão não é recente. Desde a década de 1930 já se debate sobre o estabelecimento de grandes "áreas de estudo" nos currículos escolares da educação básica, em substituição às disciplinas específicas (História, Geografia, Ciências, entre outras). O argumento principal, conforme um de seus principais defensores, Delgado de Carvalho (1953, [1957] 1970), é a interdependência dos fatos e a impossibilidade de se ensinar a complexidade dos fenômenos da vida através de disciplinas isoladas. Diferentes educadores e legisladores formularam e implantaram projetos articulando conteúdos ao longo do século XX (Santos \& Nascimento, 2013).

Um desses projetos foi desenvolvido pelo CFE, durante as décadas de 1970 e 1980, ao instituir a Doutrina do Núcleo Comum, em 1971. A partir da lei no $5.692 / 71$, que trata da Reforma do Ensino de $1^{\circ}$ e $2^{\circ}$ graus, os currículos passaram a ter um núcleo comum obrigatório em todo o território nacional, cabendo ao $\mathrm{CFE}$ fixar suas matérias. Esse "núcleo" foi definido através do parecer n 853/71 e da resolução $n^{\circ} 8 / 71$, ambos relatados por Valnir Chagas. Por meio desses institutos

\footnotetext{
${ }^{6}$ Carlos Miguel Delgado de Carvalho (1884-1980) foi professor do Colégio Pedro II, da Universidade do Distrito Federal, do Instituto de Educação do Distrito Federal e catedrático de História Moderna e Contemporânea da Faculdade Nacional de Filosofia/Universidade do Brasil. Raimundo Valnir Cavalcante Chagas (1921-2006) foi professor catedrático da Faculdade de Filosofia, Ciências e Letras da Universidade Federal do Ceará (UFC) e, posteriormente, docente na Faculdade de Educação da Universidade de Brasília (UnB). Atuou no Conselho Federal de Educação (CFE) entre 1962 e 1976. É importante salientar que o objeto analisado não será a biografia ou a totalidade da obra desses dois educadores, cujas trajetórias se confundem com importantes acontecimentos e mudanças na educação de nosso país, algumas das quais ajudaram a moldar. Usando expressões empregadas por Helena Bomeny (2001), ao analisar os perfis de Anísio Teixeira e Gustavo Capanema, poderíamos considerar Delgado como um "intelectual da educação", aquele que tomou "a educação como bandeira civilizadora", enquanto Valnir aparece na historiografia - mesmo não sendo com essa denominação - como um "gestor de políticas". Desenvolveremos mais aspectos de suas produções quando abordarmos as definições de Estudos Sociais por eles elaboradas.
} 
foram estabelecidas as matérias Comunicação e Expressão, que englobava o ensino de Língua Portuguesa e Língua Estrangeira; Estudos Sociais, dedicada à História, Geografia e Organização Social do Brasil (OSPB); e Ciências, que abrangia Matemática e Ciências Físicas e Biológicas.

Outra proposta se refere ao atual ensino médio. A Lei de Diretrizes e Bases da Educação Nacional (Brasil, 1996) também pretende uma maior integração entre as disciplinas. Um reforço para essa política foi lançado em 2000, com a publicação dos "Parâmetros Curriculares Nacionais" (PCNs) para o ensino médio, que estabeleceram a divisão do conhecimento escolar em três grandes áreas: Linguagens, Códigos e suas Tecnologias; Ciências da Natureza, Matemática e suas Tecnologias; e Ciências Humanas e suas Tecnologias. A base da concepção dos parâmetros reside na reunião de conhecimentos de forma mais completa para a vida em sociedade, para o trabalho e para as experiências humanas.

Mais recentemente, nas discussões sobre a Base Nacional Comum Curricular, o tema voltou ao debate. Diferentemente das propostas anteriores, o documento é organizado em quatro áreas: Linguagens, Matemática, Ciências Humanas e Ciências da Natureza. Para os seus formuladores, "tal organização visa superar a fragmentação na abordagem do conhecimento escolar pela integração e contextualização desses conhecimentos, respeitando-se as especificidades dos componentes curriculares que integram as diferentes áreas.” (Brasil, 2015, p. 15). Os textos que compõem o documento preconizam a integração em dois níveis: entre as disciplinas que compõem determinada área e entre as áreas.

Entre as denominadas "áreas de conhecimento", a tentativa mais antiga, e talvez a mais combatida, de integração dos conteúdos, refere-se às chamadas Ciências Humanas. Durante boa parte do século passado, educadores e políticos defenderam que a História e a Geografia deveriam ser ensinadas no interior de uma área de estudo denominada como Estudos Sociais, o que se tornou realidade durante os anos da ditadura militar (1964-1985). Muitos professores de História, historiadores e educadores, sobretudo os que atuaram na luta contra a ditadura no decorrer dos anos de 1970 e 1980, construíram uma memória que associa os Estudos Sociais à política educacional adotada após a ascensão dos militares ao poder (Nascimento, 2012) ${ }^{7}$. No processo de oposição aos Estudos Sociais, como

\footnotetext{
${ }^{7}$ Embora a análise desse processo não seja objeto direto desta tese, é preciso observar que os Estudos Sociais sobreviveram ao fim da ditadura militar, o que demonstra a persistência dessa
} 
demonstraremos mais detalhadamente no próximo capítulo, consolidou-se como uma literatura que tende a destacar os seus aspectos negativos, classificando-os, unicamente, como uma "descaracterização das Ciências Humanas". Afinal, o momento era de tomada de posição e de defesa do ensino de História nas escolas. Entretanto, mesmo passados mais de 30 anos do final da ditadura e da luta pela autonomia da História enquanto disciplina escolar, tal abordagem permanece.

A História é uma busca incessante de um objeto em constante movimento, sendo apreendida de maneiras diferentes, reescrita por cada geração e interpretada desde muitos pontos de vista (Fenelon, 1984). Um esforço "para o conhecer melhor" (Bloch, 2001, p. 46). Portanto, o conhecimento sobre determinado período pode se alterar a partir de novos olhares, novas indagações. A retomada dos debates pelo Ministério da Educação (MEC) sobre a supressão de disciplinas e integração de/entre disciplinas escolares, aponta para a continuidade de um pensamento educacional no Brasil. Isso significa questionar a literatura sobre os Estudos Sociais e ir além, problematizando outras questões. Que concepções pedagógicas $^{8}$ guiavam os defensores da inclusão dos Estudos Sociais nos currículos escolares e/ou acadêmicos? Quem eram os intelectuais/educadores que a defendiam? Quais as diferentes matrizes que caracterizaram as discussões e ensino de Estudos Sociais no Brasil? Quais os sentidos de História e Educação presentes na obra dos seus principais defensores, Delgado de Carvalho e Valnir Chagas? Tais questionamentos devem ser feitos levando-se em consideração a historicidade dos Estudos Sociais na escola brasileira. A miríade de eventos que compõe essa temporalidade nos impôs a necessidade de seleções.

O período delimitado para a pesquisa se situa entre as décadas de 1930 e de 1970 por compreender o auge das discussões sobre o ensino de Estudos Sociais no Brasil. Na década de 1930, foi publicado o "Programa de Ciências Sociais", organizado por Delgado de Carvalho dentro do contexto das reformas anisianas no Distrito Federal (1931-1935), sendo considerado como um "marco de

vertente. Ao analisar as propostas curriculares, de diferentes estados brasileiros, entre 1985 e 1995, Circe Bittencourt (2000, p. 137-138) destaca que havia "um predomínio dos Estudos Sociais nas primeiras séries do ensino fundamental, tendo a substituição por História ocorrido só a partir da $5^{\text {a }}$ série [atual $6^{\circ}$ ano]." A separação da História e Geografia, nas primeiras séries, ocorreu, efetivamente, a partir da publicação dos "Parâmetros Curriculares Nacionais" pelo MEC em 1997.

${ }^{8}$ Concepção pedagógica, entendida aqui a partir da definição de José Carlos Araújo (2009, p. 193), como "faculdade ou ato de apreender uma ideia ou questão, ou de compreender algo, um modo de ver, um ponto de vista, uma compreensão, um entendimento, uma noção", que se relaciona a ação de condução do indivíduo a sua educação. 
referência" para a implantação das propostas de Estudos Sociais no país (Fernandes, 2008). Entretanto, o programa divulgado em dois volumes, em 1934, tem sido pouco analisado pela historiografia educacional. Trata-se de uma lacuna que talvez esta tese possa começar a preencher. Delgado lançou outras obras e artigos sobre o tema, com destaque para o livro "Introdução metodológica aos Estudos Sociais" (1957). Como "professor autor"," Delgado de Carvalho contribuiu para organização do campo disciplinar brasileiro a partir da década de 1930, momento em que ele construiu sua definição de Estudos Sociais.

A publicação do "Programa de Ciências Sociais" demarca, portanto, o recorte inicial desta tese. A obra se inspira na educação progressiva defendida por Anísio Teixeira e compõe um conjunto de iniciativas visando a reformulação do currículo escolar da então capital da república. Era preciso uma escola que se adequasse às necessidades do brasileiro (Mendonça, 2002). Experiência rica, mas efêmera, acabou sendo suplantada por outros modelos de Estudos Sociais debatidos e colocados em prática nas décadas seguintes. $\mathrm{O}$ principal deles, como já destacamos nas linhas anteriores, foi desenvolvido em âmbito federal na década de 1970, tendo Valnir Chagas como principal formulador.

A opção por este recorte decorre da ausência de trabalhos que investiguem tanto as perspectivas de Estudos Sociais de Delgado de Carvalho, antes da década de 1950, quanto os pressupostos educacionais presentes na concepção defendida por Valnir Chagas, a partir de 1971. Esta última, por sua estreita vinculação a ditadura militar, é tida, quase sempre, como uma experiência isolada e sem conexão com outras propostas de ensino de Estudos Sociais na escola brasileira. Assim, temos como objetivo geral: analisar a trajetória do ensino de Estudos Sociais no Brasil, entre as décadas de 1930 e 1970, salientando as continuidades e rupturas que caracterizaram sua introdução nos currículos escolares e universitários. Para efeitos de clareza, enunciamos os objetivos específicos estabelecidos para a pesquisa:

a) Identificar e analisar as principais correntes pedagógicas que marcaram as discussões e o ensino de Estudos Sociais no Brasil, destacando os

\footnotetext{
9 "Professor-autor" é um conceito utilizado por Gasparello (2016) para definir homens, em sua maioria, que ocupavam cargos na esfera pública, no legislativo, na diplomacia e nos órgãos de administração educacional. Entre "as atividades intelectuais próprias a esse grupo estava a docência nas instituições secundárias e superiores, bem como a publicação de obras relativas ao ensino.” (p. 59). Muitos deles, como Delgado de Carvalho, publicaram obras didáticas e metodológicas.
} 
diferentes contextos históricos em que foram formuladas e/ou aplicadas;

b) Entender os modelos de ensino de Estudos Sociais que circulavam nos Estados Unidos entre as décadas de 1910 e 1930;

c) Analisar a constituição do pensamento pedagógico que guiou a introdução do ensino de Estudos Sociais, no Brasil, durante a gestão de Anísio Teixeira à frente do Departamento de Educação do Distrito Federal (1931-1935);

d) Analisar a legislação produzida nas décadas de 1960 e 1970 pelo Conselho Federal de Educação sobre os Estudos Sociais;

e) Compreender as convergências e divergências entre os projetos de Estudos Sociais de Delgado de Carvalho e Valnir Chagas.

Este trabalho parte do pressuposto de que é necessário o "reconhecimento de que os Estudos Sociais, em sua trajetória de implantação/desimplantação na escola brasileira, passaram por momentos e fases diferentes nas quais é possível captar nuances e modificações em sua própria natureza.” (Nadai, 1988, p. 1). A disciplina escolar não é monolítica. Por vezes, “com o mesmo rótulo, isto é, sob a mesma denominação, diferentes conteúdos vão sendo ensinados ao longo do tempo." (Santos, 1995, p. 61). A natureza dos Estudos Sociais e suas transformações são o principal problema de que trata esta tese. Nas suas duas principais vertentes (Delgado de Carvalho e Valnir Chagas), o que permaneceu? O que se alterou? A interpretação de Nadai (1988) é a de que existem dois discursos sobre os Estudos Sociais no Brasil. O primeiro, elaborado na década de 1930, é repetido nas argumentações em seu favor até a década de 1960. Outro discurso foi construído na década de 1970.

Temos como hipótese central que as construções de Delgado e Valnir se originaram da mesma fundamentação, partindo da experiência norte-americana. Há uma matriz de pensamento sobre os fatores que levaram à inclusão dos Estudos Sociais no currículo escolar, entre os quais se destacam a necessidade de maior integração entre os conteúdos das Ciências Humanas, o maior entrosamento entre escola e "mundo atual" e a unicidade da ciência (Delgado de Carvalho) ou do saber (Valnir Chagas). Essas perspectivas estão presentes nos escritos de Delgado de Carvalho e Valnir Chagas. Os dois, cada um ao seu tempo, influenciaram a produção sobre os Estudos Sociais. Todavia, o conselheiro Valnir 
Chagas, ao aplicar a sua interpretação em documentos normativos e no auge de um regime autoritário e repressivo, tornou a aceitação de tal disciplina/área de estudo impossível. Os embasamentos guardam semelhanças aos defendidos por Delgado de Carvalho, décadas antes, mas a obrigatoriedade era inteiramente nova.

Ao lado da obrigatoriedade, outro empecilho aos Estudos Sociais de Valnir Chagas foi a forma de pensar a formação do professor e a consolidação da disciplinarização do currículo escolar ${ }^{10}$. Na década de 1930, esse processo apenas se iniciava com a criação dos primeiros cursos de formação de professores para a escola secundária. Apesar da proposta da Universidade do Distrito Federal, criada por Anísio Teixeira, de formular cursos separados de História e Geografia, o que se materializou foi o projeto da Faculdade Nacional de Filosofia da Universidade do Brasil, modelo para todo o país, com um curso integrado de História e Geografia. Naquele momento, a discussão sobre os Estudos Sociais estava relacionada à escola elementar ou de primeiras letras, na qual as fronteiras entre as disciplinas eram menores e o professor obtinha a sua formação nas Escolas Normais. Na década de 1970, os cursos desmembrados de História e Geografia estavam em plena expansão e as entidades representativas organizadas ${ }^{11}$. A diferenciação na carreira docente, pautada pelo processo de disciplinarização, fez com que os professores estivessem menos propensos à perda de autonomia de suas disciplinas. A história do ensino e a história das disciplinas escolares são os referenciais preferenciais para a discussão das problemáticas propostas.

Para Lima e Fonseca (2011, p. 8), “a história do ensino vem, há muito, constituindo-se como importante tema de estudos no campo da História da Educação, estando, muitas vezes, próxima da história do currículo e da história das disciplinas escolares." Teoricamente esta tese se situa nessa interseção assinalada pela autora, a partir dos referenciais advindos do campo da História da Educação, privilegiando as perspectivas de análise da história do ensino de História e história das disciplinas escolares (Bittencourt, 2003; Chervel, 1990). Tais linhas de investigação apontam para a "necessidade de se entender os saberes escolares em sua especificidade, articulados às mudanças e continuidades inscritas

\footnotetext{
${ }^{10} \mathrm{O}$ currículo escolar brasileiro, sobretudo o da escola secundária ou média, está organizado em disciplinas autônomas, distribuídas pelos anos de ensino, que exigem professores especialistas.

${ }^{11}$ Oficialmente, os cursos foram desmembrados por lei federal em 1955. Entretanto, ainda na década de 1960, algumas instituições formaram as últimas turmas. Entre as associações, temos a Associação Nacional de História e a Associação dos Geógrafos Brasileiros.
} 
nos ritmos próprios da longa duração, relacionados com os contextos e estruturas de cada sociedade." (Schmidt, 2012, p. 75). Os referenciais da História Cultural têm contribuído para a compreensão da complexidade dos processos de constituição das disciplinas escolares e suas múltiplas formas de apropriação.

\section{3}

\section{Abordagem teórico-metodológica e fontes}

[...] o historiador, se ele quer compreender, deve cuidar para não se transformar em justiceiro, mas sim em procurar reconstituir em sua organicidade a gênese, a estrutura e a evolução das disciplinas escolares. (Julia, 2002, p. 42).

A História da Educação é um campo de investigação pluridisciplinar, cujos objetos são variados - escola, professor, materiais escolares, processos e formas de aprendizagem - e estudados a partir de diferentes métodos e referenciais teórico-metodológicos (Veiga, 2008). As décadas de 1970 e de 1980 se caracterizaram por uma significativa ampliação do "território" do historiador, com novos olhares sobre velhos problemas, surgimento de novas questões e diversificação das fontes, métodos e abordagens. O impacto desse movimento contribuiu para a renovação da História da Educação, levando-a a considerar outros objetos e temas. Segundo Lima e Fonseca (2008, p. 61), a partir da década de 1990, os pressupostos da História Cultural "têm inspirado parte significativa dos estudos recentemente realizados". No entendimento de Roger Chartier (1990, p. 17), a História Cultural tem "por principal objeto identificar o modo como em diferentes lugares e momentos uma determinada realidade social é construída, pensada, dada a ler”. Portanto, como observa Libânia Xavier (2011, p. 33):

[...] os estudos classificados no âmbito de uma história cultural abarcam uma gama muito diversificada de questões, que vão desde a reflexão sobre as práticas e produções culturais de uma dada época até a produção de sentidos a elas atribuídos, buscando articular as dimensões simbólicas e materiais das realidades estudadas.

Ainda de acordo com a autora, trata-se da:

[...] configuração de um campo de reflexão e de produção de pesquisas que se volta para compreender a educação em sua historicidade [...] pela compreensão de que a História da Educação em sua historicidade tem contatos, sim, com a política e a administração, com a burocracia e a dinâmica de suas instituições, ou com a sociedade e o Estado ou, ainda, com os movimentos e as práticas sociais, mas esta se realiza, antes de tudo, no âmbito dos processos de transmissão cultural. Por essa 
via, configura-se a formulação de uma matriz de interpretação de caráter históricocultural. (Xavier, 2011, p. 34).

A matriz de interpretação histórico-cultural toma a educação como uma prática sociocultural e política e a escola como lugar de produção, convivência e transmissão de cultura(s) (Veiga, 2008; Vidal \& Schwartz, 2010). Educação e escola são "filhas de seu tempo", sendo necessário, portanto, o desenvolvimento de uma abordagem atenta à inter-relação dos contextos político, econômico, social e cultural com os quais a sua constituição e desenvolvimento dialogam. Os processos de circulação, de representação, de apropriação e das práticas são pontes entre a História da Educação e a História Cultural (Lopes, 2006). Problematizar a escola a partir desse referencial possibilita um olhar mais apurado para "as práticas e produções culturais" que permeiam o cotidiano escolar.

Por que a escola ensina o que ensina? O que acontece na realidade escolar e na sala de aula? São questões norteadoras das pesquisas mais recentes em História da Educação inspiradas por essa abordagem. A “cultura escolar", na vertente definida por Dominique Julia (2001), contribui para pensarmos o papel da escola na sociedade, na formação das novas gerações, para a compreensão das práticas escolares e para a constituição das disciplinas escolares. A introdução desse termo no Brasil coincidiu com a renovação das práticas de pesquisa e aproximação dos historiadores da educação em relação aos protocolos de pesquisa histórica stricto sensu. O conceito é utilizado em diferentes perspectivas disciplinares e os autores se propõem a investigar o funcionamento interno da escola, o que tem se denominado como "caixa preta" (Vidal \& Schwartz, 2010). De acordo com Julia (2001, p. 10):

Poder-se-ia descrever a cultura escolar como um conjunto de normas que definem conhecimentos a ensinar e condutas a inculcar, e um conjunto de práticas que permitem a transmissão desses conhecimentos e a incorporação desses comportamentos; normas e práticas coordenadas a finalidades que podem variar segundo as épocas (finalidades religiosas, sociopolíticas ou simplesmente de socialização).

A escola, como outras instituições da sociedade, produz uma cultura que lhe é própria e peculiar. Não se apresenta apenas como uma instituição de transmissão de saberes e inculcação de comportamentos, mas como um lugar de construção, resistência e ressignificação de saberes (Vidal \& Schwartz, 2010). Entretanto, Julia (2001) adverte que a cultura escolar não é fechada em si, já que mantém 
relações pacíficas (e algumas vezes conflituosas) com o conjunto de culturas que lhe são contemporâneas. A escola deve ser estudada no seu contexto. O historiador francês delimita três eixos necessários para o entendimento da cultura escolar como objeto histórico: o interesse pelas normas e finalidades que regem as escolas, a avaliação do papel da profissionalização do trabalho do educador e a investigação dos conteúdos e práticas escolares (Julia, 2001). Um dos caminhos possíveis para compreensão dos conteúdos de ensino e de suas finalidades é a análise dos processos de constituição das disciplinas escolares.

O objetivo das pesquisas nesse campo é "identificar, tanto através das práticas de ensino utilizadas na sala de aula como através dos grandes objetivos que presidiram a constituição das disciplinas, o núcleo duro que se pode constituir uma história renovada da educação.” (Julia, 2001, p. 13). Circe Bittencourt (2004) chama atenção para a necessidade de se definir o que é e como se constitui uma disciplina escolar. Para a autora, uma primeira distinção necessária se relaciona ao termo utilizado: "disciplina escolar" ou "matéria escolar"? Embora apareçam como sinônimos, nem sempre existe concordância em relação a essa semelhança.

A noção de disciplina escolar, tal como conhecemos hoje, é historicamente recente e se impôs após a Primeira Guerra Mundial (Chervel, 1990). A partir de então, o termo "disciplina" perdeu seu caráter de "ginástica intelectual”, tornandose "uma pura e simples rubrica que classifica as matérias de ensino, fora de qualquer exigência de formação do espírito.” (p. 180). De acordo com Chervel (1990), ocorreu uma "banalização da palavra". Entretanto, não há como alterar profundamente o seu sentido original. O pesquisador argumenta que "uma 'disciplina', é igualmente, para nós, em qualquer campo que se a encontre, um modo de disciplinar o espírito, quer dizer de lhe dar os métodos e as regras para abordar os diferentes domínios do pensamento, do conhecimento e da arte.” (p. 180).

A partir dessa abordagem, Chervel (1990) utiliza o termo "disciplina escolar" ao se referir à escola básica e "disciplina acadêmica" quando trata do ensino superior. Já Ivor Goodson defende a distinção entre matéria e disciplina: “disciplina é entendida como uma forma de conhecimento oriunda da tradição acadêmica e, para o caso das escolas primárias e secundárias, utiliza o termo matéria escolar (school subjects)." (Bittencourt, 2003, p. 23, grifos da autora). Para Bittencourt (2004), há, ainda, outra polêmica a respeito desse conceito, que 
envolve a concepção de escola, saber, conhecimento escolar e constituição do saber docente. Existem pelo menos duas percepções que possuem divergências: “os defensores da ideia de disciplina como 'transposição didática' e os que concebem disciplina como um campo de conhecimento autônomo.” (p. 35).

A ideia de "transposição didática", defendida por Yves Chevallard, considera que as disciplinas escolares decorrem da produção científica, sendo dependentes da academia. São legitimadas pelo "saber científico". Nessa abordagem, "a escola é o lugar de recepção e reprodução do conhecimento externo, variando sua eficiência pela maior ou menor capacidade de 'transpô-lo' adequadamente." (Bittencourt, 2004, p. 37). O professor é uma espécie de intermediário na reprodução do conhecimento ${ }^{12}$. A outra perspectiva, elaborada por André Chervel (1990), salienta que as disciplinas escolares possuem autonomia em relação às "ciências de referência" e que a escola produz um saber próprio. Nesse sentido, a disciplina escolar se forma no interior de uma "cultura escolar", o que não significa que deixe de dialogar com as ciências de referência.

Para autores como Chervel (1990) e Julia (2001), a disciplina escolar não é nem uma adaptação nem uma vulgarização da ciência de referência, mas um produto da escola. Logo, toda disciplina tem uma História. Ao adotarmos a perspectiva de Chervel (1990), seguimos o pressuposto de que a disciplina escolar deve ser estudada historicamente, observando-se o papel exercido pela escola em diferentes momentos (Bittencourt, 2004). Contudo, não compreendemos os Estudos Sociais apenas como um "produto da escola", já que representam uma tentativa de didatização do conhecimento, uma construção pedagógica, a partir de elementos de várias ciências. Julia (2002) aponta para os perigos do anacronismo, isto é, identificar determinados conjuntos de saberes ou conteúdos enquanto disciplinas quando ainda não estavam estabelecidos como tal. Disciplina escolar, aceitando e complementando o sentido atribuído por Chervel (1990), é o "conjunto de conhecimentos identificado por um título ou rubrica e dotado de organização própria para o estudo escolar, com finalidades específicas ao conteúdo de que trata e formas próprias para sua apresentação.” (Lima e Fonseca, 2011, p. 15). Assim, podemos considerar os Estudos Sociais como uma disciplina

\footnotetext{
${ }^{12}$ Novas abordagens desse conceito entendem que a escola é um espaço de criação e de elaboração original de ideias e projetos, embora não seja a única produtora da disciplina escolar. Existe, por exemplo, uma série de inovações historiográficas, engendradas pela pesquisa acadêmica e por mudanças nas interpretações, que chegam até a escola. É um processo de mão dupla.
} 
escolar, embora nem sempre o seu lugar no currículo da escola tenha ficado claro. Ao longo do século XX, os Estudos Sociais tiveram diferentes denominações: "matéria escolar", “disciplina optativa”, “disciplina”, “área de estudos”, variando também suas composições disciplinares ou de conteúdo.

\begin{tabular}{|c|c|c|}
\hline \multirow[b]{2}{*}{ Documento e/ou artigo, livro } & \multicolumn{2}{|c|}{ Componentes disciplinares ou curriculares dos Estudos Sociais } \\
\hline & Teoria ou definição & $\begin{array}{l}\text { Prática ou em termos de } \\
\text { prescrição de conteúdos }\end{array}$ \\
\hline $\begin{array}{l}\text { "The Social Studies in } \\
\text { secondary education" (Dunn, } \\
\text { 1916) }\end{array}$ & $\begin{array}{l}\text { Geografia } \\
\text { História } \\
\text { Educação Cívica }\end{array}$ & $\begin{array}{l}\text { Geografia } \\
\text { História da Europa } \\
\text { História Americana } \\
\text { Educação Cívica } \\
\text { Problemas democráticos: social, } \\
\text { econômico e político }\end{array}$ \\
\hline $\begin{array}{l}\text { "Conclusions and } \\
\text { recommendations of the } \\
\text { Comission on the Social } \\
\text { Studies of Association } \\
\text { American History" (Krey et } \\
\text { al., 1934) }\end{array}$ & $\begin{array}{l}\text { História } \\
\text { Economia } \\
\text { Política } \\
\text { Sociologia } \\
\text { Geografia } \\
\text { Antropologia } \\
\text { Política } \\
\end{array}$ & $\begin{array}{l}\text { Geografia Física e Cultural } \\
\text { Economia } \\
\text { Sociologia Cultural } \\
\text { Ciência Política } \\
\text { História }\end{array}$ \\
\hline $\begin{array}{l}\text { "Programa de Ciências } \\
\text { Sociais" (1934) da escola } \\
\text { primária do Distrito Federal }\end{array}$ & $\begin{array}{l}\text { História } \\
\text { Geografia } \\
\text { Economia Política Elementar } \\
\text { Educação Cívica } \\
\text { Elementos de Ciência Política e } \\
\text { Direito Usual } \\
\text { Noções sobre profissões } \\
\end{array}$ & $\begin{array}{l}\text { História da Civilização } \\
\text { História do Brasil } \\
\text { Geografia } \\
\text { Educação Cívica }\end{array}$ \\
\hline $\begin{array}{l}\text { "As Ciências Sociais na } \\
\text { escola secundária" (Delgado } \\
\text { de Carvalho, 1940) }\end{array}$ & $\begin{array}{l}\text { História da Civilização } \\
\text { Geografia Humana } \\
\text { Economia Política } \\
\text { Ciência Política } \\
\text { Sociologia }\end{array}$ & $\begin{array}{l}\text { Não houve prescrição de } \\
\text { conteúdos }\end{array}$ \\
\hline $\begin{array}{l}\text { "Os Estudos Sociais no Curso } \\
\text { Secundário" (Delgado de } \\
\text { Carvalho, 1953) }\end{array}$ & $\begin{array}{l}\text { História } \\
\text { Geografia } \\
\text { Política } \\
\text { Sociologia } \\
\text { Economia } \\
\end{array}$ & $\begin{array}{l}\text { Não houve prescrição de } \\
\text { conteúdos }\end{array}$ \\
\hline $\begin{array}{l}\text { "Introdução metodológica aos } \\
\text { Estudos Sociais" (Delgado de } \\
\text { Carvalho, 1957) }\end{array}$ & $\begin{array}{l}\text { História } \\
\text { Economia } \\
\text { Sociologia } \\
\text { Política } \\
\text { Geografia Humana } \\
\text { Antropologia Cultural } \\
\end{array}$ & $\begin{array}{l}\text { A proposta não se efetivou na } \\
\text { prática }\end{array}$ \\
\hline $\begin{array}{l}\text { Parecer } n^{\circ} 853 / 71 \text { (Valnir } \\
\text { Chagas e a Doutrina do } \\
\text { Núcleo Comum) }\end{array}$ & $\begin{array}{l}\text { História } \\
\text { Geografia } \\
\text { Educação Moral e Cívica } \\
\text { Organização Social e Política do } \\
\text { Brasil }\end{array}$ & $\begin{array}{l}\text { História } \\
\text { Geografia } \\
\text { Educação Moral e Cívica } \\
\text { Organização Social e Política do } \\
\text { Brasil }\end{array}$ \\
\hline
\end{tabular}

Quadro 1 - Componentes dos Estudos Sociais

Fonte: Elaborado pelo autor.

Da sua institucionalização nos Estados Unidos à apropriação por autores e reformas brasileiras, os Estudos Sociais apresentaram diversas composições. Esse quadro inicial tem por objetivo familiarizar o leitor com algumas delas. Ao definirem os Estudos Sociais ou Ciências Sociais, os reformadores e educadores os apresentaram a partir da integração ou fusão de um conjunto de disciplinas ou 
assuntos. É o que delimitamos como Estudos Sociais "na teoria”. No entanto, ao formularem as propostas de currículo, por vezes, há uma síntese dos conhecimentos ou aquilo que deveria ser efetivamente cobrado "na prática".

O estabelecimento de uma disciplina escolar no currículo depende de fatores internos e externos a ela e à escola. Ao longo do tempo, pode haver variações nos conteúdos e formas da disciplina, conforme exemplificado no quadro acima. As mudanças decorrem tanto de fatores externos, relacionadas ao contexto social, político, econômico e cultural, por exemplo, quanto a partir de fatores internos, como a "emergência de grupos de liderança intelectual, surgimento de centros acadêmicos de prestígio na formação de profissionais e na pesquisa na área, organização e evolução das associações de profissionais e política editorial." (Santos, 1995, p. 61-62). Essas mudanças de nomenclatura, como abordamos nesta tese, emanam dos contextos políticos e das reformas educacionais que delimitaram o ensino de Estudos Sociais em diferentes currículos.

A pesquisa sobre a constituição e funcionamento das disciplinas escolares ocorre a partir de três problemas principais: a gênese da disciplina (como elas são produzidas?), seus objetivos e/ou funções (Para que servem? Por que a escola foi levada a ensiná-las? Como respondem as expectativas, de pais, poder público, professores?) e funcionamento, conforme compreende Chervel (1990, p. 184):

[...] desde que se compreenda em toda a sua amplitude a noção de disciplina, desde que se reconheça que uma disciplina escolar comporta não somente as práticas docentes da aula, mas também as grandes finalidades que presidiram sua constituição e o fenômeno de aculturação de massa que ela determina, então a história das disciplinas escolares pode desempenhar um papel importante não somente na história da educação mas na história cultural.

Uma chave de pesquisa é a análise das finalidades que presidiram a constituição das disciplinas escolares. Cada uma delas responde por um conjunto de objetivos gerais, expectativas e finalidades - religiosas, sociopolíticas, culturais, entre outras - atribuídas pela sociedade. A organização desses objetivos ou finalidades - que variam conforme o momento histórico e sua recontextualização em conteúdos de ensino - é uma das tarefas das disciplinas escolares. A disciplina escolar é, de acordo com Gasparello (2011, p. 106), "resultado de um processo na qual participam, em diversas dimensões e lugares, diferentes atores em suas práticas com saberes do seu tempo.” Esses sujeitos, individuais e/ou coletivos, professores, autores, intelectuais ou legisladores, 
integram a sua construção e delimitam a sua legitimidade e poder (Bittencourt, 2003). Esse processo não é pacífico, mas permeado por disputas entre campos e conhecimentos em busca de um lugar no currículo. Em vista disso,

[...] a presença de cada uma das disciplinas escolares no currículo, sua obrigatoriedade ou sua condição de conteúdo opcional e, ainda, seu reconhecimento legitimado por intermédio da escola, não se restringe a problemas epistemológicos ou didáticos, mas articula-se ao papel político que cada um desses saberes desempenha ou tende a desempenhar, dependendo da conjuntura educacional. (Bittencourt, 2003, p. 10).

A história social do currículo, proposta por Ivor Goodson (2008), adverte sobre a diferença que pode existir entre o currículo escrito (oficial, normativo) e o currículo real, praticado nas escolas. Para ele, “o currículo escrito nos proporciona um testemunho, uma fonte documental, um mapa do terreno sujeito a modificações; constitui também um dos melhores roteiros oficiais para a estrutura institucionalizada de escolarização.” (Goodson, 2008, p. 21). Esse currículo representa, portanto, as grandes finalidades sustentadas pelo Estado e seus agentes. A dimensão oficial do currículo se revela em documentos legais, nos programas de ensino e nos livros didáticos. Tais materiais concebem diretrizes básicas a serem seguidas por todos aqueles envolvidos nas atividades de ensino. A importância de sua análise não é pequena, já que após os conflitos e negociações que ocorrem em sua elaboração, o currículo definido e estabilizado, tende "a servir como guia de tudo aquilo que deverá ser feito em relação a cada disciplina, em todos os níveis da sociedade." (Oliveira, 2017, p. 11).

A análise sócio-histórica se propõe a questionar, por exemplo, quais fatores permitem ou levam à inclusão de uma disciplina no currículo? Por que determinado currículo e não outro? O currículo é sempre resultado de uma seleção a partir de um leque mais amplo de conhecimentos. Tais recortes se relacionam às finalidades que a escola responde. Uma seleção que, portanto, não é neutra. O conhecimento corporificado no currículo não é algo fixo, "mas um artefato social e histórico, sujeito a mudanças e flutuações" (Silva, 2008, p. 7), uma construção permeada por conflitos e lutas entre diferentes concepções e em constante transformação. Como uma construção social e política, as disciplinas escolares podem ser abordadas a partir de vários elementos e por uma miríade de fontes. Os conteúdos de ensino, exercícios, avaliações, práticas de motivação e estímulo são exemplos de fontes possíveis para o estudo das disciplinas (Julia, 2001). 
Os objetivos das disciplinas escolares podem ser analisados, primeiramente, a partir dos textos programáticos (leis, decretos, pareceres, programas) que fixam os planos de estudos, os métodos, os exercícios. Entretanto, outros materiais admissíveis são os "relatórios de inspeção, projetos de reforma, artigos ou manuais de didática, prefácios de manuais, polêmicas diversas, relatórios de presidentes de bancas, debates parlamentares." (Chervel, 1990, p. 190-191). Tendo em vista os limites de acesso às fontes, e os objetivos estabelecidos nesta tese, propomo-nos a analisar os projetos de Estudos Sociais em Delgado de Carvalho e Valnir Chagas. A "realidade pedagógica" ou o "currículo em ação" não será, portanto, um objeto deste estudo. Tal escolha direcionou a seleção das fontes e a metodologia adotada. Optamos por restringir o corpus documental à legislação, currículos e aos livros didáticos e/ou metodológicos. Assim, procuramos entrecruzar esses dois tipos de fontes principais, observando as condições de sua produção e as relações com o contexto e a normatização.

Ao selecionarmos esse tipo de fonte, seguimos as indicações de Cláudia Engler Cury (2010) e de Ivor Goodson (2008). Para a primeira, embora as prescrições contidas nas leis, programas ou em livros didáticos e/ou metodológicos não possibilitem perspectivas de apreensão das práticas educativas, "incidem sobre o cotidiano das aulas, sobre os comportamentos e condutas dos mestres e alunos", tendo "papel importante na consolidação de uma cultura escolar" (Cury, 2010, p. 43). Nesse sentido, não podemos pressupor que o currículo escrito seja irrelevante para a prática (Goodson, 2008). Do mesmo modo, tomamos a legislação como "uma prática ordenadora das relações sociais", que possui um caráter histórico e político e que se relaciona "com os sujeitos responsáveis por esta intervenção social.” (Faria Filho, 1998, p. 111).

Analisamos as fontes à luz do método de análise de texto, como propõem Ciro Cardoso \& Ronaldo Vainfas (1997). Para os autores, o pressuposto principal dessa metodologia é a de que "o documento é sempre portador de um discurso que, assim considerado, não pode ser visto como algo transparente.” (p. 377). Trata-se de relacionar texto e contexto, a obra em diálogo com o seu tempo, "as formas pelas quais elas se exprimem e o conjunto de determinações extratextuais que presidem a produção, a circulação e o consumo dos discursos.” (p. 378). Consideramos, portanto, o lugar social em que esses documentos foram produzidos. Os currículos, programas, pareceres, livros e escritos dos educadores, 
apresentam definições de Estudos Sociais, as metodologias mais apropriadas para o seu ensino e refletem os debates em torno do processo de constituição da disciplina.

\subsection{1}

Fontes

As indicações de Marc Bloch (2001), em seu "Ofício do historiador", exercem, desde a sua publicação no pós-guerra, profundas influências para a constituição da ciência História. O historiador, como ele argumenta, está impossibilitado de constatar os fatos que estuda por si próprio. "Nenhum egiptólogo viu Ramsés” (p. 69). Das eras que nos antecederam só podemos falar segundo testemunhos. O passado não é algo passível de mudança e muito menos poderemos conhecê-lo em sua completude. Entretanto, o conhecimento sobre o passado é algo em constante movimento, proveniente de "reconstituições". O analisamos por meio de pistas, vestígios deixados pelos homens ao longo do tempo. Ao historiador cabe questionar as fontes e analisá-las sob o rigor do método crítico, confrontando-as com tudo o que já se sabe sobre o assunto abordado, seu lugar de produção e contexto (Prost, 2012).

Ao realizar o levantamento bibliográfico para a escrita da tese, deparamonos com uma referência frequente à influência estadunidense sobre a constituição do ensino de Estudos Sociais no Brasil e o pioneirismo do Distrito Federal (Rio de Janeiro) na sua efetivação. Os trabalhos fazem menção ao "Programa de Ciências Sociais", que Delgado de Carvalho (1934b) indica ser inspirado no modelo da cidade de Denver/EUA, mas não o analisam em profundidade e em articulação com o contexto reformista da década de 1930. O primeiro passo foi identificar os documentos, publicados nos Estados Unidos, que tentaram normalizar o ensino de Estudos Sociais naquele país. A partir de referências secundárias (Fallace, 2009; Nelson, 1994), pudemos observar que desde meados do século XIX tanto a Associação Nacional de Educação quanto a Associação Americana de História se preocuparam com a formulação de um currículo para a área de Ciências Humanas. Para isso, diferentes grupos de especialistas foram formados em renomadas universidades, como a de Columbia (Nova York). Três relatórios produzidos por 
esses profissionais são importantes para nosso estudo: "The Social Studies in secondary education” (“Os Estudos Sociais na escola secundária”, em tradução livre, 1916), o primeiro a se referir especificamente aos Estudos Sociais; " $A$ charter for the Social Sciences in the schools" ("Carta das Ciências Sociais nas escolas", em tradução livre, 1932) e "Conclusions and recommendations of the Comission on the Social Studies of Association American History” ("Conclusões e recomendações da Comissão de Estudos Sociais da Associação Americana de História", em tradução livre, 1934), contemporâneos à publicação dos "Programas de Ciências Sociais" (1934) e citados por Delgado de Carvalho (1970). São fontes ainda não analisadas pelas pesquisas brasileiras.

Elza Nadai (1988), analisando o que delimita como o processo de “divulgação/absorção do ideário da escola pragmática norte-americana no Brasil”, argumenta que a "renovação educacional" operada nos anos de 1930 se inspira em "traços alienígenas". A autora faz um questionamento que merece destaque:

\begin{abstract}
Alguns autores têm insistido no fato de que a importação de novidades estrangeiras, o comportamento imitativo do que se passa nos países adiantados, sem a devida crítica ideológica, tem sido um dos pilares da modernização brasileira, sobretudo no século XX, sendo muito intenso nas questões educacionais, onde imperariam os modismos. Este processo explicaria, assim, a introdução dos Estudos Sociais na escola brasileira. Ora, pode-se perguntar, por que alguns comportamentos são aceitos e assimilados e outros não? Será esse processo mecânico e realizado de maneira ingênua, como querem uns, valorizado só pelo fato de ser estrangeiro? (Nadai, 1988, p. 4, grifos da autora).
\end{abstract}

A introdução dos Estudos Sociais no Brasil seria um "modismo"? Mais ainda: sua constituição foi realizada sem a "devida crítica"? Consideramos que três categorias podem nos ajudar a pensar esse processo. As primeiras são as noções de "internacionalização" e "sistema mundial", tal como sintetizada na abordagem de Jürgen Schriewer (2011). Para o autor, existe "uma densa rede atual de comunicação e cooperação internacional em matéria de educação.” (p. 44). Os sujeitos atuam como mediadores nessa ação. Esses fenômenos não são recentes. As "interconexões internacionais em educação" são um fato histórico que precisa ser levado em consideração quando se analisa a constituição dos Estudos Sociais na década de 1930. Há um "sistema mundial" caracterizado pela interdependência e circularidade de ideias, modelos, políticas, publicações, por exemplo, o que não elimina as variações em seu interior. A migração de ideias, estudiosos e especialistas promove a difusão e recepção de modelos, que são selecionados, 
recontextualizados e reinterpretados de acordo com necessidades específicas de cada país.

Por sua vez, o conceito de apropriação, na concepção defendida por Roger Chartier (2001, p. 233), nos leva a refletir sobre a "invenção criativa que se encontra no âmago do processo de recepção". Os mesmos bens, textos e ideias podem ter usos diferenciados. Segundo o pesquisador, "a experiência mostra que ler não significa apenas submissão ao mecanismo textual. Seja lá o que for, ler é uma prática criativa que inventa significados e conteúdos singulares." (p. 234). A apropriação do modelo de Estudos Sociais norte-americano por Anísio Teixeira e Delgado de Carvalho é fruto da circulação de ideias educacionais vigentes nos anos de 1930 e que se caracteriza por suas viagens aos Estados Unidos. Analisamos de forma relacional os textos americanos e os brasileiros.

A partir daí, um segundo leque de documentos emergiu. Foi no Distrito Federal que ocorreu a primeira experiência. Os arquivos do Centro de Memória da Educação Brasileira (Cemeb) do Instituto de Educação do Rio de Janeiro (Iserj) oferecem importantes pistas. $\mathrm{Na}$ instituição, tivemos acesso a dois periódicos publicados na década de 1930: "Arquivos do Instituto de Educação" e "Boletim de Educação Pública". Através de sua leitura, é possível identificar os principais elementos das reformas desenvolvidas durante a gestão de Anísio Teixeira (1931 1935), bem como aspectos do funcionamento e organização do Instituto de Educação, quando, pela primeira vez, os Estudos Sociais compuseram uma disciplina no ensino superior e na formação de professores. Os Estudos Sociais se inseriam num projeto maior de educação.

Há uma farta bibliografia secundária sobre a obra anisiana e que fundamenta nossas análises. Da mesma forma, pesquisamos no arquivo pessoal de Delgado de Carvalho, em fase de organização e catalogação pelo Instituto Histórico e Geográfico Brasileiro (IHGB). Composto por recortes de jornais, cadernos de aulas, notas de estudos e manuscritos, esse acervo nos permitiu avançar no entendimento das concepções deste educador. Por exemplo, para além das suas obras conhecidas, encontramos notas sobre os Estudos Sociais produzidas em 1968 e 1969. Os programas de ensino, elaborados por Maria dos Reis Campos, para o uso no Instituto de Educação do Distrito Federal, e pelo Instituto de Pesquisas Educacionais, dirigido por Delgado de Carvalho, para aplicação nas escolas primárias completam esse escopo documental. Tivemos acesso, ainda, aos 
periódicos disponíveis na Hemeroteca Digital da Biblioteca Nacional, que apresentam indícios das reformas realizadas e das viagens pedagógicas.

A fim de compreender as continuidades e rupturas entre os dois principais projetos de ensino de Estudos Sociais no Brasil - defendidos por Delgado de Carvalho e Valnir Chagas - selecionamos como fontes basilares a "Revista Documenta" 13 , periódico oficial do CFE, durante a década de 1970, e os livros dos dois educadores. Uma ressalva precisa ser feita em relação a Delgado de Carvalho. Esse intelectual foi um dos maiores autores de livros didáticos e metodológicos do Brasil, em vários campos disciplinares e com várias tiragens e edições. Portanto, foi preciso um recorte focalizando em suas obras com uma preocupação maior sobre a questão dos Estudos Sociais: as apresentações dos "Programas de Ciências Sociais" (1934a, 1934b), "Sociologia e educação" (1934c), "Didática das Ciências Sociais" (1949) e "Introdução metodológica aos Estudos Sociais” (1970). Em relação a Valnir Chagas, sua concepção se encontra sintetizada em duas obras: "Formação do magistério: novo sistema" (1976) e "O ensino de $1^{\circ}$ e $2^{\circ}$ graus: antes, agora e depois" (1984).

\section{4 Estrutura da tese}

Uma constatação, hoje um tanto evidente, é a de que os Estudos Sociais têm uma história que antecede em muito o regime militar. Por isso, nos capítulos que se seguirão, concederemos maior atenção às definições desta disciplina escolar anteriores a 1964, sobretudo, as elaboradas por Delgado de Carvalho, sem, contudo, deixar de lado as propostas de Valnir Chagas. Procuramos, assim, conhecer seus fundamentos e inspirações, delimitando a sua gênese e evolução no Brasil.

A História é um saber cumulativo, já que nunca partimos do zero. Assim sendo, "devemos muito aos historiadores que nos precederam" (Julia, 2002, p. 37). O segundo capítulo deste trabalho tem um duplo objetivo. Inicialmente, apresentamos um estado da arte sobre o ensino de Estudos Sociais no Brasil, situando as pesquisas entre as décadas de 1970 e de 2010. Trata-se de uma

\footnotetext{
${ }^{13}$ Nessa revista, foram publicados pareceres, indicações e resoluções dos conselheiros.
} 
necessidade sentida desde o mestrado, quando iniciamos um levantamento sobre a crescente literatura a respeito dessa temática. As leituras nos indicaram uma profunda relação entre Estudos Sociais e História. De certo modo, os Estudos Sociais, na década de 1930, representam uma crítica ao ensino de História. Isso direcionou a segunda parte do capítulo, quando procuramos entender como se constituiu a disciplina escolar História e como ela era ensinada no Brasil.

O modelo de ensino de História, que se consolidou no Brasil a partir do século XIX, era influenciado pelas escolas francesas. Os Estudos Sociais, por sua vez, inspiraram-se nos educadores norte-americanos e nas experiências desenvolvidas nos institutos e escolas dos Estados Unidos. Os capítulos três e quatro se dedicam a analisar os fundamentos dos Estudos Sociais desdobrados nos currículos brasileiros. No terceiro capítulo, abordamos as teorias educacionais elaboradas por John Dewey, bem como a interpretação realizada por Anísio Teixeira, e os primeiros contatos de educadores importantes na década de 1930, como Delgado de Carvalho, com a obra do filósofo americano. Foi a partir dessas trocas intelectuais que os brasileiros intentaram a renovação dos métodos de ensino praticados em nosso país e, especialmente, no Distrito Federal.

No capítulo seguinte, nos dedicamos a analisar as concepções de Estudos Sociais que circularam nos Estados Unidos nas três primeiras décadas do século XX. Para tanto, debruçamo-nos sobre o processo de constituição de duas respeitáveis comissões organizadas pela Associação Nacional de Educação e pela Associação Americana de História, responsáveis pela publicação de importantes documentos que normatizaram os Estudos Sociais nos Estados Unidos e influenciaram a produção de Delgado de Carvalho entre 1930 e 1950.

O quinto e o sexto capítulo traçam a concepção de Estudos Sociais, formulada por Delgado de Carvalho entre as décadas 1930 e 1960. No quinto capítulo, investigamos aspectos da reforma anisiana no Distrito Federal dos anos de 1930 e a primeira experiência de Estudos Sociais desenvolvida em nosso país. Anísio Teixeira, Delgado de Carvalho e os educadores vinculados à Escola Nova debatiam mudanças no modelo de ensino brasileiro e defendiam uma escola mais próxima da realidade, com conteúdos que tivessem certa utilidade para a vida cotidiana dos alunos. Nesse contexto, foi inserida na escola primária uma disciplina intitulada Ciências Sociais - formada pela junção de conteúdos de História, Geografia, entre outros, cuja função era a formação do cidadão. $\mathrm{Na}$ 
formação de professores, no Instituto de Educação, introduziram-se os Estudos Sociais. Ainda não havia uma distinção entre Ciências Sociais e Estudos Sociais, algo que ocorrerá apenas na década de 1950. Os programas publicados na década de 1930 constituíram as bases principais dos Estudos Sociais no Brasil.

O sexto capítulo aborda os embates de Delgado de Carvalho pela criação da disciplina Estudos Sociais na escola secundária. As linhas de ação do educador foram diferentes em relação a esse nível de ensino, já que não foi possível uma mudança curricular, como aquela processada no Distrito Federal. A escola secundária possuía um conjunto de disciplinas claramente definido. Por isso, a opção em dividir a abordagem de Delgado em dois capítulos. Durante três décadas, o catedrático criticou o ensino de disciplinas estanques e clamou por uma revisão dos métodos de ensino. Ele argumentava que se não era crível o ensino através da "poderosa unidade", denominada Estudos Sociais, era preciso mudar a forma como a História e a Geografia eram ministradas. Na década de 1950, seu pensamento já está refinado e o autor propõe a distinção entre Ciências Sociais e Estudos Sociais e um programa para os últimos anos na escola secundária. Conforme veremos, ao longo dos anos, alguns aspectos do pensamento mudaram, mas a base - "interdependência do conhecimento" - permaneceu em seus escritos.

No sétimo capítulo, abordamos os Estudos Sociais que se configuraram no contexto dos governos militares a partir da escrita do conselheiro Valnir Chagas e seus colegas, tentando compreender as continuidades e rupturas presentes em sua proposta. Em termos curriculares, o parecer $n^{\circ} 853 / 71$, de autoria do Conselheiro Valnir Chagas (1978), instituiu a Doutrina do Núcleo Comum e a obrigatoriedade do ensino de Estudos Sociais no então $1^{\circ}$ grau. Consequentemente, História e Geografia foram abolidas como disciplinas autônomas desse nível de ensino, ficando restritas ao $2^{\circ}$ grau. Defendemos que Chagas se apropriou de um antigo debate educacional - "com elementos como unicidade do conhecimento" - e lhe concedeu novas tonalidades, como a ideia de que os Estudos Sociais contribuem para o ajustamento do jovem ao meio. Aspectos como obrigatoriedade, difusão dos Estudos Sociais por todo o país e formação de professores de Estudos Sociais em uma licenciatura específica são inteiramente novos e objeto de intensa oposição nas décadas de 1970 e 1980.

Como uma disciplina envolta por/em uma série de polêmicas, os Estudos Sociais foram alvo, durante muitos anos, de uma recusa no meio acadêmico. 
Tema espinhoso, muitas vezes sensível, por envolver as memórias de luta contra políticas educacionais autoritárias e pela afirmação da História e da Geografia enquanto disciplinas autônomas nos currículos escolares e universitários, os Estudos Sociais possuem uma rica trajetória que começamos a tatear, junto com outros importantes trabalhos já citados ou que apresentaremos no decorrer do texto. Muito ainda precisa ser descoberto e pesquisado. Esta tese pretende, assim, contribuir para a discussão de novas perspectivas e reflexões críticas sobre o seu ensino e divulgação na escola brasileira. 


\title{
2 \\ Literatura sobre o ensino de Estudos Sociais no Brasil: da denúncia à historicidade
}

\begin{abstract}
Grande parte das publicações acadêmicas sobre o ensino de História no Brasil surgiram num contexto intelectual e político bastante específico, para nós, historiadores. Vivenciamos, nos últimos anos, um processo de revisão dos esquemas globalizantes, homogeneizantes, que durante muitos anos nortearam as práticas historiográficas; uma ampliação do campo da história, através de uma busca de novos objetos e de novos documentos. Por outro lado, tivemos de nos defrontar com uma política de descaracterização e desvalorização da história no $1^{\circ}$ e $2^{\circ}$ graus, através de uma série de medidas governamentais, explícitas na Lei 5.692/71. (Fonseca, 1989/1990, p. 197-198).
\end{abstract}

Essas palavras foram escritas no final da década de 1980 e caracterizam o processo de constituição de um emergente campo de pesquisa. As lutas pela redemocratização brasileira, após duas décadas de ditadura militar, as reformas curriculares nos diferentes estados da federação e a renovação historiográfica - a partir do alargamento de fontes, objetos, abordagens e metodologias - levaram a um crescente interesse sobre a História ensinada na escola e a maior visibilidade da produção acadêmica e pedagógica ${ }^{14}$. Pesquisadores e professores universitários e da escola básica produziram uma série de artigos acerca do tema, publicados, por exemplo, na "Revista Brasileira de História". Esses estudos, hoje, contribuem para delimitarmos uma história da escrita sobre o ensino de História. Embora não apareça no trecho do texto de Fonseca (1989/1990), os Estudos Sociais, como um dos elementos centrais da denominada "política de descaracterização e

\footnotetext{
${ }^{14}$ Ao analisar diferentes aspectos das condições sociais de produção do campo científico, Pierre Bourdieu (1983) argumenta que as práticas científicas não são desinteressadas. Para o autor, existe "a cada momento uma hierarquia social dos campos científicos - as disciplinas - que orienta fortemente as práticas, e, particularmente, as 'escolhas' de 'vocação'. No interior de cada um deles há uma hierarquia social dos objetos e métodos de tratamento.” (p. 128). O ensino de História, durante muitas décadas, esteve associado a questões pedagógicas e a uma área de formação, a cargo das Faculdades de Educação, ou seja, sendo visto como um objeto não pertinente à pesquisa histórica. Essa perspectiva reflete a dicotomia entre ensino e pesquisa, que foi transferida para os programas de pós-graduação, “quando, mais uma vez, as questões do ensino se restringiram aos Programas de Pós-Graduação em Educação, ou seja, aos profissionais de cada área abriu-se a possibilidade de pesquisas em temas variados, porém a discussão sobre o que e como ensinar o produto desse conhecimento foi tratada como uma questão menor, desvalorizada, menos nobre." (Costa \& Oliveira, 2007, p. 147). Salvo algumas exceções, como veremos mais adiante, foi na década de 1980 que esse cenário começou a se alterar e o ensino de História tornou-se objeto de reflexão dos historiadores e de suas associações representativas.
} 
desvalorização da História", foram um dos catalisadores do movimento de renovação do ensino de História, ocorrido a partir de meados dos anos de 1970.

Há, portanto, uma estreita relação entre os Estudos Sociais e o ensino de História no Brasil. Durante boa parte do século XX, e mais especificamente no período da ditadura, os Estudos Sociais se mostraram como uma alternativa de disciplina escolar em disputa com o consolidado lugar da História no currículo. Destarte, há uma literatura que se dedica a analisá-los enquanto uma ameaça ao ensino de História e um conjunto de pesquisas, mais recentes, na esteira do pioneiro artigo de Elza Nadai (1988) que se propõem a investigar a historicidade dos Estudos Sociais na escola brasileira. Entendemos que as duas disciplinas representam vertentes diferentes de ensino. Enquanto a História ensinada era de inspiração eurocêntrica, principalmente francesa, os Estudos Sociais foram informados pelos documentos, livros e educadores norte-americanos (como John Dewey). Maria Auxiliadora Schmidt (2012), em trabalho recente, defende que os Estudos Sociais, da década de 1970, representam uma forma de contestação ao código disciplinar da História ${ }^{15}$, responsável pela sua "crise". Entretanto, é possível observar os indícios dessa contestação a partir da década de 1930.

O código disciplinar da História foi construído no contexto de criação e expansão do Estado-nação "que concedeu legitimidade às disciplinas escolares" (Fernández, 2009, p. 57), e de constituição dos sistemas educativos modernos de caráter "nacional-estatal". É uma tradição social edificada e formulada em determinada circunstância histórica, no século XIX (Fernández, 2009). No Brasil, com a fundação do Colégio Pedro II, em 1837, inspirado nos liceus franceses, ficava patente a preocupação do governo imperial com a formação das elites dirigentes e com o desenvolvimento da nacionalidade. O ensino de História tinha um papel primordial e era pautado na descrição, memorização e enciclopedismo dos programas. Os Estudos Sociais, introduzidos pela reforma educacional anisiana no Distrito Federal dos anos de 1930, é uma crítica a um determinado

\footnotetext{
${ }^{15}$ Os estudos do pesquisador Raimundo Cuesta Fernández (2009), sintetizados em sua tese sobre a História ensinada na Espanha, que inspiram a produção de Schmidt (2012), são importantes contribuições para a compreensão do conceito de código disciplinar. Essa categoria heurística é definida como "uma tradição social configurada historicamente e composta por um conjunto de ideias, valores, suposições e rotinas, que legitimam a função educativa atribuída à História e que regulam a ordem de sua prática de ensino.” (Fernández, 2009, p. 8, tradução nossa do original: "una tradición social que se configura históricamente y que se compone de un conjunto de ideas, valores, suposiciones y rutinas, que legitiman la función educativa atribuida a la Historia y que regulan el orden de la práctica de su enseñanza.").
} 
modelo educacional e de ensino das disciplinas que compõem as Ciências Humanas. Naquele momento, alguns educadores, como Delgado de Carvalho, apontavam para a ausência de relação entre o ensino de História e a vida prática ou cotidiana dos alunos. É preciso entender como se conformaram as bases do código disciplinar da História no Brasil para abordarmos, nos capítulos seguintes, como os Estudos Sociais se apresentaram como uma oposição ou reação a ele.

Com esse intuito, a leitura das fontes secundárias é importante. Isso porque, conforme argumenta Raquel Glezer (2011, p. 11), "olhar para o passado - para o que foi produzido no campo historiográfico sobre o passado e analisar criticamente tal passado produzido - é desenhar perspectivas de futuro.” É, ainda segundo esta autora, "manter a capacidade de reconhecer as contribuições e as limitações, prospectando os caminhos possíveis para o futuro." Neste capítulo, apresentamos de forma crítica o levantamento bibliográfico realizado para escrita desta tese e discutimos o modelo de ensino de História que se consolidou em nosso país a partir de 1838. O objetivo é compreender de que forma os Estudos Sociais foram e/ou são inseridos nas pesquisas sobre a história do ensino de História, apontando as convergências e a necessidade da análise das especificidades de sua história na escola. Apesar dos "estados da arte" escritos por historiadores do ensino, os Estudos Sociais ocupam um lugar secundário, não existindo nenhuma obra que sistematize as diferentes pesquisas sobre o tema.

\section{1}

\section{História do ensino de História: Estudos Sociais como apêndice}

O ensino de História, como campo de investigação, apresenta "como núcleo inicial a metodologia do ensino", embora tenha, nas últimas décadas, englobado outras questões a partir de "diversos aportes teórico-metodológicos e enfoques temáticos" (Cerri, 2007, p. 59). As pesquisas têm se organizado em torno de grandes linhas de investigação: políticas públicas, currículos, linguagens, questões metodológicas, livros didáticos, formação de professores, questões étnico-raciais, educação histórica, entre outros (Fonseca \& Gatti Júnior, 2011; Monteiro et al., 2007; Silva \& Zamboni, 2013). Para Luis Cerri (2007, p. 60), "cada uma das realidades que observamos no presente pode e deve ser mais bem compreendida 
através do conhecimento de sua inserção no tempo." O que, como e para que ensinar tem uma história. As instituições e disciplinas escolares expressam, conforme argumenta Gasparello (2007, p. 76), "um lento processo de construção social e cultural", que é histórico, dinâmico e contribui para compreensão das práticas escolares e currículos organizados em diferentes tempos.

A história do ensino de História no Brasil, em sua interface com a historiografia, encontra ressonância em importantes publicações (Bittencourt, 1990; Caimi, 2001; Fernandes, 2008; Ferreira, 2013; Fonseca, 2010; Gasparello, 2004; Nadai, 1993; Martins, 2000; Lima \& Fonseca, 2011; Reznik, 1992; Santos, 2011; Vale, 2011) ${ }^{16}$ e em eventos acadêmicos, como o Simpósio Nacional de História, organizado pela Associação Nacional de História (Anpuh-Brasil), o Encontro Nacional Perspectivas do Ensino de História (Perspectivas) e o Encontro Nacional Pesquisadores do Ensino de História (ENPEH). A partir da terceira edição do ENPEH, ocorrida em 1997, na Universidade Estadual de Campinas (Unicamp), a história do ensino de História se tornou uma das linhas (ou grupo de trabalho) do evento (Zamboni, 2005), tendo lugar de destaque nos encontros posteriores ${ }^{17}$. Esse é um campo de pesquisa consolidado no cenário acadêmico.

\footnotetext{
${ }^{16}$ Entre os autores e trabalhos fundadores podemos citar: Circe Bittencourt: "Pátria, civilização e trabalho: o ensino de História nas escolas paulistas. 1917-1939" e Selva Fonseca Guimarães: "Caminhos da história ensinada: São Paulo e Minas Gerais, anos 70 e 80", ambas as dissertações foram defendidas na Universidade de São Paulo (USP), em 1988 e 1991 respectivamente. Na mesma instituição, as autoras defenderam suas teses de doutorado: "Livro didático e conhecimento histórico: uma história do saber escolar", defendida por Bittencourt em 1993, e "Ser professor de história: vida de mestres brasileiros", escrita por Fonseca, defendida em 1996. No início dos anos de 1990, importantes trabalhos foram divulgados em periódicos: "O ensino de História no Brasil: trajetória e perspectiva" (Elza Nadai) e "O ensino de História como fator de coesão nacional: os programas de 1931" (Kátia Abud), publicados em 1993, na "Revista Brasileira de História". No Rio de Janeiro, duas pesquisas importantes são as dissertações de Luis Reznik: "Tecendo o amanhã: a História do Brasil no ensino secundário - programas e livros didáticos: 1931 a 1945", defendida na Universidade Federal Fluminense (UFF), em 1992, e a de Selma Rinaldi de Mattos: "Brasil em lições: a história do ensino de história do Brasil no Império através dos manuais de Joaquim Manuel de Macedo", defendida na Fundação Getúlio Vargas (FGV) em 1993.

${ }^{17}$ Uma análise dos anais desse encontro permitiu identificarmos cinco linhas de pesquisa e seus coordenadores: Currículos: perspectivas em debate (Circe Bittencourt), Livro Didático (Luiz Carlos Villalta), Linguagens e Ensino de História (Milton José Almeida), Linguagens e alternativas do ensino de História (Fernando Seffner) e História do ensino de História e História da América (Maria de Fátima Sabino Dias e Luis Fernando Cerri). O relatório elaborado pelos coordenadores da última linha não explicitam os motivos que levaram a união de "duas preocupações tão distintas". Com visível influência da história das disciplinas escolares alguns objetivos da linha foram delineados em dois blocos: "1) historicizar as ideias e práticas no ensino de História, os termos e sua memória nas considerações sobre o ensino da disciplina, relativizando o poder de solução irrefletida de alguns termos 'formar o cidadão', 'concepção renovada de História', 'ensino crítico', 'conscientização'; 2) colocar em perspectiva histórica a interação entre os vários momentos do ensino de História: a definição social de seus objetivos, a seleção de conteúdos e a aplicação de metodologias que efetivaram esses dois momentos anteriores, bem como os momentos em que a dinâmica social e as inovações na historiografia colocam sob
} 
Quatro textos nos ajudam a situar as pesquisas sobre o ensino de História a partir de perspectivas históricas. O livro "Conversas e controvérsias: o ensino de História no Brasil (1980-1998)", fruto da dissertação de mestrado de Flávia Eloisa Caimi (2001), é “um estudo de natureza historiográfica sobre o ensino de História" e traça um inventário das pesquisas desenvolvidas entre 1980 e 1998, apontando agentes de discussão, lugares de produção, influências, referenciais teóricos. A tarefa não foi fácil, por se tratar de "um período de intensa movimentação na historiografia e no ensino de História" (Diehl, 2001, p. 13). Efetivamente é o momento de constituição do campo e de significativa ampliação dos trabalhos. O levantamento reuniu 124 títulos - livros, artigos em coletâneas, em periódicos e os artigos publicados na "Revista Brasileira de História". A organização dos capítulos através dos temas discutidos pela historiografia do ensino contribui para pensarmos os caminhos percorridos pelos pesquisadores. A partir da sistematização, análise e crítica presentes no texto, é possível depreender a visão construída sobre os Estudos Sociais e seu lugar na produção acadêmica.

O segundo texto, o livro "História e ensino de História", de Thais Nivia de Lima e Fonseca (2011), é referência fundamental para os trabalhos da área. A obra, que teve ampla divulgação, traça uma história do ensino de História no Brasil, revelando suas relações com a historiografia, objetos, fontes, tendências de análise, lacunas e caminhos. A pesquisadora apresenta um estado da arte da pesquisa entre os anos de 1988 e 2002, analisando dissertações, teses, capítulos e livros. O terceiro texto relevante para a presente pesquisa é o artigo "A produção acadêmica sobre história do ensino de História no Brasil da última década", recentemente apresentado no Congresso Brasileiro de História da Educação (CBHE), por Rafaela Costa (2015), que avança no caminho aberto por Lima e Fonseca (2011) e realiza um balanço da produção, tendo como recorte o período de 2003 a 2014. Apesar das restrições de sua investigação - uma vez que aborda apenas as dissertações e teses defendidas em programas de pós-graduação em História e Educação, avaliados com notas 5, 6 e 7 pela Coordenação de Aperfeiçoamento de Pessoal de Nível Superior (Capes) -, trata-se de uma importante referência para reconhecermos as continuidades e rupturas na pesquisa em história do ensino de História na última década e em relação ao que caracteriza 
o estudo de Lima e Fonseca (2011). Em suas apreciações, as autoras destacam o predomínio dos trabalhos que se debruçam sobre o livro didático e os currículos e programas para o ensino de História como fontes e/ou objetos de pesquisa, embora tenha havido uma diversificação de temas e abordagens na última década.

Sobre isso, Lima e Fonseca (2011, p. 33) adverte que a maioria dos títulos, publicados entre 1988 e 2002, ao privilegiar os programas e livros didáticos, analisa-os unicamente "na perspectiva da utilização do ensino de História pelo Estado e pelas elites detentoras do poder e de como as formulações para essa disciplina estiveram associadas a ideologias ou a determinações dos programas políticos." Conquanto não cite os Estudos Sociais, isso nos ajuda a entender a preponderância das pesquisas até o início dos anos 2000, que tomam esta disciplina apenas como uma imposição e tentativa de legitimação da ditadura por meio da escolarização e formação de alunos "dóceis", acríticos e pouco reflexivos.

Ainda em relação ao estado da arte, o artigo de Circe Bittencourt (2011) "Abordagens históricas sobre a História escolar" - analisa a produção entre 1988 e 2009. É, até o momento, entre os levantamentos já realizados pelos historiadores e consultados durante nossa pesquisa, o balanço mais completo, pois abarca uma maior temporalidade e analisa um amplo leque de estudos. A autora, uma das pioneiras na investigação sobre o ensino de História no país, leu 110 trabalhos, entre teses, dissertações, livros, capítulos de livros e artigos e seu texto:

[...] oferece uma caracterização de um conjunto de pesquisas identificando os diferentes momentos da produção e os lugares privilegiados em que tais pesquisas têm sido realizadas. Os momentos significativos de produção são apresentados de forma a articular as problemáticas das pesquisas da história do ensino de História aos referenciais teóricos e metodológicos que as fundamentam, visando identificar as áreas de fronteiras em que elas se situam. (Bittencourt, 2011, p. 85).

Bittencourt (2011) divide a produção no campo em dois momentos. O primeiro, entre 1988 e 1996, é caracterizado por trabalhos, sobretudo na década de 1980, que expuseram a relevância e estudaram a história da disciplina como um dos subsídios para as reformas curriculares em curso em diferentes estados e municípios brasileiros. O segundo, a partir de 1997, é influenciado por novas abordagens e aproximações com a História Cultural e a história das disciplinas escolares. Houve um significativo crescimento da produção, a consolidação e o reconhecimento do campo. Se as primeiras teses e dissertações foram defendidas em programas de pós-graduação em História, as pesquisas desenvolvidas em 
programas de pós-graduação em Educação tornaram-se predominantes nos últimos anos.

Uma das questões, presentes nos trabalhos citados, têm sido a delimitação dos primeiros autores que refletiram academicamente sobre o ensino de História no Brasil. Os historiadores têm delimitado diferentes marcos para o início das pesquisas sobre essa disciplina escolar em nosso país. Entretanto, apesar das relações e/ou conflitos entre História e Estudos Sociais, durante boa parte do século XX, persistem lacunas quando o assunto são os Estudos Sociais, que pouco aparecem como temática de pesquisa nos estados da arte destacados. Dois exemplos são ilustrativos. Para Ernesta Zamboni (2001, p. 107):

[...] os primeiros trabalhos nacionais sobre o ensino de História foram de Jonathas Serrano na década de [19]30. Entre as décadas de [19]40 e [19]50 na Revista de História, publicada pelo Departamento de História da Universidade de São Paulo, foram publicados artigos das professoras Emília Viotti e Maria Amélia Domingues de Castro e dos professores Guy de Hollanda e Paulo França. O trabalho de Guy de Hollanda - "Um quarto de século de programas e compêndios de História para o ensino secundário (1931-1956)" é clássico e fundamental estudo dos programas e currículos de História.

Aryana Costa \& Margarida Dias de Oliveira (2007), por sua vez, indicam as reflexões de Emília Viotti da Costa como pioneiras nesse tema. Viotti da Costa, que foi professora da Universidade de São Paulo (USP), aposentada compulsoriamente no período da ditadura, escreveu quatro artigos sobre o ensino de História - o primeiro publicado em 1957 e o último em $1963^{18}$. Para as autoras, "esses refletiram do ponto de vista da História, pela primeira vez no Brasil, sobre o ensino dessa área de conhecimento" (Costa \& Oliveira, 2007, p. 159-160). Oliveira (2013, p. 232), em artigo posterior, esclarece melhor os seus critérios: "textos escritos por uma profissional de História (graduada em e professora de) e que tinham como fundamento a produção do conhecimento histórico." Há, ainda, uma terceira vertente que tem considerado como seminal o livro "O ensino da história: no primário e no ginásio", de Miriam Moreira Leite (1969), no qual a autora sistematiza aspectos de sua experiência nesses níveis de ensino e apresenta

\footnotetext{
${ }^{18}$ Os artigos são: "Os objetivos do ensino da História no curso secundário" (Revista de História da USP, 1957); "O material didático no ensino da História" (Revista de Pedagogia da USP, 1959); "Sugestões para a melhoria do ensino da História no curso secundário" (Revista de Pedagogia da USP, 1960); "O problema da motivação no ensino de História" (Revista de Pedagogia da USP, 1963). Os textos nos foram gentilmente cedidos pela historiadora do ensino Margarida Maria Dias de Oliveira. Abordaremos alguns desses artigos quando formos trabalhar com a concepção de ensino de História, defendida por Delgado de Carvalho na década de 1950.
} 
as condições da escola brasileira na década de $1960^{19}$. O problema com essas rígidas demarcações são os consequentes esquecimentos e omissões.

Um exemplo é o artigo "Os Estudos Sociais no curso secundário", de Delgado de Carvalho (1953), então professor catedrático de História Moderna e Contemporânea da Universidade do Brasil. É um texto importante e que propõe uma renovação do ensino de História, mas não encontra lugar nas periodizações elaboradas pelos pesquisadores quando o assunto é historiar o ensino de História no Brasil. Nas periodizações, os Estudos Sociais aparecem como um dos mecanismos de controle educacional utilizados pelos militares no poder, sendo tratados, sobretudo, como algo negativo, nocivo e, quase sempre, em oposição à disciplina escolar História. Isso explica o esquecimento da obra do autor, vinculado, entre outros aspectos, à política educacional pós-1964 e a escrita de manuais para a disciplina Organização Social e Política Brasileira (OSPB) (Costa, 2007). Ao escrever sobre a "questão dos Estudos Sociais", Margarida Dias de Oliveira (2013, p. 232) argumenta que:

Quando se consolidam periodizações, às vezes, infelizmente, também se constroem generalizações que podem paralisar novos olhares sobre temáticas, por exemplo, quando se refere aos Estudos Sociais, raramente, se analisam experiências diferenciadas - inclusive, positivas - para além do modelo da ditadura militar, vivenciadas no Brasil.

A sua marginalização no campo da história do ensino de História tem uma explicação. Para Bittencourt (2011, p. 85), as primeiras análises sobre a história dessa disciplina escolar surgiram nas décadas de 1950 e 1960, de alguma forma, articuladas aos debates em torno da defesa dos Estudos Sociais e substituição do ensino de História e Geografia nos currículos escolares. Em 1957, Guy de Hollanda classificava essa questão como "o problema da atualidade". O contexto era de experimentações no ensino de História e de debates acerca dos projetos

\footnotetext{
${ }^{19}$ Formada em Ciências Sociais pela USP, lecionou por um breve período na Faculdade de Ciências Econômicas da USP, como assistente da historiadora e catedrática Alice Canabrava, e em escolas paulistas (Cf. Fonseca, 2006). Em depoimento a Fonseca (2006, p. 140), Miriam Moreira Leite rememora o projeto do livro e seu resultado final: "foi uma sistematização do ensino de história baseada em minha experiência escolar, na experiência de meus filhos e nas revistas que eu consegui. A proposta inicial era tornar o ensino de História menos forçado e maçante. Ao escrever o livro, percebi que o ensino não poderia ser separado das suas condições de trabalho, das relações culturais dos professores e alunos, e das expectativas da população escolar [...] teve uma boa aceitação (duas impressões e adoção pelo MEC)." Para Leite (1969, p. 11), o seu livro não se pretende um manual didático, nem uma reformulação do ensino de História, mas "um levantamento provisório da situação escolar onde ocorre o estudo dessa matéria." A professora também é autora de uma "Introdução aos estudos sociais", editado no começo dos anos de 1970, em que apresenta "noções de estatística, de demografia e de antropologia no panorama histórico".
} 
sobre a Lei de Diretrizes e Bases da Educação Nacional (LDBEN). A retomada das pesquisas no campo ocorreu durante a década de 1980, momento de reformulação dos currículos escolares, abertura política, ampliação dos cursos de pós-graduação, luta contra os Estudos Sociais e as licenciaturas curtas e retorno da História enquanto disciplina autônoma. Diferentemente das abordagens de Zamboni (2001) e Costa \& Oliveira (2007), Bittencourt (2011) considera a obra de Delgado de Carvalho como uma das precursoras nas análises sobre a História escolar $^{20}$. Por essa perspectiva, fica evidente o papel dos Estudos Sociais como um dos elementos das discussões sobre o ensino de História.

As décadas de 1970 e 1980, apesar de estarem ainda sob a vigência da ditadura, caracterizaram-se por novas tentativas de experimentação no ensino de História, com a inserção de novas fontes, recursos didáticos e métodos. Não por acaso foram publicados muitos relatos de experiência e propostas de utilização de novos métodos e técnicas no ensino, que compuseram coletâneas e dossiês sobre o ensino de História em diferentes periódicos e editoras nas décadas de 1980 e 1990. Destacam-se: “A prática do ensino de História” (Zamboni, 1984); "Ensino de História: revisão urgente" (Cabrini et al., 1986); "O ensino de História e a criação do fato" (Pinsky, 1988); "Repensando o ensino de História" (Nikitiuk, 1996); "O saber histórico em sala de aula" (Bittencourt, 1997).

As reformas educacionais, impostas pelo Conselho Federal de Educação (CFE), começaram a ser revistas e ocorreu uma maior articulação dos professores de História. Nesse contexto, houve a criação de dois importantes eventos da área que se tornaram seminários nacionais e ocorrem bianualmente desde então: o Seminário Perspectivas do Ensino de História - cujo primeiro encontro ocorreu, sob inspiração da professora Elza Nadai, na USP, em 1988 - e o Encontro de Professores e Pesquisadores em Ensino de História, coordenado por Selva Fonseca, na Universidade Federal de Uberlândia (UFU), em 1993. Caimi (2001,

\footnotetext{
${ }^{20}$ Bittencourt (2011) registra alguns trabalhos produzidos, na década de 1950, antes do processo de expansão da pós-graduação no Brasil, que já tinham preocupação em analisar a historicidade do ensino de História no país. São indicativos desse quadro os seguintes estudos: "A História no curso secundário brasileiro", publicado em 1955 na Revista de Pedagogia, escrito por Amélia Domingues de Castro, então professora-assistente de Didática da USP; "Um quarto de século de programas e compêndios de História para o ensino secundário brasileiro (1931-1956)", livro escrito por Guy de Hollanda, professor da Faculdade Nacional de Filosofia e do Centro Brasileiro de Pesquisas Educacionais (CBPE), e publicado em 1957; e o livro de Carlos Delgado de Carvalho: "Introdução metodológica aos Estudos Sociais", de 1957, em que o autor buscava historiar o ensino de História e Geografia na pretensão de defender mudanças metodológicas no ensino de tais disciplinas e a sua proposta de ensino de Estudos Sociais.
} 
p. 43), pela diversidade de discussões, denomina esse período como a "Era do Repensando", "período de transição paradigmática" e de novas proposições para a educação, para a formação docente e o ensino da disciplina escolar.

A reconfiguração da Anpuh contribuiu para o surgimento de novas pesquisas e maior debate e divulgação de trabalhos sobre a formação de professores e práticas desenvolvidas pelos docentes de História em suas aulas ${ }^{21}$. Fundada em São Paulo, em outubro de 1961, essa associação tinha como objetivos iniciais: congregar professores universitários e promover o diálogo sobre temas de pesquisa, fontes e metodologias ${ }^{22}$. Durante os seus primeiros anos, assumiu um perfil exclusivamente voltado para o ensino superior, sem muita atenção ao ensino de História na escola básica. Martins (2000, p. 111) adverte que "como uma associação científica fundada por professores-pesquisadores, a entidade manteve seu caráter acadêmico, com atividades de divulgação de trabalhos de pesquisa histórica, discutindo, quando muito necessário o ensino superior e a formação dos professores de História.” A partir de 1977, em Florianópolis, durante a realização do IX Simpósio Nacional de História, ocorrido na Universidade Federal de Santa Catarina (UFSC), procederam-se acaloradas discussões sobre a inclusão de professores da escola básica e de alunos de pós-graduação como sócios com plenos direitos (Mesquita \& Zamboni, 2008) ${ }^{23}$. Em termos numéricos, estes

\footnotetext{
${ }^{21}$ A criação da Revista Brasileira de História, em 1981, é um instrumento nesse sentido. Dois dossiês sobre o ensino de História foram editados no início da década de 1990: "História em quadro negro" (set.1989/fev.1990) e "Memória, História e Historiografia" (set.1992/ago. 1993).

22 A Associação dos Professores Universitários de História (Apuh) foi fundada no contexto do Primeiro Simpósio de História do Ensino Superior, realizado na Faculdade de Filosofia, Ciências e Letras de Marília, entre 15 e 20 de outubro de 1961. Do professor José Roberto do Amaral Lapa partiu a ideia de uma Moção (16/10/1961) de apoio à criação de uma entidade que pudesse congregar os professores universitários de História. A primeira diretoria foi composta pelos professores Eremildo Viana (presidente), Cecília Maria Westphalen, Sérgio Buarque de Hollanda, Alice Piffer Canabrava, Antônio Camilo Faria Alvim, Armando Souto Maior, Jorge Calmon e José Roberto do Amaral Lapa. Ao completar uma década, em 1971, demarcando sua presença em quase todo o território brasileiro, acrescentou ao nome o termo "nacional" (Associação Nacional dos Professores Universitários de História - Anpuh) (Canabrava, 1981). Em 1993, passou a chamar-se Associação Nacional de História, mantendo o acrônimo Anpuh.

${ }^{23}$ A reforma do estatuto só ficou pronta em 1983 e não resultou de um processo tranquilo. Os testemunhos da professora Déa Fenelon, uma das autoras da proposta e presidente da Anpuh entre 1983 e 1985, indica que a inclusão dos novos sócios "provocou uma divisão na associação" (depoimento concedido a Fonseca, 2006, p. 83). Alguns sócios fundadores, como Cecília Maria Westphalen, consideraram que a associação perderia o seu caráter científico. De acordo com Fenelon, "o professor ainda estava numa fase que não produzia, que não era considerado um pesquisador" (depoimento concedido a Mesquita, 2008, p. 285). Segundo Martins (2000, p. 114), os "professores universitários contrários a essa incorporação de novos membros romperam com a associação, afastaram-se dela (não sem antes declarar seu repúdio ao 'desrespeito' que foi cometido aos estatutos de 1961) e criaram a Sociedade Brasileira de Pesquisa Histórica (SBPH)." Cf. Martins (2000) e Mesquita \& Zamboni (2008).
} 
últimos - que frequentavam os eventos tão somente como ouvintes, sem possibilidade de apresentar comunicações e participar dos debates das diferentes sessões do simpósio - já totalizavam uma quantidade superior ao número de professores universitários (Paula, 1979).

Não é um momento qualquer da História do Brasil. Desde 1964, o ensino de História nas escolas e universidades via-se ameaçado pela maior defesa dos Estudos Sociais e a criação das licenciaturas curtas. A universidade, a Anpuh e os professores universitários não ficaram imunes a esse processo. Em 1976, o Ministério da Educação e Cultura (MEC) publicou a portaria $n^{\circ} 790 / 76$, dispondo sobre o registro de professores e especialistas. O documento indicava a obrigatoriedade da formação em licenciatura em Estudos Sociais para o ensino dessa "área de estudo" no $1^{\circ}$ grau. Diante da oposição, o MEC acabou recuando. No ano seguinte, pela primeira vez, os Estudos Sociais apareceram como objeto de trabalhos apresentados por pesquisadores paulistas e foram pauta de uma mesa no Simpósio Nacional da Anpuh. De acordo com o então presidente da Associação, Eurípedes Simões de Paula $^{24}$ (1979, p. 33), as mesas propunham debates de temas atuais e "de grande interesse para os professores de História"25.

A importância da mesa "História e o problema dos Estudos Sociais" fica patente na escolha de seu coordenador, o próprio Simões de Paula. Em São Paulo, este professor:

[...] colocou-se à frente de uma verdadeira insurreição contra os Estudos Sociais e a licenciatura curta, reunindo em torno de si professores, estudantes e todos os que se recusaram a aceitar a deformação do ensino de História e Geografia nas escolas brasileiras. (Conti, 1983, p. 398).

Parte desse grupo se reuniu na composição da mesa. Os debatedores foram três docentes da Faculdade de Filosofia, Ciências e Letras da USP, José Bueno Conti (geógrafo), Ulysses Telles Guariba Netto (filósofo), Douglas Teixeira

\footnotetext{
${ }^{24}$ Eurípedes Simões de Paula (1910-1977) foi professor catedrático de História Antiga e Medieval da Faculdade de Filosofia, Ciências e Letras (FFCL) da USP, vice-diretor e diretor da unidade e diretor do Departamento de História em diferentes ocasiões. Um dos fundadores da APUH, sendo seu presidente por sete mandatos consecutivos (1965-1977). Teve uma atuação considerável na luta por concursos para a área de História das escolas paulistas (Glezer, 1983).

${ }^{25}$ As outras mesas foram: "A História no currículo dos cursos de graduação das Faculdades de Filosofia", "Os cursos de pós-graduação em História" e "As novas técnicas do ensino da História em nível superior" (Paula, 1979, p. 34-35). Apesar da fala do presidente, a circular de convocação para o evento, publicada na Revista de História da USP, deixa claro o caráter da instituição até aquele momento: "A apresentação dos trabalhos e participação nos debates das Mesas-Redondas são reservadas aos professores de História em nível superior." (Revista de História, Noticiário, 1977). A apresentação e proposição de temas eram restritas a esse segmento do magistério.
} 
Monteiro (sociólogo) e um professor da Universidade Federal Fluminense (UFF), Francisco José Calazans Falcon (Paula, 1979). Os anais do evento não informam o teor dos debates que se processaram nessa ocasião e nem houve a publicação de eventuais textos do coordenador e debatedores. Entretanto, outros fragmentos, presentes nos anais, apresentam alguns indícios do que foi abordado na sessão. É interessante observar os termos descritos na Moção n ${ }^{\text {o }}$ 7, de 20 de julho de 1977, proposta por Ana M. de A. Camargo, professora da USP, e assinada por mais 19 professores, entre eles José Bueno Conti, debatedor na mesa sobre os Estudos Sociais. Tal documento representa uma mudança de postura no interior da Anpuh.

Tendo em vista as discussões dos debates neste Simpósio sobre a questão dos Estudos Sociais que demonstraram:

1. que seu caráter é essencialmente o de formação ideológica despido de toda e qualquer preocupação científica.

2. que sua implantação atendeu às necessidades imediatas de uma política educacional voltada essencialmente para a expansão meramente quantitativa sem a participação dos professores, estudantes e entidades profissionais e acadêmicas;

3. que o fracasso de sua implantação já é patente conforme atestam as experiências de professores e estudantes da área. (Moção ${ }^{\circ} 7$ apud Canabrava, 1979, p. 121).

A partir desses três pontos, os professores universitários, manifestaram "o mais veemente repúdio à implantação dos Estudos Sociais [...] e especialmente à forma como as mesmas vêm sendo encaminhadas sem consulta aos órgãos de representação coletiva." (Moção no 7 apud Canabrava, 1979, p. 121). Denunciaram, "através da Anpuh", a ausência de diálogo e o autoritarismo das reformas educacionais e se posicionaram "vigorosamente contra a implantação dos Estudos Sociais no ensino brasileiro" (Conti, 1979, p. 884). Há uma confluência de nomes que assinaram tanto a Moção $n^{\circ} 7$ quanto a Proposta $n^{\circ} 4$, de autoria do historiador Fernando Antonio Novais, responsável pela solicitação de inclusão de novos sócios ${ }^{26}$. Um grupo de professores preocupado com a escola básica e que reunia autores de textos sobre o ensino de História e Estudos Sociais, como Déa Fenelon (1984), Raquel Glezer (1982) e José Bueno Conti (1979).

O empenho pela manutenção da disciplina escolar História “insere-se na luta dos historiadores para legitimarem-se como categoria profissional" (Martins,

\footnotetext{
${ }^{26}$ São eles: Ana Maria de Almeida Camargo, Raquel Glezer, Iraci Galvão Salles, Dea Ribeiro Fenelon, Fernando A. Novais, Maria Stella Martins Bresciani, Maria Clementina Pereira Cunha, Edgar Salvador de Decca, Jose Jobson de A. Arruda, Valmir Martins, José Bueno Conti, Victor V. Valla, Maria Lúcia de S. Rangel Ricci, Maria Luiza Tucci Carneiro, José Ribeiro Júnior. A proposta sugeriu a inclusão de professores e estudantes de pós-graduação em todas as reuniões, "salvo o direito de voto na Assembleia Geral" (Proposta no 4 apud Canabrava, 1979, p. 105).
} 
2000, p. 11) e reflete os embates travados com o Conselho Federal de Educação, responsável pela elaboração dos currículos escolares. A partir de meados da década de 1970, a associação assumiu um maior protagonismo na luta contra a política educacional do regime militar e no início da década de 1980 seus objetivos passaram a congregar o aperfeiçoamento do ensino de História em todos os níveis de ensino (Martins, 2000). As historiadoras Ilka Miglio de Mesquita e Ernesta Zamboni (2008, p. 133) defendem que naqueles anos, constituiu-se "a luta pela formação de professores e outro ensino de História". Paralelamente, estabeleceram-se as bases acadêmicas para a literatura sobre os Estudos Sociais.

Nesse contexto, e à medida que o governo ditatorial demonstrava sua capacidade de censurar e interferir nas instituições de ensino e pesquisa, professores e pesquisadores da História começaram a reivindicar que a Anpuh passasse a assumir um caráter político acentuado, visando proteger intelectuais e também manifestarse de forma ostensiva à extinção da autonomia da disciplina História no ensino de $1^{\circ}$ graus e inclusão dos conteúdos históricos como simples matéria dos chamados "Estudos Sociais". (Martins, 2000, p. 113).

A reação e luta contra os Estudos Sociais são, portanto, de fundamental importância para se compreender o processo que levou à reconfiguração da Anpuh. Criada como uma associação apolítica (Martins, 2000), sobretudo a partir da década de 1980, com o ingresso de novos sócios teve de lançar seu olhar, mais particularmente, para o ensino desta disciplina escolar, constantemente ameaçado pelos pressupostos estabelecidos pelas reformas educacionais implementadas pelo CFE. No processo de maior engajamento político da Anpuh e de seus associados, construiu-se um discurso de denúncia sobre os Estudos Sociais e a licenciatura curta que influencia - apesar da possibilidade de utilização de novas fontes e metodologias - a produção sobre o tema.

\title{
2.2
}

\section{Estudos Sociais e ensino de História: articulações e especificidades}

\begin{abstract}
A história dos Estudos Sociais na escola de primeiro grau remonta praticamente às origens da organização do sistema público de ensino, se concordarmos com os estudiosos que têm na Revolução de [19]30 o "grande ponto de corte" do processo de definição do sistema escolar brasileiro. (Nadai, 1988, p. 1).
\end{abstract}

Refletir sobre o ensino de História, até finais da década de 1980, passava, necessariamente, pelo combate aos Estudos Sociais. Caimi (2001, p. 70) analisa 
esse processo. Duas das suas considerações nos interessam mais especificamente. Quanto à natureza dos debates assumidos pelos trabalhos publicados entre $1980 \mathrm{e}$ 1998, a autora os divide em 11 enfoques temáticos, entre os quais “A questão dos Estudos Sociais" ${ }^{, 27}$. Dos 124 títulos identificados, só três trataram diretamente desse tema como objeto principal: "Estudos Sociais: um problema contínuo" (Glezer, 1982), “A questão de Estudos Sociais" (Fenelon, 1984) e "Estudos Sociais no primeiro grau" (Nadai, 1988). Apenas o artigo de Nadai (1988) abordou historicamente a questão, isto é, analisando os Estudos Sociais em sua historicidade e além da experiência vigente durante a ditadura. Entretanto, a problemática "perpassou dezenas de obras, despertando a indignação de inúmeros autores ao longo das últimas duas décadas" (Caimi, 2001, p. 86). Assim, tendo como suporte os debates que se processavam na Anpuh desde 1977, os Estudos Sociais foram associados à política educacional pós-1964 e ao autoritarismo com que foi planejada e executada. Diferentes críticas foram feitas, mas:

[...] nenhuma medida implementada por qualquer política educacional tiraria dos "Estudos Sociais" o papel do grande vilão do ensino de História, como um dos principais responsáveis pela crise [do ensino, da educação...]. Apontada como o maior fator de atraso para o ensino de História, a implantação dos Estudos Sociais na escola fundamental foi alvo de críticas contundentes nas publicações que analisamos. (Caimi, 2001, p. 103).

A interpretação mais usual sinaliza que:

O controle sobre a disciplina histórica relacionou-se, sobretudo, à ideologia implantada com o golpe de 1964, quando o ensino foi colocado a serviço do regime ditatorial que propugnava a formação de cidadãos dóceis, obedientes e ordeiros. De um lado, ter-se-ia dado o "esvaziamento do seu caráter crítico e contestador" e, de outro, manifestado seu caráter de "instrumento de veiculação e formação do espírito cívico, entendido como aquele capaz de glorificar os feitos dos autoproclamados heróis do dia". (Nadai, 1993, p. 158).

Como consequência direta, a autora argumenta: "negou-se a História o estatuto de disciplina autônoma, chegando a desaparecer do currículo da escola fundamental, com a introdução dos Estudos Sociais." (Nadai, 1993, p. 157). Hoje, sabemos que essa afirmação precisa ser relativizada, haja vista a flexibilização da

\footnotetext{
${ }^{27}$ São os enfoques temáticos, de acordo com Caimi (2001, p. 70-71): "Relato de experiências de ensino e de pesquisa"; "Questões epistemológicas e metodológicas sobre o ensino de História"; "Livros didáticos e paradidáticos"; "Questões político-ideológicas do ensino de História"; "Ensino de História nas séries iniciais"; "Formação do professor de História"; "Políticas educacionais oficiais e currículo de História"; "História do ensino de História"; "Linguagens alternativas de ensino"; "Articulação ensino/pesquisa academia/escola"; "A questão dos Estudos Sociais". É importante salientar que a pesquisadora procurou classificar cada trabalho em apenas um enfoque.
} 
legislação, a cultura escolar, o currículo em ação e as formas de resistência dos professores (Caimi, 2001). Os Estudos Sociais são entendidos, unicamente, como "esvaziamento" de conhecimentos críticos, "esvaziamento" do ensino de História. Isto é, considera-se apenas uma de suas versões na realidade brasileira.

A literatura sobre os Estudos Sociais constituiu-se em contexto de embates a partir de enfoques, como: desqualificação e descaracterização das Ciências Humanas (Geografia e História) na escola de $1^{\circ}$ e $2^{\circ}$ graus e no ensino superior (instituição das licenciaturas curtas); eliminação da criatividade; formação de alunos acríticos e dóceis (Nadai, 1993); instrumento de controle da ditadura; forte associação entre Estudos Sociais e licenciatura curta, com a formação de professores despreparados (Caimi, 2001; Fenelon, 1984; Glezer, 1981).

Ao leitor desatento ficaria a impressão de que antes de 1964 o ensino de História e a formação do seu professor eram perfeitos. Pelo contrário, os cursos superiores de História ainda não existiam em muitas partes do país e a memorização e o ensino de uma História política ainda prevaleciam. Para Caimi (2001), é necessário combater os maniqueísmos. As políticas educacionais pós1964 aprofundaram algumas questões, embora muitos dos problemas do ensino sejam anteriores à década de 1960. Segundo Lima e Fonseca (2011, p. 55-56):

[...] no que diz respeito às concepções de História inerentes a esse ensino, não houve grandes transformações, tendo permanecido a herança tradicional de longa data, a orientá-lo. Isso significa que as diretrizes norteadoras dessa concepção de História permaneceram na formação de milhares de jovens, enfatizando-se os fatos políticos e as biografias dos "brasileiros célebres", entre os quais figuravam agora os principais personagens do novo regime.

$\mathrm{O}$ que ocorreu foi um aprofundamento dessas perspectivas e o maior cerceamento das liberdades individuais e coletivas. Além disso, os professores não foram convidados a pensar as políticas públicas educacionais. Concordamos, assim, com Caimi (2001, p. 105), quando argumenta que "negar os efeitos negativos da legislação implementada pelo Regime Militar seria ato de extrema ingenuidade", porém atribuir-lhe toda a responsabilidade não é a atitude mais correta. É necessário refletir sobre algumas afirmações e a "absolutização" de ideias. Esse é o desafio a que nos propomos nesta tese.

As análises de Caimi (2001) e o levantamento bibliográfico por nós realizado permitem a identificação de duas perspectivas que não são excludentes e coexistem, acerca dos Estudos Sociais. A primeira se caracteriza pela crítica e 
denúncia e tem sido predominante nos estudos que buscam historicizar o ensino de História. A segunda vertente, inspirada no artigo de Nadai (1988), sobretudo a partir dos anos 2000, propõe compreender diferentes experiências de ensino e divulgação dos Estudos Sociais no Brasil. Para melhor visualização da literatura sobre o tema, organizamos o quadro a seguir. Os títulos que o compõem foram selecionados a partir do levantamento bibliográfico, após consulta aos bancos de teses e dissertações da Capes, UFF, Uerj, UFRJ, UFMG, USP e Unicamp. Alguns autores publicaram artigos, em periódicos ou anais de eventos, e capítulos de livros, extraídos de trabalhos defendidos em programas de pós-graduação (teses e dissertações). Nesse caso, por serem produções de maior fôlego, incluímos apenas as teses, dissertações ou livros. As referências completas encontram-se ao final da tese. 


\begin{tabular}{|c|c|c|}
\hline Autores/Títulos & Ano & Suporte \\
\hline $\begin{array}{l}\text { PASSOS, J. A História e a Reforma do Ensino Médio no Estado de São } \\
\text { Paulo. }\end{array}$ & 1971 & $\begin{array}{l}\text { Artigo em anais de } \\
\text { evento }\end{array}$ \\
\hline BALZAN, N. Estudos Sociais: opiniões e atitudes de ex-alunos. & 1977 & $\begin{array}{l}\text { Artigo em periódico, } \\
\text { oriundo de tese }\end{array}$ \\
\hline $\begin{array}{l}\text { CONTI, J. B. A Reforma Educacional de } 1971 \text { e a situação da História } \\
\text { no ensino de } 1^{\circ} \text { e } 2^{\circ} \text { graus no Estado de São Paulo. }\end{array}$ & 1979 & $\begin{array}{l}\text { Artigo em anais de } \\
\text { evento }\end{array}$ \\
\hline $\begin{array}{l}\text { GLEZER, R. História e Estudos Sociais: um estudo comparativo dos } \\
\text { guias metodológicos do MEC. }\end{array}$ & 1979 & $\begin{array}{l}\text { Artigo em anais de } \\
\text { evento }\end{array}$ \\
\hline $\begin{array}{l}\text { NUNES, A. A. O ensino de História em Faculdades de Estudos } \\
\text { Sociais. }\end{array}$ & 1979 & $\begin{array}{l}\text { Artigo em anais de } \\
\text { evento }\end{array}$ \\
\hline $\begin{array}{l}\text { HOFLING, E. A concepção de cidadania veiculada em livros didáticos } \\
\text { de Estudos Sociais do primeiro grau. }\end{array}$ & 1981 & Dissertação \\
\hline GLEZER, R. Estudos Sociais: um problema contínuo. & 1982 & Artigo em periódico \\
\hline FENELON, D. A questão de Estudos Sociais. & 1984 & Artigo-em periódico \\
\hline $\begin{array}{l}\text { LEME, D. M. P. C.; HOFLING, E. M.; ZAMBONI, E.; BALZAN, N. } \\
\text { C. O ensino de Estudos Sociais no primeiro grau. }\end{array}$ & 1986 & Livro \\
\hline CUSINATO, R. A formação do professor da área de Estudos Sociais. & 1987 & Tese \\
\hline NADAI, E. Estudos Sociais no $1^{\circ}$ grau. & 1988 & Artigo em periódico \\
\hline $\begin{array}{l}\text { OLIVEIRA, M. A. A. Educação e cidadania: uma contribuição ao } \\
\text { ensino de Estudos Sociais. }\end{array}$ & 1993 & Dissertação \\
\hline FONSECA, S. Caminhos da História Ensinada. & $\begin{array}{c}1993 \\
{[2010]}\end{array}$ & $\begin{array}{l}\text { Dissertação publicada } \\
\text { em livro }\end{array}$ \\
\hline $\begin{array}{l}\text { MARTINS, M. C. A. História prescrita e disciplinada nos currículos } \\
\text { escolares? Quem legitima estes saberes. }\end{array}$ & $\begin{array}{c}2000 \\
{[2002]}\end{array}$ & $\begin{array}{l}\text { Tese publicada em } \\
\text { livro }\end{array}$ \\
\hline $\begin{array}{l}\text { BITTENCOURT, C. Propostas curriculares de História: continuidades } \\
\text { e transformações. }\end{array}$ & 2000 & Capítulo de livro \\
\hline $\begin{array}{l}\text { VIANA, I. "Artes de fazer" na reforma escolar: o projeto de Estudos } \\
\text { Sociais a partir da longa duração em Curitiba (décadas de 1970-1980). }\end{array}$ & 2006 & Tese \\
\hline $\begin{array}{l}\text { CHIOZZINI, D. Os Ginásios Vocacionais: a construção da história de } \\
\text { uma experiência educacional transformadora e o ensino de Estudos } \\
\text { Sociais. }\end{array}$ & 2008 & $\begin{array}{l}\text { Artigo em anais de } \\
\text { evento }\end{array}$ \\
\hline $\begin{array}{l}\text { FERNANDES, A. T. Estudos Sociais no contexto da história brasileira } \\
\text { nas primeiras décadas do século XX. }\end{array}$ & 2008 & $\begin{array}{l}\text { Artigo-em anais de } \\
\text { evento }\end{array}$ \\
\hline $\begin{array}{l}\text { LOURENÇO, E. O ensino de Estudos Sociais/História em São Paulo - } \\
\text { década de } 1970 .\end{array}$ & 2009 & $\begin{array}{l}\text { Artigo em anais de } \\
\text { evento }\end{array}$ \\
\hline $\begin{array}{l}\text { SANTOS, B. B. M. O currículo da disciplina escolar História no } \\
\text { Colégio Pedro II: a década de } 1970 \text { - entre a tradição acadêmica e a } \\
\text { tradição pedagógica: a História e os Estudos Sociais. }\end{array}$ & $\begin{array}{c}2009 \\
{[2011]}\end{array}$ & $\begin{array}{l}\text { Tese publicada em } \\
\text { livro }\end{array}$ \\
\hline $\begin{array}{l}\text { FREITAS, I. História para crianças nos currículos de Estudos Sociais } \\
\text { nos Estados Unidos da América }(2002 / 2010) \text {. }\end{array}$ & 2011 & $\begin{array}{l}\text { Artigo em meio } \\
\text { eletrônico }\end{array}$ \\
\hline $\begin{array}{l}\text { NASCIMENTO, T. R. Licenciatura curta em Estudos Sociais no } \\
\text { Brasil: sua trajetória na Faculdade de Formação de Professores de São } \\
\text { Gonçalo/RJ (1973-1987). }\end{array}$ & 2012 & Dissertação \\
\hline $\begin{array}{l}\text { FRANÇA, A. S. Propostas curriculares para o ensino de Estudos } \\
\text { Sociais: circulação e apropriações de representações de ensino de } \\
\text { História e de aperfeiçoamento de professores (Espírito Santo, 1956- } \\
\text { 1976). }\end{array}$ & 2013 & Tese \\
\hline PRADO, E. M. A disciplina História nos anos da ditadura militar. & 2014 & $\begin{array}{l}\text { Tese publicada em } \\
\text { livro }\end{array}$ \\
\hline $\begin{array}{l}\text { AZEVEDO, M. O lugar da História nos manuais brasileiros destinados } \\
\text { à formação de professores de Estudos Sociais. }\end{array}$ & 2014 & Dissertação \\
\hline $\begin{array}{l}\text { SCHMIDT, M. A.; ABUD, K. (Org.). } 50 \text { anos de ditadura militar: } \\
\text { capítulos sobre o ensino de História no Brasil. }\end{array}$ & 2014 & Livro \\
\hline $\begin{array}{l}\text { SANTOS, B. B.M; NASCIMENTO, T. R. O ensino de Estudos Sociais } \\
\text { no Brasil: da intenção à obrigatoriedade (1930-1970). }\end{array}$ & 2015 & Artigo em periódico \\
\hline $\begin{array}{l}\text { GASPARELLO, A. Delgado de Carvalho: projeto de intervenção } \\
\text { social na construção de uma disciplina escolar. }\end{array}$ & 2016 & Capítulo de livro \\
\hline
\end{tabular}

Quadro 2 - Produção acadêmica sobre os Estudos Sociais (1971-2016)

Fonte: Elaborado pelo autor. 
O levantamento realizado no banco de teses e dissertações da Coordenação de Aperfeiçoamento de Pessoal de Nível Superior (Capes) mostrou-se pouco produtivo, uma vez que os descritores "estudos" e "sociais" aparecem em muitas pesquisas sem, necessariamente, tratarem dos Estudos Sociais enquanto disciplina. O passo seguinte foi consultar os anais eletrônicos dos principais eventos da área de História e ensino ${ }^{28}$. A partir dos artigos, neles publicados, chegamos a teses, dissertações e livros. Fizemos a distinção entre textos acadêmicos, oriundos de pesquisas e manuais de formação de professores/textos metodológicos sobre os Estudos Sociais. Estes foram publicados nas décadas de 1960, 1970 e 1980, principalmente após a promulgação da lei $n^{0}$ 5.692/71. Os livros não têm uma preocupação em analisar as diferentes concepções de Estudos Sociais na escola brasileira. "O ensino de Estudos Sociais no primeiro grau” é um manual de formação. Entretanto, organizado por professores da Unicamp, com trajetória de pesquisa sobre os Estudos Sociais, como Newton Balzan e Eloisa Höfling, apresenta uma discussão inicial sobre as origens da disciplina com base em fontes primárias. Ao todo, foram selecionados 28 trabalhos $^{29}$.

No que concerne ao recorte temporal, a maioria se situa nos anos da ditadura militar, embora outras experiências e temporalidades tenham sido investigadas, como: os Ginásios Vocacionais na década de 1960, propostas curriculares estaduais (Espírito Santo, 1956-1976) e municipais (Rio de Janeiro, 1988), manuais de formação de professores, social studies na educação norteamericana e Estudos Sociais na escola brasileira (Quadro 3) ${ }^{30}$. Destacamos, pelo seu pioneirismo e/ou atualidade, alguns títulos principais para breves análises.

\footnotetext{
${ }^{28}$ Os anais dos Simpósios Nacionais de História foram digitalizados em função do cinquentenário da Anpuh, em 2011. Disponível em: <http://anais.anpuh.org/>. Acesso em: 27 jan. 2016. Os anais do Enpeh e do Perspectivas, desde os primeiros encontros, foram digitalizados a partir do esforço de docentes da Faculdade de Educação da Universidade Estadual de Campinas (Unicamp). Disponível em: <https://www.fe.unicamp.br/revistas/ged/FEH/index>. Acesso em: 27 jan. 2016.

${ }^{29}$ Uma ressalva precisa ser feita em relação ao artigo selecionado da professora Arlette Gasparello. O seu texto, originalmente, foi apresentado no XXVII Simpósio Nacional de História, em 2013, sendo publicado nos anais do evento com o mesmo título. Outro trabalho, desta autora, é "Delgado de Carvalho: livros didáticos e práticas instituintes no ensino de História e Ciências Sociais". Neste último, discute as aproximações da proposta de Delgado de Carvalho com a perspectiva dos historiadores franceses Charles Seignobos (1854-1942) e Charles Victor-Langlois (1863-1929), "divulgada principalmente na obra Introdução aos Estudos Históricos de 1898" (Gasparello, 2014, p. 381-382). Por suas semelhanças de conteúdo e metodologia, optamos por elencar no quadro a obra mais recente, publicada postumamente.

${ }^{30}$ No Quadro 3 não incluímos o livro "50 anos de ditadura militar no Brasil: capítulos sobre o ensino de História" porque, embora tenha como tema principal o ensino de História durante o regime militar, dois dos seus capítulos analisam as propostas de Estudos Sociais anteriores a 1964.
} 


\begin{tabular}{|l|c|c|c|c|c|c|}
\hline \multicolumn{1}{|c|}{ Temas } & \multicolumn{3}{c|}{ Décadas } & \multirow{2}{*}{ Total } \\
\cline { 2 - 6 } & $\mathbf{1 9 7 0}$ & $\mathbf{1 9 8 0}$ & $\mathbf{1 9 9 0}$ & $\mathbf{2 0 0 0}$ & $\mathbf{2 0 1 0}$ & 1 \\
\hline $\begin{array}{l}\text { Delgado de Carvalho e a proposta de } \\
\text { Estudos Sociais }\end{array}$ & & & 1 & 1 & 2 \\
\hline $\begin{array}{l}\text { Ginásios vocacionais na década de 1960 } \\
\text { Ensino de História e Estudos Sociais na } \\
\text { ditadura militar }\end{array}$ & 3 & 2 & 1 & 4 & 1 & 11 \\
\hline $\begin{array}{l}\text { Formação de professores da área de Estudos } \\
\text { Sociais durante a ditadura militar }\end{array}$ & 1 & 1 & & & 1 & 3 \\
\hline $\begin{array}{l}\text { Relatos de experiência sobre o ensino de } \\
\text { Estudos Sociais durante a ditadura militar }\end{array}$ & & 1 & & & & 1 \\
\hline $\begin{array}{l}\text { Estudos Sociais na escola brasileira } \\
\text { (historicidade) }\end{array}$ & & 1 & & & 1 & 2 \\
\hline $\begin{array}{l}\text { Manuais de formação de professores e livros } \\
\text { didáticos }\end{array}$ & & 1 & & & 1 & 2 \\
\hline $\begin{array}{l}\text { Propostas curriculares estaduais e } \\
\text { municipais }\end{array}$ & & & 1 & 1 & 1 & 3 \\
\hline $\begin{array}{l}\text { História e Estudos Sociais nos currículos } \\
\text { americanos do século XXI }\end{array}$ & & & & 1 & 1 \\
\hline
\end{tabular}

Quadro 3 - Principais temáticas presentes na produção sobre os Estudos Sociais Fonte: Elaborado pelo autor.

Ao contrário do que indica Caimi (2001), constatamos que os primeiros trabalhos sobre ensino de História e Estudos Sociais foram apresentados por professores universitários paulistas nos Simpósios Nacionais da Anpuh, com destaque para o emblemático evento de 1977. Os objetos foram: a formação de professores numa licenciatura curta em Estudos Sociais e o papel das disciplinas históricas no currículo do curso (Nunes, 1979); a lei no 5.692, de 1971, e o seu impacto sobre o ensino de História, ministrado nas escolas do Estado de São Paulo (Conti, 1979); e os guias metodológicos de Estudos Sociais e História patrocinados pelo MEC e distribuídos para as escolas brasileiras entre 1969 e 1971 (Glezer, 1979). Em comum, analisam os efeitos das reformas educacionais sobre o ensino, a formação docente e o currículo escolar. Nesse contexto, a preocupação recaiu sobre o lugar da História nas novas configurações da educação brasileira (Conti, 1979; Glezer, 1979; Nunes, 1979; Passos, 1971) ou os efeitos (considerados como nefastos) dos Estudos Sociais sobre a disciplina (Fenelon, 1984; Glezer, 1982) ${ }^{31}$. Apesar do predomínio desses pontos, outras abordagens foram realizadas entre as décadas de 1970 e de 1980.

\footnotetext{
31 Alguns desses aspectos foram retomados na recente obra organizada por Schmidt e Abud (2014), por ocasião dos 50 anos do golpe militar de 1964. O livro foi dividido em duas partes: "No primeiro momento, historiadores que vivenciaram o período da Ditadura Militar, como profissionais ou como alunos, apresentaram suas reflexões sobre o ensino de História nessa época, a partir de ensaios ou de análises de resultados de pesquisas. O segundo momento do livro foi proposto com o objetivo de contribuir para que alguns trabalhos, produzidos e publicados ainda
} 
Uma delas foi desenvolvida por Newton Balzan (1977) que atuou, entre 1962 e 1966, como professor de um Ginásio Vocacional paulista, situado na cidade de Americana, sendo o coordenador da área de Estudos Sociais. $\mathrm{Na}$ ocasião, ele acompanhou duas turmas e sete anos após o fim de sua atuação nessa instituição, em 1973, em pesquisa de doutorado, analisou as opiniões e atitudes dos 117 ex-alunos sobre os Estudos Sociais presentes em sua formação. Um trabalho importante para a compreensão dessa "área" nos anos que antecederam a lei $\mathrm{n}^{\circ}$ 5.692/71, que a institucionalizou. Balzan (1977) destaca seu caráter de inovação educacional durante a década de 1960 e a preocupação em desenvolver o ensino atento à integração entre as diferentes áreas do conhecimento, tendo os Estudos Sociais como "núcleo", bem como o entendimento do aluno como centro da aprendizagem. Através das entrevistas com 116 ex-alunos localizados, destaca que eles "revelaram-se altamente favoráveis ao trabalho realizado". Experiência importante, mas que acabou sendo suplantada pós-1964.

$\mathrm{Na}$ década de 1980, dois trabalhos pensaram uma história dos Estudos Sociais. O primeiro deles é a dissertação escrita por Eloisa Höfling, defendida na Unicamp com orientação de Newton Balzan. O seu objetivo foi analisar a concepção de cidadania presente nos livros didáticos dedicados aos Estudos Sociais. A "preparação para o exercício da cidadania" é um dos elementos presentes na lei $n^{\circ} 5.692 / 71$. Para a autora, apesar da procedência das críticas acerca dessa área do conhecimento, a partir de 1971, nenhuma pesquisa, até então, tinha se "aplicado ao estudo dos mecanismos concretos que possibilitam, que configuram, que expressam" (Höfling, 1981, p. 1) a escola como reprodução da ideologia dominante e os Estudos Sociais como uma imposição ideológica.

O livro didático foi a fonte privilegiada pela sua inserção no cotidiano escolar. Ao pretender "conhecer melhor os reais objetivos da presença de Estudos Sociais nos currículos das escolas brasileiras”, Höfling (1981, p. 3) se voltou para sua historicidade. A ênfase recaiu sobre as definições de cidadania presentes em algumas concepções de Estudos Sociais. Essa dissertação representa uma

durante o período da Ditadura Militar, fossem republicados e tornados acessíveis a um público maior. Essa parte do livro foi denominada de Anexos." (p. 9). Nos anexos constam textos importantes, como o de Nadai (1988) e o de Glezer (1982). Predomina, entre os capítulos, a abordagem de que o ensino de História esteve "vinculado aos interesses políticos de controle" (p. 9) e os Estudos Sociais como uma "desqualificação". Contudo, Neves (2014) e Schmidt (2014) analisam a configuração dos Estudos Sociais como uma prática inovadora antes de 1964. Agrademos à historiadora Ana Paula Squinelo pela compra e envio do livro, de circulação restrita. 
abordagem que reconhece que os Estudos Sociais antecedem a ditadura, porém apresenta um viés economicista e pautado na teoria marxista de lutas de classes:

[...] a política educacional é um meio de ação do Estado para defender os interesses da classe dominante. O sistema educacional estará a serviço dos interesses econômicos funcionando como uma das agências de controle da situação global, ou seja, como agência reprodutora de mão de obra qualificada visando o fortalecimento do modelo econômico. (Höfling, 1981, p. 16).

Por esse ponto de vista, a educação se adapta aos interesses econômicos e das classes dominantes. No caso brasileiro, a necessidade de mão de obra especializada levou à reforma de ensino de $1^{\circ}$ e $2^{\circ}$ graus e à inserção da ideia de profissionalização obrigatória nesses níveis de ensino. A "qualificação para o trabalho" induziu a uma atenção maior à parte de "formação especial" em detrimento da "formação geral" do aluno, aí contida as disciplinas de História e Geografia. A perda de espaço, no currículo escolar, das disciplinas consideradas como não técnicas se associa à introdução das áreas de conhecimento (Estudos Sociais, Comunicação e Expressão e Ciências). Ao priorizar esse aspecto do problema, a pesquisadora não avança em relação à concepção pedagógica por traz dos Estudos Sociais, nem nas linhas de continuidade entre o antes e a lei $n^{\circ}$ 5.692/71. A relação entre cidadania e Estudos Sociais também foi o tema da dissertação de Maria Antonieta A. de Oliveira (1993). Entretanto, a autora prioriza os documentos oficiais (Constituições federais e propostas curriculares), analisando a forma como a noção de cidadania se constituiu no Brasil ao longo do século XX e o papel dos Estudos Sociais na sua formulação.

Elza Nadai (1988, p. 1) segue um caminho diferente ao pretender "explicitar a natureza, as preocupações, os objetivos e os temas fundamentais que caracterizaram os debates, acerca dos Estudos Sociais" nos diferentes momentos em que estes foram pensados ou incluídos nos currículos escolares brasileiros. A historiadora defendeu que reduzir os Estudos Sociais a uma só modalidade ou articulá-los fundamentalmente à política educacional pós-1964 "não garante a totalidade necessária na qual a temática em questão deve ser abordada e explicitada". Propôs uma perspectiva abrangente e que busca captar a historicidade dos Estudos Sociais na escola básica, destacando quatro períodos:

[...] no início da década de 30, quando no contexto da divulgação/absorção do ideário da escola pragmática norte-americana no Brasil, são realizadas as primeiras discussões a respeito do assunto; nas décadas de 50/60, quando a partir de uma possibilidade criada pela Lei de Diretrizes e Bases, Lei $\mathrm{n}^{\circ}$ 4.024, de 20.12.1961, 
são instituídas as primeiras inovações na escola oficial; na década de 70, quando, no contexto das políticas que se seguiram ao golpe militar de 1964, ocorreram reformas no sistema educacional abrangendo todos os graus e a criação da licenciatura curta; nas décadas de 70/80, quando no bojo de sua institucionalização, ocorreu também o movimento de resistência e de luta contra a sua implantação. (Nadai, 1988, p. 1).

O artigo de Nadai (1988) teve pouca influência sobre a produção acerca dos Estudos Sociais até o final da década de 1990. Segundo Caimi (2001), até 1998 o artigo de Nadai (1988) foi citado apenas três vezes nos 124 trabalhos mapeados durante sua pesquisa de mestrado. Em contrapartida, a grande referência foi a obra de Fonseca (2010), fruto de dissertação defendida na USP, em 1991, e publicada pela primeira vez em 1993. O objetivo da autora é investigar as experiências de reforma curricular dos estados de São Paulo e de Minas Gerais nas décadas de 1970 e 1980. No primeiro capítulo do livro, ela analisa a História ensinada durante a ditadura e o que denomina como "projeto de desqualificação de professores". Para a pesquisadora, há um projeto de descaracterização do ensino de Ciências Humanas na escola brasileira e uma "tentativa de destruição das humanidades dentro dos currículos" (p. 24). Essa abordagem não concede - e nem essa era sua pretensão - maior espaço para a compreensão dos Estudos Sociais nas décadas que antecederam o golpe de 1964 e não investiga a atuação de educadores, como Valnir Chagas, em sua configuração a partir da década de 1970.

A argumentação de Fonseca (2010), difundida a partir da publicação da dissertação em livro com sucessivas reedições - a nossa é a $11^{\mathrm{a}}$-, tem inspirado as pesquisas sobre esse objeto. É significativo que seja a principal referência de Caimi (2001) e Lima e Fonseca (2011) - autoras de obras com grande divulgação no campo - quando apresentam os Estudos Sociais, vinculados, prioritariamente, à ditadura. Alguns pesquisadores, entre os quais nos incluímos, têm defendido uma abordagem diferente ao analisar a concepção pedagógica do ensino de Estudos Sociais. Esses trabalhos são influenciados pela maior aproximação da História da Educação e da História Cultural e se apropriam do referencial teóricometodológico da história das disciplinas escolares.

As teses de Martins (2000) e Prado (2014), embora tratem, respectivamente, da configuração da disciplina escolar História nos currículos para o ensino fundamental e das práticas cotidianas dos professores de História em escolas públicas da região metropolitana de São Paulo durante a ditadura, contribuem para 
a compreensão do ensino de Estudos Sociais entre as décadas de 1970 e 1980. Abordam o currículo prescrito, com as disputas entre o CFE e a Anpuh, e o cotidiano da sala de aula. Beatriz Boclin Marques dos Santos (2011), também em tese de doutorado, propôs-se "a investigar o currículo da disciplina escolar História no Colégio Pedro II", focalizando a década de 1970. Apesar de ser uma tradicional instituição federal, o Colégio Pedro II não seguiu as determinações contidas na lei $\mathrm{n}^{\mathrm{o}}$ 5.692/71 e manteve a disciplina História em todos os níveis de ensino. A não adoção dos Estudos Sociais e os fatores que levaram à recusa de implantação no currículo escolar dessa nova disciplina configuram-se como as principais questões levantadas pela pesquisadora. Assim,

[...] a História representava uma disciplina fundamental no currículo, marcada pela tradição dos professores catedráticos, autores de livros didáticos que ocupavam posições de poder dentro e fora do Colégio, com projeção pessoal, respeitados seja por sua atuação no ensino secundário, seja no ensino superior. (Santos, 2011, p. 236).

A questão da substituição da História e da Geografia pelos Estudos Sociais representou um conflito entre a "tradição acadêmica" e a tradição pedagógica. O currículo do Colégio Pedro II era tradicional, baseado na preparação dos jovens que ambicionavam ingressar no ensino superior. De acordo com Santos (2011, p. 237), "o status da disciplina História esteve relacionado à referência acadêmica", enquanto o ensino de Estudos Sociais tinha outra pretensão: "a educação centrada na criança e sua inserção social” (p. 238). O CFE, ao propor o ensino em grandes áreas do conhecimento, pretendeu romper a estrutura disciplinar que caracterizava a escola brasileira até então. Santos (2011, p. 232) aponta, ainda, que "os Estudos Sociais não só não entraram no currículo do Colégio Pedro II, como também não houve interferência do governo militar nas questões pedagógicas do Colégio." Isso se explica pelo "peso da tradição da disciplina História" na instituição e pela atuação dos seus professores em diferentes ambientes políticos e educacionais. Embora a trajetória dos Estudos Sociais enquanto disciplina escolar no Brasil apareça como tema importante de um dos capítulos da obra, não se constitui enquanto objeto principal da autora.

Aos poucos, pesquisas que buscam analisar os Estudos Sociais em diferentes fases de sua História e em suas especificidades estão ganhando relevância. Antonia Terra Fernandes (2008), por exemplo, investiga a introdução da disciplina no país durante as primeiras décadas do século XX, com ênfase na 
publicação do "Programa de Ciências Sociais" (1934) e na atuação de Delgado de Carvalho na década de 1930. Esse educador é referência fundamental para a constituição da disciplina no Brasil, sendo sempre citado nos estudos analisados (França, 2013; Gasparello, 2016; Nascimento, 2012; Santos, 2011).

A tese de Aldaíres França (2013, p. 20) "problematiza as representações sobre o ensino de Estudos Sociais que circularam por meio de publicações pedagógicas e propostas curriculares no Estado do Espírito Santo durante o período entre 1956 e 1976." Debruça-se sobre a questão regional, ou seja, como os Estudos Sociais foram pensados no processo de elaboração de uma proposta curricular e de formação docente em um estado brasileiro.

Em dissertação defendida no Programa de Pós-graduação em História Social da Universidade do Estado do Rio de Janeiro (Uerj), traçamos uma história das discussões sobre a formação do professor de Estudos Sociais no Brasil a partir de 1930, enfocando a legislação sobre o assunto aprovada pelo CFE entre as décadas de 1960 e 1980 (Nascimento, 2012). Nossas análises, articuladas às de Santos (2011), foram condensadas em um artigo que procura compreender a historicidade dos Estudos Sociais na escola brasileira (Santos \& Nascimento, 2015). Entretanto, mesmo com o alargamento de temporalidade, avançamos pouco em relação às diferentes fases do pensamento de Delgado de Carvalho e as influências de sua escrita sobre a obra de Valnir Chagas. Está é uma lacuna presente nos trabalhos sobre o ensino de Estudos Sociais no Brasil.

Os trabalhos retomam um velho objeto, a partir de perspectivas e metodologias diferenciadas, porém não se aprofundam quanto às ideias pedagógicas que balizaram o ensino de Estudos Sociais, concentrando-se em determinada temática ou período histórico. Do mesmo modo, não avançam em relação às continuidades ou rupturas entre os Estudos Sociais das primeiras décadas do século XX e o modelo defendido por Valnir Chagas, na década de 1970. Tais pesquisas, apesar da sua relevância, têm caráter fragmentário, em termos temporais, espaciais e temáticos, e não abordam as questões que propomos como eixo de investigação. Entendemos a escola e a educação, como defende Cynthia Veiga (2008, p. 36), não como um capítulo da história política ou reflexo ou consequência da ação de um governante ou regime político - evidente nos trabalhos que analisam os Estudos Sociais apenas entre os anos de 1964 e 1985 -, mas como uma prática cultural e social que se articula a outras. 
Propomos o estudo de um objeto ainda pouco abordado, podendo contribuir para os debates acerca do que Déa Fenelon (1984) denominava, ainda nos anos de 1980, como "a questão dos Estudos Sociais". A análise do que foram os Estudos Sociais - após o golpe de 1964 e as inovações que as legislações educacionais, produzidas entre os anos de 1970 e 1980, trouxeram para as discussões em torno da incorporação dessa disciplina nos currículos escolares -, não é possível sem um retorno necessário à influência norte-americana e às primeiras décadas do século XX, quando foram iniciados os debates iniciais sobre a temática (Santos \& Nascimento, 2015). Isso significa reconstruir a história dessa disciplina escolar em sua trajetória de divulgação e institucionalização no Brasil a partir dos anos de 1930, algo que começa a se processar no decorrer das críticas à História ensinada nos bancos escolares das primeiras décadas do século XX.

\section{3}

O ensino de História no Brasil: da constituição aos indícios da crise do código disciplinar

Ao indicar uma periodização para a história do ensino de História no Brasil, com base no conceito de código disciplinar de Cuesta Fernández (2009), Schmidt (2012, p. 78) estabelece quatro momentos centrais: "construção do código disciplinar (1838-1931)", “consolidação do código disciplinar (1931-1971)"; “crise do código disciplinar (1971-1984)" e "reconstrução do código disciplinar (1984-?)". Para a conjunção inicial, classificada como "construção" e que dura quase 100 anos, a autora tem como referência inicial a fundação do Colégio Pedro II, no Rio de Janeiro, em 1837-1838, e como marco final a década de 1930, tempo de intensas mudanças na educação brasileira, como a instituição das primeiras universidades e cursos superiores de formação de professores secundários.

Trata-se de um período bem estudado e documentado por diferentes autores, através de perspectivas diversas ${ }^{32}$. Tomamos tais trabalhos como base para tratar de alguns elementos concernentes a esse contexto, tencionando compreender como se constituiu o "modelo hegemônico de ensino de História" (Nadai, 1993). Os Estudos Sociais, que surgem na década de 1930, representam uma crítica a ele e uma nova proposta de educação e sociedade.

\footnotetext{
${ }^{32}$ Cf.: Bittencourt (2004), Gasparello (2004), Guimarães (1988), Nadai (1993) e Santos (2011).
} 


\subsection{1}

\section{A construção do código disciplinar da História no Brasil (1838-1930)}

Pode-se dizer "que algo de educação histórica existiu em toda a evolução escolar do mundo ocidental"33 (Fernández, 2009, p. 13), porém, de acordo com a historiografia do ensino, foi no século XIX que se constituíram as bases do código disciplinar da História no Brasil e em outras partes do mundo (Lima e Fonseca, 2008; Nadai, 1993; Schmidt, 2012). Naquele século, foram situados os discursos, conteúdos e práticas que legitimam a História enquanto disciplina a ser ensinada ${ }^{34}$. Apesar das mudanças, ao longo das décadas, tais normas e convenções socioculturais se mantiveram como práticas duradouras no sistema escolar: exemplos são a noção de continuidade histórica, a tradicional divisão do passado em idades (Fernández, 2009) e a ideia de "nação marcada pela unidade (do território, do Estado etc.) ao contrário da fragmentação (da América espanhola), [nação] constituída por um povo solidário e amante da paz [...].” (Nadai, 1993, p. 150). Partindo das considerações de Fernández (2009, p. 60-62), o ensino de História se integrou ao "mosaico curricular do Estado", na escola secundária, principalmente, no contexto de estabelecimento de um sistema de educação de "caráter nacional estatal" e de desenvolvimento do "modo de educação tradicional-elitista" caracterizado por três elementos centrais:

1) Elitismo: um ensino nos moldes universitários, que exclui os saberes práticos mais vinculados aos trabalhos manuais. $\mathrm{O}$ currículo expressa o domínio social e a hegemonia cultural das classes dirigentes, a quem fica restrito o acesso à escola secundária. Estabelece-se uma educação hierarquizada e desigual;

2) Centralismo: acentuação do papel interventor e controlador do Estado, que adota um currículo uniformizador, com planos de ensino, programas e livros didáticos oficiais para suas escolas;

3) Nacionalismo: o Estado atua como promotor das características fundacionais da nação e a escola promove uma socialização

\footnotetext{
${ }^{33}$ Tradução nossa do original: "En sentido muy lato puede decirse que algo de educación histórica existió en toda la evolución escolar del mundo occidental."

${ }^{34}$ É importante atentar que a construção do código disciplinar envolve um processo de longa duração que, embora se funde e se formule na circunstância histórica do século XIX, não é estático. Desse modo, é uma tradição social que se adapta a diferentes modos de educação e que não segue os ritmos impostos pelos distintos regimes políticos (Fernández, 2009).
} 
nacionalizadora, com o estabelecimento de uma língua nacional e a interiorização de hábitos patrióticos.

Ainda de acordo com Fernández (2009, p. 60), “as bases jurídicas e funcionais do modo de educação tradicional elitista se estabeleceram no século XIX pelo liberalismo moderado através de um conjunto de normas legais e ações práticas de natureza administrativa." ${ }^{35}$ A organização de um sistema educacional, preocupado com a formação do brasileiro e com uma homogeneização nacionalizante, era um dos elementos instauradores desse "projeto civilizatório do Império" (Santos \& Andrade, 2016, p. 20). Isso inclui, entre outras ações, a reorganização dos cursos de Medicina e Engenharia, a criação das Faculdades de Direito de Olinda e São Paulo, em 1827, a organização das escolas de primeiras letras (1827) e a fundação do Colégio Pedro II (Santos \& Andrade, 2016). A disciplina escolar História, inserida nesse aparelho de educação, construiu-se impregnada pelos três elementos apontados por Fernández (2009).

As disciplinas escolares, destarte, surgem em um determinado contexto social, caracterizado por certos marcos e interesses sociais e políticos. De acordo com Circe Bittencourt (2012, p. 185), o "ensino de História do [no] Brasil está associado, inegavelmente, à constituição da identidade nacional.” Importante função tornou este ensino uma questão de Estado. Poucos anos após a independência política do país, a História apareceu como conteúdo de instrução das escolas primárias ou de primeiras letras. A lei de 15 de outubro de 1827, que "manda crear escolas de primeiras letras em todas as cidades, vilas e lugares mais populosos do Imperio" ${ }^{\prime 3}$, destaca em seu artigo $6^{\circ}$ que:

Os professores ensinarão a ler, escrever, as quatro operações de arithmetica, pratica de quebrados, decimaes e proporções, as noções mais geraes de geometria pratica, a grammatica da lingua nacional, e os principios de moral christã e da doutrina da religião catholica e apostolica romana, proporcionados à comprehensão dos meninos; preferindo para as leituras a Constituição do Imperio e a História do Brazil. (Brasil, 1827, grifos nossos).

Não é uma novidade na educação luso-brasileira, no início do século XIX, que a História seja um dos conteúdos de formação ministrados nos colégios jesuítas ou nas aulas régias, após as reformas pombalinas iniciadas em 1759. Não

\footnotetext{
${ }^{35}$ Tradução nossa do original: "[...] las bases jurídicas y funcionales del modo de educación tradicional-elitista se establecen en el siglo XIX por el liberalismo moderado a través de un conjunto de normas legales y actuaciones prácticas de carácter administrativo."

${ }^{36}$ Os documentos da época (leis, livros, entre outros) serão citados respeitando a ortografia vigente em seu momento de escrita.
} 
se tratava de uma disciplina, com objetivos e métodos próprios. Tinha uma "função instrumental, com objetivos exteriores a ela" (Lima e Fonseca, 2011, p. 39). Bruter (2006, p. 11) argumenta que a História estava inserida em um ensino "não disciplinar" e vinculada ao estudo das humanidades. Os estudos humanistas tinham três finalidades principais: "prática do domínio da linguagem”, "aquisição de conhecimentos" e "acesso à ciência e virtude". Ainda segundo a autora, o objetivo era ensinar a falar e a escrever. Recorria-se aos textos de historiadores antigos sem a preocupação de se ensinar História no sentido que entendemos hoje.

No começo do $1^{\circ}$ Reinado (1822-1831), seguindo essa tradição formativa, o ensino da História "associava-se a lições de leitura, para que se aprendesse a ler utilizando temas que incitassem a imaginação dos meninos e fortificassem o senso moral por meio dos deveres com a Pátria e seus governantes." (Bittencourt, 2004, p. 61). O estudo do passado possibilitava o acesso a um conjunto de exemplos, através das "narrativas de vida e dos feitos de grandes personagens da vida pública”, que atuariam para a formação moral e cívica dos alunos.

A estruturação do Imperial Colégio de Pedro II, criado em 1837, através do seu primeiro Regulamento, em 1838, marcou a introdução da História enquanto disciplina autônoma no currículo escolar brasileiro (Nadai, 1993). O Brasil, à época, estava em plena Regência (1831-1840) e vivia os turbulentos tempos dos movimentos separatistas em diferentes províncias. "Havia, pois, a necessidade premente de se formular uma interpretação do país, que mantivesse sua extensa unidade territorial e, que ao mesmo tempo, fortalecesse o processo de centralização político-administrativa do Estado monárquico.” (Oriá, 2011, p. 144). O decreto de 2 de dezembro de 1837, publicado no dia do aniversário natalício do imperador D. Pedro II, estabeleceu em seus três primeiros artigos o nome da instituição e os principais componentes do currículo escolar.

Art. 1. ${ }^{\circ}$ O Seminario do S. Joaquim he convertido em collegio de instrucção secundaria.

Art. 2. ${ }^{\circ}$ Este collegio he denominado - Collegio de Pedro II.

Art. 3. ${ }^{\circ}$ Neste collegio serão ensinadas as linguas latina, grega, franceza e ingleza; rhetorica e os principios elementares de geographia, historia, philosophia, zoologia, mineralogia, botanica, chimica, physica, arithmetica, algebra, geometria e astronomia. (Brasil, 1837).

Criado como primeiro estabelecimento de ensino secundário do país, oficial e laico, possibilitou a estruturação da disciplina escolar História. O pensamento francês influenciou a organização do colégio e seu currículo baseado nos estudos 
das humanidades clássicas, com forte ênfase nas aulas de Latim, Grego, Retórica e Poética (Santos, 2011). Nas palavras de Bittencourt (2004, p. 77), “o currículo humanístico pressupunha uma formação desprovida de qualquer utilidade imediata, mas era por intermédio dele que se adquiriam marcas de pertença a uma elite.” Inicialmente, o regulamento aprovado em 31 de janeiro de 1838 previa um curso dividido em oito anos, com a História figurando em duas lições para cada ano entre a $1^{\mathrm{a}}$ e a $6^{\mathrm{a}}$ aulas ${ }^{37}$, totalizando 12 lições (Santos, 2011). O decreto $\mathrm{n}^{\mathrm{o}}$ 62 , de $1^{\circ}$ de fevereiro de 1841 , alterou essa norma, com a diminuição do tempo para integralização do curso de 8 para 7 anos e aumento da carga horária de História, com um total de 15 aulas ministradas entre o $3^{\circ}$ e $7^{\circ}$ anos (Gasparello, 2004). A História foi inserida no currículo dividindo espaço com a História Sagrada e articulada à Geografia. Só a partir de 1849, História e Geografia tornaram-se cadeiras ${ }^{38}$ distintas (Gasparello, 2004), embora a História do Brasil, até 1898, tenha sido ensinada sob o título de História e Corografia do Brasil (Santos, 2011). Segundo Nadai (1993, p. 146):

[...] a história inicialmente estudada no país foi a História da Europa Ocidental, apresentada como a verdadeira História da Civilização. A História Pátria surgia como seu apêndice, sem um corpo autônomo e ocupando papel extremamente secundário. Relegada aos anos finais dos ginásios, com número ínfimo de aulas, sem uma estrutura própria, consistia em um repositório de biografias de homens ilustres, de datas e de batalhas.

Significativos, nesse sentido, são os tópicos de estudo para o ensino de História Moderna, presente no $6^{\circ}$ ano, disponíveis no programa de ensino para o ano de 1849. A maioria dos 40 pontos elegia os "grandes vultos da História", sintetizados nas figuras dos monarcas e navegadores do século XVI, e denotavam uma história política e pautada em acontecimentos, sinalizada nas batalhas e nos governos, em voga no século XIX. A História Moderna se iniciava com Luís XI e terminava em Luís XV, expoentes da monarquia francesa, abordando os reinados de monarcas ingleses, espanhóis, portugueses e, com menos destaque, alemães. A exaltação das biografias dos grandes reis, como principal eixo de explicação da História, era uma forma de valorização da monarquia enquanto regime político,

\footnotetext{
${ }^{37}$ “O termo aula tinha um sentido plural, formado por um conjunto de estudos que eram desenvolvidos em determinado tempo, por diferentes professores que ensinavam as matérias de suas cadeiras respectivas. Reunidas as outras aulas, formavam uma unidade: o curso secundário." (Gasparello, 2004, p. 64). Ainda segundo a historiadora, o termo "série" só aparecerá nos programas de ensino de 1912.

${ }^{38}$ De acordo com Gasparello (2002, p. 64, 68), o termo "cadeira", neste momento, corresponde à disciplina escolar ou "especialidade de estudos a ser ministrada pelo professor".
} 
adotado pela nova Nação (Santos, 2011, p. 72). Dos 12 primeiros pontos, oito abordavam a vida de reis ou tinham seu reinado como marco histórico principal ${ }^{39}$.

A seleção dos conteúdos priorizava uma linha de continuidade com a Europa branca, considerada sinônimo de civilização e progresso. Uma marca que permaneceria no ensino da disciplina, apesar das sucessivas reformas curriculares. Manoel L. S. Guimarães (1988, p. 6), esclarece que a "construção da ideia de Nação não se assenta sobre uma oposição à antiga metrópole portuguesa; muito ao contrário, a nova Nação brasileira se reconhece enquanto continuadora de certa tarefa civilizatória iniciada pela colonização portuguesa." Era preciso escrever a História do Brasil, independente, uma das tarefas do Instituto Histórico e Geográfico Brasileiro (IHGB), “espaço de produção historiográfica”, criado em 1838, e difundi-la por meio da educação e do ensino nas escolas primárias e no Colégio Pedro II (Lima e Fonseca, 2011, p. 46). Os primeiros passos nessa direção ocorreram com a definição de "um prêmio para o trabalho que melhor elaborasse um plano para se escrever a história do Brasil." (Guimarães, 1988, p. 16). O texto vencedor foi escrito pelo alemão Karl Friedrich Philipp von Martius.

No artigo, von Martius define as linhas mestras de um projeto historiográfico capaz de garantir uma identidade - especificidade à Nação em processo de construção. Esta identidade estaria assegurada, no seu entender, se o historiador fosse capaz de mostrar a missão específica reservada ao Brasil enquanto Nação: realizar a ideia da mescla das três raças, lançando os alicerces para a construção do nosso mito da democracia racial. (Guimarães, 1988, p. 16).

Para von Martius, na escrita da História do Brasil deveriam ser levados em consideração as contribuições de brancos, índios e negros. Entretanto, o branco, civilizador tinha um papel de destaque na construção da nacionalidade brasileira. A proposta era elaborar e veicular um passado homogêneo e livre de possíveis conflitos. Essas instruções tornaram-se referência para os programas do Colégio Pedro II e para os compêndios de História do Brasil, publicados ao longo do século XIX, conforme indicam os estudos de Gasparello (2004) ${ }^{40}$. A instituição

\footnotetext{
39 Título do programa: "Perguntas para o exame de 1849: as quaes perguntas, publicamente tiradas à sorte pelos alumnos, por meio de números soltos collocados em huma urna, tem de ser respondidas immediatamente" (apud Santos 2011, p. 259).

${ }^{40}$ A pesquisa de Reznik (1992), desenvolvida no recorte temporal das décadas de 1930 e de 1940, aponta para a continuidade deste pensamento quase um século depois de sua formulação. Segundo ele, "os livros didáticos reafirmam a velha formula de Von Martius: o português é o 'grande rio' que recebe de seus afluentes alguns influxos da correnteza. Compete aos índios e negros 'colaborarem' ou 'influírem'- assim são os termos utilizados. A História do Brasil é a narração dos feitos dos portugueses-brancos.” (Reznik, 1992, p. 127).
} 
tornou-se o estabelecimento de ensino secundário padrão, durante o Império e parte da República, responsável por certa centralização da política educacional imperial para este nível de escolaridade. Dois dispositivos regulatórios, centralizadores da instrução secundária, eram os exames preparatórios, como forma de acesso ao ensino superior, e a "equiparação" (Gasparello, 2004, p. 41). O Colégio Pedro II tinha um apelo nacional. Seus professores catedráticos eram os responsáveis pela elaboração dos programas que, aprovados pela congregação, deveriam ser o parâmetro para os liceus provinciais, para as escolas privadas e para aqueles que desejavam ingressar nos cursos superiores. Eram, também, os autores dos livros didáticos $\left(\right.$ Nadai, 1993) ${ }^{41}$. A menção ao colégio, nas contracapas ou páginas de rosto dos manuais didáticos, conferia-lhes status frente a outros compêndios, favorecendo a sua utilização por outros estabelecimentos de ensino e a sua circulação por diferentes regiões do país (Gasparello, 2004).

A disciplina escolar História constituiu-se, no Brasil, tendo o Estado como principal agente da História e a partir da periodização quadripartite (Antiga, Medieval, Moderna e Contemporânea), inspirada no modelo francês. A cronologia, conforme já salientamos, privilegiava os acontecimentos políticos, grandes homens e suas biografias. A tônica da aprendizagem, seja na escola primária, seja na secundária, era a memorização. De acordo com Bittencourt (2004, p. 68), “um modelo de livro didático muito utilizado em variadas escolas elementares era o catecismo, e muitos textos de História destinados a crianças seguiam o mesmo molde.” Ensinava-se História a partir de perguntas e respostas e o aluno deveria ser capaz de repetir (oralmente ou por meio da escrita) os pontos abordados. A memorização privilegiava "a decoração de nomes e datas de grandes heróis e dos principais acontecimentos da história nacional." (p. 69). Em relação à escola secundária, exigia-se o domínio de extenso conteúdo e a repetição.

No fim do século XIX, começaram a ocorrer embates envolvendo os defensores do currículo humanístico, com ênfase nas disciplinas literárias, consideradas como essenciais para a formação do espírito, e aqueles que desejavam um currículo de cunho mais científico, com disciplinas mais técnicas e ligadas às ciências naturais. Mesmo com esses debates, a História não perdeu a

\footnotetext{
${ }^{41}$ Esta situação só se alterou com as reformas Francisco Campos e a criação do Ministério da Educação e Saúde Pública, na década de 1930, que assumiu e centralizou a elaboração dos currículos das escolas secundárias brasileiras e das instruções metodológicas a serem seguidas.
} 
sua função no currículo. Para Lima e Fonseca (2011, p. 50), "não se pode afirmar, a rigor, que o advento da República alterou a essência do ensino de História, no que diz respeito às concepções predominantes neste campo de conhecimento." Novos heróis foram adicionados ao panteão nacional e a ênfase foi posta na “formação do cidadão adaptado à ordem social e política vigente", bem como no estímulo "aos sentimentos patrióticos". Além das elites, era imprescindível incorporar outros segmentos da sociedade à escola e à instrução elementar.

Para a maioria dos educadores que concordavam com a escolarização das classes populares, a História a ser ensinada, desde o primeiro ano escolar, aos trabalhadores livres que emergiam em substituição aos escravos, deveria inculcar determinados valores para a preservação da ordem, da obediência à hierarquia, de modo que a Nação pudesse chegar ao progresso, modernizando-se segundo o modelo dos países europeus. (Bittencourt, 2004, p. 64).

$\mathrm{O}$ ensino da História era visto como um dos instrumentos para a conformação social e cultural e a escolarização era uma forma de se alcançar o direito ao voto e à cidadania, de acordo com os preceitos da Constituição republicana de 1891. Para Fernàndez (2009, p. 138), o ensino de História era ministrado "segundo os destinatários sociais". Assim, nas primeiras décadas da República, a História assumiu uma dupla função: a formação do "cidadão político", patriótico e bom trabalhador, e manancial de informações, para as elites dirigentes, de "como conduzir a Nação ao seu progresso" (Bittencourt, 2004, p. 81). A historiografia educacional aponta para a longevidade desse modelo que, com algumas alterações, predominou até a primeira metade do século XX.

\subsection{2}

\section{Disciplinarização da História na escola primária e no curso secundário}

Se a História enquanto disciplina escolar se consolidou nos programas da escola secundária brasileira ainda na primeira metade do século XIX, o mesmo não pode ser dito em relação a sua inserção nos programas da escola primária. Ao analisar a construção do código disciplinar da História, Fernández (2009, p. 139) indica haver certa divisão do trabalho entre a escola secundária e a escola primária. Desse modo, no contexto do século XIX e parte do século seguinte, elas tiveram funções diferentes no processo de socialização escolar. Cabe destacar algumas pequenas diferenciações em relação ao ensino de História praticado nos 
dois níveis de ensino, como a sua presença enquanto disciplina autônoma ou saber a ser ensinado. No decorrer das discussões sobre a admissão dos Estudos Sociais nos currículos, essa divisão ficou patente, o que favoreceu a sua inclusão na escola primária da década de 1930. Nela, a disciplinarização tinha menos raízes.

Uma primeira distinção se refere aos objetivos. No curso secundário, a História era ministrada enquanto um saber distinto, parte do capital cultural das elites dirigentes, responsável pela formação do "ethos do homem educado" e preparação para ingresso no ensino superior e na carreira política. A própria denominação "colégio" expressa, de acordo com Gasparello (2004, p. 50), uma “concepção de cultura clássica e desinteressada". Privilegiava-se a erudição, a eloquência e a retórica (Gasparello, 2004). Por outro lado, na escola primária se relacionava, principalmente, a História Sagrada, formação moral e exercícios de leitura. Neste nível de ensino construiu-se uma prática pedagógica subsidiária da religião e exemplos morais com pouco ensino de conhecimento histórico stricto sensu, sendo a História uma leitura instrutiva (Fernández, 2009). Era preciso conhecer e reconhecer os erros e acertos dos homens do passado. Em ambas, ensinava-se uma História "mestra da vida", com o passado servindo de exemplo para o presente e para a construção do futuro (Santos, 2011).

Como defende Selma de Mattos (1998), um dos primeiros autores de livros didáticos a pensar as diferenças entre o ensino de História nas escolas primárias e secundárias foi Joaquim Manoel de Macedo. A publicação de "Lições de História do Brasil para uso dos alunos do Imperial Colégio de Pedro II", cujos volumes são de 1861 e 1863, demarca a concretização do projeto defendido pelo IHGB de divulgação da história nacional e de ensino da disciplina na escola secundária.

Naquele momento, como adverte Gasparello (2004, p. 113), a produção didática indicava o Colégio Pedro II como principal referência: "lugar social do autor, como professor de História" e o dos destinatários, com as palavras -"para uso dos alunos do Imperial Colégio". Contudo, o projeto civilizatório não se restringia à "boa sociedade" ("brancos, livres e proprietários de escravos"), que chegava à escola secundária. Para os formuladores das políticas educacionais, a História tinha valor educativo valioso (Fernández, 2009). Era preciso difundir a ideia de civilização para o "povo mais ou menos miúdo", aqueles que "eram proprietários apenas de suas pessoas." (Mattos, 1998, p. 32-33). Desta maneira: 
[...] à medida que se esforçavam para formar o Povo por meio da Instrução Pública, os dirigentes imperiais avaliavam a distância que percorriam, mudando os métodos de ensino, criando tipos diferenciados de escolas, editando compêndios e sobretudo valorizando o papel do professor. (Mattos, 1998, p. 36).

Nesse contexto, Joaquim Manoel de Macedo publicou "Lições de História do Brasil para as escolas de instrução primária”, cuja segunda edição é de 1865. Os livros, embora tivessem a mesma intenção, eram concretizações diferenciadas (Mattos, 1993). As “Lições do Colégio Pedro II” se destinavam a estudantes:

[...] cuja intelligencia já um pouco dezenvolvida não tinha de contentar-se com uma restricta exposição de factos e simples recordação de datas e ainda não bastante esclarecida mal podia elevar-se ás alturas de transcendentes apreciações philosophicas. (Macedo, 1861, p. 5).

Por outro lado, as "Lições para as escolas primárias" não se referem a estudantes, mas a meninos: "Uma obra escripta para servir ao estudo de meninos não deve ser longa, e o nosso compêndio á primeira vista desagradará pela sua apparente extensão." Na instrução primária, o professor é essencial, "a alma do livro", aquele que dá vida ao método (Macedo, 1907, prefácio à primeira edição). O autor fazia, portanto, uma diferença entre os leitores: "os estudantes mais habilitados", do $7^{\circ}$ ano do Colégio Pedro II, e os meninos que precisavam de maior auxílio de seu professor (Mattos, 1998).

O contraste presente na obra do autor do século XIX não é uma exceção. No século XX, tornou-se um tema de debate. Conforme expressa Nadai \& Bittencourt (2012, p. 94), para muitos professores, e parte da literatura educacional, era inviável ensinar História nos primeiros anos da escolarização, em virtude da impossibilidade de o aluno compreender certas noções. Essa corrente de pensamento pressupunha que a aprendizagem histórica só poderia ocorrer depois dos 16 anos, "a partir do estágio das operações intelectuais abstratas", quando o aluno passa a apresentar maturidade suficiente para a apreensão dos conceitos e construção da noção de tempo (Bittencourt, 2000, p. 132; Nadai \& Bittencourt, 2012, p. 94). Isso contribuiu para o desenvolvimento de práticas de ensino em que a História era diluída entre outros conteúdos, como os Estudos Sociais.

Em termos de disciplinarização ou organização curricular através de disciplinas autônomas, esta ocorreu com mais força na escola secundária. Foi lá que se forjou um arquétipo pedagógico e os usos da educação histórica. 
Alguns usos mais duradouros foram a divisão do currículo em disciplinas rigidamente separadas e ministradas por professores distintos, a separação dos alunos em graus ou cursos segundo a idade (o já antigo estilo jesuítico), a utilização de um esquema cronológico espacial muito uniforme e rígido, a consagração do exame como prova cerimonial do mérito pessoal e consumo individualizado de livros textos. (Fernández, 2009, p. 111) ${ }^{42}$.

Outra diferença fundamental se relaciona ao currículo prescrito. A escola de "primeiras letras" concentrava-se no ensino do ler, escrever, contar e de fundamentos das doutrinas religiosas, enquanto a escola secundária, desde sua introdução, com a fundação do Colégio Pedro II, dividia-se em disciplinas escolares. A educação elementar ficava a cargo fundamentalmente das famílias. É importante lembrar que, a partir do Ato Adicional de 1834, competia às províncias legislarem sobre a educação elementar e secundária, enquanto ao Estado Imperial ficava a responsabilidade pela gestão de ambos os níveis na Corte e do ensino superior em todo o país. Tais normatizações eram de responsabilidade do Ministério dos Negócios do Império e, posteriormente, da Secretaria de Estado dos Negócios da Instrução Pública, Correios e Telégrafos, de duração efêmera, criada em $1890^{43}$. Nas principais reformas da instrução pública elaboradas no Império e nos anos iniciais da República - Couto Ferraz (decreto n ${ }^{\circ}$ 1.331-A, de 17 de dezembro de 1854), Lêoncio de Carvalho (decreto $n^{\circ} 7.247$, de 19 de abril de 1879) e Benjamin Constant (decreto $\mathrm{n}^{\circ}$ 981, de 8 de novembro de 1890) -, a serem implementadas na atual cidade do Rio de Janeiro (Corte e capital), aparecem, de formas distintas, indicações para o ensino de História na escola primária e no curso secundário.

No currículo prescrito para a escola primária, a História ("elementos" e “noções”) é um conteúdo ou saber a ser ensinado desde 1827 (Quadro 4). É interessante observar que, nas reformas Couto Ferraz (1854) e Lêoncio de Carvalho (1879), a instrução moral e religiosa aparece em primeiro lugar. A História era ensinada em estreita relação com outros saberes, como a Geografia e

\footnotetext{
${ }^{42}$ Tradução nossa do original: "Algunos de los usos más tempranos y duraderos fueron la división del curriculum en asignaturas rígidamente separadas y encargadas a profesores distintos, las egregación de los alumnos en grados o cursos según la edad (al ya antiguo estilo jesuítico), la utilización de un esquema crono espacial muy uniforme y rígido, la consagración del examen como prueba ceremonial del mérito personal y el consumo individualizado de libros de texto."

${ }^{43}$ Criada por meio do decreto $\mathrm{n}^{\circ} 346$, de 19 de abril de 1890 , e extinta a partir da lei $\mathrm{n}^{\circ} 23$, de 30 de outubro de 1891, que reorganizou a administração federal. A partir desta lei, "o desenvolvimento das sciencias, lettras e artes, [da] instrucção e [da] educação e seus respectivos institutos nos limites da competencia do Governo Federal, e inclusive a catechese dos indios" (Brasil, 1891) tornaram-se competência do Ministério da Justiça e dos Negócios Interiores.
} 
Instrução Moral. No secundário, as mesmas reformas apontam a organização em disciplinas distintas e a gradativa subdivisão da História em áreas (História Universal, História Romana, História do Brasil, entre outras). A Reforma Couto Ferraz, por exemplo, indica a estruturação do Colégio Pedro II em cadeiras, entre as quais havia duas "de historia e geographia, ensinando o professor de huma a parte antiga e media das referidas materias, e o da outra a parte moderna, com especialidade a historia e geographia nacional." (Brasil, 1854, art. 79).

A Reforma Benjamin Constant, publicada no segundo ano da República, expõe a organização em disciplinas, como: Português, Matemática, História Universal, História do Brasil e Geografia. Cada uma delas ministrada por um professor diferente (Brasil, 1890). As reformas seguintes não alteraram os "padrões pedagógicos" e os planos de estudos da escola secundária (Nagle, 1974, p. 147). A História permaneceu como uma das disciplinas obrigatórias nos exames de admissão para ingresso nos ensinos secundários e superior. Desta feita, assumiu um "caráter preparatório" e "formativo" "diante das especializações do ensino superior" (Nagle, 1974).

\begin{tabular}{|c|l|}
\hline Reforma & \multicolumn{1}{|c|}{ Forma como refere-se ao ensino de História } \\
\hline $\begin{array}{c}\text { Couto Ferraz }(1854) \\
\left(\text { Artigo } 47^{\circ}\right)\end{array}$ & $\begin{array}{l}\text { "A leitura explicada dos Evangelhos e noticia da historia } \\
\text { sagrada". } \\
\text { "Os elementos de historia e geographia, principalmente do } \\
\text { Brasil". }\end{array}$ \\
\hline $\begin{array}{c}\text { Leôncio de Carvalho (1879) } \\
\left(\text { Artigo } 4^{\circ}\right)\end{array}$ & "Noções de historia e geographia do Brazil". \\
\hline $\begin{array}{c}\text { Benjamin Constant (1890) } \\
\left(\text { Artigo } 3^{\circ}\right)\end{array}$ & $\begin{array}{l}\text { "Elementos de geographia e historia, especialmente do Brazil" } \\
\text { (Para alunos da escola primária de } 1^{\circ} \text { grau, entre 7 e 13 anos). } \\
\text { "Geographia e historia, particularmente do Brazil". (Para } \\
\text { alunos da escola primária de } 2^{\circ} \text { grau, entre 13 e 15 anos). }\end{array}$ \\
\hline
\end{tabular}

Quadro 4 - Prescrição de conteúdos de História para a escola primária nas reformas educacionais de 1854,1879 e 1890

Fonte: Elaborado pelo autor.

Uma terceira marca distintiva, relacionada diretamente ao currículo e sua divisão em disciplinas, refere-se ao docente e sua formação. A única instituição de formação de professores existente, no século XIX, era a Escola Normal, responsável pela capacitação para docência na escola elementar. Nesta, inexistia a figura do professor especialista em disciplina. A formação do professor secundário no Brasil só ocorreu, efetivamente, com a fundação das primeiras universidades na década de 1930. Contudo, pesquisas demonstram que havia uma 
estreita relação entre o IHGB, "lugar institucional de produção histórica", e os professores de História do Colégio Pedro II ("o lugar da produção didática") (Andrade, 2007, p. 219). Do "entrecruzamento institucional de intelectuais" com as mais variadas formações - Engenharia, Direito, Medicina, principalmente surgiram os primeiros professores de História da escola secundária oficial, o Colégio Pedro II, autodidatas e "letrados". Essa era uma exceção. Em outras partes do país, os docentes eram recrutados de forma precária, o que levou a uma crescente utilização do livro didático como fonte de informação de conteúdos e métodos (Bittencourt, 1990). Na escola secundária havia, portanto, uma “disciplina rigidamente demarcada" (História), ensinada por um único professor.

Apesar das diferenças de lugar, e por vezes de objetivo, da História ensinada nos níveis de escolarização (primário e secundário), seu código disciplinar (narrativa linear, cronologia, memorização, valorização do personagem político e do Estado) era o mesmo. Tais componentes tornaram-se objeto de debates e contestações ao longo dos anos finais do século XIX e início do século XX.

\subsection{3 \\ Indícios da crise do código disciplinar da História e os Estudos Sociais}

\footnotetext{
Quem de nós não se lembra de seus tempos de escola, em que éramos obrigados a responder a perguntas infindáveis nos questionários e a memorizar datas, fatos e nomes de personagens históricos, por ocasião das provas, exames e as tão temidas arguições, que nos obrigavam a ter tudo memorizado e "na ponta da língua" ou "de cor e salteado?". (Oriá, 2011, p. $155)$.
}

Ao comentar sobre o ensino de História, por ele vivido na escola primária das décadas de 1950 e 1960, Ricardo Oriá (2011, p. 165) salienta a ênfase à memorização, no estudo de personagens históricos consagrados a partir de biografias de grandes homens (reis, governadores gerais) e nas datas. Para o autor, "isso faz parte de uma cultura escolar de décadas passadas, mas que ainda persiste no imaginário coletivo de grande parte da população escolarizada.” Apesar de sua importância nos discursos oficiais, desde o período imperial, a História está associada, na mentalidade de muitos alunos e ex-alunos, como uma "matéria decoreba" (Oriá, 2011). As críticas a esse modelo foram feitas em diferentes épocas (Bittencourt, 2004; Nadai, 1993; Oriá, 2011). 
Desde as primeiras décadas do século $\mathrm{XX}$, anos de intensos debates e reformas educacionais, intelectuais e educadores questionaram o ensino de História e o "esgotamento do modelo educativo adotado", que se caracterizava pela "decoração como atividade precípua da aprendizagem" e pelo "conhecimento pronto e acabado" (Nadai, 1993, p. 143). A ausência de uma formação didática do professorado e o "apego à rotina" tornaram-se empecilhos para o aprofundamento de variações metodológicas no ensino da disciplina (Castro, 1955 apud Bittencourt, 1990, p. 71). Defendia-se uma mudança na forma de se ensinar e a necessidade de uma maior profissionalização e formação do magistério. Para os educadores, havia um descompasso entre as novas demandas impostas pela sociedade, os interesses da juventude e a educação desenvolvida pela escola. Em 1935, Murilo Mendes (apud Nadai, 1993, p. 143) sintetizou o problema:

Nossos adolescentes também detestam a História. Votam-lhe ódio entranhado e dela se vingam sempre que podem, ou decorando o mínimo de conhecimentos que o "ponto" exige ou se valendo lestamente da "cola" para passar nos exames. Demos ampla absolvição à juventude. A História como lhes é ensinada é, realmente, odiosa.

Era clara a necessidade de outras possibilidades de se ensinar História. Para Nadai (1993, p. 152), a partir do ideário escolanovista, ocorreu uma reavaliação "da prática pedagógica daquela disciplina”: "um dos aspectos visados foi a ênfase que os professores colocavam no estudo do passado". Defendia-se uma maior atenção ao estudo das sociedades contemporâneas, mais próximas da realidade do aluno (Carvalho, 1953). Outras críticas estavam relacionadas ao predomínio da história política, à memorização excessiva e à passividade do educando (Nadai, 1993). Três elementos constituintes do código disciplinar da História no Brasil, conforme demonstram os programas de ensino e os livros didáticos utilizados por gerações de alunos e professores. Nesse cenário, o aluno se tornou o centro da relação ensino-aprendizagem. Valorizava-se a "educação pela experiência", concepção formulada por John Dewey. Essa perspectiva considerava que:

[...] o aprendizado só se realiza quando referido a ação do aprendiz. Este ao estabelecer um contato imediato com o objeto de estudo, relacioná-lo com a sua problemática próxima, quiçá cotidiana e existencial, compreenderá o valor devido ao saber em questão. (Reznik, 1992, p. 31-32).

Delgado de Carvalho (1940), adepto da teoria deweyana, expôs em conferência na Associação Brasileira de Educação (ABE) um clamor pela 
renovação do ensino de Ciências Sociais na escola secundária e por uma nova didática para a História ${ }^{44}$. Defendia, a partir da atualização de conteúdos, métodos e disciplinas, um modelo educacional que orientasse os estudos para uma "visão mais prática das coisas". Conforme aponta Nayara Galeno do Vale (2011), a formação de Delgado de Carvalho era francesa e provavelmente ele acompanhou, em seus anos de estudos, as discussões que se processavam na França do início do século XX “acerca da transição de uma história diplomática e militar para uma história que desse conta de explicar os aspectos econômicos e sociais" (p. 46) e que acabariam se impondo sob a égide da "nova história francesa". Contudo, ainda de acordo com a autora, em relação à História ensinada nas décadas de 1930 e 1940, suas referências explícitas são filósofos e historiadores norte-americanos, como o próprio Dewey, Edward P. Cheyney e Charles Beard. A New History americana, vertente de Beard, caracterizava-se por uma proposta de "subordinação do estudo dos aspectos do passado ao presente" (p. 47) e pela ênfase no estabelecimento de relações com as Ciências Sociais. A partir de tais diálogos, o educador brasileiro convidou os professores de História, especificamente, a:

$\left.1^{\circ}\right)$ Abandonar um tanto a história factual, árida, mnemotécnica, crivada de nomes próprios e de datas, satisfazendo-se apenas de uma base elementar e sólida de fatos e dados essenciais para a compreensão da verdadeira História.

$2^{\circ}$ ) Concentrar seus ensinamentos na história cultural das civilizações, isto é, uma História da vida material, intelectual e moral dos povos.

$3^{\circ}$ ) Planejar as suas lições ao redor de motivos centrais que representaram grandes correntes de pensamento e ação e preparando uma interpretação sincera e imparcial do mundo contemporâneo [...]. (Carvalho, 1940, p. 37).

A valorização do "presente", a superação das aulas expositivas, proporcionadas por longas preleções, e da simples descrição dos acontecimentos políticos, pautados na memorização de datas e nomes, já destacada no texto de Murilo Mendes, associava-se, na formulação de Delgado de Carvalho, à introdução de outras questões ao ensino de História. Para o educador, era preciso valorizar o econômico, as instituições, as ideias, a cultura. Em termos

\footnotetext{
${ }^{44}$ Conforme veremos nos próximos capítulos, na década de 1930, ainda não havia uma distinção clara entre os termos Estudos Sociais e Ciências Sociais, algo que se estabeleceu nas décadas seguintes. A fala de Delgado de Carvalho se insere no conjunto de conferências proferidas entre maio e agosto de 1937, por ocasião dos debates acerca da elaboração do Plano Nacional de Educação, na sede da ABE no Rio de Janeiro. Os textos apresentados foram reunidos na obra "Um grande problema nacional (Estudos sobre ensino secundário)", organizada por Afrânio Peixoto (1940). Os conferencistas foram: Afrânio Peixoto, A. Carneiro Leão, Branca Fialho, Carlos Delgado de Carvalho, Euclides Roxo, F. Venâncio Filho, George Millardet, Gustavo Lessa, Joaquim Faria de Góes Filho e Paulo de Assis Ribeiro (Cf. Reznik, 1992).
} 
metodológicos, ele defendia a integração seja entre as diferentes "histórias" (do Brasil e geral, por exemplo) ou entre a História e as demais Ciências Sociais. De acordo com os argumentos dele, a História é melhor ensinada a partir do auxílio de Geografia, Antropologia Cultural, Sociologia, Ciência Política e Economia Política, uma vez que estas disciplinas compõem os Estudos Sociais. O projeto de integração entre as Ciências Sociais, desenvolvido no Distrito Federal, durante a gestão Anísio Teixeira, enfraqueceu-se no contexto do Estado Novo (1937-1945). Uma década após a Conferência da ABE, Carvalho (1953, p. 54) expunha que:

[...] no Brasil, a não ser a Geografia, na sua parte teórica, os Estudos Sociais são dotados de programas antiquados, ministrados por métodos atrasados e, na sua quase totalidade, alheios às necessidades dos educandos, aos interesses do momento histórico e às realidades sociais.

Temos como uma das hipóteses que, a despeito do que se tornou ao longo dos anos, a interpretação da ditadura militar, por exemplo, o projeto inicial de introdução do ensino de Estudos Sociais no Brasil era pedagógico e demonstrava o descontentamento de certos professores-autores, com o ensino vigente. A proposta de Estudos Sociais passava pelo reexame do ensino de História, de seus métodos e conteúdos. Uma "forma de superar o conteúdo livresco, decorativo e excludente que o caracterizava" (Nadai, 1993, p. 153). Mais ainda, indicava a necessidade de se repensar a sociedade, educação, escola e relação professoraluno (França, 2013). Para tanto, os intelectuais-educadores buscaram outras bases conceituais para educação brasileira e o ensino das Ciências Humanas e Sociais na escola. As principais referências foram a filosofia educacional, bem como a noção de História, desenvolvida por John Dewey (como apresentamos no capítulo 3), e as discussões sobre o ensino das Ciências Sociais nas escolas estadunidenses (conforme trataremos no capítulo 4). 


\title{
3 \\ Bases conceituais para uma escola progressiva: a escola americana, John Dewey e a educação como vida
}

\begin{abstract}
Educação passa a ser um processo contínuo de reorganização e reconstrução da experiência, a escola não é apenas preparação para a vida, mas a própria vida. São as fórmulas de John Dewey que se recomendam à atenção dos educadores. (Delgado de Carvalho, 1970, p. 143, grifos do autor).
\end{abstract}

As bases conceituais para a proposta de ensino de Estudos Sociais brasileira têm sua origem nas definições norte-americanas de educação, elaboradas a partir do final do século XIX. As pesquisas tendem a considerar essa influência principalmente a partir da segunda metade do século XX, através dos acordos bilaterais entre o Ministério da Educação e Cultura (MEC) e a United States Agency for International Development (Usaid) - convênios de cooperação técnica e financeira em questões educacionais entre Brasil e Estados Unidos - e da apropriação das ideias de Jerome Bruner e de John Michaelis, na década de 1960 (Azevedo, 2014; França, 2011) ${ }^{45}$. Entretanto, como afirma Martins (2000, p. 93), o maior desenvolvimento dos Estudos Sociais ocorreu nos Estados Unidos da década de 1930, em um contexto de renovação educacional e crítica ao academicismo e à rigidez do currículo escolar. Nesse movimento o nome de John Dewey se impôs e forneceu muitos elementos para os debates ${ }^{46}$.

[...] sua filosofia tem tido fenomenal influência na América, pois tudo quanto se relaciona com a transformação educacional, desde o mero aprendizado passivo de "ler, escrever e contar", até a educação como vida coparticipativa; tudo o que se associa com a moderna tendência pedagógica, a importância da educação sob o aspecto social e prático de vida em coparticipação [...] é direta ou indiretamente consequência de sua doutrina. (Edman, 1960, p. 17).

Nos Estados Unidos, através de sua atuação educacional e em movimentos sociais, Dewey era prestigiado nos mais variados campos do saber: da educação à

\footnotetext{
45 De acordo com Otaíza Romanelli (2007, p. 197), “os convênios conhecidos comumente pelo nome de 'Acordos MEC-USAID”,", assinados entre 1964 e 1968, lançaram as bases para as reformas educacionais implementadas durante a ditadura militar e serviram como fundamento para as diferentes comissões que definiram a política educacional pós-1964. Jerome Bruner, psicólogo estadunidense, foi um dos responsáveis pela reformulação educacional nos Estados Unidos da década de 1960. Para Nadai (1988) e Santos (2011) suas teorias exerceram grande influência no Brasil, o que favoreceu uma maior delimitação da área de Estudos Sociais. John Michaelis foi autor de um manual de Estudos Sociais, muito difundido no Brasil da década de 1960.

46 John Dewey nasceu em Vermont a 20 de outubro de 1859 e faleceu em Nova York, em 2 de julho de 1952. Doutorou-se em filosofia pela Universidade Johns Hopkins em 1884. Lecionou na Universidade de Michigan, na Universidade de Chicago e na Universidade de Columbia.
} 
tradição liberal (Edman, 1960). A extensão do seu pensamento não se restringiu às fronteiras estadunidenses, tendo encontrado adeptos em diferentes países. $\mathrm{Na}$ década de 1930, Anísio Teixeira e Delgado de Carvalho estavam impactados pelas viagens que realizaram aos Estados Unidos. A leitura dos textos de Dewey e as experiências adquiridas naquele país foram fundamentais para a formulação teórica das reformas implementadas por Anísio Teixeira no Distrito Federal. Nos seus estudos, Dewey $(2002,1959)$ aponta para o distanciamento entre a escola tradicional e o mundo em constante progresso material e propõe uma "maior integração entre o educando com o seu meio social" (Santos, 2011, p. 150). Nessa abordagem, a criança deveria estar no centro da aprendizagem e da atividade escolar. Como na revolução copernicana, "o sol em volta do qual gravitam os instrumentos da educação; ela é o centro em torno do qual estes se organizam." (Dewey, 2002, p. 40). Educação é construção, crescimento, desenvolvimento.

Nos meios escolares, esse ponto de vista concorreu para a modificação da obsoleta disciplina rígida e dos métodos de aprender decorando [...]. A extinção do divórcio entre a escola e a sociedade, entre o aprendizado livresco e a experiência vital, entre o indivíduo e o meio - o grau em que as escolas e colégios lograram remover tais separações - é uma medida de impacto direto da salutar reconstrução do pensamento deweyano. (Edman, 1960, p. 23).

A máxima de que "a educação não é uma simples preparação para a vida, mas a própria vida" está presente na produção de Anísio Teixeira e Delgado de Carvalho. Embora Dewey não aborde de forma direta o ensino de Estudos Sociais, as premissas que o balizaram, na América do Norte e no Brasil, encontram fundamentos em sua obra. É preciso ler este autor e conhecer uma das formas de contato dos brasileiros com suas concepções. A vasta produção acadêmica de Dewey, e a apropriação de seu pensamento por Anísio Teixeira foram objeto de várias análises ao longo do tempo (Barbosa, 2015; Chaves, 1999; Edman, 1960; Mendonça, 2002; Nunes, 2007, 2010). A partir da leitura de capítulos das obras "A escola e a sociedade \& A criança e o currículo"47 , "Democracia e educação"48, "Educação e experiência",49, "Vida e educação",50, bem como das

\footnotetext{
47 "The school and society", originalmente foi editado pela Universidade de Chicago, em 1900, e teve uma segunda edição publicada em 1915. "The child and the curriculum" é um texto de 1902, impresso pela University of Chicago Press. Utiliza-se como referência a edição portuguesa que reuniu, em 2002, os dois trabalhos em um único livro.

48 "Democracy and education: an introduction to the philosophy of education", originalmente, é uma edição de Macmillan Co. (Nova York, 1916). Sua primeira tradução, sob o título "Democracia e educação: introdução à Filosofia da Educação", por Anísio Teixeira e Godofredo
} 
interpretações de Teixeira (1968, 1979, 2006), objetivamos compreender aspectos da concepção de educação (como vida, como mudança, como experiência...) e a proposta de ensino de História defendidas pelo educador estadunidense.

\section{1}

\section{Alguns sentidos de educação em John Dewey e Anísio Teixeira}

John Dewey, em seus mais de 90 anos de vida, manteve uma intensa reflexão filosófica, política e educacional. Foi autor de inúmeras obras sobre essas temáticas. Entretanto, algumas questões essenciais nortearam a sua produção acadêmica. Duas delas se destacam pela centralidade que tiveram no pensamento educacional brasileiro, da década de 1930, nos escritos de Anísio Teixeira e Delgado de Carvalho. A primeira é a concepção de que educação é vida e, portanto, a escola e a sociedade não são organismos dissociados. Articulada a essa premissa, Dewey (2002) defende que a escola promove uma preparação inadequada e são necessários reajustamentos para torná-la eficaz. Seus métodos, matérias e materiais de ensino devem ser adaptados de acordo com as exigências da sociedade que a cerca. Como consequências dessa filosofia educacional, segundo Lourenço Filho (1979), há três aspectos estruturantes na obra de Dewey:

1) Não deve existir separação entre vida e educação. Desse modo, as crianças não devem ser preparadas para a vida, para depois vivê-la. A reorganização escolar, sintetiza Teixeira (1968, p. 39), busca fazer da escola um local "onde a criança venha a viver plena e integralmente. Só vivendo, a criança poderá ganhar os hábitos morais e sociais de que precisa, para ter uma vida feliz e integrada [...].";

Rangel, é de 1936. Utiliza-se como referência a $3^{\text {a }}$ edição, de 1959, comemorativa ao centenário de nascimento de John Dewey.

${ }^{49}$ Publicado originalmente em 1938 sob o título "Experience and education" (Nova York: Macmillan Co.), foi traduzido por Anísio Teixeira e editado pela Companhia Editora Nacional em 1971. Utilizamos como referência a 60ª ed., lançada pela editora Vozes, em 1998.

${ }^{50}$ A "Biblioteca de Educação", dirigida por Lourenço Filho e lançada pela editora Melhoramentos, reuniu dois textos de Dewey, "The child and the curriculum" (tradução: "A criança e o programa escolar") e "Interest and Effort"(tradução: "Interesse e esforço"), traduzidos por Anísio Teixeira. A primeira edição é de 1930 e conta com um texto introdutório, assinado por Teixeira ("A pedagogia de John Dewey") e uma apresentação escrita por Lourenço Filho. Lourenço Filho (1979) explica que por ser a educação um "processo da vida", optou-se pelo título "Vida e educação", que não corresponde a nenhuma obra de Dewey. Utilizamos a $9^{a}$ edição dessa obra, de 1979. 
2) A educação é uma contínua "reconstrução da experiência", pois se vive aprendendo, compreendendo, experimentando e construindo capacidades de pensar, comparar e decidir. A sua função é proporcionar mais e melhor educação;

3) A escola, haja vista os dois princípios anteriores, deve ser uma "comunidade em miniatura", pois necessita estar conectada com a vida social e todas as instituições que a compõem.

De acordo com essa filosofia, cabe à educação ser progressiva, pois se destina a uma civilização em constante mudança, em "permanente reconstrução". A designação "escola nova”, para Anísio Teixeira, não contemplava totalmente a amplitude do movimento de renovação. Em sua argumentação, “o que chamamos de 'escola nova' não é mais do que a escola transformada, como se transformam todas as instituições humanas, à medida que lhes podemos aplicar conhecimentos mais precisos dos fins e meios a que se destinam." (Teixeira, 1968, p. 24-25). Escola nova é uma orientação da escola no sentido de um movimento que já ocorria na sociedade. É a sociedade que primeiro se modifica e "com ela se transforma a escola, instituição fundamental que lhe serve, ao mesmo tempo, de base para sua estabilidade, como de ponto de apoio para a sua projeção." (Teixeira, 1968, p. 27). O progresso, ou "transformação material do mundo", nas palavras de Anísio, e o desenvolvimento da ciência, como geradores de uma nova mentalidade, são as grandes marcas características dessa sociedade. A ciência:

[...] trouxe consigo uma nova mentalidade. Primeiro, determinou que a nova ordem de coisas de estável e permanente passasse a dinâmica. Tudo está a mudar e a se transformar. Não há alvo fixo. A experimentação científica é um método de progresso literalmente ilimitado. De sorte que o homem passou a tudo ver em função dessa mobilidade. Tudo que ele faz é um simples ensaio. Amanhã será diferente. Ele ganhou o hábito de mudar, de transformar-se, de "progredir", como se diz. E essa mudança e esse "progresso" o homem moderno os sente: é ele que os faz. (Teixeira, 1968, p. 28-29).

A aplicação da ciência levou ao progresso, à solução de problemas e possibilitou aos homens novos instrumentos de análise e uma mudança na própria forma como veem a vida (Teixeira, 1968). Em "Experiência e educação", Dewey (1998, p. 13-14) aponta a necessidade "de uma nova ordem de concepções" que conduzisse "a novos modos de práticas". Defende um movimento na educação coerente com as novas ordens sociais em ebulição, entre finais do século XIX e as 
primeiras décadas do século XX. "Se depressa marcha a vida, mais depressa há de marchar a escola." (Teixeira, 1968, p. 99).

A ordem social em transformação impôs (e impõe) mudanças à escola. Como esta deve ser uma réplica da sociedade, precisa ser reformada para acompanhar os avanços materiais da civilização em que se insere. Cabe aos educadores essa tarefa. Desse modo, a educação não deve se restringir ao que foi elaborado no passado ${ }^{51}$. O aparecimento do que se chama educação nova ou escolas progressivas é "produto do descontentamento com a educação tradicional" (Dewey, 1998, p. 20-21). Na realidade, complementa Dewey (1998), é uma crítica a ela. Um dos principais pontos de condenação é a imposição, pela escola tradicional, de matérias e métodos de estudos, desenvolvidos por e para adultos, sobre os mais jovens. Uma escola em que se decoram as lições.

A distância entre o que é imposto e os que sofrem tal imposição é tão grande que as matérias de estudo, os métodos de aprendizagem e o comportamento esperado são incoerentes com a capacidade correspondente à idade do jovem aluno. Estão além do alcance da experiência que ele já possui. Consequentemente, precisam ser impostos; mesmo que bons professores usem artifícios para mascarar tal imposição, a fim de minimizar seus aspectos obviamente brutais. (Dewey, 1998, p. 21).

Essa organização do ensino-aprendizagem, que modela as crianças "a imagem e semelhança dos pais" (Teixeira, 1979, p. 31), impede, na argumentação de Dewey, uma participação ativa do aluno no desenvolvimento do que lhe é ensinado. A ele cabe apenas aprender e isso significa "adquirir o que já está incorporado aos livros e à cabeça das gerações anteriores”. O ensino é algo estático, a partir de produtos acabados, "sem maior atenção quanto aos modos como tal produto foi originalmente construído ou quanto às mudanças que certamente ocorrerá no futuro" (Dewey, 1998, p. 21). O ensino promove, apenas, a perpetuação da "vida social passada" (Teixeira, 1968, p. 102). Para Anísio Teixeira (1968, p. 30, 100), a escola deve ter duas preocupações principais: "preparar os homens para indagar e resolver por si os seus problemas" e "preparar

\footnotetext{
${ }^{51}$ Para Dewey (1998, p. 29), a escola tradicional é uma "questão de rotinas na qual os planos e programas são herdados do passado." Sua principal função é a transmissão destas matérias às gerações futuras. Isso ocorre "por meio da aquisição de um conjunto organizado de informações e de formas preestabelecidas de habilidades que constituem o material de instrução." (p. 19-20). Esse modelo acredita que se o aluno aprender certas habilidades e certas matérias, que poderão ser utilizadas mais tarde, seja na universidade ou na vida adulta, por exemplo, ele estará sendo, naturalmente, preparado para as necessidades e atividades do futuro. Em sua crítica, Dewey adverte que não é viável descartar as potencialidades do presente pelas de um suposto futuro.
} 
[a juventude] para um futuro rigorosamente imprevisível" (porque em permanente mudança). Assim, transforma-se no "instrumento consciente, inteligente de aperfeiçoamento social". Portanto, na argumentação anisiana, com a intenção de atingir tais objetivos,

[...] é papel da educação progressiva confirmar as tendências de uma sociedade progressiva, dando assim a direção do processo de mudança. Por conseguinte, as tendências gerais da sociedade progressiva - ciência (enquanto aplicação do método científico a todos os setores da vida social) e democracia (enquanto modo de viver aplicado a todas as dimensões da vida humana) - viriam a se constituir não só nos fundamentos, mas também nos objetivos, ou melhor, nas diretrizes, da educação progressiva. (Mendonça, 2002, p. 50).

A educação progressiva se associa ao desenvolvimento da ciência e sua aplicação à vida, atuando para o desenvolvimento de uma sociedade democraticamente construída. Democracia, segundo Dewey (1960a, p. 164), não é algo externo, institucional ou um simples regime político, mas "uma maneira de vida associada, de experiência compartilhada"; baseia-se na fé no homem comum, independente de suas origens ou riquezas, sexo ou cor, e na sua capacidade de julgar e agir inteligentemente quando lhe são oferecidas condições apropriadas para tanto. "Cada indivíduo conta como uma pessoa." (Teixeira, 1968, p. 35). A fé na democracia está na valorização da reflexão, da discussão, da formação de opinião pública, das trocas. Sua base são os interesses que se conservam comuns, bem como suas inter-relações e a cooperação com outros grupos. Esses elementos, para Dewey (1960a, p. 163), conduzem à democracia e, por conseguinte:

[...] o primeiro significa não somente pontos mais numerosos e variados de interesse comum compartilhado como maior confiança no reconhecimento dos interesses mútuos como um fator de controle social. O segundo significa não apenas uma inter-relação mais livre entre grupos sociais (uma vez isolados até o ponto em que a intenção pudesse manter uma separação), mas também mudança de hábito social - seu contínuo reajustamento através das novas situações produzidas pelo variado intercurso. (Deweya, 1960a, p. 163).

Na sociedade democrática, o homem tem a oportunidade de exprimir seus valores e têm como ideal, primordial, a não repressão de valores de outrem. Pelo contrário, deve, antes, "facilitar a máxima expressão de todos eles" (Teixeira, 1968, p. 35). De um lado, democracia é "uma forma pessoal de vida individual; que significa a posse e o emprego contínuo de certas atitudes" que formam o caráter pessoal e determina as finalidades das relações da vida. Por outro, democracia representa uma "forma de viver, [...] controlada pela confiança no 
trabalho pessoal de todos os dias executado em conjunto." (Dewey, 1960b, p. 329, 332). O trabalho cooperativo é uma forma de enriquecimento da experiência de cada indivíduo (Mendonça, 2002). As discordâncias, quando existem, configuram-se como uma possibilidade de aprendizado. Dessa maneira:

[...] uma fé genuinamente democrática e serena na possibilidade de considerar as discussões, as controvérsias e os conflitos como entendimentos cooperadores, em que ambas as partes aprendem, dando uma à outra o ensejo de expressar-se em vez de dominar o adversário pela sua supressão forçada - supressão que não é menor do que a da violência que se efetua por meios psicológicos de ridicularização, insultos, intimidação [...]. (Dewey, 1960b, p. 333).

Nessa direção,

[...] a democracia é a crença de que, mesmo quando as necessidades, os objetivos e as consequências são diferentes para cada indivíduo, o hábito de cooperação amigável - que pode incluir, como nos esportes, a rivalidade e a competição - é, por si mesmo, um inestimável acréscimo à vida. (Dewey, 1960b, p. 332).

Indivíduo e bem social, personalidade e cooperação são os dois polos da democracia em Dewey: "o homem deve ser capaz, deve ser uma individualidade, e o homem deve sentir-se responsável pelo bem social.” (Teixeira, 1968, p. 35). Para o americano, se, inicialmente, a democracia "foi principalmente o produto de uma feliz combinação de homens e circunstâncias" (Dewey, 1960b, p. 329), a sua construção, conservação e expansão, passaram a ser fruto de um esforço deliberado, já que a democracia não se perpetua por si mesma ou automaticamente. A democracia pode ser estabelecida por estatutos, mas ficará apenas no papel, nas legislações, se não se tornar ação nas atitudes dos homens entre si, em todos os acontecimentos e contatos de seu dia a dia (Dewey, 1960b). Para sua concretização, é preciso que todos os indivíduos tenham oportunidades iguais para o desenvolvimento de quaisquer aptidões que possuam. Nesse aspecto reside a importância da escola, que tem como responsabilidades:

[...] educar em vez de instruir; formar homens livres em vez de homens dóceis; preparar para um futuro incerto e desconhecido em vez de transmitir um passado fixo e claro; ensinar a viver com mais inteligência, com mais tolerância, mais finamente, mais nobremente e com maior felicidade, em vez de simplesmente ensinar dois ou três instrumentos de cultura e alguns manuaizinhos escolares. (Teixeira, 1968, p. 41, grifos do autor).

Ao lado das lições e conhecimentos que obrigatoriamente tem de ensinar, a escola progressiva propõe o desenvolvimento de "hábitos, disposições e atitudes" que habilitam o homem a ajustar-se ao seu meio e a viver melhor. A criança deve 
ser aparelhada de forma a construir atitudes críticas em relação ao mundo em que vive. E essa é a tendência principal da democracia: "a busca do maior bem do homem" (Teixeira, 1968, p. 40, 60). O ensino não é mais a simples proposição de soluções já fabricadas, mas provimento dos instrumentos necessários para que os alunos construam e resolvam seus problemas. Para uma escola com tamanhas responsabilidades, Teixeira (1968, p. 41) salienta: “só um novo programa, um novo professor e uma nova escola podem bastar". É a essa renovação que se dedicaram John Dewey e Anísio Teixeira em seus escritos e ações.

\subsection{1 \\ Experiência e educação: "educação é vida"!}

O universo se caracteriza pela constante transformação. As relações entre os homens, através dos "quais os corpos agem uns sobre os outros", modifica-os. Para Teixeira (1979, p. 13), "esse agir sobre outro corpo e sofrer do outro corpo uma reação é, em seus próprios termos, o que chamamos de experiência." No plano da vida, essas experiências levam à permanente seleção e adaptação, ação e reação, promovendo reflexão e a própria (re)construção da experiência. Experiência é, portanto, uma forma de interação em que os elementos que dela participam, "seleção e agente", são modificados (p. 14). Em sua essência, altera os nossos entendimentos e a percepção do mundo em que vivemos ${ }^{52}$.

Nessa perspectiva, a vida é "um tecido de experiências" e experiência é "tudo o que o homem sofreu, amou, conheceu". Se não se vive sem experiências, diz Anísio, a vida humana é uma forma de aprendizagem: "toda relação social que seja realmente vivida e participada é educativa." (Teixeira, 1979, p. 20). Vida, experiência e aprendizagem compõem o mesmo processo: "simultaneamente vivemos, experimentamos e aprendemos" (Teixeira, 1979, p. 16). Educação é

\footnotetext{
52 Duas noções explicitadas por Dewey (1998, p. 35-36) ajudam a compreender essa questão. O "continuum experiencial" sintetiza a percepção de continuidade da experiência. Isto é, toda experiência tem algo de experiências passadas e modifica a qualidade das experiências futuras. Do mesmo modo, a experiência se relaciona à constituição de um hábito (ou de hábitos): "A característica básica do hábito é a de que toda ação praticada ou sofrida em uma experiência modifica quem a pratica e quem a sofre, ao mesmo tempo em que essa modificação afeta, quer queiramos ou não, a qualidade das experiências subsequentes, pois, ao ser modificada pelas experiências anteriores, de algum modo, será outra a pessoa que passará pelas novas experiências."
} 
crescimento e crescimento é vida. A experiência educativa, por sua vez, é reflexiva e alarga o espírito, concedendo significação à vida. Dessa maneira:

Educar-se é crescer, não já no sentido puramente fisiológico, mas no sentido espiritual, no sentido humano, no sentido de uma vida cada vez mais larga, mais rica e mais bela, em um mundo cada vez mais adaptado, mais propício, mais benfazejo para o homem. (Teixeira, 1979, p. 17).

A experiência humana é, fundamentalmente, social e envolve contato e comunicação. Entendida, assim, a educação é um processo de organização e reconstrução da experiência que habilita os homens a dirigirem suas experiências futuras. Com isso, a noção de aprendizagem e seu papel se modificam. Aprender é mais do que memorizar uma informação, como no método catequético de perguntas e respostas. Aprender é "ganhar um modo de agir". O aprendizado ocorre "quando assimilamos uma coisa de tal jeito que, chegado o momento oportuno, sabemos agir de acordo com o aprendido" (Teixeira, 1968, p. 42). É uma função permanente do organismo humano. A educação não pode ser, portanto, uma preparação em determinado momento da vida. Ela ocorre ao longo de toda a vida, mesmo após se completar o desenvolvimento biológico e escolar. Isso torna a educação uma necessidade e uma importante função social.

\subsection{2 \\ Educação como necessidade da vida e como função social}

A maior diferença entre os seres inanimados e os seres vivos é que estes últimos se conservam pela renovação. Grosso modo, argumenta Dewey (1959, p. 1), "ser vivo é aquele que domina e regula em benefício de sua atividade incessante as energias que de outro modo o destruiriam." A vida, entendida como coisa física e costumes, instituições, crenças, vitórias, derrotas, divertimentos, ocupações, é um processo de renovação por "intermédio da ação [do homem] sobre o meio ambiente". Este é um movimento que não poderia ocorrer indefinidamente, já que tudo morre. Entretanto, a continuidade da vida ultrapassa a existência individual e se dá pela "obra da renovação" e transmissão. Por meio da educação se renovam tanto a existência física, como as crenças, ideias e valores da humanidade. O nascimento e a morte dos indivíduos, pertencentes aos grupos sociais, determinam a necessidade da educação. Para o educador americano, "o 
que a nutrição e a reprodução são para a vida fisiológica, a educação é para a vida social" (Dewey, 1959, p. 10) e por meio dela a vida se perpetua. Desse modo:

[...] a sociedade subsiste, tanto quanto a vida biológica, por um processo de transmissão. A transmissão efetua-se por meio da comunicação - dos mais velhos para os mais novos - dos hábitos de proceder, pensar e sentir. Sem esta comunicação de ideias, esperanças, expectativas, objetivos, opiniões entre os membros da sociedade, que estão a sair da vida do grupo, e os que na mesma estão a entrar, a vida social não persistiria [...]. (Dewey, 1959, p. 3).

A renovação não é automática, adverte Dewey. Inicialmente, a educação ocorre de forma natural. Os elementos constituintes do grupo nascem inexperientes. A transmissão ocorre a partir do convívio com aqueles que são "os depositários da experiência da vida de seu grupo" (Dewey, 1959, p. 2). Os jovens tomam contato com as características e objetivos principais de seu grupo social. Nas sociedades primitivas, por exemplo, não existe um local cuja função específica seja a de aprender e a de ensinar. O conhecimento e os costumes são adquiridos participando-se daquilo que fazem os mais velhos. A inserção nessas atividades lhe serve como aprendizado e a educação é o seu próprio crescimento. Para Anísio Teixeira (2006, p. 33), "não se educa senão através do meio. Meio é, porém, mais do que vizinhança e arredores.” Segundo Dewey $(1959$, p. 24):

[...] o meio consiste em todas as atividades de seres semelhantes intimamente associados para a realização de seus fins comuns. Ele é verdadeiramente educativo em seus efeitos, na medida em que o indivíduo participa de alguma atividade conjunta. Contribuindo com sua parte na atividade associada, o indivíduo adota os fins que a estimulam, familiariza-se com seus métodos e seus materiais, adquire a necessária habilidade e impregna-se de seu modo de sentir.

Educar é, portanto, uma função social pela qual o indivíduo participa da vida do grupo (Teixeira, 2006). Contudo, à medida que a sociedade se complexifica e não é mais possível a aprendizagem natural e direta, isto é, através das relações casuais, surge a educação formal. As tradições e todo o acervo social passam a ser transmitidos por meio de símbolos escritos e livros. Com o desenvolvimento da sociedade "é indispensável uma agência especial - a escola e um grupo de especialistas - os professores - para tornar possível a educação da infância." (Teixeira, 2006, p. 31-32). A escola é um "ambiente social especial", responsável pela educação dos membros da sociedade, cuja função social é controlar, guiar e dirigir a atividade infantil (Dewey, 1959). Destarte, é "um imprescindível substituto, ou, para sermos mais exatos, o atual complemento da 
educação que permanentemente recebemos da sociedade." (Teixeira, 2006, p. 32). Esse ambiente possui, na acepção deweyana, três funções principais:

1) Ambiente simplificado: "Uma civilização complexa não pode ser assimilada in toto" (Dewey, 1979, p. 21), cumpre fragmentá-la em pedaços para que os mais jovens possam assimilá-la aos poucos, de forma gradativa. A escola deve simplificar o ambiente social permitindo que as crianças o conheçam e dele possam participar. (Teixeira, 1979).

2) Meio purificado: onde se eliminam os aspectos maléficos do ambiente social. A escola progressiva não se propõe a perpetuar a sociedade em seus defeitos, mas a aprimorá-la constantemente, tornando-a significativamente melhor para as gerações futuras. (Teixeira, 1979).

3) Ambiente de integração social e harmonização: uma sociedade é, primordialmente, heterogênea e formada por diferentes grupos. "A escola deve ser a casa da confraternização de todas essas influências [políticas, religiosas, sociais, entre outras], coordenando-as, harmonizando-as, consolidando-as para a formação de inteligências claras, tolerantes, compreensivas.” (Teixeira, 1979, p. 25). O seu objetivo principal consiste em ampliar o meio em que vive o discente, coordenando as influências dos vários meios sociais em que ele se situa. (Dewey, 1959, p. 23).

A educação formal possibilita a transmissão de recursos e conquistas de uma sociedade cada vez mais complexa. As disciplinas escolares e os compêndios representam uma sistematização das experiências humanas para fins escolares e didáticos (Teixeira, 2006). Um exemplo utilizado por Dewey (1959, p. 21) esclarece essa questão: "a vida dos gregos e romanos antigos influencia profundamente a nossa e, apesar disso, o modo por que nos influencia não se patenteia na superfície de nossos atos habituais." Cabem a disciplinas escolares, como a História, relacionarem os aspectos da herança humana e o presente. Entretanto, a escolarização representa um perigo. Isso porque na educação casual a criança entra em contato com "atos reais", o que torna a aprendizagem pessoal e interessante. Os conhecimentos são postos em prática nas tarefas e necessidades do dia a dia, algo que não ocorre na educação intencional dos mais jovens. Esta, segundo Dewey (1959, p. 8-9), pode se tornar uma coisa distante, "abstrata e livresca", "isolada das coisas de nossa experiência na vida prática". 
Ao configurar-se como "um mundo dentro do mundo", na argumentação de Teixeira $(1979$, p. 21$)$, a escola se distancia da realidade em que se insere e acaba valorizando justamente os conhecimentos que não têm contato direto com a vida. Torna-se, em grande parte, apenas uma difusora de "matérias de informação". Sua função deixa de ser a de influir na vida de forma consciente, para se tornar mera "aquisição de letras" e/ou conhecimento sobre matérias de interesse remoto. O conhecimento torna-se um fim em si próprio (Dewey, 2002). Formam-se eruditos e não necessariamente homens e mulheres com uma "atitude mental social" (Dewey, 1959, p. 9). A escola é, assim, um local em que as crianças devem aprender "o que lhes é ensinado, decorando as lições que os professores marca[m], depois toma[m], e que lhes fornece[m] elementos de informação e saber, que só mais tarde deveriam utilizar." (Teixeira, 1968, p. 38, grifos do autor). Para Dewey (2002), a escola se constituiu sob o "signo do ouvir". Isso se exemplifica na própria forma como se organizou e se consolidou o espaço escolar:

[...] com suas fileiras de carteiras inestéticas dispostas numa ordem geométrica, bem encostadas umas às outras para reduzir ao máximo o espaço disponível, quase todas do mesmo tamanho, em cujo tampo cabem apenas os livros, o lápis e o papel, e se a isto acrescentarmos uma mesa, algumas cadeiras, as paredes nuas e possivelmente alguns quadros, seremos capazes de restituir o único gênero de atividade educativa que poderá ter lugar num sítio assim. (Dewey, 2002, p. 38).

Com tais características, observa Dewey (2002, p. 38):

[...] tudo foi concebido para pôr as crianças a "ouvir" - porquanto, em última análise, estudar as lições a partir dum livro é apenas uma outra maneira de ouvir, que assinala a dependência duma mente em relação à outra. A atitude de ouvir significa, comparativamente falando, passividade, absorção; significa que há um certo número de materiais já prontos, que foram preparados pelo reitor da escola, pelo conselho diretivo ou pelo professor, e cujo conteúdo a criança deve assimilar da forma mais perfeita possível, no menor espaço de tempo possível.

A organização da estrutura escolar foi disposta para que lidemos com o maior número de crianças possível, em massa, o que implica o seu tratamento enquanto sujeitos passivos. Esse ambiente favorece a uniformização de métodos e programas de ensino.

Se tudo foi concebido partindo do princípio de que à criança cabe apenas "ouvir", pode haver uniformidade de materiais e métodos. O ouvido, bem como o livro que reflete o ouvido, constituem os meios iguais para todos. As oportunidades para proceder ajustamentos de acordo com a diversidade de capacidades e solicitações reduzem-se a quase zero. (Dewey, 2002, p. 39). 
Neste caso, há uma série de resultados pré-definidos que as crianças devem atingir em determinado momento. Essa educação é herdeira de uma concepção de saber que "faz apelo somente ao lado intelectual das nossas naturezas, ao nosso desejo de aprender, de acumular informação e de dominar os símbolos do saber" (Dewey, 2002, p. 33), desconsiderando a criança e seus interesses, já que os objetivos educacionais são exteriores a ela.

A teoria educacional de John Dewey (2002) propõe um equilíbrio entre a educação formal, obtida em um ambiente criado especificamente para ministrá-la, denominado como escola, e a aprendizagem direta a partir de "experiências sociais". Para o educador, os processos normais da vida não são incompatíveis com a aquisição de informações e disciplina. Cabe à escola possibilitar, através da criação de ambientes adequados, um lugar onde a criança viva e adquira experiências de vida. A escola deve lidar com a criança viva e não com uma imagem inanimada dela, construída pelos adultos (Dewey, 2002). Para isso, necessita se basear em seis princípios: 1) cultivo e expressão da individualidade; 2) aprendizado pela experiência, em “oposição à aprendizagem através de textos e professores"; 3) construção de habilidades e técnicas que correspondam às necessidades diretas e vitais do aluno em seu cotidiano; 4) atividade livre em oposição a imposições externas; 5) aproveitamento das oportunidades do presente; 6) contato com um mundo em permanente mudança, pois a educação não é estática ou imutável (Dewey, 1998).

\subsection{3}

\section{A escola, a sociedade e a vida}

Dewey (2002) critica aqueles que encaram a escola a partir de uma perspectiva individualista, ou seja, enfatizando somente a relação entre o aluno e o professor ou entre o professor e o pai do aluno. Embora o trabalho da escola seja avaliado a partir de critérios como "os progressos feitos pela criança individual que conhecemos" e o aumento de seu conhecimento de Geografia e de História, por exemplo, o autor defende a ampliação dessa miragem. Para Dewey (2002, p. 17), “aquilo que o pai mais diligente e sensato deseja para o seu próprio filho, a comunidade deverá desejá-lo para todas as crianças que crescem em seu seio.” De 
outro modo, a própria noção de democracia não teria condições de existir. A escola tem um papel importante na (re)construção constante da sociedade e da democracia, já que: "tudo o que a sociedade alcançou para seu benefício é posto, por intermédio da escola, ao dispor dos seus futuros membros, bem como todas as utopias, que ela espera realizar através das novas possibilidades assim abertas ao seu futuro corpo.” (Dewey, 2002, p. 17).

Dito isso, a função da escola é o pleno desenvolvimento dos indivíduos. Sua reforma deve partir de um ponto de vista essencialmente social, já que o seu objetivo é o alcance de toda a sociedade. Com as mudanças sociais, um problema se impôs à escola: como introduzir atividades que "exercitem a criança no contato direto com as realidades físicas da vida?" (Dewey, 2002, p. 22-23). Uma resposta seria a introdução do "treino manual", oficinas, artes domésticas; um ensino que cativa o interesse e a atenção espontânea dos alunos, tornando-os menos passivos e mais capazes, e possibilita o acesso a algo que não obteriam de outro modo. Tais trabalhos não deveriam ser concebidos como disciplinas distintas, mas como “métodos de vida e aprendizagem”. Dewey (2002, p. 23) explica que:

[...] devemos concebê-los em todo o seu significado social, como exemplos dos processos por meio dos quais a sociedade perdura, como ferramentas para familiarizar a criança com algumas das necessidades primordiais da vida comunitária e como método que a crescente perspicácia e engenho do homem encontraram para satisfazer essas necessidades; em suma, como instrumentos graças aos quais a própria escola será convertida num genuíno centro de vida comunitária ativa, ao invés dum lugar isolado onde se aprendem lições.

A escola precisa manter uma estreita relação com a sociedade, da qual é um dos principais componentes. Segundo Dewey (2002, p. 23), a sociedade é um conjunto de pessoas "a trabalhar de acordo com linhas comuns, animadas dum espírito comum e com referência a objetivos comuns." As necessidades e trabalhos comuns levam à troca de ideias e solidariedade, algo que não ocorre na escola tradicional devido à "ausência deste componente de atividade comum e produtiva”. Da forma como se organizaram, as escolas impedem um simulacro de organização social: "a trágica debilidade da escola de hoje reside na sua ambição de preparar os futuros membros do tecido social num meio em que as condições do espírito faltam visivelmente.” (Dewey, 2002, p. 23-24). Como preparar a criança ou o aluno para o futuro, se o presente não lhes dá condições de viver a vida? Não há outro modo, senão por meio das reais situações de experiência. 
Sempre vivemos o tempo em que estamos e não algum outro tempo, e é só extraindo de cada tempo presente o sentido de cada experiência presente que estaremos preparados para fazer o mesmo no futuro. Essa é a única preparação que realmente conta ao longo da vida. (Dewey, 1998, p. 50-51).

A partir da introdução de ocupações ativas ${ }^{53}$ "a essência da escola é renovada", a instituição escolar associa-se à vida e se torna:

[...] uma segunda morada da criança, onde ela aprende através da experiência direta, em vez de ser apenas um local onde decora lições, tendo em vista, numa perspectiva algo abstrata e remota, uma hipotética vivência futura. Isto é, a escola tem a oportunidade de se converter em uma comunidade em miniatura, uma sociedade embrionária. (Dewey, 2002, p. 26).

As ocupações como centro articulador da vida escolar promovem uma mudança de motivação, de espírito. Com elas, muda-se de uma postura passiva e inerte para "uma atitude enérgica, alegre e expansiva" e a educação deixa de ser apenas um processo individual para se tornar um processo social. Desta feita,

[...] quando o trabalho escolar consiste apenas em decorar as lições, a assistência mútua, em vez de ser a forma mais natural de cooperação e associação, torna-se um esforço clandestino para aliviar o parceiro dos deveres que lhe incumbem. Quando está em curso um trabalho ativo, tudo isto muda. (Dewey, 2002, p. 24).

É um instinto original dos homens que trabalharam para viver e progredir.

Tal metodologia de ensino também pode ser aplicada ao ensino das Ciências Humanas.

Nada parece mais bizarro aos olhos do visitante médio, atento e interessado, do que ver rapazes de dez, doze e treze anos a executarem, em conjunto com raparigas da mesma idade, trabalhos de costura e tecelagem. Se encararmos isto como uma preparação dos rapazes para coserem botões e fazerem remendos, chegamos a uma concepção restrita e utilitária - com base na qual dificilmente se justificará valorizar este tipo de trabalho na escola. Porém, se encararmos estas tarefas numa outra perspectiva, verificamos que elas funcionam como ponto de partida que permite à criança reconstituir e analisar o progresso da humanidade ao longo da História, instruindo-a, além disso, sobre os materiais usados e os princípios mecânicos envolvidos. Estas atividades são pretextos para recapitular o desenvolvimento histórico do homem. (Dewey, 2002, p. 28).

Os discentes entram em contato com as dificuldades que se processaram ao longo do desenvolvimento histórico do homem. Conseguem compreender os

\footnotetext{
${ }^{53}$ Para Dewey (2002, p. 115), "ocupação" não é apenas trabalho ou exercícios ministrados para as crianças a fim de afastá-las da indisciplina ou da preguiça. Trata-se de "um modo de atividade por parte da criança que reproduz ou ocorre simultaneamente a um certo tipo de trabalho que é tido na vida social". Na escola, "estas ocupações são representadas pelos ateliers", por exemplo. O seu aspecto central reside no equilíbrio entre "as fases práticas e intelectuais da experiência". Isto é, envolve, de um lado, os sentidos (mãos, olhos, etc.), e, por outro, a observação constante dos materiais para que "o lado executivo ou prático possa ser levado a cabo com sucesso". Há a interação entre a ideia e a ação.
} 
aspectos da evolução humana em contato com materiais concretos. Por exemplo: entrega-se à criança uma matéria-prima (algodão ou fibra), estuda-se como foi feito esse material; nos passos seguintes, verifica-se como se transforma essa matéria-prima em tecido; como se processa o funcionamento da produção e distribuição. No caso da História, aborda-se, ainda, a importância de certas invenções para a humanidade. Dewey denomina essa forma de ensino que pressupõe a integração entre diferentes disciplinas e conhecimentos, como "o estudo a partir das ocupações humanas". A tarefa, de um lado, possibilita à criança "uma experiência genuína; dá-lhe a experiência direta das coisas" (Dewey, 2002, p. 29-30) e, por outro, leva à pesquisa. À medida que os conhecimentos do aluno aumentam, a tarefa prática torna-se um instrumento de compreensão e a interpretação passa a ser desenvolvida através de estudos mais especializados.

A aprendizagem não ignora os "impulsos e tendências para fazer, para executar, para criar, para produzir" (Dewey, 1998, p. 33). O fazer, para além da aquisição do conhecimento, possibilita uma motivação social, livre comunicação, troca de ideias, sugestões e experiências. Não se separa trabalho prático do trabalho intelectual. Não se trata de uma simples comparação resultante da leitura de um questionário e avaliação da criança que aprendeu mais ou menos. O fim desse modelo educacional deve ser o desenvolvimento de um espírito de cooperação e capacidade de organização social (Dewey, 2002). A integração dos conteúdos escolares, possibilitada pelas ocupações ativas, tem como função "facilitar o processo de reconstrução da experiência" (Oliveira, 1993, p. 50). Nesse movimento, o estudo da História e da Geografia tem importante papel.

\subsection{4}

\section{Ensino de História em John Dewey: a necessária contribuição para o presente e as inter-relações com a Geografia}

No texto "O objetivo da História na educação elementar", Dewey (2002) apresenta a sua primeira proposta sistematizada para o ensino dessa disciplina escolar. A História, em sua definição, não se limita a ser um registro do passado, sendo pensada como um apontamento das "forças e formas da vida social". Para o autor, existem "muitas exigências urgentes no presente e demasiadas necessidades no limiar do futuro para que a criança fique profundamente imersa" (p. 131) no 
que já passou. A vida social é uma constante e a distinção entre passado e presente é uma questão temporal. A diferenciação entre uma temporalidade e outra não é tão importante, já que em ambas "trata-se da vida". Há, desse modo, uma disparidade entre a História do historiador e a do educador. A última se constitui articulada à Sociologia, enquanto "um estudo da sociedade que representa o processo de desenvolvimento e os seus modos de organização" (p. 131). Nesse aspecto residiria a importância da História no currículo escolar. Dewey (2002, p. 131-132) esclarece que:

[...] a sociedade atual não só é demasiado complexa como demasiado próxima da criança para poder ser estudada. A criança não encontra pistas no labirinto de detalhes que a sociedade atual comporta e não consegue colocar-se numa posição distanciada donde possa ter uma perspectiva da sua organização.

Através do distanciamento, apresentam-se aos alunos as formas de organização de diferentes modelos de sociedade. A História não é entendida como vinha sendo até então, como uma "acumulação de resultados" e informações ou "mera constatação do que aconteceu", mas como "algo enérgico e ativo". O comodismo, na perspectiva deweyana, é substituído pelo movimento e pelo dinamismo. Com isso são valorizados os motivos, as forças motrizes. A informação é utilizada na "construção de uma imagem vívida sobre como e o porquê dos homens terem feito o que fizeram" (Dewey, 2002, p. 132). Os objetivos do ensino da História residem em levar a criança a apreciar os valores sociais, a observar as forças que permitiram e favoreceram a cooperação entre os homens e a identificar e a compreender as características que ajudaram a humanidade a manter essa cooperação (Dewey, 2002).

Com tais objetivos, mudam-se também os conteúdos utilizados no ensino de História. Não basta a História Política, com suas cronologias e datas, batalhas e vidas de grandes homens. Dewey (2002, p. 132) argumenta que "quando a História é concebida de forma dinâmica, os seus aspectos econômicos e industriais são enfatizados." Tais ideias são, na realidade, atemporais e expressam "o problema no qual a humanidade está incessantemente envolvida": Como os homens viveram (vivem)? Como utilizaram (utilizam) a natureza de forma que ela enriqueça a vida humana? O estudo dos grandes avanços da civilização pode conter pistas importantes para a formação infantil. O seu mundo atual é sempre tão rico e complexo que por vezes não é fácil para a criança se dar conta do 
quanto custou cada um dos passos do homem até o presente. Os avanços da humanidade, ou na definição deweyana, sua "história industrial", não são uma questão apenas materialista ou utilitarista, mas uma "questão de inteligência". Essa História é o registro

[...] de como o homem aprendeu a pensar, a pensar de forma instrumental, de modo a transformar as condições de vida no sentido de a transformar em algo de diferente. Constitui também um registro ético; o registro das condições que o homem delineou pacientemente de forma a servirem a seus fins. (Dewey, 2002, p. 133).

A apreciação mais profunda da vida e seu desenvolvimento, a partir da História, leva a outra alteração no ensino dessa disciplina. Segundo Dewey (2002, p. 134), as biografias, tão valorizadas no ensino da História entre os séculos XIX e XX, utilizadas como "meras coleções de histórias", "não levam a criança a uma melhor compreensão da vida social”. A ênfase no indivíduo (herói, geralmente o político, o militar, o rei), isolado de seu ambiente social, não possibilita ao aluno a apreensão das "situações sociais que conduziram aos seus atos" e nem a forma como os seres humanos viveram ${ }^{54}$. Entretanto, a biografia "constitui um órgão de estudo social" (p. 134) quando apresenta as necessidades e realizações sociais. O personagem (indivíduo) é abordado a partir das relações sociais que mantém ao longo do tempo. A cronologia tradicional também é questionada e Dewey (2002) defende que o ensino de História comece pelo que há de mais próximo do aluno.

Tradicionalmente a História ensinada persegue o desenvolvimento da civilização através de seus contínuos passos. Do Egito a Roma, e assim sucessivamente. Segundo Dewey (2002, p. 135), "a lógica é a de que o presente depende do passado e de que cada fase do passado depende de um passado anterior." Isso gera uma série de dificuldades aos professores e aos alunos. Uma delas se relaciona ao interesse. $\mathrm{Na}$ argumentação deweyana, o problema em se estudar a História Antiga, a Babilônia ou o Egito, por exemplo, não é tanto a distância temporal, mas a distância de objetivos e interesses em relação à vida atual. Os alunos não conseguem relacionar as sociedades estudadas e aquela a

\footnotetext{
${ }^{54}$ No capítulo "A significação da geografia e da história", Dewey (1959, p. 236) complementa a sua argumentação. Para ele, "incorrer-se-á em falta se forem postos em exagerado relevo os atos de alguns poucos indivíduos, sem se relacionarem esses atos com as condições sociais representadas por eles. Se ao escrever-se uma biografia se relatassem apenas os atos de um homem, isolados das condições que os produziram e com referência às quais estes atos eram reações, não se teria um estudo da História, pois não haveria um estudo da vida social, que é o resultado de uma associação de indivíduos. Seria como limitar-nos a recobrir de açúcar certos conhecimentos de natureza informativa, para os fazermos ser mais facilmente engolidos."
} 
qual se vinculam. Para Dewey (1998), a organização das matérias escolares deve partir de dois princípios:

1) Os conteúdos selecionados das matérias derivam das experiências da vida. "Tudo o que possa ser considerado matéria de estudo, seja aritmética, história, geografia ou qualquer uma das ciências naturais, deve derivar de materiais que, originalmente, pertençam ao escopo da experiência da vida cotidiana." (p. 75). O princípio fundamental da teoria da educação deweyana é o de que "toda instrução deve iniciar a partir das experiências que os alunos já possuem; de que essas experiências e as capacidades desenvolvidas a partir delas fornecem o ponto de partida para todo aprendizado futuro.” (p. 77). Toda nova experiência se conecta (ou deveria se conectar) com as experiências mais antigas.

2) Os conteúdos necessitam ser desenvolvidos progressivamente, levando em consideração a maturidade do aluno. Tenciona-se apresentá-los de forma mais ampla e mais organizada, "uma forma que gradualmente se aproxima daquela em que os conteúdos das matérias de estudo são apresentados para as pessoas mais habilitadas e mais amadurecidas." (p. 76). Essa perspectiva se aproxima das próprias tendências naturais de desenvolvimento da criança e a partir das experiências e suas conexões, o ambiente de aprendizado e as noções de tempo e espaço vão se expandindo naturalmente. Em suma, a organização dos conteúdos de ensino se expandem "a partir da ampliação da experiência do aluno" (Dewey, 1998, p. 77).

A escola deve produzir seu material a partir da experiência presente, capacitando o aluno a reagir aos problemas do presente e do futuro. Isso não significa um abandono do passado, como adverte Dewey (1998, p. 79-80), já que "as descobertas do passado constituem o único meio capaz de nos possibilitar compreender o presente.” Para o educador:

[...] assim como o indivíduo precisa recorrer à memória do seu próprio passado para compreender as condições em que ele individualmente se encontra, também as questões e problemas da vida social presente estão em conexão tão íntima e direta com o passado que os alunos não podem estar preparados para compreender tais problemas e nem a melhor forma de lidar com eles sem explorar suas raízes no passado. (Dewey, 1998, p. 80). 
O passado não é um fim em si mesmo, mas um meio para a compreensão do presente. A partir de seus ensaios na escola experimental da Universidade de Chicago, Dewey (2002) elaborou algumas diretrizes para o ensino de História.

\begin{tabular}{|c|c|c|c|c|}
\hline Estágio & Modalidade & Fins & Idade & Conteúdos \\
\hline \multirow{3}{*}{$1 \%$} & \multirow{3}{*}{$\begin{array}{l}\text { História } \\
\text { generalizada e } \\
\text { simplificada }\end{array}$} & \multirow{3}{*}{$\begin{array}{l}\text { Desenvolver } \\
\text { sensibilidade e simpatia } \\
\text { por atividades sociais }\end{array}$} & 6 & Ocupaşões da cidade e do campo \\
\hline & & & 7 & Invençठ̄es e suas consequências na vida \\
\hline & & & 8 & Migração, exploração e descoberta \\
\hline \multirow{3}{*}{$2 \%$} & \multirow{6}{*}{$\begin{array}{l}\text { História dos } \\
\text { fatos positivos }\end{array}$} & \multirow{6}{*}{$\begin{array}{l}\text { Desenvolver a } \\
\text { capacidade de lidar com } \\
\text { fatos limitadose } \\
\text { positivos }\end{array}$} & 9 & \multirow{3}{*}{ Experiência da cidade, estado e do país } \\
\hline & & & 10 & \\
\hline & & & 11 & \\
\hline \multirow{3}{*}{$3^{\circ}$} & & & *12 & \multirow{3}{*}{$\begin{array}{l}\text { Experiência do mundo antigo } \\
\text { mediterrâneo, história europela e } \\
\text { singularidades da história do país }\end{array}$} \\
\hline & & & 13 & \\
\hline & & & 14 & \\
\hline
\end{tabular}

Figura 1 - Programa de John Dewey para o ensino de História (1906)

Fonte: Freitas $(2014)^{55}$.

O esquema de Dewey (2002), denominado por ele como "interpretação psicológica da História", inicia-se pelo estudo das ocupações e introduz as crianças nos labores humanos. Isso porque "todas as ocupações podem ser entendidas como instâncias das relações fundamentais do homem com o mundo em que vive." (p. 119). Diariamente, lidamos com "coisas que são resultados destas ocupações” (p. 119). O passo seguinte são as invenções e suas consequências, as grandes migrações, explorações e contatos entre diferentes povos. A partir do segundo estágio de aprendizagem, o aluno entra em contato com as experiências locais, do estado e do país. No último estágio do desenvolvimento escolar, próximo ao ensino secundário, passa-se, de acordo com Dewey (2002, p. 137), a respeitar a ordem cronológica (começando pelos povos do mediterrâneo) e a maior especialização. Aqui, o aluno deve estar pronto para lidar com diferentes tipos de vida social, entendendo o significado de cada uma delas e suas contribuições para o "conjunto da história mundial".

Se as matérias escolares devem ser dosadas de acordo com o estágio de desenvolvimento do aluno, o seu ensino não pode se processar de forma isolada ou compartimentada. "A significação da Geografia e da História”, capítulo da obra "Democracia e educação", reforça muitos aspectos tratados em "O objetivo da História na educação elementar" e se propõe a analisar e a defender a interdependência e a complementaridade da História e da Geografia escolares.

\footnotetext{
${ }^{55}$ A figura foi extraída do artigo "Pensar historicamente em John Dewey?", publicado no blog do professor Itamar de Freitas. Disponível em: <http://itamarfo.blogspot.com.br/2014/10/pensarhistoricamente-em-john-dewey.html>. Acesso em: 23 out. 2017.
} 
Pois o que chamamos geografia como estudo concatenado é simplesmente o conjunto de fatos e princípios descobertos pela experiência de outros homens acerca do meio natural em que vivemos, em conexão com o qual os atos particulares de nossa vida têm uma explicação. Do mesmo modo, a história como estudo coordenado é unicamente o corpo de fatos conhecidos sobre as atividades e sofrimentos dos grupos sociais nos quais se insere, em perfeita continuidade, a nossa própria vida e com os quais se iluminam e se esclarecem os nossos próprios costumes e instituições. (Dewey, 1959, p. 231).

Ainda segundo Dewey (1959, p. 229-230), a História e a Geografia são disciplinas escolares informativas, porém, não podem ser estudadas apenas como conhecimentos dispostos em "montes isolados" e sem conexão. Ao serem ensinadas "como matérias já feitas e sistematizadas que um indivíduo estuda simplesmente porque o mandaram à escola" é natural que se aprenda grande número de conhecimentos, mas "sobre coisas remotas e estranhas à experiência cotidiana". Isto é, um "acúmulo de conhecimento, separado dos interesses diretos da vida". Tais disciplinas, articuladas à "experiência viva e atual”, possibilitam o enriquecimento da experiência individual. A partir de seu ensino, o indivíduo apropria-se da experiência do grupo ao qual se vincula. Se a Geografia permite a compreensão das relações espaciais presentes em diferentes atos, a História aumenta a capacidade de reconhecimento de suas relações humanas.

A História e a Geografia possuem o mesmo objeto, ou seja, a vida do homem em sociedade, porém enfatizam, respectivamente, os aspectos físicos (o elemento natural) e os aspectos sociais (o elemento humano). A função de seu ensino, como adverte Dewey (1959, p. 232), “é enriquecer e dar expansão aos contatos mais diretos e pessoais da vida fornecendo-lhes seu contexto, seus apoios ou fundamentos e sua perspectiva e horizonte." Ainda de acordo com o educador americano, quando se suprime a necessária complementaridade, que deve caracterizar o ensino da História e da Geografia, a História se degrada e se torna uma "lista de datas", "apêndice de acontecimentos rotulados de 'importantes", e a Geografia "apresenta-se como aquela moxinifada de fragmentos desconexos que com tanta frequência vemos." Valorizam-se os nomes dos rios, limites de municípios, em detrimento das conexões "entre os fatos naturais e os eventos sociais.” (Dewey, 1959, p. 232-233).

A História na concepção deweyana, como destacamos, é a "chave para a compreensão do presente". O grande problema de seu ensino está no divórcio entre os aspectos estudados através da História e "os interesses da vida social". 
Desse modo, nas palavras do educador, "o verdadeiro ponto de partida da História é sempre alguma situação atual com seus problemas." (Dewey, 1959, p. 236). Esse princípio deve ser levado em consideração no ensino da disciplina. O presente vivenciado por John Dewey se caracteriza pelo progresso, pelo sucessivo desenvolvimento humano, pela marcha para o oeste americano, pelo florescimento da indústria. Isso o faz valorizar, como salientamos a partir da leitura do texto "O objetivo da História na educação elementar", a história econômica ou industrial.

A história econômica ou industrial trata da atividade, da carreira e do êxito do homem comum, como não o faz nenhum outro ramo da História. A coisa mais importante que todos os indivíduos devem fazer é manter-se; a coisa mais importante que a sociedade deve fazer é obter de cada indivíduo sua eficaz contribuição para o bem-estar geral e velar para que seja dada a cada um sua justa retribuição. (Dewey, 1959, p. 237, grifos do autor).

A história da indústria se associa à Geografia e por meio dela é possível conhecer as sucessivas invenções que, aplicadas à natureza, levaram à “prosperidade da vida social” (Dewey, 1959, p. 237). A história econômica é mais democrática, na visão de Dewey, porque está preocupada não com a ascensão e a queda de principados e poderes, mas com o "domínio da natureza efetuado pelo homem comum, que é para quem existem poderes e principados" (p. 238). Outro aspecto valorizado no ensino de História é o intelectual. Dewey (1959) argumenta que o progresso da humanidade não foi feito por reis ou generais, mas pelos cientistas, descobridores e inventores que possibilitaram ao homem os instrumentos para o seu desenvolvimento. Do mesmo modo, suas vitórias e derrotas foram (re)significadas pelos artistas e poetas. Quando se omitem esses dois aspectos da História o seu ensino torna-se pouco produtivo.

Em síntese, a História "é um instrumento para analisar-se a urdidura da presente vida social, e para tornar conhecidas as forças que criaram os seus padrões." (Dewey, 1959, p. 239). A obra de John Dewey se caracteriza por salientar as inter-relações entre a vida e a educação. Os conteúdos escolares tinham que ter finalidades práticas. No Brasil, da década de 1930, a influência francesa, que caracterizou a constituição do código disciplinar da História escolar, cedeu espaço para a influência da filosofia educacional americana (Martins, 2000). A inspiração deweyana favoreceu, entre outros aspectos, a crítica ao ensino de caráter factual, descritivo e conteudista que predominava nas escolas 
brasileiras. Muito do contato com essas ideias se deu através dos intercâmbios e das viagens pedagógicas aos Estados Unidos nas primeiras décadas do século XX.

\section{2 \\ Os educadores brasileiros e as "viagens pedagógicas" americana" e o contato com a obra de Dewey}

As primeiras décadas do século XX, sobretudo a partir do decênio de 1920, caracterizaram-se por intensas modificações nos setores político, econômico e sociocultural brasileiro. Para Jorge Nagle (1974, p. 99-100), a difusão de "novos padrões de pensamento" favoreceu o aparecimento do "otimismo pedagógico" e do "entusiasmo pela escolarização". Intelectuais, políticos e educadores passaram a considerar a escolarização como um "motor da História" e o principal "problema nacional”, cuja solução contribuiria para a resolução de todos os outros problemas. A partir dela seria possível reformar a sociedade e conduzir o país ao progresso. Houve, nessa ocasião, "uma preocupação bastante vigorosa em pensar e modificar os padrões de ensino e cultura das instituições escolares, nas diferentes modalidades e nos diferentes níveis" (Nagle, 1974, p. 100). Temas como a alfabetização, a expansão da escola primária, a reforma da escola secundária e a construção de um sistema de ensino superior universitário, tornaram-se parte do programa de associações e educadores.

A maior circulação dessas ideias no Brasil deu-se a partir das revistas de educação, boletins e da criação da Associação Brasileira de Educação (ABE), em 1924. Esse órgão foi responsável pela institucionalização das discussões em âmbito nacional e reuniu diferentes figuras, de educadores a políticos, em seus cursos, palestras, inquéritos e conferências. A ABE fortaleceu o desenvolvimento de "técnicos em educação", nova categoria profissional responsável por tratar das questões educacionais (Nagle, 1974). Muitos deles, inspirados pelo movimento da escola nova, estavam inseridos nos quadros administrativos estatais e estruturaram um campo para sua atividade profissional, sendo responsáveis pelas reformas desenvolvidas em diferentes estados da federação ao longo das décadas de 1920 e

\footnotetext{
${ }^{56}$ São "viagens de caráter oficial ou particular realizadas por educadores com a intenção de se aproximar de políticas educacionais ou de práticas pedagógicas inovadoras." (Mignot \& Gondra, 2007, p. 9). Cf.: coletânea organizada por Mignot \& Gondra (2007) e a tese de Cardoso (2015).
} 
de 1930 (Lopes, 2006) ${ }^{57}$. Esses educadores não estiveram alheios às políticas desenvolvidas em outros países. Com o intuito de conhecê-las, em muitas oportunidades com financiamento da $\mathrm{ABE}$, eles realizaram diversas viagens pedagógicas a países da Europa e da América (Mignot \& Gondra, 2007).

As viagens pedagógicas, que ocorriam desde o século XIX, inseriram-se no conjunto de estratégias utilizadas por educadores e reformadores em busca da aproximação "do que havia de mais moderno em termos de educação" (Mignot \& Gondra, 2007, p. 8). Como vimos no capítulo anterior, em relação ao ensino de História, por exemplo, considerava-se que os métodos de ensino, os livros e, de forma mais geral, a própria estrutura escolar brasileira encontravam-se atrasados e em descompasso com o sentido de progresso pleiteado por diferentes grupos nacionais. Desse modo, ocorreu um estímulo ao "conhecimento de experiências pedagógicas estrangeiras" através, entre outras ações, da tradução de obras, do envio de missões docentes ao exterior e da recepção de personalidades intelectuais de outros países no Brasil. Para Mignot \& Gondra (2007), trata-se de um processo de circulação de modelos educacionais que não foi restrito ao Brasil.

$A$ intenção da $\mathrm{ABE}$ era que os viajantes vivenciassem um modelo considerado exemplar e depois pudessem contribuir para o desenvolvimento da educação em nosso país (Cardoso, 2015). Para os intelectuais-educadores, isso representou uma forma de especialização com a qual ainda não tinham contato por aqui. Não havia universidades, apenas cursos profissionais de Direito, Engenharia e Medicina, nem cursos de pós-graduação. Os educadores eram, sobretudo, autodidatas, formados em outras áreas do conhecimento. A Europa e, posteriormente, os Estados Unidos, eram os locais onde essa formação específica era obtida. Foi nesse contexto que Anísio Teixeira e Delgado de Carvalho responsáveis, respectivamente, pela reforma de ensino no Distrito Federal (19311935) e pela introdução do ensino de Estudos Sociais no Brasil - entraram em contato com o sistema educacional americano e com a obra do filósofo e educador John Dewey. Após as suas próprias viagens e estudos na Universidade de Columbia, incentivaram os colegas a trilharem o mesmo caminho.

\footnotetext{
${ }^{57}$ Entre as principais reformas educacionais do período, podemos destacar: "no Ceará, em 1922, com Lourenço Filho; sob a orientação de Anísio Teixeira na Bahia, em 1925, e no então Distrito Federal entre 1931 e 1935; em Minas Gerais com Francisco Campos, em 1927; com Carneiro Leão, no Pernambuco, em 1928; Fernando de Azevedo promoveu reformas no Distrito Federal, no período de 1927-1930, e em São Paulo, em 1932.” (Peres, 2005, p. 117).
} 
Em 1927, como inspetor geral de ensino da Bahia, Anísio Teixeira fez a primeira de suas viagens de estudos aos Estados Unidos ${ }^{58}$. Desta viagem decorrem dois importantes registros: um diário - composto por um "conjunto de notas, produzidas durante os treze dias em que esteve a bordo do navio Pan America" (Gondra \& Mignot, 2006, p. 10) - e um relatório intitulado “Aspectos americanos de educação" ${ }^{\text {59 }}$. Os documentos apresentam características diferentes. O diário de bordo é uma "escrita de intimidade", "uma forma de capturar o instantâneo, de documentar dúvidas e expectativas" e "contém impressões elaboradas ao sabor do vivido" (Gondra \& Mignot, 2006, p. 10-11). Nele, Anísio Teixeira expressa suas escolhas e expectativas. Tinha como objetivo conhecer os sistemas de ensino de outros países, enquanto buscava aprendizado e renovação:

Sigo para a América com o espírito de um estudante. Renovo as minhas disposições de curiosidade, de entusiasmo pelo novo e pelo inédito. Não prevejo qual seja o meu depoimento sobre o povo que hoje é objeto de tanta curiosidade e fonte de tantas lições. Tenho tanto a aprender. O sentido da viagem por turismo, por prazer, é que me falta. As viagens terão sempre para mim esse travo sério de alto exercício espiritual. (Teixeira, 1927 apud Teixeira, 2006, p. 201-202).

Ao assumir a direção da instrução baiana, Anísio não se encontrava preparado para os exercícios decorrentes dessa função. De acordo com Nunes (2010, p. 16), neste momento, iniciou conversas pedagógicas com outros reformadores, como Antônio Carneiro Leão e Afrânio Peixoto, e leu "Métodos americanos de educação", de autoria do belga Omer Buyse. O jovem educador, com formação católica europeia, obtida em colégios jesuítas, e egresso da Faculdade de Direito do Rio de Janeiro, procurava modelos referenciais para sua atuação enquanto educador e gestor. As viagens assumiram, para Anísio Teixeira, um "exercício espiritual" de aprendizagem. Uma oportunidade de conhecer os métodos de ensino, os programas escolares, o funcionamento das instituições, o comportamento de professores e alunos, o formato das aulas de outros países. Do mesmo modo, era uma forma de combater o cansaço proveniente da dura

\footnotetext{
58 Anísio Teixeira assumiu a Inspetoria Geral de Ensino da Bahia a convite do governador Francisco Marques de Góis Calmon, em 1924, e permaneceu nesta função até 1929. Em 1925, realizou sua primeira viagem pedagógica à Europa, o que permitiu-lhe realizar comparações entre o modelo de ensino europeu e o americano (Teixeira, 2006).

59 O diário é parte do arquivo de Anísio Teixeira, depositado no Centro de Pesquisa e Documentação de História Contemporânea do Brasil (CPDOC), da Fundação Getúlio Vargas (FGV). "Aspectos americanos de educação" foi distribuído pela Tipografia São Francisco (Bahia), em 1928. Ambos os documentos foram reunidos em publicação que compõe o primeiro volume da Coleção Anísio Teixeira da editora da UFRJ. Cf. Teixeira (2006) e Gondra \& Mignot (2006).
} 
realidade educacional com que tinha de lidar diariamente: "pobreza de recursos humanos e materiais" (Nunes, 2010, p. 16-17), corrupção, despreparo do professor, poucas escolas em funcionamento e em condições precárias.

Em suas palavras, a bordo do navio que o levava aos Estados Unidos, a vida na Bahia e o trabalho o condenavam à fadiga. De certo modo, incapacitava a sua renovação (Teixeira, 2006). A América era tida como o "novo", sinônimo de progresso e desenvolvimento. Como uma de suas atividades, "realizou uma excursão de estudos, visitando estabelecimentos de ensino em vários pontos do país” (p. 81). De grandes a pequenas cidades, de escolas rurais a urbanas, escolas normais e universidades, além da Associação Nacional de Educação, nada escapou às observações atentas do educador baiano, cujas impressões compõem o relatório "Aspectos americanos de educação". Ao visitar a Escola Normal de Towson, em Maryland, ele se encantou com a modernidade dos prédios escolares, com sua tranquilidade e espaços largos e amplos. Não se furtou a comparar com aquilo que viu na Europa e afirmou que nenhum dos colégios deste continente apresentava "os aspectos materiais prósperos e modernos dos colégios americanos" (p. 100). Outro objeto de comparação foi o currículo. Os colégios americanos se caracterizavam, segundo Anísio Teixeira (2006, p. 143-144), por:

[...] métodos de ensino vivos, práticos, em que participam igualmente professores e discípulos; um currículo flexível e rico, com extraordinária variedade de cursos, de sorte que permita uma adequada adaptação às necessidades e preferências dos discípulos; e uma vida tão diversa e variada, com tantas associações e clubes e tão grande atividade coletiva, que fazem, de fato, que a vida de colégio não seja, neste país, o período de noviciado e provação que é entre nós, mas um período rico e fecundo, de plena vida social.

A realidade americana se chocava com o desaparelhamento e a monotonia dos colégios brasileiros, centrados nas preleções dos professores, distanciados da vida e da sociedade que os cercavam. As escolas brasileiras, e o ensino de História em particular, estruturaram-se a partir do "ouvir". "Tudo foi concebido para pôr as crianças a 'ouvir'.” Nesse modelo, considerado como tradicional, segundo Dewey (2002, p. 38), os materiais estão prontos e há poucas oportunidades dos alunos trabalharem; não há atividades no sentido de criação, construção. $\mathrm{O}$ mestre concentra-se no manual e o aluno na sua leitura e na atenção às falas do professor. Apenas ouvir, para o filósofo americano, significa passividade, simples absorção e, como sinalizamos no capítulo anterior, consequente memorização para os exames. Em seu relatório, Anísio Teixeira questiona a situação brasileira. 
Ao contrário da "aula conferência" ou da "aula lição", que pressupunha apenas o ato de "ouvir" e memorizar dos alunos, na América do Norte, de acordo com a avaliação de Anísio, as aulas ocorriam por meio do "sistema de problema" e "discussão coletiva". Muitas vezes, assinala, os alunos iniciavam a discussão e o professor guiava os debates. A escola atuava "como uma comunidade unida pela participação em atividades comuns" (Dewey, 1998, p. 57). No modelo brasileiro, lia-se o que foi pensado pelo outro, no geral em grandes compêndios, com poucas possibilidades de discussão. No dizer de Teixeira (2006, p. 108), "pensamento ou conhecimento recebido passivamente é somente meio pensamento ou meio conhecimento.” Portanto, para o bom aprendizado, era preciso uma situação de real problema e de experiência, que permitisse ao aluno "fazer", construir seu próprio pensamento e reflexão original. Para Teixeira (2006, p. 100), os colégios americanos participavam da "mesma febre com que a vida está perpetuamente se elaborando do lado de fora dos seus muros". Um princípio deweyano que Anísio levaria por toda a vida: a ideia da não dissociação entre sociedade e educação.

A primeira viagem durou sete meses e, na argumentação de Nunes (2007, p. 145), pôs Teixeira em contato com as obras de Dewey, permitindo-lhe montar uma rede de sociabilidade e "ainda lhe preparou o terreno para uma visita mais prolongada àquele país”. Se a viagem a Europa lhe trouxe dúvidas - a ponto de o educador argumentar "que o aprendizado foi muito curto" - a primeira temporada americana impôs certezas ${ }^{60}$. Ao retornar ao Brasil, em carta ao pai Deocleciano Pires Teixeira, de 18 de novembro de 1927, Anísio afirmou a importância da viagem aos Estados Unidos e o desejo de não mais se afastar da educação:

Demorei-me nos Estados Unidos cerca de seis meses. Durante esse tempo estudei, visitei escolas, fiz boas relações e acredito que aprendi um pouco. A nomeação com que me surpreendeu o Dr. Calmon no princípio de seu governo, marcou a minha carreira. E hoje, por gosto e pela orientação que têm os meus estudos, pretendo não me afastar mais do campo da educação onde comecei a minha vida. São essas as disposições que trago da América e quero crer que o Brasil e a Bahia, apesar de todos os aborrecimentos dos jornais e de todas as flutuações da política, me ajudarão, ou pelo menos não me impedirão esse desejo. Nenhum trabalho poderia me apaixonar, que fosse mais vasto ou mais necessário do que este. $\mathrm{E}$, sobretudo, irredutivelmente idealista como me parece que sou, nenhum outro me será tão querido ao coração e à inteligência. Dentre as vantagens da minha excursão à América, aponto como uma das principais a renovação desse entusiasmo que me ia gastando no atrito da vida baiana e a segurança com que me

\footnotetext{
${ }^{60}$ Tais informações constam no documento intitulado "Anotações de viagem à Europa", 16 de novembro de 1925. O manuscrito original compõe o acervo Anísio Teixeira do CPDOC-FGV e está disponível em: <http://www.bvanisioteixeira.ufba.br/>. Acesso em: 25 jun. 2017.
} 
vou dedicar ao trabalho que, em circunstâncias tão excepcionais, veio a cair-me sobre os ombros $[\ldots]{ }^{61}$

Apesar das mudanças políticas que se processavam na Bahia, com a eleição de um novo governador, e das críticas que começava a sofrer na imprensa, seu objetivo inicial com a primeira viagem foi plenamente alcançado, como escreveu ao pai. Estava renovado e entusiasmado. A obra "Aspectos americanos de educação", cuja primeira edição é de 1928, é considerada a primeira grande síntese do pensamento de Dewey publicada no Brasil. A apresentação dessas ideias tinha como objetivo, de acordo com Teixeira (2006, p. 29), despertar o interesse pela revisão das concepções brasileiras. Entre 1928 e 1929, Anísio retornou aos Estados Unidos para estudar no Teachers College da Universidade de Columbia, onde se graduou em Master of Arts. Durante esse período, teve aulas com William H. Kilpatrick e com o próprio Dewey. A historiografia educacional brasileira defende que a passagem de Anísio Teixeira pelos Estados Unidos $^{62}$, no final da década de 1920, foi fundamental para sua trajetória e formação (Gondra \& Mignot, 2006; Nunes, 2007). No Brasil, Teixeira “elegeu Dewey como sua plataforma de lançamento no mundo" (Nunes, 2007, p. 152), tornando-se seu principal leitor e tradutor ${ }^{63}$. Com a leitura de Dewey, ele rompeu com o autodidatismo em questões educacionais que caracterizou seu ingresso nessa seara. "O pragmatismo deweyano forneceu-lhe um guia teórico que combateu a improvisação e o autodidatismo, permitiu-lhe operacionalizar uma política e criar a pesquisa educacional no país.” (Nunes, 2010, p. 19).

Os primeiros textos de Dewey traduzidos em português foram dispostos no livro "Vida e educação", de 1930, com uma breve apresentação escrita por Anísio. Naquele período, o educador brasileiro produziu, ainda, as obras "Educação progressiva: uma introdução à filosofia da educação" (1932), "Em marcha para a democracia" (1934) e "Educação para a democracia: introdução à administração escolar (1936). Em 1936, após deixar o Distrito Federal, traduziu “Democracia e

\footnotetext{
${ }^{61}$ Carta de Anísio Teixeira ao pai Deocleciano Pires Teixeira, Bahia, 18 de novembro de 1927. Disponível em: <http://www.bvanisioteixeira.ufba.br/index.html>. Acesso em: 15 jun. 2017.

${ }^{62}$ Retornou ao país em outras ocasiões. Em 1963, foi agraciado com a "Medalha de honra por serviços relevantes", concedida pelo Teachers College da Universidade de Columbia. Pós-1964, atuou como professor visitante em universidades americanas.

${ }^{63}$ Barbosa (2015, p. 68) afirma que, apesar de ser o principal, Anísio não foi o primeiro a expor as ideias de Dewey no país. Para ela, "desde 1927, referências e citações das obras de Dewey são encontradas em documentos e livros brasileiros. Foi a primeira influência estrangeira que os educadores locais buscaram ou, pelo menos, falaram em operacionalizar em termos nacionais, procurando adaptá-la às necessidades e características da sociedade brasileira daquele tempo."
} 
educação". Chaves (1999), ao analisar as escritas de Dewey e Teixeira, argumenta haver uma "afinidade eletiva" entre os dois autores. A simbiose é tanta que algumas passagens dos textos de Anísio têm as mesmas palavras presentes nas obras de Dewey. Isso se explica, segundo a autora, por três pontos.

O primeiro se relaciona ao caráter da produção anisiana. Os seus livros, em sua maioria, representam compilações de textos publicados em revistas, conferências, entre outros, ou trechos de relatórios, o que leva a poucas citações e referências. Esse tipo de escrita favorece a permanência de "aspectos da oratória" e exime o seu autor do "compromisso de explicitar a todo momento a fonte do seu discurso". O segundo se relaciona à intenção de Anísio, como fica explicitado na sua apresentação de "Aspectos americanos de educação", em "ser um veículo das palavras de Dewey", com as quais concorda. E, por último, a internalização. Como tradutor dos títulos de Dewey, "as ideias do filósofo americano teriam sido tão bem internalizadas pelo educador brasileiro que este as torna suas, passandoas adiante como se fossem suas." (Chaves, 1999, p. 90-91). Esta escolha intelectual, de acordo com Nunes (2010, p. 36, 41), forneceu, a Teixeira, "chaves de leitura da sociedade e da educação" e uma "resposta programática para as questões educacionais com as quais estava lidando". A filosofia deweyana, como base conceitual, deu a Anísio suporte e legitimação para sua ação na gestão da educação (Nunes, 2007). No Rio de Janeiro, Distrito Federal, buscou empreender uma reforma educacional inspirada nas suas aprendizagens na América.

As viagens pedagógicas também assumiram grande importância para alguns dos principais colaboradores de Anísio entre os anos de 1931 e 1935. Foi nos Estados Unidos, no apartamento do então Cônsul Geral do Brasil em Nova York, Sebastião Sampaio, que Anísio Teixeira conheceu o geógrafo e educador Carlos Miguel Delgado de Carvalho, a quem indicaria para ocupar importantes cargos em sua administração: direção do Instituto de Pesquisas Educacionais e docência na Universidade do Distrito Federal. Sobre esse evento, temos o relato de Delgado.

[...] em 1928, eu o encontrei em Nova York, seguindo as aulas dos mestres do dia: Dewey, Kilpatrick, Bagley e outros que, pelo seu operoso intermédio, tiveram tão grande influência nas correntes educacionais brasileiras do período de entreguerras: Anísio mestre-estudante, nas aulas de Dewey me lembrava o czar Pedro o Grande da Rússia, trabalhando como operário nos estaleiros de construção naval da Holanda para, em seguida, se dedicar com maior eficiência, à grandeza da sua terra. Era então um rapaz de vinte e tantos anos o nosso Anísio, magro, ágil, cheio de entusiasmo e de energia, dotado de impressionante mobilidade espiritual. Apesar de muito mais velho, encontrei logo nêle, não só um colega amigo, mas já 
um mestre ao qual fiquei ligado pela afeição como também pela mais sincera admiração. (Carvalho, 1960, p. 220).

O texto de Carvalho (1960) tem como objetivo celebrar os 60 anos de vida de Teixeira. Nele, o autor salienta uma filiação comum: o pensamento educacional deweyano, sinalizando a aproximação intelectual entre os dois educadores e destaca um elemento central das viagens pedagógicas realizadas por ambos: a formação nos Estados Unidos, para posterior ação no Brasil. Primeiro presidente da $\mathrm{ABE}$, da qual foi um dos fundadores, Delgado de Carvalho manteve, ao longo das décadas de 1920 e 1930, uma íntima relação de intercâmbio e de trabalho com intelectuais e professores americanos, os recebendo no Brasil, e realizando várias visitas acadêmicas aos Estados Unidos. Com a intenção de reforçar os laços de cooperação entre este país e o Brasil, atuou na fundação do Instituto BrasileiroAmericano e da Escola de Estudos Brasileiros. Enquanto o primeiro tinha como objetivo estabelecer contatos entre professores e metodologias dos dois países, o segundo se propunha a "oferecer aos professores norte-americanos cursos de formação referentes à História e Geografia do Brasil.” (Cardoso, 2015, p. 55).

Delgado, a ABE, o Instituto Histórico e Geográfico Brasileiro (IHGB) e o Ministério das Relações Exteriores convidaram o presidente do Instituto Internacional de Educação, Dr. Stephan Duggan, e um grupo de americanos, provenientes de diferentes universidades, para visitarem o Brasil em 1929 e 1930. O IHGB organizou o curso de Estudos Brasileiros, ministrado por intelectuais, como o próprio Delgado de Carvalho, Carneiro Leão, Afrânio Peixoto e Pándia Calógeras, na sala de conferências do Ministério das Relações Exteriores. Do mesmo modo, os estrangeiros se dedicaram a "observar os nossos problemas didacticos" e a visitarem as escolas do Distrito Federal (Diario Carioca, 1929, p. $2)^{64}$. Esses contatos pavimentaram a organização de viagens que Delgado de Carvalho fez, sozinho ou em grupo, aos Estados Unidos, entre 1928 e 1939.

Em 1928, Delgado realizou a sua primeira viagem aos Estados Unidos e visitou o Summer School for American Teachers e o Teachers College da Universidade de Columbia, onde assistiu cursos com Anísio Teixeira. A partir

\footnotetext{
${ }^{64}$ Os jornais fluminenses informam outra recepção a educadores americanos ocorrida em 1939. Na ocasião, Carvalho proferiu uma conferência em língua inglesa intitulada "Aspectos da geographia humana do Brasil" (Diario de Noticias, 1939, p. 4). Neste mesmo ano, Delgado de Carvalho foi convidado pela Fundação Carnegie para proferir conferências e cursos em universidades americanas: University of Washington and Lee, Rice Institute (Texas) e University of Michigan.
} 
dessa experiência, alguns princípios passaram a nortear a produção acadêmica e didática e a prática de ensino do professor Delgado de Carvalho. Temas como "aprendizagem pela experiência", "curiosidade e motivação", "interesse", “cooperação" e "democracia" tornaram-se objetos de reflexão do educador.

A concepção de Estudos Sociais, desenvolvida por Delgado de Carvalho a partir da década de 1930, também é devedora de suas viagens aos Estados Unidos e do contato com o Social Studies, praticados nas escolas americanas. Para ele, o ensino de Estudos Sociais tornou-se possível devido à educação progressiva (Carvalho, 1934c). Em seus cadernos de aulas, identificamos leituras, fichamentos e análises de livros de Dewey, como "A escola e a sociedade", que serviram como base para as suas obras sobre a educação e o ensino de Estudos Sociais:

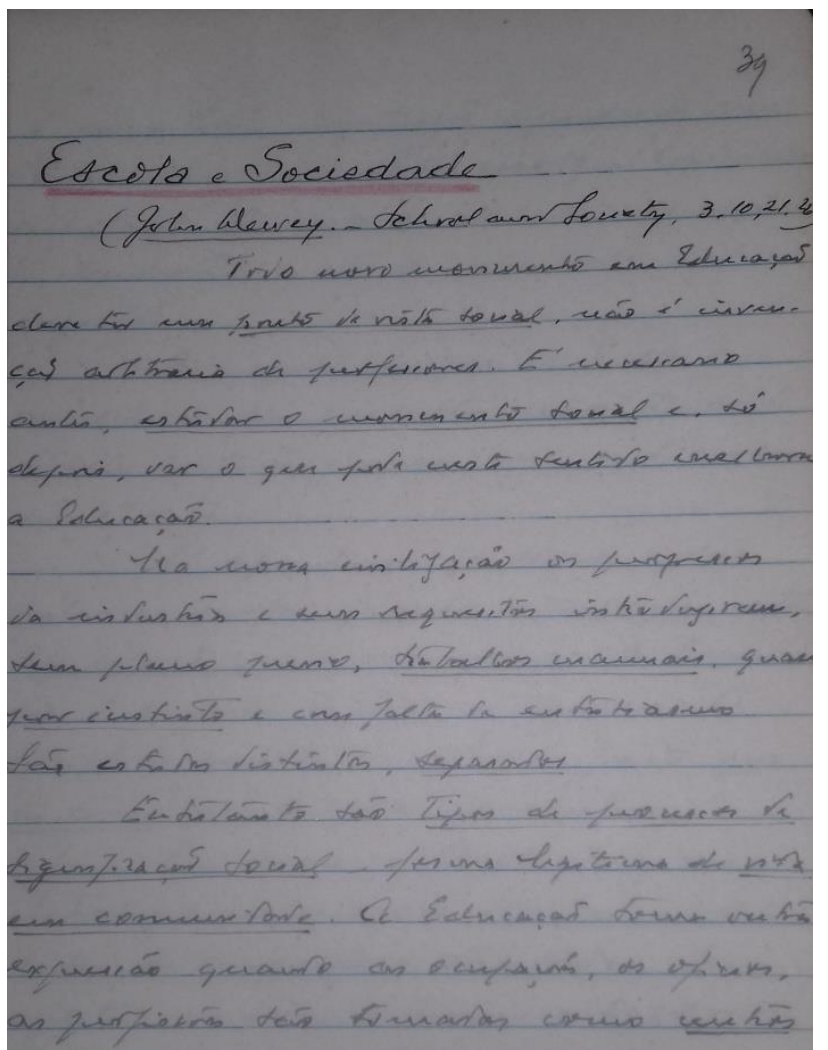

Figura 2 - Caderno de Metodologia das Ciências Sociais. O indivíduo, a escola, a educação em trechos de John Dewey (p. 35)

Fonte: Coleção Delgado de Carvalho (CDC/IHGB) ${ }^{65}$.

O meio social em constante renovação torna necessário um "processo de adaptação" ou "reconstrução da experiência". Na espécie humana, como assevera Carvalho (1934c, p. 11), a orientação e a direção das experiências futuras cabem à educação. Desse modo:

\footnotetext{
${ }^{65}$ Lata 1. Pasta 2: Estudos diversos de sociologia.
} 
[...] a Educação tem, como a experiencia o seu processo e os seus meios que se confundem com os seus próprios fins e seus resultados. Assim como a vida aprende-se vivendo, a experiencia, experimentando, assim tambem a Educação traz em si o seu processo e seu objectivo. Por isso, traduz bem o conceito moderno a formula: Educação é vida. (Carvalho, 1934c, p. 12-13).

Essa abordagem, para Carvalho (1934c), é fundamental para compreensão das novas teorias e as modificações que estas geraram nos métodos, nos programas e na interpretação de objetivos sociais e da educação. A escola é um meio artificial criado para organizar e sistematizar a reconstrução da experiência, devendo ser um ambiente simplificado que reflete a complexidade da vida, conforme sintetizam Dewey e Teixeira. Portanto, deve oferecer mecanismos para que o indivíduo continue crescendo, educando-se e renovando suas experiências ao longo da vida. Em relação ao ensino secundário, a escola deve promover a adaptação do indivíduo à vida cívica e econômica do país: “a formação do cidadão como membro consciente e activo da sociedade" (Carvalho, 1934c, p. 14). Para isso, era imperioso "desacademizar pouco a pouco os programmas", tornando-os menos sobrecarregados. Segundo Carvalho (1934c, p. 79-80):

[...] o defeito principal das concepções educativas, anteriores ao movimento pedagogico norte-americano, residia na sobrevivenvia em todos os systemas propostos, do principio de autoridade exterior, imposto aos alunmos; em vez de procurar despertar em cada um delles a autoridade interna, a escola era uma pequena monarchia absoluta que tinha a missão de preparar cidadãos para um paiz livre.

Os programas escolares eram acadêmicos, distantes da vida, e a forma como a aula era ministrada também se revelava um problema. Ao contrário das escolas americanas, democráticas em sua natureza, como também apontou Anísio em seu relatório, o modelo brasileiro era uma espécie de "monarquia absolutista", onde predominavam os interesses externos à criança e a autoridade docente. Trata-se, de acordo com Dewey (2002, p. 40), de um dos "aspectos típicos da velha educação". A educação se situa no professor, no manual, mas não leva em consideração os "instintos e atividades imediatas da própria criança". Isso causa, ainda segundo a argumentação do educador americano, um desperdício ou "isolamento da escola quanto à vida". De um lado, a escola é incapaz de utilizar as experiências que os alunos adquirem fora dela. Por outro, a criança não consegue utilizar na vida diária os aprendizados escolares. Como resultado:

[...] quando a criança entra na sala de aula tem de abdicar de uma grande parte das suas ideias, interesses e atividades, que predominam na sua casa e no mundo que a 
circunda. Desta forma, a escola, ao tornar-se incapaz de utilizar a experiência cotidiana, tenta dolorosamente outra abordagem e por vários meios para despertar na criança um interesse pelos estudos escolares. (Dewey, 2002, p. 67).

A educação progressiva parte do princípio de que a criança deve ter a oportunidade de praticar a vida. Não basta conhecer os fatos, memorizá-los para a realização de uma prova, mas é preciso praticá-los e interpretá-los para melhor reconstrução da experiência e adaptação à sociedade. Para tal, Dewey, em "A escola e a sociedade", propõe um novo prédio escolar com laboratórios, bibliotecas, cozinhas e jardins. A forma prática se relaciona às "necessidades de ação e expressão da criança, ao seu desejo de fazer algo, de ser construtivo e criativo, em vez de ser simplesmente passiva e submissa." (Dewey, 2002, p. 7071). A essa educação correspondem novos métodos e programas. Nela se incluem os Estudos Sociais, formados por disciplinas que não devem estar alheias à experiência diária e nem separadas da realidade (Carvalho, 1934c, p. 100).

A integração no ensino e a articulação entre as diferentes disciplinas permitiriam, para Delgado, a concretização da finalidade da educação, ou seja, a reconstrução da experiência e a formação para a democracia. Sociedade democrática, conforme argumenta Mendonça (2002, p. 49), analisando os escritos de Anísio Teixeira, é aquela em que há a livre circulação de ideias e triunfam as que têm maior mérito. Segundo Carvalho (1934c, p. 35), "o povo é uno, não pela igualdade de capacidades que nunca poderá existir, mas sim pela igualdade absoluta de opportunidades de que deve reinar a todo custo, para o bem da communidade." A escola deve oferecer às "crianças do povo" mais do que ler, escrever e contar, mas aquilo que elas, muitas vezes, não têm acesso em casa.

De acordo com Carvalho (1934c, p. 71), "a methodologia dos Estudos Sociais comporta uma technica que se destingue dos demais estudos, em todos os graus de ensino.” A sua função seria, justamente, fornecer os princípios para a interpretação, levando os estudantes a se interessarem pelos problemas da sociedade e gerando uma melhor adaptação à vida social. Os Estudos Sociais compõem, na visão de Carvalho (1934c, p. 69-70), “os estudos que integram o ensino da vida social". Sua finalidade é dupla: enciclopédia de conhecimentos (denominação que, conforme veremos no próximo capítulo, foi inspirada em definições norte-americanas), patrimônio a ser transmitido a todos, e conjunto de 
noções que permitem ao educando compreender melhor o mundo em que vive e se adaptar ao meio, apropriando-se melhor de seus recursos.

Esta finalidade social não pode ser visada se as differentes partes do conjuncto não se concertam, não se hamonisam, não se completam, na descripção como na explicação e nos propositos. Ora, essa integração dos conhecimentos é uma das caracteristicas da Escola Progressiva. (Carvalho, 1934c, p. 70).

Este é o elemento central da defesa de Estudos Sociais de Delgado de Carvalho, presente na sua principal obra sobre o tema: "Introdução metodológica aos Estudos Sociais" (1957) e em outros estudos: a complexidade da vida não pode ser explicada a partir de disciplinas estanques. No contexto de renovação educacional, ocorrido após a ascensão de Getúlio Vargas ao poder, Delgado chama atenção para a necessidade de formação do professor que atuava no curso secundário e no ensino superior. Para ele, era necessária a criação de Escolas de Professores, algo que começava a se materializar na legislação nacional. Para tanto, seria indispensável contratar "técnicos no estrangeiro" mais experientes do que os brasileiros autodidatas. Sem uma formação docente adequada não seria possível a aplicação das reformas, por melhores que fossem (Carvalho, 1934c). No momento anterior à criação das universidades, como a Universidade do Distrito Federal, pensada por Anísio em 1935, o caminho natural era por meio das viagens ao exterior. Em entrevista ao Jornal do Brasil, de 5 de julho de 1929, Delgado de Carvalho expôs sua experiência e a ideia de possibilitar aos professores brasileiros o mesmo movimento:

[...] mais do que nunca, durante a minha recente excursão aos Estados Unidos, lembrei-me de trabalhar para que os nossos professores pudessem enxergar o que eu estava vendo e observando nos museus e nas Universidades americanas. E veiome a ideia de apelar para a famosa filantropia americana. Indaguei daqui, dali, e procurei me aproximar das instituições subvencionadas pela Carnegie Endowment, como a União Pan-Americana, o Instituto Internacional de Educação e a Universidade de Columbia. Ciente dos caminhos a seguir, escrevi um ofício àquela Fundação sugerindo um convite aos professores brasileiros para visitarem os Estados Unidos durante as suas férias, permitindo-lhes ver o que lá existe em condições de auxiliar cada qual no aperfeiçoamento de sua especialidade. (Carvalho, 1929 apud Barbosa, 2014, p. 14-15).

A ambiência americana, sua cultura e vida escolar encantaram Delgado de Carvalho do mesmo modo que a Anísio Teixeira. Na cidade do Rio de Janeiro, onde construiu, em diferentes instituições, sua longa carreira, ele se esforçou para facilitar a visita de um grupo de professores aos Estados Unidos. A intenção era que os docentes pudessem vislumbrar o mesmo que ele, em sua visita de 1928. 
Como representante da $\mathrm{ABE}$, entrou em tratativas com diferentes estabelecimentos educacionais: a Fundação Carnegie Endowment ${ }^{66}$, a União PanAmericana, o Instituto Internacional de Educação, a Universidade de Columbia e a Associação Nacional de Educação. O primeiro contato efetivado foi com a Fundação Carnegie Endowment, instituição filantrópica estadunidense que apoiava diferentes projetos educacionais e universidades. Esta se comprometeu a financiar a estadia de 10 professores brasileiros, durante cinco semanas, e a intermediar os contatos com o Teachers College da Universidade de Columbia. A Associação Nacional de Educação se ofereceu para acolher os docentes, servindolhes de guia e o Instituto Internacional ficou responsável pela elaboração da programação. Era uma viagem de especialização e aperfeiçoamento.

Cada detalhe da viagem foi planejado por Delgado, incluindo o transporte. Como a Fundação Carnegie Endowment só financiou a estadia nos Estados Unidos, Delgado procurou Frank Mumson, diretor da "Mumson Line", e "solicitou o abatimento nas passagens em seus navios" (Carvalho, 1929). Foram abertas 10 vagas, sete para professores do Rio de Janeiro e três para professores de São Paulo (Cardoso, 2015, p. 57). Foram selecionados: Carolina Coelho do Rego Rangel, Consuelo Pinheiro, Otávio B. Couto e Silva, Décio Lyra da Silva, Eunice Caldas, Henry Othon Leonardos, Julieta Arruda, Laura Jacobina Lambombe, Maria dos Reis Campos e Noemy da Silveira Rudolfer. Entre eles, Maria dos Reis Campos ${ }^{67}$, que se tornaria responsável pelo ensino da disciplina Estudos Sociais, na Seção de Matérias de Ensino do Instituto de Educação do Distrito Federal. Uma experiência pouco discutida nas pesquisas sobre o ensino de Estudos Sociais no Brasil e que abordaremos no capítulo 5.

\footnotetext{
${ }^{66}$ A Fundação Carnegie Endowment foi criada pelo filantropo norte-americano Andrew Carnegie (1835-1919), em 1905, e se consagrou "ao fortalecimento do ensino e à melhoria da aprendizagem dos alunos". Financia pesquisas, alunos de baixa renda e a Carnegie Mellon University. Como centro de pesquisa e política independente, dedica-se a todos os níveis de educação. Ver mais informações em: <https://www.carnegiefoundation.org/who-we-are/foundation-history/>. Acesso em: 26 jun. 2017.

${ }^{67} \mathrm{O}$ arquivo do Centro de Memória da Educação Brasileira (CMEB) do Instituto de Educação do Rio de Janeiro (Iserj) não possui documentação específica sobre Maria dos Reis Campos. Sabemos, no entanto, que ela teve atuação expressiva a partir da gestão Fernando de Azevedo (1927-1930) e, posteriormente, na gestão Anísio Teixeira (1931-1935). Na década de 1930, atuou como inspetora escolar, chefe da Seção de Programas e Atividades Extraclasse do Instituto de Pesquisas Educacionais do Departamento de Educação Distrito Federal, docente na Universidade do Distrito Federal e catedrática do Instituto de Educação, onde lecionou até falecer em 1947. Ativa na sociedade carioca, Maria dos Reis Campos participou de diferentes conferências nacionais e foi sócia da ABE, da Federação Brasileira pelo Progresso Feminino e da Academia de Sciencias de Educação, entre outras.
} 


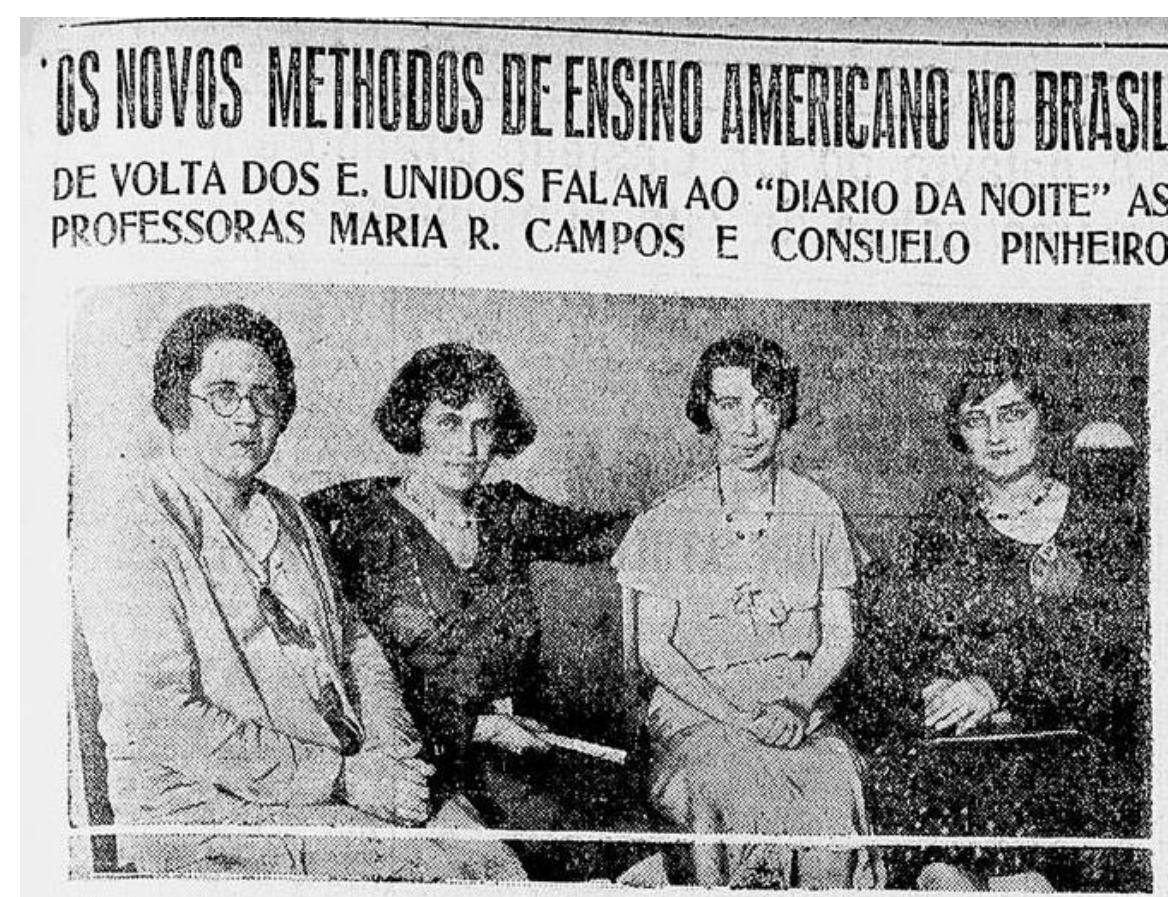

Legenda: Da esquerda para a direita, as professoras Maria dos Reis Campos, Consuelo Pinheiro, Laura Lacombe e Julieta Martins Arruda.

Figura 3 - Notícia sobre professoras que fizeram intercâmbio nos EUA Fonte: Diario da Noite (1930a, p. 5).

A seleção foi feita a partir das “credenciais apresentadas" (Carvalho, 1929), ou seja, o reconhecimento do inscrito no meio educacional das cidades. Em seu retorno ao Brasil, os docentes concederam entrevistas a jornais de grande circulação, como o Diario da Noite (Figura 3) e o Correio da Manhã, e proferiram palestras na ABE. O relato da professora Julieta Arruda, uma das indicadas para a viagem, ao Jornal Correio da Manhã é esclarecedor ${ }^{68}$ : “Ao dr. Delgado de Carvalho, devemos nossa proveitosa ida à América do Norte [...] Ao intercambio entre os Estados Unidos e as republicas latinas, destinam-se hoje avultadas sommas." (Arruda, 1930, p. 5). Sobre os critérios de seleção e as condições para a viagem, Julieta Arruda (1930, p. 5) afirma que:

A Associação Brasileira de Educação coube a escolha das professoras que se candidataram. Eram condições essenciaes para a inscripção: falar inglez, ter-se distinguido em trabalhos pedagógicos, ter um assumpto a estudar e estar em condições de pagar sua passagem. A Companhia Mumson Line offereceu grande

\footnotetext{
${ }^{68}$ O jornal "Correio da Manhã" (1930, p. 5) apresenta Julieta Arruda como "uma das figuras mais em evidencia no magisterio carioca". Entretanto, pouco se sabe sobre sua vida e atuação. À época da viagem aos Estados Unidos, ela atuava como diretora da Escola Rodrigues Alves. Foi uma das fundadoras da "Cruzada em prol da Escola Nova" e sócia da Associação Brasileira de Educação. Paschoal Lemme (2004, p. 80), em suas memórias, afirma: "Julieta Arruda, mãe de três filhos e separada do marido, mantinha uma pensão familiar à Rua Ferreira Viana, no bairro do Catete, com a qual completava os encargos da manutenção da família." Juntos, Paschoal Lemme e Julieta Arruda fundaram o Instituto de Brasileiro de Educação. De curta duração, essa experiência escolar tinha a intenção de aplicar "as aquisições mais recentes da chamada 'escola nova'." (p. 80).
} 
reducção nos preços e um tratamento especial à bordo. Partimos do Rio a $1^{\circ}$ de janeiro, chegando a Nova York a 14.

Em Nova York, estabeleceram-se próximo à Universidade de Columbia, que concentrou a maior parte das atividades desenvolvidas pela delegação da ABE. Como havia indicado o presidente da União Pan-americana, Dr. Rowe, cada docente foi destinado a estudar determinado aspecto da educação norte-americana, para que não ocorresse dispersão de esforços (Carvalho, 1929). De acordo com Maria dos Reis Campos, formaram-se quatro grupos principais, cabendo a cada um deles um estudo em específico: universidades, ensino profissional, ensino vocacional e ensino primário (Diario da Noite, 1930a). Estes se subdividiram em temas sugeridos pela $\mathrm{ABE}$, como o "methodo educativo de projetos" e a organização dos jardins de infância (O Paiz, 1929). Os dias nos Estados Unidos foram tomados por recepções, chás, banquetes, aulas, palestras e visitas. Delgado, coordenador do grupo, mostrou-se incansável na organização e planejamento das excursões e aulas em Baltimore, Filadélfia e Boston, conforme destacou Julieta Arruda (1930, p. 5): "Em todas essas cidades tivemos a companhia do casal Delgado de Carvalho que incansavel na sua obra socialista guiou-nos com muito carinho, contribuindo grandemente para o exito de nossa empresa."

Delgado de Carvalho chegou antes da delegação da ABE, para recepcionálos em companhia das autoridades americanas, e esteve mais tempo do que eles no país, ministrando "conferências sobre as condições econômicas do Brasil" (Correio Paulistano, 1930, p. 4). Nas cinco semanas em que permaneceram nos Estados Unidos, o grupo de docentes brasileiros teve a oportunidade de conhecer o sistema educacional de diferentes cidades e estabelecimentos de ensino públicos e privados. Entretanto, o Teachers College, com suas escolas anexas, Lincoln School e Horace Mann School, foi a "instituição privilegiada para uma formação especializada" (Cardoso, 2015, p. 145). Na Universidade de Columbia, segundo Dewey (2002), havia uma relação próxima entre a universidade e a formação de professores e uma preocupação com o como ensinar. Pela concepção do educador estadunidense, a universidade deveria colocar os seus recursos à disposição da escola elementar, buscando contribuir para a evolução de suas matérias e métodos. Já a escola era "o laboratório no qual os estudantes de educação vêem demonstradas, testadas, criticadas e fortalecidas as teorias e as ideias" (p. 80). 
Essa integração possibilitava o aprimoramento desses dois elementos do sistema educacional e a articulação entre teoria e prática.

No Teachers College, os brasileiros estudaram a teoria e tiveram acesso às escolas experimentais em que elas eram postas em prática. O periódico Diario da Noite publicou uma grande reportagem, intitulada "Os novos methodos de ensino americano no Brasil", na qual quatro docentes apresentaram suas impressões dos Estados Unidos, das escolas visitadas e dos métodos nelas aplicados ${ }^{69}$. Consuelo Pinheiro, por exemplo, descreveu a influência da Lincoln School sobre a educação americana: importante centro de "estudo e applicação dos novos processos de ensino" e uma escola "experimental em espirito, fins e methodos". Ali fez-se "a applicação dos methodos de Dewey, Thorndihe e outros”. As aulas se organizavam de forma diferenciada: "pequenas assembléas em que se discutiam assumptos que interessavam viva e igualmente o mestre e os alunmos". Existiam clubes de geografia, aritmética, de ciências, que despertavam nas crianças o hábito de discussão, cooperação e a capacidade de organização do debate. A análise dessa instituição foi completada pela professora Maria dos Reis Campos:

As salas de aulas são ornamentadas de quadros, decorações, flores, enfeitam-se de plantas, que as tornam jardins. E ha o "audictorum", os sports que as crianças praticam ao som de musicas adequadas tocadas ao piano por professoras, ha a cordialidade de alunmos e mestres. Encantam as escolas americanas, de quantos visitando sobressaindo a Lincoln School.

Outro elemento destacado foi a riqueza da literatura educacional infantil, sua variedade e ricas ilustrações. Para Maria dos Reis Campos, os livros eram ricamente ilustrados, magnificamente impressos e escritos. As escolas possuíam grandes bibliotecas, em que os alunos tinham acesso às obras. Ao ser questionada sobre a reforma educativa nos Estados Unidos, Julieta Arruda descreve aspectos, presentes na obra "A escola e a sociedade" (Dewey, 2002): necessidade de novos métodos, rompimento da noção de que a escola primária bastaria ensinar a ler, escrever e contar, fim da dualidade no ensino (uma escola só, para ricos e pobres), ensino de trabalhos manuais, valorização da educação física e do ensino de artes.

\footnotetext{
${ }^{69}$ Trata-se de uma reportagem publicada com grande destaque em duas edições do jornal. Para fins de referência das falas das docentes: os trechos das entrevistas de Consuelo Pinheiro e Maria dos Reis Campos foram extraídos da reportagem intitulada: "Os novos methodos de ensino americano no Brasil: de volta dos Estados Unidos, falam ao 'Diario da Noite' as professoras Maria R. Campos e Consuelo Pinheiro", publicada no jornal Diario da Noite (1930a, p. 5). Os trechos da entrevista de Julieta Arruda foram extraídos de uma outra reportagem: "Os novos methodos de ensino americano no Brasil: fixando as impressões das professoras Laura Lacombe e Julieta Arruda" também publicada no Diario da Noite (1930b, p. 1,3) do dia seguinte.
} 
Em determinado trecho da entrevista, a docente argumenta que lá "a criança vive na escola como num mundo em miniatura”. Essas impressões revelam um amplo conhecimento da teoria educacional deweyana. Significativo a este respeito é o relatório de Maria dos Reis Campos, apresentado a ABE e publicado em sua revista - "Schola"70, em que apresenta o método de projetos, seu tema de especialização na América.

O método de projetos consiste em planejar e executar determinado trabalho, proporcionando à criança a oportunidade de exercitar suas faculdades. Concretizado em três etapas principais: concepção ou o que se pretende realizar, preparo dos meios para sua consumação (estudos, observações, coleta de materiais) e realização (Campos, 1930), favorecendo, por sua essência, o trabalho cooperativo. Tal método se fundamenta em três princípios básicos, inspirados em Decroly: observação, associação e expressão. Para tanto, o projeto precisa partir de uma necessidade sentida pelos alunos, uma "necessidade que lhes despertará o interesse pelo trabalho, dando-lhes gosto por elle, fazendo-os integrar-se em seu verdadeiro sentido [...]." (Campos, 1932, p. 168-169).

Um elemento importante desse modelo, que será fundamental à definição de Estudos Sociais, é a possibilidade de “connexão estabelecida entre os differentes assumptos a ensinar" (Campos, 1930, p. 180). A associação entre as matérias é algo essencial ao desenvolvimento desse método. Em sua obra "Escola moderna: conceitos e práticas”, Campos (1932, p. 173-174) sintetiza essa questão:

Quando pretendemos realizar alguma coisa na vida pratica precisamos não de um ramo de conhecimento isolado, mas de uma serie de conhecimentos, pertencentes às mais variadas divisões da sciencia ou da arte. Taes conhecimentos são forças que atuam em conjuncto [...]. Ora quando realizamos o projeto, fazemo-lo à semelhança desses problemas que se nos apresentam na vida real. E nelles, à medida que as necessidades de realização apparecem, apparecem correlatamente as necessidades de conhecimento. Tais conhecimentos, correlativos das necessidades de acção, não vêm destacados uns dos outros [...]. E, pois, temos naturalmente de fazer o estudo de materias relacionadas mediante suas affinidades, affinidades estas reveladas pelas proprias necessidades de realização do projecto. (Campos, 1932, p. 173-174).

A realização dos projetos, por sua vez, vai além da simples aula expositiva e exige uma maior participação do aluno na construção do conhecimento. Segundo

\footnotetext{
${ }^{70} \mathrm{O}$ conhecimento deste documento se deve à leitura da tese de Cardoso (2015), que o analisa com outros objetivos. O Repositório Institucional da Universidade Federal de Santa Catarina (UFSC) disponibiliza nove edições da revista "Schola", periódico da ABE. Disponível em: $<: / /$ repositorio.ufsc.br/discover>. Acesso em: 27 jun. 2017.
} 
Dewey (2002, p. 24), o “algo para fazer", uma "atividade para executar”, leva a participação com outras pessoas em tarefas comuns, a organização, a associação e a divisão do trabalho. A renovação da escola passa, nessa perspectiva, pela introdução, em seu interior, de "ocupações ativas" e experiências motivadoras. A professora carioca afirma que o método de projetos "representa uma applicação pratica dos principios da pedagogia social de Dewey" (Campos, 1930, p. 179). Do mesmo modo, representa um "importante instrumento de educação social", levando o aluno a construir "bons hábitos sociais". Nesse sentido:

[...] alunmos acostumados ao trabalho em conjuncto pódem comprehender o alto valor cooperação e desenvolver qualidades sociais uteis [...]. Assim, o methodo de projectos está perfeitamente integrado na escola moderna, pois leva as crianças a exercerem suas actividades em condições identicas ás da vida real. (Campos, 1930, p. 179-180).

A ideia básica do método de projetos parte dos princípios deweyanos de organização escolar a partir de bases sociais e de que a criança é ativa por natureza, seus interesses devem ser aproveitados e dirigidos (Dewey, 2002). Todos contribuem e se sentem responsáveis pelo trabalho a ser desenvolvido (Dewey, 1998). A proposta se aproxima do "sistema de problema", que tanto impacto causou em Anísio Teixeira (2006). Para Teixeira (1968, p. 47, grifos do autor), “estudo - é o esforço para resolver um problema ou executar um projeto. Ensinar - é guiar o aluno na sua atividade e dar-lhe os recursos que a experiência humana já obteve para lhe facilitar e economizar esforços.” As matérias são a própria vida, "distribuída por "centros de interesse ou projetos"”. A criança deve ser colocada em situações de real ação e experiência e "o methodo de projectos contem em si mesmo uma imitação da vida real" (Campos, 1930, p. 180). Ao se utilizar esse método, de acordo com Maria dos Reis Campos, rompe-se com o isolamento da escola em relação à sociedade. Para ela:

[...] isto é tão sómente a applicação pratica dos principios educativos de Dewey, como podemos comprehender através de suas brilhantes affirmações sobre a significação das actividades naturaes da criança e dos resultados sociais da supressão de sua espontaneidade natural pela imposição de executar trabalhos que lhe são desagradáveis. (Campos, 1930, p. 180).

A inovação nos métodos, a partir dos relatos analisados, baseavam-se no Teachers College e na produção e prática de John Dewey. Além de proferir conferências e escrever importantes trabalhos, os viajantes procuraram colocar em prática os conhecimentos estudados na América do Norte. Conforme argumenta 
Cardoso (2015, p. 58, 173), esses docentes atuaram como "mediadores de uma cultura pedagógica valorizada naquele momento". Foram representantes e divulgadores de um modelo educacional, um padrão de escola e de ensino e difusores de métodos considerados como inovadores. Além das já citadas obras de Anísio Teixeira, os educadores Delgado de Carvalho e Maria dos Reis Campos publicaram textos em que transparece a influência da teoria educacional norteamericana. Não por acaso, esses docentes se reuniram em torno de um projeto educacional de reforma do ensino brasileiro, no qual tiveram grande atuação na reformulação de programas escolares e foram os principais divulgadores do ensino de Estudos Sociais na década de 1930. É a partir desse recorte que desenvolveremos o capítulo 5. Porém, antes disso, é preciso tratar do processo de configuração e delimitação dos Estudos Sociais nos Estados Unidos entre as décadas de 1910 e 1930, conforme fazemos no próximo capítulo. 


\section{4 \\ Os Estudos Sociais e a vertente americana (1916-1934): documentos e definições}

Nos capítulos anteriores, discutimos o lugar dos Estudos Sociais na crítica ao ensino de História, considerado como tradicional, baseado na cronologia e na memorização e as bases para a proposição de outro modelo educacional. Se a História ensinada até então e a própria escola, entre 1838 e 1930, inspiraram-se primordialmente na escola francesa, os defensores dos Estudos Sociais tomaram como referência a escola americana, o pensamento deweyano e a Social Science. Nesse sentido, no Brasil, "os Estudos Sociais foram introduzidos no currículo da escola elementar do Distrito Federal na gestão de Anísio Teixeira, à frente do Departamento de Educação, da Secretaria da Educação e Cultura do Distrito Federal." (Nadai, 1988, p. 4). Tornou-se, ainda, uma "matéria de ensino" da Escola de Professores do Instituto de Educação, ficando a cargo da professora Maria dos Reis Campos (1937). Em 1934, o Instituto de Pesquisas Educacionais, dirigido por Delgado de Carvalho, publicou em dois volumes o "Programa de Ciências Sociais". Este, conforme Carvalho esclareceu em sua apresentação, era uma adaptação do programa de ensino da cidade de Denver/Colorado/EUA. Cumpre analisarmos as definições de Estudos Sociais em voga nos Estados Unidos à época de publicação do "Programa de Ciências Sociais".

Uma das características centrais da educação americana é a descentralização administrativa. Conforme argumenta John Portz (2011), as políticas educacionais são moldadas pelo sistema federal dos Estados Unidos, onde a autoridade e a responsabilidade se dividem entre os entes nacional, estadual e local ${ }^{71}$. Contudo, a Constituição Federal de 1787 não menciona a educação como uma das atribuições diretas da União. Cada um dos 50 estados federados promulgou uma Constituição, "que inclui a referência à responsabilidade do estado em fornecer serviços educacionais para os seus cidadãos", e estabeleceu uma estrutura, com

\footnotetext{
${ }^{71}$ John Portz realizou através da Cátedra Fulbright da PUC-Rio duas palestras nesta universidade, em setembro de 2011. A partir delas, o autor desenvolveu o artigo "Federalism and education policy in the United States: allocating authority and responsibility among levels of government". Utilizamos como referência sua versão traduzida para a língua portuguesa: "Federalismo e a política de educação nos Estados Unidos: a distribuição de autoridade e responsabilidade entre os níveis do governo". Disponível em: rio.br/sobrepuc/depto/catedrafulbright/downloads/federalism_and_education_policytranslated.pdf $>$. Acesso em: 12 nov. 2017.
} 
distritos escolares e departamentos estaduais de educação. Ainda segundo o autor, os estados, além de concentrarem a maior parte do financiamento da educação, “costumam fornecer uma orientação geral em padrões de aprendizagem, currículo, e avaliações" (Portz, 2011, p. 6) a serem utilizadas pelas escolas públicas.

A educação, portanto, é uma função de cada estado da federação (Bomeny, 2011). Joaquim Faria Góes Filho ${ }^{72}$, um dos brasileiros que estudaram nos Estados Unidos e colaborador na reforma anisiana no Distrito Federal, esclareceu aos seus compatriotas, em texto sobre o ensino secundário, qual seria o papel do governo federal americano no desenvolvimento de políticas públicas educacionais:

Cabe-lhe, especificamente, sim, uma tarefa de notavel sentido e valimento, a de coletar dados sobre todas as atividades educacionais do país, de reunir todas as experiencias realizadas nos quatro cantos do territorio nacional e as divulgar pela nação inteira, acentuando imparcialmente os sucessos e os fracassos, os retardamentos e o progresso. Eis porque não mantém a grande nação americana em Washington, nem um Ministério da Educação, nem mesmo uma diretoria de Educação, mas um admirável "Office of Education" sob a jurisdição do Ministério do Interior. ${ }^{73}$ (Góes Filho, 1940, p. 229).

De acordo com Góes Filho (1940), na década de 1930, época em que cursou seu mestrado na Universidade de Columbia, o governo federal dos Estados Unidos, em matéria de educação, limitava-se a "prestar auxílios" e a patrocinar inquéritos e pesquisas educacionais ${ }^{74}$. $\mathrm{O}$ professor brasileiro argumentou que "a

72 Góes Filho (1901-1994), baiano, foi superintendente da Educação Secundária e Técnica do Distrito Federal (1932-1935) durante a gestão de Anísio Teixeira. Foi um dos fundadores do Serviço Nacional de Aprendizagem Industrial (Senai) e atuou como diretor do Departamento Regional do Rio de Janeiro e, posteriormente, como diretor do Departamento Nacional, entre 1948 e 1960. Barbosa (2014, p. 16) informa que ele foi um dos 20 brasileiros titulados pelo Teachers College de Columbia University, entre 1916 e 1956, obtendo o grau de mestre em 1936.

${ }^{73}$ O Departament of Education foi criado em 1867, durante a presidência de Andrew Johnson, contudo, no ano seguinte, este foi rebaixado a Office of Education ("Escritório de Educação", em tradução livre), vinculado ao Departament of the Interior. Entre os anos de 1870 e 1929, foi nomeado como Bureau of Education. A partir da década de 1930, novamente como Office of Education, esteve vinculado a U.S. Department of Health Education and Welfare ("Departamento de Saúde, Educação e Bem-estar dos Estados Unidos", em tradução livre). O presidente Jimmy Carter restabeleceu em 1979 o Departamento de Educação como um órgão independente. (Cf.: The Departament's History. Disponível em: <https://www2.ed.gov/about/overview/focus/what.html\#whatis>. Acesso em: 14 nov. 2017).

${ }^{74}$ Tal informação é corroborada por Anísio Teixeira no seu relatório de viagem aos Estados Unidos. Para o educador, que visitou o Bureau of Education em finais da década de 1920, "os quartéis-generais em Washington das grandes organizações americanas são curiosos quartéisgenerais de onde não se emanam ordens, mas onde se recolhem, se medem e estudam resultados." A partir dessas estatísticas e pesquisas, o bureau apresentava sugestões. Isso representava, na visão de Teixeira, "uma formidável atividade". Todo este trabalho era amplamente publicizado, conforme esclareceu Anísio Teixeira (2006, p. 111-114): “é extraordinário o número de publicações que os diversos departamentos especializados deste bureau editam anualmente a fim de manter em dia o estado das múltiplas e variadas atividades educativas do país." Como veremos, o relatório The Social Studies in Secondary Education foi publicado em um bulletin do bureau. 
despeito da sua alta descentralização, ha ideais comuns que presidem, da maneira mais acendrada, as atividades de todas as escolas americanas", como o de que as escolas são "o instrumento consciente e específico de vida democrática" (Góes Filho, 1940, p. 233). Na sua perspectiva, tais ideais comandavam a construção dos programas. Para explicar essa aparente ambiguidade (descentralização x unidade), Góes Filho (1940) citou como referência as explicações oriundas das aulas em Columbia. Em seu entendimento, devedor das aulas do professor Lester Wilson, a unidade educacional se fazia a partir de alguns aspectos, como a divulgação dos relatórios do Office of Education e de livros dos principais educadores americanos. Exerciam um papel importante as "associações e congressos de técnicos e de professores que reunem milhões de associados e levam aos que não puderam comparecer, pela revista e pelo radio, as decisões tomadas" (Góes Filho, 1940, p. 234). Através das associações criou-se uma rede de trocas pelo país.

Duas delas conduziram o processo de organização curricular a partir de finais do século XIX. A National Education Association (Associação Nacional de Educação, em tradução livre) foi fundada em 1857 “como um fórum que visava a elaborar planos de promoção escolar pelos líderes do movimento pela escola pública nos EUA, então em desenvolvimento.” (Urban, 2016, p. 123). Entre as questões debatidas em seus encontros, destacavam-se "as finalidades da educação pública, as formas organizacionais que assumiria, o currículo, a gestão das escolas e dos sistemas escolares e também alguns temas de pedagogia.” (p. 123). À época das viagens de Anísio Teixeira (2006, p. 118), em 1927, a associação contava com 180 mil sócios ${ }^{75}$. A American Historical Association (Associação Americana de História, em tradução livre) foi fundada em 1884 com o objetivo de promover os estudos históricos no país ${ }^{76}$. Essas duas associações, através de suas reuniões e da

\footnotetext{
75 As observações realizadas por Teixeira, no final da década de 1920, explicitam o papel da National Education Association no contexto educacional estadunidense. Segundo o educador, "em 1917, a associação transferiu sua sede central de Ann Arbor, em Michigan, para a capital do país, e data daí o seu florescimento. Quando esse fato se deu, a associação já era uma sociedade plenamente vitoriosa. Seguindo as leis de um desenvolvimento natural, ela já existia praticamente em todos os estados, quando se resolveu a dar organização definitiva ao seu órgão central." Portanto, o seu caráter nacional decorria do fato de "sua atividade se fazer sentir em todo o país por meio de inúmeras organizações locais". Isso acontecia a partir das reuniões locais e nacionais, da publicação de um jornal e de um boletim de investigações (Cf. Teixeira, 2006, p. 115-121).

${ }^{76} \mathrm{O}$ ensino de História, nos Estados Unidos, tem uma trajetória semelhante a que ocorreu no Brasil. A História, enquanto uma disciplina autônoma, apareceu nos currículos escolares americanos a partir da década de 1830. Até então, a História era ensinada "como parte da leitura, geografia ou clássicos". Massachusetts, já em 1827, foi um dos primeiros estados a tornar a História uma disciplina obrigatória no currículo da escola secundária (Smith et al., 1995, p. 1). Em
} 
elaboração de inquéritos educacionais, tiveram um papel de destaque no processo de formulação de programas de ensino de Estudos Sociais nos Estados Unidos.

Nadai $(1988$, p. 2) destaca que existem três projetos principais de Estudos Sociais nos Estados Unidos. Eles são imbricados uns nos outros e, por vezes, confundem-se. O primeiro projeto, dominante no século XIX, identifica os Estudos Sociais ao ensino de Ciências Sociais, fonte de seus conteúdos. "O seu objetivo fundamental ligava-se à divulgação do conhecimento produzido no âmbito das Ciências Sociais." O segundo se caracteriza por uma relação mais forte entre a escola e a vida e é contrária à concepção de escola "cuja meta principal é o conhecimento da herança cultural da humanidade." O conteúdo dos Estudos Sociais é identificado com a solução de problemas enfrentados por uma sociedade democrática. Por último, há uma terceira via que representa uma síntese das duas correntes anteriores e expressa uma preocupação com a questão da cidadania e com a participação do indivíduo na sociedade. Há uma ênfase da escola e dos Estudos Sociais no preparo do educando para a vida na comunidade.

Nos Estados Unidos, conforme salienta Freitas (2011, p. 1), “a trajetória dos Social Studies possui alguns pontos de emergência recorrentemente citados pela literatura histórica" (algumas datas e eventos importantes foram sintetizados no Quadro 3). As disciplinas escolares, como "arbítrio cultural criado historicamente", não surgem de repente e para sempre, mas são construídas e reconstruídas ao longo do tempo. Sua constituição está associada a certos "marcos" ou "interesses sociais" (Fernández, 2009, p. 1). O seu "significado deve ser decifrado escutando as chaves sociopolíticas de sua existência histórica” (p. 7). Uma das formas para se analisar a "dinâmica de transmutação de significado cultural e social das disciplinas", embora não exclusiva, está contida nos "textos visíveis", ou seja, currículos, leis, discursos, manuais, planos de estudos e programas escolares. Esses documentos expressam a existência de um conjunto de ideias, valores e rotinas que delimitam e caracterizam as disciplinas, além de lhes concederem legitimidade no currículo (Fernández, 2009).

relação ao ensino superior, a História passou a ser ensinada como uma disciplina acadêmica na década de 1870, quando foram nomeados os primeiros docentes. De modo a profissionalizar o campo, um grupo de historiadores propôs a fundação de uma Associação. Desde a sua criação a American Historical Association atuou na definição do currículo escolar, participando de importantes comitês a partir de 1892. Sobre o histórico da associação, cf. Brief History of the AHA. Disponível em: <https://www.historians.org/about-aha-and-membership/aha-history-and-archives/briefhistory-of-the-aha>. Acesso em: 13 nov. 2017. 


\begin{tabular}{|c|c|}
\hline Ano & Evento \\
\hline $1892-1916$ & $\begin{array}{l}\text { Diferentes comitês discutiram os currículos vigentes nos Estados Unidos. } \\
\text { Inquéritos, realizados pela Associação Americana de História e pela Associação } \\
\text { Nacional de Educação, apontaram a necessidade de mudanças e maior } \\
\text { entrosamento entre as disciplinas responsáveis pela formação cívica. }\end{array}$ \\
\hline 1893 & $\begin{array}{l}\text { O "Report of the Committee of Ten of the National Education Association" } \\
\text { ("Relatório do Comitê dos } 10 \text { da Associação Nacional de Educação", em tradução } \\
\text { livre) defendeu uma maior integração da História com as outras Ciências Sociais. }\end{array}$ \\
\hline 1913-1916 & $\begin{array}{l}\text { Trabalho do Committee on Social Studies of the Commission on the Reorganization } \\
\text { of Secondary Education of the National Education Association (Comitê de Estudos } \\
\text { Sociais da Comissão para Reorganização da Educação Secundária da Associação } \\
\text { Nacional de Educação, em tradução livre). }\end{array}$ \\
\hline 1916 & $\begin{array}{l}\text { Publicação do relatório "The Social Studies in Secondary Education” ("Os Estudos } \\
\text { Sociais na escola secundária", em tradução livre). O relatório foi editado pelo } \\
\text { Bureau of Education, compondo o seu } 28^{\circ} \text { Bulletin. } \\
\text { Primeira definição oficial de Estudos Sociais. }\end{array}$ \\
\hline $1920-1930$ & $\begin{array}{l}\text { Inclusão dos Estudos Sociais nos currículos de diferentes estados americanos. De } \\
\text { acordo com Saxe (2004), os primeiros a aderirem foram os Estados de New Jersey } \\
\text { (1917) e da Pennsylvania (1921). }\end{array}$ \\
\hline 1921 & $\begin{array}{l}\text { Fundação do National Council for the Social Studies, instituição responsável pela } \\
\text { promoção do ensino de Estudos Sociais nos Estados Unidos. }\end{array}$ \\
\hline 1926-1932 & $\begin{array}{l}\text { Nesses anos, segundo as análises de Saxe (2004), a Associação Americana de } \\
\text { História legitimou os Estudos Sociais como "principal veículo curricular para a } \\
\text { educação para a cidadania" e patrocinou a Comissão de Estudos Sociais. }\end{array}$ \\
\hline 1929-1933 & $\begin{array}{l}\text { A Associação Americana de História, através da sua Comissão de Estudos Sociais, } \\
\text { financiou e indicou os membros responsáveis pela Investigation of the Social } \\
\text { Studies in the schools. Seus resultados principais foram publicados em } 1932 \text { e } 1934 .\end{array}$ \\
\hline 1932 & Publicação do relatório A charter for the Social Sciences in the schools. \\
\hline 1934 & $\begin{array}{l}\text { Publicação das Conclusions and recommendations of the Comission on the Social } \\
\text { Studies of Association American History. }\end{array}$ \\
\hline
\end{tabular}

Quadro 5 - Elementos da institucionalização dos Estudos Sociais nos Estados Unidos (1892-1934)

Fonte: Elaborado pelo autor a partir da análise documental e bibliográfica inspirada em Saxe (2004).

A redação normativa, conforme argumenta Fernández (2009, p. 79), é muito útil para se conhecer o processo de gestação de uma disciplina. Isso ocorre porque "qualquer programa contém uma dupla funcionalidade: de orientação e de controle." Os projetos sintetizados por Nadai (1988) foram orientados por uma série de investigações realizadas por especialistas e educadores nas escolas americanas. Apesar de nominalmente citados em alguns trabalhos (Fernandes, 2008; Santos, 2011), pouco se conhece, no Brasil, sobre os documentos que delimitaram as propostas de Estudos Sociais naquele país. Dois deles precisam ser destacados pela relevância que tiveram na produção de Delgado de Carvalho (1970), que são os relatórios: “The Social Studies in secondary education” (1916) e "A charter for the Social Sciences in the schools" (1932). Esses "textos visíveis", não obstante as suas diferenças em termos de definição e componentes disciplinares, descritas no Quadro 6, preconizaram um sentido de Estudos Sociais 
voltado para a cidadania, através da formação de indivíduos aptos a tomarem decisões e a participarem das mudanças sociais (Oliveira, 1993).

\begin{tabular}{|c|c|c|}
\hline $\begin{array}{l}\text { Relatório } \\
\text { (ano) }\end{array}$ & $\begin{array}{l}\text { The Social Studies in secondary } \\
\text { education (1916) }\end{array}$ & $\begin{array}{l}\text { dations of } \\
\text { Studies of } \\
\text { (1934) }\end{array}$ \\
\hline & $\begin{array}{l}\text { "[...] assunto [que] se relaciona } \\
\text { diretamente à organização e ao } \\
\text { desenvolvimento da sociedade } \\
\text { humana e ao homem como um } \\
\text { membro de grupos sociais." (Dunn, } \\
\text { 1916, p. 9). }\end{array}$ & $\begin{array}{l}\text { "[...] abrangem todo o campo da história } \\
\text { humana, desde os tempos mais remotos } \\
\text { até os atuais, e a extensão mais ampla } \\
\text { da sociedade contemporânea, desde a } \\
\text { vida e os costumes de povos antigos às } \\
\text { práticas sociais e posses culturais de } \\
\text { regiões vizinhas." (Krey et al., 1934, p. } \\
\text { 6). }\end{array}$ \\
\hline & \begin{tabular}{llr|} 
História & Europeia, História \\
Americana, Geografia e & Educação \\
Cívica. &
\end{tabular} & $\begin{array}{l}\text { História, Economia, Política, } \\
\text { Sociologia, Geografia, Antropologia e } \\
\text { Psicologia. }\end{array}$ \\
\hline
\end{tabular}

Quadro 6 - Estudos Sociais: documentos, definições e componentes

Fonte: Elaborado pelo autor a partir de Dunn (1916) e Krey et al. (1934).

Os Estudos Sociais se constituíram imbricados com a maior sistematização da Instrução Cívica e inspirado numa concepção que defendia três finalidades principais da educação: “adaptação do indivíduo à vida cívica”, através de sua formação enquanto um membro eficiente e ativo da sociedade; "adaptação do indivíduo à vida econômica", com sua maior integração ao meio social, com o despertar de vocações, com a construção de hábitos referentes à vida; e promoção do interesse pela cultura ("cultura desinteressada", "bem-estar espiritual", "felicidade pessoal"). As experiências educativas deveriam convergir para esses objetivos (Carvalho, 1934c, p. 14-15). Tal definição pressupunha que a educação social não deveria ser ensinada em uma disciplina à parte, como Instrução Cívica (nos Estados Unidos) ou Educação Moral e Cívica (no Brasil), mas inserida nas demais disciplinas do currículo. Segundo Delgado de Carvalho (1934c, p. 86):

[...] nos Estados Unidos, não demorou em surgir uma evolução acertada e de alto valor educativo: a Social Science. A Instrucção Civica é ahi ministrada ao mesmo tempo que os ensinamentos historicos, scientificos, sociaes, economicos, ethnograficos, hygienicos, recreativos, e outros [...]. Hoje em dia, num compendio americano de Sciencia Social, cerca de $40 \%$ dos assumptos são de natureza economica; são discutidos, de modo elementar, naturalmente, as questões sociaes sobre delinquencia, immigração, profissão, socialismo, etc.

Carvalho, observador astuto da educação americana nas décadas de 1920 e 1930, apontou alguns elementos da Social Science e da educação americana. Uma das preocupações da escola progressiva estava na organização dos estudos de forma que os alunos pudessem ter uma maior capacidade de interpretação dos 
problemas diários. Esse era um dos objetivos centrais da cidadania ensinada e desenvolvida nas escolas, isto é, "o habyto de analisar os problemas correntes" (Carvalho, 1934c, p. 124). Os Estudos Sociais, na visão de seus defensores, como o assunto que mais diretamente se relaciona ao desenvolvimento humano (Dunn, 1916), assumiu um papel de relevo nessa organização curricular. Sua finalidade residiria na preservação e transmissão de certos valores sociais (liberdade, solidariedade, tolerância, direitos, deveres, etc.) para as gerações futuras.

\section{1}

\section{Consolidação de um termo: a definição de Estudos Sociais}

Os pesquisadores norte-americanos defendem - embora salientem que as origens remontam ao século XIX ${ }^{77}$ - que os Estudos Sociais se institucionalizaram na escola secundária dos Estados Unidos a partir da publicação, em 1916, do relatório "The Social Studies in secondary education”. Editado como o $28^{\circ}$ Boletim do Bureau of Education do Departament of The Interior, este documento faz parte dos trabalhos desenvolvidos, entre 1913 e 1916, pelo Committee on Social Studies of the Commission on the Reorganization of Secondary Education of the National Education Association ${ }^{78}$ (Fallace, 2009;

\footnotetext{
${ }^{77}$ Smith et al. (1995, p. 1) destacam que as suas bases se originaram na Grã-Bretanha da década de 1820 e se mudaram rapidamente para os Estados Unidos. Para os autores, "os Estudos Sociais surgiram como uma tentativa de usar a educação como um veículo para promover o bem-estar social" (Tradução nossa do original: "Social studies emerged as an attempt to use education as a vehicle to promote social welfare, and its subsequent development was influenced both by Americans and others." As citações ao artigo de Smith et al. (1995), foram extraídas de Social Studies and the Birth of NCSS: 1783-1921. Disponível em: <http://www.socialstudies.org/sites/default/files/publications/se/5907/590702.html>. Acesso em: 17 out. 2017.

${ }^{78} \mathrm{O}$ Comitê de Estudos Sociais fez parte de um projeto mais amplo denominado como Commission on the Reorganization of Secondary Education, appointed by The National Education Association Este, por sua vez, era formado por 16 comissões: Reviewing Committee (Comitê de Revisão), Administration of High Schools (Administração de Escolas de Ensino Médio), Agriculture (Agricultura), Ancient Languages (Línguas Antigas), Art Education (Ensino de Arte), Articulation of High School and College (Articulação do Ensino Médio e Superior), Business Education (Educação Empresarial), English (Inglês), Household Arts (Artes Domésticas), Manual Arts (Artes Manuais), Mathematics (Matemática), Modern Languages (Línguas Modernas), Music (Música), Physical Education (Educação Física), Sciences (Ciências), Social Studies (Estudos Sociais) e Vocational Guidance (Orientação Final). "Cardinal Principies of Secondary Education" ("Princípios Cardinais da Educação Secundária”, em tradução livre), foi o seu relatório final, publicado em 1918. Foram apresentados sete princípios, o quinto se referiu especificamente à Educação Cívica, cuja função estaria em desenvolver, nos alunos, a consciência e atenção aos problemas da comunidade, estado e nação, conhecimento das organizações sociais, compromisso com a diversidade e cooperação e capacidade de resolver problemas. O documento está disponível em: <https://archive.org/details/cardinalprincipl00natiuoft>. Acesso em: 18 out. 2017.
} 
Nelson, 1994). Murry Nelson (1994, p. 4-5) argumenta que esse relatório demarcou a "utilização do termo Estudos Sociais, que não era de uso popular antes disso." Suas recomendações estabeleceram as características principais da instrução em Estudos Sociais e Educação Cívica que, para J. Spencer Clark (2016), permaneceram praticamente inalteradas no século XX.

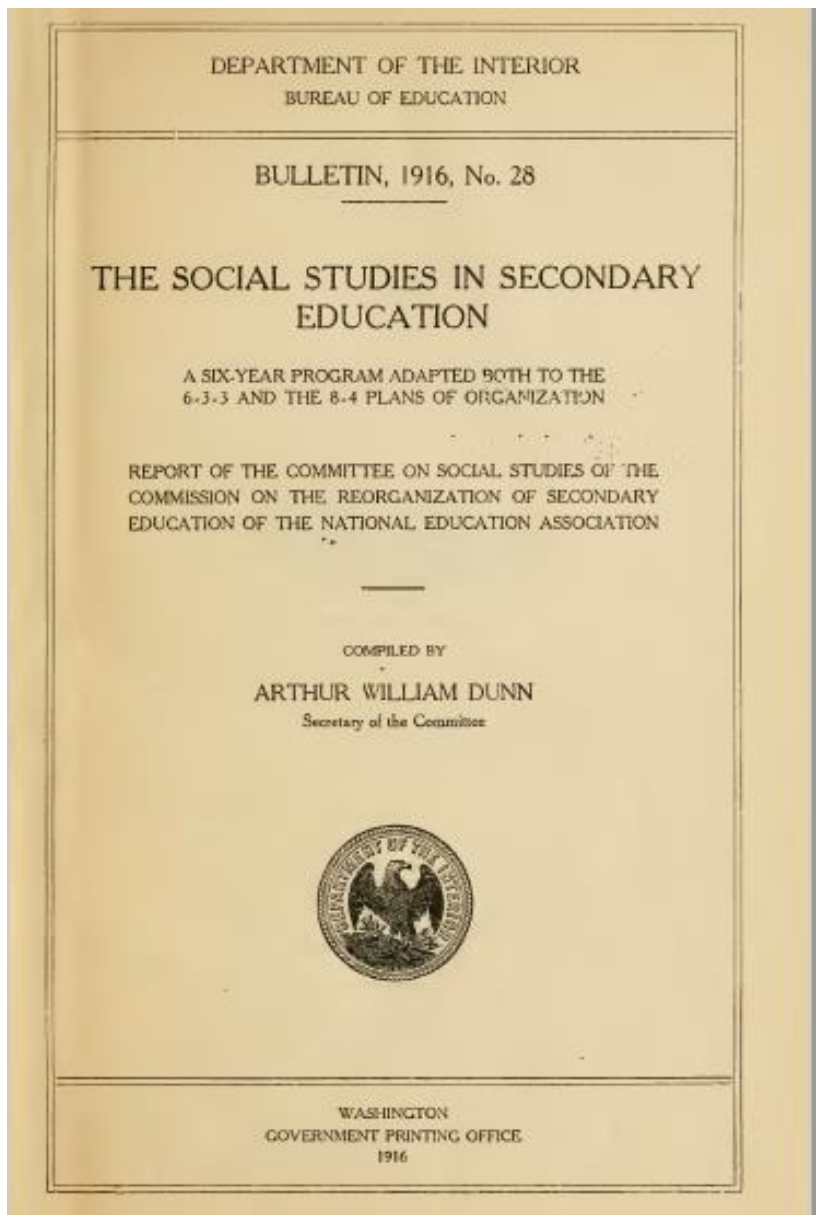

Figura 4 - Capa do relatório The Social Studies in Secondary School (1916) Fonte: Dunn (1916).

Entre 1892 e 1916, diferentes comitês pensaram o ensino de Estudos Sociais e Educação Cívica nos Estados Unidos, como um esforço para reorganização do currículo escolar americano, em decorrência das mudanças populacionais e da expansão das matrículas e do ensino secundário (Clark, 2016). "O relatório do comitê [de 1916] foi o clímax de mais de 20 anos de diversos relatórios das comissões que examinaram as escolas e fizeram recomendações para os seus currículos.” (Nelson, 1994, p. 8) ${ }^{79}$. Sucessivas indicações geraram algumas

\footnotetext{
${ }^{79}$ Tradução nossa do original: "The Committee Report was the climax of over 20 years of various committee reports examining the schools and making recommendations for their curriculum." A análise dessas comissões e seus relatórios fugiria aos nossos objetivos, contudo pode ser
} 
confusões entre os pesquisadores brasileiros. Elza Nadai (1988, p. 2), por exemplo, afirma que a expressão "Estudos Sociais" foi utilizada pela primeira vez no Report of the Committee of Ten of the National Education Association. Contudo, essa Comissão apenas afirmou "que a Economia Política e o Governo Civil deveriam se relacionar com a História e que o Inglês e a Geografia deveriam ser inseridos no estudo com a História." Embora não haja menção ao termo "Estudos Sociais", as Ciências Sociais deveriam ser subordinadas aos estudos históricos. Nelson (1994, p. 9) argumenta que "claramente este é o tipo de pensamento que levou à criação do termo e conceito 'Estudos Sociais'. ." 80

O contexto de trabalho do Comitê de 1916, dominado pelas figuras de Thomas J. Jones e Arthur W. Dunn (relator) ${ }^{81}$, caracterizou-se pela crescente industrialização e urbanização, pelas tensões na Europa e consequente eclosão da Primeira Guerra Mundial (1914-1918). Paralelamente, os Estados Unidos lidaram, desde o início do século XIX, com grandes fluxos imigratórios. Só entre 1881 e 1914 quase 22 milhões de pessoas cruzaram o Atlântico em direção ao país (Paiva \& Moura, 2008), o que gerou alterações na estrutura social americana. Os imigrantes eram explorados pelas grandes indústrias, viviam em condições precárias e houve um crescimento dos sindicalismos. As lutas por melhores condições de vida levaram a uma série de distúrbios em diferentes regiões do país.

\footnotetext{
encontrada em Nelson (1994). Pela ordem em que foram publicados os seus resultados, segue uma lista das principais: 1) Madison Conference on History, Civil Government and Political Economy made to the Committee of Ten on Secondary-School Studies of the National Education Association (Conferência de Madison sobre História, Governo Civil e Economia Política feita ao Comitê dos Dez de Estudos sobre a Escola Secundária da Associação Nacional de Educação", em tradução livre) (1893-1894); 2) Committee of Seven of the American Historical Association/ Report: The Study of History in Schools, 1898 (Comitê dos Sete da Associação Americana de História/ Relatório: "O Estudo da História nas Escolas", em tradução livre); 3) Committee of Eight of the American Historical Association, 1909 ("Comitê dos 8 da Associação Americana de História", em tradução livre); 4) Committee of Five of the American Historical Association, 1911 (Comitê dos Cinco da Associação Americana de História, em tradução livre). Os dois últimos investigaram, respectivamente, o ensino de História na escola primária e no curso secundário. Paralelamente, foram apresentados relatórios da American Political Science Association (Associação Americana de Ciência Política, em tradução livre) em 1908 e em 1916.

${ }^{80}$ Ambas as citações foram extraídas de Nelson (1994, p. 9). Tradução nossa do original: “They stated that political economy and civil government should be coordinated with history and that English and geography should be brought into close study with history. Clearly, this is the kind of thinking that led to the creation of the term and concept social studies."

${ }^{81}$ Presidente: Thomas Jesse Jones (País de Gales, 1873 - Estados Unidos, 1950) mestre e doutor em Filosofia pela Universidade de Columbia (1899 e 1904, respectivamente). Especialista em Educação do United States Bureau of Education, 1912-1919, e Diretor Educacional da Phelps Stokes Fund (1913-1946). Relator: Arthur Willian Dunn (1868-1927) foi um especialista em educação cívica, tendo atuado no United States Bureau of Education.
} 
Nesse cenário, a escola assumiu um importante papel na harmonização e modelagem dos jovens. Os conteúdos selecionados seriam aqueles que despertassem o interesse do aluno pelas questões da comunidade e o facultassem a "pensar e viver civicamente" (Bureau of Education, 1913, p. 17). Os filhos dos imigrantes precisavam ser educados, mais ainda, educados como americanos (“conhecimento da língua”, "costumes”, “cultura", "práticas de saúde”, por exemplo - Nelson, 1994, p. 7). A Comissão de Estudos Sociais, como não poderia deixar de ser, estava envolvida nesses debates.

A preocupação em capacitar os jovens imigrantes a compreenderem os seus deveres cívicos fez com que a Comissão "mudasse o foco do curso ofertado passando de História para cursos com maior fundamentação social e cívica, os quais são atualmente conhecidos como Estudos Sociais." (Clark, 2016, p. 88). A oficialização desse modelo é atribuída a John Dewey, cujas citações forneceram "credibilidade e coerência" ao relatório de 1916 (Fallace, 2009, p. 618; Freitas, 2011). The Social Studies in Secondary Education apresentou uma primeira definição de Estudos Sociais como "assunto [que] se relaciona diretamente à organização e ao desenvolvimento da sociedade humana e ao homem como um membro de grupos sociais. $" 82$ (Dunn, 1916, p. 9). Apesar dessa conceituação, as referências principais são a História, a Geografia e a Educação Cívica. O relatório possui 63 páginas, incluindo capa, contracapa e sumário. Apresenta um pequeno prefácio assinado por Thomas J. Jones, presidente da Comissão, e por Clarence D. Kingsley, presidente do Comitê de Revisão, e se divide em quatro partes: Parte I) Introdução; Parte II) Estudos Sociais para sétimo, oitavo e nono anos; Parte III) Estudos Sociais para os décimo, décimo primeiro e décimo segundo anos; e Parte IV) Critérios - preparação do professor - disponibilidade de material.

Nas primeiras décadas do século XX, a organização escolar americana se baseava em dois modelos. O primeiro era denominado como 8-4 (eight and four), ou seja, oito anos de elementary school (escola elementar) e quatro de high school (colegial ou secundário). O outro era nomeado como 6-3-3 (six three and three): seis anos de elementary school, três anos de junior high school (etapa inicial da escola secundária) e três anos de senior high school (etapa final da escola

\footnotetext{
${ }^{82}$ Tradução nossa do original: "Definition of the social studies: The social studies are understood to be those whose subject matter relates directly to the organization and development of human society, and to man as a member of social groups."
} 
secundária) (Cf. Góes Filho, 1940; Teixeira, 2006). Esse segundo padrão foi o utilizado por Dunn (1916) na sua proposição para uma distribuição dos Estudos Sociais entre os anos de escolarização. Ao longo do texto não há menção à palavra “disciplina”, corroborando a argumentação de Chervel (1990) de que este termo só passou a ter uso corrente após a Primeira Guerra Mundial. História, Geografia e Educação Cívica são mencionadas como "subjects" ou "courses", que poderiam ser traduzidos como "sujeitos", "assuntos" e "cursos", respectivamente. Optamos por utilizar a nomenclatura original, conforme citada no documento.

\begin{tabular}{|l|l|l|}
\hline \multirow{4}{*}{ Estudos Sociais } & \multicolumn{2}{|c|}{ Subjects ou Courses/Anos de escolaridade } \\
\cline { 2 - 3 } & \multicolumn{1}{|c|}{$\left(7^{\circ}, 8^{\circ}\right.$ e $9^{\circ}$ anos $)$} & \multicolumn{1}{c|}{$\left(10^{\circ}, 11^{\circ}\right.$ e $12^{\circ}$ anos $)$} \\
\cline { 2 - 3 } & Geografia & História da Europa \\
\cline { 2 - 3 } & História da Europa & História Americana \\
\cline { 2 - 3 } & História Americana & $\begin{array}{l}\text { Problemas democráticos - social, econômico e } \\
\text { político }\end{array}$ \\
\cline { 2 - 3 } & Educação Cívica & \\
\hline
\end{tabular}

Quadro 7 - Plano geral dos Estudos Sociais no curso secundário

Fonte: Elaborado pelo autor a partir de Dunn (1916, p. 12).

Para Dunn (1916) e para os membros da Comissão, os Estudos Sociais difeririam dos demais estudos por seu "conteúdo social", que lhe possibilitaria a atuação na "formação do indivíduo como um membro da sociedade". Sua finalidade primordial, portanto, residiria no "estímulo à boa cidadania"83. Tal objetivo seria atingido "através do desenvolvimento de uma apreciação da natureza e das leis da vida social, um senso de responsabilidade individual como membro de grupos sociais, bem como a inteligência e a vontade de participar de maneira eficaz na promoção do bem-estar social." ${ }^{84}$ (p. 9). A política isolacionista, praticada pelos Estados Unidos no início do século XX, fica evidente na construção do relatório. Apesar de considerarem que a "humanidade é maior do que qualquer uma de suas divisões" e que a sociedade inclui a "raça humana como um todo", a política de "boa vizinhança" dependeria da "lealdade" e do "senso de

\footnotetext{
${ }^{83}$ A boa cidadania foi definida, em publicações anteriores, por Jones e por Dunn. Para Jones, se a escola tem como função primeira "contribuir para o bem-estar social da comunidade", aos Estudos Sociais caberia "a apreciação de métodos de melhoria humana." (Bureau of Education, 1913, p. 16-17). O bom cidadão, conforme Dunn, seria possuidor de "um interesse permanente pelo bemestar da comunidade, um conhecimento prático das agências sociais e um bom julgamento quanto aos meios e métodos que promoverão um fim social sem, ao mesmo tempo, derrotar outros fins sociais." (Bureau of Education, 1915, p. 9).

${ }^{84}$ Tradução nossa do original: "They should accomplish this end through the development of an appreciation of the nature and laws of social life, a sense of the responsibility of the individual as a member of social groups, and the intelligence and the will to participate effectively in the promotion of the social well-being."
} 
obrigação" para com a cidade, o estado e a Nação. Antes de o cidadão americano compor uma "comunidade mundial", ele deveria estar imbuído de "um elevado ideal nacional e uma inteligente e genuína lealdade para com estes" (p. 10). O "internacionalismo" deveria ser precedido pelo "patriotismo" e pelo nacionalismo. Para isso, os conteúdos valorizariam os ideais e "autoestima nacionais" (Dunn, 1916). Os tópicos e conteúdos de ensino seriam buscados na História americana e europeia, eixo central dos Estudos Sociais neste relatório.

O Comitê não se propôs a oferecer instruções detalhadas para um curso de Estudos Sociais, uma vez que "a seleção de temas e organização dos assuntos devem ser determinadas em cada caso através de necessidades imediatas." (Dunn, 1916 , p. 10$)^{85}$. Isto é, o documento apresenta uma sugestão de organização (Quadros 8 e 9), alguns princípios e exemplos práticos, extraídos da experiência de seus formuladores e de expoentes da educação americana de então. Um dos elementos centrais seguidos pela Comissão foi inspirado em Dewey (1998), que defende não haver sentido em guiar toda a escola para supostas necessidades futuras em detrimento do presente. É no presente que as crianças vivem! A sua experiência de vida, não pode ser ignorada pela escola. Para Dunn (1916, p. 11), analisando uma passagem da obra de Dewey ${ }^{86}$ :

[...] o fator importante aqui não é preparar o aluno para viver, mas reconhecer que ele está vivendo e que há uma necessidade imediata de alimento intelectual e social

\footnotetext{
${ }^{85}$ Tradução nossa do original: "The selection of topics and the organization of subject matter should be determined in each case by immediate needs." Por exemplo, pode-se enfatizar mais a História Americana para alunos oriundos de famílias imigrantes ou valorizar os aspectos industriais em comunidades de trabalhadores. Os temas deveriam atender a necessidades específicas e as circunstâncias locais (Dunn, 1916, p. 13).

${ }^{86}$ Dunn (1916, p. 11) faz menção ao seguinte trecho: "We are continually uneasy about the things we adults know, and are afraid the child will never learn them unless they are drilled into him by instruction before he has any intellectual or practical use for them. If we could really believe that attending to the needs of present growth would keep the child and teacher alike busy, and would also provide the best possible guarantee of the learning needed in the future, transformation of educational ideals might soon be accomplished, and other desirable changes would largely take care of themselves." (Tradução nossa: "Estamos continuamente inquietos diante de coisas que nós adultos sabemos e tememos que a criança nunca as aprenda, a menos que tais coisas sejam absorvidas por elas através do ensino antes que ocorra qualquer uso intelectual das mesmas. Se realmente acreditamos que atender às necessidades de crescimento presente iria ocupar a criança e o professor igualmente e que da mesma forma garantiria a melhor forma possível de aprendizagem necessária no futuro, então a transformação dos ideais educacionais pode em breve ser alcançada e outras mudanças desejáveis se resolveriam sozinhas."). A citação em questão foi extraída de "Schools of to-morrow". A obra foi escrita por John Dewey e sua filha Evelyn Dewey a partir de uma série de experiências em escolas americanas. Sua primeira edição é de 1915 (Cf. Dewey \& Dewey, 1915, p. 5; Dunn, 1916, p. 11).
} 
e de formação suficientes a fim de permitir-lhes que se ajustem ao seu ambiente e condições sociais presentes. ${ }^{87}$

Os métodos e conteúdos de ensino deveriam ser adaptados às necessidades de crescimento dos discentes e as suas "necessidades reais". Assim, o aluno estaria sendo, naturalmente, preparado para as futuras condições que teria de lidar.

\begin{tabular}{|c|c|c|}
\hline \multirow{2}{*}{ Ano } & \multicolumn{2}{|c|}{ Subjects ou Courses } \\
\hline & $1^{a}$ Opção & $2^{\mathrm{a}}$ Opção \\
\hline $7^{\circ}$ & $\begin{array}{l}\text { Geografia ( } 1 \text { semestre). } \\
\text { História Europeia ( } 1 \text { semestre). } \\
\text { Educação Cívica ensinada como parte da } \\
\text { Geografia, da História Europeia e de } \\
\text { outros courses/ ou como subject constante } \\
\text { de um ou dois tempos semanais. }\end{array}$ & $\begin{array}{l}\text { História Europeia ( } 1 \text { ano). } \\
\text { Geografia como complemento e como um } \\
\text { fator dentro da História. } \\
\text { Educação Cívica ensinada como parte da } \\
\text { Geografia, da História Europeia e de } \\
\text { outros courses / ou como subject constante } \\
\text { de um ou dois tempos semanais. }\end{array}$ \\
\hline $8^{\mathbf{o}}$ & $\begin{array}{l}\text { História Americana ( } 1 \text { semestre). } \\
\text { Educação Cívica ( } 1 \text { semestre). } \\
\text { Geografia como complemento e como um } \\
\text { fator dentro da História. }\end{array}$ & Não apresentam. \\
\hline $9^{\circ}$ & $\begin{array}{l}\text { Educação Cívica com ênfase nos aspectos } \\
\text { estaduais, nacionais e mundiais (1 } \\
\text { semestre). } \\
\text { Educação Cívica: aspectos econômicos e } \\
\text { profissionais (1 semestre). } \\
\text { A História abordada em relação aos temas } \\
\text { do curso de Educação Cívica. }\end{array}$ & $\begin{array}{l}\text { Educação Cívica: econômica e } \\
\text { profissional. } \\
\text { História Econômica. } \\
\text { (Os dois courses seriam abordados ao } \\
\text { longo do ano, em sequência ou em } \\
\text { paralelo). }\end{array}$ \\
\hline
\end{tabular}

Quadro 8 - Os Estudos Sociais nos $7^{\circ}, 8^{\circ}$ e $9^{\circ}$ anos do ensino secundário Fonte: Elaborado pelo autor a partir de Dunn (1916, p. 15).

Os courses presentes na junior high school, $7^{\circ}, 8^{\circ}$ e $9^{\circ}$ anos, eram de Geografia, História e Educação Cívica. Apesar de especificarem o tempo em que cada um deles poderia ser trabalhado, na prática há a defesa de inter-relação entre elas. No $7^{\circ}$ ano, os três Estudos Sociais deveriam ser ensinados de forma correlacionada, com dependência direta de uns com os outros e "com boa parte de um tema ensinado como um aspecto dos outros dois". A ênfase recaía sobre o ensino de História e Geografia, com a Educação Cívica ministrada como uma "fase" delas e de outros subjects. No $8^{\circ}$ ano, a História Americana e a Educação Cívica assumiam maior centralidade em detrimento da Geografia, que passava a ser ensinada como um aspecto das duas primeiras. Esta organização partia do pressuposto da abordagem de "certos fenômenos da vida sob dois aspectos - o

\footnotetext{
${ }^{87}$ Tradução nossa do original: "The important act is not that the pupil is getting ready to live, but that he is living, and in immediate need of such mental and social nourishment and training as will enable him to adjust himself to his present social environment and conditions. By the very processes of present growth he will make the best possible provision for the future."
} 
histórico e o cívico" (Dunn, 1916, p. 16). Era uma preparação para um curso específico de formação para a cidadania: a Educação Cívica Comunitária.

A Educação Cívica Comunitária tinha como responsabilidade cultivar nos alunos os hábitos de cidadania necessários à vivência na sociedade americana. Para isso, os trabalhos focariam em ação, expressão e julgamento. Os alunos precisariam "expressar sua convicção com palavras e ações", "pesar os fatos e julgar", formar suas próprias conclusões e sujeitá-las à crítica. A ideia de comunidade é ampliada e não se relaciona apenas a territorialidade local, mas se articula ao nacional, mundial e redes de interesses. Entre os conteúdos, seriam expostos: educação, saúde, transporte, migração e imigração, comunicação, distribuição de riquezas, etc. Toda situação real que se relacionasse à vida do aluno poderia ser um tema do curso. A própria escolha da profissão era um objeto de discussão (Dunn, 1916). O ensino teria que partir de problemáticas e para resolvê-las seriam necessários o estudo dos fatos "não como pedaços isolados de conhecimento, mas como meios de contribuir na solução de problemas" (Dunn, 1916, p. 18) ${ }^{88}$. A educação é entendida como um processo de vida e crescimento, no qual se desdobram inúmeros aspectos (políticos, éticos, sociais, etc.).

\begin{tabular}{|c|c|}
\hline \multirow{5}{*}{ Estudos Sociais } & Courses \\
\hline & $\begin{array}{l}\text { I - História Europeia até aproximadamente o fim do século XVII - História } \\
\text { Antiga e Oriental, História Inglesa até o final do período indicado e o período } \\
\text { da exploração americana. }\end{array}$ \\
\hline & $\begin{array}{l}\text { II - História Europeia (incluindo a inglesa) desde aproximadamente o final do } \\
\text { século XVII. }\end{array}$ \\
\hline & III - História Americana desde o século XVII. \\
\hline & IV - Problemas na democracia americana. \\
\hline
\end{tabular}

Quadro 9 - Estudos Sociais nos $10^{\circ}, 11^{\circ}$ e $12^{\circ}$ anos da escola secundária Fonte: Elaborado pelo autor a partir de Dunn (1916, p. 35).

Se nos anos iniciais da escola secundária os Estudos Sociais eram estudados de um modo mais geral, na senior high school havia um maior detalhamento daquilo que deveria ser ensinado. Os Estudos Sociais passavam a ser dominados pela História, course central entre o $10^{\circ}$ e o $12^{\circ}$ anos. Portanto, "o processo de afastamento da História como carro chefe das humanidades (substituída pelos Social Studies)", como argumenta Freitas (2011, p. 1) em suas análises, não ocorreu antes da década de 1930. O modelo de ensino de História é baseado em

\footnotetext{
${ }^{88}$ Tradução nossa do original: "[...] they should not, however, be given as isolated scraps of knowledge, but should be made to contribute to the working out of the problem."
} 
Dewey $^{89}$ e em James H. Robinson ${ }^{90}$, para os quais o passado, enquanto registro daquilo que passou, não tem nenhum valor educacional. Isso muda quando são reforçadas as relações entre o passado e a sua contribuição para o entendimento do presente. $\mathrm{O}$ ensino desse subject se processaria articulado a outros cursos: "isto significa que qualquer curso de ensino de História deve estar organizado de forma que o aluno adquira inevitavelmente alguma familiaridade com os fatores econômicos, sociais e cívicos da vida comunitária." 91 (Dunn, 1916, p. 36).

Nesse nível de ensino, a seleção de conteúdos priorizaria “os Estudos Sociais que mais diretamente auxiliem o aluno a entender as relações de sua própria vida social" (Dunn, 1916, p. 35). Para atingir esse objetivo, não bastaria apenas a História cronológica ou política, predominante nos cursos de "cultura geral" herdados do século XIX. Thomas J. Jones, em um estudo preliminar ao relatório de 1916, sintetizou da seguinte maneira essa abordagem:

A História também deve responder ao teste da boa cidadania. O cronista que registrou os atos de reis e guerreiros e negligenciou os trabalhos do homem comum "está morto". Os grandes palácios e catedrais e pirâmides são, muitas vezes, as conchas vazias de um crescimento parasitário no grupo de trabalho. As elaboradas descrições dessas antigas tumbas são composições de latão e cimentos de tinir em comparação com o registro da alegria e das dores, as esperanças e decepções das massas, que são infinitamente mais importantes do que qualquer arranjo de madeira

\footnotetext{
${ }^{89}$ Dunn (1916, p. 121) citou o seguinte trecho de "Moral principles in education": "History is vital or dead to the child according as it is, or is not, presented from the sociological standpoint. When treated simply as a record of what has passed and gone, it must be mechanical, because the past, as the past, is remote. Simply as the past there is no motive for attending to it. The ethical value of history teaching will be measured by the extent to which past events are made the means of understanding the present [...]." (Dewey, 1909, p. 36-37, tradução nossa: "A História torna-se vida ou morte para a criança dependendo de como é ou não apresentada do ponto de vista sociológico. Quando tratada simplesmente tal qual registro do que se passou e do que se foi, ela torna-se mecânica, porque o passado, enquanto tal, é remoto. Simplesmente sendo passado, não há motivo para que se atente a ela. O valor ético do ensino em História será medido pela extensão com que eventos passados são utilizados como meios para compreender o presente.”). É uma obra não traduzida no Brasil, mas os seus princípios, conforme analisamos no capítulo anterior, foram reforçados pelo educador em outros trabalhos (Cf. Dewey, 1959, 2006).

90 James Harvey Robinson (1863-1936) foi um importante historiador americano. Foi professor, entre 1895 e 1919, da Columbia University e presidente da American Historical Association em 1929. Atuou como membro da Comissão. Foi um dos fundadores da New School for Social Research em Nova York. Em uma de suas principais obras, The New History (1912), defendeu uma modernização nos métodos e conteúdos da História, maior aproximação entre a História e as outras Ciências Sociais e, sobretudo, a concepção de que a História deve abordar os aspectos passados de forma que "nos sirvam melhor para compreender os problemas mais vitais do presente" (Dunn, 1916, p. 41). Essa concepção histórica, que teve força nos Estados Unidos nas primeiras décadas do século XX, defendia que a História tinha que ter uma conexão maior com a vida moderna. Uma biografia do historiador está disponível em: <https://www.britannica.com/biography/James-Harvey-Robinson>. Acesso em: 27 out. 2017.

91 Tradução nossa do original: "this means that any course of history instruction should be so organized that the pupil will inevitably acquire some familiarity with the economic, social, and civic factors in community life [...]."
} 
e pedra e ferro. Neste espírito, a história recente é mais importante do que a dos tempos antigos; a história do nosso país do que a das terras estrangeiras; o registro de nossas próprias instituições e atividades do que a dos estranhos; os trabalhos e os planos das multidões do que os prazeres e sonhos dos poucos. ${ }^{92}$ (Bureau of Education, 1913, p. 17-18, grifos nossos).

Jesse Jones defendeu a ampliação do estudo da História, para além dos reis e guerreiros, e a inclusão de outras temáticas. Cada homem é um sujeito da História e como tal deveria ser reconhecido e estudado. Contudo, de que adiantaria conhecer sobre as catedrais e pirâmides e nada saber sobre os seus construtores? De que adiantaria compreender a vasta História de outros povos e desconhecer a História de seu próprio país e povo? A comunidade de historiadores, essencial na definição de Estudos Sociais ao longo das primeiras décadas do século XX, considerava, ao menos até a década de 1930, que a sua "função pública" residia em "promover o nacionalismo norte-americano ao rastrear a História dos Estados Unidos e suas funções." (Harrison et al., 2011, p. 68). Assim, a História "era apresentada como um processo contínuo de desenvolvimento, cujo produto final era a democracia norte-americana e o crescimento dos Estados Unidos.” (p. 69). O movimento de organização nacional passava pela “identificação dos 'germes' da liberdade norte-americana supostamente plantados no novo mundo pelos primeiros colonos ingleses." (p. 69). Daí a ênfase no estudo da História Inglesa na senior high school.

A definição do assunto a ser tratado dependeria do contato com os alunos e do contexto. Um exemplo citado por Dunn (1916, p. 44-45) ajuda a esclarecer essa questão. Os principais conteúdos dos Estudos Sociais na senior high school eram a História Europeia e a História Americana. A intenção era proporcionar aos alunos uma compreensão acerca dos fundamentos dos Estados Unidos. Para isso, abordavam-se aspectos da "construção da nação", tais como a "Revolução Americana" e “A Constituição". Um desses temas era a "Guerra de 1812" entre os Estados Unidos e a Inglaterra. Uma indicação de como trabalhar esse assunto, de

\footnotetext{
${ }^{92}$ Tradução nossa do original: "History, too, must answer the test of good citizenship. The bid chronicler who recorded the deeds of kings and warriors and neglected the labors of the common man 'is dead. The great palaces and Ai cathedrals and pyramids are often but the empty shells of a parasitic growth on the working group. The elaborate descriptions of these old tombs are butt minding brass and tinkling cymbals compared to the record of the joy and sorrows, the hopes and disappointments of the masses, who are infinitely more important than any arrangement of wood and stone and iron. In this spirit recent history is more important than that of ancient times; the history of our own country than that of foreign lands; the record of our own institutions' and activities than that of strangers; the labors and plans of the multitudes than the pleasures and dreams of the few."
} 
acordo com os princípios da New History e dos Estudos Sociais, foi extraído da prática de uma docente e indicado como uma referência para outros professores de

Estudos Sociais. Embora longa, sua citação se faz necessária:

Normalmente nós consideramos a guerra de 1812, como não intimamente relacionada a esses interesses [das crianças] nem essencial para o desenvolvimento do tema central do termo, "A construção da nação"; logo, abordamos o assunto muito superficialmente, sobrando algum tempo para o estudo mais intensivo da revolução e da elaboração da Constituição, temas que são essenciais para o tema central, e que podem ser mais realistas para as crianças através de suas atividades em um clube de escola. Este clube elabora e retifica sua própria constituição, ganha dinheiro, vota sobre seus gastos; em suma, gerencia seus assuntos em princípios democráticos e então traz aos seus membros o significado de certos termos políticos e situações envolvidas nestes tópicos [...]. Em 1915, no entanto, o assunto da guerra de 1812 apareceu-nos sob uma ótica diferente. As crianças estavam lendo manchetes nos jornais em que a palavra "neutralidade" tinha um lugar conspícuo. Eles ouviram a palavra repetida em casa e em cada esquina e estavam começando a usá-la eles mesmos, embora com noções vagas acerca de seu significado. Consequentemente, o tema anterior no curso de história foi menos abordado que nos anos comuns, e o tempo era adequado a um estudo da guerra de 1812. O estudo foi abordado da seguinte maneira: o que se entende pela expressão "uma nação neutra", "nação beligerante"? Que Nações são agora beligerantes? Qual delas são neutras? Quais são algumas das formas através das quais os cidadãos de uma nação neutra entram em contato com os cidadãos ou com o governo de uma nação beligerante? (algumas das respostas: "comprar as coisas deles"; "vender produtos"; "ter nossas mercadorias transportadas em seus navios"; "viajar por seus países"). Desde que qualquer nação permanece neutra, que direitos tem os seus cidadãos nesses e em outros aspectos? ${ }^{93}$

A História, como ensinada pela professora Hannah M. Harris, da State Normal School at Hyannis, e explicitada nessa passagem, é utilizada para explicar as condições e instituições do presente. Nesse sentido, qualquer fato histórico

\footnotetext{
${ }^{93}$ Tradução nossa do original: "Ordinarily we have regarded the War of 1812 as not closely related to those interests (of the children) nor essential to the development of the central theme of the term. 'The building of the Nation'; hence we have passed over the subject rather lightly, and have saved time for the more intensive study of the Revolution and the making of the Constitution, topics which are necessary to the central theme, and which can he made real to the children by means of their activities in a school club. This club makes and amends its own constitution, earns money, votes its expenditures; in short, manages its own affairs on democratic principles, and so brings home to its members the meaning of certain political terms and situations involved in these topics, such as taxation without representation, majority rule, compromises, etc. In 1915, however, the subject of the War of 1812 appeared to us in a different light. The children were reading headlines in the newspapers in which the word 'neutrality' had a conspicuous place. They heard the word repeated at home and on every street corner, and were beginning to use it themselves, though with but vague notions of its meaning. Consequently the preceding topic in the history course was less fully treated than in ordinary years, and time was appropriated for a study of the War of 1812. The study was approached in the following way: What is meant by the expression ' neutral nation', 'belligerent nation'? What nations are now belligerent? Which ones neutral? What are some of the ways in which the citizens of a neutral nation come into contact with the citizens or with the government of a belligerent nation? (Some of the answers: 'Buy things of them'; 'sell them goods'; 'have our goods carried in their ships'; 'travel in their countries'). So long as any nation remains neutral, what rights have its citizens in these matter sand others?"
} 
pode ser empregado desde que favoreça a compreensão de "problemas atuais" da vida social. Tais problemas são aqueles que o aluno enfrenta ou está envolvido em seu dia a dia. A docente se aproveitou do interesse dos alunos e de uma situação vigente, a Primeira Grande Guerra, para elaborar o seu plano de aula. Isto é o que Dunn (1916, p. 43) denominava como "interpretação pedagógica” da História. O estudo da História, entendida como um método para abordagem dos problemas do presente e um meio para interpretá-los, culminaria no curso "Problemas da Democracia Americana". Tal course deveria "conferir um conhecimento mais definido, abrangente e profundo de alguns dos problemas vitais da vida social" e seria construído a partir de princípios e assuntos provenientes da Ciência Política, da Sociologia e da Economia (Dunn, 1916). Aqui reside a defesa dos Estudos Sociais e cursos mais articulados na escola básica. Para Dunn (1916, p. 53):

[...] nenhum dos defensores das Ciências Sociais está disposto a ceder totalmente seu espaço para outros cursos, e também não é justificável, do ponto de vista da educação social do aluno, limitar seu ensino a um campo da Ciência Social e excluir todos os outros. A mais grave dificuldade, no entanto, é que nenhuma das Ciências Sociais, como desenvolvido e organizado pelos especialistas, é adaptada às necessidades do ensino secundário, e todas as tentativas de cumprir tais exigências têm sido obstruídas pela tradição, como é o caso em História. ${ }^{94}$

Segundo o relator, as diferentes Ciências Sociais não foram pensadas para o ensino. A divisão do conhecimento, na forma como vinha sendo feita, pouco auxiliava no crescimento do aluno, enquanto pessoa e cidadão. $\mathrm{Na}$ escola secundária, o ideal seria a "socialization of social studies", pois na vida enfrentamos problemas e não "Ciências" que, por sua vez, têm como função auxiliar na resolução de problemas. Então, o curso secundário deveria, em seus anos finais, estar organizado a partir de "problemas concretos", importantes para a sociedade e para os alunos, e não em termos estritamente disciplinares. Tais questões deveriam ser estudadas sob diversos pontos de vista: político, econômico, sociológico, ético (Dunn, 1916) ${ }^{95}$. Cada um deles teria sua cota de

\footnotetext{
${ }^{94}$ Tradução nossa do original: "The advocates of none of the social sciences are willing to yield wholly to the others, nor is it justifiable from the standpoint of the pupil's social education to limit his instruction to one field of social science to the exclusion of others. The most serious difficulty, however, is that none of the social sciences, as developed and organized by the specialists, is adapted to the requirements of secondary education, and all attempts to adapt them to such requirements have been obstructed by tradition, as in the case of history."

${ }^{95}$ Um exemplo de problema vital que envolveria (envolve) o aluno e a sociedade se relaciona ao custo de vida. Essa poderia (pode) ser uma questão de interesse do discente, por mudanças no seu modo de vida, diminuição ou ausência de "mesada", entre outros aspectos. De acordo com Dunn (1916, p. 54), "esse problema envolve, do lado econômico, questões fundamentais como valores,
} 
contribuição para o crescimento do aluno. O predomínio da História e seus conteúdos refletiu o trabalho da American Historical Association e seus sócios em prol da defesa do lugar desta disciplina no currículo. Entre as décadas de 1890 e de 1910, os historiadores "eram [considerados] a autoridade apropriada para fazer recomendações sobre os Estudos Sociais" (Smith et al., 1995, p. 1). Com a fundação e a consolidação de outras associações profissionais, como a American Political Science Association (1903) e a American Sociology Association (1905), "os cientistas sociais viram o currículo escolar como um terreno fértil para suas respectivas disciplinas" (Smith et al., 1995, p. 1) e defenderam acréscimos aos conteúdos de Estudos Sociais.

Para Smith et al. (1995, p. 1), as Ciências Sociais passaram a ser vistas “como um veículo para estudar e propor soluções para os problemas resultantes de uma paisagem americana dinâmica e em evolução." 96 Através de um estudo articulado das Ciências Sociais, os estudantes seriam capazes, primeiro, de entender a sua sociedade e, depois, de participar das mudanças. Aos poucos, os Estudos Sociais se firmaram no currículo americano. A perspectiva era a de que as "necessidades atuais deveriam ser os princípios organizadores" para o seu emergente programa (p. 1). A História passou a ser examinada, seguindo as indicações dos historiadores progressistas, a partir de suas relações com as outras Ciências Sociais. Para isso, os defensores dos Estudos Sociais impuseram um novo sentido à História com ênfase no presente e no "valor prático" dessa disciplina. O currículo de Estudos Sociais se propunha, assim, "a envolver os estudantes em um exame do seu mundo político, econômico e social circundante" (Smith et al., 1995, p. 1). Ao analisar os problemas contemporâneos estariam aptos a atuarem e a contribuírem para a melhoria da sociedade.

O Relatório do Comitê de Estudos Sociais da Associação Nacional de Educação, publicado pelo Escritório de Educação dos Estados Unidos, projetou os

preços, salários, etc.; do lado sociológico, questões como os padrões de vida, taxa de natalidade, etc.; do lado político, assuntos como legislação tarifária, controle de fundos e afins e o funcionamento adequado da legislação, a aplicação das leis e procedimento judicial." (Tradução nossa do original: "This problem involves, on the economic side, such fundamental matters as values, prices, wages, etc.; on the sociological side, such matters as standards of living, birth rate, etc.; on the political side, such matters as tariff legislation, control of trusts and the like, and the appropriate machinery of legislation, law enforcement, and judicial procedure.").

96 Tradução nossa do original: "The social sciences were increasingly viewed as a vehicle for studying and proposing solutions to the problems resulting from a dynamic and evolving American landscape." 
Estudos Sociais no cenário educacional americano e levou a sua inclusão nos currículos de diferentes estados da federação. O depoimento de Laura Lacombe ${ }^{97}$ é significativo a esse respeito. Integrante da comitiva aos Estados Unidos organizada por Delgado de Carvalho no final da década de 1920, ela visitou várias instituições que ofereciam a junior high school. Entre elas, a Lincoln School, anexa ao Teachers College, onde concentrou suas observações por considerá-la mais progressiva ${ }^{98}$. Em seus relatórios, Laura Lacombe (1930) apontou para a flexibilidade dos programas americanos. A orientação moderna do ensino, segundo a educadora, desprezava a memorização e desenvolvia-se a partir do julgamento, raciocínio e iniciativa. A organização curricular e disposição de conteúdos não escaparam ao seu olhar curioso:

[...] notam-se ainda os vestigios da globalização adoptada nas escolas primarias: as mathematicas são estudadas em conjuncto assim como a sciencias physicas e naturaes, e tambem os estudos sociaes que comprehendem a historia com a geographia e instrucção cívica. (Lacombe, 1930a, p. 185).

Em outro documento, ela compara a estrutura curricular observada com a brasileira:

Não há aulas de instrução moral e cívica como nas nossas escolas. Quanto à moral, todos os professores estão compenetrados que a par da sciencia que ensinam, são responsáveis pela formação da consciência de seus alunos. Aproveitam toda a oportunidade para um conselho que calará profundamente por vir no momento preciso e não em dissertação teórica [...]. A preocupação de cada professor não é a física, a química, ou a matemática que leciona, porém o aluno que tem a formar. A instrução cívica é dada na aula chamada "Social Studies", conjuntamente com a História e a Geografia. (Lacombe, 1930c apud Cardoso, 2015, p. 196-197) ${ }^{99}$.

Em seus relatórios e entrevistas a jornais cariocas, Laura Lacombe destacou importantes elementos do sistema educacional americano, como a preocupação com o aluno e sua formação e a integração entre conteúdos. A articulação entre os courses ocorria em outras áreas e não apenas em relação à História e à Geografia.

\footnotetext{
${ }^{97}$ Laura Jacobina Lacombe (1897-1990) foi uma importante militante católica, vice-diretora e diretora do Colégio Jacobina. Sócia de diferentes associações, como: a Associação Brasileira de Educação (ABE), a Associação dos Professores Católicos do Distrito Federal (APC) e a Organização Mundial de Educação Pré-escolar (OMEP). Entre as décadas de 1920 e 1940 empreendeu diversas viagens de estudos para a Europa e os Estados Unidos.

${ }^{98}$ Outras escolas visitadas foram a Horace Mann School, também anexa ao Teachers College, além da Spaulding School, Edgemont School e Rand School (Nova Jersey) e escolas de Washington, capital dos Estados Unidos, Baltimore (Maryland), Filadélfia (Pensilvânia) e Boston (no Estado de Massachusetts). Paralelamente, Laura Lacombe visitou o Bureau of Education, onde pôde conversar com o especialista em junior high school (Cf. Lacombe, 1930b, p. 90-96).

99 Esse trecho foi extraído de uma reportagem intitulada "A pedagogia nos Estados Unidos", publicada no periódico A Ordem, em março de 1930. Utilizamos a versão transposta de acordo com as normais gramaticais atuais, disponível em Cardoso (2015, p. 187).
} 
Quanto à "methodologia de cada materia", os Estudos Sociais se mostravam de "real interesse" em virtude de seu programa e pelo "methodo adoptado que se denomina 'socialisado"'. Em 1921, como apontou Delgado de Carvalho (1970, p. 16), foi criado o "Conselho Nacional de Estudos Sociais" (National Council for the Social Studies, em inglês), consolidando a definição e a aceitação dos Estudos Sociais como "o estudo integrado das ciências sociais e humanas para promover a competência cívica"100. Enquanto "estudo integrado", com base em conteúdos selecionados entre as Ciências Humanas, os Estudos Sociais assumiram um papel predominante na formação do cidadão, algo que permeava o currículo.

\section{2 \\ Matriz de referência: os Estudos Sociais nos Estados Unidos da década de 1930}

Com o intuito de recomendar reformulações curriculares, um grupo de intelectuais, capitaneados pela Associação Americana de História, articulou a formação de uma Comissão, em 1925, responsável pela realização de um inquérito sobre o ensino de Estudos Sociais. No ano seguinte, um plano preliminar de pesquisa foi elaborado por membros nomeados pela associação. Em 1927, a Fundação Carnegie fez uma dotação a fim de que a investigação pudesse ser iniciada. Intitulada "Investigation of the Social Studies in the schools" ("Uma investigação de Estudos Sociais nas Escolas”, em tradução livre), composta por professores de diferentes universidades - como as de Minessota, Chicago e Columbia - foi realizada entre janeiro de 1929 e dezembro de $1933^{101}$. Para August C. Krey (1934, p. VII) ${ }^{102}$, presidente-diretor da investigação,

\footnotetext{
${ }^{100}$ Mais informações sobre o National Council for the Social Studies, no site oficial, disponível em: <https://www.socialstudies.org/about>. Acesso em: 17 nov. 2017.

${ }^{101}$ A comissão foi composta por professores de diferentes áreas e atuantes em diferentes universidades americanas, com destaque para as Universidades de Columbia, Chicago e Minessota, que atuaram como instituições sede da pesquisa. Os seus membros foram: Frank W. Ballou (superintendente de escolas, Washington, Dc); Charles A. Beard (professor de História da Universidade de Columbia); Isaiah Bowman (diretor da Sociedade Americana de Geografia, sede Nova York); Ada Comstock (Faculdade Radcliffe); George S. Counts (Faculdade de Formação de Professores da Universidade de Columbia); Avery O. Craven (professor de História da Universidade de Chicago); Edmund E. Day (Fundação Rockfeller/ Universidade de Michigan); Guy Stanton Ford (Universidade de Minessota); Evarts B. Greene (professor de História da Universidade de Columbia); Carlton J. H. Hayes (professor de História da Universidade de Columbia); Ernest Horn (Universidade de Iowa); Henry Johnson (professor de História da Faculdade de Professores da Universidade de Columbia); A. C. Krey (professor de História e
} 
[...] professores e administradores escolares, forçados a atender às demandas diárias e imediatas de um número cada vez maior de alunos, bem como às mudanças nas condições sociais, passaram a buscar orientação, elaborando combinações variantes de muitos relatórios díspares isolados; nenhum deles, entretanto era adequado ${ }^{103}$.

A Comissão, embora pretenda a superação de relatórios anteriores, não apresentou um currículo detalhado ou uma proposta de livros didáticos a serem utilizados nas escolas. Do mesmo modo, rejeitou a ideia de que houvesse um só conjunto de disciplinas, uma organização inequívoca de temas e apenas um método de ensino que, quando aliados, pudessem dar conta dos propósitos discutidos em seu relatório. Pelo contrário, limitou-se a apresentar alguns quadros referenciais sobre o ensino de Ciências Sociais nas escolas. Caberia, portanto, aos “idealizadores de programas em Ciências Sociais em cidades, povoados e estados avaliarem as descobertas e conclusões deste relatório e reformularem currículos e esquemas de ensino existentes de acordo com seu julgamento." (Krey et al., 1934, p. 145-147) ${ }^{104}$. Como resultados do trabalho foram publicados dois documentos principais: "A charter for the Social Sciences in the schools", 1932 ("Carta das Ciências Sociais nas escolas", em tradução livre) e "Conclusions and recommendations of the Comission on The Social Studies of Association American History”, 1934 (“Conclusões e recomendações da Comissão de Estudos Sociais da Associação Americana de História”, em tradução livre).

A primeira questão que se colocou aos membros da Investigação de Estudos Sociais nas Escolas foi uma consideração sobre os seus objetivos. Como não

professor de História de Educação da Universidade de Minnesota); William E. Lingelbach (professor de História da Universidade de Pennsylvania); L. C. Marshall (Universidade de Chicago); Charles E. Merriam (professor de ciência política da Universidade de Chicago); Jesse H. Newlon (diretor da Escola Lincoln da Faculdade de Professores da Universidade de Columbia); Jesse F. Steiner (professor de sociologia da Universidade de Washington).

${ }_{102}$ August Charles Krey (1887-1961) foi um historiador e professor americano formado pela Universidade de Wisconsin, entre 1907 e 1914, e especialista em História das Cruzadas e História Medieval. Atuou como professor na Universidade de Minessota, onde foi diretor do Departamento de História. Com grande interesse pelo ensino de História, "em 1925, foi nomeado presidente do Comitê da Associação Americana de História sobre a História nas Escolas, cargo que ocupou até 1929, quando assumiu a presidência da Comissão da Associação Americana de História sobre a Investigação de Estudos Sociais nas Escolas.” Disponível em: <http://snaccooperative.org/ark:/99166/w6dz0pdv>. Acesso em: 11 out. 2017.

${ }^{103}$ Tradução nossa do original: "Teachers and school administrators, forced to meet the immediate and daily demands of constantly increasing numbers of pupils as well as of changing social conditions, were reaching out for guidance. They were drawing from the several separate reports in varying combination and finding none of them adequate."

${ }^{104}$ Tradução nossa do original: "Makers of programs in the social sciences in cities, towns, and states may be expected to evaluate the findings and conclusions of this report and to recast existing syllabi and schemes of instruction in accordance with their judgment respecting the new situation." 
houve consenso, delimitou-se uma subcomissão interna formada por Charles Beard, George Counts, Guy Stanton Ford, August Krey, Charles Merriam, acrescida por iminentes educadores que desenvolviam pesquisas sobre os objetivos na e da educação: Franklin Bobbit, Boyd H. Bode e Harold O. Rugg (Krey, 1932). Cada membro apresentou, por escrito e oralmente, os seus argumentos acerca do problema, ficando a cargo de Charles Beard a síntese final que consagrou um "ponto de vista coletivo"105. Os temas debatidos foram apresentados à Comissão Geral em maio de 1931, sendo aprovada por unanimidade (Krey, 1932). Todas as contribuições foram reunidas no relatório intitulado "A charter for the Social Sciences in the schools", escrito pelo historiador Charles Beard e publicada em $1932^{106}$.

A Carta foi elaborada com a intenção de munir os professores e pensadores de abordagens educacionais para a compreensão do mundo, bem como apresentar caminhos para as futuras gerações, responsáveis por moldar o amanhã. Para os seus organizadores, "é um tributo ao elevado senso de responsabilidade pública, que educadores e acadêmicos em Ciências Sociais possuem, não estando alheios, nem indiferentes às implicações educacionais dessas mudanças.” (Krey, 1932, p. $\mathrm{V}-\mathrm{VI})^{107}$. Diferentemente de relatórios anteriores, como o publicado em 1916 (“Os Estudos Sociais no ensino secundário”), os membros da Comissão não

\footnotetext{
${ }^{105}$ Foram signatários da Carta: August C. Krey (professor de História da Universidade de Minessota); Frank Ballou (superintendente de escolas, Washington, D.C.); Charles Beard (relator); Isaiah Bowman (Sociedade de Geografia Americana de Nova Iorque; presidente da União Internacional de Geografia); Ada Comstock (Colégio Radcliffe); George Counts (Universidade de Columbia); Avery Craven (professor de História da Universidade de Chicago); Edmund E. Day (diretor de Ciências Sociais, Fundação Rockefeller); Ford Guy Stanton (professor de História da Universidade de Minessota); Carleton J. H. Hayes (professor de História da Universidade de Columbia); Henry Johnson (professor de História da Universidade de Columbia); Charles E. Merriam (professor de ciência política da Universidade de Chicago); Jesse H. Newlon (Universidade de Columbia. diretor da Escola Experimental Lincoln); Jesse Steiner (professor de sociologia da Faculdade Grinnell); Leon C. Marshall (Universidade Johns Hopkins); Ernest Horn (Universidade de Iowa).

${ }^{106}$ Charles Austin Beard (1874-1948) foi um historiador e cientista político americano, com formação obtida na Universidade de Oxford (Inglaterra) e PhD em História, pela Universidade de Columbia (1904). Tornou-se docente desta última, lecionando Ciência Política até 1917, quando se demitiu após uma série de controvérsias sobre o ideal de liberdade acadêmica na universidade. Em 1919, juntamente com outros intelectuais e educadores, como John Dewey, fundou a New School for Social Research em Nova York. Especialista em História dos Estados Unidos e instituições políticas, ele atuou em associações como American Political Science Association (presidente em 1926) e American Historical Association (presidente em 1933). Entre suas obras, destaca-se "An economic interpretation of the Constitution of the United States" (1913). Disponivel em: <https://www.britannica.com/biography/Charles-A-Beard>. Acesso em: 11 out. 2017.

${ }^{107}$ Tradução nossa do original: "It is a tribute to the high sense of public responsibility held by educators and scholars in the social sciences that they were neither unconcerned about, nor indifferent to, the educational implications of these changes."
} 
expuseram exemplos de aplicação, mas apresentaram critérios e pontos de referência para o debate de questões candentes no cenário educacional americano. Em termos organizacionais, a Carta, de 122 páginas, divide-se em sete motes: 1) As exigências da pesquisa; 2) A natureza das disciplinas sociais; 3) Conjunto dos requisitos estabelecidos pelas realidades sociais de nosso tempo; 4) $\mathrm{O}$ contexto das ideias americanas; 5) Enquadramento legal e programas estabelecidos; 6) As exigências do processo de ensino-aprendizagem; 7) O objetivo supremo no ensino cívico - a criação de identidades plurais e multifacetadas.

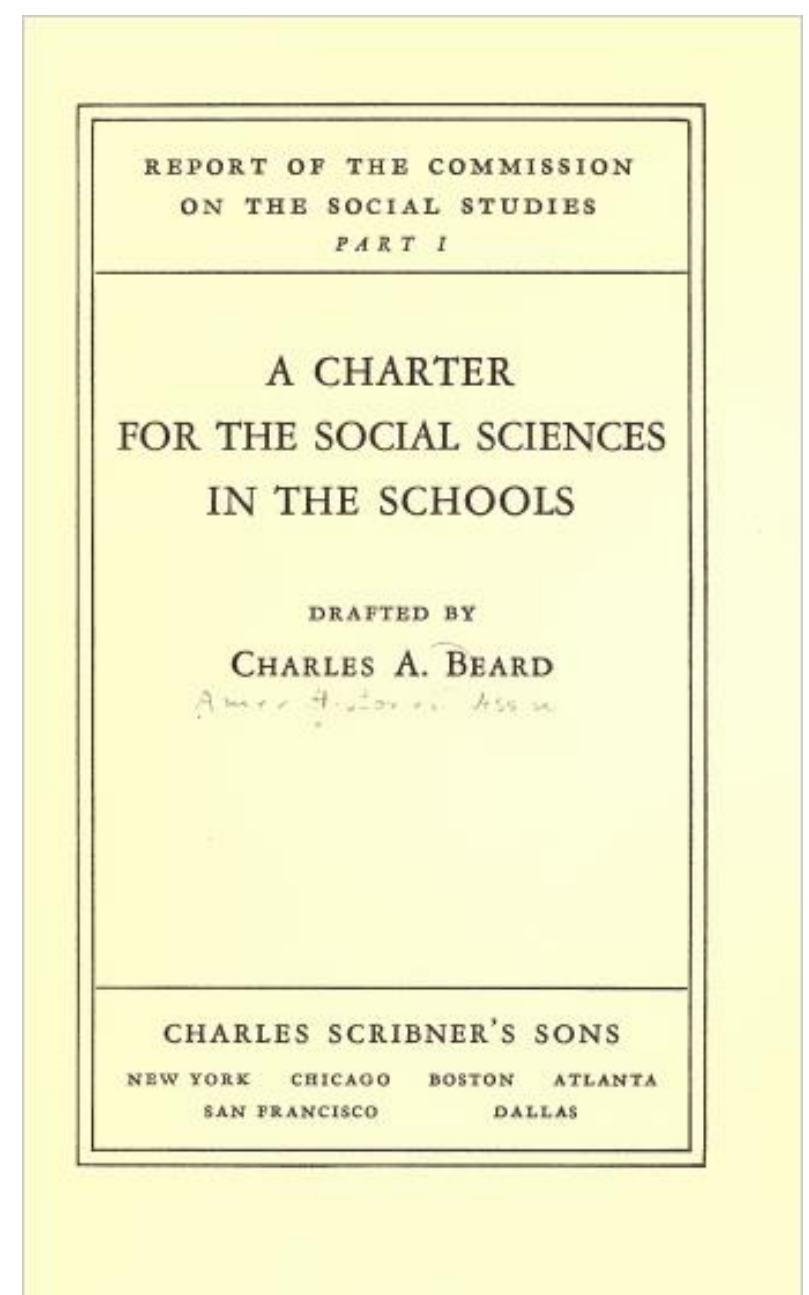

Figura 5 - Capa da "Carta", relatório preliminar da "Investigation of the Social Studies in the schools"

Fonte: Beard (1932).

Para Beard (1932), o ensino de Estudos Sociais está condicionado, sobretudo, pela pesquisa, motivação, condições de estudo, realidades e ideias da sociedade em que é ministrado e pela natureza e limitações de ensinoaprendizagem dos níveis a que se destina. Tudo o que o homem fez ou faz é um 
possível objeto de investigação: "Pelos votos de seu ofício, eles [os cientistas sociais] devem abordar o mundo inteiro e todas as eras em suas pesquisas."108 Desde os impérios da antiguidade até as organizações sociais do presente, como construções da humanidade ao longo do tempo, nada está alheio aos seus interesses. Cada um desses aspectos gera um manancial de pesquisas e trabalhos. Beard (1932, p. 6-8) salienta que:

[...] a título de esclarecimento, nenhum de nós é forte o suficiente para reunir os frutos de todas essas pesquisas em uma síntese magnífica, para construir um esquema de ideias proporcionalmente e artisticamente paralelas a toda realidade a qual elas buscam descrever. ${ }^{109}$

Entretanto, para o historiador americano, das diversidades dos especialistas surgem imagens ofuscadas e fragmentárias de um todo. Cada pesquisador contribui para o nosso conhecimento sobre o mundo, concedendo novos significados para (e sobre) a herança humana.

Os Estudos Sociais são definidos como uma espécie de acervo literário que aborda os assuntos humanos. Há, portanto, um enorme acervo literário, com variadas combinações de tópicos de estudos possíveis, o que torna difícil reduzi-lo ou encaixá-lo de forma que possa ser facilmente apresentado às crianças. É a partir desse vasto campo de ideias, observações, acumulações de tradições, entendidas como "matérias-primas do mundo e da vida", que se deveria formular as Ciências Sociais e construir os esquemas de Estudos Sociais ensinados nas escolas americana (Beard, 1932, p. 16). A divisão em disciplinas se impôs "sob o estresse da especialização moderna" e como uma forma de se analisar cada aspecto com mais precisão e intensidade (Beard, 1932). Dessa forma, a Ciência Social se dividiu em diferentes disciplinas, como a História, a Economia, a Política, a Geografia, com ênfases diferentes, mas um objeto comum.

De acordo com Beard (1932), os limites convencionais entre as disciplinas não são inflexíveis, com fronteiras intransponíveis, havendo uma tendência a ultrapassá-los em quaisquer que sejam as direções. Contudo, como argumenta o autor, "isto não significa que uma ou a Ciência Social tenha sido criada, uma síntese que transcenda as disciplinas em si. Nem ao menos no estado atual das

\footnotetext{
${ }^{108}$ Tradução nossa do original: "By the vows of their craft, they must cover the wide world and all time with their searchings."

${ }^{109}$ Tradução nossa do original: "To be sure, none of us is strong enough to gather the fruits of their researches into one mighty synthesis, to construct a scheme of ideas proportionately and artistically mirroring the total reality which they are seeking to describe."
} 
coisas tal conquista parece possível."110 (p. 20-21). Isso porque cada uma das disciplinas têm seus próprios centros de gravidade e fornecem pontos de vista a partir dos quais cada tópico pode ser pesquisado. Nesse sentido:

[...] uma síntese, se esta pode ser alcançada, seria mais um quadro habilmente forjado, do que uma integração subliminar na qual as disciplinas separadas desapareceriam e perderiam completamente sua identidade como Direito, Política, Economia, Geografia e História. ${ }^{111}$ (Beard, 1932, p. 21).

Pela proposta, a valorização da "unidade", através da possibilidade de novas disposições dos tópicos de ensino, poderia ser realizada, mas as identidades e elementos principais das disciplinas continuariam presentes no ensino escolar.

O objeto de estudo dos cientistas sociais é a própria vida em que o aluno se insere. A vida é um laboratório para o ensino de Ciências Sociais (Beard, 1932). A indústria descrita e analisada pelo economista, em seus trabalhos, prospera ou não nas cidades em que seus livros são estudados. Não bastam os pressupostos acadêmicos ou esquemas exclusivamente desenhados com suporte em livros. A partir disso, o documento complementa: "muitos dos materiais de base com os quais eles [os professores] trabalham são abertos a todos e são os objetos da experiência, se não contemplação, daqueles a quem eles ensinam.” (Beard, 1932, p. 22-23) ${ }^{112}$. Tal constatação se aproxima do que Dewey (2002) já defendia em finais do século XIX, quando apontava para o isolamento da escola em relação à sociedade e à vida. O exemplo do filósofo é justamente pensado a partir do ensino de uma disciplina social:

[...] quando a Geografia é simplesmente uma matéria associada à sala de aula, constitui um despertar para muitas crianças descobrir que tudo isto não passa de uma afirmação mais formal e definitiva dos fatos que veem, sentem e tocam todos os dias. (Dewey, 2002, p. 67-68).

Isso significa dizer que o ensino de Ciências Sociais se funda em dada realidade, levando-se em consideração o que ocorre na sociedade que a circunda, com as suas mudanças, características e objetivos.

\footnotetext{
${ }^{110}$ Tradução nossa do original: "This does not mean, however, that a or the social science has been created, a synthesis transcending the disciplines themselves. Nor in the present state of things does such an achievement seem possible."

${ }^{111}$ Tradução nossa do original: "Apparently a synthesis, could it be effected, would be a skillfully wrought mosaic rather than subliminal coalescence in which the separate disciplines would disappear and completely lose their identity as law, politics, economics, geography, and history."

${ }^{112}$ Tradução nossa do original: "[...] many of the raw materials with which they work are open to all and are the objects of experience, if not contemplation, for those whom they teach."
} 
Os programas deveriam ser elaborados a partir das várias divisões da Ciência Social, tendo como preocupação central o ensino cívico. Sua função seria a de fortalecer as instituições democráticas, iluminando seu funcionamento, apontando defeitos, formando líderes, promovendo hábitos (Beard, 1932). Assim, três dados são essenciais à sua formulação. O primeiro é o caráter mutável da sociedade a qual os alunos viveriam e trabalhariam. "É o inevitável impulso a mudança sob a acumulação de ideias e tradições, sob os implacáveis impactos da ciência e da invenção, que define o problema fundamental na organização dos Estudos Sociais para as escolas.” (p. 28). A educação, como argumenta Dewey (1959, 2002), já não pode ser considerada como estática. Em um regime onde não se é possível "estabelecer responsabilidades, direitos e deveres com um grau aceitável de certeza, sempre eficientes"113 (Beard, 1932, p. 27-28), o programa de Ciências Sociais não poderia permanecer o mesmo de séculos anteriores. Beard (1932, p. 32-33) assinala, com a influência deweyana, que "o pressuposto de que as escolas podem doutrinar os alunos com ideias fixas e dar-lhes habilidades definitivas que sejam sempre adequadas, em qualquer parte, tem pouca garantia em nossa civilização industrial." 114 Portanto, o currículo de Estudos Sociais se voltaria para a vida como é vivida e como pode vir a ser vivida, lida com o "hoje" e com o que está emergindo a partir das condições presentes (Beard, 1932).

Outro condicionante é o industrialismo. Como também salienta Anísio Teixeira (1968), a civilização moderna se fundamenta economicamente na ciência e no maquinário. É uma civilização tecnológica, em contraposição à agrícola, baseada na invenção, reconstrução, o que a torna ainda mais dinâmica. A indústria gera a necessidade de novas formações, habilidades e atitudes. A principal exigência dessa sociedade é a capacidade de constante adaptação. Por último, o sistema governamental sob o qual os alunos viverão enquanto participantes ativos. A democracia americana pressupõe o "direito de discordar". Por isso é tão importante a discussão acerca da cidadania nas escolas. $\mathrm{O}$ seu ensino não pode omitir nenhuma característica da sociedade, da política, da economia, seja ela

\footnotetext{
${ }^{113}$ Tradução nossa do original: "It is the inescapable drive of change under the accumulation of ideas and traditions, under the relentless impacts of science and invention, that sets the fundamental problem in organizing social studies for the schools. In a fixed regime it is possible to establish duties, rights, and responsibilities with a fair degree of definiteness, effective always, everywhere."

${ }^{114}$ Tradução nossa do original: "Therefore, the assumption that the schools can indoctrinate the pupils with fixed ideas and give them definitive skills good always and everywhere has little warrant in our industrial civilization."
} 
negativa ou positiva, a fim de estimular a inteligência e a criticidade dos alunos. Só assim eles poderiam agir no meio em que vivem. A própria manutenção da democracia dependeria do constante debate sobre os seus fundamentos. Os alunos, se entendidos como simples robôs, não teriam condições de participar ativamente da vida democrática americana (Beard, 1932).

A Comissão foi formada majoritariamente por historiadores, sendo a sua relatoria ocupada por um deles. Um dos temas levantados se refere ao que seria o foco de ensino dos Estudos Sociais. Seriam apenas as questões do presente? Beard (1932, p. 41-42) sintetizou a questão:

[...] às vezes é encorajado que o objetivo principal dos Estudos Sociais deva ser assegurar uma apresentação e discussão de temas atuais. A partir daí, acredita-se, surgirá à preparação adequada das pessoas em sua missão histórica. Mesmo que esta tese seja fascinante e esteja apoiada por grandes autoridades, ela não deve ser difundida sem uma avaliação. ${ }^{115}$

Para o relator, a principal dificuldade se relacionava à mutabilidade dos problemas. Não há garantia de que os problemas discutidos hoje serão os mesmos quando as crianças atingirem a maturidade. Diferentemente do que defende Dewey (1959) em suas análises sobre o ensino de História, de que as discussões devem começar pela "experiência presente", Beard (1932) argumenta que antes de se abordar as questões ditas da vida atual é preciso que os alunos tenham contato com uma ampla gama de registros históricos da experiência humana.

O objetivo dos Estudos Sociais, a partir do ensino cívico, estaria relacionado à construção de "identidades plurais e multifacetadas". Tal formação, para Beard (1932), habilitaria os jovens a tomarem consciência de suas responsabilidades pessoais e coletivas, a entender o mundo em constante mudança e a se adaptarem a ele. Como argumenta Dewey (1959), a função da educação é proporcionar mais e melhor educação. O que é transmitido em sala de aula é apenas um aparato da vida, segundo Beard (1932, p. 99), sendo fundamental a busca por novos conhecimentos: "Um conhecimento sobre como adquirir o conhecimento é uma aquisição permanente que pode ser usada durante toda uma vida." ${ }^{116}$ Cabe ao

\footnotetext{
115 Tradução nossa do original: "On this assumption it is sometimes urged that the chief purpose of the social studies is to assure a presentation and discussion of current issues. Out of this, it is said, will come the proper preparation of the people for their historic mission. While this thesis is alluring and is supported by high authority, it should not be taken for granted without examination."

${ }_{116}$ Tradução nossa do original: "A knowledge of how to acquire knowledge is a permanent possession which can be used throughout life."
} 
professor desenvolver essas habilidades em seus alunos. Ao utilizar fontes, dados estatísticos, vivências empíricas, questionamentos, o professor constrói habilidades analíticas que prosseguem para além dos bancos escolares.

Os Estudos Sociais, desse modo, representam mais do que a transmissão de informações, mas atua na construção de hábitos sociais (higiene pessoal, cortesia, cooperação), de atitudes (tolerância, respeito, zelo, orgulho), de capacidades (comparar, contrastar, combinar, construir). As informações só têm utilidade se contribuírem para análise, validação, escolha, determinação e ação com sabedoria. O que conta é a capacidade de compreensão (Beard, 1932).

A "Carta das Ciências Sociais nas escolas" foi uma das bases para a escrita do relatório final, apresentado em 1933 e publicado no ano seguinte: "Conclusions and recommendations of the Comission on The Social Studies of Association American History" 117 . Contudo, este avançou em aspectos como o papel do professor e a definição dos conteúdos fundamentais ao ensino de Estudos Sociais. O documento foi discutido em dois encontros realizados em outubro e dezembro de 1933. Após novas leituras, foi apresentado à Comissão Geral, em 1934. Diferentemente da "Carta" (Beard, 1932), as "Conclusões e recomendações" não expõem um autor. No decorrer do relatório aparece sempre a referência "A Comissão", denotando uma tentativa de construção coletiva do documento. No prefácio, A. C. Krey (1934, p. XI), presidente da investigação, defende que "as conclusões da Comissão apoiam-se na experiência, no estudo e na reflexão que seus membros trouxeram para o seu trabalho e deliberações."118

Apesar disso, por divergências quanto à formulação e algumas colocações, quatro dos membros que assinaram o relatório preliminar de 1932 se recusaram a assinar o documento final. Foram eles: Frank Ballou, Edmund Day, Ernest Horn e Charles Merriam. Não foi possível encontrar os motivos que os levaram a tomar tal atitude, algo que não ficou claro nem mesmo naquele momento. $\mathrm{O}$ professor Robert Clarkson Brooks (1934), em resenha publicada na American Political Science Review, lamentou o fato desses docentes não apresentarem as suas opiniões dissidentes.

\footnotetext{
${ }^{117}$ Ao nos referirmos a esse relatório, utilizaremos como referência: Krey et al. (1934).

118 Tradução nossa do original: "Finally, the conclusions of the Commission rest upon the experience, study, and thought which its diverse membership brought to its work and deliberations".
} 


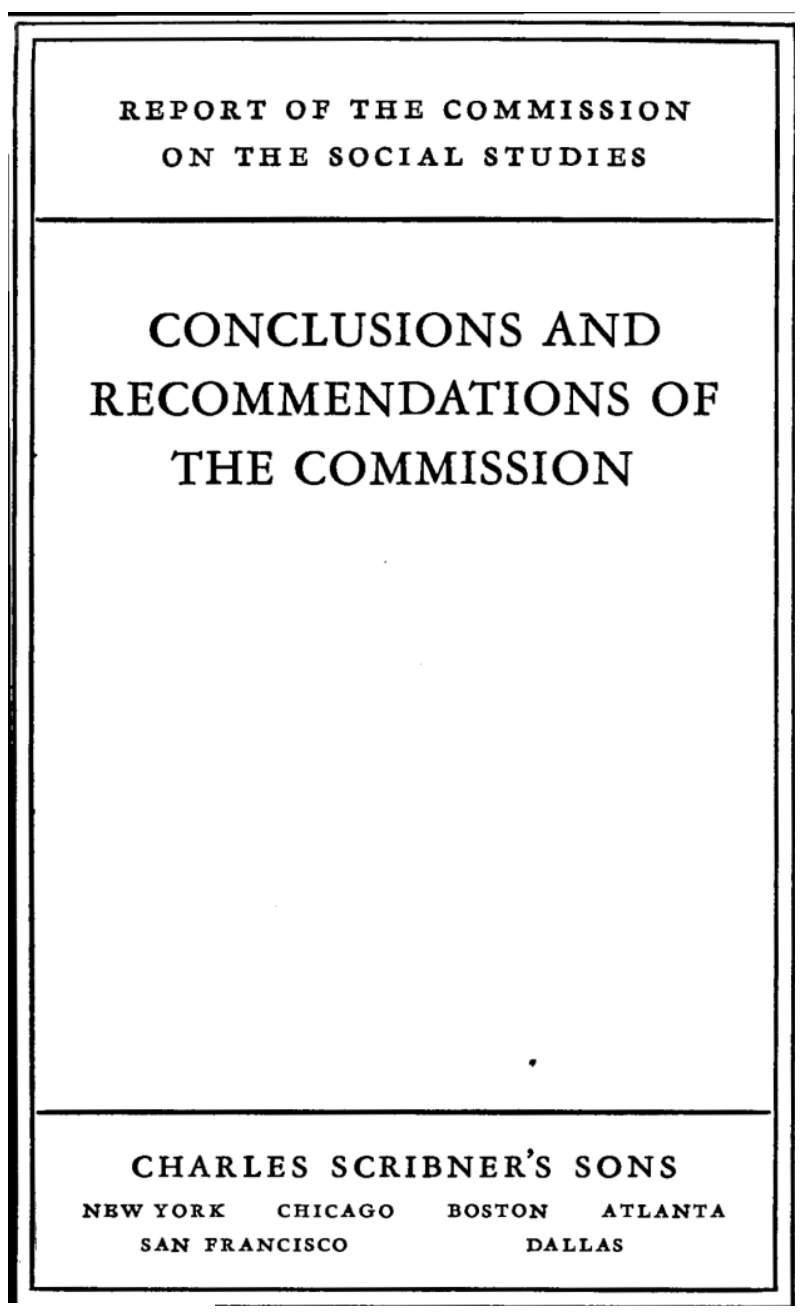

Figura 6 - Capa do relatório final da "Investigation of the Social Studies in the schools"

Fonte: Krey et al. (1934).

O documento está dividido em 8 capítulos e 3 apêndices, distribuídos em 179 páginas: 1) As obrigações e procedimentos da Comissão; 2) O quadro de referência; 3) Filosofia e propósito da educação; 4) Seleção e organização dos tópicos de ensino; 5) Método de ensino; 6) Avaliação; 7) O professor; 8) Relações e administração pública. Os apêndices apresentam o percurso da Comissão. O subitem "Natureza e funções das Ciências Sociais", ao mesmo tempo em que corrobora aspectos do texto de Beard (1932), esclarece a distinção entre Ciências Sociais e Estudos Sociais, que na carta são tomados como sinônimos ${ }^{119}$.

As Ciências Sociais abrangem todo o campo da história humana, desde os tempos mais remotos até os atuais, e a extensão mais ampla da sociedade contemporânea,

\footnotetext{
${ }^{119} \mathrm{Na}$ "Carta das Ciências Sociais nas escolas", os termos "educação social", "Ciências Sociais", "Estudos Sociais", "ensino ou educação cívica" aparecem como indicadores de estudos formados a partir de conteúdos de várias disciplinas escolares, como História e Geografia.
} 
desde a vida e os costumes de povos antigos às práticas sociais e posses culturais de regiões vizinhas. ${ }^{120}$ (Krey et al., 1934, p. 6).

Essa definição é semelhante à produzida em 1916. Entretanto, naquele momento, o conteúdo dos Estudos Sociais se restringiu essencialmente à História Europeia e à Americana, à Geografia e à Educação Cívica. Nas recomendações, houve uma significativa ampliação desse escopo, embora se tenha mantido a finalidade social do ensino de Estudos Sociais. Para Krey et al. (1934), as Ciências Sociais são formadas pelas disciplinas tradicionais que são: História, Economia, Política, Sociologia, Geografia, Antropologia e Psicologia. Cada uma delas possui características intrínsecas e um conjunto de dados, estando intimamente interligadas, em suas abordagens e análises, através de um objetivo comum que é a busca do maior conhecimento sobre o homem e a sociedade. Os autores do documento de 1934, reafirmando a posição de Beard (1932), repudiaram a criação de uma Ciência Social geral que unificasse todas as outras. Eles defenderam a vantagem advinda do rompimento dos "limites convencionais" que as distanciaram (Krey et al., 1934, p. 6). Nesse sentido:

[...] a principal função das Ciências Sociais é a aquisição de conhecimento preciso e percepção informada do homem e da sociedade; já a do ensino das Ciências Sociais é a transmissão de tal conhecimento e percepção, com habilidades e fidelidades correspondentes, aos indivíduos que compõem a sociedade [...] as funções são de suma importância e podem ser eficazes para mensurar a extensão e profundidade de sua concepção, envolvendo um conhecimento real de homem e sociedade sob as mais diversas condições e circunstâncias. ${ }^{121}$ (p. 7).

Se as Ciências Sociais representam a pesquisa, "aquisição de conhecimento", os Estudos Sociais, instrumento de ensino da primeira, são a sua "transmissão", vulgarização. Apesar da diferenciação que realizaram sobre a pesquisa e o ensino em Ciências Sociais, ambos deveriam ser informados pelo método científico que, neste caso, tem uma dupla funcionalidade: é instrumento de reflexão, criação e investigação e elemento, indispensável, para o

\footnotetext{
${ }^{120}$ Tradução nossa do original: "The social sciences take as their province the entire range of human history, from the earliest times down to the latest moment, and the widest reaches of contemporary society, from the life and customs of the most remote peoples to the social practices and cultural possessions of the immediate neighborhood."

${ }^{121}$ Tradução nossa do original: "The main function of the social sciences is the acquisition of accurate knowledge of, and informed insight into, man and society; that of social science instruction is the transmission of such knowledge and insight, with attendant skills and loyalties, to the individuals composing society. Regardless of the special circumstances of a given time, these functions are vitally important and are likely to be effective in the measure of the breadth and depth of their conception, involving a real knowledge of man and society under most diverse conditions and circumstances."
} 
desenvolvimento de senso crítico. No ensino, o método científico, contribui para que os "indivíduos aprendam a pesquisar e pesar evidências, comparar e contrastar e agir com informação e não com preconceito." ${ }^{122}$ (Krey et al., 1934, p. 8). Para tanto, um elemento crucial é a manutenção dos ideais de liberdade de pesquisa e ensino. A seleção dos conteúdos e a elaboração dos programas teriam como condicionante a própria vida americana enquanto parte da civilização ocidental. Isso faria do seu ensino algo prático, não abstrato ou inútil (Krey et al., 1934). Tal ideal já fazia parte dos anseios das comissões anteriores.

De forma semelhante às constatações de Anísio Teixeira (1968), ao analisar a situação educacional brasileira e carioca dos anos de 1930, Krey et al. (1934) argumentaram que a seleção dos conteúdos, bem como a elaboração dos programas de ensino, era o principal problema educacional. Isso ocorre uma vez que há a escolha de conhecimentos, ideias, julgamentos, valores, entre outros, que devem ser introduzidos e transmitidos às futuras gerações através da escola.

Os cinco princípios que guiariam a organização e seleção dos tópicos de Ciências Sociais eram: “[o] propósito da educação, as competências da criança, o tempo gasto dentro da escola, a vida da comunidade local e as obrigações associadas à competência profissional."123 (Krey et al. 1934, p. 46). Nessa concepção, o currículo e os tópicos de ensino fornecem aos estudantes elementos para que sejam capazes de entender, julgar e avaliar as mudanças em andamento, de modo que tenham condições de "agir de forma inteligente e de acordo com o interesse comum ao enfrentar os inúmeros problemas que estão à frente." "124 (Krey et al., 1934, p. 46, 47). O programa deveria ser derivado da Geografia Física e Cultural, Economia, Sociologia Cultural, Ciência Política e História, caracterizando-se por 10 tópicos ou objetivos centrais:

1) Conhecimento e entendimento sobre a terra enquanto "casa física do homem", sobre a relação dos fatores geográficos e a evolução do

\footnotetext{
${ }^{122}$ Tradução nossa do original: "[...] individuals learn to seek and weigh evidence, to compare and contrast and to act with an informed rather than a prejudice."

${ }^{123}$ Tradução nossa do original: "In the selection and organization of the materials of instruction in the social sciences the educational statesman should be guided by five controlling principles or considerations-the purpose of education, the powers of the child, the time allotment of the school, the life of the surrounding community, and the obligations associated with professional competence."

${ }^{124}$ Tradução nossa do original: "[...] to appreciate and to evaluate the great changes under way and to act intelligently and in the common interest in facing the innumerable issues that lie ahead."
} 
homem, a distribuição dos recursos, a luta dos indivíduos, grupos e nações pela posse das terras, planejamento da economia e “enriquecimento geral da vida comum" (Krey et al., 1934, p. 50) ${ }^{125}$;

2) Conhecimento e entendimento sobre os processos sociais através das quais se perpetua a vida em sociedade. A adaptação do homem ao “mundo físico externo", o processo de distribuição das populações, as formas de organização social, as mudanças e as continuidades na cultura (p. 50-51);

3) Valorização de "uma concepção ampla e abrangente da evolução da civilização, destacando a ideia de desenvolvimento, traçando contrastes entre o presente e o passado, abordando as diversas contribuições das raças e dos povos, religiões e culturas e dando uma ampla perspectiva das riquezas, problemas e conquistas da humanidade."126 (p. 51);

4) Estudo detalhado da evolução da civilização ocidental, com ênfase nas modificações nos sistemas de produção, "formas de vida e concepções éticas", na sucessão dos sistemas sociais, desenvolvimento de ideais e práticas democráticas, avanço da ciência e da tecnologia e valorização do ideal de integração da cultura mundial (p. 51-52);

5) Estudos detalhados da história do povo americano, a partir da conquista material do continente, do desenvolvimento da democracia, das lutas populares por liberdade e mais oportunidades, da ascensão da nova economia industrial e tecnológica, do planejamento nacional, das relações políticas, econômicas e culturais dos Estados Unidos com outros povos e nações do mundo (Krey et al., 1934, p. 52);

\footnotetext{
${ }^{125}$ Não por acaso, esse é o primeiro ponto a ser lembrado quando da definição de conteúdos possíveis para os Estudos Sociais. Esse tópico é devedor de uma concepção que considera que a "unidade de todas as ciências encontra-se na Geografia. A importância da Geografia reside no fato de apresentar a Terra como a sede permanente das ocupações do homem. Sem a sua relação com a atividade humana, o mundo seria um mundo diminuído. A indústria e os empreendimentos humanos, quando desenquadrados de suas raízes na Terra, perdem significado e deixam de suscitar emoções. A Terra é a fonte última de todo o alimento do homem. É o seu abrigo e proteção a cada momento, a matéria-prima de todas as suas atividades e a morada para cuja humanização e idealização concorrem todos os seus feitos.” (Dewey, 2002, p. 27). Para Dewey (1959, p. 232), portanto, uma definição clássica da Geografia é a de "descrição da terra em seu caráter de morada do homem". Entretanto, a disciplina precisa ser apresentada, como propõem os membros da comissão, a partir de suas relações com a vida humana.

${ }^{126}$ Tradução nossa do original: "The program of social science instruction should give a broad and comprehensive conception of the evolution of civilization, laying stress on the idea of development, drawing contrasts between the present and the past, embracing the diverse contributions of races and peoples, religions and cultures, and giving a broad perspective of the fortunes, problems, and achievements of mankind."
} 
6) Ênfase em análises e estudos realistas sobre a vida, as instituições e as culturas dos principais povos do mundo contemporâneo, salientando "as rivalidades", conflitos de interesse e possíveis causas de guerras e valorizando a "interdependência crescente das nações" e os esforços para a "promoção da paz internacional". Para tanto, devido ao seu rápido crescimento, seria preciso conceder uma atenção especial à América Latina, África e Ásia (em especial ao Extremo Oriente), consideradas "regiões jovens", mas com significativa importância no cenário internacional (p. 52-53);

7) Estudos realistas sobre a vida, as instituições e a cultura da América contemporânea, não omitindo "o estudo sobre as ineficiências, as corrupções, as tensões, os conflitos, as contradições e as injustiças de nossa época, ou a consideração do potencial material e intelectual

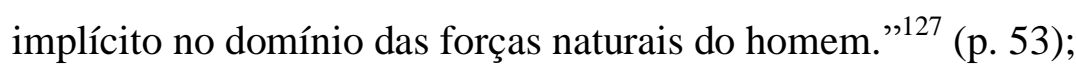

8) Estudo atento e crítico de todas as teorias, filosofias e programas, mesmo que radicais e/ou conservadoras, elaboradas para "lidar com as crescentes tensões e problemas da sociedade industrial” (p. 53-54);

9) Conhecimento das fontes para estudos de "assuntos novos e atuais" e utilização dos métodos de pesquisa, buscando "escrutinização, crítica, autenticação e verificação" (p. 54), como um dos objetivos principais de todo ensino em ciência social;

10) Estímulo às "responsabilidades e deveres da cidadania e vida social", encorajamento de simpatia e de curiosidade intelectual e promoção do “crescimento do interesse vocacional e prático". O programa deve proporcionar a cada aluno um "amplo campo para os encantos visuais, afetivos e mentais - para o cultivo rico e saudável do interesse estético, emocional e intelectual, valorizações e atividades." ${ }^{28}$ (p. 54).

\footnotetext{
${ }^{127}$ Tradução nossa do original: "The program of social science instruction should provide for a realistic study of the life, institutions, and culture of contemporary America. In doing this, it cannot omit study of the inefficiencies, the corruptions, the tensions, the conflicts, the contradictions and the injustices of the age, or consideration of the material and spiritual potentialities implicit in man's mastery of natural forces."

${ }^{128}$ Tradução nossa do original: "The program of social science instruction should not be regarded as wholly instrumental to the induction of boys and girls into the responsibilities and duties of citizenship and social living. It should also stimulate intellectual curiosity and sympathy and foster the growth of avocational as well as practical interests. It should open up to every pupil a wide
} 
Os conteúdos deveriam refletir os propósitos da sociedade americana, relacionar-se às realidades da cena social, descrever tendências e hábitos da sociedade, bem como prever algumas das necessidades com as quais as crianças lidariam no futuro, apresentando ideais éticos (Krey et al., 1934). Mais do que qualquer outra área do currículo escolar, como salientaram os membros da Comissão, as Ciências Sociais se relacionam intimamente com a vida, as instituições e as "políticas nacionais em sua configuração mundial" (Krey et al., 1934, p. 1). Esse ponto nos permite contestar uma afirmativa de Nadai (1988, p. 3), em que a autora - ao analisar a obra de John Udell Michaelis, "Social Studies for children in a democracy",129, publicada pela primeira vez em 1950 argumenta "que a ênfase maior [dos currículos de Estudos Sociais] recai sempre na história nacional e nos americanos ilustres que são tomados como modelos a serem seguidos na formação do futuro cidadão." (grifos da autora). Se essa premissa era válida no Relatório da Comissão de Estudos Sociais de 1916 e nas décadas de 1950 e de 1960, não o era no momento em que os Estudos Sociais foram introduzidos no Brasil da década de 1930. Nesse contexto, documentos como a "Carta das Ciências Sociais nas escolas" (Beard, 1932) criticaram a ênfase excessiva a uma história nacional em detrimento de uma história da civilização.

[...] normalmente ele [o aluno] é ensinado a acreditar realisticamente na existência de apenas uma nação. Certamente, através da Geografia e da História ele aprende alguma coisa sobre outros países, mas eles são geralmente vistos como abstrações remotas de sua vida como um cidadão americano. É claro que durante a era agrícola e auto-suficiente dos Estados Unidos, isto era bastante natural e talvez defensável, mas em uma época de comércio exterior, migração, créditos internacionais, rádios e cabos, os limites políticos não são tão absolutos e as relações internacionais tornam-se tão significativas e fatídicas quanto assuntos nacionais. A educação social não pode ajudar uma dada sociedade a atingir seus fins justos a menos que esta revele a estrutura das relações internacionais e enfatize a importância do tipo de comportamento nacional essencial à condução racional de questões internacionais. Em outras palavras, a cena nacional deve estar solidamente atrelada à cena mundial. ${ }^{130}$ (Beard, 1932, p. 50-51).

\footnotetext{
field for the delights of the eye, the heart, and the mind-for the rich and wholesome cultivation of xsthetic, emotional, and intellectual interests, appreciations, and activities."

${ }^{129}$ A versão traduzida, "Estudos Sociais para crianças numa democracia", foi publicada no Brasil em 1963. Para uma análise desta obra cf.: França (2013).

${ }^{130}$ Tradução nossa do original: "[...] and it may be added that ordinarily he is taught to believe realistically in the existence of only one nation. To be sure, through geography and history he learns something about other countries, but they are generally viewed as abstractions remote from his life as an American citizen. Once, of course, when the United States was agricultural and more largely self-sustained, this was quite natural and perhaps defensible, but in this age of foreign trade, migration, international credits, radios, and cables, political boundaries are not so absolute and international relations become as significant and fateful as domestic affairs. Social education
} 
A Comissão defendeu um modelo de ensino de Estudos Sociais que articulasse a "vida americana com a do restante do mundo". Uma de suas bases está na crítica a uma noção estreita de nacionalismo e ao isolacionismo americano, considerado até mesmo como uma das causas da crise econômica da década de 1930 (Arruda, 2000). Desse modo, os Estados Unidos, enquanto nação, fazem parte da "Civilização Ocidental”, "uma comunhão mundial de nações”. Ignorar essa condição seria "promover uma indiferença presumida e provinciana de elementos básicos da vida americana e fazer um convite ao empobrecimento, intolerância, e desastre nacional." ${ }^{, 131}$ (Krey et al., 1934, p. 11). Além disso, a constituição do que se caracteriza como um "mundo globalizado" (desenvolvimento das tecnologias, transportes, comunicações, etc.) impossibilitaria o isolamento das nações (Krey et al., 1934).

Krey et al. (1934) ampliaram o cenário a ser estudado pelos Estudos Sociais, reforçando a ideia de que era preciso pensar as relações dos Estados Unidos com a África, a Ásia e o restante do continente americano. Isso representa uma novidade, uma vez que os relatórios anteriores concentraram-se, prioritariamente, na herança europeia e nas relações dos Estados Unidos com a Europa. Um "nacionalismo limitado e intolerante e [um] imperialismo agressivo e predatório" levaram ao desenrolar de inúmeras guerras (Krey et al., 1934, p. 25). Conhecer as histórias e condições dos outros países para desenvolvê-las nos sistemas escolares, seria uma contribuição à "promoção da paz" e à cooperação internacional. Esse ideal, que vai impregnar os escritos de educadores de vários países, como Delgado de Carvalho, no Brasil, fez parte de um movimento internacional, surgido nos anos pós-Primeira Guerra, “cujo objetivo era a manutenção da paz mundial” (Reznik, 1992, p. 41) e o estímulo "ao espírito de cordialidade internacional” (p. 43).

Constituiu-se, nas décadas de 1920 e 1930, um amplo debate "acerca da influência que o ensino da História [e de outras Ciências Humanas] poderia ter nas relações entre povos e nações" (Leite, 2011, p. 303). Essa disciplina, em especial, passou a ter, nesse contexto, um papel central numa possível pacificação

cannot help agiven society attain its just ends unless it lays bare the structure of international relations and emphasizes the importance of the kind of national behavior essential to the rational conduct of international affairs. In other words, the domestic scene must be firmly fitted into the world scene."

131 Tradução nossa do original: "To ignore the historical traditions and usages which have contributed, and still contribute, to this unity is to betray a smug and provincial disregard of basic elements in American life and to invite national impoverishment, intolerance, and disaster." 
do mundo através da formação das futuras gerações (Reznik, 1992). A Liga das Nações e uma série de congressos se esforçaram em prol da revisão de programas e livros didáticos, o que explica a maior atenção concedida pela Comissão de 1934 à necessidade de se estudar a História de outros países. No Brasil, Delgado de Carvalho (1934c, p. 8) defendia a "necessidade de se inspirarem os mestres de Sciencias Sociais do espírito internacional." Tal espírito guiaria a construção de programas em que a História internacional seria ensinada em correlação com a História nacional, tentando-se evitar a exaltação de sentimentos belicosos.

Outros tópicos importantes do Programa de Ciências Sociais, levantados pela Comissão, referiram-se à manutenção dos ideais democráticos americanos e à economia. São dois temas candentes no momento de escrita dos relatórios da Comissão de Estudos Sociais. De um lado, o mundo enfrentava os efeitos de uma grave crise econômica, que impôs profundas mudanças nas relações entre o Estado americano e a economia, com o maior intervencionismo do Estado na vida econômica e, de outro, ascendiam, em diferentes países, regimes autoritários. Os Estudos Sociais deveriam formar homens e mulheres aptos a atuar em um modelo econômico integrado e a reafirmar o ideal democrático: tradição de que o governo tem como propósito o bem-estar dos cidadãos, tanto individualmente quanto coletivamente, e de que "cada pessoa possui em si valor moral e dignidade" (Krey et al., 1934, p. 12). A defesa das liberdades deveria ser reforçada.

A comissão considera desejável a ênfase continuada e incansável pela motivação à ciência e ao estudo, liberdade de pensamento e expressão, liberdade de imprensa e plataforma, e estudo e consideração tolerantes das mais diversas ideias, internas e estrangeiras, modernas, medievais e antigas, já que este é o melhor meio de defesa contra a tirania e a burocracia, de um nacionalismo limitado, e de um poder extremamente desinformado. ${ }^{132}$ (Krey et al., 1934, p. 26).

Os membros da Comissão assumiram a tarefa de propor a formação para a democracia, como defendia Dewey (1959), uma vez que ela não é dada. Para isso, "um programa de Estudos Sociais deve reafirmar a importância da crítica e da criatividade como uma potente força para o progresso e uma condição precedente para a sobrevivência.” (Beard, 1932, p. 112). As atividades selecionadas deveriam levar em consideração a "capacidade e experiência do aprendiz" a fim de que este

\footnotetext{
${ }^{132}$ Tradução nossa do original: "The Commission deems desirable continued and unremitting emphasis on the spirit of science and scholarship, liberty of thought and expression, freedom of press and platform, and tolerant study and consideration of the most diverse ideas, domestic and foreign, modern, medieval, and ancient, as the chief means of defense against the tyranny of bureaucracy, of narrow nationalism, and of brutal uninformed power."
} 
pudesse "lidar efetivamente com dados e situações sociais" (Krey et al., 1934, p. 47), tendo uma contínua expansão do entendimento. O amadurecimento do aluno se dá a partir de algumas fases e critérios: a experiência e as competências são aprofundadas com o tempo; o conhecimento deve se iniciar do "próximo ao mais remoto no tempo e espaço", das respostas sensoriais elementares para formas mais abstratas de pensamento, do presente para o passado e futuro ("do núcleo familiar para o bairro, a comunidade, a nação e o mundo"). Nesse percurso, o aluno vai sendo habilitado a conhecer conceitos mais universais, como liberdade e igualdade, a participar ativamente da vida em grupo e a contribuir para as próprias reformas que são necessárias à sociedade (Krey et al., 1934, p. 55). Demarcando uma influência de Dewey, os formuladores do documento argumentaram que o programa deve basear-se sempre em experiências reais. Desta feita,

[...] cada tópico de ensino nas Ciências Sociais, se preocupado com a realidade, contém pelo menos seis elementos ou aspectos: localização em espaço fisicamente condicionado, ocorrência em algum ponto no tempo, ação por seres humanos, relação com outros acontecimentos sociais (econômicos, políticos e culturais), relação com outras ideias e aplicação a situações da vida. $\mathrm{O}$ assunto aparentemente mais simples é, de fato, extremamente complexo e capaz de desenvolvimento igualmente infindo [...] quase qualquer evento social, prática, instituição ou ideia, se relacionada à experiência do aprendiz, pode ser estudada com algum sucesso quase em qualquer nível de maturidade. ${ }^{133}$ (Krey et al., 1934, p. 57).

Tais princípios pressupõem que o programa deva fornecer uma ampliação dos horizontes dos mais jovens, aprofundando seu conhecimento da sociedade humana e reforçando suas capacidades de cooperação e liderança cívica. Nos primeiros anos de escolaridade o foco não seriam as sociedades mais remotas, como também defende Dewey (2002), mas a vida e as instituições presentes na comunidade (relações familiares, vestuário, habitação, educação, etc.). Na escola primária a atenção reside no surgimento da comunidade e da nação. $\mathrm{O}$ programa se iniciaria com o "estudo direto da vida", as mudanças sociais na localidade, história do lugar, da civilização indígena que ali residiu e a cultura americana. Assim, a "ênfase seria posta em toda a real participação nas atividades sociais da

\footnotetext{
${ }^{133}$ Tradução nossa do original: "Every topic of instruction in the social sciences, if concerned with actuality, contains at least six elements or aspects: location in physically conditioned space, occurrence at some point in time, action by human beings, relationship to other social happenings (economic, political, and cultural), relationship to other ideas and application to life situations. The seemingly most simple subject is in fact extremely complex and capable of comparatively infinite development. Consequently, almost any social event, practice, institution or idea, if brought into relationship with the experience of the learner, may be studied with some profit at almost any level of maturity."
} 
escola e do bairro e cada parte ou fase do programa começa e termina na comunidade local e contemporânea que a criança conhece diretamente"134 (Krey et al., 1934, p. 60). Na escola secundária, os temas avançavam para o desenvolvimento da cultura humana e sua evolução, tendo como referência o presente e a civilização americana. O estudo, através de "materiais concretos e vivos" e de "literatura social e histórica", culminaria em análises da economia, da geografia, de ações sociais e possibilitaria "uma perspectiva realista do mundo" e a capacidade de "avaliar pessoas, eventos, programas e ideias (p. 60-62).

$\mathrm{Na}$ argumentação dos autores, uma instrução eficaz exige materiais de apoio e uma biblioteca bem equipada. Apesar da visão das professoras brasileiras que visitaram os Estados Unidos em finais dos anos de 1920, Krey et al. (1932, p. 63 64) consideraram que as bibliotecas escolares americanas eram "lamentavelmente inadequadas". As bibliotecas devem ser compostas por livros de referência, fontes, escritos contemporâneos, periódicos atuais, clássicos do pensamento social, mapas, atlas, etc. Todos esses materiais deveriam ser utilizados como fonte de estímulos pelos professores de Estudos Sociais. Para a Comissão, os alunos não são meros recipientes inertes em que os professores despejam conhecimentos acumulados da raça humana. A aprendizagem requer a participação do aluno e uma resposta ativa, já que o objetivo da educação é o crescimento de personalidades independentes, capazes de guiar os seus próprios estudos. Cumpre ao professor de Ciências Sociais familiarizar os alunos com diversas ideias, tornando-os capazes de refletirem e questionarem (Krey et al., 1934).

A "Carta das Ciências Sociais nas escolas" e as "Conclusões e recomendações da Comissão de Estudos Sociais da Associação Americana de História" não explicitaram uma disciplina-eixo dos Estudos Sociais e nem de que forma o programa se estabeleceria na realidade escolar. Escreveram pensando um modelo ideal. Ao recusarem a fusão de disciplinas, leva-nos a acreditar que refletiram em termos de uma maior interdisciplinaridade. A análise documental permite apresentar um contraponto a uma visão muito difundida no Brasil, devido à experiência do regime militar, de que os Estudos Sociais representam, unicamente, "uma forma de organização de conteúdos da escolarização básica e,

\footnotetext{
${ }^{134}$ Tradução nossa do original: "Emphasis would be placed throughout on actual participation in the social activities of school and neighborhood, and every part or phase of the program would begin and end in the contemporary and surrounding community which the child knows directly."
} 
aos olhos da tradição escolar brasileira, o lado oposto à disciplinarização" (Freitas, 2011, p. 1). As disciplinas, integradas, convergiriam para um objetivo comum: o ensino cívico ou exercício da cidadania. Contudo, não há um conteúdo predefinido, já que eles podem ser retirados de quaisquer das Ciências, sem a necessidade de vinculação a nenhuma delas em particular (Nadai, 1988).

\section{3 \\ O professor e o ensino de Estudos Sociais: do conhecimento da realidade social à liberdade de ensino}

[...] o professor competente deve conhecer profundamente a disciplina que ele afirma ensinar, deve enxergar a relação da mesma com a vida da humanidade e deve ter um entusiasmo contagiante sobre ela $-\mathrm{a}$ isto, todos os métodos de ensino estão subordinados. $^{135}$ (Krey et. al, 1934, p. 84).

Nos três relatórios analisados, a capacitação docente apareceu como um dos problemas para o ensino de Estudos Sociais. Os professores são descritos como despreparados na "arte do ensino". Nas palavras de Dunn (1916, p. 51, 58), o "professor de ensino médio graduado pode ser um especialista em sua disciplina, mas não tem qualquer treinamento como professor". Isto levava ao conservadorismo e ao "maior obstáculo para a dinamização dos Estudos Sociais". A formação do cidadão obrigava o docente a ser um profundo conhecedor de "fatos e leis da vida social” (Dunn, 1916, p. 58), já que toda a instrução teria como base a própria vida. Pelas características e valores que deveria estimular, a sua função não se limitaria ao ensino de alguns fatos, datas ou nomes. Não bastava dominar determinado conhecimento, era preciso saber ensiná-lo. O relatório de 1916 já defendia uma mudança nas escolas de professores:

O que quer que seja feito nessas escolas nos domínios das Ciências Sociais como tal, recomenda-se que os cursos sejam ministrados nas linhas gerais para as escolas de ensino médio recomendadas neste relatório, pelo menos até que as escolas tenham feito um planejamento adequado para as mesmas. Entretanto, em escolas de formação de professores maior ênfase deve ser dada aos métodos pelos quais o ensino em Estudos Sociais pode ser realizado a fim de atender às "necessidades de

\footnotetext{
135 Tradução nossa do original: "Above all, the competent teacher should know thoroughly the subject matter which he professes to teach, should see its relation to the life of mankind, and should have an infectious enthusiasm about it-to this, all teaching methods are subordinate."
} 
crescimento presentes" de alunos em idade escolar dos ensinos fundamental e médio. ${ }^{136}$ (Dunn, 1916, p. 59).

As escolas de formação de professores, faculdades e universidades deveriam conceder uma maior ênfase nos métodos de ensino de Estudos Sociais. Isso se faria através da organização de cursos em que se discutissem as formas como os Estudos Sociais poderiam ser ensinados na realidade escolar. Entretanto, Dunn (1916, p. 61) apontou em seu texto para a persistência da "tradição" que valorizava o conhecimento em detrimento da metodologia na formação docente. Tal problema não poderia, na perspectiva do autor, impedir a realização de um "trabalho com ousadia e sem quaisquer reservas tímidas a fim de trazer nossa educação a mais próxima relação possível com a vida real." ${ }^{\text {"137 }}$ (p. 61). A despeito da importância dos professores, especificada no próprio documento, o relatório “The Social Studies in secondary education” não avançou em relação a essa questão. Bastaria seguir as suas determinações e exemplos para a realização de um ensino de Estudos Sociais eficaz. Duas décadas depois, as investigações realizadas pela Associação Americana de História reforçaram o olhar sobre o problema. O professor foi descrito como a "pedra angular". Para uma educação de qualidade não satisfariam "prédios escolares luxuosamente mobiliados", algo que tanto encantou o viajante Anísio Teixeira, ou o "requinte de aspectos materiais e mecânicos de administração e supervisão", mas seria, antes, necessário um “aumento da habilidade e motivação do professor" (Krey et al., 1934, p. 103).

August Krey, ao prefaciar "A charter for the Social Sciences in the schools", oferece essa obra como um instrumento de trabalho para os professores. Entre suas indicações estava a necessidade de o docente construir uma "filosofia de vida pessoal e pensamento" que lhe auxiliasse em suas "árduas tarefas". Tal filosofia partiria de "uma imagem clara e realista da sociedade moderna", da compreensão de conceitos e características sociais, da aquisição de hábitos acerca de temas e problemas centrais da sociedade e, sobretudo, de uma "capacidade para lidar

\footnotetext{
${ }^{136}$ Tradução nossa do original: "Whatever is done in these schools in the fields of the social sciences as such, it is recommended that courses be given on the general lines recommended in this report for high schools, at least until the high schools shall have made adequate provision for them. In teacher-training schools, however, special attention should be given to methods by which instruction in the social studies may be made to meet the 'needs of present growth' in pupils of elementary and high school age."

${ }^{137}$ Tradução nossa do original: "[...] to work boldly and without any timid reservations to bring our education into the closest possible relation with the actual life and future duties of the great majority of those who fill our public schools."
} 
equitativa e corajosamente com os atuais modos de viver" (Beard, 1932, p. 9091). O relatório final - "Conclusions and recommendations of the Comission on the Social Studies of Association American History" - não apresentou "fórmulas pedagógicas", com prescrições detalhadas de método ou um curso de formação de professores de Estudos Sociais, mas apontou para algumas características que deveriam guiar o professor no desenvolvimento do ensino de Ciências Sociais.

Primeiramente, toda a organização das aulas deveria partir da realidade, ou seja, da vida. Para isso, necessitaria o professor conhecer os objetivos gerais da educação, de forma a "conduzir meninos e meninas a uma compreensão mais completa de uma participação mais efetiva no mundo social complexo e dinâmico de coisas materiais, pessoas, instituições, conflitos, pensamentos, ideais e aspirações."138 (Krey et al., 1934, p. 78). O docente deveria ser capaz de ajustar o ensino à experiência e à capacidade do aluno, de modo que o conhecimento the fosse útil em seu dia a dia. $\mathrm{O}$ verbalismo excessivo ou aulas puramente baseadas nos livros didáticos pouco contribuíam para o alcance desse objetivo geral. A utilização de outros materiais foi recomendada: jornais, fotografias, gráficos, filmes, museus, viagens, estudos de campo, entre outros.

O ensino de Ciências Sociais seria integrado ao trabalho de outras especialidades, como Literatura, Matemática e Línguas. Por fim, caberia aos professores o conhecimento dos alunos, despertando experiências adequadas ao seu crescimento, estimulando os impulsos criativos, adaptando o ensino às divergências de personalidade (Krey et. al, 1934). O ensino preconizado pela Comissão de Estudos Sociais, na década de 1930, pressupunha a participação ativa do aluno na aquisição do conhecimento e definia o professor como força orientadora e guia na relação ensino-aprendizagem. Seguindo essa premissa, Krey et al. (1934, p. 83) defenderam que os professores possibilitassem, aos seus alunos, "hábitos de estudo independente, questionamento, pensamento e ação". Só assim os educandos se libertariam da "possível dependência da tutela formal e autoritária do professor, da escola e dos mais velhos". Em síntese, como o programa educacional depende "tanto do ajuste de seu conteúdo e procedimentos à natureza do aluno, quanto da correspondência de seus propósitos com as

\footnotetext{
${ }^{138}$ Tradução nossa do original: "[...] special responsibilities of the social sciences in leading boys and girls to a fuller understanding of and a more effective participation in the complex and dynamic social world of material things, persons, institutions, conflicts, thought, ideals, and aspirations."
} 
riquezas reveladoras, o potencial e as esperanças da sociedade" (Krey et al., 1934, p. 71), o professor deveria ser um conhecedor desses dois elementos fundamentais para relação ensino-aprendizagem (fases de crescimento dos alunos e o valor que cada conhecimento e/ou conteúdo tem para a sociedade).

Para os membros da Comissão, o professor competente não precisava de prescrições de métodos e disciplinas. Nesse sentido, o problema se limitaria a três questões centrais: formação de professores, seleção docente e melhores condições de trabalho e ensino. Os dois últimos são específicos à realidade americana de então $^{139}$. O problema da formação de professores se relacionava à dicotomia entre conhecimento e ensino. Krey et al. (1934) argumentaram que enquanto as faculdades de formação de professores se preocupavam com as técnicas, as faculdades de Ciências Sociais se especializaram, a partir das pesquisas, sem preocupação com o ensino. Enquanto as primeiras negligenciaram a discussão sobre o pensamento social, as universidades e cursos de Ciências Sociais desprezaram a relação entre o estudo de suas disciplinas, a vida e a educação.

A formação de professores teria que se assemelhar à formação de estadistas, concebida em termos de enriquecimento cultural, a partir de pensamentos gerais e diversificados e ideais de crescimento físico, intelectual e moral da criança (Krey et, al., 1934). Não deveria, à vista disso, limitar-se ao ensino de técnicas e fórmulas a serem dominadas nos mínimos detalhes para, posteriormente, serem colocadas em prática. O sucesso desse modelo formativo decorreria de uma dupla percepção: os "alunos de ciências sociais devem ver na educação o principal canal através do qual seu trabalho dê frutos; e [os] indivíduos engajados na formação de professores devem tornar-se estudiosos dedicados da sociedade humana." ${ }^{, 140}$ (Krey et al., 1934, p. 110). A reforma implicaria em:

\footnotetext{
${ }^{139}$ Krey et al. (1934, p. 106) argumentaram, de forma sintética, que "uma vez que o Estado não exerce nenhum poder de recrutamento de pessoas para a profissão de ensinar, ele somente poderá contratar os mais talentosos caso melhore as condições e gratificações de trabalho e se fizer desta tarefa algo digno do mais alto potencial de intelecto e caráter na humanidade. No entanto, pode-se esperar que o Estado siga essa direção somente sob a pressão advinda de um grupo ou grupos de cidadãos." Tradução nossa do original: "Since the state exercises no power of conscripting persons for the profession of teaching, it can bring the more gifted into the service only by improving the conditions and rewards of work and by making the work worthy of the highest qualities of mind and character potential in humanity. But the state can be expected to move in this direction only in response to pressure arising from some group or groups of citizens."

${ }^{140}$ Tradução nossa do original: "[...] students of the social sciences will have to view education as one of the main channels through which their work may find fruition; and persons engaged in teacher training will have to become earnest students of human society."
} 
(a) uma redução drástica no número de cursos com especializações com ênfase em história, política, economia e sociologia oferecidos a professores em faculdades e universidades; (b) a criação de cursos gerais e bem elaborados para professores nestas disciplinas; (c) a organização de seminários nos quais professores devam receber treinamento rigoroso nestes métodos de pesquisa, operações bibliográficas, análise, verificação, síntese, e crítica indispensáveis ao avanço da aprendizagem e formação eficaz. ${ }^{141}$ (Krey et al., 1934, p. 111).

Embora não tenham defendido a criação de uma grande área de Ciências Sociais que englobasse todas as disciplinas, há uma ambiguidade em relação à formação docente. Na prática, Krey et al. (1934) propuseram a criação de cursos gerais de férias para os docentes, em que se articulassem as disciplinas, com a gradativa redução das especializações. Na estruturação dos cursos de formação docente, os formadores de professores das diversas ramificações de estudos deveriam ser pesquisadores dessas áreas. Os departamentos de Ciências Sociais, presentes em faculdades e universidades, teriam que ter uma maior atenção tanto em relação à formação do futuro docente quanto na própria organização dos tópicos de ensino a serem trabalhados nas escolas. No campo da educação, era preciso romper com a ideia de uma "ciência da educação" apartada das outras correntes de conhecimento (Krey et al., 1934). Tais mudanças levariam a uma maior e mais profunda articulação entre a universidade e a escola.

Para que pudesse exercer satisfatoriamente a sua função e responsabilidades sociais, o professor precisaria ocupar uma importante posição na comunidade, no estado e na nação. O professor, antes de tudo, deveria ser um estudioso da cultura americana em seus contextos histórico e mundial, das tendências dominantes de sua época e do pensamento e ação social do mundo contemporâneo. Era, assim, necessária uma segurança econômica, com uma renda proporcional ao papel que o professor desempenhava na sociedade, e condições de trabalho que possibilitassem ao docente prosseguir os seus estudos, crescendo em competência e capacidade profissional e pessoal. Por último, dois elementos importantes, o professor precisava romper com seu isolamento, ou seja, ter um interesse ativo "pela vida da sociedade atendida pela escola", e precisava ter liberdade para ensinar. Era o docente responsável por apresentar "aos seus alunos um

\footnotetext{
${ }^{141}$ Tradução nossa do original: "(a) a drastic reduction in the number of highly specialized courses in history, politics, economics, and sociology offered to teachers in colleges and universities; (b) the establishment of general and balanced courses in these subjects for teachers; (c) the organization of seminars in which teachers may receive rigorous training in those methods of research, bibliographical operations, analysis, verification, synthesis, and criticism indispensable to the advancement of learning and effective instruction."
} 
entendimento minuciosamente realístico e independente da sociedade contemporânea - suas tensões, contradições, conflitos, movimentos, e propósito." (Krey et al., 1934, p. 126-128). Pelo caráter das Ciências Sociais, por lidarem diretamente com as condições da vida, a defesa da liberdade do trabalho docente é amplamente reforçada.

Uma vez que o professor é a força direcionadora e criativa primária na educação, quaisquer medidas confeccionadas para limitar ou arbitrariamente controlar o exercício de sua habilidade profissional e julgamento ou sua participação de acordo com sua habilidade no desenvolvimento do programa educacional de sua comunidade, desmerece sua posição e, embora adotadas em nome da eficiência, na verdade tendem a frustrar os propósitos da educação. A comissão deposita sua confiança no desenvolvimento docente em vez de uma perfeição dos aspectos técnicos da administração. ${ }^{142}$ (Krey et al., 1934, p. 130).

Até mesmo a administração escolar e os governos deveriam respeitar as liberdades docentes e o trabalho exercido pelo professor no dia a dia do ensino.

O emprego de quaisquer instrumentos ou dispositivos na administração e fiscalização, que não levem em conta a função abrangente do professor na evolução da cultura tende a diminuir sua personalidade, a desenvolver nele uma mentalidade servil e a impedir o cumprimento eficaz das obrigações mais fundamentais impostas a ele pelos objetivos educacionais. Muito do efeito social da educação pode permanecer imperceptível por anos após o fim do período escolar, pode permanecer desconhecido até que o longo drama da história humana esteja por fim terminado; enquanto outros efeitos de maior importância para o enriquecimento da vida estejam totalmente além de qualquer aferição. ${ }^{143}$ (Krey et al., 1934, p. 131).

Os professores, no exercício de seu dever profissional, necessitavam estar protegidos do "capricho", "ignorância e hostilidade de grupos, organizações e classes específicas". Segundo os membros da Comissão, sem essas condições, liberdade de pensamento, ensino e investigação, “o ensino das ciências sociais [tornava-se] uma verdadeira piada" (Krey et al., 1934, p. 134-135). A proteção

\footnotetext{
${ }^{142}$ Tradução nossa do original: "Since the teacher is the immediate directing and creative force in education, any measures calculated to limit or arbitrarily to control the exercise of his professional skill and judgment or his participation according to his ability in the development of the educational program of his community, degrade his status and, even though adopted in the name of efficiency, actually tend to defeat the purposes of education. The Commission places its trust in the improvement of the teacher rather than in the perfection of the technical aspects of administration."

${ }^{143}$ Tradução nossa do original: "The employment in administration and supervision of any instruments or devices which fail to take into account the broad role of the teacher in the evolution of culture tends to dwarf his personality, to develop in him a servile mentality and to hamper him in the effective discharge of the most fundamental obligations imposed upon him by the purposes of education. Many of the social results of education may not be discernible for years after the period of schooling is over, cannot be fully known until the long drama of human history is finally closed; while other results of the highest importance for the enrichment of life are utterly beyond measurement of any kind."
} 
contra "as ameaças de maiorias ignorantes, minorias caçadoras de heresias, e todos os autointitulados guardiões da moral e pensamento coletivo" (Krey et al., 1934, p. 133) se faria através da criação de uma associação docente que englobasse os professores do jardim de infância a universidade, com um duplo objetivo: partilha do pensamento e sabedoria da profissão, através da maior participação na formulação de políticas públicas, educacionais, amparo ao docente e busca por seus direitos (Krey et al., 1934).

\section{4 \\ Os Estudos Sociais para além das fronteiras americanas: das intenções da comissão ao elogio de Delgado de Carvalho}

Nas intenções dos membros da Comissão de Estudos Sociais transparece o desejo de que sua escrita transpusesse as fronteiras políticas que delimitavam os Estados Unidos e a sua atuação. Na verdade, reflete uma maior preocupação dos educadores americanos com os rumos da educação em outros países, especialmente os do continente americano. Nas "Conclusões e Recomendações", que contaram com a colaboração de professores e ex-professores da Columbia University, instituição que acolheu inúmeros brasileiros entre as décadas de 1920 e 1930, Krey et al. (1934, p. 135-136) advertiam que "através das migrações dos povos, das jornadas de estudantes e acadêmicos e do movimento para além das fronteiras nacionais, o sistema americano exerce enormemente sua influência no mundo." 144 A atuação dessa Comissão não passou despercebida pelos intelectuais e pela imprensa brasileira. Em suas "Cartas de Nova York", publicada no Correio da Manhã, Gondin da Fonseca (1934, p. 11) refletiu sobre algumas características do trabalho desenvolvido por ela:

Reunida, afim de estudar as condições da nossa época, a Social Studies Comission of The American Historical Association, de que fazem parte alguns dos mais notaveis educadores americanos, chegou a conclusão de que [...] haverá cooperação obrigatoria de todos os cidadãos.

O jornalista fazia referência à crítica ao excessivo individualismo da sociedade americana de então e a valorização da cooperação pelos membros da

\footnotetext{
${ }^{144}$ Tradução nossa do original: "Indeed through the migrations of peoples, the travel of students and scholars and the movement of ideas beyond the national borders, the American system of education makes its influence felt increasingly throughout the world."
} 
Comissão. Nesse processo, os Estudos Sociais, inseridos na educação progressiva, contribuiriam para o aperfeiçoamento de indivíduos, instituições e sociedade. Afinal, como argumentava Beard (1932, p. 34), “o mundo no qual nossas crianças irão formar-se, e para o qual elas devem ser preparadas, será um mundo em que a racionalidade, o planejamento e a cooperação inteligente terão influência crescente em questões nacionais, industriais e governamentais." ${ }^{145}$ As finalidades individuais e sociais da educação são conjugadas. "Toda educação social é obtida por meio da educação individual”, o indivíduo é valorizado, mas "a sua educação e seu preparo visam a sua vida em sociedade" (Carvalho, 1970, p. 39). As qualidades requeridas pela sociedade, entendida naquele momento como moderna e mutável, são as que serão cultivadas no indivíduo. Caberiam às Ciências Sociais exprimir a vida e refletir sobre os problemas da democracia e possibilitar aos alunos um conjunto de informações, habilidades, hábitos e atitudes.

Ainda que a "Carta das Ciências Sociais nas escolas" não tenha representado, como argumenta Santos (2011, p. 149), “a inserção dos Estudos Sociais como disciplina escolar na organização pedagógica norte-americana”, algo que ocorreu a partir de 1916, teve um papel predominante nas reflexões desenvolvidas no Brasil. Delgado de Carvalho (1970, p. 63), escrevendo na década de 1950, argumentou que essa carta, "redigida por 16 historiadores, geógrafos e sociólogos norte-americanos de incontestável autoridade" e responsável por formular alguns princípios para os Estudos Sociais, "marcou uma data na expressão do pensamento educacional nos Estados Unidos e, nestes últimos vinte anos, em nada perdeu sua oportunidade." Para ele, a maior parte das "sciencias", ao se constituírem em objetos de estudo, formaram disciplinas distintas e campos de atividades diferentes. Contudo, "estendendo-se estes campos de investigações e pesquizas, avolumando-se o material accumulado, os especialistas passaram a encontrar as connexões naturaes que existem entre ellas." (Carvalho, 1934c, p. 61). Tais conexões poderiam ser sentidas com maior força no âmbito das Ciências Sociais, cujo objeto central é a análise dos diferentes aspectos que compõem a experiência humana. Foi com esse espírito e essa influência que se estabeleceu a primeira proposta de ensino de Estudos Sociais no Brasil.

\footnotetext{
${ }^{145}$ Tradução nossa do original: "The world into which our children are to be graduated, for which they are to be prepared, will be a world in which rationality, planning, and intelligent cooperation will have increasing sway in domestic affairs, industry, and government."
} 


\section{5 \\ Introdução do ensino de Estudos Sociais no Brasil: da discussão metodológica à constituição de uma disciplina escolar}

As primeiras décadas do século $\mathrm{XX}$ se caracterizaram por uma intensa circulação de intelectuais e modelos pedagógicos. Nas décadas de 1920 e de 1930, os principais reformadores intentaram uma série de intercâmbios com outros países e suas universidades, professores e técnicos educacionais. A introdução do ensino de Estudos Sociais no Brasil se articula a esse movimento. Como analisamos nos capítulos anteriores, suas bases se encontram solidamente demarcadas na perspectiva americana, inspirada nas obras de John Dewey e nos documentos definidores produzidos pela Associação Nacional de Educação dos Estados Unidos e pela Associação Americana de História. Isso não significa dizer que outras influências não possam ser sentidas no interior das ciências que compõem os Estudos Sociais, através das definições de cada uma delas.

Os debates em torno da construção de um currículo de Ciências Sociais ${ }^{146}$ no Brasil, a partir de 1934, diferentemente do que ocorreu nos Estados Unidos em que os Estudos Sociais foram pensados em termos de ensino secundário e delimitados como uma disciplina -, estão associados a uma questão eminentemente metodológica e, inicialmente, circunscrita à escola primária e à formação docente para este nível de ensino. Mais ainda, as discussões se inserem num projeto maior de educação e reconstrução dos programas escolares defendidos por Anísio Teixeira. O problema, como argumentava Teixeira (1997, p. 80), não se restringia à necessidade de expansão escolar, mas tratava-se, antes, de "adaptar e ajustar a escola existente às reais necessidades do meio brasileiro, tornando-a eficaz e proveitosa aos que busquem se educar." Para isso, três ordens de questões precisavam ser atacadas: a reformulação da formação docente, o melhor aparelhamento da escola e a necessária reorganização do currículo escolar.

\footnotetext{
${ }^{146}$ Note-se que até o final da década de 1940 não há uma distinção entre Estudos Sociais e Ciências Sociais na legislação, nos currículos e textos de Delgado de Carvalho, o principal proponente da disciplina. Tais termos são usados indiscriminadamente e como sinônimos de ensino a partir da contribuição das diferentes ciências. Conforme veremos, na década de 1930, o programa da escola primária era denominado: "Programa de Ciências Sociais" (PCS); na Escola de Professores do Instituto de Educação, então responsável pelo ensino superior e pela formação da professora primária, havia uma matéria intitulada: "Estudos Sociais".
} 
Ao assumir a Diretoria Geral de Instrução Pública do Distrito Federal ${ }^{147}$, entre os anos de 1931 e 1935, o educador baiano, aproveitando-se de um vácuo nas políticas públicas nacionais, pôde colocar em prática muitos dos elementos que tinha lido nas obras de John Dewey e vislumbrado nas escolas americanas.

A constituição de um sistema educacional, após a criação do Ministério da Educação e Saúde Pública (1930), significou a maior centralização de algumas decisões. A reforma federal tratou de organizar o "sistema educacional das elites", concedendo atenção especial ao ensino secundário e ao ensino superior. Contudo, as Reformas Campos, intituladas a partir do nome do primeiro ministro da educação e realizadas entre os anos de 1931 e 1932, deixaram "completamente marginalizados os ensinos primário e normal” (Romanelli, 2007, p. 141). Só uma década e meia após a instituição dessas reformas, em 1946, é que foram editadas as Leis Orgânicas do Ensino Primário e do Ensino Normal - dois dos níveis de ensino reformulados no Distrito Federal por Anísio Teixeira e seus colaboradores. Em ambos foram incluídas disciplinas relativas aos Estudos Sociais.

O capítulo investiga aspectos do projeto educacional de Anísio Teixeira e de que forma os Estudos Sociais a ele se articula. Focaremos na organização de dois institutos: o Instituto de Educação do Distrito Federal e o Instituto de Pesquisas Educacionais, responsáveis pela primeira experiência de ensino de Estudos Sociais em nível superior e pela elaboração dos programas de ensino das escolas primárias, respectivamente. Consideramos que nesses anos, mesmo com as mudanças posteriores, foram estabelecidas as bases desta disciplina no Brasil.

\section{1 Reforma Anísio Teixeira (1931-1934): a criação dos "dois institutos"}

A Revolução de $1930^{148}$ estabeleceu o fim da Primeira República (18891930) e significou a possibilidade de realização de uma série de mudanças em

\footnotetext{
147 A Diretoria Geral de Instrução Pública teve seu nome alterado em 8 de setembro de 1933, passando a se chamar Departamento de Educação. Em 3 de setembro de 1935, passou a ser nomeada como Secretaria de Educação.

${ }^{148}$ Utilizamos a expressão "revolução", na chave desenvolvida por Nunes (2011, p. 292), para analisar o Distrito Federal: "Embora as mudanças políticas fossem decorrentes de uma negociação entre elites, a representação de que teria havido uma revolução total trouxe como desdobramento outras representações: de cisão, de renovação, de aceleração do tempo, cuja projeção no espaço carioca se chocou contra a manutenção de práticas dos governos republicanos que antecederam a
} 
torno das diretrizes que guiavam a política brasileira até então. Para tanto, concorriam intelectuais dos mais diferentes matizes e correntes de pensamento, que acabaram incorporados à burocracia estatal. Em 14 de novembro, como um dos primeiros atos de Getúlio Vargas, foi criado o Ministério da Educação e Saúde Pública, cujo primeiro titular foi o mineiro Francisco Campos. Uma série de decretos dispusera sobre a criação do Conselho Nacional de Educação, a organização da Universidade do Rio de Janeiro, a reforma do ensino secundário, a organização do ensino comercial (Romanelli, 2007) ${ }^{149}$. Pela primeira vez na história brasileira, de fato, avançava-se em termos de "montagem de um sistema educacional" (Bomeny, 2001, p. 44). Essa elaboração foi palco de inúmeras disputas de "orientações para a definição dos rumos da educação no país" (p. 45).

No centro desses embates estavam os católicos e os escolanovistas. Os primeiros defendendo o ensino religioso (a formação moral como papel da Igreja), o lugar das escolas privadas no sistema de ensino, a educação diferenciada para meninos e meninas (Shiroma et al., 2011), enquanto os "pioneiros", que acabariam por expor e divulgar as suas ideias através do "Manifesto dos Pioneiros da Educação Nova" (1932), advogavam uma educação obrigatória, pública e gratuita, leiga e a coeducação - uma escola única para todos os sexos (Azevedo, $2003)^{150}$. Foi nesse contexto de disputas entre projetos de educação e país que Anísio Teixeira foi convidado, por Pedro Ernesto Batista (1931-1936), a assumir a Direção Geral da Instrução Pública do Distrito Federal, em outubro de 1931. Pedro Ernesto havia sido nomeado interventor no mês anterior. Sua gestão, como interventor, e depois como prefeito eleito do Distrito Federal a partir de 1935, foi marcada por uma atenção especial às áreas da saúde e da educação.

O projeto político de Pedro Ernesto trazia em si, na expressão de Carlos Eduardo Sarmento (2001, p. 128), uma "utopia renovadora", que se caracterizava por "uma grande proposta de renovação da sociedade" e maior atenção à

\footnotetext{
famosa revolução e que evidenciaram uma forma de ver as classes populares e de ver a manifestação da vida própria da cidade. Sem ter havido propriamente uma ruptura política, houve a possibilidade de uma ruptura ideológica, o que teria constituído o lado fecundo da modernidade brasileira nesse período. Mesmo que a experiência concreta não pudesse ser considerada radicalmente revolucionária, a possibilidade de reinvenção da revolução acentuou-se.”

${ }_{149}$ Entre eles, o Decreto $\mathrm{n}^{\circ} 19.890$, que dispôs sobre a organização do ensino secundário, e o Decreto $\mathrm{n}^{\circ}$ 21.241, de 14 de abril de 1932, que consolidou as disposições sobre a organização do ensino secundário. Sobre os diferentes aspectos da reforma cf. Romanelli (2007).

${ }^{150}$ Utilizamos como referência a edição do "Manifesto dos Pioneiros da Educação Nova" publicada em livro organizado por Magaldi \& Gondra (2003).
} 
promoção e manutenção do "bem-estar da população". Como responsabilidade do Estado estaria a "proteção às camadas mais pobres, buscando a elevação física, moral e cultural deste segmento" (p. 131). A reforma da educação pública assumia um papel de relevo por estar responsável pela formação dos novos cidadãos. Para isso, contou o interventor com o apoio de um seleto grupo de intelectuais capitaneados por Anísio Teixeira. Delgado de Carvalho (1960, p. 122) define os anos em que este dirigiu a educação no Rio de Janeiro, então Capital da República, como uma "das fases mais brilhantes da história da educação no Brasil”. Foram muitas as mudanças promovidas por Anísio entre 1931 e 1935.

Nas décadas posteriores às reflexões de Delgado de Carvalho, uma série de pesquisas se propôs a destrinchar a obra educacional de Anísio Teixeira em suas nuances ${ }^{151}$. Dessa forma, analisamos alguns aspectos concernentes a dois institutos organizados por ele: o Instituto de Educação (1932) e o Instituto de Pesquisas Educacionais (1933). Ambas as instituições tiveram um papel importante para a institucionalização do ensino de Estudos Sociais no Brasil. Em sua reforma, Anísio Teixeira procurou, entre outros aspectos, expandir a escolarização como um dos contributos necessários à democratização do país, e pensou uma estrutura educacional que articulasse os níveis de ensino, da escola primária à universidade. A qualificação do magistério e a preocupação em promover a inovação nos currículos e programas escolares são duas marcas características da reforma anisiana no Distrito Federal (Xavier, 2007). Com o objetivo de tornar a administração mais eficiente, Teixeira começou por reformular a sua estrutura.

O decreto $n^{\circ} 3.763$, de $1^{\circ}$ de fevereiro de 1932, reorganizou a Direção Geral e criou vários "serviços especializados": "matrícula e frequência escolares", "classificação e promoção de alunos", "programas escolares", "obras sociais escolares, peri-escolares e pós-escolares", "educação de saúde e higiene escolar", "educação física", "música e canto orfeônico", "ensino secundário geral e

\footnotetext{
${ }^{151}$ Um conjunto de teses, já publicadas em forma de livro e defendidas entre as décadas de 1990 e 2000, analisaram diferentes aspectos da reforma implementada por Anísio no Distrito Federal. São referências fundamentais sobre o tema e com as quais dialogamos. Entre elas citamos: Nunes (2000a), Vidal (2001), Mendonça (2002) e Lopes (2006). Vale conferir, ainda, a tese produzida por Pinto (2006) a respeito da prática de ensino no Instituto de Educação. Uma fonte primária fundamental é o livro "Educação para a democracia" (Teixeira, 1997), um "relatório" elaborado por Anísio Teixeira, enquanto diretor do Departamento de Educação, e publicado originalmente, com pequenas alterações e acréscimos, em 1936. Nele, o autor incorpora antigos relatórios, discursos e exposições de motivos que apresentavam decretos legislativos (Mendonça, 2002).
} 
profissional", "prédios e aparelhamentos escolares", "estatística e cadastro", "expediente e publicidade administrativa", "pessoal e arquivo" e "contabilidade". Este decreto estabeleceu, ainda, a Biblioteca Central de Educação e o Museu Central de Educação (Teixeira, 1997). Cada um desses órgãos técnicos, responsáveis pelo "estudo de condições e execução de planos" (p. 135), bem como pela confecção das normas e verificação da eficiência do trabalho escolar, estavam diretamente subordinados ao Diretor Geral da Instrução Pública e tinham como função auxiliá-lo no desenvolvimento de suas atividades de coordenação do sistema escolar carioca. Não eram meras peças decorativas.

O Serviço de Programas Escolares, desde a sua criação, assumiu um papel na renovação dos métodos e dos programas. Para Teixeira (1997, p. 145), esse aparelho tinha a responsabilidade de traçar roteiros de ensino. Sua existência se justificava pela necessidade do programa escolar ser uma "peça viva", funcional, constantemente estudada, planejada, verificada e modificada no exercício diário da sala de aula. Era um órgão de auxílio ao professor. A consolidação da reforma administrativa do Departamento de Educação se deu através do decreto $\mathrm{n}^{\circ} 4.387$, de 8 de setembro de 1933. A nova organização, de acordo com o legislador, representava a quebra de uma importante lacuna a partir da concepção de "órgãos de estudo, de elaboração de planos, revisão e verificação de resultados, que a importância e dificuldade do trabalho [de aperfeiçoamento do aparelho escolar] justificavam e impunham." (Teixeira, 1997, p. 150). Algumas das divisões, criadas em 1932, passaram a compor o Instituto de Pesquisas Educacionais (IPE).

Na perspectiva de Anísio Teixeira (1997, p. 153), o Instituto de Educação e o Instituto de Pesquisas Educacionais teriam funções complementares, sendo:

[...] o primeiro de formação e aperfeiçoamento dos quadros de professores e técnicos de educação, o segundo de estudo e de elaboração dos planos atuais de trabalho, construindo e revendo os programas e cursos, medindo a eficiência e rendimento dos mesmos, examinando e classificando o aluno, no seu aspecto físico ou mental, bem como seus desvios e afastamentos da normalidade média apurada, e a organização e controle das instituições de bibliotecas e museus, órgãos complementares de todas as escolas.

Um instituto estaria voltado à formação do magistério, incumbido de criar uma nova mentalidade docente, enquanto o outro seria responsável por auxiliar a sua prática, através de uma mudança na cultura pedagógica predominante nas escolas (Nunes, 2011; Pinto, 2006). O Instituto de Educação, principalmente através da sua Escola de Professores, depois Escola de Educação (1935), é uma 
materialização do que defendeu o "Manifesto dos Pioneiros da Educação Nova" (1932) em relação à formação de professores. A sua criação, não por acaso, ocorreu no mesmo dia de publicação do manifesto nos principais jornais do país, em 19 de março de 1932 (Lopes, 2006). O documento defendia que a formação de professores de todos os graus deveria ocorrer em cursos de nível superior, o que Fernando de Azevedo (2003, p. 141) denominava como "a unidade de formação de professores e a unidade de espírito". A direção do Instituto de Educação do Distrito Federal foi confiada ao educador Lourenço Filho.

O Instituto de Pesquisas Educacionais foi criado a partir da nova organização do Departamento de Educação do Distrito Federal, em 1933, tendo como função "o estudo e elaboração de planos, programas, métodos e processos de educação e ensino e de medidas de rendimento e eficiência, tendo por base investigações sociais e psicológicas.” (Teixeira, 1997, p. 156). Organizava-se a partir da Divisão de Pesquisas Educacionais e da Divisão de Obrigatoriedade Escolar e Estatística. O seu primeiro diretor foi Carlos Miguel Delgado de Carvalho, que permaneceu no cargo até 24 de julho de 1935. Seus substitutos foram Antônio Carneiro Leão (1935), Gustavo Lessa (1935) e Lourenço Filho (1936). A Divisão de Pesquisas Educacionais, diretamente chefiada pelo diretor do instituto tinha diferentes divisões, entre elas a de Programas e Atividades Extraclasse, cuja função era a elaboração e revisão dos programas e guias de ensino "oferecidos ao magistério como sugestões e auxílio aos planos de trabalho" (Teixeira, 1997, p. 159). Entre 1934 e 1935, sob a gestão de Ignacia Ferreira Guimarães, essa divisão publicou os seguintes documentos: "Programa de Linguagem", "Programa de Mathematica", "Programa de Ciências Sociais" (PCS - volumes 1 e 2) ${ }^{152}$, "Programa de Musica", "Programa de Ciências" (volumes 1 e 2) e "Guia de Jogos infantis"153. Nas contracapas dos programas constava a

\footnotetext{
152 Sempre que nos referirmos ao PCS sem ano de publicação, reportamo-nos aos dois volumes que o compõem, publicados em 1934. Nas citações literais, indicamos a referência do volume consultado, a saber: volume 1 (Programa..., 1934a) e volume 2 (Programa..., 1934b).

153 As publicações do Instituto de Pesquisas Educacionais foram organizadas em várias séries: "Boletim de Educação Pública, Série A - Monografias e Estudos originais, Série B - Planos e Inquéritos, Série C - Programas e Guias de Ensino, Série D - Vulgarização, Série F - Informação e Divulgação." (Teixeira, 1997, p. 190). Apesar de Nadai (1988, p. 4) informar que o "Programa de Ciências Sociais [...] teve várias edições sucessivas até 1955", só encontramos duas. Uma de 1934 e outra de 1955. Neste ano, o programa foi relançado com o título "Ciências Sociais na Escola Elementar". A nota explicativa presente no livro nos ajuda a confirmar a existência de apenas duas edições: "Considerando-se êsse Programa [o de 1934] como edição preliminar, o Instituto Nacional de Estudos Pedagógicos, do Ministério da Educação e Cultura, retoma-o agora,
} 
informação: "edição preliminar", porque deveriam ser revisados e reeditados de dois em dois anos a partir das práticas docentes.

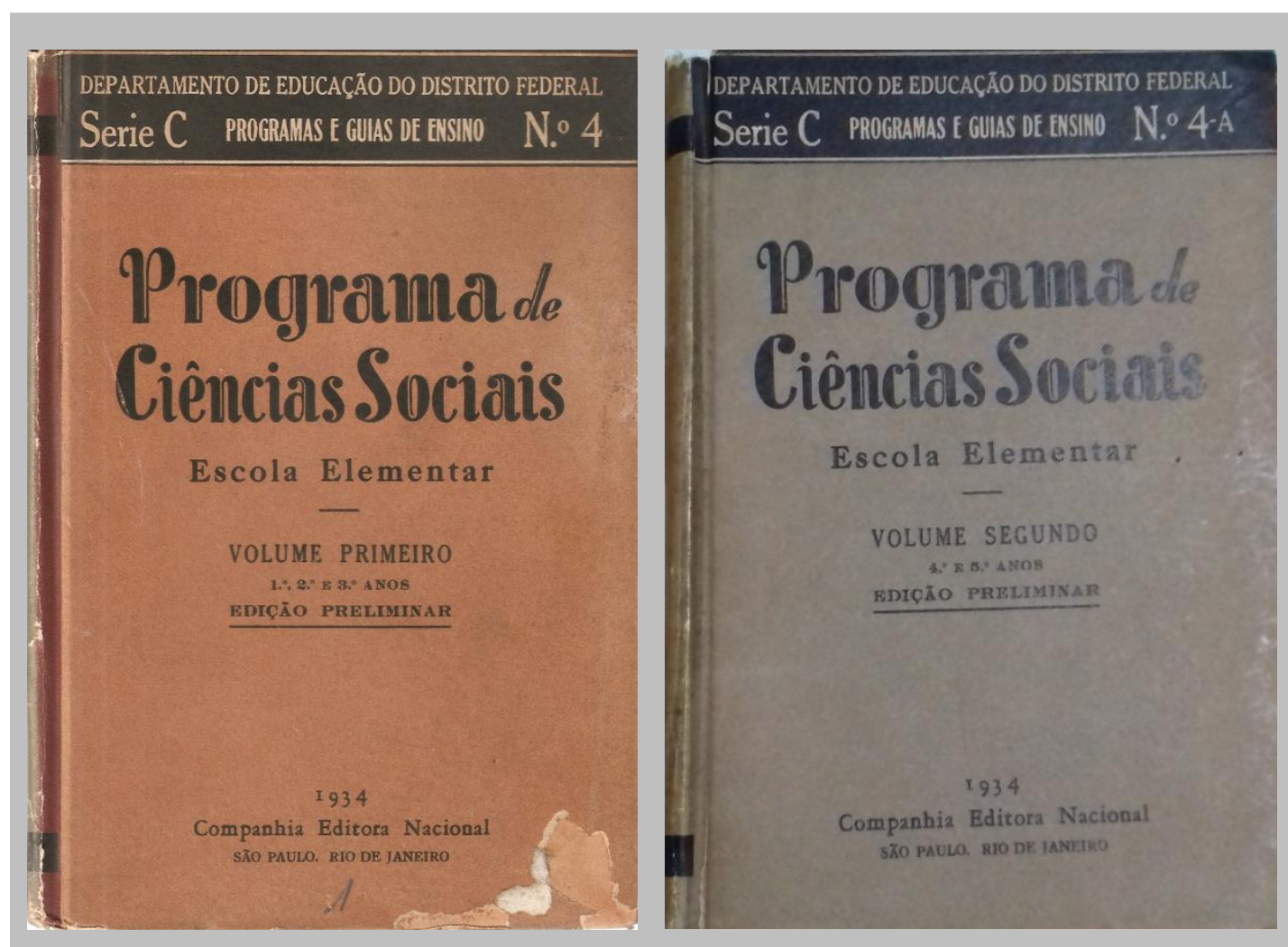

Figura 7 - PCS para a escola primária do Distrito Federal, volume $1\left(1^{\circ}, 2^{\circ}\right.$ e $3^{\circ}$ anos) e volume $2\left(4^{\circ}\right.$ e $5^{\circ}$ anos $)$

Fonte: Acervo do autor.

Essas mudanças visavam a melhoria dos processos de escolarização em curso no Distrito Federal. A própria escola primária foi reorganizada através da sua distribuição em duas etapas, com diferenciação de objetivos: o primário, de três anos, cuja finalidade principal era ensinar a ler, escrever e contar e o intermediário, de dois anos, que, além de desenvolver as técnicas anteriores, ocuparia-se de "enriquecer a bagagem intelectual do aluno" e do aprofundamento em "setores diversos" (Teixeira, 1997, p. 182). Na concepção do educador, é a escola primária, aglutinando alunos entre 7 e 12 anos de idade, que oferece os

por intermédio da Campanha do Livro Didático e Manuais de Ensino, para que sua reedição constitua o prosseguimento daquêle esforço de recuperação do ensino de ciências sociais na escola elementar." Previam-se sucessivas reedições, o que não ocorreu. Foram reimpressos todos os outros programas: "Linguagem na Escola Elementar" (1955), "Matemática na Escola Elementar" (1955), "Ciências na Escola Elementar" (1955), "Jogos Infantis na Escola Elementar" (1955), "Música para a Escola Elementar" (1 $1^{\mathrm{a}}$ - 1955 e $\left.2^{\mathrm{a}}-1962\right)$. Compunham a Série 1 - Guias de Ensino, publicada pelo Instituto Nacional de Estudos Pedagógicos (Inep), à época dirigido por Anísio Teixeira. Na mesma série foi editado "Estudos Sociais na Escola Primária", de Josephina Castro e Silva Galdenzi (1962), que Elza Nadai (1988) considera como uma reedição do PCS, mas não é. Trata-se de trabalho original realizado pela autora. 
"conhecimentos fundamentais", introduzindo discussões sobre História, Ciências, Artes, entre outros. Não é considerada, assim, uma simples escola de "instrução", "ler, escrever, e contar", ou alfabetização, mas torna-se responsável pela constituição de hábitos, costumes e capacidades. Trata-se de um discurso que permeia os debates da Associação Brasileira de Educação desde os anos de 1920, em que seria necessário educar integralmente a criança, instruindo-a, moralizando-a (Reznik, 1992). Na visão de Anísio Teixeira, era a escola elementar que se destinava a formar todos os cidadãos do país.

Com esse objetivo, o educador baiano alterou o currículo do Distrito Federal e as seguintes disciplinas passaram a ser ensinadas na escola primária: Linguagem, Matemática, Ciências Físicas e Naturais, Ciências Sociais, Educação Física e Recreação, Música, Desenho e Artes Aplicadas. Enquanto nos três primeiros anos do ensino primário os alunos teriam apenas um professor responsável pelo desenvolvimento de todos os conteúdos de ensino, nos dois últimos os professores seriam especialistas nas diferentes disciplinas. Era uma aproximação com a experiência que teriam no secundário. A tendência geral era a da integração, conforme explica Anísio Teixeira (1997, p. 182, grifos nossos):

[...] tal sistema de especialização é o mesmo do ensino secundário. Note-se, entretanto, que o ensino é dado por grupos de matérias, em que de fato não se encontram os males consumados da desconexão. Infelizmente, ao se distribuírem os professores, pareceu, à primeira vista, que valia a pena haver um para matemática e outro para linguagem e literatura. E assim se fez na maioria das escolas. De preferência, e assim já se fez em 1935, o ensino de linguagem e matemática deve ficar com um só professor, que poderá ser designado como professor de ensino fundamental, enquanto os professores de ciências, ciências sociais, desenho e artes aplicadas, música, educação física e recreação representarão o ensino de desenvolvimento e enriquecimento do programa.

Essa perspectiva entendia que as diferentes disciplinas deveriam ser ministradas segundo suas ligações naturais, sem uma preocupação com as classificações científicas, horários ou rígidos programas e a partir de "centros de interesse" ou "ensino por assumptos relacionados" (Campos, 1932, p. 149). A integração entre as disciplinas na escola primária não é, portanto, uma inovação da gestão de Anísio, mas é uma herança das reformas que o precederam. Vejamos como Fernando de Azevedo (1930, p. 17), antecessor de Anísio na Diretoria Geral de Instrução Pública, apresentava os programas da escola primária:

As materias que constituem o curso primario, não são ensinadas isoladamente, mas em "conjunto", grupadas, "associadas", em torno de centros de interesse. É o 
principio da "concentração dos estudos em centros de interesse", tambem chamado "ensino global ou concentrico", que presidiu á elaboração do novo plano de estudos. Esse principio, que se oppõe a toda especialização prematura e a toda mutilação arbitraria, levado ás suas ultimas consequencias, não tolera o horario, inalteravel e rigido, com que se interrompe o ensino a intervallos regulares.

Os fundamentos se relacionam à crítica à especialização excessiva que caracterizava a educação desde os primeiros anos de escolarização. A integração entre os conteúdos tem sua base, segundo a argumentação de Fernando de Azevedo (1930), na necessidade psicológica e no interesse de cada um dos alunos. O programa se organizaria através de "centros de interesse", a partir dos quais os conhecimentos se desenvolveriam do particular para o geral, do concreto para o mais abstrato. Entretanto, o reformador apontava a necessidade "de transição de um regimen tradicional para outro inteiramente diverso" (p. 17). Por isso, mesmo apontando que a aplicação do programa se faria a partir da integração, organizou o currículo de forma disciplinar, conforme aponta Vidal (2001, p. 61):

Este era o compêndio das disciplinas ministradas, ou melhor, experienciadas em classe, nos cinco anos do ensino primário: 1. Disciplinas de observação: Geografia e Ciências Físicas e Naturais; 2. Disciplinas de expressão: Linguagem, Desenho e Trabalhos Manuais; 3. Disciplinas de iniciação à matemática: Aritmética e Geometria; 4. História Pátria; 5. Educação Social; 6. Educação higiênica: Higiene e Puericultura; 7. Educação Doméstica.

Desse conjunto de disciplinas não aparece Instrução Moral e Cívica, já que preparar o aluno para a "vida social e cívica" deveria ser uma função de todos os professores a partir de qualquer matéria ou atividade escolar. E para isso contribuiria a própria organização do ambiente escolar (Azevedo, 1930). A História, por sua vez, aparece como uma disciplina autônoma e dedicar-se-ia apenas à pátria. Em comum, todas as disciplinas deveriam partir da realidade concreta dos alunos. Assim, algumas das proposições de Anísio Teixeira não eram desconhecidas da realidade escolar do Distrito Federal. Contudo, ao reunir História, Geografia, Educação Moral ou Social, bem como outros conhecimentos em torno de uma disciplina denominada como Ciências Sociais, o educador baiano contribuiu para a construção das bases de uma nova disciplina escolar. 


\section{2}

\section{PCS: fundamentação, organização e estrutura}

Seja qual for o programa seguido pelas escolas, há nele alguma teoria educacional que o governa, orienta e lhe impõe os critérios para a avaliação dos resultados a que visa (Teixeira, 1968). Os conteúdos e métodos adotados também se relacionam a essa teoria. Por muito tempo, os pesquisadores consideraram os Estudos Sociais apenas como uma fusão de História e Geografia eliminadas em prol de uma nova disciplina: "Uma salada sem sentido". Contudo, a introdução da disciplina no Brasil se deve a uma consideração pedagógica acerca da construção dos programas escolares. Ela pode ser encontrada, sobretudo, em "Diretrizes da educação e elementos de sua técnica", capítulo do livro "Educação Progressiva" ${ }^{154}$, publicado por Anísio Teixeira em 1932. Juntamente com "Educação para democracia" (1936), esse livro congrega os fundamentos do pensamento pedagógico do educador e as bases da "sua ação políticoadministrativa à frente da educação pública da cidade do Rio de Janeiro." (Mendonça, 2002, p. 44).

A franca inspiração de Anísio Teixeira neste capítulo, em especial, é o pequeno artigo "The child and the curriculum", publicado por John Dewey no início do século XX, ou "A criança e o programa escolar" em sua tradução para o livro "Vida e educação" (1930). "Diretrizes da educação e elementos de sua técnica" é um texto esclarecedor para compreendermos a teoria educacional que fundamentou a organização dos programas escolares publicados pelo Instituto de Pesquisas Educacionais do Distrito Federal entre os anos de 1934 e 1935. A característica essencial dessa abordagem, como exposto no terceiro capítulo desta tese, está na crítica aos processos mecânicos de ensino e a criança como eixo central da escola ou o centro de toda a atividade escolar. A criança deixa de ser um meio e torna-se um fim em si mesma. Para Anísio Teixeira, essa perspectiva impunha todo um processo de reorganização escolar e dos programas de ensino.

A confecção dos programas da escola primária se inspirou, ainda, na tradução de um documento norte-americano de 13 páginas, intitulado "Bases do Preparo de Programmas". Produzido pela Comissão de Technica de Preparo de

\footnotetext{
${ }^{154}$ Originalmente foi publicada com o título "Educação progressiva: uma introdução à filosofia da educação". Posteriormente foi reeditado como "Pequena introdução à filosofia da educação: a escola progressiva ou a transformação da escola". Nesta tese, utilizamos a $5^{\text {a }}$ edição, de 1968.
} 
Programmas da Sociedade Nacional de Estudo de Educação (The National Society

for the Study of Education, no original) ${ }^{155}$, provavelmente entre as décadas de 1920 e 1930, propunha-se a apresentar alguns princípios básicos para a elaboração de programas que poderiam ser aplicados a qualquer nível de ensino, do nível elementar ao universitário desde que com as necessárias adaptações. Duas cópias deste texto estão depositadas nos arquivos pessoais de Anísio Teixeira e de Lourenço Filho, disponíveis no Centro de Pesquisa e Documentação de História Contemporânea do Brasil da Fundação Getúlio Vargas (CPDOC-FGV) ${ }^{156}$. Nele fica explícita uma defesa da maior integração, e mesmo fusão, entre as disciplinas, especialmente as que se relacionam mais diretamente com a vida.

\subsection{1 \\ "Organização psicológica das matérias escolares": a crítica à disciplinarização como fundamento do programa escolar anisiano}

Ao partir da criança e de suas necessidades, Anísio e seus colaboradores na reforma educacional do Distrito Federal defenderam a organização do programa escolar a partir de uma série de "experiências reais e socializadas", e não simplesmente através da distribuição de "matérias escolares"157 por anos de ensino. Na argumentação de Teixeira (1968, p. 68), "as matérias escolares [...] deveriam ser tudo sôbre que incidissem o inquérito, a reflexão, o estudo, no desenvolvimento de uma determinada atividade", mas se tornaram apenas "os diferentes ramos classificados do saber." O que a escola tradicional não se deu conta, segundo essa perspectiva, foi de que, apesar de representarem elementos da vida em sociedade, os conhecimentos consubstanciados nos "diferentes ramos do saber humano" se encontravam "desligados de sua matriz social", tendo pouco efeito sobre "as atividades reais dos homens" (p. 69). Assim, "o seu êrro estêve

\footnotetext{
${ }^{155}$ A Comissão reunia alguns dos principais expoentes da educação norte-americana, professores de Delgado de Carvalho e Anísio Teixeira em suas especializações nos Estados Unidos. São eles: Willian C. Bagley, Franklin Bobbitt, Frederick S. Bonser, Werrett W. Charters, George S. Counts, Stuart A. Courtis, Ernest Horn, Charles H. Sudd, Frederick S. Kelly, Willian H. Kilpatrick, Harold Rugg (presidente) e Georges A. Works.

${ }^{156}$ Arquivo Anísio Teixeira/CPDOC, AT pi IE, 32.00.00. Arquivo Lourenço Filho/CPDOC, LF t Inst. Educ., pasta XI. Pinto (2006) analisa este documento tentando compreender a organização do Instituto de Educação. Utilizamos como referência a cópia disponível no arquivo de Anísio.

157 Nos escritos de Anísio Teixeira, o termo utilizado é "matérias escolares". Em Dewey, a nomeclatura é "assunto-matéria". Já no documento "Bases do Preparo de Programmas" são "matérias de ensino". Contudo, as definições têm o sentido de disciplina escolar.
} 
em organizar esse meio pelo estudo de matérias que não se achavam devidamente impregnadas do sentido social necessário à sua perfeita compreensão" (p. 69).

Para Dewey (2002, p. 158), “a criança vive num mundo de contatos pessoais relativamente limitado." O seu mundo ainda é o de pessoas e interesses pessoais mais imediatos, não sendo regido "pelo reino de fatos e leis" que caracteriza a vida dos adultos. Cada novo aspecto do conhecimento e das relações humanas penetra na experiência da criança com certa dificuldade. É preciso que esses aspectos se relacionem de forma mais direta e íntima com o seu bem-estar, da sua família e amigos. Em contrapartida, o currículo escolar, através da sucessão de estudos possibilitada pela escola, "apresenta material que se estende indefinidamente no passado e no espaço" (p. 158). Como consequência:

A criança é retirada do seu meio físico familiar, pouco mais do que uma milha quadrada de área, para o mundo alargado, e mesmo até os limites do sistema solar. O seu leque restrito de memórias e tradições é invadido pelos longos séculos da história de todos os povos. (Dewey, 2002, p. 158).

A vida e o mundo da criança, nesse sentido, representam uma totalidade, em que ela constrói e reconstrói não apenas os conteúdos ensinados pelos professores, mas a sua própria vida. Segundo Dewey (2002, p. 158-159), “as coisas que ocupam [a criança] são mantidas em conjunto pela unidade dos interesses pessoais e sociais que a vida acarreta" e isso simboliza todo o seu universo. Este universo é "fluido e fluente", uno. A escola, por sua vez, fraciona o mundo da criança e o divide em diferentes disciplinas: "a geografia seleciona, abstrai e analisa um conjunto de fatos, de um ponto de vista particular. A aritmética é outra divisão, a gramática outro departamento e assim infinitamente.” (p. 159). No ambiente escolar, os conhecimentos são classificados, retirados de "seu lugar original na experiência" e rearranjados de outros modos, seguindo princípios gerais. Portanto, essa "classificação" não representa uma dimensão própria da experiência infantil, já que "as coisas não chegam ao indivíduo compartimentadas" (p. 159). Trata-se de um produto das ciências de cada época. Com isso, a escola afastou-se da vida. Complementa Anísio Teixeira (1968, p. 69):

Com efeito, as "matérias escolares" - linguagem, matemática, história, ciências naturais, etc. - nada mais são do que resultados sistematizados dos conhecimentos humanos em sua forma lógica e abstrata. Como tais, só interessam ao especialista que pode compreender a sua linguagem simbólica ou técnica e perceber as relações que existem entre as diferentes partes da sua estrutura lógica. São matérias de estudo para o especialista. Não o podem ser para as crianças. 
Dewey e Teixeira parecem preocupados em transformar o conhecimento científico, sintetizado na "organização lógica" das disciplinas escolares em um saber a ser ensinado aos alunos. Tal conhecimento precisaria ser mais bem adaptado à realidade escolar. Segundo Ana Maria Monteiro (2007, p. 83), a constituição de um "saber escolar" pressupõe a "compreensão de que a educação escolar não se limita a fazer uma seleção entre o que há disponível da cultura num dado momento histórico, mas tem por função tornar os saberes selecionados efetivamente transmissíveis e assimiláveis." Para que isso ocorra é preciso um processo de "reorganização, reestruturação ou de transposição didática". O conceito de "transposição didática", cunhado a partir dos anos de 1970, é mobilizado pela autora a partir da definição de Chevallard (1991, p. 45):

Um conteúdo de saber que foi designado como saber a ensinar sofre, a partir de então, um conjunto de transformações adaptativas que vão torná-lo apto para ocupar um lugar entre os objetos de ensino. Ao trabalho que transforma um objeto de saber a ensinar em um objeto de ensino denominamos transposição didática ${ }^{158}$.

Para Chevallard (1991 apud Monteiro, 2007, p. 84), há uma diferença entre o "saber acadêmico" e o "saber ensinado": "o saber-tal-como-é-ensinado, o saber ensinado, é necessariamente distinto do saber-inicialmente-designado-comoaquele-que-deve-ser-ensinado, o saber a ensinar." São vários os saberes: saber sábio, produto da pesquisa acadêmica; saber a ensinar ou o que se considera como um conteúdo escolar, com uma linguagem mais acessível e atendendo as necessidades do ensino; e, saber ensinado, o que se pratica na sala de aula. O processo de transposição didática ocorre, assim, em diferentes etapas (Chevallard, 1991). De acordo com Monteiro (2007, p. 85):

[...] a transposição didática, lato sensu, se inicia com a definição dos saberes a ensinar a partir do saber acadêmico, realizada pela noosfera, e a transposição didática, stricto sensu, realizada pelos professores, dá continuidade ao processo quando estes elaboram algumas versões possíveis do saber ensinado.

Anísio Teixeira não estava tão preocupado em definir os saberes a ensinar, mas em criticar a forma como eles vinham sendo ensinados. Para o intelectual, não havia sentido na distância entre ciência e ensino, já que ambos têm origem na

\footnotetext{
158 Tradução nossa do original: "Un contenido de saber que ha sido designado como saber a enseñar, sufre a partir de entonces un conjunto de transformaciones adaptativas que van a hacerlo apto para ocupar un lugar entre los objetos de enseñanza. El 'trabajo' que transforma de un objeto de saber a enseñar en un objeto de enseñanza, es denominado la transposición didáctica." Para um aprofundamento sobre esse conceito, ver: Monteiro (2007) e Chevallard (1991).
} 
experiência. De fato, o autor propõe uma nova forma de transpor o conhecimento científico em saber escolar. Se a organização "lógica e abstrata" das "matérias escolares" atende aos objetivos dos pesquisadores e especialistas nos diferentes ramos do saber, é de pouca serventia para as crianças porque desconsidera as diferentes fases pelas quais passa o crescimento infantil. Teixeira (1968) salienta três delas: aprendizado pelo fazer, fazendo coisas (caminhando, falando, brincando, etc.); aprendizado pela comunicação, por intermédio da informação; e, a última fase, quando a criança está apta a uma organização lógica do conhecimento. É a esta que se dedica a escola, iniciando a educação pelo fim e não pela etapa inicial de desenvolvimento infantil. A lógica é a de dosagem do conhecimento, da imensidão e complexidade dos materiais acumulados pela humanidade, em pequenos pedaços oferecidos a "colheradas" aos alunos (exposições mais simples aos alunos mais novos; mais complexas para os alunos mais adiantados, e assim sucessivamente durante toda a escolarização).

Para o adulto é fácil compreender essas ramificações, já que sua mente está acostumada com a organização lógica e ordenada dos fatos. A escola, nesse sentido, apresenta a "matéria" como foi pensada pelo especialista, em seu resultado final, pronto e acabado. Isto é, trata-se de um fato conhecido pelos outros e exige-se que a criança também o conheça. Muitas vezes, o que se faz é retirar algumas dificuldades científicas, reduzindo-as a um nível inferior, de forma que possa ser ensinada aos alunos. Por não ter contato com aquilo que a criança já viu, sentiu ou tocou, esse material torna-se simplesmente simbólico e formal e a instrução é meramente mecânica (Dewey, 2002). Segundo Teixeira (1968, p. 75):

A simplicidade dos grandes princípios e regras, com que se iniciava o ensino da gramática ou da física, está muito acima da capacidade da criança naquele momento dado. Porque não é uma simplicidade inicial; mas uma resultante de muitas, de sucessivas generalizações e sínteses. A simplicidade dos primeiros conhecimentos não deve ser, não pode ser a que se supunha existir nos princípios fundamentais de uma ciência feita, aos quais ela só chegou ao final do caminho percorrido de sua formação, mas a que existe em idéias que são ensinadas globalmente por exemplos concretos, e desenvolvidas, depois, em todos os seus corolários ou premissas.

A esse modelo, Anísio Teixeira (1968, p. 71) coloca como alternativa a "organização psicológica" ou "a disposição da matéria ou da lição na ordem em que se realiza a experiência da criança”. Esse tipo de organização não abandona totalmente a "organização lógica". O conhecimento é sempre organizado de modo 
que seja aplicado, utilizado. Cada experiência representa um trecho de vida, cada resultado é uma "ordenação lógica do que foi aprendido daquela experiência" (p. 72). Os conhecimentos das crianças também são classificados, embora através de critérios diferentes dos adultos. O aluno precisa ter uma visão global do que está estudando. O programa é, igualmente, uma parte de um todo maior, o processo educativo pelo qual passa o homem desde que nasce (Teixeira, 1968).

Educação, assim, é “o próprio processo de viver, o próprio processo de refazer, reconstruir e melhorar a vida." (Teixeira, 1968, p. 62). O conhecimento ministrado pela escola assume, portanto, uma importância para a vida. Para isso, o programa deve se constituir não em lições ou matérias, mas a partir de uma série de atividades e experiências que a criança possa se empenhar na escola. Não qualquer experiência. O programa se divide, essencialmente, em "atividades da vida presente", que são necessárias ou desejáveis ao desenvolvimento da criança, e os "processos adquiridos pela experiência humana", fundamentais para o aprimoramento das primeiras. A partir de tais princípios, conclui o reformador:

[...] o ensino passará a ser dado por meio de projetos, em vez de lições. E os projetos não acompanharão, é bem de ver, a sequiência lógica em que hoje é dividida a matéria, por isso que se devem organizar em harmonia com os impulsos, as tendências, os interêsses e a capacidade da criança. As matérias serão ensinadas à medida que se tornem precisas, na sequiência de cada projeto. (Teixeira, 1968, p. 78).

A disciplina é pouco importante se a criança não for capaz de assimilá-la, expandindo a sua mente. Por isso, John Dewey e Anísio Teixeira defendem que abandonemos a noção de disciplina como algo fixo, ou seja, construída a partir de um conteúdo pronto, acabado e fora da experiência da criança. Os projetos levam a outra relação com a própria ciência. Um problema para Dewey (2002), na abordagem tradicional, é que quando o assunto deixa o campo científico para se tornar um assunto escolar, ele perde um pouco da sua qualidade. Isso porque ao sofrer modificações, que visam tirar os aspectos mais complicados e difíceis de entender, perde-se o seu caráter desafiador do pensamento. Não ousa usar as capacidades de raciocínio, abstração e generalização das crianças. $\mathrm{O}$ "assuntomatéria" perde o "seu valor lógico", sendo apresentado apenas como algo para a memorização. A "criança que se educa" e o cientista agem de modo semelhante, já que ambos usam de forma inteligente os recursos que possuem em busca de um determinado fim. Com o método de projetos teria o aluno uma visão do método 
científico e seus processos, através de reflexão, inquérito, análise, crítica e sistematização. Um fim deve ser sempre atingido na resolução de problemas.

Dos programas publicados entre 1934 e 1935, o único que conta com uma apresentação de Anísio Teixeira é o de "Linguagem" "159. Nele, o autor afirma que os novos programas deveriam ser escritos "dentro das condições especiais do sistema escolar do Rio de Janeiro" e a partir de "princípios gerais modernos" (Teixeira, 1933, p. 9). Mais ainda, defende a necessidade de "planos antecipados", mesmo em uma escola que se preocupa, primordialmente, com "situações da vida diária". Isso porque são os programas que estabelecem as atividades cotidianas, em que se empenharão alunos e professores, apontam os objetivos fundamentais destas atividades e estabelecem os resultados que deverão ser atingidos. Para tanto, os programas confeccionados pelo IPE não apresentavam apenas as tradicionais listas de pontos, mas propunham objetivos de ensino, um conjunto de experiências e atividades, conteúdos mínimos a serem trabalhados e a indicação de resultados a serem obtidos a partir de cada ano de ensino.

Tais "guias didáticos" contavam com pequenas introduções, geralmente análises do "sistema escolar moderno" elaboradas pelos educadores responsáveis por sua organização (Vidal, 2001). Era uma "vulgarização da norma legal, traduzindo-a para o domínio do professorado" (p. 73). Nos programas "a voz de Anísio diluía-se, sendo substituída por outras vozes, de outros técnicos, como ele.” (p. 74). Sobre o "Programa de Linguagem" (1933), o próprio Anísio Teixeira (1933, p. 11) afirma que:

A sua elaboração foi confiada á Professora Maria dos Reis Campos, autoridade reconhecida nos meios do professorado do Rio de Janeiro e que está imprimindo ao trabalho de progrâmas escolares, com a cooperação de suas dignas auxiliáres, o feitìo de pesquizas e investigação que o caracteriza nos centros mais avançados de cultura.

Dois elementos são importantes no agradecimento de Anísio Teixeira a Maria dos Reis Campos e indicam o contorno em que se previa a escrita dos programas escolares do Distrito Federal. A organização encabeçada por um professor de reconhecida autoridade educacional e a cooperação que se pretendia entre os técnicos educacionais, vinculados ao Departamento de Educação, e os

\footnotetext{
${ }^{159}$ Este programa foi editado pelo Serviço de Programas Escolares, na gestão de Maria dos Reis Campos, antes da criação do Instituto de Pesquisas Educacionais, em 1933, e reeditado através da Divisão de Programas e Atividades Extraclasse já sob a chefia de Ignacia Guimarães.
} 
professores que atuavam no dia a dia das diferentes unidades escolares. Essa é uma regra fundamental ditada nas "Bases do Preparo de Programmas". Para os seus formuladores era de grande importância que fosse "creado um apparelho central adequado para estudo continuo do programma escolar. Isso se deve fazer mediante a cooperação de professores experimentados e de especialistas de preparo de programas.” (Bagley et al., s/d, p. 10). Sobre a formulação do PCS (1934b, p. 13), os organizadores informam que:

O plano geral de trabalho foi delineado pelo diretor do Departamento de Educação e obedeceu, em suas linhas gerais, ao plano de "Social Science" organizado para as escolas públicas de Denver, Colorado, E.U.A, que tem sido copiado por várias cidades americanas e diversos países estrangeiros.

Isso significa que a ideia de criação da disciplina Ciências Sociais foi de Anísio Teixeira. Apesar de tomar o Programa de Denver como inspiração, convocou-se uma comissão de professores responsáveis por adaptá-lo à realidade brasileira e carioca. Coordenada por Ignacia Guimarães, chefe da Seção de Programas e Atividades Extraclasse, a comissão foi composta por Augusta Queiroz de Carvalho Oliveira, Iza Goulart Bueno, Eurídice Dias Passos, Onêida de Almeida, Vanda de Matos Cardoso e Marília Hasselman. Não poderia ser realizada uma simples “imitação", já que as condições americanas eram diferentes das condições da cidade do Rio de Janeiro. Nesse sentido, mesmo aproveitando-se da "orientação geral", métodos e processos indicados, que eram os representativos da escola progressiva, o material, ou os conteúdos e problemas, eram "exclusivamente nosso[s], isto é, brasileiro[s], em suas origens e fontes de informação, em seus interesses e preocupações, em seus detalhes locais." (Carvalho, 1934a, p. 18). Duas décadas após a sua participação no projeto desenvolvido por Anísio, Delgado de Carvalho (1960, p. 220) explicava as escolhas do diretor do Departamento de Educação:

[...] devo dizer que duas cousas sempre me pareceram caracterizar as opiniões de Anísio a respeito da educação: em primeiro lugar, precisamos de soluções nossas, bem brasileiras e não calcadas em padrões alheios; em segundo lugar, o Brasil não pode esperar efetuar por si próprio a evolução científica que se processou no mundo em quatro séculos, isto é, o Brasil não pode dispensar as contribuições estrangeiras.

A interpretação de Delgado de Carvalho sobre o pensamento de Anísio Teixeira acerca desse ponto, em particular, certamente se construiu através da prática de trabalho conjunta e da leitura de "Educação para a democracia" (1936) 
- obra que cita em seu artigo. Neste livro, Anísio Teixeira (1997, p. 40) defendia que "a educação é um fenômeno de civilização". Isso significa dizer que "para nossas condições precisamos de soluções nossas" (p. 41). Para tanto, é preciso estudar as nossas próprias condições ou situações, o que só se faz com recursos técnicos, métodos eficazes e pessoas que possam aplicá-los. Não havia mal em buscar inspiração no exterior, pelo contrário era um sinal dos tempos. Todos os países participavam dessa troca, independente da sua posição no cenário internacional. As interconexões internacionais em educação são, portanto, um fato histórico (Schriewer, 2011). Isso não significa que os modelos que chegaram ao Brasil da década de 1930, por exemplo, sejam simples "traços alienígenas", como salienta Nadai (1988, p. 4), ao analisar a proposta de Estudos Sociais.

A difusão global de modelos educativos não elimina a "persistência de varias redes de inter-relação sociocultural" (Schriewer, 2011, p. 72). A "indigenization" - termo desenvolvido pelo autor alemão - pode ser entendida como um processo de "interpretação" de teorias exteriores. Desse modo:

[...] a difusão transcultural do conhecimento, dos modelos organizacionais, dos padrões de resolver problemas ou políticas, é enfrentada pelos grupos culturais receptores com procedimentos de reinterpretação e adaptação. Conseqüentemente, os modelos oferecidos transculturalmente são, neste novo ambiente, selecionados de acordo com os interesses maiores, adaptados às específicas situações e necessidades, reinterpretadas através das linhas culturais e, em graus historicamente variados, transmutadas em novas formações estruturais. (Schriewer, 2011, p. 76) ${ }^{160}$.

Há características que atravessam os vários sistemas nacionais e estão presentes em nível transnacional, porém os conhecimentos passam por "procedimentos de adaptação" e apropriação, sendo reinterpretados. Apesar de inspirados na perspectiva norte-americana, os Estudos Sociais introduzidos no Brasil foram pensados para a escola primária. Isso porque a disciplinarização, ou o lugar de cada uma das disciplinas no currículo, era plenamente consolidado na escola secundária, cujos programas eram definidos pelo Colégio Pedro II e, posteriormente, pelo Ministério da Educação e Saúde Pública. Já os programas

\footnotetext{
${ }^{160}$ Tradução nossa do original: "[...] la difusión transcultural del conocimiento, los modelos de organización, las pautas o políticas de resolución de problemas, encuentran una reiterpretación y unos procedimientos de adaptación específicos por parte de los grupos culturales o nacionales que los reciben. Como consecuencia de ello, los modelos ofrecidos transculturalmente son selecionados, en este nuevo ambiente, según los interesses prevalecientes, adaptados a situaciones y necesidades específicas, reinterpretados de acuerdo com líneas culturales y, en grados históricamente diversos, transmutados en reformas estructurales."
} 
primários eram de competência dos estados e no seu currículo ainda não estava claro o lugar de cada uma das disciplinas (conforme apresentamos no segundo capítulo desta tese). Era comum o ensino de História estar articulado ao de Geografia, Educação Moral e Cívica e mesmo ao de outras disciplinas. Contudo, pela primeira vez se unia as três em torno de uma disciplina denominada Ciências Sociais. Era um programa inovador, até mesmo para as suas formuladoras.

As discussões metodológicas iniciadas no contexto de crítica a um ensino passivo e distanciado da realidade e dos interesses dos alunos aos poucos caminharam para a construção de uma nova disciplina escolar. Além de se inscrever objetivos, conteúdos, problemas, métodos e processos de ensino, era preciso estabelecer o significado dos Estudos Sociais na escola básica. Tal função coube ao professor Carlos Miguel Delgado de Carvalho.

\subsection{2}

\section{Delgado de Carvalho na década de 1930: um professor a serviço da renovação educacional}

A apresentação dos dois volumes do PCS coube ao diretor do IPE, Carlos Miguel Delgado de Carvalho. De todos os programas publicados pelo instituto, este é o único que conta com um texto assinado pelo seu diretor. Isto se deve à maior proximidade que ele tinha com a área de Ciências Humanas. Nos capítulos anteriores, apresentamos alguns aspectos da sua trajetória que dão indícios do lugar de fala e a posição ocupada pelo educador no cenário nacional ${ }^{161}$. Para Vale (2011, p. 22), "sua produção, dessa forma, é sempre influenciada pela participação em associações e em uma série de 'lugares de sociabilidade', como revistas, manifestos e abaixo-assinados." A partir da década de 1930, foi ele um crítico do ensino de História que se processava nas escolas brasileiras, um entusiasta das viagens pedagógicas como um elemento de formação e defensor da maior articulação entre as Ciências Sociais. Apesar de ser um dos "construtores" do

\footnotetext{
${ }^{161}$ Tomamos de empréstimo a abordagem de Michel de Certeau (1982, p. 66-67), para quem toda produção "se articula com um lugar de produção socioeconômico, político e cultural. Implica um meio de elaboração que é circunscrito por determinações próprias: uma profissão liberal, um posto de observação ou de ensino, uma categoria de letrados, etc. Ela está, pois, submetida a imposições, ligada a privilégios, enraizada em uma particularidade. É em função deste lugar que se instauram os métodos, que se delineia uma topografia de interesses, que os documentos e as questões, que lhes serão propostas, se organizam."
} 
campo disciplinar brasileiro, a crítica à especialização era um dos elementos presentes no pensamento do educador naquele momento.

Não pretendemos analisar toda a trajetória do educador, tarefa já realizada por Costa (2007) e Vale (2011), mas discutir alguns aspectos que auxiliam a compreensão de sua atuação na década de 1930. Delgado de Carvalho nasceu na França, em 1884, período em que seu pai estava a serviço da diplomacia do Império. Faleceu, quase um século depois, em 1980, deixando uma vasta produção composta por 49 livros editados. De acordo com Andrade (2014, p. 411), Delgado teve uma "sólida formação humanística" em importantes instituições de ensino superior na França, Inglaterra e Suíça. Sua formação foi multidisciplinar - Letras, Direito, Diplomacia, Ciências Sociais e Políticas -, o que se refletiu em sua prática e defesa de uma maior integração entre as diferentes disciplinas que compõem as Ciências Humanas. Para desgosto do pai monarquista, Carvalho conheceu o Brasil em 1906. Como afirma Costa (2007, p. 19), "fez o caminho inverso de muitos intelectuais brasileiros que sonhavam estudar na França." Tal capital cultural lhe permitiu propor mudanças nos métodos de pesquisa e ensino que vigoravam no Brasil no começo do século XX.

Aqui encontrou "um campo científico" ainda em desenvolvimento e composto por intelectuais que não possuíam uma formação específica (Costa, 2007). Atuou em diversas instituições - Colégio Pedro II, Instituto de Educação, Universidade do Distrito Federal, Faculdade Nacional de Filosofia da Universidade do Brasil, Instituto Brasileiro de Geografia e Estatística -, além de ter sido sócio do IHGB, fundador da ABE, em 1924, e signatário do "Manifesto dos Pioneiros da Educação Nova", em 1932. Autor de vasta produção em diversos campos do conhecimento, com destaque para História, Sociologia e Geografia, era, antes de tudo, um educador (Costa, 2007). Na década de 1930, a carreira de Delgado de Carvalho estava plenamente consolidada. Entre os elementos de sua consagração estão "a cátedra, a admiração de intelectuais estrangeiros por seu trabalho, o sucesso editorial e a escolha para cargos administrativos no governo Vargas." (Costa, 2007, p. 23). Nesses anos, ficou explícita sua capacidade de transitar pelas principais instituições e espaços políticos e acadêmicos que discutiam os rumos da educação nacional (Vale, 2011).

Delgado aproximou-se de diferentes governos, inserindo-se nos projetos como uma estratégia de legitimação e difusão de algumas de suas ideias nas 
políticas públicas educacionais (Vale, 2011). No momento em que os catedráticos do Colégio Pedro II perdiam o poder de elaborar os programas de ensino, tarefa que passou à responsabilidade do Ministério da Educação e Saúde Pública, ele participou das reformas de Francisco Campos e de Gustavo Capanema e atuou como um dos formuladores dos programas de ensino da escola primária durante a reforma anisiana no Distrito Federal (1934). Nem sempre, conforme demonstra Mendonça (2002), os projetos do governo federal e os organizados por escolanovistas, como Anísio Teixeira, mantinham uma relação amistosa.

A colaboração em diversos empreendimentos desenvolvidos por Anísio Teixeira, como o Instituto de Pesquisas Educacionais e a Universidade do Distrito Federal, não impediu Delgado de Carvalho de ingressar na Faculdade Nacional de Filosofia da Universidade do Brasil quando, no processo de radicalização política iniciado em 1935, a primeira foi extinta e o seu fundador deixou a Secretaria de Educação do Distrito Federal. O Estado, conforme aponta Costa (2007), teve um papel importante no reconhecimento da autoridade de Delgado de Carvalho como intelectual e professor. Na Universidade do Distrito Federal, lecionou Sociologia Educacional, disciplina que ministrava como docente da Escola de Professores do Instituto de Educação, Geografia Humana e História da Civilização. De acordo com Mendonça (2002, p. 96), a perspectiva de Anísio Teixeira era a de que "só se aprende com quem sabe”. Destarte, para Anísio:

[...] os que iram formar professores deveriam ser os mestres dos mestres, os mais competentes em seus respectivos campos de conhecimento, dada a relevância do papel da educação, da escola e do professor no processo de reconstrução nacional que pressupunha a construção de uma sociedade progressiva e democrática. (Mendonça, 2002, p. 97-98).

A cátedra na Universidade do Distrito Federal não era vitalícia, como em outras instituições, mas temporária, e observando-se o desempenho dos docentes, contratavam-se aqueles que tivessem demonstrado "competência no exercício da prática docente" (Mendonça, 2002, p. 98) e "renomada capacidade científica" (Costa, 2007, p. 72). O contrato de Delgado de Carvalho foi assinado em $1^{\mathrm{o}} \mathrm{de}$ julho de 1935 e renovado em 1936, evidenciando que o intelectual assumia os critérios estabelecidos por Anísio Teixeira na construção da sua universidade. Ele só deixou a Universidade do Distrito Federal quando da proibição de acúmulo de cargos, em 1937, optando por continuar no Colégio Pedro II. Contudo, poucos anos depois, ingressou na Universidade do Brasil, o que mais uma vez demonstra 
a sua legitimação e revela "outros laços com o poder" (Costa, 2007, p. 73). Como lembram Mendonça (2002) e Costa (2007), nem todos os professores da extinta Universidade do Distrito Federal foram contratados pela Universidade do Brasil. Nessa instituição tornou-se catedrático de Geografia Humana (1939-1942) e de História Moderna e Contemporânea (1943-1955) (Ferreira, 2013).

A inserção em diferentes projetos de universidade contribuiu para a sua intervenção no processo de constituição do campo científico no Brasil e definição das disciplinas escolares, atuação que teve início quando chegou ao país na primeira década do século XX. Ele atuou como docente de diferentes disciplinas. No Colégio Pedro II foi professor, inicialmente, de Inglês e o primeiro catedrático de Sociologia. Em escolas privadas do Rio de Janeiro e na França, lecionou História. Desta disciplina foi autor de obras didáticas entre as décadas de 1930 e 1950 e colaborador nas definiçõoes de ensino de História presentes nas reformas da escola secundária, formuladas por Campos e Capanema nas décadas de 1930 e 1940: ambas preocupadas em "reconhecer a preeminência do ensino de História para a formação do cidadão - a 'educação política' e o 'sentido patriótico'." (Reznik, 1992, p. 30). É importante salientar que Delgado de Carvalho estava inserido em uma série de debates em relação às propostas de currículo.

No que concerne ao ensino de História, a grande questão se relacionava à extinção da cadeira de História do Brasil e o estabelecimento da disciplina História da Civilização, nos cinco anos do curso secundário fundamental, englobando o estudo da História Geral, da História da América e da História do Brasil. Segundo Guy de Hollanda (1957), os programas e suas instruções foram elaborados em 1931 e publicados sem se esclarecer, ao menos oficialmente, os seus autores. Apesar disso, Reznik (1992) e Vale (2011) sustentam que Delgado de Carvalho teve algum tipo de envolvimento em sua formulação. Américo Jacobina Lacombe, em entrevista a Reznik (1992, p. 41), afirma que "Delgado 'fez a cabeça' de Francisco Campos para a criação da cadeira de História da Civilização." O historiador salienta, contudo, não ter encontrado mais evidências a respeito de tal participação. Fato é que "Delgado era um entusiasta e defensor da História ensinada na perspectiva da civilização" (Vale, 2011, p. 33-34) e apoiador da Reforma Campos. Sua posição quanto a ela fica explícita em "Sociologia e Educação" (1934c), quando argumenta que esta: 
[...] foi uma grande reforma, bem pensada por um technico competente e patriota, ella ainda não deu todos os fructos porque a sua execução completa ainda não foi possivel: nella, porém já se acham, em germen, todos os remedios para os nossos casos. Criticada por amadores ou pelos que tinham interesses contrariados nella, a Reforma Campos traduz um pensamento educacional moderno: é o que de melhor tempos tido até hoje. (Carvalho, 1934c, p. 25).

Se não é possível afirmar com toda certeza que Delgado de Carvalho tenha sido autor dos programas de História da Reforma Campos, podemos argumentar que a perspectiva da História da Civilização foi adotada pelo PCS do Distrito Federal, destinado à escola primária e organizado pelo educador enquanto diretor do IPE. Nesse programa, os seus formuladores romperam com a perspectiva de que a escola primária deveria se dedicar apenas ao ensino da História do Brasil e Delgado pôde aplicar sua visão "universalista do ensino de História" (Reznik, 1992, p. 54), em que o objeto de estudo da História é a humanidade. Mais do que apresentar a História Pátria aos futuros cidadãos, formando-os e inculcando valores, conformando uma identidade nacional, o programa do Distrito Federal percorria diferentes aspectos da História Geral. Tendo como base explicativa a ideia de progresso contínuo e o reconhecimento da interdependência entre povos e nações, a História do Brasil era uma consequência dos longos passos percorridos pela humanidade. Sua amplitude era reconhecida pela imprensa carioca.

Este Programa de Ciências Sociais (Escola Elementar), que agora aparece, é bem a prova do que dizemos. Trata-se de um programa de real utilidade para o aluno e para o mestre; e eu digo mais: de real utilidade para todos os estudiosos. Qualquer assunto de que queiramos tratar, e que seja atinente ao nosso país ou ao mundo, aqui encontramos com suas fontes de melhor estudo indicadas. É [palavra ilegível] um precioso apontamento para uma enciclopédia, amplificado sobretudo com referencia ao nosso país. (Leão, 1934, p. 8).

Em sua coluna "Registro Literário", no "Jornal do Brasil”, Múcio Leão importante personalidade do jornalismo do Rio de Janeiro na primeira metade do século XX e respeitado orador e escritor - elogiava o programa de mais de 370 páginas recém-publicado pela Companhia Editora Nacional:

Dos programas até hoje publicados, esse de Ciências Sociais é incontestavelmente o melhor. Traz um prefacio do Sr. Delgado de Carvalho, encerrando, em poucas páginas, muitas ideias gerais sobre o ensino e a maneira de ministra-lo. E traz uma introdução da professora Ignacia Ferreira Guimarães. Como a principio eu dizia: estou certo de que toda a gente que se interesse pelos assuntos de Sociologia no Brasil deveria pelo menos examinar esse programa. (Leão, 1934, p. 8).

A resenha de Múcio Leão apresenta alguns indícios interessantes sobre o PCS e o seu organizador. Em relação a Delgado de Carvalho, mais uma vez, era 
reforçada a sua legitimidade enquanto professor e formulador de propostas educacionais. Uma figura capaz de pensar "o ensino e a maneira de ministrá-lo". Em relação ao programa, salientava o seu caráter de "enciclopédia", onde se poderia encontrar "qualquer assunto de que queiramos tratar" seja do Brasil ou do mundo. Uma obra útil, na opinião de Leão, para alunos, professores e todos os estudiosos. Contudo, nos questionamos até que ponto seria tal programa aplicável, tendo em vista sua extensão e generalidade, por professores sem uma formação específica e para alunos entre 7 e 12 anos de idade. Uma questão que retomaremos mais adiante, quando analisarmos a distribuição de conteúdos do programa.

\subsection{3}

\section{Delgado e as apresentações do programa: uma abordagem teórica}

[...] a escola, numa democracia moderna, não se pode desinteressar da vida social do ambiente em que se acha e permanecer estranha aos problemas da comunidade que, em última análise, ela representa. (Carvalho, 1934a, p. 11).

O programa se insere em um contexto de reformulação da escola, inspirado na educação progressiva defendida por Anísio Teixeira: ensino mais próximo da realidade imediata do aluno e que acompanhasse os avanços científicos. Nesse cenário, a escola exerce um papel central no processo de regulação da evolução social. Entretanto, antes de cumprir tal função, necessitava estar em "condições de estudar os elementos desta evolução" (Carvalho, 1934a, p. 11). Só a partir daí seria possível auxiliar no seu desenvolvimento natural e progressivo. A liberdade de pensamento e a circulação de ideias, principalmente nos meios educacionais e como um condicionante da democracia, da mesma forma como defendiam os intelectuais norte-americanos, é fundamental neste movimento, mas Delgado as subordina "à preocupação com o método", sem o qual a sua assimilação e concretização não seria completa. Para o educador, cinco ordens de problemas se apresentavam à escola primária. Era preciso:

$1^{\circ}$ - despertar na criança um interesse ativo por tudo quanto a cerca, tanto no quadro natural como no quadro social; ensinando menos a repetir do que a observar inteligentemente. $2^{\circ}$ - ensinar a criança a procurar no livro, e nos conhecimentos adquiridos por quaisquer outros meios, a resposta aos problemas que se lhe apresentam, e persuadí-la de que o livro é o repositório do pensamento científico da humanidade. $3^{\circ}$ - revelar à criança o valor do trabalho coletivo, da organização 
social, da cooperação e da solidariedade. $4^{\circ}$ - dotar a criança de conhecimentos e de hábitos tais que lhe permitam continuar, por si mesma, a obra iniciada pela Escola, prosseguir na sua cultura, mantê-la em dia e tirar o maior proveito da experiência. $5^{\circ}$ - levar a criança a respeitar em si própria e nos outros não só os direitos à saúde física, como também os preceitos da moral social mais elevada e as necessidades do espírito. (Carvalho, 1934a, p. 11-12).

Os princípios estabelecidos por Delgado de Carvalho procuravam romper com os métodos tradicionais que caracterizavam a escola brasileira. Em síntese: observar mais, melhor e atentamente, ao invés de apenas ouvir e repetir; utilizar o livro como um instrumento do conhecimento, mas não a partir de uma leitura passiva. Toda leitura pressupunha a busca pela solução de um problema, seja oriundo das discussões na escola ou da própria vida; valorização dos elementos colaborativos, em detrimento da educação individualista e baseada na memorização. A colaboração é o fundamento principal da vida em comunidade e a escola deve prenunciar essa dinâmica presente na sociedade; incentivar a constante educação, demonstrando que a escola é apenas uma das etapas do processo de crescimento da criança. O seu objetivo, por conseguinte, como defendiam Dewey e Anísio, é proporcionar mais e melhor educação; e, por fim, uma preocupação com a formação física e moral dos alunos (Carvalho, 1934a).

Para uma educação baseada nesses princípios, era nos Estudos Sociais que se encontravam "os elementos mais preciosos para a formação do cidadão" (Carvalho, 1934a, p. 12). Entretanto, para o seu sucesso, e aproveitamento das ciências que o compunham, seria necessária uma distribuição acertada de cada uma delas e o replanejamento dos programas. Quanto à distribuição de conteúdos, partia-se do princípio de que os Estudos Sociais deveriam começar "por um estudo das atividades na família e na comunidade, para alargar progressivamente o horizonte do educando" (p. 12). Os conteúdos eram abordados de forma progressiva, portanto, as relações entre os diferentes meios sociais deveriam ser apresentadas de forma gradativa aos alunos, alargando-se a sua complexidade. Trata-se de uma nova roupagem para o que defendia Fernando de Azevedo (1930) na elaboração dos programas durante a sua reforma. A educação, assim, partiria do mais íntimo para o mais estranho, de "dentro" para "fora", do interno para o externo, o que na visão de Carvalho (1934a) faz com que o conhecimento não seja uma imposição, favorecendo a noção de interdependência, de solidariedade nas atividades sociais e o espírito de participação do aluno. 
A educação, segundo as análises do intelectual, por ter como objetivo principal a vida real, necessitava ter novos métodos. Para Carvalho (1934a, p.12):

[...] a vida não apresenta uma separação marcada das diferentes matérias de ensino. Existem ligações entre elas e foi exatamente o intuito de respeitar estas ligações que levou ao agrupamento dos fatos, dos fenômenos e das idéias ao redor de certos temas capitais, as unidades, os projetos ou centros de interêsse que, em certos países, são chamados também complexos.

Essa proposta de organização do conhecimento partia do fundamento de que não poderia haver um hiato, uma ruptura, entre o livro, o programa e a vida. $\mathrm{O}$ conhecimento precisa ter uma utilidade e ser fonte do interesse da criança. $\mathrm{O}$ programa escolar deveria, portanto, refletir a vida (trabalho, casa, comunidade, país, mundo) em sua complexidade. Era preciso um novo modelo educacional que orientasse os estudos para uma "visão mais prática das coisas". Os programas e compêndios de Ciências Sociais deveriam se afastar "das normas tradicionais e batidas, das operações militares, dos detalhes políticos, dos nomes próprios e da pesada cronologia que caracterizavam a história de outrora." (Carvalho, 1934b, p. 10). Para Delgado, nem todos os alunos se destinavam ao generalato, à diplomacia ou à carreira de estadista. Assim, as "questões de ordem cívica, econômica e social tomariam na vida de cada um deles maior importância do que as guerras e os tratados, detalhadamente estudados." (Carvalho, 1934b, p. 10).

Esse novo quadro não poderia ser estudado tendo como base apenas a memorização, ou um padrão único de explicação, mas deveria ser abordado através da utilização de uma variedade de métodos e processos de acordo com o ambiente social e as circunstâncias a que se destinam. Os "pontos de partida", problemas ou situações guiariam os programas de Ciências Sociais e serviriam como elo entre o conhecimento e a realidade (Carvalho, 1934a). A reformulação dos métodos levaria à constituição de uma nova disciplina. Na escola primária, conforme Delgado de Carvalho (1934b, p. 12), não haveria vantagem na tradicional divisão em disciplinas “compartimentadas e estanques", pois:

[...] a íntima ligação que deve existir entre os pontos de vista histórico, geográfico, econômico e moral, restitue aos elementos estudados a vitalidade e a significação que perdem na sua exposição pura e simples por matéria, isto é, como se pertencessem a compartimentos, independentes, a disciplinas isoladas. (Carvalho, 1934a, p. 14).

Os autores das "Bases do Preparo de Programmas", documento que influenciou a formulação dos programas do Distrito Federal, consideravam que a 
especialização excessiva favorecia uma "estreita concepção de mundo" (Bagley et al., s/d, p. 8). A complexidade da vida exigia mais.

[...] certas separações entre as materias escolares difficultam o estudo, em vez de auxilial-o. Do estudo da vida industrial, politica e social são tirados abundantes exemplos de que as actuaes divisões do assumpto do programma tendem em certos casos a isolar finalidades, principios, movimentos e forças que, para serem verdadeiramente comprehendidas, deveriam ser estudadas à luz dos relacionamentos profundos que têm em sua situação natural. (Bagley et al., s/d, p. $8)$.

Ainda de acordo com o documento:

Tomando um único exemplo: é impossível levar os alunnos á boa comprehensão dos acontecimentos do mundo, sem reunir, em intimo relacionamento, factos, movimentos e generalizações a respeito de recursos naturaes, imperialismo economico, diplomacia internacional, comercio mundial, nacionalismo e outros semelhantes. Taes factos e generalizações estão espalhados actualmente por diversos assumptos de geographia, historia politica, economia, historia industrial e social, etc. Estes e outros exemplos revelam a necessidade de grupar em conjunctos mais amplos muitos elementos actualmente distribuidos por varios assumptos escolares distinctos. (Bagley et al., s/d, p. 9).

Apesar de Bagley et al. (s/d) defenderem "um íntimo relacionamento" e Carvalho falar em termos de uma maior integração entre as disciplinas que compõem as chamadas Ciências Humanas, na prática o que preconizaram, pelo menos em termos de escola primária, foi a fusão de disciplinas de acordo com suas estreitas afinidades. Os Estudos Sociais abarcariam "todos os estudos que integram o ensino da vida social." (Carvalho, 1934c, p. 70). Bagley et al. (s/d, p. 9) salientam que na organização curricular proposta por eles, algumas divisões deveriam desaparecer, enquanto outras seriam mantidas e até mesmo criadas:

[...] o criterio, entretanto, que deveria exercer a maior influencia na organização dos elementos de instrucção devia ser o da utilidade do saber. Finalidades, principios, instituições e modos de viver deviam ser estudados em suas relações naturaes, de modo que a mocidade os pudesse compreender cabalmente, para ser capaz de servir-se delles com efficiencia. Os alunos deviam ter uma visão de conjuncto tanto das forças como das estructuras da sociedade (p. 9).

Eram a História, a Geografia e a Educação Cívica, sobretudo, que se prestavam a explicar as estruturas sociais e a conformar o cidadão do amanhã, nisso reside a sua utilidade no currículo escolar. Portanto, deveriam estar unidas em torno de uma única disciplina. Anísio Teixeira ${ }^{162}$ exemplifica:

\footnotetext{
${ }^{162}$ Manuscrito de 23 páginas intitulado "As idéias básicas de Dewey e o método de projeto". Datamos como sendo da década de 1960, por conter referências ao Censo Escolar de 1964. Arquivo Anísio Teixeira/CPDOC, AT pi. 1956/1964.00.00/2.
} 
Estou estudando Estudos Sociais, e o professor me leva a refletir e ver as influências do clima, das condições do solo sôbre os recursos do local, as razões históricas, geográficas ou econômicas de certos problemas que o Brasil enfrenta, leva a refletir, a pesquisar, a trabalhar em grupo. Não estou apenas adquirindo conhecimentos de Estudos Sociais, estou aprendendo a conviver, a cooperar, a trabalhar em grupo, a usar dos recursos de estudo disponíveis, a me habituar a fazer anotações úteis, a amar o Brasil, a desejar compreender o passado, a sentir que o futuro do país depende do meu esfôrço e do dos outros, a perceber a importância que a educação - pelo alargamento de horizontes que traz - pode desempenhar no desenvolvimento do país. (Teixeira, s/d, p. 3).

A partir de elementos das diferentes ciências constituintes, os Estudos Sociais ofereceriam ao estudante "os dados julgados interessantes ao seu conhecimento sob estes vários aspectos." (Carvalho, 1934b, p. 12). É uma disciplina que deveria ser informativa e formadora de hábitos, ideias, disposições. O seu objetivo fundamental, tal como já defendiam os norte-americanos, era a formação do "bom cidadão", definido como "o indivíduo que, por espontânea vontade e iniciativa própria, contribue ao bem estar da comunidade." (Carvalho, 1934a, p. 15). Essa acepção está presente na definição de Estudos Sociais sintetizada por Dunn (1916). O "good citizen" tem como função primeira o bemestar da comunidade, tanto que o currículo de Social Science, de acordo com o relatório de Dunn, deveria priorizar os "elements of welfare" ("elementos de bemestar", em livre tradução), referentes a lazer, saúde, educação, transporte, entre outros. Cabem às instituições educativas a finalidade de ajudar a criança a compreender a "sua responsabilidade pelo progresso e pelos problemas, práticas e instituições da vida social e instituições da vida social." (Bagley, s/d, p. 4). Nesse percurso, os Estudos Sociais eram uma disciplina privilegiada.

\subsection{4}

\section{PCS: entre projetos e conteúdos tradicionais}

Se Delgado de Carvalho ficou responsável por estabelecer os fundamentos teóricos da nova disciplina escolar, coube a Ignacia Guimarães a organização das diretrizes que deveriam seguir as professoras no dia a dia da sala de aula ${ }^{163}$. O

\footnotetext{
163 Ignacia Guimarães conheceu Anísio Teixeira durante seus anos de estudos no Teachers College, onde obteve o Master of Arts em 1928. Antes, já havia frequentado cursos nos Estados Unidos, entre 1922 e 1924. Em decorrência desta experiência, recebeu de Francisco Campos, Diretor de Instrução Pública de Minas Gerais, "a incumbência de conduzir até o Teachers College quatro professoras que ali iriam aperfeiçoar-se.” (Barbosa, 2015, p. 20). Atuou como docente na
} 
objetivo principal do ensino de Ciências Sociais nos três primeiros anos da escola primária era a "socialização da criança" a partir de três aspectos principais que buscavam familiarizá-la com o mundo em que vive: possibilitando a compreensão da interdependência da vida social, o valor do indivíduo na sociedade e a construção do sentimento de colaboração e participação do indivíduo como membro da sociedade. Seguindo a premissa colocada por Delgado de Carvalho (1934a, 1934b), o $1^{\circ}$ ano se dedicava à "vida no lar e na escola", partindo das relações mais imediatas da criança, suas necessidades primordiais e interesses. No $2^{\circ}$ ano, o pressuposto de interdependência social se expandia para o exame da comunidade. Em ambos os anos, as discussões eram mais gerais, sem o estudo propriamente dito de História, Geografia ou Educação Cívica.

No $3^{\circ}$ ano, o curso se dividia em dois momentos principais. No primeiro, era examinada a vida do homem primitivo, exemplificando-a a partir da vida do índio, a fim de realizar uma comparação entre a vida deste e a do homem civilizado, para que o aluno compreendesse a complexidade do momento atual ${ }^{164}$. É como se o índio não existisse no século XX. Como afirma Delgado de Carvalho (1934c, p. 105): "os elementos fundamentaes se encontram em ambos os quadros e deixam perceber mais facilmente as differenças de formas.” As relações sociais e a "ação organizada" começam por ser estudadas de forma simplificada até as origens das principais instituições e diretrizes da civilização contemporânea. É o que o autor denomina como uma "história industrial" ou "história do progresso humano"165. O segundo momento se relacionava ao estudo da "vida do homem em outros países", com o intuito de "criar interêsse e simpatia pelos povos de outras terras" e de desenvolver "o sentimento de responsabilidade do indivíduo como membro da grande família universal.” (Guimarães, 1934a, p. 26). A mesma abordagem estava presente nos documentos norte-americanos de 1932 e 1934. A partir dessa série

Escola Normal de Belo Horizonte e foi convidada a trabalhar no Distrito Federal por Anísio Teixeira.

${ }^{164}$ Esse tópico, especificamente, é devedor das viagens de Delgado aos Estados Unidos: "Nos Estados Unidos, onde o caso indigena é igual ao nosso, o ensino primario tira muito maiores proveitos para o ensino da historia social. Em uma instituição que visitavamos, a vida selvagem de uma nação india tinha sido tomada como centro de interesse e já estava no seu segundo mez sem ter esgotado a curiosidade dos educandos nem os recursos do mestre." (Carvalho, 1934c, p. 106).

${ }^{165}$ Como apontamos no terceiro capítulo, a definição de "história industrial" é de John Dewey (2002). De acordo com Delgado de Carvalho (1934c, p. 108), "o contraste entre a simplicidade da vida primitiva e os recursos numerosos da vida atual, apresenta a vantagem de estabelecer um abysmo entre as duas que precisa ser explicado e que necessita uma historia industrial, isto é, uma historia do progresso humano, cujos detalhes são do mais alto interesse e valor educativo." 
fica mais clara a presença das ciências constitutivas dos Estudos Sociais, que servirão de base para discussões mais específicas no $4^{\circ}$ e $5^{\circ}$ anos de escolarização.

No $4^{\circ}$ ano, o aluno teria que ser capaz de perceber a herança legada pelos colonizadores do país e as bases dos principais problemas brasileiros, além de compreender a evolução econômica e social da cidade, do país e do mundo. Nessa abordagem considerava-se que os colonizadores lançaram as bases fundamentais da nacionalidade brasileira (Guimarães, 1934b). O $5^{\circ}$ ano era dedicado a demonstrar a interdependência de agricultura, indústria, comércio, invenções e descobertas, bem como a sua importância para a vida humana, e uma compreensão mais aprofundada acerca das características do Distrito Federal, conforme disposto no quadro a seguir:

\begin{tabular}{|c|l|}
\hline Ano de escolaridade & \multicolumn{1}{c|}{ Tema } \\
\hline $1^{\mathbf{o}}$ ano & A vida no lar e na escola \\
\hline $2^{\mathbf{o}}$ ano & A vida na comunidade \\
\hline $3^{\mathbf{o}}$ ano & $\begin{array}{l}\text { A vida do índio } \\
\text { A vida do homem em outras terras }\end{array}$ \\
\hline $4^{\mathbf{o}}$ ano & $\begin{array}{l}\text { Brasil Colônia } \\
\text { O Brasil independente }\end{array}$ \\
\hline & $\begin{array}{l}\text { Agricultura } \\
\text { Indústrias } \\
\text { Transporte e comunicação } \\
\text { Invenções e descobertas } \\
\text { Inquérito geral sobre a cidade do Rio de Janeiro }\end{array}$ \\
\hline
\end{tabular}

Quadro 10 - Temas em Estudos Sociais e sua distribuição na escola primária Fonte: Elaborado pelo autor com base no PCS.

Para cada ano de escolarização eram indicados objetivos, problema principal, problemas secundários ou parciais, sugestões para um projeto geral e os mínimos de fatos a conhecer. O programa seguia as diretrizes de Dewey e Anísio Teixeira, que entendiam ser tarefa da escola progressiva proporcionar aos alunos a “oportunidade de praticar a vida social” (Guimarães, 1934b, p. 17). Para tanto, o programa e as aulas se organizariam de modo que "os estudos permitam a interpretação satisfatoria dos acontecimentos diarios, isto é, das Actualidades." (Carvalho, 1934c, p. 122). É uma proposta contrária em relação aos "historiadores que buscavam um distanciamento no tempo" (Vale, 2011, p. 46). Os ensinos da História e de Estudos Sociais deveriam partir dos problemas do presente, pois só assim os jovens estariam aptos a participar do mundo em que vivem.

A solução de problemas foi o caminho encontrado pelos organizadores do programa para que as Ciências Sociais atingissem seu objetivo máximo no 
processo de escolarização: "aparelhar a criança a viver bem na sociedade" (Guimarães, 1934b, p. 18). Viver melhor, como salientam os documentos norteamericanos, é condição essencial ao pleno exercício da cidadania (Dunn, 1916). Cada ano escolar tinha um problema central e outros tantos secundários. Para Guimarães (1934b, p. 18): “ao estudar êstes problemas, a criança reconhece a interdependência da vida social moderna e verifica o grau de responsabilidade que, como membro dessa sociedade, já lhe cabe, tanto em direitos como em deveres."

\begin{tabular}{|c|c|c|}
\hline & Ano de escolaridade & Problema(s) principal(is) \\
\hline & $1^{\circ}$ ano & $\begin{array}{l}\text { "Como pode a escola ajudar a criança a tornar-se um membro valioso } \\
\text { de sua família?" }\end{array}$ \\
\hline & $2^{\circ}$ ano & "Como pode a escola familiarizar a criança com a comunidade?" \\
\hline & \multirow[b]{2}{*}{$3^{\circ}$ ano } & $\begin{array}{l}\text { "De que modo o índio, como tipo de homem primitivo, satisfazia suas } \\
\text { necessidades fundamentais?" }\end{array}$ \\
\hline & & $\begin{array}{l}\text { "Como conseguem os povos de outras regiões do mundo prover as } \\
\text { suas necessidades de alimentação, abrigo, vestuário, transporte, } \\
\text { recreação?" }\end{array}$ \\
\hline & \multirow[t]{2}{*}{$4^{\circ}$ ano } & $\begin{array}{l}\text { "Como primitivamente conseguiram os colonizadores instalar-se no } \\
\text { Brasil e aí viver?" }\end{array}$ \\
\hline & & "Como se desenvolveu o Brasil após a independência?" \\
\hline & \multirow{5}{*}{$5^{\circ}$ ano } & $\begin{array}{l}\text { "Como contribui a agricultura para satisfazer as necessidades } \\
\text { primordiais da vida?" }\end{array}$ \\
\hline & & $\begin{array}{l}\text { "Como tem o desenvolvimento das indústrias concorrido para } \\
\text { estreitar e aumentar as relações de interdependência de regiões de um } \\
\text { mesmo país ou de países entre si?" }\end{array}$ \\
\hline 8 & & "Por que parece o mundo, hoje, menor do que há cem anos atrás?" \\
\hline & & $\begin{array}{l}\text { "Como têm concorrido invenções e descobertas para o progresso da } \\
\text { humanidade?" }\end{array}$ \\
\hline$=$ & & "Que um aluno de $5^{\circ}$ ano deve saber sobre a sua cidade?" \\
\hline
\end{tabular}

Quadro 11 - Problemas principais a serem discutidos pelas Ciências Sociais na Escola Primária

Fonte: Elaborado pelo autor com base no PCS.

O fundamento central do programa e seus problemas giravam em torno do que se considerava essencial ao desenvolvimento da vida econômica, política, social e cultural do homem: alimentação, vestuário, habitação, ocupação, transporte, comunicação, religião, educação, recreação, entre outros. Como a humanidade vem resolvendo esses problemas? Todos os povos, no tempo e no espaço, debruçaram-se sobre essas questões e todos contribuíram, de forma harmônica, para o progresso humano. Então é uma constante a presença de questões que poderiam variar no passado ou no presente, como: Por que se vestem desta ou daquela forma? Do que se alimentam? Constroem casas? Com que material? Quais são as ocupações? Qual o lugar da criança nessa sociedade? 
Como se relacionam com o meio geográfico em que vivem? Como são educadas? Quais as distrações? Religiosidades? - tais questões poderiam ser discutidas em articulação com as outras disciplinas do currículo da escola primária. Desse modo:

Da necessidade de alimentação, vestuário e habitação, decorre uma série de estudos: origem de alimentos e matéria-prima, fontes de onde podem ser obtidos, melhor meio de adquirí-los, cuidados que devem observar em seu preparo, motivos determinantes de preferência por certos vestuários e certos alimentos; efeitos do calor e da luz do sol - perigos de insolação; necessidade de um lar confortável, de recreio, de descanso etc. (Programa..., 1934a, p. 36).

O centro dessa abordagem é a forma como vivem ou viveram os homens, concepção apropriada da teoria defendida por Dewey (2002, p. 132) em relação ao ensino de História:

Estas ideias não constituem senão termos técnicos que expressam o problema no qual a humanidade está incessantemente envolvida; como viver, como manobrar e utilizar a natureza de forma a que ela dê seu contributo para o enriquecimento da vida humana. Os grandes avanços da civilização resultaram destas manifestações de inteligência que ajudaram o homem a libertar-se da sua subjugação face à natureza e mostraram-lhe como podia fazer estas forças cooperarem com os seus propósitos.

A partir desse eixo central, todas as atividades tinham como função principal a formação de hábitos, ideias e atitudes. Esses três elementos seriam essenciais, conforme Beard (1932, p. 101), para a formação de cada "identidade plural e competente", sendo "indispensáveis para a eficiência na vida privada e a estabilidade nas relações públicas.” Desde cedo se procurava inculcar nos alunos a noção de higiene, indústria, cooperação e responsabilidade do indivíduo enquanto membro de grupos sociais: responsabilidade para com a família, mestres, colegas, pais; o "desejo de participar" da vida em sociedade; tolerância em relação a indivíduos, crenças, instituições, outros povos; respeito às opiniões alheias; simpatia; honestidade; lealdade; cortesia; altruísmo; atitudes convenientes em relação ao trabalho; "hábito de observar e estudar; de investigar e avaliar, antes de chegar a conclusões" (Guimarães, 1934b, p. 19), e muitos outros. A cooperação, por exemplo, deveria ser adotada com o fim de eliminar o "isolamento" e o "egoísmo do homem que se fecha em si mesmo" (Carvalho, 1970, p. 71). Dois exemplos retirados do primeiro e segundo anos ajudam a ilustrar como se previa a "formação de bons hábitos e aptidões".

$\mathrm{O} 1^{\circ}$ ano era considerado de adaptação do aluno à escola. Na ausência dos jardins de infância - necessários na posição dos autores do programa e que só 
começavam a ser discutidos no Brasil de então -, era primordial acolher as crianças que ingressavam na escola e ainda não estavam preparadas para o convívio nesse ambiente. Partia-se do princípio de que educando a criança, a vida da sua família seria "melhorada". Portanto, ela precisava "aprender a alimentar-se, a banhar-se, a vestir-se, a cuidar dos dentes, arranjar e conservar em ordem e asseio sua casa, a dar a seu lar um aspecto cuidadoso e guarnecido, não incompatível com a pobreza." (Programa..., 1934a, p. 33). O horário da merenda escolar possibilitaria uma oportunidade ideal para o ensinamento. $\mathrm{O}$ modelo da professora seria essencial para a demonstração de cuidados básicos com seus objetos individuais e asseio. Também se incentivaria a alimentação saudável e a troca entre colegas. As questões debatidas deveriam ter relação com estímulos oferecidos pela vida, como os seguintes:

Quando no início e, mais tarde, no decorrer do ano, o professor pergunta às crianças: "Que devemos fazer para que A., não sinta tanta falta de casa?". "Como devemos sair da sala para o pátio?". "Que devemos fazer antes da merenda?". "Que devemos fazer para o lugar onde merendamos não fique como hoje cheio de migalhas, cascas, papéis etc.?". "Há na turma alguns alunos que não têm dinheiro para comprar os objetos de que necessitam. Que faremos para auxiliá-los?" (Programa..., 1934a, p. 55).

A preparação para o trabalho também era um tema importante. Como se estrutura uma comunidade? Para esse tema recomendava-se a utilização de uma tendência considerada natural à criança: a imitação.

O projeto do $2^{\circ}$ ano consistia em uma reprodução da comunidade na escola, dividido em duas etapas. A primeira versava sobre a "representação material da comunidade" e a segunda enfatizava sua vida social e econômica. Para tornar a comunidade mais próxima possível dos alunos, caberia ao professor a divisão da turma em pequenos grupos e a distribuição de atividades diárias correspondentes a serviços presentes na vida comunitária. Um grupo responsável por auxiliar os alunos mais atrasados (representação de escola); um grupo responsável por zelar pelos livros e objetos da turma (representação de biblioteca e museu); outro atento à limpeza de bebedouros e objetos de usos diários da turma, como copos e pratos (representação de um sistema de abastecimento); uma equipe encarregada de transmitir recados (representação dos correios); outra incumbida de auxiliar os alunos machucados (representando assistência e saúde pública).

As atividades eram formuladas para que as crianças pudessem observar, pensar, trabalhar, participar e opinar. São todos problemas reais, atividades 
presentes na vida social, que a professora utilizaria para que o aluno pudesse se habituar a pensar, agir e resolver. Mais do que a aquisição do conhecimento, o que se defende é a construção dos instrumentos que levam a ele. É uma adaptação espontânea que, ao menos em teoria, capacitaria os discentes a reagirem às situações que lhes apresentassem à vida e levariam ao não esquecimento do que foi aprendido. Os exemplos ilustrados são abundantes e tinham como objetivo primordial acostumar as crianças a assumirem responsabilidades de trabalho, e cooperação, além de hábitos de linguagem e trato com o outro. Em síntese, estariam sendo habilitadas, desde a escola, a "pensar e a viver civicamente". É a aplicação daquilo que Anísio Teixeira $(1968$, p. 82) considerava como “o mínimo essencial de educação" e elemento necessário à formação do novo cidadão:

A escola deve ensinar a todos a viver melhor, a ter a casa mais cuidada e mais higiênica; a dar às tarefas mais atenção, mais meticulosidade, mais esforço e maior eficiência; a manter padrões mais razoáveis de vida familiar e social; a promover o progresso individual, através dos cuidados de higiene e os hábitos de leitura e estudo, indagação e crítica, meditação e conhecimento. (p. 82).

A escola primária, nesse sentido, apresenta um caráter de "reformadora social". Apesar de Delgado de Carvalho (1934a, p. 20) afirmar que estava reunindo em um único programa o estudo de matérias, como "história, geografia, economia política elementar, educação cívica, elementos de ciência política e de direito usual, noções sobre profissões, etc.”, há um predomínio da História como eixo principal dos Estudos Sociais. Isso, como já argumentamos, não é novidade, uma vez que a principal proposta de ensino de Estudos Sociais norte-americana, consubstanciada no relatório "Os Estudos Sociais na Escola Secundária" (Dunn, 1916), também priorizava a História. Uma explicação para essa ênfase pode ser encontrada em Delgado de Carvalho (1934c, p. 63), que considerava que a "História abrange todas as sciências sociais: há uma história das ideias, uma história da economia, uma história da política." Isso favoreceria, nesta perspectiva, uma profunda articulação com as outras ciências.

É a História, no dizer de Carvalho (1940a, p. 36), que "serve a modelar o nosso conhecimento das coisas, o nosso pensamento e nossa ação." Não qualquer História, mas uma História da Civilização, isto é, "da evolução lenta das instituições, dos habitos, dos costumes, das ideias e das sciencias." (Carvalho, 1934c, p. 53). Entre os hábitos e atitudes principais que se deveria construir estava o "sentimento de simpatia para com os outros povos pelo conhecimento de seus 
problemas e das causas que determinam as diferenças que caracterizam êsses povos." (Guimarães, 1934b, p. 19). Como apontamos no capítulo anterior, após a Primeira Guerra Mundial surgiu um clamor, inicialmente na Europa, "em favor da expansão de um espírito internacional entre os povos" (Carvalho, 1934c, p. 120). Esse princípio guiou a formulação de programas e a produção de livros didáticos nas décadas de 1920 e de 1930 (Ferreira, 2013; Reznik, 1992; Vale, 2011). Em relação aos objetivos do PCS, as formuladoras seguem um conjunto de ideias de Claparède ${ }^{166}$, sintetizadas por Delgado de Carvalho (1934c, p. 120-121):

a) Não conter exaltação propria dos sentimentos nacionaes, nem excitação de odio aos estrangeiros por meio de affirmações subjectivas ou juizos definitivos sobre pontos discutidos. b) Dar maior importancia aos factos que illustram a solidariedade internacional, procurando na historia nacional os factos que a isso se prestam. c) Insistir mais sobre a historia da civilização do que sobre a historia militar e politica, apresentando uma concepção universalista da Historia. d) Trazer uma contribuição á educação moral e não somente scientifica; e) Visar um ensino da historia internacional, independente ou em correlação com a historia nacional, etc.

O PCS incorporou a perspectiva difundida pela Liga das Nações e uma série de associações internacionais e comissões que defendiam que as "histórias nacionais, da forma que eram ensinadas, ensejavam o ódio entre as nações e o belicismo." (Vale, 2011, p. 39) ${ }^{167}$. Para Carvalho (1934c, p. 119), “a civilização é una e sobre esta unidade é que deverá ser edificada a solidariedade entre as nações." Ainda segundo o autor, com programas que valorizavam exclusivamente a História Pátria, calcados em certo isolamento, os alunos seriam levados a "acreditar que somos os autores da actual civilização e que della temos o monopólio.” (p. 110). A perspectiva da História da Civilização foi adotada na escola secundária, mas em relação aos programas da escola primária, o do Distrito Federal é singular, já que neste nível de ensino a ênfase recaía sobre a História Pátria. Uma comparação despretensiosa com o programa de História de São

\footnotetext{
${ }^{166}$ Édouard Claparède (1873-1940) foi um psicólogo do desenvolvimento infantil. Seus estudos influenciaram o movimento de renovação educacional das primeiras décadas do século XX.

${ }^{167}$ A própria concepção de Estudos Sociais nos Estados Unidos se alterou. Se a proposta de 1916 tinha uma matriz mais nacionalista, enfatizando apenas a História americana e europeia (inglesa, sobretudo), de quem a primeira era tida como herdeira, a difundida em 1932 e 1934 apresenta uma orientação voltada para as relações entre Estados Unidos e os outros países. Nesse sentido, conforme afirma Beard (1932, p. 48): "Não é somente através de determinadas instituições nacionais, políticas, econômicas e sociais, que o cidadão vive e cumpre suas obrigações [...]. O ensino cívico deve contar com essa realidade. Até mesmo a História Nacional não é feita exclusivamente por forças nacionais." Portanto, como enfatiza o historiador: "lançar as bases para o entendimento mútuo e instaurar o respeito às opiniões dos outros é certamente uma das funções fundamentais a ser cumprida por professores de Ciências Sociais." (p. 70).
} 
Paulo, adotado entre 1918 e 1935, analisado por Bittencourt (1990), e o de Estudos Sociais do Rio Grande do Sul, publicado em 1939, demonstra isso.

O Programa de História das escolas primárias de São Paulo se limitava a tópicos da História do Brasil, sem relação com outros países. Segundo Bittencourt (1990, p. 119), revestia-se de um "conteúdo nacionalista que atingiu o auge no período do Estado Novo." Partia-se do princípio de que esta disciplina tinha como fim primordial "a construção de uma imagem de nação e de povo". Era justamente esse ensino de História que Delgado de Carvalho criticava, pelo predomínio do fato político. Por sua vez, o "Programa de Estudos Sociais" do Rio Grande do Sul parece se inspirar no programa do Distrito Federal. Concedia-se uma atenção especial ao regionalismo, aos fatores econômicos e abria-se um tópico no $4^{\mathrm{o}}$ ano para "a vida e cultura de outros povos". Contudo, o PCS era mais extenso e abrangente. Poderíamos classificá-lo como um programa preocupado com as relações internacionais, pois a partir do $3^{\circ}$ ano tratava das relações entre o Brasil e outros povos, através da interdependência entre todos. Delgado de Carvalho (1970) esclarece que, ao se revelar às crianças outras civilizações e outros povos, com costumes e estruturas sociais e políticas diferentes das que conhecem, tenciona-se acostumá-las com outros modos de ver, sentir e viver para além daquelas provenientes do seu meio. A perspectiva é a de que a vida contemporânea exige o conhecimento, cada vez melhor e mais avançado, "do que se passa em todo mundo, além dos limites de circunscrição em que a criança vive, fora, portanto, de sua observação direta." (Programa..., 1934a, p. 107).

No $3^{\circ}$ ano, um dos temas eram as formas como os homens em outras terras lidaram com questões, como abrigo, alimentação e vestuário. Tratava-se de uma introdução baseada no "pitoresco, atraente e expressivo" de cada cultura. Deveriam ser estudadas em grupos: África (sem distinção de países, como ocorreria na análise do continente europeu); Arábia e Síria (existia à época uma grande colônia de sírios no Rio de Janeiro); Noruega, Suécia e Rússia; Japão e China; Portugal, Espanha, Itália, Suíça e Holanda. A partir daí poderia o aluno apreciar e conhecer os costumes desses povos, aprendendo a respeitá-los.

O $5^{\circ}$ ano ia além. Ao abordar cada temática (agricultura, indústria, comércio, etc.) buscava-se investigar o seu progresso ao longo dos séculos. $\mathrm{Na}$ definição de Dewey (2002, p. 133), seguia-se “o processo pelo qual o homem reconheceu as necessidades da sua situação e desenvolveu as armas e os 
instrumentos que o ajudaram a lidar com elas." Mais ainda, abordava-se de que modo "esses recursos abriram outros horizontes de desenvolvimento e criaram novos problemas.” (p. 133). De forma semelhante, Beard (1932, p. 47) defendia que antes de se discutir "questionamentos mais evasivos da vida atual" era preciso conferir aos alunos "uma base completa acerca dos registros históricos da experiência humana." Sobre o tema "Transporte e Comunicação", o PCS (1934b) apresentava os seguintes "problemas parciais":

A. Como os antigos faziam a locomoção, o transporte e as comunicações? (p. 172). B. Qual a contribuição dos povos da Idade Média para o progresso dos meios de transporte e comunicação, acentuado na Idade Moderna? (p. 175).

C. A evolução dos meios de transporte no Brasil (p. 177).

D. Que melhoramentos se têm feito nos sistemas de transporte e comunicação desde a invenção da máquina a vapor? (p. 182).

E. Como se faz a aviação em outras regiões do mundo? (p. 185).

Todos os tópicos são formulados a partir de questões. O método de Dewey e Anísio se baseia no método científico, que parte de um questionamento e da construção de uma hipótese. Não era um ensino pela simples lição, mas acreditava-se que através das perguntas os alunos ficariam mais motivados. É a crítica à organização lógica da disciplina escolar que "ignora o processo e considera o resultado" (Dewey, 2002, p. 169). O conteúdo é utilizado como elemento de orientação/direção visando à expansão do pensamento. Busca-se o processo de construção de conhecimento, "os passos reais que lhe deram origem" (p. 169). O conhecimento existente é desenvolvido como se o aluno tivesse que descobri-lo. Em relação ao tema "Agricultura", a exposição era a mesma. Apresentam-se experiências consideradas necessárias à vida social:
A. Como se desenvolveu a agricultura entre os povos antigos? (p. 110).
B. Como se desenvolveu a agricultura na Idade Média? (p. 112).
C. Como evoluiu a agricultura no Brasil? (p. 114).
D. Quais os produtos agrícolas de maior importância no comércio mundial? - 1 . Contribuição do Brasil (p. 119). 2. Contribuição de outros povos (p. 120).
E. Como passaram as Repúblicas do Prata de Estado pastoril a Estado agro- pecuário? (Programa..., 1934b, p. 123).

A "pesada cronologia" criticada por Delgado na apresentação do programa deixa de lado os fatos políticos para tratar outros objetos. A formulação das questões seguia as indicações presentes em Beard (1932, p. 51), pois entendia que 
"a cena nacional deve estar solidamente atrelada à cena mundial" ${ }^{168}$, e os apontamentos das "Conclusões e recomendações da Comissão de Estudos Sociais da Associação Americana de História" (1934), que defendiam o seguinte:

$\mathrm{Na}$ organização do ensino de todas as ciências sociais deve-se fazer um esforço para desenvolver no aluno o conceito do princípio da continuidade - o conceito de que nada já existiu ou existe isoladamente, de que tudo sempre está ou estará em processo de mudança, que não há evento sem antecedentes e sequências. (Krey et al., 1934, p. 62).

A cronologia, a sequência e a ideia de continuidade eram elementos presentes no PCS. Adotava-se uma abordagem criticada por Dewey (2002) e exigia-se do professor um amplo conhecimento enciclopédico da História da Civilização. Os problemas levantados pelo programa se iniciavam nas civilizações antigas (fenícios, egípcios, gregos, romanos), passando pelo mundo feudal e a formação dos estados nacionais, até a contemporaneidade e as relações entre os diferentes países. A vida no Brasil contemporâneo era um resultado dos esforços levados a cabo pela civilização. Valorizava-se, assim, a perspectiva de Delgado de Carvalho (1934c) de unicidade da civilização, solidariedade entre nações e o "progresso do homem" como "motor da história" (Vale, 2011, p. 48). Conforme salienta Vidal (2001, p. 74), "muito mais do que nacionalizar o brasileiro, o programa preocupava-se em formar cidadãos preparados a lidar com as questões mundiais." A História do Brasil ensinada no interior dos Estudos Sociais mantinha o objetivo comum aquele período, conforme sintetiza Bittencourt (1990, p. 96):

Cabia a História mostrar "a nossa capacidade para o trabalho" e os feitos dos nossos líderes, construtores da nossa nacionalidade. O conhecimento do passado dirigia-se a uma meta comum a todo cidadão: construir, pelo trabalho, o "engrandecimento da nação". A dignidade do homem realizava-se pelo trabalho produtivo, dirigido para o fortalecimento do "bem comum" [...].

Com tal característica, apareciam objetivos como: "respeitar e admirar a inteligência e o expediente daqueles que souberam vencer com os poucos recursos de que dispunham" (Programa..., 1934b, p. 27) ou "respeitar aqueles que deram exemplo de intrepidez, coragem e perseverança” (p. 27). Apesar de Nadai (1988) argumentar que o programa defende que "na construção da nacionalidade, todos,

\footnotetext{
${ }^{168}$ Beard (1932, p. 51) argumentava que: "Tal objetivo não será alcançado tratando as relações internacionais casualmente ao fim de um determinado curso educacional, mas admitindo-as como fundamentais para o desenvolvimento de quase todos os aspectos da vida nacional. Os laços econômicos e culturais que ligam todos os povos da terra em uma única rede são não menos reais do que as forças da evolução nacional."
} 
igualmente - colonizadores portugueses, índios nativos, africanos, estrangeiros despenderiam esforços nessa ação [...]”, o negro e o índio aparecem muito pouco. O índio é sempre aquele que presta algum tipo de auxílio ao colono: o conhecedor do clima, alimentos, medicamentos, caminhos, tribos, etc. É o primitivo. O negro é a mão de obra, citado em momentos como o fim do tráfico negreiro e a abolição da escravatura. O colonizador branco é o desbravador, enérgico, resistente. Era preciso "reconhecer e apreciar a contribuição do africano para o desenvolvimento econômico do país" e "reconhecer a influência social que a aristocracia rural exerceu no Brasil” (Programa..., 1934b, p. 69), mas não se discutia, por exemplo, as relações entre esses dois segmentos e o lugar do negro na sociedade.

A construção da ideia de harmonia reside na não discussão das deficiências da sociedade brasileira, algo que os programas americanos indicam como função dos Estudos Sociais. Beard (1932) argumentava que nenhuma característica da sociedade, positiva ou negativa, poderia ser omitida. Era uma obrigação de o ensino cívico apontar os defeitos. No contínuo progresso, descrito no PCS, não há espaço para falhas, erros e tropeços. Em relação aos conteúdos de História do Brasil não há uma mudança significativa em termos do que era cânone no começo do século XX. Avança-se na inclusão do econômico, do social e do cultural, como tópicos de ensino, e os métodos vão muito além das aulas expositivas tão criticadas por Delgado de Carvalho: excursões a museus, feiras, coleção, construção de maquetes e miniaturas, confecção de álbuns, discussões em grupo, dramatização. São sugeridos vários projetos e atividades, que Ignacia Guimarães (1934b) indica poderem ser escolhidos pela professora de acordo com as suas condições. No tema "Brasil Colônia" previa-se:

Tentar reproduzir no tabuleiro de areia ou em argila: feições características da costa oriental e meridional - lagoas costeiras, recifes, bancos de areia, ilhas [...]. Nas aulas de trabalhos manuais, reproduzir uma casa colonial, em miniatura; construir ou desenhar uma fazenda dessês primeiros tempos [...]. Visita ao Museu Nacional e ao Museu Histórico para observar alguns dos meios de transporte da época colonial. (Programa..., 1934b, p. 33, 38, 44).

Contudo, no entendimento de Ignacia Guimarães (1934b, p. 21), isso não era o mais importante do programa:

Os objetivos e o programa mínimo de fatos a conhecer, que se encontram respectivamente, no principio e no fim da matéria indicada para cada um dos anos do curso primário, constituem as partes mais importantes do programa. Se a professora quiser e puder dar orientação diferente ao ensino da matéria, deve-lhe 
ser permitido fazê-lo, desde que possa alcançar os objetivos indicados no programa. Em nada ficará, por isso alterada a essência básica do trabalho.

Assim, se durante as explanações sobre os projetos não são indicados conteúdos bases em que cada uma das questões elaboradas devem ser trabalhadas, ao final dos capítulos são apontados os "mínimos a conhecer" em Geografia, História e Educação Social e Moral ou Educação Político-Social, que na prática configuram o ensino de Ciências Sociais na escola primária do Distrito Federal.

Os eventos, datas nacionais, heróis da pátria não foram abandonados (Fernandes, 2008). Na teoria, o tradicional era redefinido. Por exemplo: O "methodo biographico", de acordo com Delgado de Carvalho (1934c), deveria ser utilizado como uma forma de despertar o interesse pelo estudo da História, através da "humanização" dos fatos abordados. As preocupações do estudo se relacionariam à época e não propriamente ao biografado: “o heróe escolhido foi tomado apenas como personagem representativo, isto é, como expoente de seu tempo" (p. 104). A sua vida é um pretexto para análises dos acontecimentos em que participou. É mais uma apropriação do que defendia Dewey (2002). Entretanto, consideramos que o "Programa Mínimo" ou os "mínimos a conhecer" configuram um programa dentro do programa. Para cada uma das componentes das Ciências Sociais eram dispostas listas enormes de conteúdos (Anexo A).

Transcrevemos, para melhor visualização pelo leitor, o Programa Mínimo de História do $4^{\circ}$ ano da escola primária presente no PCS (1934b). Ele abarca tópicos tradicionais da História brasileira, com ênfase no fator político e nos ciclos econômicos, embora se inclua pontos sobre "vida" e "educação" no período colonial. Cumpre lembrar que esta é apenas uma parte do que se deveria aprender a partir do estudo do "Brasil Colônia", porque há ainda os Programas Mínimos de Geografia, tão extenso quanto o de História, e o de Educação Cívica. 
Aparecimento do homem no mundo civilizado.

Colonização: luta do homem com o meio para satisfazer suas necessidades primordiais; principais núcleos de colonização.

Açúcar - principal fator agrícola da colonização.

O colonizador e o índio: auxilio prestado pelos índios.

Educação nos tempos coloniais.

Govêrno: Capitanias - razões da prosperidade de umas e fracasso de outras; Tomé de Souza; Mem de Sá; O colonizador, o jesuíta e o índio - lutas.

Cobiça dos povos estrangeiros - razões: Villegagnon; Daniel de La Touche; Maurício de Nassau.

O interesse de Portugal pela colônia: desenvolvimento da colonização; expansão litorânea de N. a S.

Expansão sertaneja - causas que a determinaram. Consequências: as missões; as bandeiras paulistas e baianos; organização de uma bandeira; principais bandeiras - os três grandes centros de expansão; principais vias de penetração; a colônia após a penetração - desenvolvimento físico e econômico.

Escravidão - a vida do escravo.

O jesuíta: contribuição para o desenvolvimento econômico e social da colônia; Marquês de Pombal; expulsão dos jesuítas - consequências.

Mineração: desenvolvimento dos três centros mineiros. Minas, Cuiabá, Goiaz. A administração das Minas - vida; o minerador e o emboaba. A mineração e a prosperidade da colônia. Vida em S. Paulo. Rio de Janeiro. Ouro Preto. Olinda. Salvador. Belém.

Formação da nacionalidade: o branco, o índio e o negro. Primeiras revoltas contra o jugo português - Bequimão. Felipe dos Santos. Tiradentes. Côrte portuguesa no Brasil. Independência econômica da colônia. Visconde de Cairú. Vida na cidade do Rio de Janeiro. A Côrte, os portugueses e os brasileiros. Desenvolvimento do espírito nativista. José Bonifácio. D. Pedro. O 7 de setembro.

Quadro 12 - Programa Mínimo de História para o $4^{\circ}$ ano da escola primária Fonte: Elaborado pelo autor com base no PCS (1934b, p. 62-63).

$\mathrm{O}$ ensino destes tópicos exigiria alguém com formação específica em História - algo que era apenas um projeto naquele momento, já que a Universidade do Distrito Federal só foi fundada no ano seguinte à publicação do programa, em 1935. As formuladoras do PCS pareciam prever a dificuldade que as professoras do Distrito Federal teriam em aplicá-lo, uma vez que não tinham uma formação e instrumentos para isso. Para cada questão formulada eram indicadas referências bibliográficas específicas para alunos e professoras. Quanto a isso, foi importante a experiência de Delgado de Carvalho:

O auxílio prestado à comissão organizadora dos programas pelo Diretor do Instituto de Pesquisas Educacionais foi inestimável: além de atender solicitamente as consultas que lhes eram feitas sôbre as matérias de sua especialização (geografia e sociologia), franqueou a sua bibliotéca particular. (Programa..., 1934b, p. 14).

A referência mais indicada aos alunos era a enciclopédia "Tesouro da Juventude", composta por 18 volumes e publicada inicialmente na década de 1920, com grande circulação no Brasil na década de 1930. Para os professores eram recomendadas as leituras de inúmeras obras e autores, com destaque para: Afrânio Peixoto, Erasmo Rocha, Frei Vicente do Salvador, Jonathas Serrano, 
Manoel Bonfim, Olavo Bilac, Oliveira Viana, Pedro Calmon, Rocha Pombo, Visconde de Porto Seguro, com predomínio das obras de Geografia escritas por Delgado de Carvalho. O objetivo era, respectivamente, capacitar o aluno a formar o hábito de pesquisa, procurar em outras fontes as informações exploradas em sala, e facilitar o trabalho do professor. Para tanto, a gestão Anísio Teixeira concedeu especial atenção à criação de bibliotecas públicas.

De acordo com Julia (2001, p. 10-11), “normas e práticas não podem ser analisadas sem se levar em conta o corpo profissional dos agentes que são chamados a obedecer a essas ordens e, portanto, a utilizar dispositivos pedagógicos encarregados de facilitar sua aplicação." Devido à ausência de fontes, infelizmente, só podemos inferir sobre a dificuldade de aplicação do PCS. Tratava-se de um extenso programa (abarcava conteúdos de várias disciplinas), específico (compreendia múltiplos conhecimentos que requeriam uma formação particular), novo em termos de integração entre componentes disciplinares e exigia outros procedimentos metodológicos para além da "aula-conferência". Além disso, pela estrutura do método de projetos, indicado como metodologia principal, sua aplicação requeria considerável tempo e, certamente, não comportava todos os tópicos do programa. As docentes chamadas a analisar o programa apontaram um problema básico: "a aparelhagem material das escolas" era necessária para que se executasse a norma (Programa..., 1934b, p. 15). A prescrição não levava em consideração as reais condições das escolas do Distrito Federal. Talvez na prática docente, utilizando-se da sua "ampla liberdade de manobra" (Julia, 2001, p. 33), as professoras tivessem que escolher entre a inovação (o método de projetos) e o tradicional (as listas de conteúdos, alvo da crítica de Anísio, mas presentes nos programas).

Os professores são um elemento central para o processo de instauração e funcionamento de uma disciplina escolar. Destarte, "a taxa de renovação do corpo docente é então um fator determinante na evolução das disciplinas." (Chervel, 1990, p. 197). Para Anísio Teixeira e Delgado de Carvalho não adiantava a formulação de novos métodos sem uma mudança na formação de professores. Os mestres precisavam ser capazes de compreender e executar os programas escolares. Com esse objetivo, foi pensado um curso de Estudos Sociais na Escola de Professores do Instituto de Educação do Distrito Federal. 
5.3

\section{Instituto de Educação do Distrito Federal: formação de professores e ensino de Estudos Sociais}

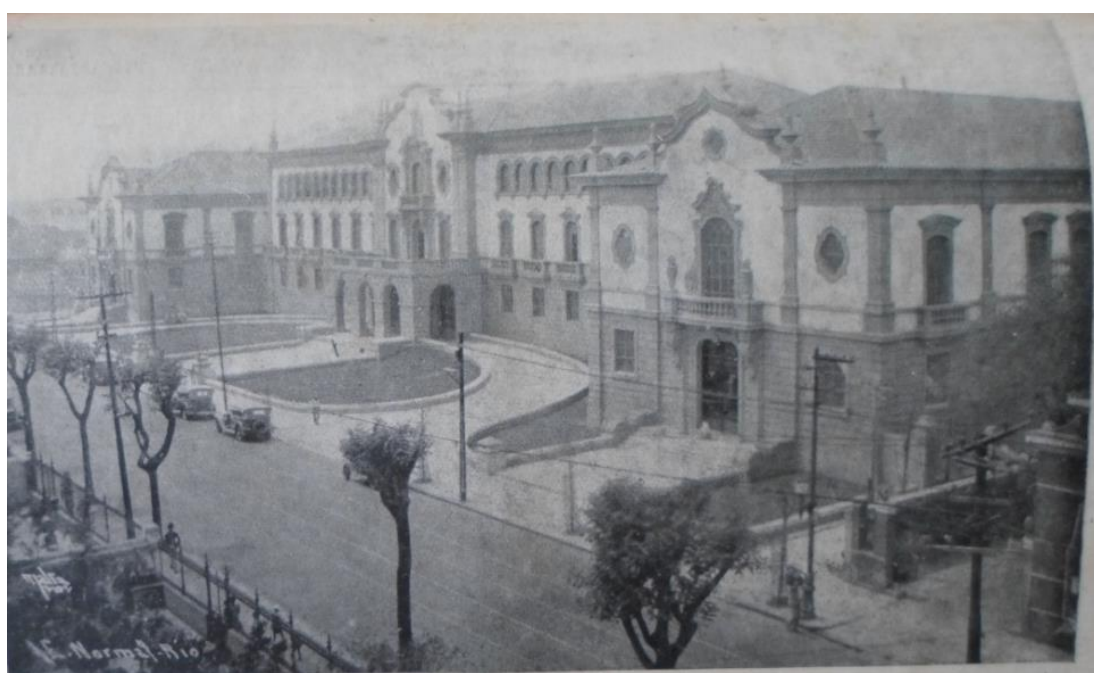

Figura 8 - "Fachada principal do INSTITUTO DE EDUCAÇÃO, Rio de Janeiro" Fonte: Arquivos do Instituto de Educação (1934, p. 153) ${ }^{169}$.

Um dos objetivos do Instituto de Educação era a formação de professores primários, secundários e especializados para atuarem no Distrito Federal. Sua estrutura era resultado da incorporação da Escola Normal, fundada no século XIX, e das escolas anexas, Jardim de Infância e Escola Primária, com as devidas modificações de estrutura e funcionamento. A principal delas dizia respeito à criação de uma Escola de Professores ${ }^{170}$, em nível superior, bem como de uma Escola Secundária, cuja função seria a preparação e a seleção dos candidatos à formação do magistério (Arquivos..., 1934). A pretensão dos reformadores era ofertar um curso especializado de formação docente, com a separação entre as

\footnotetext{
169 Os "Arquivos do Instituto de Educação" (1936, p. 154) tinham "por fim registrar e divulgar trabalhos e investigações sobre ensino e organização escolar, realizados no Instituto de Educação, do Rio de Janeiro, Brasil.” Foram publicadas edições em 1934, 1936, 1937, 1945 e outras esparsas. Neles figuram artigos de docentes de todas as escolas que compunham a instituição e, mesmo, de alunas e ex-alunas da Escola de Professores. Na argumentação de Lopes (2006, p. 106), esses arquivos, sobretudo os publicados nos anos de 1930, podem ser entendidos como um objeto cultural, que veiculava práticas escolares e alguns dos dispositivos normatizadores de saberes, e como um suporte de memória e de legitimação do movimento reformista que se encontrava em curso no Distrito Federal e, mais especificamente, no próprio Instituto de Educação. São, portanto, uma importante fonte primária para a compreensão da formação de professores na década de 1930. ${ }^{170}$ A Escola de Professores passou a designar-se como Escola de Educação, quando de sua incorporação à Universidade do Distrito Federal, fundada em 1935.
} 
disciplinas de caráter propedêutico, que ficariam a cargo do curso secundário, e as disciplinas técnico-profissionais ministradas pela Escola de Professores ${ }^{171}$.

O Instituto tinha, ainda, como uma de suas funções principais, a pesquisa e a experimentação. Para tanto, possibilitava às alunas ${ }^{172}$ que nele conseguissem ingressar, um "sistema educacional completo", podendo passar até 16 anos em suas diferentes unidades: três anos no Jardim de Infância, cinco na Escola Primária, seis na Escola Secundária e dois anos na Escola de Professores. Isso permitia, para os idealizadores do Instituto, uma "observação continuada da criança e do adolescente" e a experimentação "dos processos didáticos modernos". Os resultados dessas análises e experimentações possibilitavam ao instituto ser um "arquivo de pesquisas educacionais" e centro de referência educacional para o país (Arquivos..., 1934, p. 4-5). O ingresso na Escola de Professores era exclusivo para as alunas que tivessem cursado a Escola Secundária do Instituto, não sendo admitidas matrículas por transferência. Desse modo, exigia-se uma obrigatoriedade mínima de oito anos de curso na instituição, permitindo estudos individuais das discentes e a sua seleção com base nas “condições de saúde, temperamento e inteligência" (Arquivos..., 1934, p. 5).

Cada uma das escolas mantinha estreita relação com as outras. O Jardim de Infância, que recebia crianças entre 4 e 6 anos de idade, tinha como preocupação o aprimoramento das condições de vida e o desenvolvimento dos alunos. A Escola Primária, organizada de acordo com o programa geral do Distrito Federal, em cinco anos, funcionava como um centro de observação e experimentação para a Escola de Professores, cujos alunos ali faziam os cursos de Prática de Ensino.

$\mathrm{Na}$ Escola Primária, o ensino era especializado em "educação física, desenho e música, para todos os anos; e nas demais disciplinas, para o $4^{\circ}$ e $5^{\circ}$ anos." (Arquivos..., 1934, p. 9). A base para o desenvolvimento das disciplinas,

\footnotetext{
${ }^{171} \mathrm{Na}$ visão de Lourenço Filho, essa iniciativa rompia com um grave problema que comprometia o funcionamento da Escola Normal e a qualidade da formação de professores. A Escola Normal pretendia dar a futura professora, em um curto espaço de tempo e logo após o ensino das primeiras letras, "uma cultura geral e uma formação técnica". Era, portanto, uma instituição, ao mesmo tempo, propedêutica e profissional, o que tornava a "formação técnica" bastante precária. O autor argumentava, em sua crítica, que "a brevidade do curso, o exíguo preparo dos alunos", as poucas matérias de cunho eminentemente profissional, "a inadequação dos processos de ensino, principalmente nas matérias de cunho técnico", impediam uma verdadeira preparação do docente (Lourenço Filho, 1934, p. 15-16).

172 Referimo-nos às "alunas" e "professorandas" com termos sempre no feminino, porque as mulheres eram maioria, sobretudo, na Escola de Professores. Segundo Vidal (2001, p. 37), "a frequência era quase exclusivamente feminina, incentivada pelo Departamento de Educação.”
} 
neste nível escolar, era o método de projetos. Outra influência norte-americana, introduzida aqui pelas viagens pedagógicas e adaptada à realidade escolar do Instituto de Educação, referia-se à socialização dos alunos e à organização de "clubes", que deveriam ser dirigidos por eles.

A Escola Secundária se dividia em dois cursos: o fundamental, de cinco anos, organizado tendo como base a legislação federal, e acrescido de Higiene, Puericultura e Trabalhos Manuais e o complementar, em um ano, composto pelas disciplinas Literatura, Inglês ou Alemão, Psicologia, Estatística Aplicada à Educação, História da Filosofia, Sociologia, Desenho e Educação Física. O curso complementar era obrigatório para aquelas que tencionassem o ingresso na Escola de Professores. A divisão era a mesma proposta pela Reforma Campos, em que o ciclo fundamental era responsável por uma formação geral e o complementar era obrigatório para a matrícula nos cursos superiores ${ }^{173}$. Na Escola Secundária do Instituto, o ensino visava a construção de hábitos de observação e reflexão, bem como a formação integral da personalidade da adolescente. A livre iniciativa era estimulada através dos processos de ensino e organização de clubes e associações discentes e atividades extraclasses (Arquivos..., 1934).

É importante salientar que apesar de os Estudos Sociais aparecerem como disciplina na Escola de Professores e na Escola Primária do Instituto de Educação, estes não aparecem na Escola Secundária, que mantém a lógica disciplinar. Tradicionalmente, este nível de ensino era regulado pelo governo federal (imperial e republicano), responsável pela estrutura curricular e pelos programas de ensino, que deveriam ser seguidos pelos estados e pela capital. Entretanto, uma inovação em relação ao curso secundário oficial foi a distribuição das disciplinas em seções ${ }^{174}$, tendo como objetivo principal romper com “a extrema divisão e

\footnotetext{
${ }^{173}$ O decreto $\mathrm{n}^{\mathrm{o}} 19.890$, de 18 de abril de 1931, dispôs sobre a organização do ensino secundário, estabelecendo as disciplinas que deveriam constar do seu currículo. Em relação ao complementar foram pensadas disciplinas obrigatórias para ingresso nos cursos de Direito, Medicina, Farmácia e Odontologia e Engenharia e Arquitetura. O oitavo artigo determinava que "o regulamento da Faculdade de Educação, Sciencias e Lettras discriminará quaes as materias do curso complementar que serão exigidas para a matricula em seus cursos." (Brasil, 1931a). Contudo, tal instituição, prevista no "Estatuto das Universidades Brasileiras" (Brasil, 1931b) não chegou a funcionar. Havia, assim, um vácuo no que se refere à formação docente, o que possibilitou experiências como as desenvolvidas no Instituto de Educação e, posteriormente, na Universidade do Distrito Federal. 174 As disciplinas eram divididas em 10 seções: “1) Português, Latim e Literatura; 2) Francês, Inglês e Alemão; 3) Geografia, Cosmografia e Geofísica, História da Civilização; 4) Matemática, Estatística, Noções de Economia; 5) Ciências Naturais, Física, Química, História Natural e Biologia Geral; 6) Fisiologia, Psicologia e Higiene; 7) Psicologia e Lógica, História da Filosofia,
} 
independência das matérias", que fazia do ensino "um conjunto de conhecimentos fragmentários e isolados" (Teixeira, 2010, p. 57) ${ }^{175}$. Tencionava-se a promoção da unidade do ensino nas/entre as diferentes seções e disciplinas.

Com a formação propedêutica toda ministrada pela Escola Secundária, a etapa seguinte podia se dedicar ao desenvolvimento de matérias de interesse à formação profissional (Lourenço Filho, 1934). A Escola de Professores foi criada com dupla função: formação dos futuros docentes e oportunidade dos docentes que já atuavam nas escolas do Distrito Federal e até mesmo de outros estados, de atualizarem-se e aperfeiçoarem-se em relação "à execução das modernas práticas de organização escolar" (Arquivos..., 1934, p. 11). O sistema de ensino era o de “"seminário', para livre pesquisa bibliográfica ou experimental, sobre os vários temas ou assuntos propostos e discussão do material obtido e das conclusões a que, por este material, se possa chegar." (p. 11). Objetivava-se estimular "a personalidade do futuro mestre", suas capacidades e "espírito e iniciativa de trabalho" (p. 11-12). Da mesma forma que a Escola Secundária, a Escola de Professores também se organizava tendo como base seções de ensino, e não "matérias discriminadas" ou "cadeiras", distribuídas da seguinte forma:

I - Biologia Educacional e Higiene; II - História e Filosofia da Educação, Educação Comparada e Administração Escolar; III - Psicologia Educacional e Sociologia Educacional; IV - Matérias de Ensino Elementar, Primário e Intermediário; V - Matérias de Ensino Secundário; VI - Desenho e Artes Industriais e Domésticas; VII - Música; VIII - Educação Física, Recreação e jogos; IX - Prática de Ensino Elementar; X - Organização e Prática de Ensino Secundário. (Arquivos..., 1934, p. 11).

Cada uma das seções era dirigida por um "professor-chefe" e composta por professores assistentes. Os programas eram organizados por trimestres letivos, cada um "dos quais comportando uma disciplina de estudo intensivo obrigatório, com aulas e trabalhos práticos diários." (Arquivos..., 1934, p. 11). A partir do cruzamento do histórico escolar das alunas, disponíveis no arquivo geral do atual Instituto de Educação do Rio de Janeiro, e de documentos depositados no Arquivo de Lourenço Filho do Centro de Pesquisa e Documentação de História Contemporânea do Brasil (CPDOC/FGV), Lopes (2006) delimitou a primeira

Sociologia, Noções de Direito Público e Privado; 8) Desenho e Trabalhos Manuais; 9) Música e Canto Orfeônico; 10) Educação Física.” (Arquivos..., 1934, p. 9).

175 Tal afirmação está na exposição de motivos, escrita por Anísio Teixeira e dirigida ao Interventor Pedro Ernesto por ocasião da criação da Escola de Professores do Instituto de Educação (1932). 
matriz curricular, que vigorou entre 1933 e 1935. Essa matriz sofreu algumas pequenas modificações até 1942. Apesar do currículo da Escola de Professores não ser objeto direto desta tese, cumpre visualizarmos o lugar que os Estudos Sociais ocupavam nessa organização curricular.

\begin{tabular}{|c|c|c|c|c|c|c|}
\hline \multirow[b]{2}{*}{ Disciplinas } & \multicolumn{3}{|c|}{$1^{\circ}$ ano } & \multicolumn{3}{|c|}{$2^{\circ}$ ano } \\
\hline & $\begin{array}{c}1^{\circ} \\
\text { trim. }\end{array}$ & $\begin{array}{c}2^{\circ} \\
\text { trim. }\end{array}$ & $\begin{array}{c}3^{\circ} \\
\text { trim. }\end{array}$ & $\begin{array}{c}1^{0} \\
\text { trim. }\end{array}$ & $\begin{array}{c}2^{\circ} \\
\text { trim. }\end{array}$ & $\begin{array}{c}3^{\circ} \\
\text { trim. }\end{array}$ \\
\hline Biologia Educacional & $6 \mathrm{~h}$ & & & & & \\
\hline Biologia e Higiene & & $1 \mathrm{~h}$ & & & & \\
\hline Psicologia da Criança & $4 \mathrm{~h}$ & & & & & \\
\hline Psicologia Educacional & & $6 \mathrm{~h}$ & $2 \mathrm{~h}$ & & & \\
\hline Sociologia Educacional & & & $6 \mathrm{~h}$ & & & \\
\hline História da Educação & $1 \mathrm{~h}$ & $1 \mathrm{~h}$ & $2 \mathrm{~h}$ & & & \\
\hline Filosofia da Educação & & & & & & $4 \mathrm{~h}$ \\
\hline Introdução ao Ensino & $3 \mathrm{~h}$ & & & & & \\
\hline Educação Comparada & & & & $2 \mathrm{~h}$ & & $2 \mathrm{~h}$ \\
\hline Testes e Medidas & & & & & & $3 \mathrm{~h}$ \\
\hline Música & $2 \mathrm{~h}$ & $3 \mathrm{~h}$ & $3 \mathrm{~h}$ & $1 \mathrm{~h}$ & $1 \mathrm{~h}$ & $1 \mathrm{~h}$ \\
\hline Desenho e Artes & $6 \mathrm{~h}$ & $4 \mathrm{~h}$ & $4 \mathrm{~h}$ & & & \\
\hline Educação Física & $2 \mathrm{~h}$ & $3 \mathrm{~h}$ & $3 \mathrm{~h}$ & $1 \mathrm{~h}$ & $1 \mathrm{~h}$ & $1 \mathrm{~h}$ \\
\hline Literatura Infantil & & $3 \mathrm{~h}$ & & & & \\
\hline Cálculo & & & $4 \mathrm{~h}$ & & & \\
\hline Leitura e Linguagem & & & & $5 \mathrm{~h}$ & & \\
\hline Ciências Naturais & & & & & $6 \mathrm{~h}$ & \\
\hline Estudos Sociais & & & & $4 h$ & & \\
\hline Prática de Ensino & & & & $10 \mathrm{~h}$ & $12 \mathrm{~h}$ & $12 \mathrm{~h}$ \\
\hline
\end{tabular}

Quadro 13 - Matriz Curricular da Escola de Professores entre 1933 e 1935 Fonte: Lopes (2006, p. 136, grifos nossos).

No $1^{\circ}$ ano do curso, as matérias de estudo intensivo eram: Biologia Educacional $-1^{\circ}$ trimestre, Psicologia Educacional $-2^{\circ}$ trimestre e Sociologia Educacional $-3^{\circ}$ trimestre. Ainda no $1^{\circ}$ trimestre, as alunas eram apresentadas à Introdução ao Ensino, responsável por discutir, entre outros aspectos, “a função da escola e as qualidades do professor" (Lourenço Filho, 1934, p. 22; Lopes, 2006). Ao longo do curso, eram ofertadas as disciplinas de História da Educação, Música, Desenho, Educação Física, Recreação e Jogos. Ao final do $1^{\circ}$ ano iniciava-se o estudo das Matérias de Ensino, que se completava no primeiro trimestre do $2^{\circ}$ ano. No último ano do curso, a ênfase central era a Prática de Ensino em seus aspectos de "observação, experimentação e participação" (Arquivos..., 1934, p. 11). Além disso, eram obrigatórios os cursos de Educação Comparada, Testes e Medidas e Filosofia da Educação. Este último enquanto um curso de sistematização, ministrado após "terem os estudantes o necessário 
cabedal de fatos e informações, e de viva experiência de ensino." (Lourenço Filho, 1934, p. 22). De acordo com idealizadores do Instituto:

A Prática de Ensino está perfeitamente coordenada com a secção de Matérias, e esta, por sua vez, aos princípios gerais que dão substância aos cursos de Educação, Psicologia e Sociologia Educacionais. O curso visa formar professores conscientes de sua missão, não só capazes de realizar, mas também de entender os fundamentos de seus processos de ação, e capazes de perceber quais as modificações que a experiência venha aconselhar, em vista das diferenças individuais dos alunos e dos grupos sociais em que êles vivam. (Arquivos..., 1934, p. 12).

O $1^{\circ}$ ano, em vista disso, era dedicado aos Fundamentos da Educação e o $2^{\circ}$ à aplicação, ou seja, à Prática Docente. No último trimestre do $1^{\circ}$ ano e em parte do ano seguinte, responsáveis por "unir a parte teórica à parte essencialmente prática do ensino, encontravam-se os estudos de caráter intermediário, pelos quais os princípios da teoria e os problemas da prática eram confrontados.” (Lopes, p. 2006, p. 112). Os estudos intermediários, na argumentação de Lourenço Filho (1934), eram a maior originalidade do sistema de formação que influenciou a criação e estruturação da Escola de Professores. Concepção dos Teachers College americanos, não se confundiam com Didática Geral ou Metodologia. Tais estudos permitiriam o "exame dos princípios informadores da técnica, em conjunto com as condições da própria realidade prática. São os que facultam o discernimento entre o real e o ideal, entre a teoria perfeita e a prática imediatamente possível e conveniente.” (Lourenço Filho, 1934, p. 22). Era a base profissional, composta pela seção de Matérias do Ensino Primário: Cálculo, Leitura e Linguagem, Literatura Infantil, Ciências Naturais e Estudos Sociais, ministrada por professores especialistas. Segundo Lopes (2006, p. 112), a importância dessas matérias na grade curricular:

[...] traduzia-se como produto das reflexões de Anísio Teixeira à luz do pensamento de John Dewey, para quem o material básico de estudo não poderia ser colhido de maneira acidental e desordenada, e sim da experiência atual do aluno, em que residem as fontes dos problemas a serem investigados.

A principal função das matérias que compunham esta seção, entre elas a de Estudos Sociais, era ensinar o conhecimento a partir do "ponto de vista do interesse da profissão" (Teixeira, 2010, p. 65) ${ }^{176}$, ou seja, através dos problemas específicos de cada matéria. O conhecimento não deveria ser ministrado para a

\footnotetext{
${ }^{176}$ Tomamos como referência um pequeno artigo escrito por Anísio Teixeira em 1932, intitulado "Como ajustar os 'cursos de matérias' na escola normal com os 'cursos de prática de ensino"”. A versão utilizada consta no Anexo 3 do artigo "Escolas de Educação" (Teixeira, 2010, p. 41-75).
} 
simples formação cultural do aluno, mas tendo em vista as necessidades decorrentes do exercício da sua futura profissão. Isto, para Anísio Teixeira (2010), tomando como referência o professor James Russel da Universidade de Columbia, era o que diferenciava uma escola de cultura geral de uma escola de cultura profissional, como a Escola de Professores do Instituto de Educação pretendia ser. $\mathrm{Na}$ definição do reformador, as matérias de ensino representariam, mais especificamente, os cursos de cunho profissional. Assim,

[...] as matérias, nas escolas normais, não devem ensinadas com o caráter do ensino de nível secundário, nem com o caráter especializado do ensino de nível superior ou universitário. São ensinadas do ponto de vista da profissão do magistério. Se o grau deste magistério é o primário, os cursos de matérias serão cursos especiais em que se ministre o conhecimento da matéria apropriada às crianças da escola primária, e o conhecimento das dificuldades dessas crianças em aprendê-las, dos métodos especiais de organizá-la, dosá-la e distribuí-la, para o ensino, sempre que possível, da história do seu desenvolvimento e da sua função na educação da infância. (Teixeira, 2010, p. 68).

As matérias de ensino, assim estudadas, tornavam-se um instrumento de trabalho para as "professorandas". As suas discussões possibilitavam, no dizer de Lourenço Filho (1934, p. 23), a "libertação do espírito do futuro mestre" e a desenvoltura para analisar os diferentes processos de ensino e selecionar aqueles que melhor se ajustassem ao tipo de aluno, aos objetivos a serem atingidos, ao material e ao tempo disponíveis no exercício do magistério. Para que isso fosse possível, as matérias de ensino tinham uma estruturação diferenciada. Primeiramente era discutido o histórico da disciplina, seus conteúdos, psicologia da aprendizagem e o desenvolvimento da relação com outras matérias componentes do programa. A partir daí se discutiam os processos didáticos.

Essa abordagem procurava articular conteúdo e o método, bem como o conteúdo e os objetivos gerais do ensino, e defendia uma profunda relação entre a formação do professor, escola elementar e o meio social. A partir de 1936, a matriz curricular sofreu pequenas modificações que não alteraram a sua estrutura geral. As disciplinas Introdução ao Ensino e Educação Comparada se tornaram componentes da Filosofia da Educação. A disciplina Testes e Medidas deixou de existir, tendo parte dos seus conteúdos passado à Biologia Educacional, que teve a sua carga horária aumentada e incorporou, ainda, a disciplina Biologia e Higiene (Lopes, 2006). A matéria Estudos Sociais manteve a sua carga horária, passando a ser abordado em dois trimestres no $2^{\circ}$ ano do curso. 
A edição dos "Arquivos do Instituto de Educação" de 1937 dedicou-se a publicização dos programas da Escola de Professores, que foram discutidos e aprovados pelo Conselho Técnico da Escola, composto pelos professores-chefes das Seções de Ensino e pelo Diretor da Escola (Lourenço Filho, 1937). Segundo o diretor do Instituto, os programas haviam "sido pacientemente experimentados e ajustados, cada ano, ao desenvolvimento do nível de preparação dos alunos" (Lourenço Filho, 1937, p. 293). Evidenciavam, para ele, o "espírito novo", que guiava os trabalhos dos docentes da Escola, e não representavam uma obra definitiva. Foram publicados os programas de Biologia Educacional, Psicologia Educacional, Sociologia Educacional, História da Educação, Filosofia da Educação, Leitura e Linguagem, Cálculo, Estudos Sociais, Ciências Naturais, Literatura Infantil, Música e Canto Orfeônico, Educação Física, Recreação e Jogos, Desenho e Artes Industriais e Prática de Ensino.

Apesar de publicados em 1937, os programas têm como data dezembro de 1935. Desse modo, podemos inferir que foram "experimentados" nos anos de 1933 - que demarca a criação e início do funcionamento da Escola de Professores - e 1934, como salienta Lourenço Filho (1937). Isso significa que, além de serem documentos normativos, representam "a expressão de experiências pedagógicas efetivamente realizadas." (Julia, 2001, p. 50). Os programas tinham uma estrutura padrão, composta por: 1) Objetivo(s) do ensino da matéria; 2) Requisitos fundamentais para o estudo da matéria; 3) Programa da matéria; 4) Processos de trabalho ou ensino; e, 5) Bibliografia para os alunos (Arquivos do Instituto de Educação, 1937). Para nossos objetivos, interessam, especificamente, os Programas de Sociologia Educacional, Filosofia da Educação e Estudos Sociais. Sociologia Educacional, matéria de ensino intensivo no $3^{\circ}$ trimestre do $1^{\circ}$ ano do curso, era ministrada por Delgado de Carvalho, que aparece como autor do programa. O programa de Filosofia da Educação tem como base o trabalho desenvolvido por Anísio Teixeira em $1934^{177}$ e o de Estudos Sociais foi escrito

\footnotetext{
${ }^{177}$ Em dezembro de 1935, Anísio Teixeira já havia pedido demissão da Secretaria de Educação do Distrito Federal. Ao fim do programa consta a seguinte nota: "As bases deste programa, como a orientação geral do trabalho, foram propostas, em dezembro de 1934, pelo prof. Anísio Teixeira (prof. da Secção de História da Educação, Administração Escolar, Educação Comparada e Filosofia da Educação) estando a matéria dividida em duas partes, das quais, a primeira, deveria ser dada no I trimestre do $1^{\circ}$ ano, sob a denominação de 'Introdução ao Ensino'. A experiencia demonstrou a vantagem da unificação do curso, tal como é agora apresentado, sem que, no entanto, se tenha alterado, em substância, a matéria então proposta.” (Arquivos..., 1937, p. 315). Diferentemente dos outros programas, este data de dezembro de 1936.
} 
por Maria dos Reis Campos, professora-chefe da seção de Matérias de Ensino e responsável por ministrar esta disciplina na Escola de Professores.

Na definição de Delgado de Carvalho (1937), a Sociologia Educacional tinha dois objetivos principais: habilitar a futura professora primária a compreender o meio social em que viveria e atuaria e a entender os objetivos sociais que permeavam a construção dos programas, dos planos de estudos, das matérias de ensino e da própria organização escolar. Como pré-requisitos para o seu estudo, eram necessários conhecimentos de elementos de Biologia e Psicologia que detinham, conforme demonstra Lopes (2006), um grande peso na grade curricular da Escola de Professores, além de noções de História da Civilização, Geografia e Sociologia Geral, partes constituintes dos Estudos Sociais e do PCS, organizado por Delgado de Carvalho (1934a) para atender às necessidades da escola primária do Distrito Federal. Para ele, as Ciências Sociais exerciam um papel essencial na educação, sendo a Sociologia, no grau superior, "uma matéria indispensável e capital, visto representar uma sistematização das Ciências Sociais." (Carvalho, 1937, p. 307).

Apesar de ter formação europeia, Delgado indica que a sua inspiração em relação à Sociologia era norte-americana e "o desenvolvimento considerável que nela tomou a Sociologia Educacional, que muito cedo penetrou nas escolas normais." (Carvalho, 1970, p. 54). Em uma das edições do seu livro "Sociologia Educacional", ele esclarece que a obra era "apenas uma tentativa de aclimação, em nosso meio, de um ramo de estudos sociológicos especiais, hoje já correntes nos Estados Unidos. Este fato explica, em parte, as referências tão freqüentes a fontes norte-americanas." (Carvalho, 1940b apud Castro, 2009, p. 30). Na realidade, Delgado de Carvalho expressa uma discordância quanto aos fundamentos da Sociologia francesa e os estudos de Durkheim. Defendia que era:

[...] altamente prejudicial aos estudos sociólogos ${ }^{(\text {sic })}$ em nosso pais serem guiados segundo diretrizes e modelos franceses. A Sociologia de Durkheim, por exemplo, que traz interessantes pontos de vista metodologicos que merecem ser conhecidos como tais, desvia entretanto os nossos estudos para o terreno religioso, predispõe a discussões dogmaticas em favor ou contra teorias que nada tem de util, de importante, nem de pratico. É Durkheim um autor que devem evitar nossos programas. (Carvalho, 1938, p. 1). ${ }^{178}$

\footnotetext{
${ }^{178}$ Trechos do relatório enviado a Luís Vergara, Secretário da Presidência da República, em 1938. Nele, Carvalho tecia críticas ao Programa de Sociologia elaborado pelo Departamento Nacional de Ensino e apresentava suas concepções sobre as finalidades da disciplina na escola secundária.
} 
Em contraposição, continuava o educador:

As tendencias atuais da Sociologia norte-americana se recomendam muito mais a nossa atenção porque, em vez de levantar problemas sobre assuntos controvertidos e discussões puramente academicas, despertam um real interesse para o estudo e conhecimento racional das estruturas sociais em que vivemos, para o seu mecanismo, para as suas imperfeições, para os desajustamentos que prejudicam seu bom funcionamento. (Carvalho, 1938, p. 1).

A função da Sociologia se relaciona à descrição e explicação das condições sociais e seus problemas, ao mesmo tempo em que representa uma análise da sociedade e das instituições que a compõe. "Deseuropeizava-se Delgado de Carvalho", defende a sua discípula e colaboradora Terezinha de Castro (2009, p. 30, grifos da autora), ao analisar suas abordagens sociológicas. Entretanto, preferimos a afirmativa de Costa (2007, p. 86), ao argumentar que "a viagem aos Estados Unidos enriquecera os seus conhecimentos adquiridos na França.” Isso lhe permitiu obtemperar ideias e construir a sua própria perspectiva em relação a esta ciência. No entendimento de Delgado de Carvalho, era a Sociologia responsável pela "formação social do professor" (Carvalho, 1940b apud Castro, p. 2009, p. 30). Com esse objetivo, escreveu o "Programa de Sociologia Educacional” (1937), que era distribuído em seis pontos:

a) Análise da Sociedade em que a Escola desempenha suas funções de instituição social: Noções de organisação social; situação do indivíduo na coletividade - Os tipos de grupos: família, visinhança, recreio, comunidade, associação, Estado.

b) Noção sumária de valores sociais, sua classificação e suas consequências educacionais.

c) Valor social dos conhecimentos: 1. Finalidades, currículos e planos de estudos.

2. Interpretação sociológica das matérias de ensino.

d) Estudo da população escolar - A questão da disciplina. Atividades extra-classes.

e) Análise do mecanismo social em que o professor desempenha a sua missão. Noção de processo social: interação, concorrência, conflito, acomodação e assimilação.

f) Estudo das principais categorias de ajustamento social da condição do espírito, da saúde, da economia e da conduta. (Carvalho, 1937, p. 307-308, grifos do autor).

A professora primária precisaria, na compreensão do autor, ser uma conhecedora da realidade social ("organização social", "economia", elementos de saúde e conduta) e dos objetivos gerais da educação fundamentais à elaboração dos currículos e matérias de ensino: o mestre deveria ser também um sociólogo (Carvalho, 1934c). Em uma obra editada na década de 1950, "para uso das Escolas Normais do Brasil”, o educador esclarece melhor o sentido e o lugar da Sociologia Educacional na formação docente. Para Carvalho (1956, p. 209), a 
Sociologia possuía três divisões essenciais: a Sociologia Geral - "que define teoricamente os grupos humanos, os fatores culturais e as estruturas sociais", além de descrever os processos sociais de "concorrência e conflito", "acomodação" e "assimilação"; a Sociologia Aplicada - que classifica os desajustamentos sociais, analisando-os à luz da realidade social; e a Sociologia Especial - que aborda os fenômenos sociais segundo as instituições a que se referem. A Sociologia Educacional é um ramo desta última, responsável pelo estudo das “inter-relações sociais sob o ponto de vista da transmissão da herança cultural e, em particular, o papel que nisto cabe à Escola, como sistematizadora, ampliadora e coordenadora das atividades educativas da comunidade." (Carvalho, 1956, p. 209-210).

Os temas essenciais da Sociologia Educacional eram as "finalidades da educação", "funções da escola", "instituições de natureza educacional" e "vida escolar", mas tais assuntos não poderiam ser explicados, na visão de Carvalho (1956, p. 9), sem uma análise dos grupos sociais, dos fatores sociais e culturais. Caberia a essa disciplina, em especial, apontar aos educadores a complexidade da realidade social, habilitando-os à sua interpretação conveniente. Só conhecendo a comunidade o docente conseguiria desempenhar a sua nobre função de educador. No Programa de Sociologia Educacional da Escola de Professores, em relação à bibliografia indicada às alunas, Carvalho (1937) apontava para a "restrita literatura sociológica em língua nacional" e para a ausência de "compêndios e livros de consulta". Embora tenha sido um dos pioneiros da ciência no Brasil e autor de inúmeras obras de divulgação sociológica durante a década de 1930, não indicou nenhum dos livros de sua autoria, ou mesmo de outros autores, nas referências ${ }^{179}$. Como solução para esta questão, indicava a construção de "fichas das melhores revistas" e artigos que tratassem do tema. Entendemos que o professor estava muito mais preocupado com a "livre iniciativa", a independência e a capacidade das suas alunas de pesquisarem e encontrarem suas próprias referências do que com a indicação de leituras, que já estavam disponíveis no mercado editorial brasileiro de então. Vidal (2001, p. 168) esclarece que:

\footnotetext{
${ }^{179}$ A Sociologia foi inserida no currículo da escola secundária em 1925, a partir da Reforma Rocha Vaz. No Colégio Pedro II, o primeiro catedrático efetivo foi Delgado de Carvalho, que além de ter escrito os programas, foi autor de inúmeras obras entre 1931 e 1937: "Sociologia" (1931), "Sociologia Educacional" (1933), "Sociologia Aplicada" (1934) e "Sociologia e Educação" (1934). Os três primeiros eram manuais escolares, dedicados à escola secundária e à escola normal, enquanto o último se propunha a "uma análise do contexto educacional do período" (Costa, 2007, p. 42).
} 
[...] o novo conceito de formação de professores, proposto pela reforma anisiana, influía decisivamente para a ampliação das consultas e do número de obras da biblioteca do Instituto. Estavam privilegiadas as atividades de livre pesquisa, bibliográfica ou experimental, sobre temas surgidos em sala de aula. A pesquisa era seguida de discussões e análises sobre o material coletado. O hábito de leitura, da investigação em fontes secundárias era estimulado.

As viagens pedagógicas possibilitaram a aquisição e a ampliação do acervo da biblioteca do Instituto de Educação. Em 1935, ano em que os professores Lourenço Filho, Carneiro Leão e Delgado de Carvalho viajaram aos Estados Unidos em missão oficial do Departamento de Educação, 47\% dos novos livros da biblioteca do instituto tiveram procedência norte-americana, superando inclusive as entradas de livros em português (Vidal, 2001). Em setembro deste ano, prossegue a autora, foram gastos 2.189 dólares em livros das "firmas" "Macmillan Company", "United Government Printing Office" e "The National Education Associaton of United States" (Vidal, 2001, p. 171). Em contrapartida, diminuía-se consideravelmente a intensidade das obras francesas. Era comum que autores norte-americanos, como o próprio Dewey, chegassem até as alunas através de traduções espanholas. Isso fez com que seis dos noves programas publicados em 1937 indicassem como requisito para o curso de suas disciplinas o "conhecimento de francês, inglês e espanhol" (Vidal, 2001, p. 190).

$\mathrm{O}$ acesso à literatura internacional, atinente a diferentes temas educacionais, levou a uma prioridade, em diferentes programas publicados em 1937, da pesquisa bibliográfica "como forma de aquisição de conhecimentos" (Vidal, 2001, p. 169). Um dos grandes incentivadores de tal prática, na Escola de Professores, foi Delgado de Carvalho. No Programa de Sociologia Educacional, Carvalho (1937) estabeleceu quatro processos de trabalho principais: preleção do professor, investigação bibliográfica, aulas de discussão em grupos e excursões e visitas. Um destes métodos foi desenvolvido por Delgado de Carvalho (1934c) em texto intitulado "A dissertação, em aula: instruções para o preparo de dissertações sobre trechos previamente escolhidos". Juntamente com o artigo “A discussão nos trabalhos de seminário", de autoria de Lourenço Filho, cujo objetivo era "otimizar a leitura" e produzir "critérios de leitura" (Vidal, 2001, p. 231-233).

Foram encontradas duas versões do texto de Delgado de Carvalho, que não apresentam diferenças em termos de escrita. A primeira foi publicada nos “Arquivos do Instituto de Educação", em 1934, indicando que era para uso dos 
alunos do ciclo complementar da Escola Secundária. A segunda compõe o Acervo de Delgado de Carvalho, depositado no IHGB. Com várias cópias e um cabeçalho com informações relativas à Escola de Professores, há indícios de que o autor utilizava as suas instruções também na formação docente. $\mathrm{O}$ documento se estrutura em quatro partes. A Parte A (ou Precaução Fundamental) recomendava a leitura atenta do texto, para compreensão de seu sentido e dos principais termos. Logo em seguida, o aluno deveria ser capaz de analisar o pensamento (Parte B), realizando comparações, extraindo as informações principais e o significado dos termos adotados. A intenção principal era possibilitar "hábitos de pensamento" que deveriam estar claros na "coleta de dados" (Parte C) e na organização do plano de escrita da dissertação (Parte D) (Carvalho, 1934d).

A leitura proposta não era passiva, visando a simples memorização, algo que caracterizava a educação livresca criticada pelos expoentes do movimento da Escola Nova. Toda leitura, conforme salientam as instruções de Delgado, pressupõe da parte do leitor pensamentos e ideias a respeito do assunto. Cada leitor, por sua vez, tem noções sobre variadas coisas. A reflexão e a experiência pessoal permitem a sistematização dessas ideias. O hábito de pensar, meditar ou refletir sobre elas é o primeiro passo para o entendimento de um texto, mas só isso não basta. É preciso verificar o que os outros pensam ou já pensaram sobre o mesmo assunto. Por isso é importante a discussão com os colegas de turma, por possibilitar a compreensão do que os "outros pensam", e a leitura de distintos livros, que fornece o acesso ao que "já pensaram" os intelectuais e autores (Carvalho, 1934c, p. 107). A construção do conhecimento é coletiva e não baseada no trabalho individual. Segundo a instrução:

Devemos lêr, lêr sempre e, mais do que lêr, termos o hábito de resumir o que lemos, organisando fichas. As idéias capitais de um livro, um novo ponto de vista expresso num artigo de revista ou jornal, uma aula sobre o assunto - podem ser resumidos numa ficha, de fácil consulta e classificação. (Carvalho, 1934d, p. 107).

A prática de organização de fichas e notas de leitura era um importante instrumento de trabalho para ordenação de planos de expressão dos assuntos estudados, fosse ele oral ou por escrito. A recitação dos achados de leitura não representa uma simples demonstração do quanto os alunos aprenderam a partir da leitura de um manual, mas se torna, como defendia Dewey (2002, p. 53), uma "espécie de casa de câmbio social, onde as experiências e ideias são trocadas e 
sujeitas a críticas, onde as concepções errôneas são corrigidas e onde se estabelecem novas linhas de pensamento e de investigação." A linguagem é utilizada como meio de expressão de pensamentos e instrumento social, forma pela qual o aluno compartilha e conhece experiências. Toda dissertação, encerrava Carvalho (1934d), deve seguir um plano previamente traçado, prevendo a disposição e encadeamento de suas partes. O ponto de partida deveria ser sempre um problema. A análise textual, conforme demonstrou Vidal (2001), a partir de entrevistas com ex-alunas da Escola de Professores era uma prática recorrente nas aulas do professor Delgado de Carvalho.

Em 1933 ou 34, eu fui aluna do Delgado de Carvalho [...]. Ele colocava os livros dele à nossa disposição e indicava outros livros da biblioteca. Propunha problemas. Tudo que nós aprendíamos de teórico, logo se objetivava, através de estudos feitos pelos grupos, com o seu coordenador. Cada aluno fazia sua ficha de resumo, síntese ou mesmo ficha cópia. Discutia em grupo. Depois o grupo chegava a uma conclusão. Formulava uma ficha com essa síntese das conclusões. Depois, os grupos se reuniam e apresentavam o produto do seu trabalho com novas discussões. Geralmente, dois grupos, pelo menos, estudavam o mesmo assunto e discutiam suas conclusões. Nunca me esqueço de um dos problemas que meu grupo desenvolveu, que era uma afirmação, para a gente concordar, discordar e dar embasamento, argumentos. "A Igreja é uma das instituições sociais mais conservadoras" [...]. O prof. Delgado de Carvalho dava trabalhos em grupo para serem debatidos. Cada grupo escolhia um tópico para discussão. Ali se tinha que trabalhar o pensamento e aprender a fazer a ficha. (Entrevista realizada com D. Maria Violeta C. Villas Boas, em 26 de set. de 1994 apud Vidal, 2001, p. 236).

Os princípios que guiavam a formação de professores mantinham relação com a sua futura prática na escola primária. Para ser capaz de "ensinar a criança a procurar no livro", como pressupunha Delgado de Carvalho (1934a, p. 11) na apresentação do PCS, a professora precisava antes aprender a pesquisar nos livros. Era ele o repositório do conhecimento, um elemento importante na relação de ensino-aprendizagem e uma "fonte de experiência". Os novos métodos de ensino não excluíam o livro e a leitura como elemento de formação intelectual (Vidal, 2001). Isso fica evidente no segundo volume do PCS (1934b). Na introdução, Ignacia Guimarães (1934b, p. 25) afirma que "durante o curso primário, a criança deve formar o hábito de usar livros, revistas, jornais e outras publicações como fonte das informações necessárias ao estudo da matéria incluída no programa.” A professora primária deveria, portanto, ter também esse hábito, que era construído desde os seus anos de formação. Assim, ela poderia orientar e guiar.

Não se orienta sem uma perspectiva ou filosofia de mundo, escola, educação. O desenvolvimento da "noção de responsabilidade do educador" e da 
capacidade de indagar sobre as diferentes concepções filosóficas sobre a vida e os programas escolares eram um dos objetivos principais da Filosofia da Educação, ministrada até 1935 por Anísio Teixeira. O professor precisaria "ser um estudioso dos mais embaraçosos problemas modernos, [...] ser estudioso da civilização, [...] ser estudioso da sociedade e [...] do homem; [...], enfim, filósofo.” (Teixeira, 1968, p. 149). Com um objetivo tão ambicioso, no entendimento de Lourenço Filho (1934, p. 22), essa disciplina representava a "sistematização" e o "coroamento de todos os estudos" cursados na Escola de Professores. Por isso era ministrada apenas no último ano de formação, quando era possível integrar tanto a teoria, aprendida nas matérias de fundamento, quanto a prática de ensino. A marca de Anísio Teixeira fica explícita na seleção dos conteúdos:

1) A educação como processo geral da vida social; 2) A profissão de educar. $O$ professor, suas qualidades pessoais, sua função social, seus direitos, seus deveres; 3) Necessidade da formação filosofica do professor; 4) A educação e vida; 5) Educação e aprendizagem; 6) Os fins e os meios da educação; 7) Experiência, vida e educação; 8) A educação como reconstrução da experiência; 9) Influência da direção filosofica do educador, na interpretação dos programas, do metodo e da disciplina. O problema da liberdade e da autoridade, em educação; 10) Educação e democracia. (Programa de Filosofia da Educação, 1937, p. 313-314, grifos nossos).

Os tópicos destacados salientam a influência do pensamento de John Dewey sobre o ensino de Filosofia da Educação. Contudo, a leitura das obras do educador americano não ficava restrita a essa disciplina. Dos nove programas acompanhados de bibliografia, publicados em 1937, sete indicavam como leitura obrigatória ou recomendável a obra "Como Pensamos" e cinco, "Vida e Educação", ambas de John Dewey. Quatro programas recomendavam "Educação para uma civilização em mudança”, escrita por Kilpatrick, discípulo de Dewey, e "Educação Progressiva", livro escrito por Anísio Teixeira e fundamentado nas análises deweyanas (Vidal, 2001). Se, conforme demonstram as pesquisas de Ferreira (2013), as missões francesas foram importantes para o processo de construção dos cursos da Universidade do Distrito Federal e, posteriormente, da Universidade do Brasil, o mesmo não pode ser dito em relação ao Instituto de Educação. Sua organização, conforme apontamos nas linhas anteriores, e bases filosóficas são americanas e, especialmente, deweyanas.

Por ter origem em uma escola já existente, criada no século XIX para atender a necessidade de formação de professores para as escolas de primeiras 
letras, o Instituto de Educação contava já com os seus professores catedráticos, mas a sua formação era uma preocupação constante de Anísio Teixeira. No primeiro relatório de sua gestão à frente da Diretoria de Instrução Pública do Distrito Federal, publicado em 1932, apontava a necessidade de especialização dos professores formadores em escolas de países estrangeiros: "onde a preparação do magistério assumiu já os caracteristicos technicos e scientificos, a par de uma organização pratica, que desejariamos prevalecessem na Capital do Paiz." (Teixeira, 1932, p. 357). Só assim estariam eles habilitados a melhor atuar na "reforma dos planos e methodos de preparo de professores" (p. 357). Essa era a condição para a contratação dos professores da Seção de Matérias de Ensino e da Seção de Prática de Ensino da Escola de Professores. Trata-se de uma estratégia diferente da que foi realizada em outros cursos criados na Universidade do Distrito Federal em que se priorizou a vinda de professores estrangeiros ${ }^{180}$.

Os professores que retornavam de suas especializações tinham como função principal "transmitir ou aplicar o que aprenderam para os futuros mestres" (Cardoso, 2015, p. 62-63). Maria dos Reis Campos, como salientamos no terceiro capítulo desta tese, foi uma das professoras que realizaram essas viagens pedagógicas e especializações no exterior, especificamente nos Estados Unidos. Como consequência assumiu uma posição de relevo na reforma anisiana, tornando-se a professora-chefe da Seção de Matérias de Ensino da Escola de Professores e docente responsável pelo curso de Estudos Sociais.

\footnotetext{
${ }^{180}$ Ana Waleska Mendonça (2002) realiza uma análise tanto das missões brasileiras na Europa, em busca da formação do quadro docente da Universidade do Distrito Federal, quanto o empenho de Anísio Teixeira para que professores do Instituto de Educação realizassem viagens de estudos aos Estados Unidos. Uma análise sobre viagens pedagógicas e as missões organizadas por Anísio Teixeira (1931-1935) foi construída por Cardoso (2015). Para a análise sobre a importância das missões francesas para a constituição do curso de História no Brasil, conferir Ferreira (2013).
} 


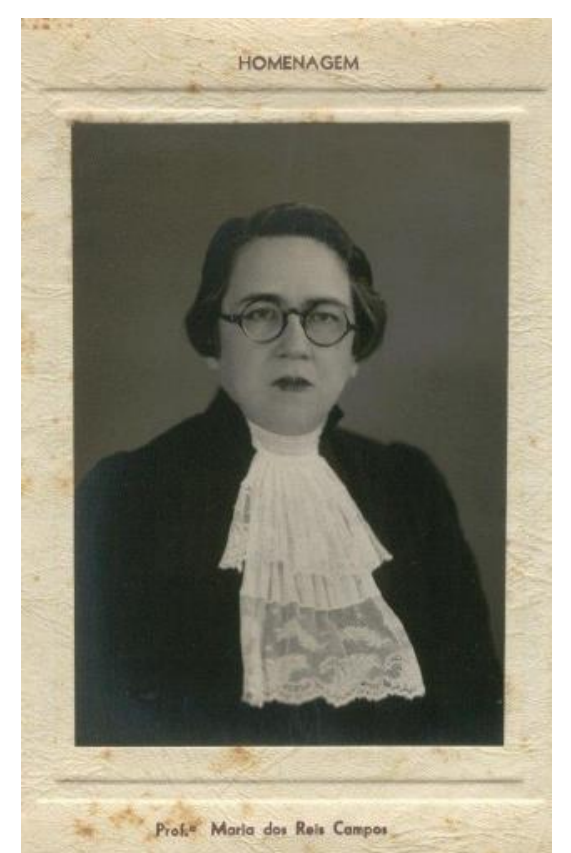

Figura 9 - Álbum de professores homenageados. Escola Normal do Distrito Federal, década de 1940

Fonte: Cardoso (2015, p. 93).

Os professores do Instituto de Educação, muitos ligados às questões práticas da vida escolar carioca, "funcionaram como tradutores de uma cultura norteamericana e da própria realidade cultural que os tinha constituído.” (Nunes, 2011, p. 298). Eram docentes e produtores de ideias, autores de importantes manuais. "Escola Moderna", de Maria dos Reis Campos (1932), era a ampliação do relatório apresentado à Associação Brasileira de Educação, por ocasião de sua viagem aos Estados Unidos em 1930. Sobre a produção do livro, ela escreve:

[...] me comprometti à apresentação, quando de volta, de um relatorio a respeito do methodo de projectos, methodo que constituia o fim particularizado do estudo a que me propunha. Durante um mez e uma semana, que durou minha estadia, appliquei-me exhaustivamente a ver escolas e acompanhar às vezes por dias inteiros, classes, onde pude apreciar não só, pormenorizadamente, a applicação pratica do methodo que ia estudar, mas, de modo geral, o ensino nas escolas americanas, mesmo porque, dada a generalização de tal methodo nessas escolas, estudal-o, ou ao seu ensino, importa quasi exactamente no mesmo trabalho. (Campos, 1932, p. 7-8).

Maria dos Reis Campos (1932) afirma que pode ver realizado muito daquilo que já havia lido. A experiência lhe proporcionou uma espécie de conversão à Escola Nova, trazendo-lhe a convicção das vantagens que teria sua aplicação nas escolas brasileiras. "Escola Moderna" é um agradecimento à $\mathrm{ABE}$, bem como às diferentes associações que lhe receberam nos Estados Unidos, e uma forma de divulgação dos novos métodos para aqueles que não tiveram a oportunidade de 
conhecê-los por meio das viagens. Mais ainda, era destinado "aos alunnos de escola normal, como auxilio a seu curso de pedagogia" (p. 8). Na organização das Matérias de Ensino, a docente imprimiu a sua experiência e opção pelo método de projetos, conforme nos informa no pequeno artigo "Execução de um 'projeto", fruto de sua experiência no ensino de Estudos Sociais, publicado na segunda edição dos "Arquivos do Instituto de Educação" (1936).

A consideravel importância que, para a escola moderna, oferece o sistema de 'projetos', graças à identificação de seus processos com as fórmas da vida real e, consequentemente, suas altas qualidades educativas, levou lógicamente esta Secção a elegê-lo como ótimo instrumento de aplicação para o estudo feito pelos alunos, no $1^{\circ}$ e no $2^{\circ}$ anos letivos. (Campos, 1936, p. 223).

Explica a autora que:

Concluindo os alunos, ao fim do $1^{\circ}$ trimestre do $2^{\circ}$ ano, o estudo das matérias da Secção, iniciado no $1^{\circ}$ ano (Leitura e Linguagem, Literatura Infantil, Cálculo, Estudos Sociais e Ciências Físicas e Naturais) - fica o $2^{\circ}$ trimestre naturalmente indicado para o planejamento e execução do projeto, com a maior intensidade de trabalho na Secção de Prática [...]. (Campos, 1936, p. 233).

No ensino de Estudos Sociais, a professora Maria dos Reis Campos seguia fielmente aquilo que previam os formuladores da Escola de Professores, ou seja, as matérias de ensino deveriam ser lecionadas tendo em vista o interesse da profissão e não como uma matéria de ensino superior ou secundário. Essa era a função dos Estudos Sociais ministrados na Escola de Professores, conforme indica o seu programa: a matéria visava "fornecer aos futuros professores os conceitos e conhecimentos de ordem técnica necessários ao ensino da matéria na escola primária.” (Campos, 1937, p. 229). A escolha do método de projetos ia ao encontro daquilo que previa o programa da escola primária de modo geral. A sua utilização, conforme demonstramos a partir da análise do PCS, não era uma exclusividade deste. Na introdução do Programa de Educação e Saúde, Ignacia Guimarães (1935, p. 127) afirmava que "a experiencia demonstra que, dentre os meios de apprendizagem, os projectos são aquelles que mais interessam às creanças porque se aproximam da situação real em que ellas, naturalmente, desenvolvem suas atividades." Ao ser estudado na Prática de Ensino, reforçava-se a utilização desse método na escola primária e o ideal de renovação do magistério.

O Programa de Estudos Sociais da Escola de Professores é abrangente. Seus objetivos cardinais eram: a) compreender os Estudos Sociais e sua função na escola primária; b) destacar das ciências constituintes dos Estudos Sociais aqueles 
elementos que deveriam ser abordados na escola primária; c) mostrar as formas como a disciplina deveria ser tratada (dosagem, métodos, relacionamento com as outras disciplinas); d) apresentar elementos auxiliares de ensino (recursos bibliográficos, materiais didáticos e forma de verificação da aquisição dos conhecimentos pelos alunos); e) apresentar o histórico da matéria e de seu ensino (Campos, 1937). Não fica muito claro na escrita do programa quais são os componentes dos Estudos Sociais; aparecem duas indicações de disciplinas e conteúdos constituintes dos Estudos Sociais na Escola de Professores.

Nos objetivos da disciplina são constituintes dos Estudos Sociais: Geografia, História, Educação Moral e Cívica, Noções de Sociologia, Direito e Economia. Por sua vez, no tópico denominado "Programa propriamente dito", "os assuntos que constituem o grupo de Estudos Sociais são: Geografia, História, e Sociologia, Educação Social, Moral e Cívica (direito, administração, economia, política." (Campos, 1937, p. 330). Essa pequena "confusão" reflete uma ausência de definição quanto à diferença entre o que era considerada uma ciência constituinte dos Estudos Sociais e o que era considerado como um assunto a ser ministrado. Também reverbera o PCS que apresenta uma visão abrangente dos Estudos Sociais, mas os restringem no item "mínimo de fatos a aprender" a Geografia, História e Educação Moral e Cívica.

Os conteúdos do Programa de Estudos Sociais da Escola de Professores são distribuídos em duas partes. A Parte Geral, teórica, e a parte prática, denominada "Aplicada". Na primeira parte, de um lado deveriam ser abordados temas mais gerais, como a sociedade (interdependência, cooperação, normas de vida, ética), a criança como membro da comunidade (vida atual e futura), a função dos Estudos Sociais na construção de visões de mundo e formação da personalidade e a utilidade do conhecimento dos componentes dos Estudos Sociais para o homem. Por outro, ganhavam relevo os fundamentos dos Estudos Sociais. De início, deveria ser debatido o ensino das matérias constituintes dos Estudos Sociais, partindo-se da escola tradicional até o "conceito moderno".

Como características deste "ensino moderno": "matérias isoladas", "ensino relacionado", "centros de interesse e projetos", além de instrumentos e métodos utilizados pela escola primária e apontados no PCS - dramatização, modelagem, mapas, brinquedos, leituras, excursões, entre outros. Entretanto, ao tratar de História, Geografia e Sociologia, o programa as apresenta como tópicos 
diferentes: "7 - Geografia - seu estudo como 'conhecimento' e como instrumento de formação mental. Matéria do ensino, aspectos e delimitação. Técnicas; 8 História e Sociologia - mesmo estudo.” (Campos, 1937, p. 330).

A matrícula na disciplina apontava como pré-requisitos um conhecimento acerca da História e da Geografia, o que indica que os conteúdos stricto sensu dessas disciplinas não seriam alvo de uma discussão aprofundada. Ao que parece, a integração deveria ser demonstrada na Parte Aplicada, quando se analisariam os programas de ensino da escola primária e os materiais didáticos, seriam esboçados os planos de aula e ocorreriam "observações diversas e inqueritos na escola primária" (Campos, 1937, p. 333).

A matéria Estudos Sociais deveria analisar o programa vigente na escola primária e "aplicar seus diferentes tópicos ao ensino" (Campos, 1937, p. 331). A Parte Aplicada do programa é importante porque, conforme argumenta Chervel (1990), o exercício é indispensável ao funcionamento das disciplinas, sem ele não há uma "fixação possível". O sucesso das disciplinas depende fundamentalmente da "qualidade dos exercícios aos quais elas podem se prestar" (p. 204). Como salientamos, o PCS era extenso. Entendemos que a professora Maria dos Reis Campos fazia seleções e estudos exemplificativos a partir dos seus diferentes temas e tópicos. Os “Arquivos do Instituto de Educação" apresentavam como uma de suas funções a divulgação dos trabalhos e inquéritos realizados no instituto, o que constitui uma fonte única sobre o desenvolvimento das práticas de ensino no interior das suas escolas. "Execução de um "projeto", de autoria de Maria dos Reis Campos (1936) é representativo nesse sentido.

A docente relata a sua prática no ensino de Estudos Sociais a partir da realização de projetos, nos fornecendo algumas pistas sobre a cultura escolar da Escola de Professores. Em 1935, o tema escolhido, para discussão com as professorandas, foi "Indústrias". No ano anterior, discutiram sobre "Transportes" - ambos os tópicos estudados no $5^{\circ}$ ano da escola primária. O objetivo da atividade era "dar aos alunos da Escola de Educação o conhecimento efetivo da técnica de realização de projetos" (Campos, 1936, p. 224), aplicando o conhecimento teórico estudado na disciplina a um caso concreto. Para tanto, esclarece Maria dos Reis Campos (1936), o projeto deveria ser realizado em caráter de "projetos de alunos da escola primária" (p. 224, grifos da autora), para que as professorandas tivessem noção de como se realiza tal trabalho, suas 
dificuldades, os problemas que pudessem surgir e a capacidade de orientar seus futuros alunos. Assim, de acordo com essa concepção, estariam sendo preparadas para o papel que lhes caberia desempenhar na escola primária.

A organização foi minuciosa. Eram três turmas de alunas. Dos diferentes assuntos que tratam o item "Indústrias" do PCS (1934b), e a partir da flexibilidade que este possibilitava, a professora selecionou três, posteriormente, subdividindoos em quatro tópicos cada. O projeto foi constituído por três subprojetos que se repartiam em quatro seções. Portanto, cada turma ficou com um tema (subprojeto), que foi distribuído em quatro grupos cada:

Turma 21 - Indústria extrativa, vegetal e mineral:

Grupo 1 - Madeiras, babassú, carnaúba, côco da Baía, jarina, mamoma, plantas taníferas e plantas fibrosas.

Grupo 2 - Pedras preciosas, pedra e barro, calcáreos, sal e águas minerais.

Grupo 3 - Erva-mate, cacau, fumo e borracha.

Grupo 4 - Ferro, carvão, manganez e ouro.

Turma 22: Manufatura:

Grupo 1 - Calçado e chapeus.

Grupo 2 - Conservas e bebidas.

Grupo 3 - Manufatura em geral, especialmente seu aspecto econômico e social

Grupo 4 - Indústria têxtil: algodão, seda, lã e juta.

Turma 23: Indústria de criação e pesca:

Grupo 1 - Carne e outros produtos (peles, gordura, ossos, chifres, etc.).

Grupo 2 - Leite e produtos derivados (coalhada, queijo e manteiga).

Grupo 3 - Aves e peixes.

Grupo 4 - Criação de gado. (Campos, 1936, p. 225).

Para o conhecimento dos temas em questão, as estudantes chegaram à conclusão, após discussão processada em três aulas, que seria necessária a realização de uma etapa preliminar composta por pesquisas bibliográficas, sem delimitação de prazo de entrega ou pressa, e excursões. Aqui reside um dos problemas da prática relatada pela professora Maria dos Reis Campos. Como eram diferentes os objetivos de cada grupo, distintos locais foram visitados (Quinta da Boa Vista, Casa da Moeda, Ministério da Agricultura, fábricas, matadouros, entre outros). As visitas, realizadas em áreas rurais e urbanas do Distrito Federal e na cidade de Niterói, ocorreram em um dia de semana, com a dispensa das aulas na escola por parte do diretor. Contudo, das visitas cumpridas pelos 12 grupos, apenas duas contaram com a participação de professores do Instituto de Educação, algo que não poderia acontecer em uma excursão da escola primária. Nesse ponto, rompe-se com a ideia de um projeto realizado com caráter 
de alunos da escola primária, que não teriam tamanha liberdade de locomoção por diferentes pontos do Distrito Federal e do Estado do Rio de Janeiro.

As próprias alunas estabeleceram um roteiro de observação para uniformizar os aspectos que deveriam ser considerados em cada visita, contendo os seguintes itens: "turma e grupo; data e hora da visita; denominação e local do estabelecimento; secções de que consta, trabalho das secções, seriação do trabalho; matéria prima empregada, proveniência; aparelhamento usado; observações diversas." (Campos, 1936, p. 227). Após a excursão, cada grupo elegeu um representante responsável por socializar as suas descobertas para os outros. A etapa seguinte foi de construção de fichas a partir das leituras realizadas, um método que era central para os estudos da Escola de Professores e estimulado nas aulas de professores como Delgado de Carvalho e Lourenço Filho. Feitas as excursões e finalizadas as pesquisas bibliográficas, cada grupo se pôs a organizar os seus planos de trabalho e a projetar os resultados finais.

Embora não apareça transcrito no artigo, à professora Maria dos Reis Campos (1936) coube apenas a orientação, com certo distanciamento e respeitando-se a iniciativa das alunas. Os resultados finais variaram de pequenas construções em madeira e cartolina (parque de diversões, matadouros, barcos) a álbuns e mostruários. Na realidade, tais resultados nada mais são do que os indicados pelo PCS (1934b), que recomendavam como atividades para os alunos da escola primária a confecção de álbuns e miniaturas, a coleção de fotografias e estampas, entre outras produções ${ }^{181}$. Apesar de bem detalhado, o PCS não apresenta nenhuma atividade avaliativa ou prova. Um aspecto que precisa ser salientado no projeto desenvolvido na Escola de Educação se refere à conexão entre as disciplinas, já que os trabalhos contaram com a participação e orientação dos professores Francisco Venâncio Filho (Ciências Naturais) e Elvira Nizynska da Silva (Leitura e Linguagem). Como informa Campos (1936, p. 231):

$\mathrm{Na}$ parte construtiva e na documentária, reunida em mostruário e albuns, procuraram os alunos atender aos Estudos Sociais e às Ciencias Naturais, enquanto a parte de Linguagem foi tratada, mais especialmente, no texto dos albuns, em correlação com as respectivas gravuras e com os mostruários e coleções.

\footnotetext{
181 Duas das atividades previstas no PCS (1934b) em relação ao tema "Indústrias", para exemplificação, eram: "Fazer, em miniatura, redes, instrumentos e barcos de pesca" (p. 145); "Organizar um mostruário de pequenos produtos manufaturados no Brasil, escolhendo, para isso, o exemplar mais perfeito de cada artigo, indicando sua proveniência.” (p. 155).
} 
A integração entre conteúdos e disciplinas, conforme apontamos, era prevista na escola primária. O próprio programa oferecia tais oportunidades. Por exemplo: ao tratar do leite e da carne um dos objetivos era promover a discussão sobre os seus elementos e valores nutritivos, algo que facultava uma articulação com as Ciências Físicas e Naturais. Os trabalhos realizados na Seção de Matérias de Ensino procuravam, assim, atingir a dois objetivos principais: contribuir para o conhecimento de determinado tópico ou tema estudado nas escolas primárias, a partir da utilização do método de projetos, e integrar as diferentes matérias de ensino que compunham a formação da professora. Contudo, Maria dos Reis Campos (1936) não aborda os diferentes problemas que possam ter surgido na sua prática e nem em que condições ela foi realizada. Por certo que as condições materiais do Instituto de Educação eram significativamente distintas da realidade escolar de outras instituições do Distrito Federal. Do mesmo modo, pouco se debate sobre uma questão central para os formuladores dos currículos naquele momento: a dosagem do conhecimento e o nível de desenvolvimento dos alunos.

Para os seguidores da escola progressiva, a matéria a ser ensinada deve estar subordinada às "necessidades e interesses do indivíduo" (Carvalho, 1934c, p. 13). $\mathrm{Na}$ Escola de Educação só poderiam conjecturar quanto a isso, já que os projetos eram realizados de acordo com o interesse das alunas da formação de professores que tinham visões de mundo e experiências diferentes das crianças da escola primária. Ao se preocupar em destacar os bons resultados obtidos ao final do trabalho, Reis Campos também não discute de que forma se processaria a integração entre os conhecimentos de História, Geografia e Educação Cívica, no ensino de Estudos Sociais. Como cada um dos seus conteúdos contribuem para o desenvolvimento do projeto? É uma questão que, infelizmente, não temos condições de responder. Contudo, podemos argumentar que a formação não dava conta daquilo que o programa da escola primária exigia enquanto conteúdos mínimos. Aprender o método de projetos era apenas uma das muitas exigências do PCS. Cada projeto requeria da professora o conhecimento de uma enormidade de fatos históricos, geográficos, econômicos, sociais e políticos. Por exemplo: de que forma as indústrias visitadas pelas alunas da Escola de Educação evoluíram? Ou qual a sua influência para o desenvolvimento do Distrito Federal? São dois conteúdos mínimos de História previstos no programa da escola primária. 
Esperava-se que a professora de alguma forma se especializasse em Ciências Sociais e pudesse se dedicar exclusivamente à disciplina, por isso as longas indicações bibliográficas, tanto no PCS quanto no "Programa de Estudos Sociais" $(1937)^{182}$. O curso não tinha a pretensão de ser o único espaço formativo das professoras de Estudos Sociais. Objetivava, antes, fornecer os instrumentos para elas continuarem seus estudos. Por sua conta, a aluna deveria procurar informações sobre a "agricultura na Antiguidade e na Idade Média" ou sobre "o serviço prestado á humanidade pelos monges da Idade Média" (Programa de Ciências Sociais, 1934b, p. 127, 216). Para isso seriam essenciais os métodos ensinados por Delgado de Carvalho em sua disciplina Sociologia Educacional. Mesmo com a perspectiva de profissionalização da formação docente, persistia certo autodidatismo, justificado pela "livre iniciativa" discente e docente. Ainda assim, tal proposta representava um avanço em relação ao que ocorria nos Estados Unidos, onde os documentos normatizadores dos Estudos Sociais não refletiram sobre a constituição de um curso de Estudos Sociais nas escolas superiores.

\section{4 Ocaso de um projeto, persistência de uma ideia: seriam vitoriosos os Estudos Sociais?}

Lopes (2006) denomina 1935 como “o ano crítico" em decorrência da série de disputas entre Anísio Teixeira e a Câmara Municipal e o início do processo de radicalização política, que culminaria com a instauração da ditadura do Estado Novo, em $1937^{183}$. Uma das divergências se relaciona à obrigatoriedade do ensino religioso nas escolas públicas do Distrito Federal. Anísio defendia a laicização do ensino e, devido a essa posição, era "constantemente definido como um pensador marxista, principalmente entre os intelectuais católicos, que [...] viam o educador como um inimigo da religião e da tradição brasileira." (Sarmento, 2001, p. 196).

\footnotetext{
${ }^{182}$ No Programa de Estudos Sociais da Escola de Educação as referências são, sobretudo, metodológicas, com indicações de leituras de Delgado de Carvalho, Dewey, Anísio Teixeira, Lourenço Filho, Sampaio Dória, Claraparède, Jonathas Serrano, Venâncio Filho, entre outros. As indicações bibliográficas em relação aos conteúdos a serem ensinados na escola primária eram apresentadas no PCS.

${ }^{183}$ Foram vários outros enfrentamentos que não cabe esmiuçar aqui. Citamos dois: Mendonça (2002) analisa as concepções de universidade de Anísio Teixeira e do ministro da educação Gustavo Capanema, que de certa forma os colocavam em campos opostos; Nunes (2011) e Sarmento (2001) investigam as disputas no interior do Partido Autonomista do Distrito Federal.
} 
Os debates sobre o tema e a regulamentação do ensino religioso pela Câmara Municipal significaram uma primeira derrota política de Anísio Teixeira. A Intentona Comunista, em novembro de 1935, "propiciou um maior fechamento e endurecimento da estrutura do Estado, que passou a tomar atitudes cerceadoras dos direitos políticos" (Sarmento, 2001, p. 200). No Rio de Janeiro, um grupo de professores da Universidade do Distrito Federal e colaboradores diretos de Anísio foram presos. O ápice da crise seria o seu pedido de demissão da Secretaria de Educação, em $1^{\circ}$ de dezembro. De acordo com Nunes (2011, p. 312):

À medida que a modernização autoritária se afirmou, a gestão de Anísio Teixeira como secretário municipal da Educação na cidade carioca foi avaliada como uma estratégia de oposição dentro da estratégia oficial, e como tal foi combatida e interrompida. A mais completa reforma da Instrução Pública dos idos de 1930 foi apagada da história da educação.

Em uma espécie de intervenção branca, assumiu a Secretaria de Educação o ex-ministro Francisco Campos. Contudo, a organização curricular que incluía a disciplina Estudos Sociais no Instituto de Educação e a disciplina Ciências Sociais na escola primária do Distrito Federal vigorou, com pequenas alterações, até o começo da década de 1940. Um inquérito realizado em 1935 por Lourenço Filho, enquanto diretor do Instituto de Pesquisas Educacionais, com superintendentes de ensino e diretoras das escolas cariocas, aponta que os Estudos Sociais não eram um consenso entre as 61 diretoras. Trata-se de respostas a um questionário contendo 27 perguntas, a maioria comportando "sim" ou "não" ou escolhas de alternativas (visando sua tabulação). Transcrevemos a $23^{\mathrm{a}}$ e suas respostas:

23 - Como compreender o ensino de Estudos Sociais (geografia, história, educação cívica e moral) no curso primário? 30,29\% em conjunto; 23,53\% de modo prático, $13,73 \%$ em branco; $9,80 \%$ como matéria específica desde o $3^{\circ}$ ano; $7.84 \%$ como nos programas; $1,96 \%$ Geografia e História fundamentalmente; $1,96 \%$ tudo que diz respeito ao Brasil e noções ligeiras sobre o restante do mundo. (Lourenço Filho, 1935, p. 294).

Apesar da maior parte das diretoras concordarem com o Ensino de Estudos Sociais como preconizado no PCS, aparecem divergências: necessidade de ensino de História e Geografia como disciplinas escolares específicas a partir do $3^{\circ}$ ano da escola primária e maior ênfase na História do Brasil em detrimento da História da Civilização. Reznik (1992) argumenta que o IHGB e intelectuais, como o professor Jonathas Serrano, defenderam a especificidade da história nacional e a autonomia da História do Brasil, culminando com a expedição de uma portaria 
federal, em 1939, “obrigando a existência de aulas separadas de História do Brasil em todas as séries do curso secundário fundamental.” (p. 80). A base do PCS era a História da Civilização, o que o levava a estar em descompasso com o que se ensinava na escola primária e com os novos tempos políticos em que se valorizava a História do Brasil, o civismo e a formação do sentimento patriótico.

Uma sucessão de reformas tanto federais quanto locais, desenvolvidas no próprio Distrito Federal, levaram à reorganização da escola primária e da formação de professores para esse nível de ensino. A própria denominação "Escola Normal" foi revivida com o objetivo de "desestruturar de fato a reforma docente de 1932” (Lopes, 2006, p. 280). A partir de 1943, com a publicação do decreto $\mathrm{n}^{\mathrm{o}} 7.941$, de 25 de março, o curso normal deveria ser feito em três anos após o curso colegial - nova nomenclatura para o curso complementar da escola secundária ${ }^{184}$. Em relação a nossa temática, o novo currículo da formação de professores eliminou o ensino de Estudos Sociais em prol da Metodologia da História e da Geografia. A Seção de Matérias de Ensino, em que se ministrava a matéria de acordo com o "interesse da profissão", levando em consideração todas as disciplinas da escola primária, deixou de existir. Posteriormente, a "Lei Orgânica do Ensino Normal", de 1946, estabeleceu uma única disciplina intitulada Metodologia do Ensino Primário, em que se perdia a especificidade do ensino.

A reorganização do ensino primário, a partir do decreto $\mathrm{n}^{\circ} 7.718$, de 5 de fevereiro de 1944, impôs uma nova matriz curricular ao Distrito Federal. Logo no primeiro artigo ficava implícita a referência aos católicos: “A escola primária, inspirada, nos valores e ideais da civilização cristã e baseada nas tradições do povo brasileiro, terá por finalidade a educação integral da infância.” (Distrito Federal, 1944, p. 1). O curso primário permanecia tendo cinco anos, mas mudavam-se seus desígnios. Os três primeiros anos ou ciclo fundamental era responsável pela "educação integral da criança", enquanto os dois últimos ou ciclo pré-vocacional visava a iniciação ao trabalho. O currículo extinguiu a disciplina Ciências Sociais e tornou obrigatório o ensino de História do Brasil e de Geografia, juntamente com Linguagem, Matemática, Ciências Físicas e Naturais, Desenho, Trabalhos Manuais, Economia Doméstica, Orientação Pré-Vocacional,

\footnotetext{
${ }^{184}$ A esse respeito, conferir os Arquivos do Instituto de Educação (1945). O decreto-lei $n^{\circ} 4.244$ de 9 de abril de 1942, ou "Lei Orgânica do Ensino Secundário", estabeleceu a divisão do curso secundário em Ginásio, com a duração de quatro anos, e Colégio, apresentando as modalidades Clássico e Científico, com a duração de três anos.
} 
Educação Física e Canto Orfeônico. Mantinha-se a ideia de que as disciplinas deveriam ser ensinadas de forma correlacionada, "em caráter de globalização" ou articulação entre elas, mas independentes umas das outras.

O foco do novo currículo escolar residia na educação pré-vocacional e nos trabalhos manuais. O seu objetivo era "criar nas novas gerações a consciência do valor e da dignidade do trabalho manual e despertar seu interêsse pelas atividades técnicas e problemas econômicos do país." (Distrito Federal, 1944, p. 4). Essa perspectiva fazia uma distinção entre o trabalho intelectual e o trabalho manual, algo que não estava presente na concepção de ensino de Anísio Teixeira. Na sua escola não se separava preparação técnica e cultura desinteressada, oficina e laboratório: "toda educação escolar é profissional. Toda educação visa preparar o homem para algum dos grandes tipos de ocupação.” (Teixeira, 1997, p. 42). A escola primária, fundamentalmente, identificava-se com a vida e suas necessidades e, nesse processo, eram essenciais as Ciências Sociais.

O projeto de Estudos Sociais desenvolvido por Delgado de Carvalho, Ignacia Guimarães e Maria dos Reis Campos perdeu o seu lugar no currículo da escola primária do Distrito Federal, mas a sua ideia sobreviveu. Em diferentes momentos da história da educação brasileira, os Estudos Sociais foram retomados ou rediscutidos, tornando-se uma disciplina escolar em tempos autoritários (como durante a ditadura militar) e democráticos. Até a década de 1990, era comum estudarmos História e Geografia a partir do nosso livro "Eu gosto de Estudos Sociais". É verdade que nem sempre o seu sentido e intenções foram os mesmos, mas os fundamentos, pelo menos em termos de alguns dos conteúdos, foram lançados pelo PCS: o aluno, sua família, a escola, o bairro, o país. O método de projetos aos poucos foi sendo esquecido, mas os "mínimos a saber" - depurada a sua ênfase na História da Civilização - tornaram-se a base dos Estudos Sociais na escola primária brasileira. De que forma essa discussão se processou na escola secundária, cujos programas eram estabelecidos a nível federal, e como a ditadura militar se apropriou dela são os temas dos próximos capítulos. 


\title{
Propostas de Delgado de Carvalho para o ensino de Estudos Sociais na escola secundária (1930-1960): integração, disciplinarização e fusão de disciplinas
}

\begin{abstract}
Mais uma vez, venho tentar a apresentação de métodos didáticos para os Estudos Sociais. Solicito novamente a atenção de meus colegas que ainda não desanimei de convencer. Reconheço que muitas idéias são tidas por irrealizáveis ou, pelo menos, prematuras em nosso meio. Não desisto, entretanto, pois algumas são aprovadas por autoridades pedagógicas de primeira grandeza. Neste mundo de perpétua mudança, onde minha idade avançada me permitiu assistir a tantas inovações, estou convencido que estamos em vésperas de profundas transformações em matéria de processos de ensino, de currículos, de programas, de estudo-dirigido. (Carvalho, 1970, Preâmbulo).
\end{abstract}

Em manuscrito não datado, mas provavelmente escrito na década de 1930, Carvalho (s/d) afirmava que um dos problemas educacionais que mais preocupavam os intelectuais que pensavam a escola secundária era o da integração entre disciplinas ${ }^{185}$. Essa deficiência era sentida com mais intensidade através da ausência de conexões entre a História e a Geografia - vistas como disciplinas que já dialogam por natureza - que assim não cumpriam com sua função na formação cultural do indivíduo. Para ele, a integração já havia sido conquistada na escola primária. A referência estava, certamente, nas reformas produzidas por Anísio no Distrito Federal, da qual havia sido um dos formuladores. As disciplinas foram integradas em seções: Ciências Naturais, Ciências Sociais, Linguagem, Matemáticas: "ali, em cada um destes departamentos, não há mais subdivisões em aulas especializadas" (p. 2). Contudo, Carvalho (s/d) se questionava: "Mas esta perfeita integração seria possível e aceitável no ensino secundário?” (p. 2).

Não apenas seria possível, como aconselhável, argumentava o professor ao considerar esta como uma das tarefas da escola progressiva no Distrito Federal. O momento era o de preparar a discussão e, se possível, concretizá-la. Contudo, o caminho para tal integração não foi o mesmo realizado na escola primária. Primeiro, pela ausência de ingerência que os educadores do Distrito Federal tinham sobre as políticas públicas para a escola secundária, o que impediu Anísio Teixeira e seus colaboradores de formularem um currículo como haviam feito em

${ }^{185}$ CDC/IHGB. Lata 1: Sociologia. Documento: “A integração das matérias de Ciências Sociais" (s/d), 5 páginas. 
relação à escola primária. Havia um currículo e programas produzidos pelo Ministério da Educação e disciplinas que deveriam ser ministradas. Segundo, pela convulsão política que culminou na demissão de Anísio Teixeira e na ditadura do Estado Novo a partir de 1937. Nas décadas seguintes, Delgado buscou formas de expor e defender sua proposta de Estudos Sociais, porém não mais pela via da elaboração das políticas públicas, como havia ocorrido na sua participação na reforma anisiana, mas através de conferências e produção de manuais didáticos.

Significativa a esse respeito é a escrita de "Introdução metodológica aos Estudos Sociais", em 1957, que sintetiza muitas das discussões travadas pelo educador: "Mais uma vez, venho tentar a apresentação de métodos didáticos para os Estudos Sociais." (Carvalho, 1970, Preâmbulo). Apesar de defender a criação de uma nova disciplina escolar, o catedrático sempre trabalhou no terreno do possível, ou seja, na proposição de mudanças metodológicas e programáticas para as disciplinas por ele consideradas como tradicionais: História e Geografia, sobretudo. Daí decorre a confusão presente nos Estudos Sociais entre disciplina e metodologia escolar. Se entre as décadas de 1930 e 1940, os Estudos Sociais no curso secundário podem ser entendidos muito mais como uma metodologia que busca uma integração entre os conteúdos e a vida social, através do estudo da sociedade, a partir da década de 1950, Delgado propõe de forma mais clara a fusão de disciplinas e um programa de Estudos Sociais para o ciclo colegial da escola secundária. Este capítulo abordará algumas das mudanças que ocorreram no pensamento de Delgado de Carvalho entre as décadas de 1930 e 1970. 


\section{1}

"Meu cavalo de batalha": Delgado de Carvalho e os Estudos Sociais no curso secundário

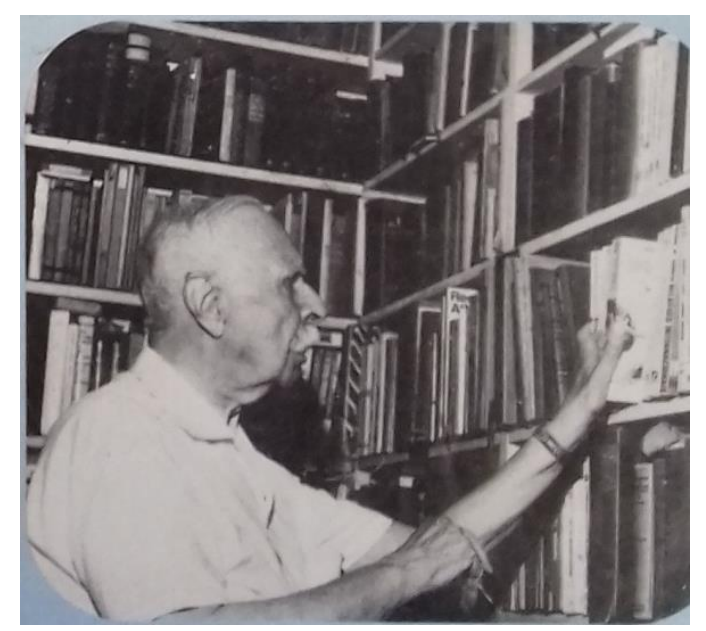

Figura 10 - Delgado de Carvalho em sua biblioteca particular (década de 1970) Fonte: Revista do Gás (1975, p. 31) - CDC/IHGB.

Apesar da extensa produção bibliográfica, Delgado de Carvalho não deixou nenhuma obra autobiográfica. Contudo, em artigos publicados na "Revista do Instituto Histórico e Geográfico Brasileiro", na primeira metade da década de 1970, o educador, com seus mais de 90 anos de idade, apresenta algumas reflexões sobre sua longa carreira no magistério. Ao escrever o discurso de agradecimento por ocasião da concessão do Prêmio Boilesen ${ }^{186}$, Delgado reconstituiu o que delimita como as suas preocupações e trabalhos em oito décadas e delegou um destaque a sua defesa dos Estudos Sociais, reafirmando que:

A tradicional divisão dos Estudos Sociais em: Geografia, História, Sociologia, Economia e Direito, se impôs para facilitar o conhecimento das relações humanas. Mas, esta divisão lógica, em grupos de matérias afins, se leva a conhecê-las, por si só, não ajuda a compreendê-las, e ainda menos a interpretá-las. (Carvalho, 1975b, p. 158-159).

\footnotetext{
186 O prêmio Henning Albert Boilesen foi instituído em 2 de abril de 1970 pela Associogás Associação Brasileira dos Distribuidores de Gás Liquefeito de Petróleo e era distribuído anualmente a duas personalidades brasileiras ou estrangeiras que tivessem contribuído para a educação, tecnologia, ciência e cultura e para o desenvolvimento socioeconômico do Brasil. Os nomes eram indicados por "autoridades" (professores, acadêmicos, ministros, etc.), instituições culturais e associações de classe e, posteriormente, os vencedores eram selecionados por uma comissão julgadora composta por personalidades, como membros da Associação Brasileira Letras e reitores de universidades. Entre os laureados em anos anteriores aparecem nomes como Eugênio Gudin (1971), Luís da Câmara Cascudo (1972) e Helena Antipoff (1973). Em 1974, além de Delgado, foi laureado o Almirante Paulo de Castro Moreira da Silva, pelos serviços prestados ao desenvolvimento do país.
} 
O discurso não era novo. Era o mesmo utilizado por ele 40 anos antes, por ocasião da publicação do "Programa de Ciências Sociais" (PCS), em 1934. As bases eram: a "organização psicológica das matérias escolares", proposta por Anísio Teixeira, e as definições do americano Charles Beard (1932). O contexto era, por assim dizer, radicalmente novo. O Brasil vivia o auge da ditadura militar, imposta há pouco mais de uma década. Os Estudos Sociais haviam se tornado uma disciplina obrigatória do currículo da recém-reformada escola de $1^{\circ}$ grau, há apenas quatro anos, e as associações acadêmicas já se manifestavam em prol da especificidade da História e da Geografia. O campo científico era outro, as universidades e a formação do professor de História já se encontravam consolidadas, a ponto de poderem reagir e lutar contra as determinações impostas pelas reformas produzidas pelo Conselho Federal de Educação (CFE). Portanto, não foi Delgado de Carvalho quem mudou, mas o seu lugar de fala. E ele tinha plena consciência disso. O intelectual generalista ${ }^{187}$ tinha perdido espaço para o historiador, o geógrafo, o sociólogo. Mesmo assim, os Estudos Sociais permaneciam como o seu "cavalo de batalha", conforme ele próprio argumenta:

No meu "cavalo de batalha", como dizem os franceses, foi uma constante a preocupação de tratar os diferentes setores das Ciências Sociais como conjunto de influências recíprocas. Bem entendido, semelhante coquetel só pode ser oferecido aos estudantes dos últimos anos dos cursos secundários, isto é, depois de ter seguido, nos primeiros anos do curso ginasial os programas paralelos, mas separados das duas disciplinas básicas. Depois de alguns anos de meditação e planejamento, se assim posso dizer, diante de programas que com isso não concordavam, a aposentadoria me silenciou. (Carvalho, 1975b, p. 159).

Duas décadas antes, por atingir a idade legal, Delgado havia sido aposentado da sua cátedra na Faculdade Nacional de Filosofia da Universidade do Brasil e quase automaticamente elevado à categoria de "professor emérito", tendo em vista se tratar de uma "personalidade há muito consagrada no magistério e nas letras nacionais"188. A sua autoridade não é mais decorrente da ocupação de cargos oficiais, mas é tributária da longa experiência no ensino de Ciências Sociais e na produção de obras didáticas. Em manuscrito, produzido em duas pequenas folhas de fichário e datado de 27 de janeiro de 1975, o intelectual se situava no campo educacional brasileiro entre a sua aposentadoria e a concessão

\footnotetext{
187 Entendemos o generalista como um intelectual cujas pesquisas e atuações se estendem a vários campos do conhecimento, não se confinando em apenas uma especialização.

188 Parecer da Congregação da Faculdade Nacional de Filosofia, 19 de agosto de 1955. CDC/IHGB. Lata 13. Pasta 2: Homenagens e Prêmios.
} 
do Prêmio Boilensen, em reconhecimento a sua contribuição ao desenvolvimento da História, da Geografia e da Sociologia no Brasil:

Há mais de vinte anos, sem me afastar das atividades educacionais, perdi um pouco do contato com meus colegas de magistério e tenho hoje a surpresa de ser lembrado pela Comissão do Prêmio Boilesen com a concessão de seu prestigiado prêmio. $\left(\right.$ Carvalho, 1975a, p. 1) ${ }^{189}$.

O campo científico havia se especializado e as primeiras gerações de professores, formados pelas universidades criadas na década de 1930, consolidavam-se nas cadeiras universitárias. De acordo com Costa (2007, p. 139), com "a nova geração de intelectuais, cada vez mais especializados, com o desenvolvimento das pesquisas que determinaram novas questões, a obra de Delgado de Carvalho foi alvo de críticas.” As homenagens e apresentações eram uma oportunidade de lembrar os objetivos de sua atuação "na vida profissional, no campo dos Estudos Sociais" (Carvalho, 1975a, p. 1) e uma forma de defender o seu papel na construção do campo disciplinar e seu legado no campo educacional. Os livros didáticos e discursos apresentavam e discutiam aquilo que não the era mais possível "comunicar em sala de aula" (Carvalho, 1975b, p. 159). Portanto, na década de 1970, o velho educador reafirmou suas posições sobre "batalhas" perdidas no campo educacional brasileiro. Duas delas se relacionavam aos conteúdos ensinados na escola básica e as definições de Estudos Sociais - objeto de uma vida e de inúmeras publicações, que analisamos a seguir.

\section{2}

Ensino de Ciências Sociais na escola secundária entre as décadas de 1930 e 1940: o papel das disciplinas e a Sociologia como elo ${ }^{190}$

Paralelamente ao processo de afirmação dos campos científicos no Brasil, com a maior especialização do conhecimento, que tem efeito, sobretudo, a partir da criação das primeiras universidades e dos cursos superiores para a formação do professor, Delgado de Carvalho pensou em formas de como ensinar as disciplinas compartimentadas na escola secundária. Tal nível de ensino, na década de 1930,

\footnotetext{
${ }^{189}$ CDC/IHGB. Lata 13. Pasta 6. Item 8: Discursos e Recortes de Jornal.

${ }^{190}$ Uma apresentação preliminar de trechos desta seção foi realizada no IX Congresso Brasileiro de História da Educação, em coautoria com os professores Jefferson Soares e Patrícia Coelho da Costa, no artigo intitulado: "Carlos Delgado de Carvalho: um professor secundário em defesa da especialização (1920-1950)" (Soares et al., 2017).
} 
era considerado "um problema nacional" (Peixoto, 1940), um sistema elitista, e foi alvo de constantes debates de educadores e políticos. Foram discutidas as suas funções e finalidades na formação do aluno brasileiro ${ }^{191}$. No interior desse "grande problema", Delgado se debruçou, especificamente, sobre o ensino das disciplinas que compõem a área das Ciências Sociais, pelo seu "tão importante e decisivo papel educativo" (Carvalho, 1940a, p. 31), e sobre a formação e prática do seu professor. $\mathrm{O}$ autor criticava o enciclopedismo e a rigidez dos currículos e programas, que não atendiam as novas demandas colocadas pela sociedade. Os Estudos Sociais na escola secundária são apresentados, nas décadas de 1930 e 1940, como uma questão de método e de reformulação dos objetivos de ensino.

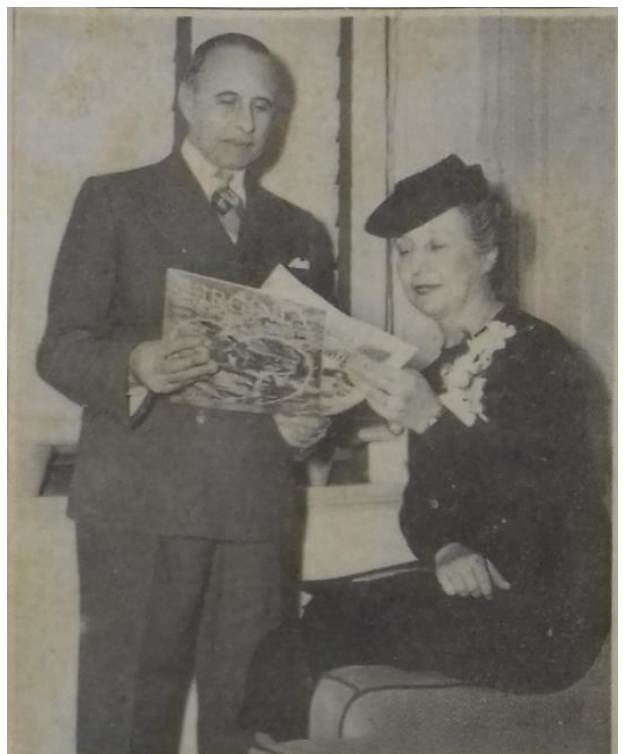

Figura 11 - Delgado de Carvalho e a sua esposa, Vera Roxo de Carvalho, em viagem aos Estados Unidos (década de 1930)

Fonte: CDC/IHGB. Lata 13. Pasta 6. Item 8: Discursos e Recortes de Jornal.

Como professor-autor de livros didáticos e metodológicos, Delgado assumiu a defesa de um padrão de produção intelectual preocupado com o desenvolvimento das ciências autônomas e com o estímulo à construção de pensamento original, através da pesquisa e leitura de textos. Era indispensável

\footnotetext{
${ }^{191}$ Não cabe aqui uma análise aprofundada desses debates, mas é importante lembrar que o ensino secundário, como salientado nos capítulos anteriores, era de competência do governo federal (no Império e na República). Isso significa que os currículos e programas eram estabelecidos pelo Colégio Pedro II, até o início da década de 1930, e depois pelo Ministério da Educação. Nas décadas de 1930 e 1940, este nível de ensino foi objeto das Reformas Campos e Capanema. Os dois ministros o consideravam como "lócus privilegiado para educação das "elites condutoras" (Reznik, 1992, p. 6) e responsável pela formação da personalidade. Tais reformas estabeleceram o conjunto de disciplinas que deveriam compor o currículo da escola secundária. Entre elas figuravam, como disciplinas independentes e distintas, a História e a Geografia.
} 
"transpor didaticamente o conhecimento desenvolvido na academia, em um processo que envolve bem mais do que a simplificação dos conteúdos." (Costa, 2007, p. 23). Nesse movimento, o aluno assumia uma posição central na relação ensino-aprendizagem. Para Delgado de Carvalho (1940a, p. 33), "o grande erro dos pedagogos de todas as épocas, é [o] de enxergar muito menos o que os discentes querem e precisam do que os docentes preferem, julgam melhor ou mais interessante." As metodologias de ensino deveriam ser pensadas levando-se em consideração os estágios de desenvolvimento dos alunos e os objetivos colocados pelos programas. Entretanto, os Estudos Sociais não foram incluídos, naquele momento, no currículo da escola secundária, sendo apenas objeto de debate, assumindo a designação genérica de um conjunto de disciplinas. A preocupação maior de Delgado era com a divulgação de novas práticas de ensino.

O ponto de partida era a superação da ausência de relação entre a educação e a vida prática ou cotidiana dos alunos. $\mathrm{O}$ meio social, em perpétua transformação, necessitava de uma nova educação: "a mentalidade criada pelo cinematógrafo, pelo rádio e pelo avião tem que ser alimentada com material de ensino adequado e não com a mentalidade formada pelo carro de bois e o 'próprio cavalo'." (Carvalho, 1940a, p. 33). A escola deveria se adequar ao desenvolvimento material, capacitando o aluno à vida em sociedade. Neste percurso, os Estudos Sociais assumiam uma função de ligação entre o "conhecido" e as novas informações. Mas em que consistiam os Estudos Sociais nos anos de 1930?

A maior parte das ciências, ao se constituírem em objetos de estudo, formaram disciplinas distintas, campos de atividades diferentes, mas pouco a pouco, estendendo-se estes campos de investigações e pesquisas, avolumando-se o material acumulado, os especialistas passaram a encontrar conexões naturais que existem entre elas. As relações se estreitaram com os progressos científicos: os biólogos ficaram interessados nos progressos da química; os químicos encontraram terrenos de colaboração com os físicos. O mesmo se deu nas Ciências Sociais: de descritivas passaram a ser analíticas. Sendo o homem objeto central destas ciências humanas, concentrou-se maior interesse na natureza dele, para daí tirar a explicação de seus atos [...]. (Carvalho, 1934c, p. 61).

A "ciência é una", as disciplinas que compõem as Ciências Sociais História da Civilização, Geografia Humana, Economia Política, Ciência Política e Sociologia - são "divisões que fazemos na grande unidade que é a Ciência da Humanidade" (Carvalho, 1940a, p. 29). As disciplinas em seu processo de constituição e afirmação nos contextos escolar e universitário se diversificaram e delimitaram seus campos de atuação. Entretanto, para Delgado de Carvalho se 
essa delimitação era útil para fins de pesquisa, não o era para o ensino escolar. Este deveria fornecer aos educandos uma visão global dos fenômenos. Como o homem é o objeto primeiro das Ciências Sociais, as conexões entre elas são naturais. Até aqui a base da argumentação de Delgado de Carvalho se inspira na "Carta das Ciências Sociais nas escolas", de Charles Beard (1932). Para o historiador americano, a especialização decorre de "esforços para ver as coisas com mais precisão e mais intensamente" (p. 17), o que faz com que cada disciplina conceda uma ênfase em análises de determinados aspectos selecionados entre os assuntos humanos. Ainda assim, "adjacente a isto, encontra-se uma fronteira incerta onde todos se fundem em um interesse transcendente. Cada um contribui para o nosso discernimento do mundo de fato e de opinião sob os quais vivemos e trabalhamos." (p. 18). Contudo, Beard (1932) não advogava a criação de uma Ciência Social una que transcendesse todas as outras e aqui há uma pequena distinção entre o pensamento de Delgado e o do mestre americano. $\mathrm{O}$ educador brasileiro acreditava na possibilidade de uma "ciência una" capaz de chegar "a uma filosofia final dos seres e das coisas" (Carvalho, 1940a, p. 32). Era uma utopia tida pelo próprio Delgado como irrealizável em curto prazo. De um lado, porque "a vida social de inter-relações é tão complexa que ainda não foi possível constituir um corpo de princípios e temas enquadrando todos os dados importantes das Ciências Sociais.” (Carvalho, 1968, p. 3). Por outro:

Por mais modernistas e avançados que pretendam [e] que desejem ser os corpos docentes, ainda ficaremos apegados por muito tempo à distribuição tradicional de matérias. É assim que, apesar da interdependência dos estudos sociais, os programas se decompõem em disciplinas distintas, com professores diferentes, em horários diversos, com provas e exames separados e sem a desejável coordenação entre si. São como "fatias" de saber humano entregues aos educandos para que delas façam o uso que quiserem ou puderem. (Carvalho, 1970, p. 23-24).

Desse modo, embora ministradas como disciplinas distintas, o objetivo era a "integração de todas elas em uma poderosa unidade" que pudesse "refletir toda a vida social, na sua complexidade irredutível" (Carvalho, 1934c, p. 61). Trata-se da mesma argumentação utilizada para inclusão dos Estudos Sociais na escola primária. Contudo, enquanto isso não fosse possível, na escola secundária, era necessária a transformação dos seus métodos e a maior articulação entre as diferentes disciplinas. Esse foi o intento da obra de Delgado entre 1930 e 1960. Diferentemente das propostas americanas, contemporâneas, os Estudos Sociais na 
perspectiva de Delgado apresentam uma forte preocupação com o lugar e o papel que cada uma das disciplinas tem no interior dos Estudos Sociais.

Em conferência ministrada na ABE, no ano de 1937, Delgado de Carvalho expôs sua visão sobre o ensino das disciplinas constituintes das Ciências Sociais. As duas primeiras, a História e a Geografia, disciplinas-irmãs presentes no currículo da escola secundária desde a criação do Colégio Pedro II no século XIX, pautavam-se na extrema memorização de datas, nomes e afluentes de rios e na passividade do aluno. Tanto uma como a outra precisavam abandonar o factual e árido em mnemotécnicas de nomes próprios: “A decoração de uma lista telefônica seria preferível por ser mais útil.” (Carvalho, 1940a, p. 39). No caso da História, era necessário, ainda, avançar para além da história política e incluir o econômico, o social, o intelectual, o cultural. O professor deveria apresentar aos seus alunos as diferentes correntes intelectuais presentes na escrita do pensamento históricogeográfico. As lições deveriam ser planejadas a partir de situações de interesse para o indivíduo, grupo ou nação, isto é, na multiplicidade de fenômenos históricos e geográficos, era recomendável a seleção daqueles que possibilitassem a "realização de melhoramentos, de progressos e aspirações sociais no contexto em que vive o estudante.” (p. 39). A proposta de Delgado toma como referência os escritos de Dewey (1959) em "Democracia e educação", percebendo o ensino de História e Geografia como uma fonte de desdobramentos de sentidos. Portanto:

Localisando no tempo e no espaço as nossas próprias ações, ellas tomam novo significado. Tomamos consciencia do papel que desempenhamos como continuadores, no tempo, de um processo continuo, e as nossas experiencias de cada dia deixam de ser cousas de um instante e tomam uma significação duradoura. (Carvalho, 1934c, p. 99).

Na escola secundária, tais disciplinas teriam como função o alargamento dos sentidos e significados da experiência discente. Como "estudos de informação por excelência”, na compreensão de Carvalho (1934c) a partir Dewey (1959), elas deveriam ser ensinadas de forma integrada ou, pelo menos, de modo mais articulado, uma vez que se "auxiliam na apresentação de homens vivendo em sociedade" (Carvalho, 1934c, p. 101). A exceção de uma breve experiência desenvolvida no Colégio Pedro II, ainda nos anos do Império (1822-1889), a História e a Geografia se constituíram enquanto disciplinas independentes na 
escola secundária ${ }^{192}$. Nas primeiras universidades apareceram concepções diferenciadas em relação às licenciaturas em História e Geografia. Na Universidade do Distrito Federal, criada em 1935, por exemplo, os cursos eram independentes, mesmo com toda a defesa de integração propagada por Anísio Teixeira e seus colaboradores na definição dos currículos da escola primária e do Instituto de Educação. Ferreira (2013) afirma que era praticamente inexpressivo o peso da Geografia no curso de História da instituição. Por outro lado, a Universidade do Brasil, que se tornou o padrão a ser seguido pelas universidades brasileiras após 1939, uniu os cursos de História e de Geografia.

Não nos parece que tal unificação dos cursos no ensino superior mantenha relação com as discussões desenvolvidas pelos intelectuais americanos e por Delgado de Carvalho. Conforme aponta Ferreira (2013), as missões francesas foram importantes para o processo de constituição e institucionalização dos cursos de História no Brasil. É preciso lembrar, como salienta Prost (2012, p. 36), que na França havia um "parentesco bastante forte que unia a História à Geografia". Segundo o autor, "todos os historiadores franceses fizeram Geografia porque esta disciplina é obrigatória no concurso de agrégation ${ }^{193}$ e, com a História, todos eles a ensinaram aos alunos do ensino médio.” Ferreira (2013) destaca que enquanto alguns membros da comunidade geográfica brasileira produziram uma série de moções solicitando a separação dos cursos, professores da Universidade de São Paulo, liderados pelo francês Pierre Monbeig "propunham a permanência da união dos dois cursos e sugeriam sua fixação em quatro anos em vez de três." (p. 42). Os docentes vinculados à universidade paulista argumentavam que "a História, a Geografia e a Etnografia eram disciplinas que se complementavam; [e] seu divórcio seria prejudicial à formação do professor secundário.” (p. 42).

A julgar pelos escritos de Delgado de Carvalho, autor de manuais de Geografia e de História, a articulação entre essas disciplinas, defendida na formação de professores entre as décadas de 1930 e 1940, não se efetivava na prática docente da escola secundária, onde elas eram ministradas de forma

\footnotetext{
${ }^{192}$ Santos (2011, p. 75) afirma que "no período compreendido entre a fundação do Colégio Pedro II e o ano de 1849, a História e Geografia formavam uma única cadeira, cujos estudos se caracterizavam pela História identificada com as humanidades clássicas. Desse modo, estudava-se a História Universal dando prioridade às civilizações grega e romana, e a Geografia limitava-se ao acompanhamento e à ambientação da História - segundo Gasparello (2004), em posição subalterna." Sobre o significado do termo "cadeira", neste momento, cf. nota 38.

${ }^{193} \mathrm{O}$ concurso de agregação tornava o profissional apto a lecionar nos liceus franceses.
} 
desarticulada. Por fim, a partir de 1955 os dois cursos foram separados também no ensino superior, muito pelo entendimento que começava a se afirmar acerca da dificuldade de se formar especialistas para ambas as disciplinas em um único curso $^{194}$. Além dessas disciplinas tradicionais, “As Ciências Sociais na escola secundária" (1940a) apresentava as chamadas "Ciências Tabu" (Economia Política, Ciência Política, Antropologia Cultural e Sociologia), ou seja, aquelas:

[...] que a vigilância de nossos técnicos de educação julgam perigosas para a mentalidade de um país ainda novo e essencialmente agrícola como o nosso. São as Ciências Tabu, porque em boa regra, o educando, depois de convenientemente preparado em sete anos de estudos, deve ser entregue ao mundo, ao grupo social em que terá de trabalhar e lutar, sem prevenções nem preconceitos sobre o que nele vai encontrar. Tudo que lhe é reservado deve ser surpresa, novidade, inesperado, inexplicado. Só assim poderá ele manifestar em suas opiniões e atos toda a sua originalidade juvenil que dele espera à Nação. (Carvalho, 1940a, p. 40).

A formação do "membro da aristocracia de letras", a qual vinha se dedicando a escola secundária brasileira, excluía o ensino das "Ciências Tabu". Destas, apenas a Sociologia possuía lugar obrigatório no currículo escolar, mesmo que recente na altura da conferência de Delgado de Carvalho ${ }^{195}$. Todas elas tinham como objetivo fornecer aos educandos os meios para o entendimento da vida em sociedade. Sua ausência nos anos de formação, consequentemente, levava ao despreparo dos alunos quando colocados a lidar com certas questões sociais. A Economia Política é o "estudo das condições de produção", cujos objetos são os recursos, o capital, o trabalho, por exemplo, em sua relação com as atividades humanas. A Ciência Política "é o estudo social do Estado, de suas formas, de sua

${ }^{194}$ Lei $\mathrm{n}^{\circ} 2.594$, de 8 de setembro de 1955. A esse respeito consultar a recente tese de Patrícia Aranha (2017), em que a pesquisadora analisa, entre outros aspectos, as disputas entre os geógrafos sobre a constituição do curso de Geografia. Aranha (2017) defende que Delgado teve uma atuação no processo de separação dos cursos de História e Geografia, já que o autor do projeto de lei foi o deputado José Alves Linhares, esposo da sua então assistente Maria Yedda Linhares: "Delgado de Carvalho esteve à frente de todas as argumentações e disputas em relação à conformação do curso de Geografia e História, chegando até à proposição da lei que efetivamente separou o curso, cuja autoria é de José Linhares, marido de sua auxiliar (Maria Yedda Linhares) na Universidade; informação esta que nos leva a crer que as movimentações para tal recomendação deveriam ser do professor Delgado de Carvalho. Pode parecer inicialmente um tanto paradoxal que a mesma pessoa a advogar a interdisciplinaridade e interdependência destas disciplinas tenha sido a que pede a separação da formação universitária, no entanto, chamo a atenção para o fato de que os conteúdos relacionados à geografia na história e os relacionados à história na geografia estavam assegurados pela lei, o que se coaduna com a posição de Delgado de Carvalho.” (p. 141). Mesmo que o educador tenha tido alguma participação na separação dos cursos, algo que não podemos afirmar a partir dos documentos que investigamos, ele passou a criticar, conforme apontamos mais à frente, a pouca articulação entre os novos cursos e os já existentes.

195 A Reforma Rocha Vaz (decreto $n^{\circ}$ 16.782-A, de 13 de janeiro de 1925) implantou a Sociologia como disciplina obrigatória no $6^{\circ}$ ano da escola secundária. Já a Reforma Capanema (1942) retirou a obrigatoriedade da disciplina no currículo escolar. Entretanto, a Sociologia manteve o seu lugar no currículo da escola normal, responsável pela formação do professor da escola primária. 
autoridade, de suas funções e de suas condições." (Carvalho, 1940a, p. 45). Se o jovem não tem acesso aos mecanismos econômicos e políticos que regem a sociedade em que vive, como poderia lutar pelos seus interesses e construir a sua personalidade? Como poderia agir na sociedade? Por isso, tanto a escola primária quanto a escola secundária não poderiam ficar restritas ao ensino de apenas duas Ciências Sociais, História e Geografia, e deveriam incluir as "Ciências Tabu".

Tais disciplinas capacitariam ao pleno exercício da cidadania, já que a elas caberiam apresentar e discutir as estruturas, funções de governo, feições econômicas, entre outros assuntos. A terceira "Ciência Tabu" era a Sociologia que, segundo Delgado de Carvalho (1940a), sofria as maiores desconfianças. Como destacado em seus livros constituintes dessa disciplina escolar no Brasil, para ele, a Sociologia ainda não tinha um "círculo fechado de conhecimento" e estava "modificando seus métodos, reunindo material" (p. 47). A Sociologia servia como elo entre as diferentes Ciências Sociais, já que:

[...] o social não se resume na vida econômica, na vida política, na história do passado e no quadro geográfico do presente. Outros aspectos da humanidade nos interessam e chamam nossa atenção. O mundo das inter-relações de toda ordem, no plano mental, cria laços de interdependência e de interação que precisam ser analisados em seus elementos, seus processos e suas estruturas. (Carvalho, 1940a, p. 47).

Destarte, os seus "objetivos abrangem as próprias bases dos conhecimentos sociais" (Carvalho, 1970, p. 75). Ainda de acordo com o autor, em virtude dos seus temas (família, associação, instituições, etc.), a Sociologia tem uma função prática, "tanto é sentida sua necessidade atual, que raro é, entre nós, o historiador, o político, o economista, o educador, que não fale em 'razões sociológicas', em 'objetivos sociológicos' ou sociais" (Carvalho, 1949, p. 48). A Sociologia, dedicada à "interpretação da experiência humana" e deixando de lado as divergências doutrinárias, levaria os educandos à construção de atitudes (Carvalho, 1970). Delgado de Carvalho, a partir da apropriação que faz da obra de Irene Mello de Carvalho, salienta cinco delas:

1) de respeito às instituições vigentes sem impedir uma crítica serena de suas falhas; 2) de compreensão e de tolerância em face de outros modos de pensar, sentir e agir, combatendo o etnocentrismo; 3) de ponderação e reflexão crítica antes de aceitar interpretações unilaterais e simplistas; 4) de aceitação esclarecida das mudanças culturais valiosas; e, 5) de desenvolver o ideal de colaboração nas atividades construtivas. (Carvalho, 1970, p. 75-76). 
As Ciências Sociais integradas, portanto, tinham como objetivo a formação da personalidade do aluno, apresentando-lhe a complexidade da vida social. Por último, as Ciências Sociais "também representam na escola secundária as atividades extra-classe, ou, como dizem os americanos, extra-curriculares, isto é, as atividades legítimas não previstas no programa." (Carvalho, 1940a, p. 48). Tais atividades visavam alargar os objetivos da educação, tornando seu currículo mais flexível e articulado. A atividade extraclasse (sociedades literárias, clubes, centros de excursão, entre outros) era a ligação entre os programas das diferentes Ciências Sociais, sendo um "complemento prático e necessário de sua ação educativa na escola secundária" (Carvalho, 1940a, p. 50). Sua organização deveria proporcionar ao aluno a socialização, a integração, o ideal democrático, a responsabilidade e, principalmente, a motivação para os estudos.

À primeira vista, os Estudos Sociais parecem antagônicos à ideia de especialização das ciências autônomas, também defendido por Delgado, porém, para ele, a integração entre as disciplinas só é possível a partir da organização dos campos disciplinares. Se cada uma das ciências ilumina a outra quanto aos caminhos a percorrer, a direção das pesquisas a fazer, isso só é possível quando conseguem fixar suas especificidades, seus objetivos, métodos, campos de ação e seus problemas (Carvalho, 1940a). O progresso científico levou às conexões naturais, apesar de cada ciência encarar "um mesmo assunto sob pontos de vista diferentes, sob vários aspectos." (p. 30). No ensino, "cada um destes ramos de conhecimentos têm a sua função educativa num currículo elaborado pra um país de cultura ocidental, para uma civilização em mudança.” (p. 33). Há um claro reconhecimento das fronteiras disciplinares, embora se entenda que elas não são rígidas e que as Ciências Sociais sintetizam "a própria humanidade em toda a sua complexidade.” (p. 30). É um movimento de especialização e integração. Enquanto uma ciência una não fosse possível, as Ciências Sociais deveriam continuar:

[...] a acumular conhecimentos dados comprovados, a provocar e a estimular o pensamento, a aperfeiçoar os métodos de pesquisa desinteressados, a manter e enriquecer o patrimônio hereditário que permite o progresso da civilização, processo ingente que, entretanto, exige cuidado, critério, esforço constante e espírito crítico, nos menores detalhes. (Carvalho, 1940a, p. 32, grifos do autor).

$\mathrm{Na}$ escola secundária, as Ciências Sociais proporcionariam, de acordo com as intenções de Delgado de Carvalho (1940a, p. 31-32): 1) “uma grande massa de 
fatos autênticos e organizados a respeito das atividades humanas". A representação da continuidade social da humanidade, ou seja, é "o patrimônio da civilização" e um conhecimento indispensável a indivíduos e sociedade; 2) imparcialidade, interpretação justa e sincera sobre todos os pensadores da humanidade. Os Estudos Sociais visam interpretação; e, 3) estímulo ao pensamento e ao espírito crítico. Para o seu pleno desempenho, era necessária uma rediscussão dos métodos em Estudos Sociais.

\section{3}

"Didática das Ciências Sociais" (1949): o primado da Geografia e o ensino como uma questão de método

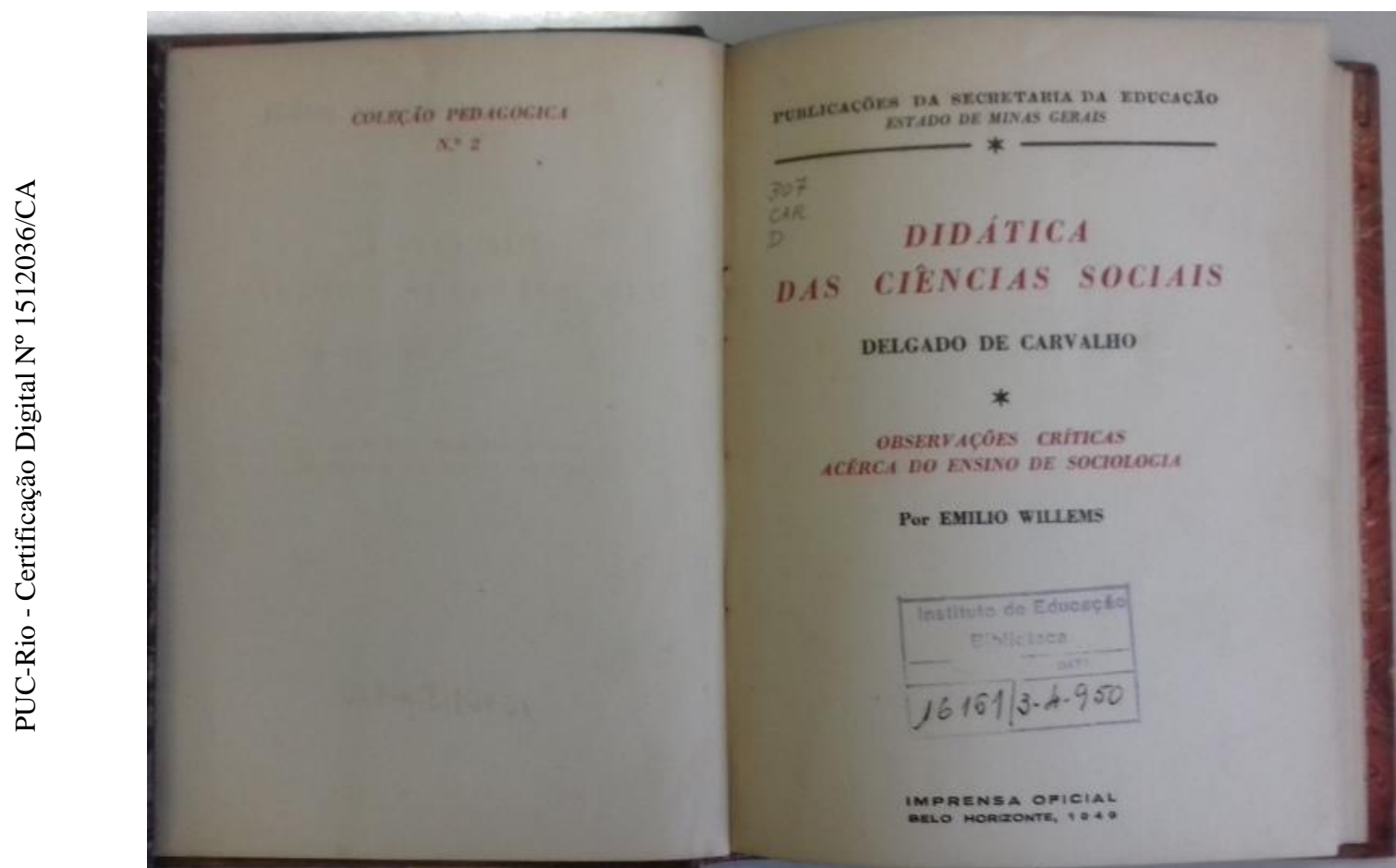

Figura 12 - Publicação aulas ministradas por Delgado de Carvalho em Minas Gerais (década de 1940)

Fonte: "Didática das Ciências Sociais" (Carvalho, 1949). Acervo do Centro de Memória da Educação Brasileira do Instituto de Educação do Rio de Janeiro (CMEB/ISERJ).

"Didática das Ciências Sociais" (1949) tem a sua origem em "cursos de férias", organizados pelo governo do Estado de Minas Gerais, nos anos de 1948 e 1949, tendo como público-alvo os professores do ensino secundário e do ensino 
normal $^{196}$. Segundo Abgar Renault ${ }^{197}$ (1949), no prefácio da obra em questão, a didática da História e da Geografia foi um dos objetos desses cursos, considerando-se a importância das duas disciplinas e a incapacidade dos métodos, então em vigor, denominados como "fatigados e fatigantes". Criticavam-se os métodos tradicionais e o foco excessivo em exercícios mnemônicos, que impediam o ensino de História e de Geografia de "seduzir a atenção dos alunos e transformá-lo em processo de esclarecimento" (p. 9). O objetivo do livro, portanto, é a proposição de outros procedimentos didáticos. Entre eles, o "estudodirigido", em que os professores ensinariam os alunos a estudarem, e a organização de textos e fichas, buscando-se uma melhor compreensão dos livros lidos e a construção de hábitos de pesquisa e formulação de ideias.

O curso de metodologia da História e da Geografia foi entregue ao “eminente Professor Delgado de Carvalho", que recebeu extensos elogios de Renault. Sobre suas aulas, esclarece o então Secretário de Educação do Estado de Minas Gerais: "Fê-lo com a maestria, a segurança e a dedicação exemplares que o caracterizam e com aquêle espírito de sacrifício dos que têm no magistério antes um modo do que um meio de vida." (Renault, 1949, p. 13). Em sua primeira frase na obra "Didática das Ciências Sociais", Delgado de Carvalho (1949) reforça a defesa de um curso de Ciências Sociais. Para ele, "no estudo de Ciências Sociais, o ideal seria, talvez, a organização de um Curso em que figurassem tôdas: Geografia, História, Economia, Sociologia, Ciência Política, etc.” (p. 17). Isso porque existem "bases didáticas gerais" que serviriam ao ensino de todas elas, mesmo com pequenas modificações para cada uma. Três princípios gerais de aprendizagem tornariam o seu ensino mais científico:

a) uma modificação do comportamento; b) resultante da experiência; c) com um sentido de integração. Êste sentido de integração, na idade escolar, pode ser orientado por propósitos definidos que tenham em vista uma adaptação a novas situações. (Carvalho, 1949, p. 17).

\footnotetext{
${ }^{196}$ Em 1952, trechos de "Didática das Ciências Sociais" foram publicados nos números 107, 108, 109 e 110 do "Boletim Geográfico" do Instituto Brasileiro de Geografia e Estatística (IBGE), na seção "Contribuição à didática da Geografia". Ainda nesse ano a obra foi traduzida para o espanhol sob o título "La historia, la geografia y la instrucción cívica: nuevas aportaciones para su enseñanza", compondo volume da Biblioteca de Cultura Pedagógica, organizada pelo Editorial Kapelusz e dirigida por Clotilde Guillén de Rezzano na Argentina.

${ }_{197}$ Abgar de Castro Araújo Renault (1901-1995), mineiro, bacharel pela Faculdade de Direito de Minas Gerais (1924), foi professor em instituições como a Escola Normal Modelo de Belo Horizonte, Colégio Pedro II e Universidade do Distrito Federal. Ocupou, ainda, diferentes cargos políticos, tendo sido Secretário de Educação de Minas Gerais em duas ocasiões (1947-1951 e 1956-1961) e Ministro da Educação (1955-1956).
} 
Ainda que Delgado utilize a noção de aprendizagem, proposta por Lourenço Filho, fica patente a perspectiva anisiana e deweyana. Ao longo do livro, escrito a partir de notas de aulas, não são poucas as citações diretas ao filósofo norteamericano. Conforme salientamos no capítulo 3, para Anísio Teixeira (1968, p. 42), mais do que expressar algo memorizado, aprender é "ganhar um modo de agir" ou, nas palavras de Delgado de Carvalho (1949, p. 18), "uma transformação da mentalidade" e uma "capacidade adquirida pelo aluno de modificar o seu comportamento" (p. 129). Por conseguinte, toda aprendizagem decorre de uma experiência que contribui para novas situações ou experiências futuras. A própria disciplina escolar é uma "experiência sistematizada", fruto de sucessivas reflexões e acumulação dos esforços do homem. Os fatos contidos na experiência da criança e aqueles contidos e ensinados nos/pelos "assuntos-matéria" são desta feita "os termos inicial e final de uma mesma realidade" (Dewey, 2002, p. 163). De acordo com Carvalho (1949, p. 17):

A experiência geográfica tem por propósito um conhecimento do meio em relação às necessidades do homem; a experiência histórica tem por propósito o conhecimento do passado, em vista de melhor explicação das situações presentes; a experiência econômica tem por propósito o conhecimento da produção e distribuição das riquezas; a experiência social e política têm por propósito o conhecimento das instituições sociais, que visam o desejável ajustamento do homem à sociedade. (Grifos do autor).

Nos escritos do educador brasileiro, como fica bem evidente na citação acima, cada uma das disciplinas que compõem as Ciências Sociais têm um papel claramente definido. A História, por exemplo, era a chave para a compreensão do presente. Contudo, em "Didática das Ciências Sociais" (1949), é a Geografia que ocupa a "posição estratégica" no interior das Ciências Sociais e, portanto, no ensino de Estudos Sociais advogado por Delgado: "pois a ela recorrem tôdas as demais para a localização e a explicação de seus respectivos fenômenos." (Carvalho, 1949, p. 18). É a Geografia que apresenta a terra como centro em que ocorrem todos os processos, sejam eles políticos, econômicos sociais e culturais. É a "casa física do homem", nos documentos americanos da década de 1930, e é a "morada do homem" (Dewey, 1959, p. 232). Por esta abordagem, na década de 1940, é a Geografia que influencia todas as demais atividades sociais.

Delgado é considerado como um dos precursores da Geografia brasileira, tendo sido autor de várias obras no campo. Já em 1913 publicou “Geographia do Brasil”, um manual escolar destinado ao curso secundário. Na década de 1920, 
veio à luz "Methodologia do ensino Geográfico" (1925), um dos primeiros livros de didática e metodologia de ensino desta disciplina em nosso país. Essa larga experiência no ensino da Geografia é sinalizada em "Didática das Ciências Sociais" (1949). Na exposição do que considera como condição essencial à aprendizagem geográfica, fica evidente a independência de Delgado de Carvalho frente às teorias que circulavam no campo acadêmico das primeiras décadas do século XX. Se as bases para a sua proposta sociológica têm grande influência das abordagens norte-americanas, a construção da perspectiva geográfica é devedora da sua formação no velho mundo. Orientadoras, nesse sentido, são as produções de Ratzel e La Blache, contudo, Delgado não se filia a uma escola de pensamento.

As suas obras valorizaram a Geografia Humana ou "Antropogeografia”, isto é, o estudo dos homens em suas relações com a terra. A análise das "condições físicas do meio" era essencial para que o estudante pudesse aplicar seus conhecimentos sobre certos valores primordiais à vida humana. Para o educador brasileiro era necessário um meio termo entre o "determinismo geográfico", atribuído ao alemão Friedrich Ratzel, em que as condições naturais do meio determinam tanto as atividades humanas quanto a vida em sociedade (relação causa e efeito), e o "possibilismo" identificado a Paul Vidal de La Blache, em que o homem é um agente ativo na relação com o meio ambiente. Apesar de sofrer influências do meio, o homem pode transformá-lo em seu favor. É importante salientar que tais termos foram cunhados pelo historiador Lucien Febvre ${ }^{198}$.

François Dosse (2003, p. 119) aponta que desde o início do século XX, Lucien Febvre ficou responsável por "acompanhar as produções da escola geográfica francesa". Seus achados foram, inicialmente, publicados na "Revue de Synthèse Historique", onde "utiliza suas resenhas bibliográficas para travar um diálogo interdisciplinar e para elogiar os méritos de trabalhos geográficos, para que os historiadores neles se inspirem.” (p. 119). As relações entre História e Geografia são pensadas em termos de "solidariedade". Em "La terre et l'évolution humaine: introduction géographique à l’histoire" ("A terra e a evolução humana:

\footnotetext{
198 Friedrich Ratzel (1844-1904) foi um pensador alemão, considerado um dos precursores da Geografia. Sua principal obra foi "Antropogeografia" ("Anthropogeographie"), publicada em dois volumes, entre 1882 e 1891. Paul Vidal de la Blache (1845-1918) foi um geógrafo francês e catedrático da Sorbonne. Fundou os "Annales de géographie", em 1891. Lucien Paul Victor Febvre (1878-1956) foi um historiador francês e cofundador, juntamente com Marc Bloch (18861944), da "Annales d'histoire économique et sociale", em 1929. Ocupou uma cátedra no importante Collège de France e fundou a VI Seção da École Pratique des Hautes Études, em 1947.
} 
introdução geográfica à história", em livre tradução), publicado em 1922, Febvre "associou o termo determinismo (que já existia) a Ratzel e chamou a geografia lablacheana de possibilismo (termo que Vidal nunca utilizou), criando uma polarização que não existia" (Campos, 2014, p. 20). Era uma obra conhecida de Delgado de Carvalho, que a analisa e a critica em um manuscrito de 14 páginas, não datado, intitulado: "Geografia Física e Geografia Humana"199. Para ele, Lucien Febvre era "o mais meticuloso e exigente dos possibilistas, especialmente irredutível em suas discussões" (Carvalho, s/d, p. 2), com uma visão nacionalista e marcada por sua posição como historiador. Escreve-nos Delgado:

A sua obra interessantissima, "La Terre et l'évolution humaine" é uma incansavel critica do determinismo geografico. No seu desejo de provar que o homem escapa mais facilmente pelo seu pensamento á ação direta do meio, ele critica com vivacidade tudo quanto tem sido acumulado por conta da geografia humana. Muitas vezes os argumentos aduzidos por Fevbre representam apenas o zelo do historiador em defender o livre arbitrio do homem contra a influencia que certos geografos atribuem ao meio. (Carvalho, s/d, p. 2-3).

"A Terra e a evolução humana", embora lance as bases da colaboração entre historiadores e geógrafos, enfrentou resistências de importantes geógrafos, como Camille Vallaux e Albert Demangeon, um futuro colaborador dos Annales (Dosse, 2003). Peter Burke (1997, p. 25) explica essa resistência "por ser o trabalho de um não especialista". Mas nos parece ser mais do que isso. Essa é uma distinção que não aparece na análise de Delgado de Carvalho, que aborda o texto de Febvre juntamente com os escritos pelos geógrafos. Pelas suas críticas, a obra de Febvre falhava ao desconsiderar os avanços promovidos pela Geografia Humana e possuía uma visão estreita das teorias de Ratzel, muitas vezes o desqualificando. Delgado alerta que a preocupação do historiador estava mais em "demolir a produção alemã ratzeliana e geopolítica" (Carvalho, 1941, p. 426), do que com o "movimento geográfico moderno" e a própria obra de La Blache ${ }^{200}$. Nesse processo, eram mais profícuos os trabalhos de outros dois importantes intelectuais presentes nas missões francesas na Universidade de São Paulo e na Universidade

\footnotetext{
${ }^{199}$ CDC/IHGB. Lata 11. Pasta 1: Programas de aulas: geografia humana e geografia física; estudos sociais.

${ }^{200}$ Como salienta Campos (2014, p. 21), "Ratzel foi uma das referências intelectuais, com a sua Antropogeografia, para o estabelecimento da Geografia Humana de Vidal. Apesar de algumas pequenas divergências, os dois convergiam no tratamento dado à região e ao Estado, tanto na defesa do colonialismo quanto na própria visão geopolítica. O papel realizado pelo meio físico nas diversas atividades humanas analisadas por Vidal possuía, muitas vezes, uma visão 'determinista'." Sobre essa discussão, ver, ainda: Dosse (2003) e Burke (1997).
} 
do Distrito Federal: Pierre Monbeig, "a quem já muito devemos", e "o amigo do Brasil Pierre Deffontaines" (Carvalho, 1941, p. 425, 426) ${ }^{201}$. Na leitura do geógrafo brasileiro, de acordo com a abordagem de Febvre:

[...] tal meio e taes condições naturaes podem possivelmente ter taes e taes efeitos sobre um grupo humano, dado o estado social deste grupo. O fator vontade, idéa, conhecimento ou preconceito modifica as relações que as cousas podem ter entre si. O homem é agente ativo e não passivo, mesmo quando recebe imposições do meio. Mas isso não é novo, pois Ratzel já dizia que "cada povo traz comsigo as marcas de seu paiz" [...]. (Carvalho, s/d, p. 3).

Outro problema com a interpretação de Febvre se referia ao nacionalismo, que buscava o fortalecimento da Geografia francesa. O contexto histórico, na década de 1920, amplia esta antiga rivalidade entre os franceses e os alemães, decorrentes de conflitos bélicos, como a derrota francesa em 1871 e a Primeira Guerra Mundial (1914-1918), e disputas por territórios (Alsácia e Lorena). O nacionalismo encobria o fato de que os termos "determinismo" e "possibilismo" não se limitavam às fronteiras de determinado país.

Para simplificar a questão, digamos que existem duas grandes correntes da geographia humana: a corrente germânica, chamada determinista pelos seus adversários, e a corrente franceza, chrismada por si própria de possibilista. Não quer dizer que a divisão por nacionalidades seja tão marcada, há deterministas na França, na Escola de Science Sociale, por exemplo, onde ha verdadeiros predestinistas mesmo. Os americanos do norte são, em geral, ratzelianos, assim como alguns brasileiros que se ocupam da geographia humana. (Carvalho, 1935, p. 84 apud Costa, 2007, p. 84).

A "nova geografia", proposta por Delgado de Carvalho, não desconhecia as contribuições dos alemães para a feição moderna da Geografia e representava uma interpenetração dos dois polos, tão firmemente polarizadas em Lucien Febvre. Haveria um determinismo do meio, como uma imposição das barreiras naturais, por exemplo, que aos poucos podem ser superados pelos progressos científicos do homem. Por isso, argumentava no IX Congresso Brasileiro de Geografia (Florianópolis, 1940), que seria preferível examinar os conceitos emitidos pelos geógrafos, de diferentes correntes e países, do que priorizar "definições pouco satisfatórias". Classificações e "definições que delimitam são artificiais".

\footnotetext{
${ }^{201}$ Os três geógrafos - Delgado de Carvalho, Pierre Monbeig e Pierre Deffontaines - "construíram uma rede sociabilidade pautada na admiração, respeito e conhecimento mútuo. Compartilhando do mesmo espaço universitário - a UDF -, tinham o mesmo objeto de estudo: a geografia humana brasileira." (Costa, 2007, p. 83). Isso fazia com que Delgado de Carvalho (1941, p. 426) definisse Deffontaines como "o grande construtor, no momento presente" da Geografia Humana.
} 
(Carvalho, 1941, p. 422). Toda fórmula proposta, não passa de um ponto de vista Em uma das edições de "Geographia Humana: política e econômica”, advertia:

As citações de mim mesmo que acima fiz, não me collocam, evidentemente, em escola alguma, mas me permitem tomar discretamente posição entre as duas correntes principaes que actualmente occupam o campo dos estudos da geographia humana. Sem serem antigas, estas palavras não são de hontem e deixam acreditar que não se tem modificado muito profundamente os meus pontos de vista sobre a matéria [...]. (Carvalho, 1935, p. 84 apud Costa, 2007, p. 84).

Ao defender diferentes intercâmbios, destacando intelectuais anglo-saxões, americanos, embora com a primazia de alemães e franceses, Delgado segue um caminho próprio e que reconhece a necessária integração entre a Geografia e as outras ciências. A sua opção intermediária, "condicionalismo geográfico", leva em consideração o "conjunto de probabilidades de realização em determinado momento histórico": "as probabilidades se multiplicam com as condições" (Carvalho, 1949, p. 26). Condições sociais, políticas, científicas, econômicas, militares, entre outras, levam, em determinadas circunstâncias históricas, os grupos humanos a utilizarem o meio natural deste ou daquele modo. Sobre o meio age o homem, do mesmo modo que o meio também atua sobre o homem.

Em relação ao ensino da Geografia, algumas premissas são consideradas essenciais. A primeira delas é uma "memória regular". Alguns fatos, mesmo que reduzidos ao mínimo indispensável, são considerados fundamentais para a compreensão de determinados conhecimentos. O dado memorizado é utilizado para a resolução de problemas. Igualmente, uma "imaginação visual” é necessária: "porque a Geografia é menos uma coleção de nomes do que uma coleção de paisagens e quadros." (Carvalho, 1949, p. 25). Discernimento "para interpretar as influências geográficas" e "largueza de espírito" são necessários a "uma interpretação simpática das nações e de suas condições de cultura” (p. 25-26). Tal teoria, "condicionalismo geográfico", e as condições de ensino induziram, primeiramente, a uma mudança de conteúdo. Da nomenclatura e do descritivo, passou-se à explicação e à interpretação dos fenômenos. Da exclusividade da Geografia Física, chegou-se à necessidade da Geografia Humana e Regional.

A crítica ao método é uma constante na produção de Delgado de Carvalho e ocupa posição importante em "Didática das Ciências Sociais" (1949). Isso porque o método, na concepção do educador, consiste numa série de atividades organizadas pelo professor com o intuito de gerar nos alunos certo número de 
resultados. Desse forma, como definiu Anísio Teixeira (1979, p. 33) os métodos não são "nenhum conjunto de fórmulas ou regras pedagógicas, mas o modo por que devemos dirigir a vida das crianças para o seu máximo crescimento e máximo aprender." Para um “aluno novo" era preciso, antes, uma renovação nos métodos.

Os programas secundários melhoraram e os compêndios se foram transformando aos poucos. Possuimos hoje excelentes manuais de Geografia e de História; os nossos programas equivalem aos estrangeiros tidos por adiantados. Temos também bons professôres. Entretanto, há razões para não estarmos satisfeitos com os resultados da aprendizagem em Geografia e História. O ponto fraco é o método. (Carvalho, 1949, p. 41).

Há 70 anos, Delgado criticava a ênfase na preparação para os exames em detrimento da compreensão. $\mathrm{O}$ aluno se preocupava em memorizar e não necessariamente em estudar e para isso contribuíam os métodos adotados nas escolas brasileiras. Os métodos tradicionais, baseados em "processos de autoridade", algo que ele apontava desde a década de 1930, balizavam-se na preleção do professor, lição, recitação (pelos alunos, do "aprendido" durante as aulas) e explicações complementares. O objetivo final, no curso secundário, era a realização das "provas parciais", que estimulavam a memorização pura e simples e o recurso à "cola" (Carvalho, 1949). Era um modelo que não levava em consideração as possíveis diferenças individuais de aprendizagem e de interesse. Formava-se em série (Teixeira, 1968), como em uma grande indústria. Dito isso, Delgado assinala que uma das principais finalidades da escola secundária deve ser, como apontavam John Dewey e Anísio Teixeira, possibilitar o educando a "aprender a aprender" (p. 42). Para tanto indicava o "estudo-dirigido" como:

[...] a arte de ensinar os jovens a aprender. Talvez mais do que em outras ciências, esta arte é necessária em ciências sociais. $O$ aluno se lembra mais do que compreende; pensa que o essencial não é compreender, mas memorizar porque pode "cair" em prova. Aí está o êrro que o estudo-dirigido precisa combater: devemos convencer o educando de que precisa memorizar não apenas para a prova, mas em vista de um aproveitamento ulterior. (Carvalho, 1949, p. 42).

A memorização teria, assim, uma utilidade. Os fatos retidos seriam mobilizados na construção de argumentos para os debates, na comparação e na ilustração de raciocínios. Não se entrega ferramentas (compêndios, por exemplo) a um aprendiz (aluno) sem que lhe ensine como manejá-las (Carvalho, 1949). O mestre é apenas um orientador e o compêndio apenas um auxiliar para o estudo, existindo outros materiais e fontes de estudo que permitem a ampliação do conhecimento sobre determinado assunto. Portanto, logo nos primeiros anos da 
escola secundária, os alunos deveriam ser apresentados ao estudo-dirigido. O seu fim prático residiria em habituá-los a utilizarem os compêndios, notas de aulas, mapas, atlas, dicionários e outras fontes necessárias às aulas em Ciências Sociais. A partir daí, seria possível guiar o pensamento, promover reflexões e "desenvolver o espírito crítico do educando" (Carvalho, 1970, p. 227), bem como desenvolver as capacidades de observação, julgamento e raciocínio. No interior dessa metodologia, haveria o estímulo à construção de resumos, fichas, dissertações históricas, quadros sinópticos, isto é, "técnicas de trabalho intelectual" para além da aula expositiva e que romperiam com a cultura livresca da escola secundária. No quadro abaixo, sintetizamos os principais procedimentos didáticos indicados por Delgado de Carvalho (1949) e os seus objetivos centrais.

\begin{tabular}{|c|l|}
\hline Método & \multicolumn{1}{c|}{ Objetivo principal na escola secundária } \\
\hline $\begin{array}{c}\text { Organização de fichas } \\
\text { de estudo }\end{array}$ & $\begin{array}{l}\text { Iniciar o trabalho de pesquisa. } \\
\text { Demonstrar que existem outras possibilidades para se adquirir o } \\
\text { conhecimento, além da fala do professor. } \\
\text { Estimular o aluno a estudar durante todo o período letivo e não apenas } \\
\text { em vésperas de provas. }\end{array}$ \\
\hline $\begin{array}{c}\text { Textos e leitura } \\
\text { explicada }\end{array}$ & $\begin{array}{l}\text { Estimular a interpretação escrita e exposição oral. } \\
\text { Analisar "textos-documento" (fontes primárias) ou "textos-leitura" } \\
\text { (textos contemporâneos aos alunos). }\end{array}$ \\
\hline $\begin{array}{c}\text { Dissertação histórica } \\
\text { Geografia }\end{array}$ & $\begin{array}{l}\text { Preparar para uma "expressão escrita lógica, planejada e sistemática } \\
\text { de seus conhecimentos". }\end{array}$ \\
\hline $\begin{array}{c}\text { Socialização em sala de } \\
\text { aula }\end{array}$ & $\begin{array}{l}\text { Capacitar à leitura de diferentes materiais de análise (livros, mapas, } \\
\text { pequenas experiências). }\end{array}$ \\
\hline Excursão geográfica & Possibilitar o contato com diferentes realidades. \\
\hline Teste-questionário & Incentivar o conhecimento dos tópicos estudados e o questionamento. \\
\hline
\end{tabular}

Quadro 14 - Métodos de ensino em Ciências Sociais

Fonte: Elaborado a partir de Carvalho (1949).

Para uso dessas metodologias, são apontados exemplos oriundos exclusivamente das disciplinas Geografia e História. Contudo, para o autor, tal pedagogia poderia ser transposta para as demais disciplinas componentes das Ciências Sociais. Uma das grandes dificuldades na leitura das obras e textos de Delgado de Carvalho é entender, de forma mais ou menos clara, como ocorreria a reunião das disciplinas em um curso de Estudos Sociais. Se o ideal, nas argumentações do autor, seria uma disciplina com esse nome, ele trabalha em termos de disciplinarização, ou seja, com o ensino de disciplinas compartimentadas tal como ocorria na escola secundária brasileira da década de 1940. As "unidades didáticas" se mostravam como uma forma de integração das 
ciências humanas. Na definição de Carvalho (1949, p. 51, grifos do autor), "as unidades didáticas são unidades de atividade-experiência que correspondem a propósitos e atitudes em face de cousas para aprender ou fazer por experiência. Esta palavra é usada no sentido mais largo, bem entendido.” Ou seja, experiência como uma parte integrante da vida. A referência, uma vez mais, é a Dewey e a intelectuais vinculados à sua escola de pensamento.

"A unidade, diz H. Harap, envolve uma variedade de atividades, de comportamentos, incluindo respostas a perguntas, observação, demonstração, discussão, preparação de material, processos comparativos e o resto. Traz para a sala de aula os próprios materiais, como eles se apresentam na vida". Pois Dewey não disse: educação é vida? (Carvalho, 1949, p. 51).

Uma das características das "unidades didáticas" residiria na apresentação de outras possibilidades de ensinar, partindo-se da ampliação dos meios didáticos. Seu desenvolvimento poderia durar de uma a seis semanas, onde se estabeleceriam "propósitos específicos" para a obtenção de conhecimentos sobre as matérias estudadas em História e Geografia, por exemplo. Em suma, é uma nova roupagem para o método de projetos tal como defendido na década de 1930 por intelectuais, como Maria dos Reis Campos. O método de projetos e as unidades didáticas apoiavam-se em questões e subsequente pesquisa. Com isso, na análise de Carvalho (1949, p. 53), tende-se a eliminar as barreiras existentes entre as disciplinas, já que "pesquisas se estendem e um argumento leva a outro".

A utilização desses novos métodos de ensino não significava o abandono do considerado como tradicional. Mesmo a rotineira "recitação" pelos alunos não poderia ser eliminada. Se como um processo de verificação do aprendizado ela é falha e desigual, já que nem sempre o aluno que melhor recita é o que mais aprendeu, é uma forma de construção de hábitos de expressão oral e elocução (Carvalho, 1949). Em outra passagem da obra, Delgado de Carvalho (1949, p. 79) esclarece o que entende enquanto educação como vida e de que forma tal abordagem se insere no ensino de Ciências Sociais por ele preconizado:

"Educação é vida". Esta fórmula de Dewey tem orientado ultimamente o ensino para práticas mais vitalizadas, isto é, para maiores contactos dos educandos com realidades históricas, geográficas, econômicas e sociais. A palavra do mestre, o texto do compêndio, o mapa do atlas são agentes transmissores indiretos dos fatos e fenômenos por estudar e conhecer. A tendência atual é estabelecer contactos diretos. (Carvalho, 1949, p. 79). 
Anos depois, de forma complementar a esta afirmação, Delgado também refletiu sobre um pressuposto da pedagogia deweyana: "o aprender fazendo":

O método de exposição vem sendo o objeto de muitas críticas recentes, baseadas sobre a falta de atividade por parte do aluno, que "só aprende fazendo" e fica condenado a passividade, principalmente no ensino de Estudos Sociais. O argumento não é inteiramente justo: o aluno pode ser ativo, procurar fontes de informação e a preleção ouvida é apenas uma delas. Nem toda atividade é de movimento; pode, também, ser intelectual. (Carvalho, 1970, p. 148).

O "fazer" não necessariamente se enquadra numa camisa de força como “colocar a mão na massa”. Se na escola primária, como vimos a partir da análise do PCS (1934), o aluno produzia, construía uma maloca, no curso secundário esse fazer se relaciona a análises, busca por compreensão, abstração. Em relação ao ensino de História, isso poderia ser feito através do exame de um "textodocumento", um escrito da época em que os alunos estivessem estudando. É importante assinalar que, ao indicar tal prática, Delgado não se apoia na noção restrita de documento da escola metódica. Embora não seja possível afirmar com ampla certeza, já que não há uma citação direta, o educador parece se inspirar na concepção de documentos defendida pela historiografia francesa a partir da década de 1930. O documento não é apenas o oficial, escrito e preservado nos arquivos. São considerados documentos possíveis de serem utilizados nas aulas, leis, jornais, correspondências, memórias, relatórios de viagem, entre outros. Mais ainda: ele preconiza uma análise documental na escola através de "uma reconstituição preliminar do quadro histórico da época, indicando as datas, o local, os personagens, o sincronismo histórico e, se possível, algo a respeito do autor." (Carvalho, 1949, p. 82). Para tanto, seriam indispensáveis os auxílios prestados pelo professor e o acesso a uma biblioteca.

Cada uma das metodologias indicadas tinha como fim primordial a transformação do aluno em um "aprendiz pesquisador", apto a participar do processo de construção do conhecimento e capaz de consultar diferentes fontes, organizando o seu pensamento de forma a construir uma cultura que sobreviveria aos anos escolares. A socialização em sala de aula permitiria um trabalho mais ativo. Isso ocorreria porque neste ambiente o aluno tem acesso a documentações, livros, mapas, anuários, ilustrações e pode realizar pequenos trabalhos de investigação. $\mathrm{O}$ acesso ao conhecimento ocorre de forma mais direta, não dependendo exclusivamente do verbalismo e explanação do professor. Ao 
explicar este método, Delgado de Carvalho (1949) realiza uma crítica a uma característica que permeia a educação brasileira ainda no século XXI: o número excessivo de alunos nas turmas. A divisão em pequenos grupos permitiria uma maior socialização entre os discentes, melhor cooperação e maior atenção às necessidades individuais de cada um. A partir da delimitação de um problema geográfico ou de um tema histórico, divide-se a turma em grupos e iniciam-se as pesquisas. O professor, nesse caso, só orienta o desenvolvimento dos trabalhos.

Os novos métodos impõem outras formas de avaliação. Ao consultar o acervo de Delgado de Carvalho no IHGB nos deparamos com um conjunto de provas e testes padronizados de História Contemporânea, datadas de 1962, que nos ajuda a entender o sentido de avaliação presente em "Didática das Ciências Sociais" (1949) e a contrapor as distâncias entre a teoria e a prática do professor Delgado. Teste é uma prova escrita, convencional que, muitas vezes, só admite uma resposta e exclui a possibilidade de várias interpretações. Pode ser utilizado para o conhecimento das lições. Trata-se de uma recitação por escrito, que mede a capacidade do aluno de retenção daquilo que foi estudado. Contudo, "o seu objetivo final não é sómente habilitar o mestre a dar uma nota, mas visa a averiguar a integração de conceitos que vão capacitar o educando para aplicá-los a novos problemas.” (Carvalho, 1949, p. 60). É uma avaliação diagnóstica.

De acordo com Carvalho (1949, p. 63-64), “a exposição oral do professor, feição tradicional, sempre foi e continua a ser uma das mais indispensáveis no ensino, tanto da História, como da Geografia ou da Economia Política." O teste aplicado após as primeiras pesquisas e estudos dirigidos possibilita ao docente reconhecer o desenvolvimento da turma e a constituição da sua preleção, corrigindo, complementando e salientando determinados tópicos. A recomendação é que ela deva ser feita após o teste, considerando-se que este apresenta ao professor as deficiências da turma. Os testes de Delgado de Carvalho, elaborados a partir de cinco questões, apresentam tendências tradicionais e aspectos mais inovadores, por assim dizer. 


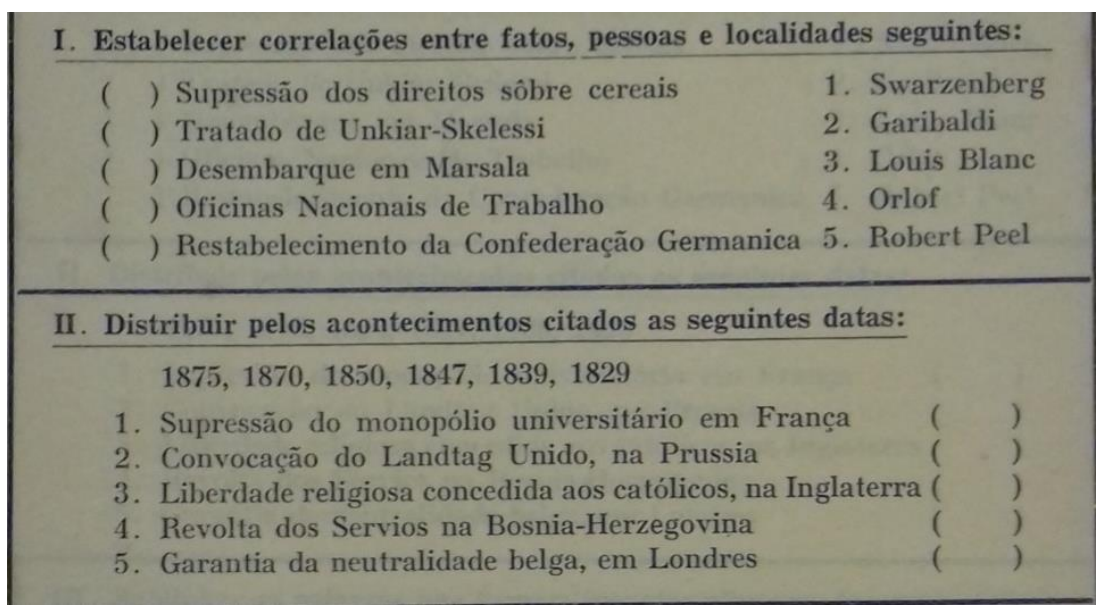

Figura 13 - Fragmento 1 de História Contemporânea, III série, Teste de Revisão Fonte: CDC/IHGB. Lata 11. Pasta 1: Testes.

O teste de conhecimentos é considerado por Delgado de Carvalho (1949) como uma forma de "aferição rápida" dos resultados do estudo. Não é um questionário porque não admite explicações. Contudo, apesar das inovações em termos metodológicos e crítica a certa cronologia, as datas continuam mantendo uma posição importante no modelo de avaliação apresentada. É um "teste de memória" e baseado em eventos! As questões acima apresentam duas feições salientadas por Carvalho (1949) em relação a testes de História: "teste de distribuição de correlações entre fatos, pessoas e lugares", buscando-se as relações entre eles (Questão I); e, "testes de distribuição de datas", objetivando analisar se o estudante localizou no tempo os fatos estudados (Questão II). Outros elementos indicados são "testes de melhores razões", que consistem em sublinhar fatores importantes de determinado fato histórico e os "testes de certo ou errado", em que o aluno teria de informar o erro em determinada afirmação. Entretanto, tais questões mediam exclusivamente a memorização e não possibilitavam uma apreensão da articulação entre o dado memorizado e a construção do pensamento por parte do discente. Tal tarefa ficava restrita à última questão, que não se articulava com as anteriores. Todos os testes terminavam com a formulação de uma "dissertação histórica". Era uma oportunidade de o aluno organizar o seu pensamento através da escrita e discorrer sobre determinado tema. 


\section{Escrever no verso dez linhas sôbre um dos temas seguintes:}

a) O tratado de San-Stefano e seu destino ulterior

b) A questão austro-prussiana dos ducados de 1864 a 1866

c) A atuação de Garibaldi depois de 1860

Figura 14 - Fragmento 2 de História Contemporânea, III série, Teste de Revisão, Dissertação Histórica

Fonte: CDC/IHGB. Lata 11. Pasta 1: Testes.

$\mathrm{Na}$ "dissertação histórica", conforme o posicionamento do docente, o aluno poderia consultar os materiais por ele coletados e organizados durante as aulas, as suas fichas, como um substituto das fraudes e "colas" tão habituais nas escolas brasileiras. De acordo com Delgado de Carvalho (1949), tal avaliação levaria a uma reflexão sobre nomenclaturas que não poderiam ser evitadas, coordenação de ideias, seleção de referências e ao aprimoramento dos hábitos de escrita em linguagem correta. Desse modo, a avaliação deve levar o aluno à argumentação, ao raciocínio sobre determinado assunto, a "coligir dados, estabelecer sequências, fazer comparações, aplicar princípios gerais a casos particulares, em suma, dissertar.” (p. 130). Tratava-se de uma máxima de Delgado de Carvalho (1970, p. 275): “aprender para si é uma coisa, aprender para explicar aos outros é coisa diferente." Delimitados os métodos, era necessário apresentar uma proposta de currículo de Estudos Sociais. "Introdução metodológica aos Estudos Sociais" (1957) dedica-se a pensar o programa escolar.

\section{4}

Para além dos métodos: a definição de um programa escolar de Estudos Sociais para a escola secundária

\footnotetext{
O termo "Estudos Sociais" se refere aqui ao conjunto das matérias de ensino cujo conteúdo científico é proporcionado aos educandos de grau secundário pelas "Ciências Sociais" propriamente ditas, isto é, a Geografia, a História, a Política, a Sociologia e a Economia. (Delgado de Carvalho, 1953, p. $54)^{202}$.
}

Embora "Introdução metodológica aos Estudos Sociais" seja a principal referência dos pesquisadores (Azevedo, 2014; França, 2013; Nadai, 1988; Nascimento, 2012; Santos, 2011) que analisam a concepção de Delgado de

\footnotetext{
${ }^{202}$ Quatro anos após essa definição de Estudos Sociais, em "Introdução metodológica aos Estudos Sociais", Carvalho (1970) acrescentou a Antropologia Cultural como um dos seus componentes.
} 
Carvalho sobre o ensino desta disciplina, trata-se da sistematização de argumentos defendidos pelo autor desde a década de 1930. Consideramos que naqueles anos Delgado construiu sua visão geral sobre os Estudos Sociais, mesmo que alguns aspectos tenham sido repensados posteriormente. $\mathrm{Na}$ obra originalmente publicada em $1957^{203}$, foram retomados aspectos de títulos, como o "Programa de Ciências Sociais" (1934) do Distrito Federal, "As Ciências Sociais na escola secundária" (1940a), palestra proferida na Associação Brasileira de Educação, e "Didática das Ciências Sociais" (1949), publicização do conjunto de aulas para docentes mineiros. A obra inova ao distinguir Ciências Sociais e Estudos Sociais e ao propor um programa escolar para o ensino destes últimos na escola secundária.

Na década de 1950, além da já mencionada "Introdução metodológica aos Estudos Sociais", Delgado de Carvalho escreveu "Os Estudos Sociais no curso secundário" (1953) ${ }^{204}$, artigo publicado na "Revista Brasileira de Estudos Pedagógicos", de onde extraímos a epígrafe desta seção. O artigo representa uma síntese do livro, que amplia as discussões reunidas em apenas sete páginas. Em ambos os trabalhos, Delgado argumenta que era no campo dos Estudos Sociais que se encontravam as maiores falhas nos currículos e programas escolares e como resultado a educação não conseguia "prender o espírito dos educandos", muito menos despertar sua curiosidade e interesse pelo conjunto de disciplinas ministradas na escola secundária (Carvalho, 1953). Isso ocorria porque elas não refletiam as preocupações do momento histórico em que viviam os alunos: "o abismo existente entre o progresso material da nossa civilização e o atraso mental do momento é a tragédia do mundo moderno e cada vez mais irá acentuando, se a educação não preparar os indivíduos para o meio em que são chamados a viver." (Carvalho, 1970, p. 73). Ao ministrar conhecimentos considerados, pelo autor, como tradicionais, o ensino secundário dificultava o desejo de aprender dos alunos. Essa perspectiva era a mesma defendida por Anísio Teixeira (1979, p. 36):

Tal ensino divorcia-se de todas as condições de uma verdadeira aprendizagem. O aluno, não vendo nenhuma relação da "matéria" com sua vida presente ou qualquer empreendimento em que esteja empenhado, não pode ter motivo para se esforçar; não tendo motivo, não pode ter desejo ou intenção de aprender (salvo motivos

\footnotetext{
203 Uma segunda edição, revista e ampliada, foi publicada em 1970, contudo, não apresenta alterações significativas em relação à primeira. Utilizamos nesta tese a segunda edição.

${ }^{204} \mathrm{O}$ artigo tem o intuito de esclarecer o que são os Estudos Sociais, seus objetivos, conteúdos e métodos e foi dividido em quatro partes: 1) O campo dos Estudos Sociais; 2) Os objetivos dos Estudos Sociais; 3) O que deve ser ensinado; e, 4) Como pode ser ensinado (Carvalho, 1953).
} 
artificiais ou falsos); não tendo a intenção de aprender, não pode assimilar ativamente a matéria, integrando-a a sua própria vida.

Por isso mesmo, como argumentava Carvalho (1970, p. 175):

Deve o educando ser mantido, o mais próximo possível, da vida real. Nas suas experiências escolares, quanto mais reais forem as situações, maiores probabilidades terão de reconhecer as ocasiões de aplicá-las. Reduzir-se-á assim o verbalismo, visando sempre um pouco além do material escolar disponível, pois este não pode fornecer experiências para todas as situações.

Para Delgado de Carvalho (1970), escrevendo após duas guerras mundiais e em plena Guerra Fria, o mundo estava vivenciando uma época de transição e de rápidas e intensas transformações, decorrentes tanto de acontecimentos políticosociais quanto do desenvolvimento dos conhecimentos técnico-científicos. Esse processo impunha a necessidade de uma nova filosofia educacional e aos Estudos Sociais cabia a tarefa de explicar e preparar para a vivência neste mundo de transformações aceleradas, não podendo o professor se furtar de discutir situações da complexa vida real. Esta é formada por elementos interpendentes, "isto é, a vida social, em momento nenhum, é exclusivamente geográfica, exclusivamente histórica ou exclusivamente econômica. Por isso mesmo, um só deles não é suficiente para explicá-la.” (Carvalho, 1953, p. 56).

$\mathrm{Na}$ vida não há subdivisões, os intelectuais e professores as criaram por conveniência e para facilitar suas análises. Para a compreensão de determinados temas seria importante a contribuição de várias disciplinas, como já salientavam as "Bases do Preparo de Programmas" (Bagley et al., s/d) - referência para elaboração dos programas da reforma anisiana nos anos de 1930. A justificativa, utilizando o educador inglês James Hemming, é a de que a escola ao ministrar conhecimentos a partir de "departamentos estanques" não corresponde a todas as necessidades das crianças. Nesse sentido, os resultados desta educação se tornam fragmentos ou "remendos", já que não há "um plano específico de curso, para a formação da compreensão social da criança" (apud Carvalho, 1970, p. 69). Segundo essa argumentação, "há, pois, uma integração, [e] é natural que a tendência da educação moderna seja para esta integração, único meio de restituirlhes a realidade que refletem." (Carvalho, 1970, p. 21). Assim, a sociedade humana deixaria de ser estudada em abstração e passaria a ser abordada a partir da realidade. Daí decorre o sentido dos Estudos Sociais no currículo. 
É exatamente esta dependência de um fato histórico, por exemplo, de fatores geográficos e de circunstâncias econômicas, em certas condições culturais, que o ensino de professores de estudos sociais não consegue, na hora presente, explicar e interpretar claramente, por falta de elementos de informação, por deficiência de treino e preparo ou por pura rotina. (Carvalho, 1953, p. 56).

Tendo em vista este princípio, Delgado defende que o ensino deveria visar à restituição da complexidade da vida, ou seja, "a realidade da vida social" e a interdependência dos diferentes elementos que a compõem. Portanto, "os estudos sociais, pois a eles cabe essa disciplina, deveriam, no currículo, constituir uma única disciplina." (Carvalho, 1953, p. 56). Para isso seria fundamental a formação do professor. $\mathrm{O}$ educador indica que o currículo só se tornaria funcional ou reflexo da realidade quando o magistério secundário fosse instruído na aplicação dos Estudos Sociais. Delgado não aborda esta questão de forma objetiva nos seus escritos da década de 1950, nem defende a criação de uma licenciatura em Estudos Sociais que formasse o professor para a disciplina que idealizava. Argumenta que naquele momento era "mais prudente observar a divisão por disciplinas", que teria duas vantagens principais: "a primeira de dividir e classificar os fenômenos para apreendê-los mais facilmente, a segunda de permitir um exame mais aprofundado de cada um deles” (p. 56). Respeitar a divisão disciplinar não significava, na sua argumentação, esquecer que cada uma delas História, Geografia, Sociologia, entre outras - só oferece uma visão parcial da vida social, um aspecto das coisas. Para uma "visão global dos fenômenos", completa e capaz de uma "significação dos fatos e a sua explicação" o ideal seria uma disciplina intitulada como Estudos Sociais. De acordo com Carvalho (1970, p. 67-68) estes seriam os cinco objetivos da disciplina na escola secundária:

1. Conhecer e compreender os conceitos sociais e o valor das instituições;

2. Desenvolver, no indivíduo, a capacidade de estudar, ler e interpretar, com senso crítico, o que leu, ouviu e viu;

3. Despertar a personalidade do educando, desenvolvendo seus interesses culturais e seu senso de responsabilidade;

4. Integrar o indivíduo na sociedade democrática em que deve viver, promovendo a sua cooperação como bom cidadão;

5. Compreender a interdependência das nações no mundo moderno, respeitando as funções particulares dos diferentes grupos e contribuindo à compreensão internacional. 
Os objetivos se articulavam a atividades que levassem os alunos a terem plena consciência do lugar que ocupavam na sociedade. Pela perspectiva anisiana, "não se aprende nunca uma coisa só". Junto com conteúdos são ensinadas atitudes que os alunos levam para as suas vidas. Do mesmo modo, "só se aprende o que se pratica", o que significa que é na escola que começam a ser construídos sentimentos democráticos e senso crítico (Teixeira, 1979). É importante observar que para Carvalho (1970) os Estudos Sociais não deveriam ser ministrados segundo nenhuma doutrina, pois se tratam de estudos objetivos: "na realidade, os estudos são essencialmente objetivos e não comportam doutrinas econômicas, políticas ou sociais" (Carvalho, 1970, p. 16) e não podem "reconhecer valores e manifestar preferências" (p. 62). Portanto, não era e não poderia ser uma disciplina de caráter doutrinário. A educação era entendida como um processo constante, em que caberia a escola e, especificamente, aos Estudos Sociais fornecer os instrumentos necessários à formação de um homem capaz de continuar aprendendo e fazendo uso daquilo que já aprendeu. A cooperação, como já destacamos, seria algo essencial, bem como o conhecimento da sociedade e suas instituições. Tudo isso seria abordado de forma crítica e mais imparcial possível, para que o aluno construísse seus posicionamentos e caminhos ${ }^{205}$.

Na década de 1950, Delgado realizou uma diferenciação entre Ciências Sociais e Estudos Sociais, algo que não fica claro nas suas obras anteriores. Para ele, tal distinção começou a ser produzida pela Associação Nacional de Educação dos Estados Unidos, com a criação, em 1916, da "Comissão de Estudos Sociais" e a afirmação, em 1921, do "Conselho Nacional de Estudos Sociais". Na realidade, como abordamos no capítulo 4, foi a Associação Americana de História, através da sua investigação sobre o ensino de Estudos Sociais nas escolas no início da década de 1930, que estabeleceu as diferenças. Na definição de Krey et al. (1934, p. 7): “a função principal das ciências sociais é a aquisição de conhecimento preciso, e percepção informada do homem e da sociedade; já a do ensino das ciências sociais é a transmissão de tal conhecimento e percepção." ${ }^{206}$ Delgado de Carvalho se apropriou desta delimitação. Para ele:

\footnotetext{
205 De acordo com Carvalho (1970), em Ciências Sociais não há como ser neutro, porque o pesquisador pertence a um "quadro social", em que está envolvido pelos fatos e fenômenos que observa e analisa, mas ele pode ser justo nas suas apreciações.

${ }^{206}$ Na década de 1950, a distinção já havia se consolidado entre os educadores norte-americanos. Duas obras que tiveram grande circulação no Brasil das décadas de 1960 e 1970 seguem
} 
As Ciências Sociais ocupam um campo bastante vasto, se não impreciso, pelo menos, suscetível de extensões e complexidades, à medida que vão evoluindo os conhecimentos. Como disciplinas especiais, elas são produtos de pensamento, de pesquisa, de experiência, de descoberta. Resultam de estudos científicos, desinteressados e elevados que contribuem para o progresso humano. (Carvalho, 1970, p. 15).

As Ciências Sociais seriam ensinadas sob a forma de Estudos Sociais. Se até a década de 1950 os dois termos foram utilizados no pensamento educacional brasileiro de forma imprecisa, a partir deste momento passou-se a compreender os Estudos Sociais enquanto uma disciplina escolar e talvez até universitária, uma organização de cunho pedagógico e cujo objetivo não era a investigação científica, mas o ensino e a vulgarização daquilo que é produzido no âmbito das Ciências Sociais. Seu campo, como argumenta Carvalho (1970), era idêntico ao das Ciências Sociais, pois ambos tratam das relações humanas, o que mudam são os propósitos de uma e outra: a finalidade dos Estudos Sociais "não é fazer progredir a ciência, mas educar. Sem ser ciência normativa, as Ciências Sociais guiam os Estudos Sociais e os levam a conclusões práticas, instrutivas e úteis.” (p. 16). Isso não significa que Delgado dispensasse a "inserção da análise e da pesquisa, próprias do método científico, na prática escolar.” (Santos, 2011, p. $151)$.

As fontes primárias, inclusive as ainda não analisadas, segundo as facilidades de sua posse, deveriam ser material básico dos Estudos Sociais. Carvalho (1970, p. 17) argumenta que seria "pouco provável que [suas análises nesta disciplina] acarretem progressos ou mudanças fundamentais no campo de conhecimentos científicos a respeito do Homem." Ao analisar o conceito de transposição didática de Chevallard, Ana Maria Monteiro (2007) afirma que, para essa perspectiva, "apesar de haver uma pluralidade de saberes ("saber acadêmico", "saber a ensinar", "saber ensinado", "saber aprendido"), o saber acadêmico é sempre anterior ao saber ensinado.” (p. 84). Entretanto, Delgado não desconsiderava a importância dos outros saberes, incluso o saber escolar, e não

definições semelhantes. Ralph Preston (1965), em seu livro "Ensinando Estudos Sociais na Escola Primária", publicado nos Estados Unidos em 1950, sintetizava que "os Estudos Sociais são capítulos das Ciências Sociais selecionados para serem utilizados no ensino. As Ciências Sociais são ramos de conhecimento que abrangem o comportamento social do homem, sua vida social e suas instituições sociais." (p. 16-17). Por sua vez, John Michaelis (1963), autor de "Estudos sociais para crianças numa democracia", publicado nos Estados Unidos em 1956, afirmava que: "as Ciências Sociais são estudos acadêmicos e adiantados das relações humanas, ao passo que os Estudos Sociais constituem uma área do currículo semelhante às artes da linguagem.” (p. 5). 
entendia o saber acadêmico como única referência para aquilo que poderia ser ensinado na sala de aula. Portanto, o material produzido pelas Ciências Sociais é reelaborado na forma de Estudos Sociais, cuja função "seria a de construir interpretações tanto sobre o material fornecido pela sua congênere científica quanto sobre as posturas do homem em sociedade." (Nascimento, 2012, p. 52).

Explicitada a distinção entre as disciplinas científicas e as disciplinas escolares, Carvalho (1970, p. 15-16) defende que "os Estudos Sociais podem constituir matéria de ensino em todos os graus escolares, tanto no primário quanto no secundário e no superior." O seu grau de simplificação, dosagem e aprofundamento dependeria do nível de ensino em que porventura fosse ministrada. Entretanto, em nenhuma passagem encontramos uma defesa explícita quanto à criação de um curso superior de Estudos Sociais, como o que viria a ser criado e institucionalizado pelo Conselho Federal de Educação nas décadas de 1960 e 1970, embora se critique a "tendência marcada, entre nós, de separar os departamentos de História, Geografia, Filosofia, Ciências Sociais em cursos independentes e interligados." (p. 128-129). Talvez Delgado pensasse numa matéria de Estudos Sociais que interligasse os diferentes cursos de Ciências Sociais na universidade brasileira, nos moldes da experiência desenvolvida na década de 1930 no Instituto de Educação do Distrito Federal.

Patrícia Aranha (2017) salienta que em proposta enviada ao ministro Gustavo Capanema, em 1944, o catedrático da Universidade do Brasil apresentou uma estrutura para o curso de História e Geografia em que os alunos frequentariam, no primeiro ano, disciplinas de Geografia e de História e a partir do segundo ano disciplinas mais específicas. Deste modo, "mesmo o aluno que se especializasse em geografia, teria um ano de história na sua formação. Também sublinho que as disciplinas de antropologia e sociologia constituíam um diferencial em relação aos outros currículos.” (p. 87). Contudo, o que prevaleceu foi a ausência de articulação entre os cursos superiores de Ciências Sociais. O curso de História da Universidade do Brasil, por exemplo, passou a contar com apenas uma disciplina de Geografia após 1955 (Ferreira, 2013). Para Delgado de Carvalho, tal lacuna impactava, diretamente, a prática docente do professor de História e Geografia. A explicação deriva da ausência de "interdependência".

Como consequência desse "problema", as disciplinas, que deveriam se integrar como instrumentos complementares, não se harmonizavam na escola 
secundária. O professor era essencial para a realização da proposta de Delgado de Carvalho e é a ele que o catedrático se dirige ao expor novos métodos, propostas de programas e a renovação escolar. Para o educador, seria "mais eficiente o ensino de um bom professor com material pobre do que o ensino dispondo de bom material, com professor deficiente." (Carvalho, 1970, p. 118). A expansão do ensino secundário não foi acompanhada da ampliação dos cursos de formação de professores, o que fazia com que, ainda na década de 1950, muitos docentes fossem autodidatas. A deficiência, na análise de Delgado, tornava-se ainda mais complexa em relação aos professores de Estudos Sociais, consideradas como disciplinas "inexplicavelmente mais fáceis" (p. 118). Ele esclarecia tal posição:

Um candidato a professor de matemáticas ou português precisa conhecer a sua matéria, pois, em caso contrário, não será contratado pela administração do colégio. Mas, se se trata de um cargo de professor de História ou de Geografia, a diretoria do colégio não hesitará em aceitar os serviços do candidato, pois, basta saber ler e escrever para seguir, nos compêndios, o que tiverem de recitar os alunos. Um bom memorizador diplomado de datas e nomes próprios passa, ainda em nossas escolas, por um bom professor de História e Geografia e sua cátedra comporta, em geral, as duas disciplinas. (Carvalho, 1970, p. 118).

A ausência de uma preocupação maior com a formação e a seleção dos professores de Estudos Sociais não correspondia ao papel que suas disciplinas tinham na formação do aluno. Aos professores de Estudos Sociais, responsáveis por disciplinas cujo objeto é o homem e suas relações, para além do obrigatório conhecimento dos conteúdos que se há de ministrar na escola básica, são necessárias qualidades que aos outros docentes talvez não sejam tão cobradas.

A personalidade de um professor de Estudos Sociais necessita de predicados como sejam atitudes, capacidade de apreciação, ideais, cidadania de tipo superior; a ele incumbe manter, em grupos sociais discentes, um conceito democrático e uma prática das inter-relações sociais na altura das instituições de seu país. Até certo ponto, pode-se dizer que suas responsabilidades na Escola são maiores do que as de seus colegas de outras disciplinas, menos intimamente ligadas à ordem social e à vida internacional. (Carvalho, 1970, p. 119).

O professor de Estudos Sociais é, antes de tudo, um intérprete da sua comunidade, do seu tempo, da longa experiência humana em suas relações com o tempo presente. Tais qualidades o distinguem do cientista social. Para Delgado de Carvalho há diferenças entre o cientista e o professor, embora a função deste último seja primordial para a compreensão da realidade social. $\mathrm{Na}$ sua argumentação, o cientista é "o descobridor de primeira mão", o especialista em determinado ramo de conhecimento e responsável pelo "progresso da ciência". 
Como um "organizador do conhecimento", sua principal função é a formação de "novos pesquisadores e novos cientistas" (Carvalho, 1970, p. 34). Quase sempre atua na universidade, embora nem todos os professores do ensino superior possam ser considerados historiadores, geógrafos ou sociólogos. O próprio Delgado, embora catedrático de História Moderna e Contemporânea da Universidade do Brasil, não se considerava um historiador, mas um professor de História. Em palestra no IHGB, Carvalho (1971, p. 201) apontou que historiador "é o estudioso que pesquisa e escreve o resultado de suas pesquisas nos domínios da História." Aos professores, Delgado preferia a definição "pardais de Clio": "não pesquisam nem nada produzem de original, a não ser o modo de apresentar os assuntos." (p. 201-202). Os "pardais de clio" buscavam entre os materiais desenvolvidos pelos pesquisadores os elementos necessários às suas lições. A distinção entre o pesquisador e o professor era forte à época e estava institucionalizada no próprio modelo de formação de professores vigente. Emília Viotti da Costa (1957), em texto considerado clássico no campo do ensino de História, apontava as diferenças entre a "História Ciência" e a "História Matéria". De acordo com a professora da Universidade de São Paulo:

O problema dos objetivos do ensino de História no curso secundário, da finalidade do seu estudo, nos obriga a fazer uma distinção primeira entre História "ciência" e História "matéria". Há perigo de confusão dos conceitos. Uma e outra tem características diferentes. Para a História "ciência" não precisamos buscar uma finalidade. Esta, diria Marc Bloch, justifica-se por si mesma. (Costa, 1957, p. 118).

A História "matéria", por sua vez, tem que ter, necessariamente, uma finalidade. $\mathrm{Na}$ escola secundária seria a formação da personalidade integral dos alunos e a transmissão de conhecimentos básicos específicos (Costa, 1957). Há, claramente, um distanciamento entre o "fazer História" (História "ciência") e o “ensinar História" (História "matéria") ${ }^{207}$. As análises de Ferreira (2013) sobre o curso de História e Geografia da Universidade do Brasil, em que o próprio Delgado atuou, são importantes para a compreensão dessa distinção presente no

\footnotetext{
207 É importante salientar, também, de acordo com Costa (1963), que não necessariamente a História "matéria" precisava seguir os critérios que estavam presentes na História "ciência". Por exemplo: segundo a sua interpretação, na primeira fase da escola secundária, os alunos estariam muito mais interessados pelos grandes feitos artísticos, políticos ou militares, ou seja, pelas ações individuais, enquanto as tendências da historiografia naquele momento estavam mais preocupadas em "desvanecer a ação individual nos atos coletivos" (p. 29). Para Costa (1963), tal proposição não correspondia às tendências psicológicas dos adolescentes nas primeiras séries ginasiais e isso levava ao seu desinteresse pelo estudo histórico. Portanto, ao professor caberia ficar atento às questões pedagógicas e psicológicas, mesmo que isso o fizesse se distanciar da história científica.
} 
contexto e na obra deste intelectual. A autora nos esclarece que a proposta do curso de História da Universidade do Distrito Federal procurava "articular a profissionalização docente e a formação do pesquisador" (p. 31). Já o curso de História e Geografia da Faculdade Nacional de Filosofia optou por um caminho diferente ao enfatizar "a preparação de professores secundários sem maiores preocupações com o desenvolvimento da pesquisa.” (p. 36). Não havia uma introdução à pesquisa nas disciplinas de graduação. Maria Yedda Linhares, em depoimento a Ferreira (2013, p. 223), sintetiza as aulas de Delgado:

A concepção dele era muito de cursos gerais, amplos, introdutórios, sem qualquer pretensão a fazer qualquer tipo de pesquisa ou qualquer crítica bibliográfica. O que ele fazia era interpretação de texto, e isso já foi uma grande contribuição. Delgado de Carvalho foi uma pessoa extraordinária na sua época. Agora, não se pode dizer que ele fosse um scholar americano. Era um grande professor francês, preocupado em dar uma visão global de tudo.

As memórias de Maria Yedda são importantes porque indicam que Delgado levou para as suas aulas no ensino superior a mesma prática que tinha enquanto professor do Colégio Pedro II e do Instituto de Educação. Interpretação de texto era metodologia básica de suas aulas e proposta fundamental presente nas suas obras didáticas. A "visão global de tudo" era uma característica necessária ao professor de Estudos Sociais. A originalidade do seu trabalho estaria na recontextualização de assuntos, que poderiam ou não ser objeto dos cientistas. Ao professor caberia tornar inteligível aos alunos o mundo em que vivem, apresentando o seu lugar na sociedade, as atualidades sociais, e despertando o seu interesse pelas atividades sociais, para que nelas os discentes pudessem exercer a sua ação. Não é um simples vulgarizador, mas orientador, guia, conselheiro, auxiliar, colaborador. O professor não é um agente externo do processo de ensinoaprendizagem, mas "um líder das atividades do grupo" (Dewey, 1998, p. 60).

Os alunos compõem comunidades. O professor é um membro ativo desse grupo e, como elemento mais maduro, atua como coordenador das atividades: "ele tem a responsabilidade especial de conduzir as interações e intercomunicações que constituem a própria vida do grupo enquanto comunidade.” (Dewey, 1998, p. 60). Por isso, é alguém que precisa ter "uma sólida cultura geral, vistas largas, perspectivas sociais e, além de tudo, se manter continuamente a par da evolução social, política, econômica do mundo em que vive.” (Carvalho, 1970, p. 128). A 
ideia de professor como um cientista social é tributária do "Manifesto dos Pioneiros da Educação Nova" (1932), do qual Delgado foi um dos signatários:

[...] o educador, como o sociólogo, tem necessidade de uma cultura múltipla e bem diversa; as alturas e as profundidades da vida humana e da vida social não devem estender-se além do seu raio visual; ele deve ter o conhecimento dos homens e da sociedade em cada uma de suas fases, para perceber, além do aparente e do efêmero, "o jogo poderoso das grandes leis que dominam a evolução social", e a posição que tem a escola, e a função que representa, na diversidade e pluralidade das forças sociais que cooperam na obra da civilização. Se têm essa cultura geral, que lhe permite organizar uma doutrina de vida e ampliar o seu horizonte mental, poderá ver o problema educacional em conjunto, de um ponto de vista mais largo, para subordinar o problema pedagógico ou dos métodos ao problema filosófico ou dos fins da educação. (Azevedo, 1932 [2003], p. 126).

O conhecimento exigido do professor não é pouco. Além da "cultura geral", bem como pleno domínio de aspectos gerais da sociedade humana e do papel que a escola exerce sobre a civilização, era preciso compreender os discentes, sua situação, hábitos, personalidade. O auxílio prestado aos alunos não se limitaria aos conteúdos dos Estudos Sociais, mas seria necessário em questões que vão além do ensino, já que se tratava de uma disciplina essencialmente formativa. Por tudo isso, Carvalho (1970, p. 129) argumentava que "quaisquer que tenham sido as práticas de ensino em escolas de aplicação, o novo professor sempre encontra problemas de sala de aula que, para ele, ainda não foram esclarecidos, principalmente no ensino de Estudos Sociais.” Uma contribuição, nesse sentido, seria a última parte do seu livro, intitulada: "Técnica geral para integração dos Estudos Sociais". Se as duas primeiras partes da obra, "Conceituação dos Estudos Sociais" e "Fundamentos gerais dos Estudos Sociais", são mais teóricas, a terceira é prática, isto é, Carvalho (1970) descreve os métodos e avaliações, algo que já analisamos a partir de "Didática das Ciências Sociais" (1949), e propõe um programa escolar para os Estudos Sociais no curso secundário. 


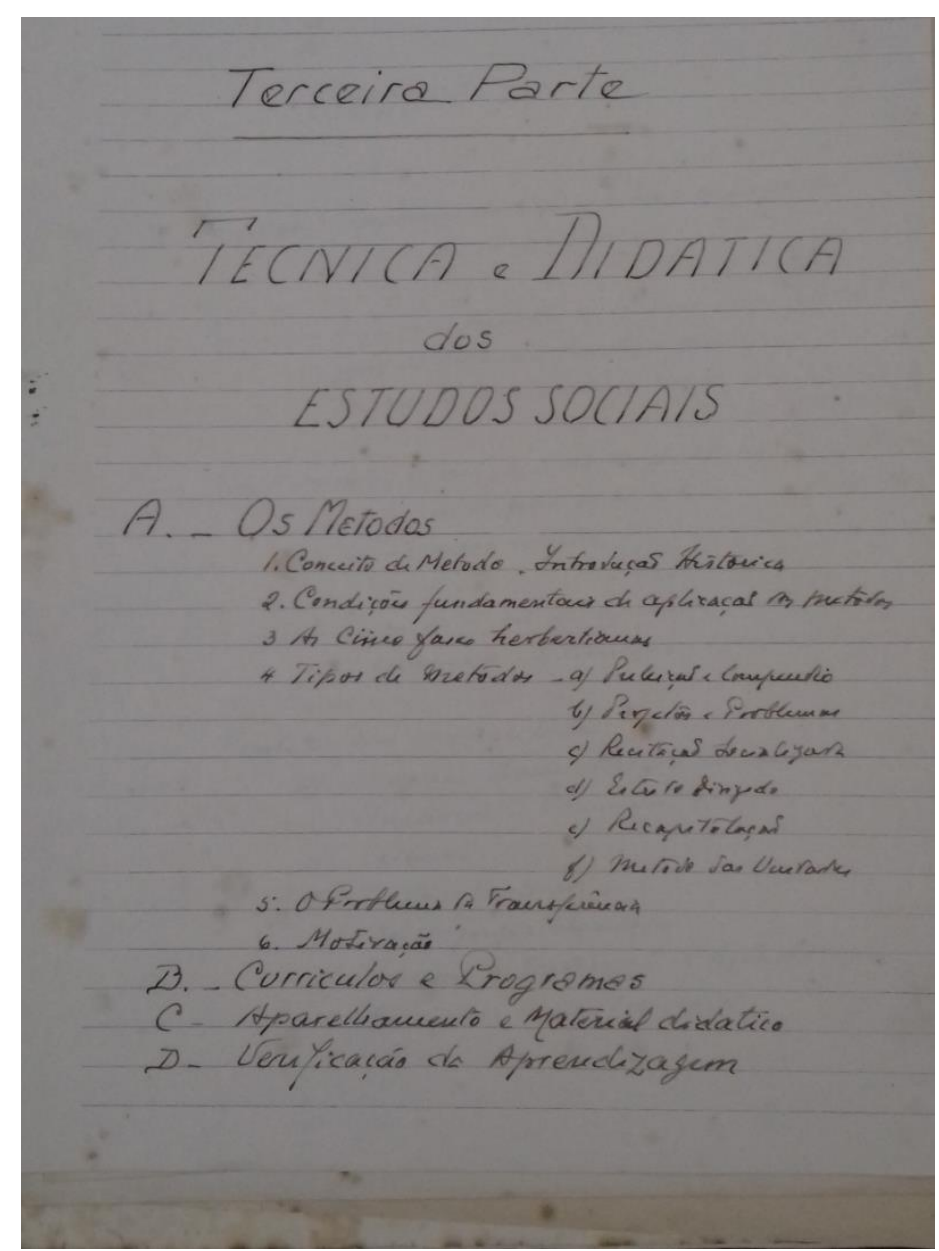

Figura 15 - Esboço de "Introdução metodológica aos Estudos Sociais" (1957) Fonte: CDC/IHGB. Lata 11. Pasta 3: Ensino de Estudos Sociais.

\subsection{1 \\ Programa de Estudos Sociais para a escola secundária}

Na argumentação de Carvalho (1970, p. 196), a primeira condição para a elaboração do currículo de Estudos Sociais é uma máxima deweyana: "toda experiência nova deve ter, como base ou ponto de partida, um conhecimento, isto é, uma experiência anterior (por mais elementar que seja)." O segundo aspecto a ser lembrado é o nível de maturidade (física, social e intelectual) do aluno a que se destina. Outro elemento é a inclusão de conteúdos que tenham valor e satisfaçam a uma necessidade do educando mesmo que, inicialmente, ele próprio não se dê conta disso. Cabe à escola despertar o seu interesse e apontar tal necessidade. A articulação entre o que se conhece e o desconhecido é o que promove a expansão da experiência. Por fim, os conteúdos precisam estar articulados à comunidade local e aos problemas de seu estado e nação. Na década de 1950, ocorreu uma 
mudança significativa no pensamento de Delgado a respeito do lugar da disciplina. Para ele, os Estudos Sociais deveriam ser ensinados nos anos finais da escola secundária, quando o aluno teria mais maturidade e após ter estudado as disciplinas escolares de forma independente. $\mathrm{O}$ objetivo do programa se articula à construção do senso crítico nos alunos. Nas palavras de Carvalho (1970, p. 198):

O currículo, por fim, destinado a alargar o horizonte espiritual do educando deve fornecer elementos que o levem a pensar bem, isto é, dotá-lo de juízo crítico. Necessita o indivíduo deste espírito de discernimento na sociedade de hoje mais do que em qualquer das épocas passadas. A imaginação é de tal modo solicitada pela propaganda e pelo noticiário, de sinceridade muito relativa, que o educando só pode ganhar acostumando-se, nas matérias do currículo, a pensar com sobriedade e imparcialidade. (Grifos nossos).

Tal disciplina habilitaria, pelo menos em termos de teoria, a "utilizar fontes de informação, a consultar livros em bibliotecas, a ler revistas entendendo do assunto, a interpretar relatórios e notícias, a discutir sem se revelar desprevenido." (Carvalho, 1969, p. 3, grifos nossos). Mais uma vez aparece a perspectiva de que os Estudos Sociais deveriam fornecer os instrumentos para uma boa cidadania: consciente e participativa. Delgado de Carvalho cita os principais elementos constituintes da aprendizagem em Estudos Sociais. Para tanto, baseia-se em "uma comissão de educadores americanos", embora não os localize no tempo ou no espaço. Pelos princípios defendidos, acreditamos se tratar das comissões da década de 1930. São cinco elementos:

1. Mentalidade mundial: a velha proposta do entreguerras de despertar "simpatia internacional" a partir da compreensão das experiências vividas por outros povos. A marcha do progresso fez diminuir a distância entre as nações e isso não poderia mais ser ignorado pelas escolas e currículos. Com as atrocidades da Segunda Guerra Mundial, o conceito de interdependência deveria ser mais bem desenvolvido;

2. Civismo ou instrução cívica não se limita apenas ao conhecimento dos direitos e deveres que um cidadão possui ou exerce em uma democracia, mas se relaciona a um estudo das estruturas políticas, sociais e econômicas das nações, visando uma compreensão de suas instituições e o lugar que nela ocupam os indivíduos;

3. Conhecimento econômico cujo objetivo era tornar o indivíduo um "consumidor esclarecido"; 
4. Compreensão vocacional visa proporcionar ao educando conhecimentos sobre as qualidades requeridas pelas diferentes profissões, as responsabilidades, problemas e possibilidades de cada uma delas;

5. Apreciação das relações de família, demonstrando a importância da família para o bem-estar da comunidade.

Tais princípios, tidos como "necessidades atuais do educando", só seriam possíveis a partir, primeiramente, de uma maior integração entre as disciplinas, com estreita cooperação entre professores e, posteriormente, através da fusão de disciplinas. Em um primeiro momento, os Estudos Sociais podem ser entendidos como uma área de estudo - embora o próprio Delgado de Carvalho (1970) não use tal expressão -, em que cada professor colaboraria com o outro na formulação de planos de ensino. No segundo momento, aparecem, de forma clara, como uma disciplina. O educador defende que, no ciclo ginasial do ensino secundário, cada uma das disciplinas dos Estudos Sociais - leia-se História e Geografia, aquelas que tinham um lugar oficial no currículo - manteriam a sua independência, porém com reformulações em seus programas e métodos e uma organização mais flexível e menos compartimentada. Os conteúdos seriam assim distribuídos:

[...] nas três primeiras séries do Curso Ginasial, a Geografia Geral do Brasil seria ensinada paralelamente à História do Brasil, Colônia, Império e República; a Geografia Física e Humana acompanharia a História Antiga e Medieval; por fim, a Geografia dos Continentes, na $3^{\mathrm{a}}$ série, corresponderia à História Moderna e Contemporânea. (Carvalho, 1970, p. 209).

Diferentemente da proposta americana de 1916, que tinha os Estados Unidos como conteúdo principal, Delgado propôs um currículo com forte ênfase na História Moderna e Contemporânea e nas relações internacionais - assuntos que dariam “a necessária visão do Mundo Atual” (Carvalho, 1953, p. 59). Uma abordagem mais próxima do que defendiam as comissões da American Historical Association na década de 1930 e em consonância com aquilo que indicavam os diferentes seminários organizados pela Organização das Nações Unidas para a Educação, a Ciência e a Cultura (Unesco) na década de 1950. Tópicos importantes se relacionavam às organizações internacionais, como a Organização das Nações Unidas, e comércio, comunicações, transportes. A História do Brasil deveria ser articulada à História Universal. A última série do curso ginasial seria dedicada a uma Geografia Regional do Brasil, com ênfase na sua evolução econômica, e a 
História Econômica e Política do Mundo Contemporâneo, com proeminência do continente americano, conforme indica o quadro a seguir:

\begin{tabular}{|c|c|}
\hline $\begin{array}{c}\text { Geografia Regional do Brasil e sua evolução } \\
\text { econômica }\end{array}$ & $\begin{array}{c}\text { História Econômica e Política do Mundo } \\
\text { Contemporâneo, especialmente das } \\
\text { Américas }\end{array}$ \\
\hline $\begin{array}{l}\text { 1. Regiões Naturais - descrição física, social e } \\
\text { política. } \\
\text { 2. Feições econômicas - Agricultura e criação - } \\
\text { influência social do café. As minas. } \\
\text { 3. Imigração e Colonização. } \\
\text { 4. Comércio e Transportes. } \\
\text { 5. A industrialização e os recursos econômicos } \\
\text { atuais. } \\
\text { 6. O Brasil e os mercados mundiais. }\end{array}$ & $\begin{array}{l}\text { 1. A queda do Antigo Regime na Europa e nas } \\
\text { Américas. A independência. } \\
\text { 2. A Revolução Industrial e suas } \\
\text { consequiências. } \\
\text { 3. As Revoluções burguesas e a formação dos } \\
\text { Impérios Continentais. } \\
\text { 4. As Repúblicas Americanas e suas lutas } \\
\text { internas. } \\
\text { 5. A expansão imperialista - A África. } \\
\text { Questões do Oriente e do Extremo-Oriente. } \\
\text { 6. A civilização material do século XX - } \\
\text { Industrialização e Capitalismo. } \\
\text { 7. As Guerras Mundiais e as crises da } \\
\text { Democracia. }\end{array}$ \\
\hline
\end{tabular}

Quadro 15 - Programa de História e Geografia, enquanto disciplinas autônomas $-4^{\mathrm{a}}$ série do ciclo ginasial da escola secundária

Fonte: Elaborado a partir de Carvalho (1970, p. 209).

Ministrado o conjunto das disciplinas do ciclo ginasial e os seus conteúdos, o ciclo colegial ficaria responsável por explicações que levariam a conhecê-las melhor. Não se trataria mais de ter acesso a "conhecimentos enciclopédicos", mas de adquirir conhecimentos, tendo "vistas reais com fins de adaptação ao meio social" (Carvalho, 1968, p. 2). O sentido de adaptação, presente na fala do autor, não se associa à passividade, conformidade ou acomodação, e sim a uma melhor compreensão do mundo e a um "preparo social". Assim, os jovens não ficariam restritos a aprender a viver no mundo apenas de acordo com as experiências decorrentes da sua vida prática. Portanto, no ciclo colegial, as disciplinas tradicionais (História e Geografia) deixariam de existir, sendo substituídas pelos Estudos Sociais, enquanto uma disciplina escolar. O Programa de Estudos Sociais do Curso Colegial é inspirado nos 10 objetivos centrais apresentados por Krey et al. (1934) nas "Conclusões e Recomendações da Comissão de Estudos Sociais da Associação Americana de História”, discutidos no quarto capítulo desta tese.

É preciso relativizar a afirmativa de Santos (2011, p. 152), de que "nos Estudos Sociais entendia-se que qualquer conteúdo das ciências humanas poderia ser utilizado para o objetivo de levar o aluno ao conhecimento humano." Talvez ela se aplique à definição norte-americana, principalmente a partir da década de 
1930, em que os conteúdos variam de acordo com as disciplinas priorizadas como integrantes dos Estudos Sociais. No Brasil, o mesmo não ocorre, já que há uma definição de conteúdos a serem ministrados e uma ênfase nos conhecimentos histórico-geográficos. Embora Delgado enfatize as metodologias de ensino, ele é bem claro quanto àquilo que deveria ser abordado pelos Estudos Sociais. Da mesma forma que o PCS, por ele organizado no Distrito Federal, o programa do secundário também é extenso e parte do estudo detalhado da evolução da civilização. Ao analisar os Estudos Sociais, temos que evitar a tentação de "pensar que uma disciplina não é ensinada porque ela não aparece nos programas escolares, ou porque não existem cátedras oficialmente com o seu nome.” (Juliá, 2002, p. 44). O programa de Delgado, composto por um conjunto de conteúdos da História e da Geografia, é dividido pelos três anos do ciclo colegial (Anexo B).

$\mathrm{Na} 1^{\text {a }}$ série havia uma primazia da Geografia. As duas primeiras unidades analisariam as "influências climáticas" e o "meio físico"; a terceira e quarta versariam sobre a "cultura social" e a "organização econômica"; a quinta sobre as estruturas políticas. Até aqui, todos esses aspectos são apresentados de forma atemporal e conceitual. As duas últimas unidades, sexta e sétima, começam a salientar o predomínio da História na proposta de Delgado, destacando a evolução política, no sentido cronológico mesmo, começando nos Impérios da Antiguidade até chegar aos Estados Modernos e ao Estado Brasileiro (colonização e Império). A $2^{\text {a }}$ série também enfatiza a História, com inserções de aspectos econômicos, sociológicos e geográficos: "revolução espiritual” (“descobrimentos", reformas, mercantilismo); "revolução política" (Antigo Regime e sua queda na Europa e nas colônias); "revolução industrial"; "o Estado e a ordem econômica"; "atividade agrícola e industrial"; "a economia brasileira"; e "o Brasil atual” (Constituições, produção agrícola e industrial, entre outros).

A última série se dedicava às relações internacionais e à sua compreensão:

- Unidade I: Os Estados Unidos da América do Norte;

- Unidade II: A República Argentina e o Prata;

- Unidade III: A Comunidade das Nações Britânicas;

- Unidade IV: As Repúblicas Soviéticas;

- Unidade V: A Alemanha e os problemas da Europa Central;

- Unidade VI: A Franca e a África Ocidental; 
- Unidade VII: A Península Ibérica;

- Unidade VIII: A Itália e o Oriente Médio;

- Unidade IX: O Extremo Oriente (Japão e China). A África.

Em cada unidade seriam abordados, sucessivamente, o meio físico e os habitantes, as regiões naturais e os recursos econômicos, a evolução política de 1815 a 1940 e os principais problemas econômicos e sociais da atualidade. Apesar da detalhada descrição, não era esclarecido como esse programa se estabeleceria na prática ou a carga horária necessária para a sua efetivação. A proposta exigia um professor especialista e capaz de realizar a integração e a associação entre conhecimentos. Tais características eram contrárias à situação do magistério, descrita pelo próprio Delgado de Carvalho: formação sem articulação entre os cursos universitários e deficiência nos processos de seleção do professor secundário. Uma de suas críticas é, justamente, a dificuldade que os docentes tinham de ministrar todo o programa escolar, seja de Geografia ou de História. Como iriam ministrar então o extenso programa de Estudos Sociais? Em suas obras, Delgado passa ao largo das condições de trabalho do professor brasileiro comum e as suas dificuldades para além do interior da escola. Ao se preocupar excessivamente com os métodos e os programas de ensino, esquece-se daqueles que os poriam em prática. À guisa de comparação, são sugestivas as análises de Emília Viotti da Costa - contemporânea de Delgado no ensino universitário e na reflexão sobre o ensino secundário - publicadas entre 1957 e 1963.

Ao analisar os problemas da disciplina escolar História, a historiadora entendia que eles não estavam divorciados das dificuldades maiores que atingiam o ensino secundário em geral, tais como a seleção docente, a organização das classes e o seu tamanho excessivo, os materiais didáticos e equipamentos escolares e a questão salarial. Sem se pensar em soluções para esses problemas, haveria um contínuo déficit na concretização dos objetivos específicos das disciplinas escolares, sejam quais fossem. Um exemplo é interessante e pode nos ajudar a entender as dificuldades com as propostas de Delgado. Para Costa (1960), uma necessidade primordial do professor de História, e das demais Ciências Sociais, era a aquisição de livros para a atualização e estudos constantes: "Ora, não há ensino de História eficiente sem que se disponha de bons livros.” (p. 95). O Programa de Estudos Sociais de Delgado os exigia, embora não explicite isso, devido a conteúdos que certamente os docentes não teriam acesso em seus cursos 
de graduação. Entretanto, esclarecia Costa (1960, p. 95) que: "o preço do livro nacional e estrangeiro escapa hoje à capacidade aquisitiva do professor." O seu salário era aquém das suas necessidades pessoais e profissionais.

Outro ponto analisado pela professora paulista, relacionado à ausência de recursos, referia-se ao distanciamento existente entre as inovações científicas e pedagógicas e os professores, principalmente os afastados dos grandes centros urbanos. Estes contavam, ainda, com a ausência de bibliotecas públicas que pudessem atender aos seus estudos. Como solução, Costa (1960) apontava a necessidade de cursos de férias, publicação e distribuição de revistas com resenhas de obras importantes, programas de compra de livros, ou seja, grandes mudanças na estrutura de ensino que facilitassem o trabalho docente. Delgado produziu sua proposta de Estudos Sociais sem considerar as discussões sobre reformas estruturais que começavam a mobilizar os intelectuais brasileiros na década de 1950, embora seja um dos signatários do "Manifesto dos Educadores mais uma vez Convocados" (1959). Publicado no contexto de disputas pela elaboração da Lei de Diretrizes e Bases da Educação Nacional, que seria publicada apenas em 1961, este documento reafirmou os ideais de educação pública, laica, obrigatória e gratuita presente no "Manifesto dos Pioneiros da Educação Nova" (1932) e realizou um balanço da educação nacional.

\begin{abstract}
A organização do ensino é má, arcaica e, além de antiquada, deficiente a tantos respeitos, todos o afirmam; que a educação primária, em dois, três ou quatro turnos, se reduziu a pouco mais do que nada, que são em número extremamente reduzido as escolas técnicas e baixou o nível do ensino secundário, ninguém o contesta; que se agravaram desmedidamente os problemas de edificações e instalações escolares, é outra afirmação que caiu no domínio comum e já não precisa, por sua evidência, nem de pesquisas para pô-la à prova dos fatos nem do reforço de pareceres de autoridades na matéria. O professorado de ensino primário (e mesmo o do grau médio), além de, geralmente, mal preparado, quer sob o aspecto cultural quer do ponto de vista pedagógico, é constituído, na sua maioria, por leigos ( $2 / 3$ ou 3/4 conforme os Estados); não tem salário condizente com a alta responsabilidade de seu papel social nem dispõe de quaisquer meios para a revisão periódica de seus conhecimentos. (Azevedo, [1959] 2003, p. 158).
\end{abstract}

Ao enfatizar apenas um dos elementos que afetavam o ensino secundário - a "arcaica" organização do ensino -, Delgado impossibilitava a aplicação de suas propostas de Estudos Sociais. Ele advertia que sem uma formação de professores adequada, o ensino de Estudos Sociais não seria possível na escola secundária. 
Mas, se ele vislumbrava os princípios dessa formação, não deixou entrever ${ }^{208}$. Os seus livros, "Didática das Ciências Sociais" (1949) e "Introdução metodológica aos Estudos Sociais" (1970), tinham como intenção sanar algumas deficiências, como se a prescrição de um receituário de práticas pudesse levar, quase que automaticamente, à renovação educacional e à apreciação dos Estudos Sociais na escola secundária. A crítica de Hannah Arendt (2016, p. 231) à escola progressiva nos ajuda compreender essa perspectiva. Para a pesquisadora, "sob a influência da Psicologia moderna e dos princípios do Pragmatismo, a Pedagogia transformou-se em uma ciência do ensino em geral a ponto de se emancipar inteiramente da matéria efetiva a ser ensinada." ${ }^{209}$ Por isso a descrição tão detalhada de métodos de ensino e avaliações, como um contributo aos professores em sua tarefa de ensinar. Em relação aos conteúdos amplos, de conhecimento tão necessário e que começariam a ser aprendidos nos anos de formação em cursos superiores, não há indicações. Mesmo pensando na proposta ideal, os Estudos Sociais, Delgado formulava um "plano B". No artigo de 1953 ele deixa isso bem claro:

[...] por enquanto, vejamos de que modo podem ser atenuados os inconvenientes de disciplinas isoladas, aparentemente independentes e que, na orquestração em que se deveriam integrar como instrumentos complementares, tocam um, uma valsa, outro, uma marcha, o terceiro, uma ária de ópera, sem preocupação da cacofonia resultante, à qual se dá o nome glorioso de Educação. Do conjunto dos Estudos Sociais, separemos, em primeiro lugar, a História para o exame rápido dos valores que apresenta. (Carvalho, 1953, p. 56-57, grifos nossos).

A disciplina escolhida por Delgado para se tentar atenuar "os inconvenientes de disciplinas isoladas" era a História, da qual ele se considerava professor desde 1904 e que fora alvo do seu esforço na produção de livros

\footnotetext{
${ }^{208}$ Um contraponto a essa ausência de perspectiva de formação de professores de Estudos Sociais, pode ser encontrado em Guy de Hollanda (1957). Para ele, a incorporação dos Estudos Sociais na escola dependeria de uma reorganização do plano de estudos universitários dos cursos de História, Geografia e Ciências Sociais: "Melhor solução houvera sido aquela que assegurasse uma base comum a historiadores, geógrafos e 'cientistas sociais', para depois, dar-lhes o ensejo de uma especialização mais proveitosa, porque fruto de uma escolha, plenamente, consciente e com alicerces numa sólida formação interdisciplinar. Caso essa primeira parte de estudos universitários em apreço fosse completada por uma adequada preparação pedagógica, poderia fornecer ao ensino médio os professores de 'Estudos Sociais'. Os que se especializassem em Geografia, História, Sociologia e ciências afins seriam, uma vez providos da formação pedagógica correspondente, os mais indicados para o ensino da Geografia, História, e Sociologia e outras ciências sociais como disciplinas autônomas nas escolas médias, em séries mais adiantadas." (p. 250-251).

${ }^{209}$ Arendt (2016, p. 231) acrescenta, ainda, que esse modelo pressupunha que o "professor não precisa conhecer a sua própria matéria". Como analisamos no capítulo anterior, o PCS do Distrito Federal indicava longas listas de referências bibliográficas para atualização e conhecimento da professora primária. Em relação ao ensino secundário, Delgado indica apenas os conteúdos que deveriam ser abordados pelo professor. Portanto, o docente deveria deles ter conhecimento. O problema com a fórmula, para este nível de ensino, é a ausência de referências aos docentes.
} 
didáticos entre as décadas de 1930 e 1960 (Costa, 2007; Vale, 2011). Devido ao grande acúmulo de documentos históricos e a extrema velocidade com que se processavam os acontecimentos no século XX, seria impossível uma "restituição integral do passado": "maiores são os vestígios que ele deixa entre nós e maior a influência que ele exerce ainda sobre nós." (Carvalho, 1953, p. 57). Caberia, portanto, uma seleção dos temas que deveriam ser ensinados no ensino secundário. $\mathrm{O}$ educador propunha uma valorização da História Contemporânea, uma História explicativa em detrimento da mera descrição e a maior conexão da História com as outras disciplinas, argumentando: "Que mal há que o professor de História apele para outras disciplinas nas suas explicações?” (p. 58). Entretanto, outros historiadores e professores também passaram a se dedicar a reflexões sobre a História ensinada.

\subsection{2}

"Do conjunto dos Estudos Sociais, separemos, em primeiro lugar, a História": a propósito da crítica à Delgado na década de 1950

A atuação de Delgado de Carvalho na produção de livros didáticos de História remonta às décadas de 1930 e 1940, quando participou nas reformas educacionais promovidas pelo Ministério da Educação e escreveu livros que representavam uma interpretação delas. Suas obras buscavam favorecer a autonomia dos alunos, algo que não era comum à época. Outra inovação foi a utilização de amplos recursos: mapas, imagens, exercícios, documentos textuais (Vale, 2011). Na década de 1950, Delgado de Carvalho foi convidado a escrever livros de História Geral para a Campanha do Livro Didático e Manuais de Ensino (Caldeme) e chancelados pelo Centro Brasileiro de Estudos Pedagógicos (CBPE). Idealizado por Anísio Teixeira, à frente do Instituto Nacional de Estudos Pedagógicos (Inep), o Caldeme "consistia em um projeto de assistência técnica ao professorado, por meio de manuais elaborados por pessoas de reconhecida autoridade científica." (Costa, 2007, p. 104). Entre 1956 e 1966, o educador produziu quatro livros para essa coleção: "História Geral: Antiguidade" (1956), "História Geral: Idade Média", tomo 1 (1959), "História Geral: Idade Média", tomo 2 (1959) e "História Geral: Idade Contemporânea" (1966). 
Essa proximidade com a História, através da escrita de manuais didáticos para a disciplina escolar, a tornou um tema de suas reflexões metodológicas. Contudo, Delgado de Carvalho não era o único a refletir sobre a questão, como demonstram as publicações das professoras da Universidade de São Paulo (USP), Emília Viotti da Costa e Amélia Americano Domingues de Castro ${ }^{210}$. O processo de elaboração dos seus livros de História, publicados nas décadas de 1950 e 1960, foi cercado de tensões. Costa (2007) analisa as críticas realizadas por Eurípedes Simões de Paula, catedrático da USP, um dos fundadores do que se tornaria a Associação Nacional de História e parecerista da obra de Delgado. De um lado, como argumenta Kazumi Munakata (2004), um paulista representante da nova geração dos historiadores do Brasil, de outro, um elemento da velha escola.

Formados pelos primeiros cursos universitários de História, influenciados pela historiografia francesa reunida em torno dos Annales, alguns desses novos historiadores pensavam em termos de uma História científica, cuja metodologia de ensino possuía um lugar menor. Simões de Paula se recusou, por exemplo, a comentar os aspectos pedagógicos do livro ${ }^{211}$. Nas suas palavras:

[...] não teremos necessidade de levar em conta, aqui, uma série de aspectos didáticos que deveriam ser considerados num manual a ser utilizado pelos estudantes. Poderemos libertar-nos da maior parte de preocupações deste tipo, no que diz respeito à exposição da matéria, o que nos permite tratar do assunto em nível mais elevado, contando com o preparo especializado que o professor já deverá apresentar. (Carta de Eurípedes Simões de Paula e Pedro Moacyr de Campos a Gustavo Lessa, de 8/10/1953, p. 1 apud Munakata, 2004, p. 525-526).

A resposta de Delgado de Carvalho demarca uma preocupação com os aspectos didáticos e a função da História escolar muito mais do que com a produção de uma história científica: "Confesso que os aspectos didáticos, que o professor paulista preferiu afastar das discussões, me preocuparam mais do que a

\footnotetext{
${ }^{210}$ Amélia Americano Franco Domingues de Castro tornou-se bacharela e licenciada em Geografia e História pela USP em 1941. No ano seguinte, começou a trabalhar nesta universidade como assistente da Cadeira de Didática Geral e Especial, onde atuou por 35 anos. Lecionou ainda na Universidade Estadual de Campinas (Unicamp). Foi uma das pioneiras na reflexão sobre o ensino de História no Brasil, ao defender, em outubro de 1950, a tese "Princípios do método no ensino de História", na Cadeira de Didática Geral e Especial da Faculdade de Filosofia, Ciências e Letras da USP. A defesa contou com a participação, entre outros, dos professores Eurípedes Simões de Paula, catedrático de História e Antiga e Medieval, e do professor Émile Leonard, professor de História Moderna e Contemporânea.

${ }^{211}$ Essa atitude de Simões de Paula não foi isolada. Ao arguir a tese de Amélia Domingues de Castro sobre os métodos no ensino de História, o historiador procedeu do mesmo modo. Em uma resenha da defesa, publicada na Revista de História da USP, Arrigo Leonardo Angelini (1951, p. 243) salienta que Simões de Paula argumentou que "se pode constatar duas partes principais na tese: uma referente à Filosofia da História e outra à Metodologia dessa matéria", tecendo seus comentários apenas sobre a primeira parte.
} 
'narrativa' sobre a qual recaem a maior parte de suas observações." (Carta de Carlos Delgado de Carvalho a Gustavo Lessa, de 27/10/1953 apud Munakata, 2004, p. 526). Tal polarização, na argumentação de Munakata (2004), dava-se entre os que privilegiavam a pesquisa e as discussões acadêmicas, como Eurípedes Simões de Paula, e "os que mantêm certa incompreensão a respeito de novas proposições teóricas e metodológicas, pois preferem preocupar-se mais com os 'aspectos didáticos'.” (p. 528). Não entendemos que Delgado desconsiderasse “as novas proposições teóricas”, já que algumas das críticas de Simões de Paula se relacionavam a aspectos combatidos pelo educador desde a década de 1930, como a excessiva europeização do currículo e a ênfase à História Política. Entretanto, para alguém que construiu a sua vida profissional preocupado com métodos de ensino, desconsiderá-los na escrita e na análise de livros didáticos era um erro imperdoável. Não há ensino sem pedagogia. A História refletida por Delgado de Carvalho era a escolar, conforme salienta em discurso na década de 1970:

À maioria dos professôres reconhece atualmente que a fase das lições sobre os fatos, reinados, guerras, isto é, a história fatual ou acontecimental está em pleno declínio, na Europa principalmente; mas infelizmente não aqui, talvez por culpa de alguns programas. Ninguém se opõe, entre nós, a considerar os acontecimentos, isto é, os lugares, homens e datas como objeto de narrativas às quais fica presa a história como disciplina. Mas vai-se verificando, aos poucos, que a história total é de maior importância pela significação das situações que relata, isto é, as estruturas sociais, as instituições, as leis, as condições de vida, o trabalho e suas modalidades, da economia e também os conhecimentos científicos da fase histórica em estudo. (Carvalho, 1971, p. 202-203).

A ênfase nos aspectos didáticos faz com ele não construa uma definição clara de História científica, embora nela busque elementos centrais para suas abordagens. "História total" é uma concepção típica da historiografia francesa pós-1929: o princípio de que a História não se limita ao político e aos grandes homens, mas se relaciona a todas as atividades humanas (Burke, 1997). O acontecimento é apenas um pano de fundo que leva a estruturas sociais, intelectuais, econômicas e políticas. Uma definição científica não tem muita necessidade em suas interpretações, já que a História é tratada como um dos componentes dos Estudos Sociais. Talvez por isso, Delgado busque maior inspiração não nos historiadores, mas em pedagogos como John Dewey, cujas citações aparecem de forma contínua nos trabalhos publicados entre 1930 e 1950. Em uma época em que a historiografia brasileira começava a se afirmar, com historiadores pensando o ensino, uma pessoa com uma formação generalista, 
perdia espaço e influência. Portanto, a influência de Delgado de Carvalho sobre o ensino de História se diluía cada vez mais com o passar dos anos.

Seria a inspiração deweyana um fator para a condenação da obra de Delgado sobre os Estudos Sociais na década de 1950? A filosofia educacional de Dewey foi objeto de críticas, principalmente a partir da década de 1950, "por parte dos adversários da educação progressista, que o tornaram responsável, praticamente, por todos os erros do sistema de ensino público estadunidense." (Westbrook, 2010, p. 31-32). Para Hannah Arendt (2016) - em um texto clássico publicado originalmente em 1957 e contemporâneo a "Introdução metodológica aos Estudos Sociais" -, a "crise educacional" americana, como um dos tópicos da crise do mundo moderno, tinha origem em três pressupostos basilares da educação pragmática $^{212}$ : a concepção de existência de um mundo próprio à criança; a ênfase no ensino em detrimento do conhecimento da matéria, isto é, a formação do professor "é no ensino e não no domínio de qualquer assunto particular" (p. 231); e a máxima de que só se aprende fazendo. Embora não cite John Dewey, tais elementos eram característicos de suas obras e aparecem nos textos de Delgado sobre os Estudos Sociais ${ }^{213}$. Uma análise detalhada dos apontamentos de Arendt (2016) não cabe aqui e não se limitaria à educação, mas, como salientam Ana Waleska Mendonça et al. (2006, p. 99), “ecos dessa polêmica chegavam até nós”.

Mendonça et al. (2006) analisam as particularidades da apropriação brasileira de Dewey. Para os autores, a ideologia desenvolvimentista que pautou os debates acerca da reestruturação econômica, política e social do Brasil, entre as

\footnotetext{
${ }^{212}$ Mendonça et al. (2006) indicam o livro "A educação americana em crise", publicado em 1956 e traduzido para o português por iniciativa de uma editora vinculada ao Partido Comunista Brasileiro, que segue um caminho semelhante ao de Arendt, ao "vincular essa situação de crise à influência do ideário pragmatista sobre o sistema escolar norte-americano, além de alertar para o risco dessa influência em outros contextos nacionais." (p. 99). Para os pesquisadores, as críticas eram feitas tanto por elementos vinculados à esquerda quanto à direita.

${ }^{213}$ Embora Delgado seja tributário de algumas premissas da escola progressiva, como já tivemos a oportunidade de apontar ao longo desta tese, ele as reconstruiu em suas reflexões. Mais uma vez, a definição de Arendt (2016, p. 131-132) é importante: um dos pressupostos básicos da escola progressiva "é o de que só é possível conhecer e compreender aquilo que nós mesmos fizemos, e sua aplicação à educação é tão primária quanto óbvia: consiste em substituir, na medida do possível, o aprendizado pelo fazer." Uma das consequências desse modelo, ainda segundo a pesquisadora, é a pouca importância ao domínio da matéria pelo professor, que assim não a transmitiria de forma "petrificada". Ora, mesmo na escola primária anisiana da década de 1930, em que predominava a lógica do "aprender fazendo", e a ênfase no desenvolvimento de habilidades, o "aprender" não é deixado de lado, basta lembrarmo-nos das listas de conteúdos e das referências bibliográficas para professores e alunos. Na proposição de ensino de Estudos Sociais para a escola secundária, Delgado também não marginalizou o conhecimento, mas construiu uma proposta em que o aluno adquirisse os instrumentos para a busca do conhecimento para além daquilo que era transmitido pelo professor.
} 
décadas de 1950 e 1960, "constituiu-se em um solo fértil para a retomada e a expansão do ideário da Escola Nova, e particularmente do pragmatismo deweyano entre os educadores brasileiros.” (p. 98). Relevante, nesse sentido, foi a atuação de Anísio Teixeira, na direção do Instituto de Pesquisas Educacionais (Inep), como um difusor desse ideário, através de publicações (incluindo as didáticas), conferências e escolas experimentais. Delgado mais uma vez estava próximo a Anísio Teixeira e aos seus colaboradores e não se furtou em utilizar Dewey como uma importante referência para o seu trabalho, mesmo com a intensa polêmica quanto ao legado educacional deweyano, inclusive nos Estados Unidos. A persistência no desenvolvimento de uma teoria educacional contestada não nos parece ser o principal elemento de crítica a Delgado. Ao escrever o artigo "O Problema da motivação no ensino de História", Costa (1963) toma como referência "Vida e educação", obra de Dewey (1979), organizada por Anísio.

Ao pensar os problemas metodológicos do ensino de História, Castro (1955) também utiliza termos claramente deweyanos:

Em se tratando de matéria na qual os fatos não são diretamente observáveis, não se repetem nunca de modo idêntico e não suportam experimentação, resta-nos verificar que sentido teriam os novos ideais pedagógicos que pedem à escola uma "reconstrução da experiência", uma "redescoberta", uma "aprendizagem motivada" e ligada aos reais interesses dos alunos, e que a transformam, de instituição à margem da vida, em instituição na qual se desenvolvem experiências vitais? (Castro, 1955, p. 265, grifos nossos).

A atenção de Delgado se revela muito mais sobre as funções do ensino de História e os seus métodos. Nesse quesito, suas reflexões não diferem de Emília Viotti da Costa ou Amélia Domingues de Castro. Em artigo publicado na "Revista de História", da USP, intitulado: "Alguns problemas no ensino de História", Castro (1955, p. 257) alertava que as "as principais críticas a esse respeito referem-se à inadequação do curso secundário às necessidades da vida moderna." Contudo, para ela, o professor de História deveria possuir uma concepção da História tanto científica quanto a ser ensinada. A História deveria ser apenas um relato ou uma tentativa de explicação e interpretação? O ensino não se limitava à didática. Passava, antes, por uma definição da História enquanto ciência.

A História "deveria ajudar o indivíduo a resolver questões da sua vida individual e social" (Castro, 1955, p. 262), não podendo ser ensinada como algo tão remoto e sem articulação com a vida do aluno. Quanto aos métodos de ensino, percebem-se ainda mais proximidades entre a professora da USP e Delgado de 
Carvalho. Ela sugere alguns caminhos: "o processo de trabalho histórico" ou uma crítica histórica rudimentar, em que fosse apresentado aos alunos o trabalho do historiador através de análise documental ${ }^{214}$; o método de problemas - tão defendido por Delgado - em que os alunos buscariam as informações necessárias para solucionar problemas. Costa (1957) também apresenta semelhanças de posição, ao considerar que a História contribui para o desenvolvimento de "hábitos de expressão e sistematização do pensamento" (p. 119). Além disso, para ela, seu estudo possibilitava o hábito de refletir sobre os problemas da sociedade: “o estudo dos problemas dos mundos antigos, desenvolve o interesse pela participação na vida política e social, contribui para uma boa formação da consciência patriótica e internacional.” (p. 120). São elementos facilmente encontráveis na produção de Delgado, contudo ele os pensava como uma função dos Estudos Sociais e não apenas de uma disciplina independente.

Para Guy de Hollanda (1957), se não havia incompreensões tão marcadas sobre os Estudos Sociais na escola primária, o mesmo não ocorria em relação aos professores secundários. O autor esclarecia o seu posicionamento:

Há entre a maioria dos professôres brasileiros de História e Geografia, uma ojeriza em relação aos Estudos Sociais, de cunho norte-americano. Recentemente, uma competente professôra escrevia a respeito: "Não concordamos com a orientação do projeto de reforma tirando a independência da História e da Geografia, unindo-as numa só designação - Estudos Sociais. Não vemos a melhoria que isso possa trazer ao ensino." (Hollanda, 1957, p. 246).

A professora citada por Guy de Hollanda é Olga Pantaleão, uma das primeiras mulheres formadas pelo curso de História e Geografia da USP, e uma das fundadoras da Associação de Professores Universitários de História, em $1961^{215}$. O trecho do seu depoimento revela que a resistência aos Estudos Sociais é anterior aos governos militares, embora seja menos intensa, já que nas décadas

\footnotetext{
${ }^{214}$ Para Carvalho (1975b), a "História Acontecimental" deveria ser substituída pela História Integral ou História Documental, consistindo na análise de um documento (memórias, cartas, decretos, documentos oficiais ou privados) do período estudado: "com o auxílio de enciclopédias, mapas, livros, revistas, são examinadas as condições em que se deram os acontecimentos, os seus atores e a importância relativa dos fatos no seu quadro histórico." (p. 160). Assim, para cada período histórico abordado, seria realizada uma "pesquisa" em sala de aula. No colegial, de acordo com seu programa, os fatos históricos seriam abordados a partir de um documento.

${ }^{215}$ Pantaleão se referia, segundo Hollanda (1957), ao "Projeto Jost" que era debatido no legislativo federal em 1954 e que tinha a intenção de alterar a Lei Orgânica do Ensino Secundário de 1942 e facultar uma maior flexibilização do currículo. Contudo, garante-nos o pesquisador que o termo "Estudos Sociais" não aparece no projeto. Para ele, a proposta pretendia unir no ciclo ginasial História e Geografia em torno de uma única disciplina, nos moldes das cadeiras que existiram no século XIX. É um projeto que não chegou a ser aprovado pela Câmara dos Deputados.
} 
de 1950 e de 1960 se tratavam apenas de propostas indicativas e discussões nos meios acadêmicos. Consideramos que, nesse momento, a recusa às ideias de Delgado estava muito mais na defesa de uma nova disciplina, em detrimento das existentes, do que na forma como construía a metodologia para o ensino de História escolar. Esta não se distanciava muito daquilo que as historiadoras, que sobre ela refletiam, defendiam. Contudo, especialistas como Amélia Domingues de Castro, Emília Viotti da Costa e Olga Pantaleão argumentavam que não haveria a necessidade de criação de uma nova disciplina que proporcionasse ao aluno o "estudo das instituições políticas do país" e/ou "uma compreensão suficiente dos problemas sociais, econômicos e políticos do Brasil e do mundo atual" (Hollanda, 1957, p. 249). Isso, a História e a Geografia, como disciplinas obrigatórias no currículo escolar, já faziam.

\section{5 \\ Formação para a cidadania: uma proposta na raiz dos Estudos Sociais}

Elza Nadai (1988) defende, em seu pioneiro trabalho, a existência de dois discursos sobre os Estudos Sociais no Brasil. Para ela, o primeiro, elaborado na década de 1930, é repetido nas argumentações em favor dos Estudos Sociais, até a década de 1960. O outro discurso, “completamente diferente" (p. 5), foi construído na década de 1970. Em síntese Nadai (1988, p. 5) argumenta que:

O primeiro [...] tem como eixo central o destaque do papel dos Estudos Sociais na elaboração de uma sociedade harmônica e equilibrada, sem divergências e conflitos, resultante da contribuição igualitária de indivíduos, etnias e grupos. Por outro lado, os documentos oficiais que sustentam a utilização dos Estudos Sociais, na década de 70, não valorizam mais a questão da formação social harmoniosa, mas sim, a questão da cidadania, como eixo central do discurso.

A análise do PCS do Distrito Federal, bem como das obras de Delgado sobre a disciplina na escola secundária, indicam que no processo de constituição de um ideário em defesa do ensino de Estudos Sociais no Brasil, a partir da década de 1930, a preocupação central dos seus formuladores, inspirados nas propostas americanas, era com a "questão da cidadania" e com o desenvolvimento de jovens que pudessem "viver melhor". Anísio Teixeira, Delgado de Carvalho e Maria dos Reis Campos, entre outros, refletiram sobre os Estudos Sociais tencionando a formação do homem para a vida em uma democracia, a bem da 
verdade utópica, formada pela interdependência, cooperação e contribuição entre indivíduos e nações. A despeito da apropriação que os conselheiros do CFE realizaram em sua versão de Estudos Sociais, e a própria concepção de cidadania adotada após 1964, a associação entre a disciplina e a formação para a cidadania não é uma construção da década de 1970. Contudo, concordamos com Nadai (1988) quando argumenta que só após o golpe militar de 1964 a disciplina se institucionalizou no Brasil. Este é o objeto do próximo capítulo. 


\section{Da intenção à obrigatoriedade: Estudos Sociais, núcleo comum e marcas do autoritarismo}

Os Estudos Sociais, antes de se tornarem uma área de estudos/disciplina na escola brasileira da década de 1970, em nível nacional, teve uma longa trajetória de discussões e implementações nos anos anteriores ao golpe militar de 1964 e às reformas de ensino formuladas pelo Conselho Federal de Educação (CFE). Privilegiamos, como recorte para as nossas análises, até aqui, a perspectiva defendida pelo professor Delgado de Carvalho. No Brasil, esse intelectual foi o pioneiro e incentivador dessa disciplina seja através da sua participação na reforma anisiana no Distrito Federal dos anos de 1930 ou nas inúmeras publicações que escreveu sobre a temática. Suas ideias são essenciais para a compreensão do sentido de Estudos Sociais em um período democrático. A partir da década de 1960, os Estudos Sociais "retornam" ao cenário educacional por meio de experiências consideradas inovadoras e como proposta indicativa do CFE. De disciplina optativa, sob os anos de redemocratização, passou a ter caráter obrigatório na ditadura militar. Neste capítulo, investigamos as continuidades e rupturas entre os projetos de Delgado de Carvalho e a política formulada por Valnir Chagas e outros conselheiros do CFE a partir de 1971.

7.1

Década de 1960 e os Estudos Sociais: a proposta indicativa e os Ginásios Vocacionais

A Lei de Diretrizes e Bases da Educação Nacional (LDBEN), publicada em 1961, após mais de uma década de intensos e longos debates, estabeleceu os fundamentos para a criação do $\mathrm{CFE}^{216}$. Considerava-se que as funções do conselheiro eram de relevante interesse nacional, tendo o seu exercício prioridade sobre quaisquer outros cargos que possuíssem (Brasil, 1961). Sua nomeação era atribuição direta da Presidência da República e eram selecionados "dentre pessoas de notável saber e experiência, em matéria de educação" (Brasil, 1961). Entre as suas atribuições: "decidir sobre o funcionamento dos estabelecimentos isolados de

${ }^{216}$ Lei n ${ }^{\circ} 4.024$, de 20 de dezembro de 1961. 
ensino superior, federais e particulares"; decidir sobre o funcionamento e o reconhecimento das universidades, bem como a aprovação de seus estatutos; e, “indicar disciplinas obrigatórias para os sistemas de ensino médio e estabelecer a duração e o currículo mínimo dos cursos de ensino superior" (Brasil, 1961, Art. 9). A partir dessa jurisdição, o CFE pode criar a disciplina Organização Social e Política do Brasil (OSPB) em 1962, e instituir a licenciatura curta como uma modalidade de formação de professores em 1964.

As atividades do CFE foram iniciadas em fevereiro de 1962 e uma das suas primeiras tarefas foi indicar as "Normas para o Ensino Médio"217. O Ensino Médio era dividido em dois ciclos: o ginasial, de quatro anos, e o colegial, compreendendo três anos. Abrangia os cursos secundários, técnicos e de formação de professores (Brasil, 1961, Art. 34). Na primeira indicação do CFE foram expostas as disciplinas obrigatórias e optativas do currículo escolar do sistema federal, sua responsabilidade de acordo com o Art. 35 da LDBEN. Tornaram-se disciplinas obrigatórias: Português (sete séries), História (seis séries), Geografia (cinco séries), Matemática (seis séries) e Ciências (sob a forma de Iniciação à Ciência, duas séries, e sob a forma de Ciências Físicas e Biológicas, quatro séries). Indicavam-se, como obrigatórias, mas a critério dos sistemas de ensino: Desenho, OSPB, Língua Estrangeira Moderna, Língua Clássica e Filosofia (Documenta, 1962a). Quanto às optativas, foram incluídas:

a) no ciclo ginasial: línguas estrangeiras modernas, música (canto orfeônico), artes industriais, técnicas comerciais e técnicas agrícolas.

b) no ciclo colegial: línguas estrangeiras modernas, grego, desenho, mineralogia e geologia, estudos sociais, psicologia, lógica, literatura, introdução às artes, direito usual, elementos de economia, noções de contabilidade, noções de biblioteconomia, puericultura, higiene e dietética. (Documenta, 1962a, p. 15).

Os Estudos Sociais aparecem como uma disciplina optativa para o ciclo colegial do Ensino Médio, "a partir de uma legislação indicativa, mas não obrigatória.” (Santos, 2011, p. 166). A posição ocupada pelos Estudos Sociais no

\footnotetext{
${ }^{217}$ A primeira composição do CFE foi nomeada pelo presidente João Goulart em 31 de janeiro de 1962 e era formada por: Anísio Spindola Teixeira, Alceu Amoroso Lima, Antonio Ferreira de Almeida Junior, Abgar Renault, Dom Helder Câmara, Josué Montello, Francisco Brochado da Rocha e Antonio Balbino de Carvalho Filho, para exercerem o mandato de seis anos; D. Cândido Padin, Joaquim Faria de Góes Filho, Maurício Rocha e Silva, Hermes Lima, Padre José Vieira de Vasconcellos, Edgar Rego Santos, Newton Sucupira e Clóvis Salgado da Gama, com mandatos de quatro anos; e, José Borges dos Santos, José Barreto Filho, Celso Ferreira da Cunha, João Brusa Neto, Francisco Maffei, Roberto Bandeira Accioli, Deolindo Couto e Raimundo Valnir Cavalcante Chagas, para exercerem o mandato de dois anos (Saraiva, 2004).
} 
currículo escolar, nos anos finais da escola secundária, é a aconselhada por Delgado de Carvalho (1970) em "Introdução metodológica aos Estudos Sociais", o que indica que a inclusão da disciplina como optativa do ciclo colegial pode ter sido uma recomendação dos conselheiros Abgar Renault e Anísio Teixeira. Nesse momento, Renault e Teixeira compunham a Comissão de Ensino Primário e Médio $^{218}$. Não custa lembrar que ambos tinham contato com Delgado de Carvalho e patrocinaram a publicação de suas obras didáticas sobre os Estudos Sociais, respectivamente, "Didática das Ciências Sociais" (1949) e "Ciências Sociais na escola elementar" (1955), reedição do PCS (1934) do Distrito Federal.

Para a escola primária foi publicada, em 1962, a obra "Os Estudos Sociais na escola primária $-1^{\circ}$ ano ao $4^{\circ}$ ano", de autoria de Josephina de Castro e Silva Gaudenzi, compondo a "Biblioteca da Professora Brasileira" do Programa de Emergência do Ministério da Educação e Cultura. Uma iniciativa do INEP, baseada na reforma anisiana realizada no Distrito Federal da década de 1930. A obra de Gaudenzi (1964), apesar de se inspirar no PCS (1934), não tinha tópicos sobre as outras civilizações e sua história, concentrando-se no Brasil.

Verão os prôfessores o empenho pôsto em que as crianças conheçam o Brasil, o seu Estado, a sua cidade, em seus problemas e em suas conquistas, e se capacitem das responsabilidades que lhes cabem participar de empreendimentos que conduzam ao progresso individual e social. Procurou-se fazê-lo levando as crianças a melhor se integrarem na sociedade em que vivem e a valorizar as tradições positivas e combater os preconceitos desfavoráveis contra o trabalho manual, a educação não acadêmica, etc. E, ainda, tentou-se desenvolver atitudes relativas ao trabalho em geral, ao estudo, à vida social e moral - atitudes de reflexão, de busca de esclarecimentos, responsabilidade, de bom convívio social, cortesia, justiça, generosidade, iniciativa, objetividade, e habilidades, como as relativas ao uso de instrumentos de estudo, à pesquisa, ao trabalho em grupo etc. (Gaudenzi, 1964, p. 14).

Os Guias de Ensino editados pelo INEP sugeriam aos professores as linhas gerais de orientação da matéria para cada ano de ensino e possíveis recursos didáticos a serem utilizados. Na década de 1960, o objetivo principal dos Estudos Sociais na escola primária era a integração do aluno ao seu meio social através da edificação de uma sociedade melhor, por isso a ênfase colocada na construção de habilidades e atitudes, como o combate às formas de preconceito. Na distribuição de temas por séries, Gaudenzi (1964) reforça o ensino de Estudos Sociais a partir da vida em família e no ambiente escolar ( $1^{\circ}$ ano), da integração à comunidade $\left(2^{\circ}\right.$

218 Os outros membros eram: Dom Cândido Padin, Roberto Accioli, Padre José Vieira de Vasconcelos, José Borges dos Santos e Joaquim Farias de Góes Filho. 
ano), da integração ao Estado e ao País ( $3^{\circ}$ ano) e do conhecimento da realidade brasileira (geográfica e historicamente) e da constituição da cidadania ( $4^{\circ}$ e $5^{\circ}$ anos). Aspectos que estarão presentes entre os conteúdos de Estudos Sociais até a década de 1990: a família, a escola, o bairro, ocupações da comunidade, instituições e outros. Por fim, rudimentos ou noções de Geografia e História.

No que concerne à escola secundária, diferentemente das reformas implementadas por Francisco Campos e Gustavo Capanema nas décadas de 1930 e de 1940, a LDBEN concedia maior flexibilização à organização de currículos e programas das escolas de nível médio. Não havia programas, ou instruções metodológicas, previamente traçados, mas indicações como as expostas em “Amplitude e Desenvolvimento das Matérias Obrigatórias" (Documenta, 1962b). Desta forma, a década de 1960 foi uma época de "intensa experimentação educativa". (Saviani, 2013, p. 336) ${ }^{219}$. O ensino de Estudos Sociais é aceito e considerado como inovador. Em alguns estados, como São Paulo e Minas Gerais, chegou a ser incluído nos currículos de $1^{\circ}$ grau, através de perspectivas de ensino integrador e interdisciplinar, e nos Ginásios Vocacionais (Nadai, 1988). Segundo Nunes (2000b), os ginásios começaram a ser instalados, em São Paulo em 1962. Foram criadas seis unidades, na Capital e cidades do interior (polos industriais, zonas agrária e pecuária, centros ferroviários, entre outros). Tinham como perspectiva situar "o adolescente brasileiro no processo histórico de desenvolvimento" (p. 54), estimulando a "consciência da realidade e a participação em todos os setores da vida social”. A prática pedagógica objetivava, entre outros aspectos, "a apreensão integrada do conhecimento" e "a disposição para atuar no próprio meio". (p. 54). Para Nunes (2000b, p. 55):

A área de maior peso era, portanto, os Estudos Sociais, que incluía noções de História, Geografia, Economia, Sociologia e Antropologia. Uma ou outra dessas disciplinas poderia ser explorada mais profundamente, dependendo da unidade em estudo. A partir dos Estudos Sociais desenvolvia-se um sistema de relações com as demais áreas.

Nesta experiência, fica evidente a ideia de integração entre as disciplinas, que não perderam suas identidades. Os Estudos Sociais são apresentados como

\footnotetext{
${ }^{219}$ Quanto à flexibilidade, é significativo o Art. 104 da LDBEN (1961): "Será permitida a organização de cursos ou escolas experimentais, com currículos, métodos e períodos escolares próprios, dependendo o seu funcionamento para fins de validade legal da autorização do Conselho Estadual de Educação, quando se tratar de cursos primários e médios, e do Conselho Federal de Educação, quando de cursos superiores ou de estabelecimentos de ensino primário e médio sob a jurisdição do Governo Federal."
} 
uma "área" (Nadai, 1988, p. 9) e "um espaço de construção pedagógica" (Neves, 2014, p. 19). Balzan (1977), professor do Ginásio Vocacional de Americana entre os anos de 1962 e 1966, aponta que os Estudos Sociais eram a "área núcleo" do currículo escolar, de onde partiam todos os temas que constituíam as unidades didáticas de cada série e para onde deveriam convergir os resultados das reflexões nas diferentes áreas. O modelo adotado era o do "círculo concêntrico", em que os conteúdos são abordados a partir das realidades mais próximas dos alunos, o seu contexto social e econômico, passando ao mais distante. Para isso, os temas eram: a Comunidade ( $5^{\mathrm{a}}$ série), o Estado ( $6^{\mathrm{a}}$ série), o País ( $7^{\mathrm{a}}$ série) e o Mundo ( $8^{\mathrm{a}}$ série). Muitos dos objetivos listados por Balzan (1977) se aproximavam das intenções presentes nas obras de Delgado de Carvalho (1970, 1940a):

1. Por o adolescente em contacto com o mundo que o cerca; [...] 2. Contribuir para integrar o indivíduo na sociedade em que vive (desde a comunidade em que vive, até o país e o mundo dos quais participa como cidadão); [...] 4. Desenvolver a consciência da necessidade de estabelecer contactos com os diferentes meios de comunicação; [...] 5. Formar o sentimento de nacionalidade; [...] 9. Desenvolver o raciocínio do educando [...] 12. Desenvolver no educando a capacidade de estudar, interpretando com senso crítico, o que viu, leu e ouviu. (Balzan, 1977, p. 35).

O último dos objetivos citados é uma paráfrase, embora sem citação de referência, de um objetivo formulado por Delgado de Carvalho (1970) em "Introdução metodológica aos Estudos Sociais". A intenção desta "área núcleo" nos Ginásios Vocacionais era formar um aluno ativo e consciente, com "uma visão global acerca do mundo em que vive" (Neves, 2014, p. 19). Para tanto, seria desenvolvida a capacidade de compreensão da realidade histórica e social, em sua dimensão nacional e internacional, fazendo com que o adolescente se sentisse "responsável perante a sociedade" (Balzan, 1977, p. 35). A construção do sentimento nacional e do "desejo de desempenhar seus deveres cívicos" eram elementos trabalhados a partir da própria integração do indivíduo ao meio social que o cercava. $\mathrm{O}$ aluno era o agente da aprendizagem. As atividades também mantinham relação com aquilo que já advogava o primeiro programa de Estudos Sociais aplicado no Brasil, na década de 1930: estudo-dirigido; estudos em bibliotecas; estudos do meio, ou seja, "oportunidades para que os alunos transcendessem a sala de aula tomando contacto direito com a realidade" (Balzan, 1977, p. 37); e, discussões em grupo, entre outras atividades.

O estado de São Paulo se antecipou à reforma da ditadura militar e à lei ${ }^{\circ}$ 5.692/71. A lei $\mathrm{n}^{\mathrm{o}} 10.038$, de 5 de fevereiro de 1968, que "Dispõe sobre a 
organização de ensino do Estado de São Paulo", indicava que a "Geografia e a História poderão ser integradas em Estudos Sociais nas duas primeiras séries do colegial.” (Passos, 1971, p. 548, grifos nossos). Enfatizamos o poderão porque mais uma vez é uma indicação e não uma obrigatoriedade. A integração é sempre tomada como um aspecto necessário. A crítica dos historiadores é contra a simples fusão de disciplinas. Nestes termos, José Passos (1971), durante comunicação apresentada no "V Simpósio Nacional dos Professores Universitários de História", considerava que a aliança entre disciplinas no curso secundário, bem ao estilo da argumentação de Delgado de Carvalho, "estabelece estreitos vínculos entre escola e vida" (p. 548). Contudo, argumentava o professor da Faculdade de Filosofia de Santos, que "o modo de execução da idéia é que, em nosso caso concreto e quanto ao pormenor indigitado, nos parece lesivo à cultura." Para isso contribuía a ausência de uma definição clara do que eram os Estudos Sociais, algo que será acentuado pela política educacional da ditadura.

A inserção dos Estudos Sociais nos currículos escolares de Minas Gerais remonta a década de 1950, conforme aponta Fonseca (2010, p. 51):

Em Minas Gerais, os Estudos Sociais são implantados na escola primária na década de [19]50, amparados pelo Programa de Assistência Brasileiro-Americano ao Ensino Elementar (PABAEE). Este órgão nasceu de um convênio firmado em 1953 entre o governo federal do Brasil, o governo do estado de Minas Gerais e o governo dos Estados Unidos da América do Norte, com o objetivo de formar e aperfeiçoar professores para a Escola Normal e Primária, além de produzir e distribuir novos materiais didáticos.

Neste contexto foram traduzidas e publicadas as obras de John Michaelis e Ralph Preston, além do livro "Habilidades em Estudos Sociais" (1964), escrito pela brasileira Maria Onolita Peixoto. Essas propostas - cuja análise mais aprofundada fugiria aos nossos objetivos - advertem que os Estudos Sociais eram um tema amplamente aventado no cenário educacional brasileiro das décadas de 1950 e $1960^{220}$. Apesar de suas diferenças, estavam relacionadas a debates e experiências processados em vigência de um regime democrático e de possibilidades, a partir da aplicação de uma LDBEN recém-promulgada. Discutiam-se o papel dos Estudos Sociais na formação para a democracia. Contudo, não era uma "disciplina" presente em todas as escolas e currículos. Eram experiências pontuais e, quase sempre, vinculadas a inovações educacionais.

\footnotetext{
${ }^{220}$ Para sua compreensão, ver: França (2013), Fonseca (2010), Nadai (1988) e Schmidt (2014).
} 
Com o objetivo de subsidiar o ensino de Estudos Sociais, a Fundação Nacional do Material Escolar (Fename), já sob a ditadura militar, editou o "Guia Metodológico Cadernos MEC - Estudos Sociais-1" (1969), para os professores, e “Cadernos MEC Estudos Sociais-1" (1969), conjunto de exercícios para ser utilizado pelos alunos. Ambos foram escritos por James Braga Vieira da Fonseca e Lydnéa Gasman, formados no curso de História e Geografia da Universidade do Brasil e professores do Colégio de Aplicação desta universidade ${ }^{221}$. Publicados dois anos antes da lei $\mathrm{n}^{\mathrm{o}} 5.962 / 71$, o Guia e o Caderno foram influenciados pela escrita de Delgado de Carvalho e pensados para uma disciplina optativa que convivia no currículo com História e Geografia ${ }^{222}$. Assim, Humberto Grande, diretor da Fename, definiu os Estudos Sociais:

Constituem os Estudos Sociais, atividade interdisciplinar, que se processa com a História e Geografia, Economia e Política, Sociologia e Antropologia Cultural, ciências sociais essas, cujo ensino, ministrado através de metodologia especial, tem por fim realizar valores sociais exigidos pela época. Assim, as Ciências Sociais investigam as relações humanas em função dos nossos tempos e os Estudos Sociais servem-se do conhecimento global delas para obter conclusões práticas, úteis à vida em sociedade. (Fonseca \& Gasman, 1969, prefácio).

É a distinção cunhada por Delgado de Carvalho (1970) entre Ciências Sociais, como pesquisa, e Estudos Sociais, como uma disciplina essencialmente pedagógica que se utiliza de elementos fornecidos pelas Ciências Sociais para formar o aluno. Exigiam, para tanto, um professor preparado. Como atividade interdisciplinar, os Estudos Sociais não deveriam tomar o lugar de outras disciplinas no currículo. E isso os autores do Guia fizeram questão de reafirmar:

Não se pode aceitar os Estudos Sociais como um mero artifício para se reduzir nominalmente o número de disciplinas [...] Isto que tem ocorrido em várias escolas é um "desserviço" à educação, pois não chega a ser Estudos Sociais e deturpa ou quase acaba com a Geografia e História, ambas de considerável valor pedagógico! (Fonseca \& Gasman, 1969, p. 10).

A proposta de Fonseca \& Gasman (1969) visava tratar os conhecimentos da área de Ciências Humanas de forma mais sintonizada com a realidade dos alunos. O programa formulado pelos autores era pautado em quatro temáticas principais:

\footnotetext{
${ }^{221}$ Cf.: França (2013), Glezer (1979) e Santos (2011).

${ }^{222}$ Em depoimento a Santos (2011, p. 173), Gasman sintetizou a sua relação com Delgado de Carvalho: "Cooperando com o professor Delgado na elaboração dos seus livros, desde os tempos de aluna na Universidade do Brasil, fui fortemente influenciada pelas suas ideias de inclusão de uma abordagem mais voltada para o social na escola secundária. Ele sempre acentuava a importância da oxigenação do currículo escolar com visões mais amplas e próximas do cotidiano dos alunos."
} 
Comunidade-Família, Vida Social, Herança Cultural e Relacionamento Internacional. A despeito das intenções dos autores, em integrar o educando à sua comunidade, formar cidadãos responsáveis, desenvolver o sentimento de nacionalidade, os Estudos Sociais já começavam a ser instrumentalizados em sentido doutrinário. Não por acaso, Humberto Grande lembrava, em seu prefácio ao Guia, que o seu ensino tem "por fim realizar valores sociais exigidos pela época”. E não era um momento qualquer. Vivia-se sob um regime de exceção e os Estudos Sociais não ficariam imunes às influências do contexto. As reformas promovidas pelo CFE, a partir de 1971, trouxeram novos contornos aos Estudos Sociais, tornando-os um componente obrigatório do currículo.

\section{2}

\section{O golpe militar e as reformas educacionais: o papel de Valnir Chagas}

A partir da década de 1940, o Brasil passou por um acelerado processo de industrialização e um rápido crescimento urbano, com o aparecimento de novos atores sociais que exigiam profundas reformas nas estruturas vigentes no país. As décadas de 1950 e 1960 se caracterizaram por uma sucessão de crises políticas e econômicas, crescentes agitações sociais e greves. Eram os anos da Guerra Fria e de disputas constantes entre os Estados Unidos e a União Soviética, que buscavam ampliar as suas esferas de influência. O Brasil "não conseguiria naturalmente ficar imune a esta atmosfera." (Reis Filho, 2004, p. 34). Tanto a direita quanto a esquerda radicalizavam as suas posições. De um lado, o presidente João Goulart (1961-1964) tentava aprovar as Reformas de Base - bancária, fiscal, urbana, administrativa, agrária e universitária, embora crescesse, entre a "esquerda radical", "a descrença na possibilidade de que as reformas pudessem ser conquistadas nas margens legais". (p. 36). Por outro lado, uma frente heterogênea, composta por políticos, empresários, setores da Igreja Católica e das forças armadas resistiam a qualquer projeto de reforma. Se João Goulart foi capaz de reunir 150 mil pessoas no famoso "Comício da Central", na cidade do Rio de Janeiro em 13 de março de 1964, como um dos primeiros atos de sua reforma, a "Marcha da Família com Deus pela Liberdade", aglutinou, em São Paulo, 500 mil pessoas contra o governo. O golpe da direita foi desfechado de forma rápida. João 
Goulart, temendo uma guerra civil e o derramamento de sangue, não reagiu e o Congresso Nacional declarou vaga a Presidência da República.

O Ato Institucional (AI) $\mathrm{n}^{\circ} 1$, que seria seguido por muitos outros nos anos seguintes, mantinha a Constituição de 1946, mas aumentava substancialmente os poderes do Executivo, absorvendo funções do Legislativo e do Judiciário. Iniciavam-se a repressão política, as cassações e as perseguições. A partir daí, de acordo com Shiroma et al. (2000, p. 28), constituiu-se um:

Executivo hipertrofiado e repressor que controlava os sindicatos, os meios de comunicação, a universidade. A censura, os expurgos, as aposentadorias compulsórias, o arrocho salarial, a dissolução de partidos políticos, de organizações estudantis e de trabalhadores chegaram para ficar por longo tempo. Pouco mais tarde, introduzir-se-ia também a prática da tortura.

Dermerval Saviani (2008) salienta que logo após o golpe militar, organizaram-se simpósios com o objetivo de pensar a educação nacional. É o caso do encontro patrocinado pelo Instituto de Estudos Políticos e Sociais (IPES), em dezembro de 1964, e do Fórum “A Educação que nos convém”, realizado em 1969, no Rio de Janeiro. Algumas das suas conclusões seriam encampadas pelas reformas educacionais como aspectos constituintes da "visão pedagógica assumida pelo regime militar": "o ensino médio teria como objetivo a preparação dos profissionais necessários ao desenvolvimento econômico e social do país" (p. 295), baseado na "teoria do capital humano", em que a educação tem como função a formação de recursos humanos para o desenvolvimento econômico; conformava-se a "concepção produtivista de educação", abalizada na ideia de racionalidade, eficiência e produtividade e nos princípios de "máximo resultado com o mínimo dispêndio" e "não duplicação de meios para fins idênticos" (p. 297). Com isso, valorizavam-se os elementos quantitativos em detrimento dos qualitativos e abria-se caminho para a expansão da iniciativa privada, tanto no ensino médio quanto no superior. Segundo Shiroma et al. (2000, p. 28):

É inegável que as reformas do ensino empreendidas pelos governos do regime militar assimilaram alguns elementos do debate anterior, contudo fortemente balizados por recomendações advindas de agências internacionais e relatórios vinculados ao governo norte-americano (Relatório Acton) e ao Ministério da Educação nacional (Relatório Meira Mattos). Tratava-se de incorporar compromissos assumidos pelo governo brasileiro na Carta de Punta Del Este (1961) e no Plano Decenal de Educação da Aliança para o Progresso - sobretudo os derivados dos acordos entre o MEC e a AID (Agency for International Development), os tristemente célebres Acordos MEC-USAID. 
Concomitante às discussões sobre a necessidade de reformas educacionais, a Constituição promulgada em 1967 não previa os percentuais mínimos que a União deveria investir na educação. Conforme Fonseca (2010, p. 19), “a partir daí o Estado passa a diminuir sucessivamente os investimentos no setor educacional". A legislação educacional do regime militar, consubstanciada em decretos, leis e pareceres, foi desenvolvida, sobretudo, entre 1964 e 1971, em um clima de gradativo fechamento político do país e sistematização do aparato repressivo através da publicação de AIs, em especial o AI-5 em dezembro de 1968. Portanto, as políticas foram realizadas de cima para baixo, excluindo amplos setores da sociedade na sua formulação. Nos "anos de chumbo" foram editadas a lei ${ }^{\circ}$ 5.540/68, de 28 de novembro de 1968, que reformou o ensino superior, e a lei $\mathrm{n}^{\mathrm{o}}$ 5.692/71, de 11 de agosto de 1971, de Reforma do Ensino de $1^{\circ}$ e $2^{\circ}$ graus. De certo modo, as reformas se complementavam ${ }^{223}$. A lei $\mathrm{n}^{\mathrm{o}} 5.540 / 68$ impôs o vestibular unificado e classificatório, eliminando o problema dos "excedentes". Os relatórios Meira Matos e o produzido pelo Grupo de Trabalho da Reforma Universitária propunham uma reforma do ensino médio em "consonância com a problemática existente na Universidade.” (Romanelli, 2007, p. 234).

A conexão que tinham em vista estabelecer entre um e outro nível não era a da integração de ambos, mas da reformulação dos objetivos do ensino médio de $2^{\circ}$ ciclo (atual $2^{\circ}$ grau) com vistas a um desvio de demanda social de escola superior. [...] E eles entenderam que isso só seria possível na medida em que aquele grau de ensino fosse capaz de proporcionar uma formação profissional. Uma vez adquirida uma profissão, antes de ingressar na Universidade, o candidato potencial a ela ingressaria na força de trabalho e se despreocuparia de continuar lutando pela aquisição de uma profissão que, na maioria dos casos, só era obtida através de curso superior. (Romanelli, 2007, p. 234).

Com essa perspectiva, logo no primeiro artigo, a lei $\mathrm{n}^{\circ} 5.692$ estabelecia novos objetivos para o ensino de $1^{\circ}$ e $2^{\circ}$ graus: “Art. $1^{\circ} \mathrm{O}$ ensino de $1^{\circ}$ e $2^{\circ}$ graus tem por objetivo geral proporcionar ao educando a formação necessária ao desenvolvimento de suas potencialidades como elemento de auto-realização, qualificação para o trabalho e preparo para o exercício consciente da cidadania."

A "qualificação para o trabalho" incorporou a perspectiva da "teoria do capital humano", na definição de Theodore W. Schultz, e a estreita vinculação entre educação e economia. O "exercício consciente da cidadania" era um elemento presente nas falas dos conselheiros desde a década de 1960, conforme

\footnotetext{
${ }^{223}$ Para uma análise acerca das reformas cf.: Germano (2011), Romanelli (2007), Saviani (2008).
} 
abordaremos no próximo tópico. A "autorrealização" tem como ênfase o desenvolvimento de potencialidades no aluno. Entre elas, está a perspectiva de “mais educação". Como referência, Valnir Chagas (1984, p. 81) recorre ao que considera a "voz mais autorizada: John Dewey”. Para o conselheiro, a explosão de conhecimentos ocorrida nas décadas posteriores ao pensamento de Dewey, lhe deu um realce crescente. É impraticável ensinar, na escola regular, "tudo a todos". Em consequência, Chagas argumentava que (1984, p. 91, grifos do autor):

[...] outra solução não há senão tomar como norma de comportamento o princípio segundo o qual o que o aluno aprende é, sobretudo, a aprender, empregando os conhecimentos e experiências como simples meios, num contínuo processo de reconstrução.

É o que Chagas (1984) denomina como "aprendizagem de auto-realização". A lei $\mathrm{n}^{\mathrm{o}} 5.692 / 71$ elevou a obrigatoriedade escolar de quatro para oito anos e incorporou o antigo ensino elementar (escola primária) ao primeiro ciclo da escola secundária (ginásio), compondo o $1^{\circ}$ grau, responsável pela formação geral e por uma iniciação ao trabalho. A referida lei eliminou o exame de admissão ao ginásio e extinguiu a distinção entre ginásio comercial, agrícola e secundário, promovendo o $2^{\circ}$ grau profissional. Para a disciplina História, na prática, isso significou uma redução da sua carga horária em favor de disciplinas profissionalizantes. Segundo Martins (2000, p. 47), “a reforma não envolveu somente a definição da quantidade de anos que comporia cada nível de ensino, mas passou a definir também que conteúdos essenciais seriam parte do ensino no Brasil." Nesse contexto, o CFE adquiriu ainda mais importância. A sua estrutura foi plenamente aproveitada pela ditadura militar (Martins, 2000, p. 67-68):

Quando os militares instauraram a ditadura no Brasil após o golpe de 1964, já encontraram, portanto um sistema jurídico-administrativo consolidado no que se refere à educação. Esse sistema não se apresentava como um problema para o governo militar. Tanto a Reforma Universitária realizada em 1968 (sobre a organização do ensino superior) quanto a Reforma do Ensino de $1^{\circ}$ e $2^{\circ}$ graus, a partir de 1971, mantiveram essa estrutura utilizando-se plenamente dela para alcançar seus objetivos. Sob esse aspecto, pode-se dizer que a reforma educacional da ditadura militar interferiu direta e enormemente no cotidiano da educação escolar e em todo o sistema de ensino, mas não pode ser vista como uma reformulação de todo o sistema educacional, uma vez que manteve funcionando os órgãos públicos desse setor, anteriores à reforma, e usufruiu, ao máximo, das prerrogativas legais e jurídicas para tal setor. Nisso, o CFE passou a exercer papel principal, uma vez que se tornou o órgão de maior capacidade executiva no período. 
Ainda segundo Martins (2000, p. 73):

[...] o CFE dos anos [19]70 esteve fortemente ligado à administração do Estado militar e funcionou como colaborador daquele regime político, mas não o fez por ter corrompido suas funções e sim porque as exerceu em conformidade com o seu regimento e prerrogativas legais, exacerbando as funções normativas.

Os fundamentos da lei $\mathrm{n}^{\mathrm{o}} 5.692 / 71$ foram propostos pelo conselheiro Raimundo Valnir Cavalcante Chagas, relator do Grupo de Trabalho encarregado de elaborar o projeto de Reforma de Ensino de $1^{\circ}$ e $2^{\circ}$ graus. Chagas foi autor, ainda, da concepção de Estudos Sociais desenvolvida a partir de 1971. Diferentemente de Delgado de Carvalho, existem poucos trabalhos sobre este educador. O livro mais completo sobre seu pensamento e atuação foi escrito por Aloylson Pinto (2010), por ocasião da coleção "Educadores" do MEC. Outros trabalhos importantes são os textos de Célio da Cunha (2002), "Valnir Chagas: ideias e práticas pedagógicas", e de Dermeval Saviani (2013), "Valnir Chagas e as reformas de ensino" (Capítulo de "História das Ideias Pedagógicas no Brasil"). Estas são referências com as quais dialogamos. Uma análise mais aprofundada da obra de Valnir Chagas ainda precisa ser feita ${ }^{224}$. Aqui apresentamos alguns aspectos de sua trajetória, sem a intenção de esgotá-la. Valnir Chagas é vinculado à ditadura militar e às suas políticas educacionais autoritárias, embora sua atividade profissional anteceda em muito aos governos militares.

Valnir Chagas, cearense, nasceu em 1921 e faleceu em 2006. Tendo como formação inicial o bacharelado em Direito, pela Faculdade de Direito do Ceará, cursou, já atuando como conselheiro, a licenciatura em Pedagogia da Faculdade Católica de Filosofia do Ceará, instituição da qual foi um dos fundadores e onde lecionou. Segundo Pinto (2010, p. 13), essa dupla formação garantiu a Valnir o "conhecimento jurídico e o de sistemas e processos educativos". Entre as décadas de 1940 e 1950, organizou e dirigiu o Departamento Regional do Serviço Nacional de Aprendizagem Comercial (Senac) e atuou no Conselho Estadual de Educação do Ceará entre 1956 e 1962. Pelas mãos de Anísio Teixeira teve a oportunidade, através de bolsas de estudos, de realizar observações sobre o ensino

\footnotetext{
${ }^{224}$ Referimo-nos a uma análise específica sobre a concepção educacional deste educador, para além de algumas facetas do seu pensamento e obra. Ele é sempre lembrado pelos principais pareceres das reformas educacionais dos anos de 1970, pelo projeto de formação de professores, pela autoria do parecer $\mathrm{n}^{\circ}$ 251/1962, que estabeleceu o currículo mínimo do curso de Pedagogia, e pela relatoria do parecer $\mathrm{n}^{\circ} 853 / 71$, que estabeleceu a Doutrina do Núcleo Comum. Como salienta Saviani (2013, p. 375), "talvez o único assunto que não lhe coube relatar foi o que se refere à pósgraduação, que ficou a cargo de Newton Sucupira."
} 
secundário norte-americano e cursar uma especialização nas Universidades de Michigan e Columbia (Secondary Education and Teachers College, 1959). Em Michingan cursou, ainda, a especialização Manpower Planning and Analysis (1969). Graduou-se pelas universidades de Londres, Exeter e Sheffield e Lancaster em University Administration (1965).

$\mathrm{Na}$ Universidade Federal do Ceará, foi diretor e professor catedrático da Faculdade de Filosofia, Ciências e Letras, e fundador da Faculdade de Educação, da qual foi um dos primeiros diretores. Atuou nesta instituição até 1974, quando foi transferido para a Universidade de Brasília, onde lecionou na pós-graduação até sua aposentadoria em 1991, como membro do Conselho Diretor. Ingressou no CFE em 1962, inicialmente com um mandato de dois anos, sendo reconduzido em 1964 e em 1970. O convite para compor esse Colegiado partiu de Anísio Teixeira, segundo o relato de Valnir Chagas aos pesquisadores Ester Buffa e Paolo Nosella (1991). Consideramos que o contato inicial entre os dois educadores se deu através do processo de produção da obra "Didática especial de línguas modernas", cuja primeira edição é de 1957. Valnir Chagas relatou a Buffa e Nosella (1991, p. 128) sobre isso: "eu tinha publicado o livro didático, com experiências de todos esses 15 anos. Foi aí que eu fui conhecer Anísio, por esses anos [19]50, quando levei os originais do livro ao INEP." Anísio Teixeira prefaciou o livro sobre a Didática. A carta escrita pelo educador baiano ao seu colega cearense demonstra que ambos ainda não tinham tido um contato mais aprofundado. Diz-nos Anísio:

Não sei porque, depois de ler êste livro, encontrei-me em dúvida sôbre se devia ou não escrever o prefácio que o professor Walmir ${ }^{(\text {sic) }}$ Chagas me pede. Sabia que a obra não precisava de prefácio. Pessoas de maior autoridade que a minha já a haviam julgado, considerando-a excepcional no seu campo. (Teixeira, 1957, p. 1).

A escolha de Anísio parece ter sido uma tentativa de Valnir Chagas de expandir as suas relações para além do seu estado natal e da Região Nordeste, onde já possuía uma trajetória reconhecida como educador e reformador. Sobre a obra prefaciada, Anísio Teixeira (1957, p. 1) teceu elogios consideráveis:

Constitui, por todos os títulos, um manual para o professor de línguas, que só um mestre poderia escrever e que vai, sem dúvida, concorrer para estimular, esclarecer e tornar mais capazes os professôres experimentados ou inexperientes, que o lerem e o estudarem. Com efeito, não se trata de um livro de receitas, destinado a guiar os passos do professor de línguas, mas um livro de pensamento e de ciência, destinado a lhe iluminar a cabeça, a lhe aumentar a visão, a lhe aguçar a análise para melhor achar o seu caminho pessoal de educador e mestre. 
Apesar dos elogios, Anísio Teixeira criticou a apropriação feita por Valnir Chagas acerca das análises de John Dewey, argumentando que as citações realizadas nem sempre eram fiéis à posição do filósofo americano. Ao concluir a missiva, Anísio declarava o interesse em continuar as discussões com Valnir:

Gostaria de poder conversar mais longamente com um colega do seu porte, mas, já que não o posso fazer, permita-me que lhe peça não ler Dewey - em traduções, nem a dos outros nem as minhas - e lê-lo mais, pois evitaria, assim, creio, certas injustiças com o seu pensamento que, aqui e ali, se encontram em seu esplêndido trabalho. (Teixeira, 1957, p. 5).

Talvez essas conversas tenham ocorrido durante o período em que ambos atuaram no CFE e na Universidade de Brasília, durante meados dos anos de $1960^{225}$. Fato é que apesar das divergências no pensamento entre os educadores, é possível encontrar convergências e inspirações deweyanas e anisianas na concepção educacional de Valnir Chagas, cuja intervenção mais direta na educação brasileira e ápice da carreira ocorreram nos anos em que foi membro do CFE (1962-1976). Em quase 15 anos de pertença ao Conselho, participou ativamente das reformas educacionais do período, sobretudo a Reforma de Ensino Superior (1968) e a Reforma de Ensino de $1^{\circ}$ e $2^{\circ}$ graus (1971), da qual foi relator. "Afora os três livros que publicou, seus escritos estão espalhados por numerosas publicações, separatas e opúsculos.” (Pinto, 2010, p. 22) 226 . Ficou marcado por sua atuação durante os "anos de chumbo", cujas políticas foram alvo de severas críticas durante a sua formulação e implementação e, sobretudo, nas décadas seguintes. E aqui há uma grande distância entre Anísio Teixeira e Valnir Chagas: o primeiro jamais atuaria em um governo ditatorial. Não há como negar que Valnir Chagas foi um "ideólogo educacional do regime militar" (Saviani, 2013, p. 379). Sobre a sua interpretação acerca do golpe é significativo o depoimento a Buffa e Nosella (1991, p. 163) em 1986.

Eu mesmo nunca usei a palavra Revolução, esperei que ela fosse e não foi. E, então, eu apenas convivi. Para falar sinceramente, não acreditei em nenhum momento, mas acho que tinha que se fazer o que pudesse. A minha geração só teve

\footnotetext{
${ }^{225}$ Saviani (2013, p. 375) salienta que "esgotada a 1ª edição [de "Didática especial de línguas modernas"], publicada em 1957, Valnir redige, em setembro de 1966, um prefácio à $2^{\text {a }}$ edição, que saiu em 1967. Valnir lembra as palavras de Anísio, que denominou essa publicação 'um livro de educação geral ilustrado com o caso da aprendizagem das línguas estrangeiras'. E lhe agradece chamando-o de 'grande mestre e amigo, que hoje mais admiramos após cinco anos de convívio no Conselho Federal de Educação'."

${ }^{226}$ São eles "Formação do magistério: novo sistema" (1976) e "O ensino de $1^{\circ}$ e $2^{\circ}$ graus: antes, agora e depois?" (1978), ambos reunindo a sua produção e os principais pareceres publicados durante o mandato no CFE, e a já citada "Didática especial de línguas modernas" (1957).
} 
de liberdade, mesmo, os anos do governo Juscelino Kubitscheck, desde que nasci. Se a gente for esperar, não faz nada; e, mesmo assim, o JK foi de certo modo autoritário; fez Brasília "na marra". De maneira que a gente vive no Brasil como ele é, se a gente for esperar um Brasil, comme il faut [como deveria], a gente nunca vai fazer nada. Você sabe o que é trabalhar em termos de escola única, numa lei de 1970 e poucos, no governo de Médici?

Apesar de argumentar que apenas "conviveu" com o golpe e a ditadura militar, Valnir Chagas foi extremamente próximo às estruturas de poder. Tanto que não foi alvo dos expurgos processados no CFE. O próprio Anísio Teixeira, que já havia sido afastado da Universidade de Brasília, foi exonerado em 1968, juntamente com Alceu Amoroso Lima e Antônio Almeida Júnior. Ao escrever o livro "O ensino de $1^{\circ}$ e $2^{\circ}$ graus: antes, agora e depois?"227, em plena ditadura militar, Chagas (1984, p. 41) trata o golpe como a "terapeuta de choque de 1964". Um mal necessário no combate à inflação e à crise econômica e cujas conquistas possibilitaram o contexto reformista no qual se situava. Saviani (2013, p. 379) destaca que Valnir era o "homem de confiança do ministro da educação, coronel Jarbas Passarinho" e "fundamentou e justificou as medidas relativas à política educacional implementada pelo regime militar." ${ }^{228}$ A ideia de autoritarismo está presente no depoimento do conselheiro. Passado o fim da ditadura - o depoimento é de 1986 - ele tinha plena consciência de ter atuado num dos momentos de maior fechamento do período militar, o governo Médici (1969-1973). A legislação e os pareceres de sua autoria só puderam existir em um contexto de total ausência de liberdade. Valnir Chagas se aproveitou da proximidade com o regime vigente para formular e aplicar as suas ideias sobre a escola única, que tencionava romper com a dualidade "formação de uma elite" versus "formação profissional", e sobre a divisão do conhecimento em três grandes linhas. As características do contexto

\footnotetext{
${ }^{227}$ O livro publicado por Valnir Chagas logo após a sua saída do CFE, em 1978, é uma resposta às críticas que já se avultavam em relação às reformas educacionais impostas entre os anos $1968 \mathrm{e}$ 1971. A obra se propunha, no entender do seu autor, a "uma 'explicação' mais sistemática e que alcance além dos frios textos legais" (Introdução). Em pouco mais de 400 páginas, Valnir se propõe a destrinchar e a defender a sua obra educacional sob os anos do regime militar. Isso se reflete na estrutura da obra: o antes, abordado em dois capítulos - o primeiro analisa quatro séculos de educação no Brasil, da colônia as diretrizes estabelecidas pela Primeira República (1889-1930), e o segundo se debruça sobre a "construção de quatro décadas", do movimento escolanovista às discussões da década de 1960; o agora, com oito capítulos de defesa da concepção educacional por ele aplicada às reformas elaboradas pelo CFE; e, por último, o depois, sintetizado em um capítulo que se interroga sobre a educação da próxima geração.

${ }^{228}$ Saviani (2013, p. 378) destaca que Valnir Chagas (1984) chega a justificar "a eliminação da vinculação de recursos para a educação, que fora iniciada com a Constituição de 1934, alegando que se tratou de medida geral de disciplina financeira não restrita à educação [...] ocultando o fato de que, com a abolição da vinculação constitucional, o orçamento do MEC despencou nesse período, caindo dos 12\% previstos na Constituição de 1946 para 7,6\% em 1970 e 4,31 em 1975."
} 
permitiram que a lei $\mathrm{n}^{\mathrm{o}}$ 5.692/71 fosse aprovada pelo Congresso Nacional em apenas 30 dias - enquanto a LDBEN levou 13 anos para ser aprovada - e sancionada sem vetos pelo presidente da República.

\section{3}

\section{Núcleo comum: os Estudos Sociais como "matéria"}

A lei $n^{\circ} 5.692 / 71$ delimitou, no seu quarto artigo, que os currículos das escolas de $1^{\circ}$ e $2^{\circ}$ graus teriam um núcleo comum, obrigatório em âmbito nacional, e uma parte diversificada, atenta às necessidades e particularidades locais, aos planos pedagógicos dos estabelecimentos de ensino e às diferenças individuais dos alunos. Caberia ao CFE fixar as "matérias" relativas ao núcleo comum, com os seus objetivos e amplitudes. A conselheira Terezinha Saraiva ${ }^{229}$ afirma, em entrevista a Santos (2011), que Valnir Chagas fez questão de elaborar o parecer que tornaria os Estudos Sociais obrigatórios na escola de $1^{\circ}$ grau. De acordo com Martins (2000, p. 22), os conselheiros se manifestavam através de pareceres, indicações e resoluções, além de produzirem "Estudos Especiais":

Os Pareceres correspondem à forma como os conselheiros apresentam os argumentos e os resultados dos estudos e das opiniões sobre as matérias encaminhadas ao órgão e que são discutidas e sistematizadas nas Câmaras, Comissões ou Plenário. As Indicações são as proposições apresentadas pelos Conselheiros para os assuntos sobre os quais as Comissões ou as Câmaras se pronunciaram e que devem então ser apreciadas pelo Plenário. Manifestavam-se ainda por meio das Resoluções, de caráter mais objetivo, decorrentes dos pareceres e que deveriam ser seguidos como normas pelos sistemas estaduais de ensino. Há ainda os Estudos Especiais, textos quase sempre produzidos por um conselheiro, sobre um assunto genérico que poderia resultar em processos a serem deliberados pelo CFE. (Martins, 2000, p. 22).

O CFE era dividido em duas Câmaras Setoriais: a Câmara de Ensino Superior (CESu) e a Câmara de Ensino de $1^{\circ}$ e $2^{\circ}$ graus (CE de $1^{\circ}$ e $2^{\circ}$ graus), além de possuir um conjunto de comissões: Planejamento, Legislação e Normas, Moral e Cívica, Currículos e Encargos Educacionais (Martins, 2000). Em 1971, compunham a CE de $1^{\circ}$ e $2^{\circ}$ graus o Padre José de Vasconcellos (presidente),

\footnotetext{
${ }^{229}$ Maria Terezinha Tourinho Saraiva, professora primária do Rio de Janeiro. Foi Secretária de Educação e Cultura do Estado da Guanabara no final do governo Carlos Lacerda (1965) - a primeira a ocupar tal posição no Brasil - e a primeira Secretária de Educação do Município do Rio de Janeiro (1975-1979). Pertenceu ao Conselho Federal de Educação, tendo presidido a Câmara de Ensino de $1^{\circ}$ e $2^{\circ}$ graus, e ao Conselho Estadual de Educação do Rio de Janeiro. Atuou, ainda, como Secretária Executiva Adjunta do Movimento Brasileiro de Alfabetização (Mobral).
} 
Valnir Chagas, Esther de Figueiredo Ferraz, Maria Terezinha Tourinho Saraiva, Vicente Sobrinho Porto e Lenna Castello Branco. Em cada parecer aparece o nome do seu autor (ou relator), seguido pelo voto do pleno ou da Câmara e a decisão final do Plenário composto por todos os conselheiros. Martins (2000, p. 23) afirma que "não aparecem ementas ou discordâncias dos conselheiros, caso existissem" e que "são documentos produzidos para expressar a decisão plenária". Contudo, identificamos "a declaração de voto" ou "o voto em separado", quando um conselheiro discordava de algum aspecto tratado pelo relator e solicitava alterações nos pareceres. Sobre isso é elucidativa a fala de Terezinha Saraiva:

Funcionava assim: na Câmara de Ensino de $1^{\circ}$ e $2^{\circ}$ graus, definia-se o relator. O relator era responsável pelo trabalho inicial. Na reunião, ele já trazia alguma coisa pronta. Então, a Câmara discutia, aprovava integralmente, acrescentava ou rejeitava alguma coisa. Aprovada pela Câmara, a proposta ia para o plenário [...]. (Depoimento a Santos, 2011, p. 190).

Essa informação é importante porque, conforme veremos mais adiante, nem todas as argumentações contidas no parecer relatado por Valnir Chagas foi consenso entre os demais membros do CFE. Houve um "voto em separado", embora Terezinha Saraiva indique que a concepção final seja toda do conselheiro.

Valnir Chagas (1993) considerava a fixação do núcleo comum como o mais importante desdobramento da lei $\mathrm{n}^{\circ}$ 5.692/71, de 11 de agosto de 1971: um "prolongamento de suas formulações iniciais e primeira medida concreta de sua implementação.” (p. 385). O parecer no 853/71, aprovado pelo CFE em 12 de novembro de 1971, seria, no seu entender, responsável por constituir uma "nova concepção da escola" através da consideração do "problema do currículo globalizado"230. Os elementos básicos desta "nova escola" seriam o núcleo comum e a parte diversificada do currículo, a educação geral e a formação especial, e a organização do currículo em "atividades, áreas de estudo e disciplinas". A composição curricular foi proposta em "camadas que sucessivamente se acrescentariam” (p. 387): núcleo comum - constituído pelo parecer $\mathrm{n}^{\circ}$ 853/71, relatado por Chagas, e pela resolução $n^{\circ} 8 / 71$, de $1^{\circ}$ de dezembro de 1971; as disciplinas obrigatórias previstas no sétimo artigo da lei $n^{\circ}$ 5.692/71 - Educação Moral e Cívica, Educação Física, Educação Artística, Programas de Saúde e Ensino Religioso, este obrigatório nos estabelecimentos de ensino oficiais e facultativo para os alunos; a parte diversificada, indicada pelos

\footnotetext{
${ }^{230}$ Utilizamos a versão publicada na "Revista Brasileira de Estudos Pedagógicos” em 1993.
} 
Conselhos Estaduais de Educação e pelas próprias instituições de ensino; e, por último, as matérias destinadas às habilitações profissionais previstas no ensino de $2^{\circ}$ grau. Tais componentes formavam o currículo pleno.

O currículo pleno abarcava mais do que um "grupo de disciplinas" ou a “seriação dos estudos". Era o desenvolvimento do currículo, reelaborado em nível da escola, e a fase final de operacionalização das normas desenvolvidas pelo CFE, pelos Conselhos Estaduais e pelas escolas. Segundo Saraiva (1975, p. 80):

É trabalho dos professores. Implica o modo pelo qual essa escola organiza os conteúdos do núcleo comum e da parte diversificada da educação geral e da formação especial e o tratamento dinâmico desses conteúdos sob formas flexíveis de atividades, áreas de estudos ou disciplinas, segundo características da clientela a que se destine.

As duas primeiras camadas do currículo pleno, o núcleo comum e as matérias obrigatórias previstas na lei $\mathrm{n}^{\circ} 5.692 / 71$, configuravam os conteúdos e conhecimentos cuja ausência tornaria incompleta a formação no ensino de $1^{\circ}$ e $2^{\circ}$ graus. Eram responsáveis pela "educação básica de qualquer cidadão" (Chagas, 1993, p. 397). Tinham caráter obrigatório e visavam a uma "unidade nacional". A lei $\mathrm{n}^{\mathrm{o}} 5.692 / 71$ previa que os componentes curriculares se distribuíssem em uma parte dedicada à "educação geral" e outra de "formação especial", ambas compondo o que se delimitava como a "educação integral" dos alunos. Para isso, buscava-se eliminar a dualidade existente na escola secundária brasileira, harmonizando o "uso da mente e das mãos" e "abrindo sempre o caminho para mais estudos e preparando o aluno para a vida, para o trabalho e 'para o exercício consciente da cidadania'." (p. 394). Enquanto a parte de "educação geral” era responsável pela transmissão de uma base comum de conhecimentos indispensável a todos os brasileiros, a parte de formação especial tinha como objetivos a "sondagem de aptidões" e a "iniciação para o trabalho", em relação à escola de $1^{\circ}$ grau, e à preparação para o trabalho na escola de $2^{\circ}$ grau. Essa composição curricular tinha como objetivo final as concepções de continuidade e terminalidade presentes na lei $n^{\circ} 5.692 / 71$ :

Conforme os termos expressos da lei (art. $5^{\circ}, \S 1^{\circ}$, letras a e b), a educação geral será exclusiva nos anos iniciais de escolarização e predominará sobre a especial até o fim do ensino de $1^{\circ}$ grau. A formação especial surgirá após estes "anos iniciais", de certo modo em segundo plano, e crescerá gradativamente até predominar sobre a educação geral no ensino de $2^{\circ}$ grau. (Chagas, 1993, p. 394). 
A parte geral habilitava a "continuidade" dos estudos e a formação especial, com a iniciação ao trabalho e a "habilitação profissional", caracterizava a "terminalidade". Contudo, na concepção dos legisladores, não haveria conhecimentos que se configurassem apenas como gerais ou apenas como especializados, já que a sua definição dependeria do contexto em que figurassem. Por exemplo: o ensino de línguas estrangeiras seria considerado como parte da "educação geral" do adolescente, na escola de $1^{\circ}$ ou de $2^{\circ}$ grau, ou como um elemento da "formação especial" em um curso de $2^{\circ}$ grau com habilitação em secretariado. O parecer $n^{\circ} 853 / 71$, ao introduzir o "núcleo comum", apresenta uma percepção diferente de disciplina e de "matéria", que não são apreendidas como sinônimos pelo CFE. Na definição do CFE, matéria seria todo:

[...] campo de conhecimentos fixado ou relacionado pelos Conselhos de Educação, e em alguns casos apresentado pela escola, antes de sua reapresentação, nos currículos plenos, sob a forma "didaticamente assimilável" de atividades, áreas de estudo ou disciplinas. (Chagas, 1993, p. 390).

O termo matéria é entendido como "matéria-prima" a ser desdobrada e desenvolvida pelo currículo pleno de cada escola ${ }^{231}$. Uma potencialidade, que poderia adquirir formas diversas. A divisão entre atividades, áreas de estudo e disciplinas segue a premissa do "mais para o menos amplo e do menos para o mais específico". (Chagas, 1993, p. 390). Nas atividades, as aprendizagens deveriam ser construídas a partir de experiências concretas mais do que através da “apresentação sistemática de conhecimentos”; nas áreas de estudo, formadas pela integração tradicional de conteúdos afins, deveria haver um equilíbrio entre as "situações de experiência" e os "conhecimentos sistemáticos". Por último, nas disciplinas, com o caráter especializado, a aprendizagem ocorreria a partir dos “conhecimentos sistemáticos". A distinção entre cada uma destas "categorias curriculares" era em relação ao grau de ensino (início da escolarização, $1^{\circ}$ e $2^{\circ}$ graus). Contudo, de acordo com Chagas (1993, p. 391), o conhecimento deveria estar presente desde as atividades. Do mesmo modo, não se poderia dispensar "alguma conexão com o real no estudo das disciplinas, sem o que se descambará para um intelectualismo vazio e inconsistente". Todas, apesar de lecionadas sobre rubricas distintas, "devem convergir para uma reconstrução, no aluno, da substancial unidade do conhecimento humano" (p. 391). Assim, do conjunto

\footnotetext{
${ }^{231}$ Delgado de Carvalho, em suas obras sobre Estudos Sociais, utiliza o termo "matéria", mas em sentido diferente do propagado pelo CFE. Ele entende matéria como disciplina escolar.
} 
resultaria um "todo orgânico e coerente" (p. 392). Numa inspiração deweyana, Chagas (1984, p. 134) argumentava que "a melhor escola é a que se aproxima do real”. A partir desta premissa ele justificava a constituição do núcleo comum.

O núcleo comum parte da perspectiva de que o conhecimento humano deve ser "encarado em suas grandes linhas", do mais para o menos geral e do menos para o mais específico. A fundamentação é dupla. De inspiração americana e brasileira. Maria A. Schmidt (2014) revela que em 1959, ano em que Valnir Chagas esteve nos Estados Unidos para a realização de uma de suas especializações, ocorreu uma reunião em Wood Hale (Massachusetts) cujo tema foi a "integração do conhecimento", questão que estava em pauta no final da década de 1950. Sobre as conclusões deste encontro, em síntese:

Partindo da hipótese de que a atividade intelectual é a mesma em toda parte (Bruner) e de que haveria a possibilidade de lidar do mesmo modo com toda a realidade - que seria supostamente única também, propôs-se o ensino de uma ciência integral, uma estrutura conceitual. Houve um consenso de que se poderia ensinar na escola "a ciência geral" como introdução às ciências disciplinares dos graus superiores, estruturando-se as áreas de conhecimento: Ciências, Língua e Estudos Sociais. (Schmidt, 2014, p. 183-184)

Paralelamente, a argumentação de Valnir Chagas recorreu a um debate que permeava a escrita de intelectuais brasileiros desde a década de 1930 e a introdução do ensino de Ciências Sociais na escola primária do antigo Distrito Federal, cidade do Rio de Janeiro. O conselheiro defendia que o "Saber é um só" e, portanto, a sua compartimentação tem sempre um caráter mutilador do conhecimento. Na sua visão, um duplo problema se impunha: nem seria possível a apresentação de um tópico curricular sob um título único, denominado como "Conhecimento"; nem se poderia permanecer com a "divisão arbitrária" que caracterizava o currículo escolar de então. Argumentava-se que a repartição em disciplinas tornaria impossível, na prática, a sua reinclusão no conjunto. Chagas considerava tais premissas como um "sediço lugar comum" e não explícita as suas referências quanto à questão. Contudo, há semelhanças com o que já defendia Delgado de Carvalho em meados dos anos de 1930. Basta lembrar que para este educador a "Ciência é una" e toda divisão é efeito do trabalho de cientistas e professores para melhor compreensão de determinados temas, mesmo que isso não dê conta de uma explicação global dos fenômenos. Mas Delgado refletiu exclusivamente sobre a integração ou fusão das disciplinas que compõem o campo das Ciências Sociais. Valnir Chagas (1984) ampliou essa perspectiva para 
as outras áreas do conhecimento e na definição de todo o currículo escolar, conforme exemplificou em "O ensino de $1^{\circ}$ e $2^{\circ}$ graus: antes, agora e depois?".

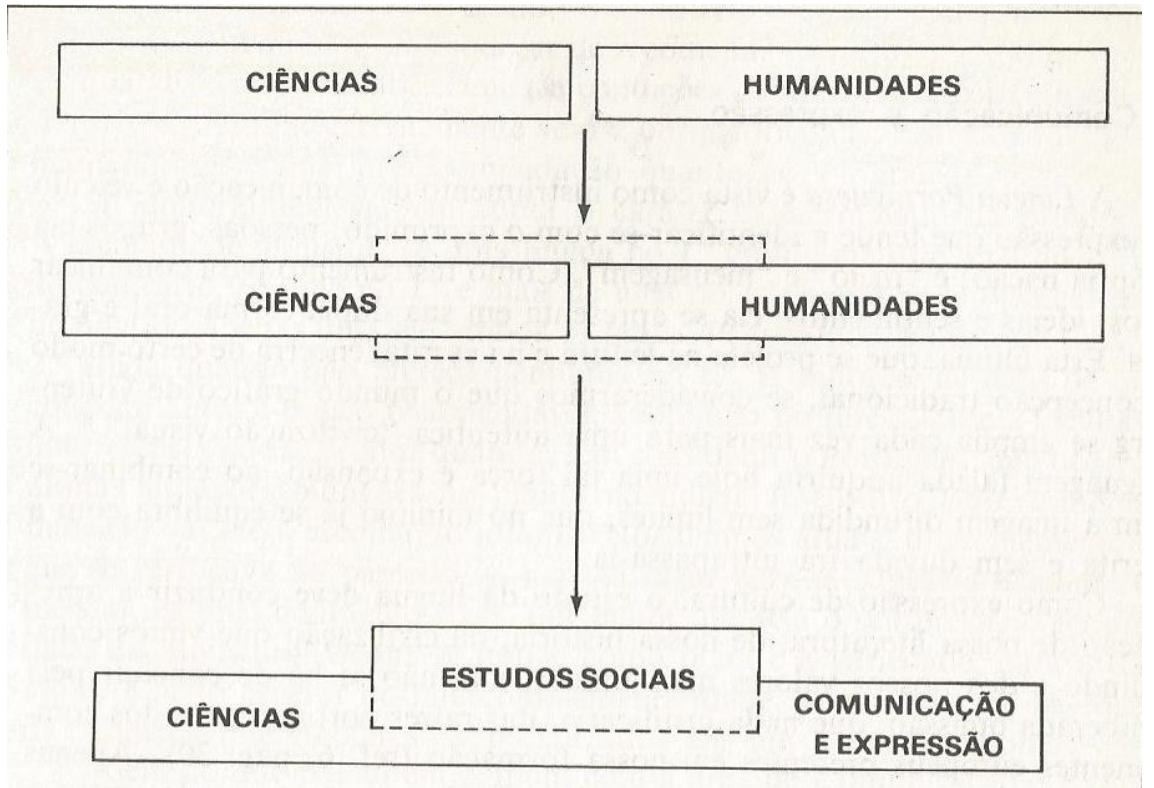

Figura 16 - "Divisão e integração do conhecimento" Fonte: Chagas (1984, p. 137).

$\mathrm{Na}$ divisão em "grandes linhas do Conhecimento", inspirada em definições americanas e indicada pelo parecer $\mathrm{n}^{\circ} 853 / 71$, sintetizando o mínimo a que se deveria ter acesso nos processos de escolarização, Chagas (1993, p. 398) propôs “o destaque de partes sem retirá-las funcionalmente do seu todo natural". Segundo essa orientação, entre as formas possíveis de visualizar as matérias, optou-se pela tríplice classificação em: Comunicação e Expressão, Ciências e Estudos Sociais, com estes últimos representando o elo a ligar as duas primeiras. Isso porque, na defesa do conselheiro, os Estudos Sociais "têm uma abordagem mais científica do que estas últimas, ao tempo que para muitos chegam a confundir-lhes com elas e, sobretudo, colocam no centro do processo a preocupação do Humano.” (p. 398). Chagas (1984) alegava que esta divisão do conhecimento se mostrava mais integradora do que a classificação dupla - Ciências e Humanidades - que caracterizava as discussões sobre o currículo escolar brasileiro. Como aponta Santos (2011, p. 194), o fundamento central desta abordagem é "o homem como o centro de toda a ação e o sujeito do processo de ensino-aprendizagem". Fixadas as grandes linhas, o legislador determinou os "conteúdos obrigatórios" de cada uma delas. $\mathrm{O}$ artigo $1^{\circ}$ da resolução $\mathrm{n}^{\circ}$ 8/71 fixou a seguinte distribuição: 
1) Comunicação e Expressão: Língua Portuguesa e uma Língua Estrangeira Moderna, recomendada no $1^{\circ}$ grau e obrigatória no $2^{\circ}$ grau;

2) Estudos Sociais: Geografia, História e OSPB.

3) Ciências: Matemática e Ciências Físicas e Biológicas.

As matérias e os seus "conteúdos específicos" não deveriam ser vistos de forma isolada ou como compartimentos estanques, levando-se em consideração que "tudo está em tudo" (Chagas, 1993, p. 400): "as matérias fixadas diretamente e por seus conteúdos obrigatórios deverão conjugar-se entre si e com outras que se lhes acrescentem para assegurar a unidade do currículo em todas as fases do seu desenvolvimento." (Resolução no 8/71 apud Chagas, 1993, p. 419). A Língua Portuguesa não poderia ser abordada, como uma forma de Comunicação e Expressão, separada da Educação Artística ou de um Desenho que lhe pudesse acrescentar, correndo-se o risco de um empobrecimento do ensino. Em relação aos Estudos Sociais, o parecer $n^{\circ} 853 / 71$ defendia que a "Geografia, a História e a Organização Social e Política do Brasil adquirem tanto mais sentido e vigor quanto mais se interpenetram com vistas à integração do aluno ao meio próximo e remoto." (Chagas, 1993, p. 400). Para isso, convergiriam as matérias e seus conteúdos. Partindo desta premissa, Chagas incorporou ao núcleo comum as disciplinas obrigatórias previstas na lei $\mathrm{n}^{\mathrm{o}} 5.692 / 71^{232}$, conforme a figura abaixo. No caso dos Estudos Sociais: Educação Moral e Cívica (EMC) e OSPB.

\footnotetext{
${ }^{232}$ Destas disciplinas apenas deixou-se de incluir o Ensino Religioso. Valnir Chagas (1984, p. 149) se mostra desfavorável ao ensino desta disciplina na escola: "por envolver matéria de fé e não chegar, em rigor a caracterizar-se como um componente exigível de todos. Só os estabelecimentos oficiais são obrigados a ministrá-lo e, ainda assim, como 'disciplina' sempre 'facultativa' para os alunos. O cidadão é livre para ter a sua crença ou para não ter nenhuma e, mesmo tendo-a, poderá recusar-se a 'estudá-la' na escola."
} 


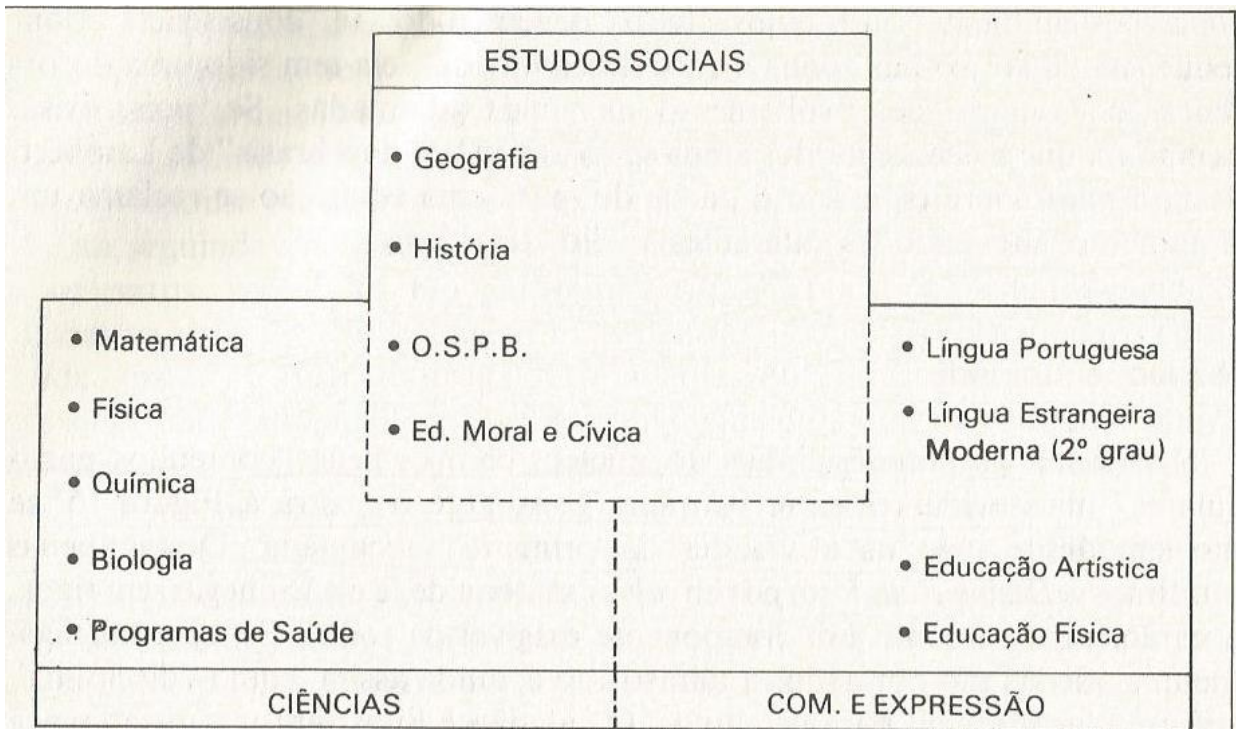

Figura 17 - Núcleo comum

Fonte: Chagas (1984, p. 150).

A EMC e a OSPB têm uma trajetória anterior à reforma elaborada por Valnir Chagas e a sua inclusão no núcleo comum ${ }^{233}$. Os debates sobre a formação moral e cívica do brasileiro antecederam a ditadura militar, embora tenham ganhado maior relevo nos currículos escolares da década de 1970. A Lei Orgânica do Ensino Secundário, promulgada em 1942, ainda sob a ditadura do Estado Novo (1937-1945), possui um capítulo inteiro intitulado "Da Moral e Cívica". Os artigos 22 e 23 são indicativos da política educacional que se intentava:

Art. 22. Os estabelecimentos de ensino secundário tomarão cuidado especial e constante na educação moral e cívica de seus alunos, buscando neles como base do caráter, a compreensão do valor e do destino do homem, e, como base do patriotismo, a compreensão da continuidade histórica do povo brasileiro, de seus problemas e desígnios, e de sua missão em meio aos outros povos [...].

Art. 23. Deverão ser desenvolvidos nos adolescentes os elementos essenciais da moralidade: o espírito de disciplina, a dedicação aos ideais e a consciência da responsabilidade. Os responsáveis pela educação moral e cívica da adolescência terão ainda em mira que é finalidade do ensino secundário formar as individualidades condutoras, pelo que força é desenvolver nos alunos a capacidade de iniciativa e de decisão e todos os atributos fortes da vontade.

A reforma Capanema, entretanto, não estabeleceu um programa específico de educação moral e cívica ou indicou um tempo delimitado no currículo escolar. Ela deveria ser desenvolvida em todas as atividades e circunstâncias da vida

\footnotetext{
${ }^{233}$ José W. Germano (2011, p. 134) esclarece que: "Na realidade, trata-se de uma reintrodução, pois a cadeira de 'Instrução Moral e Cívica' foi instituída em 1925, pela Reforma Rocha Vaz, justamente como forma de combater o protesto estudantil contra o Governo Arthur Bernardes. Foi reforçada durante o Estado Novo e, com a Constituição de 1946, teve o seu caráter de obrigatoriedade revogado."
} 
escolar. As disciplinas História e Geografia, na escola secundária, eram as responsáveis principais pela "formação da consciência patriótica", além de discutir os "problemas vitais do país". Somavam-se a elas outras práticas, como o Canto Orfeônico e a Educação Física. A LDBEN de 1961 compreendia a formação moral e cívica dos alunos como parte do processo educativo. O CFE, através da indicação $n^{\circ} 1 / 62$, responsável por recomendar as normas do ensino médio, determinou que a Educação Cívica fosse uma "prática educativa", o que gerou certas dúvidas no próprio Conselho. Valnir Chagas solicitou que a "Comissão de Ensino Primário e Médio" apresentasse uma distinção entre disciplina e prática educativa. $\mathrm{O}$ parecer $\mathrm{n}^{\circ}$ 131/62, relatado pelo conselheiro Cândido Padin (1962, p. 43), salientava que a "prática educativa" abrangia atividades, de ordem física, moral, cívica, artística e religiosa, que deveriam atender às necessidades dos adolescentes colocando o "acento principal na maturação da personalidade, com a formação dos hábitos correspondentes."234

Ainda em 1962, o CFE criou a OSPB como uma disciplina da escola secundária. O conselheiro Newton Sucupira (1962, p. 99) argumentava que tal criação preenchia uma "lacuna injustificável no que diz respeito à preparação do jovem para o exercício consciente da cidadania democrática." Sua finalidade era a formação cívica do jovem brasileiro, promovendo a sua inserção na vida política e social do país. Isso se faria através do conhecimento das instituições, da estrutura governamental, dos processos políticos e administrativos que caracterizam a vida em um regime democrático. Sucupira (1962) aproveitava o seu pequeno artigo, publicado na "Documenta", para rebater aqueles que argumentavam que a formação do cidadão estava além do conhecimento formal de direitos e deveres políticos. Para o conselheiro, um dos difusores de Dewey no interior do CFE, a escola deve ser entendida "enquanto comunidade de vida", responsável por proporcionar a vivência de certas virtudes. À escola caberia, fundamentalmente, esclarecer o sentido de "consciência cívica" e zelar por sua constituição.

Após o golpe militar de 1964, tanto a EMC quanto a OSPB tiveram o seu sentido alterado, conforme salienta Juliana Filgueiras (2006), assumindo um

\footnotetext{
234 As disciplinas são "as atividades escolares destinadas à assimilação de conhecimentos sistematizados e progressivos, dosados conforme certos endereços. Nesse caso, evidentemente, a assimilação do conjunto de conhecimentos programados é passível de mensuração e é condição de prosseguimento dos estudos." (Padin, 1962, p. 43). As disciplinas representam os conhecimentos sistematizados necessários à interpretação e compreensão do mundo (Padin, 1962).
} 
caráter de maior doutrinação do aluno. Segundo a autora, a "formação moral e cívica era considerada necessária para impedir que as idéias subversivas tomassem conta dos jovens, além de prepará-los para uma futura participação na sociedade, de acordo com a proposta do regime militar" (Filgueiras, 2006, p. 39). Isso fez com que as discussões retornassem ao $\mathrm{CFE}^{235}$. Conselheiros como Cândido Padin, Clóvis Salgado e Abgar Renault consideravam que "a moral e o civismo não seriam apreendidos pelos estudantes na escola, se seus valores e princípios não fossem vivenciados pela sociedade" (p. 39). De um lado, era uma forma de crítica, mesmo tímida, à ditadura militar. Como exercer a cidadania em tempos autoritários, com as liberdades individuais e coletivas ameaçadas? E bastava, por outro lado, a já existente disciplina OSPB, indicada pelo CFE a partir da interpretação da LDBEN. Já os militares formularam a EMC como parte da Doutrina de Segurança Nacional que, entre outros aspectos, previa o combate ao "inimigo interno" e à oposição. As condições para a sua implementação definitiva nos currículos escolares ocorreram pós-1968 e o endurecimento do regime.

Se em outubro de 1968, o CFE ainda foi capaz de aprovar um parecer contrário à introdução de EMC nos sistemas de ensino do país (Filgueiras, 2006), após a edição do Ato Institucional $\mathrm{n}^{\circ} 5$, em dezembro, e a súbita doença do presidente Costa e Silva, tal resistência teve pouco efeito. O decreto-lei $n^{\circ}$ 869/69, de 12 de setembro de 1969, assinado pela Junta Militar ${ }^{236}$, que substituiu o presidente Costa e Silva, e pelo Ministro da Educação Tarso Dutra, estabeleceu a EMC em caráter obrigatório como disciplina e também como prática educativa nas escolas de todos os graus e modalidades do país. No ensino superior seria ensinada sob a forma de Estudos de Problemas Brasileiros (EPB), devendo ser ministrado em no mínimo dois semestres. Este mesmo documento tornou obrigatório o ensino de OSPB nos currículos escolares do país e criou a Comissão

\footnotetext{
${ }^{235}$ Os debates ocorreram na sessão do CFE do dia 30 de abril de 1964. O Ministro da Educação solicitou que o Conselho se pronunciasse, com urgência, em relação ao ensino de EMC nas escolas de ensino médio. Tratava-se, segundo consta do requerimento ministerial, de pedidos dirigidos por "entidades cívicas femininas." O parecer, relatado por Cândido Padin, e as falas dos conselheiros Newton Sucupira, Clóvis Salgado, Abgar Renault e Almeida Júnior foram publicadas sob o título "Sobre o ensino de Moral e Cívica em estabelecimentos de Ensino Médio" (Documenta, 1964).

${ }^{236}$ A Junta Governativa Provisória de 1969 era composta pelos três ministros militares: General Aurélio de Lira Tavares, ministro do Exército; Almirante Augusto Rademaker, ministro da Marinha; e Brigadeiro Márcio de Sousa Melo, ministro da Aeronáutica. Em agosto, o presidente General Artur da Costa e Silva sofreu um derrame, que o deixou paralisado e causaria o seu falecimento meses depois. Os ministros militares impediram que o vice-presidente, o civil Pedro Aleixo, assumisse a Presidência do Brasil. Governaram o país entre 31 de agosto e 30 de outubro.
} 
Nacional de Moral e Civismo (CNMC), com a função de contribuir para a elaboração dos currículos e programas de EMC e de influenciar instituições e órgãos formadores de opinião pública e difusão cultural (jornais e revistas, teatros, emissoras de rádio e televisão, entidades esportivas, por exemplo). A lei ${ }^{\circ}$ 5.692/71 e o parecer $n^{\circ} 853 / 71$, ambos relatados por Valnir Chagas, reafirmaram aquilo que havia sido instituído por legislação do executivo federal militar.

Valnir Chagas (1984) demonstra ser contrário à EMC, pelo menos nos termos em que foi constituída, como mais uma disciplina escolar e acadêmica. No seu livro, o conselheiro argumenta que na década de 1970 crescia uma preocupação com a promoção expressa e formal da educação moral e cívica, o que levava a uma dispersão. Ao explicar a sua posição, Valnir desconsidera momentos anteriores ao que ajudou a moldar enquanto membro do CFE e as propostas de Estudos Sociais desenvolvidas entre as décadas de 1930 e 1960. Para ele, durante séculos, não houve a preocupação com a formação para a "cidadania brasileira" “pela simples razão de que vivíamos de olhos fitos em nações 'adiantadas' e procurávamos realizar outros projetos que não o nosso.” (Chagas, 1984, p. 144). Entretanto, em poucas décadas, três componentes curriculares passaram a cuidar do mesmo tema: Estudos Sociais, OSPB e EMC. Não custa salientar que para Delgado de Carvalho os próprios Estudos Sociais, a partir de cada uma das disciplinas que o compunham, já davam conta da formação para a cidadania. $\mathrm{Ou}$ seja, a educação social e política permeava todas as disciplinas escolares e a própria educação, não havendo necessidade de uma disciplina específica com essa função. Chagas concorda com tal perspectiva sobre o ensino de civismo:

$\mathrm{Na}$ realidade, ele não se esgota com uma ou diversas disciplinas, cujo número tende a multiplicar-se ante o desencanto que o seu formalismo vai gerando. É preciso não esquecer que o "preparo para o exercício consciente da cidadania" se insere entre os três grandes objetivos proclamados no pórtico das diretrizes atuais. Nessa condição, repetimos, constitui, sobretudo, um endereço que se deve imprimir a todo o ensino de $1^{\circ}$ e $2^{\circ}$ graus no contexto de toda a escolarização. (Chagas, 1984, p. 144-145).

De acordo com o seu entendimento, as crianças aprendem, diariamente, sobre valores, ética, moralidade, caráter e conduta, a partir do comportamento de pais, mestres, da sociedade e da própria forma como a escola se organiza: "uma atividade geral e permanente que não se exaure nos limites de uma disciplina" (Chagas, 1984, p. 97). A escola é a sociedade e "o preparo do cidadão é, assim, 
toda a Educação com endereço cívico." (Chagas, 1984, p. 94) ${ }^{237}$. O plano curricular traduz em disciplinas e lições formais os comportamentos considerados como desejáveis ao bom desenvolvimento da sociedade. No caso da ditadura, elementos que contribuíssem para uma sociedade pacífica e ordeira. A inclusão de EMC no currículo demonstra os limites da atuação do CFE em um contexto de extremo autoritarismo, o que não significa que alguns conselheiros, como Celso Kelly, não a tenham apoiado como uma disciplina do currículo escolar.

Dos componentes dos Estudos Sociais, defendidos por Delgado de Carvalho entre as décadas de 1930 e de 1950, apenas permaneceram a História e a Geografia. Tanto no parecer $n^{\circ} 853 / 71$ quanto nos pareceres produzidos em defesa da proposta de Valnir Chagas e publicados ao longo de 1972, a História e a Geografia são delimitadas como "conteúdos obrigatórios" ou "conteúdos específicos" da matéria Estudos Sociais. Isso é interessante porque, por vias tortas a bem da verdade, eliminava-se um problema presente entre os defensores dos Estudos Sociais na escola secundária. O que são Estudos Sociais? Uma disciplina? Uma área de estudo? A própria abordagem de Delgado tem certa dificuldade com essa distinção, algo que Valnir Chagas resolveu com a força da caneta que segurava e a sua posição em um órgão deliberativo como o CFE. Do mesmo modo que a proposta de Delgado de Carvalho, os Estudos Sociais em Valnir Chagas - associado à Comunicação e Expressão e Ciências - não tinham como função apenas a transmissão do conhecimento, mas constituíam "um meio para o enriquecimento da personalidade em conjunto." (Chagas, 1984, p. 164). Com isso, cada uma das três linhas do conhecimento tinha uma função. $O$ ensino visava:

[...] em Comunicação e Expressão, o "cultivo de linguagens que ensejem ao aluno o contacto coerente com os seus semelhantes (comunicação) e a manifestação harmônica de sua personalidade, nos aspectos físico, psíquico e espiritual" (expressão), sem deixar de ressaltar a importância da Língua Portuguesa "como expressão da Cultura Brasileira".

[...] nos Estudos Sociais, o "ajustamento crescente do educando ao meio, cada vez mais amplo e complexo, em que deve não apenas viver como conviver", sem deixar de atribuir à devida "ênfase ao conhecimento do Brasil na perspectiva atual do seu desenvolvimento";

\footnotetext{
${ }^{237}$ Uma posição compartilhada por outros membros do Conselho. Valnir Chagas se inspira, claramente, no que defendeu Clóvis Salgado nas discussões sobre a não inclusão da EMC no currículo escolar: "Trata-se, no fundo, da formação de hábitos de natureza ética, causada não apenas pela aquisição de conhecimentos através de aulas, mas principalmente pelo calor afetivo das relações de pessoa a pessoa pelo atrativo dos ideais vividos em comunidade. Consequentemente, para esse fim, importa muito mais o ambiente humano em que se educa o adolescente, do que as matérias e técnicas empregadas." (Documenta, 1964, p. 16).
} 
[...] nas Ciências, o "desenvolvimento do pensamento lógico e a vivência do método científico", sem deixar de pôr em relevo as tecnologias que resultam de "suas aplicações". (Chagas, 1993, p. 401).

A Língua Portuguesa é vislumbrada como instrumento de comunicação não apenas no sentido de transmissão, mas também de compreensão de ideias, fatos e sentimentos sob a forma de leitura, escrita e comunicação oral. Não deixa, portanto, de ser um dos mecanismos de/para a integração do educando ao meio. O parecer $n^{\circ} 853 / 71$ sinalizava que as crianças possuem um "saber lingüístico prévio" que a escola cabe orientar e disciplinar: "No início da escolarização, a aprendizagem se fará principalmente à base de atividades, a serem desenvolvidas de modo e com intensidade que o idioma surja diante do aluno menos como uma sucessão de palavras do que sob a forma natural de comportamento." (Chagas, 1993, p. 402). Segundo Dewey (2002, p. 54), nesse estágio da escolarização, com crianças pequenas, a linguagem não deve ser ensinada "como uma coisa em si", mas através do "instinto verbal socialmente estimulado". Chagas (1993) consagrou em seu parecer uma visão semelhante, se não inspirada nas perspectivas deweyanas: a partir daquilo que a criança traz para a escola, é que se ampliaria a preocupação com a língua e se chegaria às "sistematizações gramaticais". A seleção de textos selecionados para a leitura deveria valorizar a História, a Literatura e a civilização brasileira, salientando "nossos valores mais típicos" e "suas raízes portuguesas" e europeias (p. 402). Não há menção aos elementos da cultura afro-brasileira e indígena presentes na nossa formação.

Os Estudos Sociais apresentam como função principal "a integração espácio-temporal e social do educando em âmbitos gradativamente mais amplos" (Chagas, 1993, p. 403): da região em que vive o aluno, do seu país, do seu grupo, do seu tempo em relação a outros grupos, países, tempos e assim por diante. Os dois componentes principais são a Geografia, com foco na Terra e nos "fenômenos naturais referidos a experiência humana", e a História responsável por analisar “o desenrolar dessa experiência através dos tempos”. Ambas deveriam ser encaradas em sua necessária interdependência e ensinadas com o intuito de situar o aluno "em sua circunstância" ou o meio em que vive. Nesse sentido, os Estudos Sociais têm como fim uma visão integrada do homem e do meio. Apesar de não expor um programa, o parecer $n^{\circ} 853 / 71$ indica que os Estudos Sociais deveriam começar pelo "estudo do meio", o mais próximo do 
aluno, e pelo "atual" ("o aqui-e-agora do mundo em que vivemos"), sem se deixar de lado "o legado de outras épocas" e a "experiência de outros povos" como um contributo necessário à "compreensão entre indivíduos e nações”, num sucessivo alargamento de horizontes. Era essa a abordagem, em termos de conteúdos, proposta pelo PCS (1934), organizado por Delgado de Carvalho, no então Distrito Federal. Contudo, na argumentação do conselheiro, não bastaria uma justaposição de conteúdos, situando os elementos históricos e geográficos de forma paralela. Para Valnir Chagas (1993), a separação da Geografia como uma disciplina individualizada, desde os anos iniciais da escolarização, resultava no seu “inevitável empobrecimento". Com isso, sua abordagem impõe a interpenetração de conteúdos. O centro dos Estudos Sociais proposto por Chagas é a OSPB:

[...] introduziu-se nos Estudos Sociais um terceiro ingrediente representado pela Organização Social e Política do Brasil. Vinculando-se diretamente a um dos três objetivos do ensino de $1^{\circ}$ e $2^{\circ}$ graus - o preparo ao "exercício consciente da cidadania" - para a OSPB e para o Civismo devem convergir, em maior ou menor escala, não apenas a Geografia e a História como todas as demais matérias, com vistas a uma efetiva tomada de consciência da Cultura Brasileira, nas suas manifestações mais dinâmicas, e do processo em marcha do desenvolvimento nacional. (Chagas, 1993, p. 403, grifos do autor).

Na década de 1960, em manuscrito intitulado "Nôtas sobre programas de Estudos Sociais", Delgado de Carvalho $(1969$, p. 2) incluiu a OSPB como um componente dos Estudos Sociais: "A Geografia explica a Economia, a Economia explica a História e a Organização Social e Política do Brasil é a conclusão prática destas disciplinas". Não era qualquer OSPB, mas aquela que seguia "as instruções do Sr. Conselheiro Newton Sucupira" (p. 4) para uma educação para a democracia. Como lembra Costa (2007), Delgado foi o primeiro a escrever um manual desta disciplina. A obra, publicada inicialmente em 1963, possui mais de 11 edições, que mantiveram o mesmo conteúdo dividido em sete capítulos: a população e a imigração; a família e a comunidade; a economia nacional; o trabalho e o direito social; o Estado e a nação; a vida cultural; e, o Brasil no mundo atual (Carvalho, 1963) ${ }^{238}$. Para o catedrático, a reconstituição da realidade

\footnotetext{
${ }^{238}$ Carvalho (1963, p. 12) esclarece seus objetivos no Preâmbulo: “O trabalho que aqui apresento a meus patrícios e colegas do Magistério é uma primeira tentativa de corresponder à disciplina criada pelo Conselho Federal de Educação para a execução das recentes Diretrizes e Bases, destinadas a remodelar os nossos sistemas educacionais. Não existindo ainda programas, pois estes serão provavelmente elaborados pelos próprios Docentes, apresentei ao professor Anísio Teixeira um plano que me parece interpretar os objetivos do Conselho." Não por acaso, antes mesmo do
} 
social passava pelo necessário "conhecimento dos ambientes nacionais" e pela discussão das "principais questões que constituem elementos de solução para os problemas nacionais" (p. 12). De certo modo, em Carvalho (1963), a Geografia e a História também convergiriam para a OSPB. Não se poderia estudar tal disciplina sem o conhecimento das duas primeiras. Portanto, Valnir Chagas não inovou ao incorporar a OSPB aos Estudos Sociais. Porém, a sua proposta era diferente das intenções de Carvalho na elaboração do manual de OSPB em 1963.

A concepção de OSPB presente em Valnir Chagas, e consequentemente na sua formulação de Estudos Sociais, não é a mesma defendida por Newton Sucupira quando da criação da disciplina em 1962. Ali se objetivava a integração do indivíduo na sociedade democrática, algo que sequer aparece no parecer $n^{\circ}$ 853/71. A preparação para o "exercício consciente da cidadania democrática", com o estudo das leis e conhecimento das questões políticas que caracterizam a sociedade democrática, na acepção difundida por Sucupira (1962), foi substituída pela "participação" no processo de "desenvolvimento nacional", com o objetivo de transmissão da ideologia do regime e de ampliação do sentimento patrióticonacionalista e do civismo. Ou seja, tornou-se uma disciplina que pouco contribuía para o pensamento e a crítica. Constituía-se, assim, como um dos mecanismos utilizados para o controle e repressão a opiniões e pensamentos que fossem contrários ao regime (Fonseca, 2010) e elemento de formação de cidadãos conformados. Uma forma de tentar diminuir as possíveis resistências à ditadura militar estabelecida em 1964. Cabe entender o sentido de "ajustamento".

Anísio Teixeira (1968, p. 59, grifos nossos), em "Pequena Introdução à Filosofia da Educação", salienta que o "processo educativo não tem outro fim, senão o de habilitar a viver melhor, senão o de melhor ajustar o homem às condições do seu meio". Isso significa, em sua teoria educacional, que a escola é uma parte integrante da própria vida e, portanto, deve associar as suas experiências às realizadas fora dos seus muros. Como leitor de Anísio, Valnir Chagas parece se inspirar, pelo menos em parte, nessa definição. Contudo, em Anísio Teixeira esse "ajustar" não é simples adaptação, mas observação, reflexão e compreensão da sociedade. Se possível, uma participação atuante na mudança e na construção de uma sociedade melhor. Delgado de Carvalho, ao propor os 
Estudos Sociais na década de 1950, defendia que eles possibilitam a "libertação do espírito", pois se baseiam em documentação, que precisa ser procurada, estudada e analisada. O seu ensino permitiria a observação, a pesquisa, a independência e a capacidade de pensar. Para que isso fosse possível, Carvalho (1970, p. 91) advogava um ensino livre da "mecanização ambiente e das tentativas de doutrinação". O fundamento, como sinalizavam os documentos americanos produzidos na década de 1930, era a liberdade de expressão e de pensamento.

A declaração utilizada por Delgado de Carvalho (1970, p. 67) é enfática quanto ao objetivo dos Estudos Sociais, em um contexto democrático: "integrar o indivíduo na sociedade democrática em que deve viver, promovendo a sua cooperação como bom cidadão", o que pressupunha a capacidade de estudar, ler, interpretar e possuir senso crítico. No acervo pessoal de Carvalho, depositado no IHGB, encontramos dois documentos sobre os Estudos Sociais produzidos em plena ditadura militar. Um escrito em 1968, outro em 1969, ambos em papel com cabeçalho "Ministério da Educação e Cultura". Infelizmente, não conseguimos identificar se foi uma consulta deste ministério ao educador e a razão da sua escrita neste papel timbrado. São textos que nos ajudam a compreender as permanências e descontinuidades no seu pensamento. No final da década de 1960, Carvalho (1968) sinalizava a função dos Estudos Sociais no currículo escolar:

Os Estudos Sociais constituem uma disciplina que visa a submeter à atenção e à reflexão da geração estudantil os acontecimentos sociais da hora presente e, por meio do conhecimento do passado, de pesquisas e de comparações, orientá-la no sentido de sua mais fácil adaptação às atualidades sociais. (p. 2).

Pouco mais de uma década após a produção de "Introdução metodológica aos Estudos Sociais", publicada em 1957, o termo "integração ao meio social” foi substituído por "mais fácil adaptação às atualidades sociais". Mesmo assim a "disciplina” Estudos Sociais permanece com seu caráter de reflexão e, como argumentamos no capítulo anterior, associa-se à ideia de preparo social e construção, nos alunos, de "juízo crítico" (Carvalho, 1970, p. 198). No objetivo dos Estudos Sociais formulado por Valnir Chagas não aparecem termos como reflexão ou julgamento, elementos formativos que são citados tanto no parecer $\mathrm{n}^{\circ}$ 853/71 quanto na resolução $n^{\circ} 8 / 71$, mas de forma geral. Trata-se, simplesmente, de ajustar a ordem vigente, desconsiderando o elemento de crítica presente na abordagem de Delgado de Carvalho. Por isso, o parecer $n^{\circ} 853 / 71$ reforça o 
“conviver", sem contestar. Pelo menos na letra desta legislação, não há indicativo de uma educação que ajudasse o aluno a refletir sobre o seu papel na sociedade. Por outro lado, a preocupação parece estar muito mais na difusão de valores do regime, daí a ênfase que o parecer $n^{\circ} 853 / 71$ coloca no "conhecimento do Brasil na perspectiva atual do seu desenvolvimento." (Chagas, 1993, p. 401).

Valnir Chagas (1984) entendia a cidadania como uma categoria política, cujo ponto de referência é o Estado e as relações que daí provém. Na sua argumentação, para o controle do Estado ser mais efetivo é preciso reunir o consenso dos cidadãos, "ao tempo que a cidadania se fará tanto mais fecunda quanto mais com ela se harmonizem as individualidades". (p. 96). O sentimento nacional é o elemento básico a se considerar na preparação do cidadão. Naquele momento, conforme argumenta o conselheiro, urgia "fazer de cada indivíduo um fator de segurança e estabilidade para si, para a sociedade e para o Estado.” (p. 95). A "harmonização das individualidades" e o "indivíduo como fator de segurança" seriam criados através da "preservação do espírito religioso", do "culto a Pátria, aos seus símbolos, tradições, instituições e grandes vultos da sua História" e do "culto a obediência" - finalidades da EMC, indicadas pelo decretolei no 869/69 (Brasil, 1969), transpostas para o ensino de Estudos Sociais.

O ensino de Matemática e Ciências Físicas e Biológicas não se limitaria a transmissão do conhecimento relativo às matérias, mas teria como função "tornar o educando capaz de explicar o meio próximo e remoto que o cerca e atuar sobre ele, desenvolvendo para tanto o espírito de investigação, invenção e iniciativa, o pensamento lógico e a noção de universalidade das leis científicas." (Chagas, 1993, p. 403). Há uma proximidade tanto em relação ao pensamento de Delgado de Carvalho quanto ao de Anísio Teixeira: apesar de não desprezar o "conhecimento feito e compendiado", o conselheiro argumentava que os alunos deveriam chegar até ele "pela redescoberta dos princípios gerais", ou seja, como defendiam os educadores oriundos da Escola Nova, era preciso compreender os mecanismos que levam à produção de determinado conhecimento ${ }^{239}$. A conselheira Terezinha Saraiva (1975, p. 84) reafirmou o mesmo postulado:

${ }^{239}$ Carvalho (1970, p. 5) argumentava que: "Em Estudos Sociais a instrução não deve ser dada 'as colheres', como problemas de solução já conhecida; deve ser deixado algo à iniciativa pesquisadora que desenvolva o senso de responsabilidade. A escola secundária condena à atitude de passividade a quem já poderia ativamente enfrentar certas questões." 
Ele [o conhecimento] é formado de duas linhas paralelas: o próprio conhecimento a informação - e as operações lógicas necessárias à manipulação do conhecimento. Deve, assim, ser possível ensinar ao aluno tanto a informação quanto os processos que uma determinada disciplina ou área de estudo usa para adquiri-la e utilizá-la.

Valnir Chagas (1993) salientava, ainda, que o processo pedagógico não se dá por concluído através do cumprimento dos objetivos das matérias e dos seus conteúdos: "é necessário também que 'os conhecimentos, experiências e habilidades' se transmudem em atitudes e capacidades harmônicas entre si, individualmente significativas e socialmente desejáveis." (p. 404). A escola transmite não apenas conhecimentos, distribuídos em disciplinas e conteúdos, mas fornece atitudes e capacidades, que algumas vezes, como defendia Anísio Teixeira (1968, p. 60), "têm maior importância educacional do que o objeto original de ensino". Foram apontadas pelo parecer n 853/71: “as de observação, reflexão, criação, discriminação de valores, julgamento, comunicação, convívio, cooperação, decisão e ação". (Chagas, 1993, p. 404). A elas convergiriam o ensino das matérias fixadas pelo núcleo comum. Cada uma das capacidades, que deveriam transparecer nos planejamentos docentes, "poderá armar o homem moderno", contra, por exemplo, "as sutis agressões dos meios de comunicação que ameaçam escravizá-lo.” (p. 404). Apesar da preocupação do legislador com a formação de um homem capaz de interpretar o noticiário - algo que Delgado de Carvalho (1970) apontava como uma das tarefas dos Estudos Sociais - não há uma indicação de como as escolas trabalhariam tais atitudes e muito menos se discutia a ausência de liberdade para essa tarefa. Tal como a organização curricular, era essa uma responsabilidade de cada estabelecimento escolar.

\section{4}

Organização curricular: Estudos Sociais como atividade, área de estudo e disciplina

As matérias do núcleo comum deveriam ser ensinadas de forma escalonada nos currículos das escolas de $1^{\circ}$ e $2^{\circ}$ graus, da maior para a menor amplitude da linha do conhecimento. Portanto, a matéria se constituiria em atividade, área de estudo e disciplina. De acordo com o depoimento de Terezinha Saraiva (Apud Santos, 2011, p. 190), Valnir Chagas se apropriou das teorias de Piaget: "[existe] uma idade em que a pessoa vê a coisa como um todo [de forma integrada] e, 
depois, vai particularizando." O próprio conselheiro admitia que tal distribuição considerava a evolução psicológica da criança e do adolescente: "a formação preconizada deve ajustar-se em conteúdo, método, ritmo e intensidade às variações de amadurecimento, capacidade e motivação dos alunos." (Chagas, 1984, p. 112). Entretanto, isso já estava presente no pensamento educacional brasileiro das décadas anteriores. Quanto aos Estudos Sociais, como apontamos no quinto capítulo, Carvalho (1934a, p. 12) defendia que o conhecimento deveria ser ministrado de forma a "alargar progressivamente o horizonte social do educando". A sua complexidade era apresentada aos poucos.

Anísio Teixeira também já havia refletido sobre essa questão e é pouco provável que os outros conselheiros não tenham lido a obra deste educador, nomeado por Terezinha Saraiva (2004, p. 105) como o "Mestre de todos nós". O próprio "Valnir considerava-se discípulo e, de certo modo, continuador de Anísio Teixeira.” (Saviani, 2013, p. 375). O livro “O ensino de $1^{\circ}$ e $2^{\circ}$ graus: antes, agora e depois?" (Chagas, 1984) é dedicado “á memória de um grande amigo: Anísio Teixeira”. Para Saviani (2013, p. 379), as visões pedagógicas dos dois educadores não coincidem, embora haja "eventuais pontos em comum". Consideramos que a organização do currículo proposta por Valnir Chagas se inspira em elementos tratados por Anísio Teixeira (1968) em "Pequena introdução à Filosofia da Educação", que por sua vez se baseiam na teoria deweyana. Dito isso, retomamos aspectos já discutidos nesta tese, especificamente no quinto capítulo, acerca da organização psicológica do currículo escolar. Segundo Teixeira (1968, p. 63):

As atividades infantis são os começos incertos e tateantes que devem conduzir à experiência organizada e lógica, já consubstanciada em livros. Essa última representa mais do que o conjunto de leis e instrumentos já aperfeiçoados para solução das dificuldades reais que a vida apresenta.

Ainda de acordo com essa argumentação, Teixeira (1968, p. 68) esclarecia que: "Partindo da criança e de suas necessidades, chegamos à conclusão de que o programa escolar se deve organizar em uma série de experiências reais e socializadas, e não como uma simples distribuição de matérias escolares." As atividades escolares seriam extraídas entre as atividades naturais exercidas pela criança em seu grupo. Para Anísio Teixeira (1968), o erro dos elaboradores do currículo escolar estava na não consideração das fases do crescimento infantil. Nesse sentido, desde os anos iniciais da escolarização o aprendizado se faz pela 
"organização lógica, racionalizada e sistematizada" (p. 70) do conhecimento, ou seja, pela distribuição em disciplinas. A organização psicológica, por sua vez, dispõe a disciplina consoante cada fase do desenvolvimento infantil. A disciplina escolar, através da sua organização lógica, é o último estágio do currículo. Valnir Chagas (1993) se apropriou desse pensamento na sua perspectiva de currículo. Assim indicava a resolução $n^{\circ}$ 8/71 (Chagas, 1993, p. 421):

I - No ensino de $1^{\circ}$ Grau,

a) nas séries iniciais, sem ultrapassar a quinta, sob as formas de Comunicação e Expressão, Integração Social e Iniciação às Ciências (incluindo Matemática), tratadas predominantemente como atividades;

b) em seguida, e até o fim desse grau, sob as formas de Comunicação em Língua Portuguesa, Estudos Sociais e Matemática e Ciências, tratadas predominantemente como áreas de estudo;

II - No ensino de $2^{\circ} \mathrm{Grau}$, sob as formas de Língua Portuguesa e Literatura Brasileira, História, Geografia, Matemática e Ciências Físicas e Biológicas, tratadas predominantemente como disciplinas e dosadas segundo as habilitações profissionais pretendidas pelos alunos.

Chagas (1984, p. 112) entendia que essa "progressividade" ou "avanço flexível e ordenado da escolarização" não se confundia com a educação progressiva que se desenvolveu nos Estados Unidos a partir de finais do século XIX, e que tinha em John Dewey o seu maior expoente, embora com ela concordasse em algumas soluções. Ao tentar clarificar a doutrina do núcleo comum para os sistemas de ensino e professores que, no final do ano letivo de 1975, ainda tinham dificuldade em compreendê-la, a conselheira Terezinha Saraiva (1975) utiliza Dewey como justificativa para a elaboração do CFE:

Considerando-se como Dewey que "toda experiência vive e se prolonga em experiências que se sucedem" e que "nenhuma experiência será educativa se não tender a levar simultaneamente ao conhecimento de mais fatos e a entreter mais idéias e o melhor e mais organizado arranjo desses fatos e idéias", fica evidenciada a importância da elaboração sequencial de conteúdos, de modo a evitar lacunas, saltos ou empecilhos ao fluxo livre do processo educativo. (Saraiva, 1975, p. 79).

A abordagem imposta pelo CFE contém um amálgama de questões que já eram discutidas por educadores brasileiros e estrangeiros, como Delgado, Anísio, Dewey e Jerome Brunner. Santos (2011, p. 192) salienta que na visão deste último, "apresenta-se a criança uma versão rudimentar [do conhecimento ou do conteúdo], que poderá ser subsequentemente refinada, à medida que ela progrida na escola". As atividades, entre elas Integração Social, um dos formatos dos Estudos Sociais, tomariam como base as necessidades, problemas e interesses dos alunos "para a seleção, orientação e avaliação das experiências de aprendizagem" 
(Saraiva, 1975, p. 78). Portanto, partiriam, no entendimento do CFE, das relações mais imediatas dos alunos (relações sociais e cívicas, econômicas, entre outras), isto é, tendo como origem as "áreas de vida pessoal". O tratamento da matéria seria, nos primeiros anos de escolarização, amplo e generalizado e se faria através da integração dos conteúdos. Valorizava-se não tanto o conhecimento, mas as experiências que levam a sua construção. Sintetiza Saraiva $(1975$, p. 78$)$ que:

Em outras palavras, o conhecimento não vem "pronto", para ser consumido, ao contrário, ele será reelaborado, a partir das "experiências vividas" [...] Daí ser importante que as atividades selecionadas propiciem situações de experiência de onde possam fluir 'conteúdos' que dêem as bases para a aquisição da dimensão profundidade em etapas posteriores.

No outro extremo desta organização curricular se situavam as disciplinas, como "um corpo sistematizado de conhecimentos, que serve de base às experiências de aprendizagem" (Saraiva, 1975, p. 78) e organizado de forma lógica, de acordo com a tradição e estrutura conceitual de cada uma delas. Saraiva (1975) reconhecia, ainda, que cada uma delas possui "um modo próprio de comprovar a validade de seus conhecimentos e uma linguagem especial, constituída por termos ou símbolos próprios.” (p. 79). A forma intermediária era a área de estudo, que “integra os 'conteúdos' em vastas áreas, mostrando o conhecimento como unidade, se bem que caracterizado pela pluralidade.” (p. 79). Isso ocorreria, na concepção do CFE, uma vez que, os conteúdos são parte do todo, "não são estranhos em si", e possuem limites "indefinidos e diluídos". Utilizava-se a velha argumentação de que se deveria evitar a transmissão compartimentada do conhecimento, conforme indica Saraiva (1972a, p. 194):

Não admitimos a aplicação de currículos com categorias estanques, nem aceitamos que conteúdos tão afins, como Geografia, História e OSPB, continuem a ser ministrados segundo "programas", de modo geral completamente divorciados entre si, levando a um condenável excesso de compartimentação da aprendizagem.

A proposta de atividades e áreas de estudos na escola de $1^{\circ}$ grau parte do princípio de que os conteúdos devem ser (re) integrados, como na vida, já que "a divisão é apenas um artifício na unidade do conhecimento humano" (Saraiva, 1975, p. 79). Com as disciplinas, como já argumentava Delgado de Carvalho em sua defesa de Estudos Sociais, corre-se o risco de um currículo "estanque" ou sem interfaces, na argumentação da conselheira Terezinha Saraiva (1975). Mesmo assim, é necessária uma abordagem mais especializada em cada campo do 
conhecimento, conforme sejam aprofundadas diferentes discussões, o que torna a disciplina um componente das etapas superiores de escolarização. Nessa altura da vida, o aluno tem maior capacidade de integrar o conhecimento. Cabe às escolas, manter a integração entre as disciplinas na escola de $2^{\circ}$ grau.

Em relação aos Estudos Sociais, no início da escolarização, sob o título Integração Social, seria abordado predominantemente por meio de atividades. Nas séries seguintes, da $5^{\mathrm{a}}$ a $8^{\mathrm{a}}$ séries, ministrados sob a forma de áreas de estudo e no ensino de $2^{\circ}$ grau, "tratadas predominantemente como disciplinas e dosadas segundo as habilitações pretendidas pelos alunos." (Resolução $n^{0}$ 8/71 apud Chagas, 1993, p. 421). Essa organização curricular entendia a História e a Geografia como "conteúdos específicos" ou "obrigatórios dos Estudos Sociais na escola de $1^{\circ}$ grau." Com essa nova "nomenclatura" elas perdiam o caráter de disciplina neste grau de escolaridade. Apenas na escola de $2^{\circ}$ grau, elas mantinham-se como disciplinas independentes e autônomas, embora com carga horária diminuída em decorrência da profissionalização deste grau de ensino.

$\mathrm{Na}$ sua proposta inicial, Valnir Chagas cogitou retirar a Geografia como disciplina específica do $2^{\circ}$ grau. Não nos foi possível identificar as razões para essa tentativa de exclusão, da qual temos notícias apenas pela reação contrária dos outros conselheiros. Pelo "voto em separado", assinado por Terezinha Saraiva, Esther de Figueiredo Ferraz, Vicente Sobrinho Porto, Lenna Castello Branco, Nair Fortes Abu-Merhy e Arlindo Lopes, podemos analisar a concepção de Geografia formulada pelos membros do CFE. É uma oportunidade singular, já que na letra do parecer $n^{\circ}$ 853/71 não há uma reflexão aprofundada sobre o papel dos “conteúdos” constituintes dos Estudos Sociais. Embora longa, vale a sua citação:

O Homem necessita compreender o Universo e, especialmente, a posição que nele ocupa. A própria atitude do educando em relação à vida depende da compreensão do meio geográfico em que se situa. Sem a Geografia, dificilmente se compreende o fenômeno histórico. Sem ela, não apreende bem o valor da ecologia na adaptação do homem ao meio. Sem a Geografia Humana ficam sem alicerces os estudos sociológicos. A Geografia ocupa, pois, posição primacial. Não aquela Geografia de nomenclatura, mas a Geografia que Vidal de La Blache e tantos outros elevaram a posição de Ciência, que objetiva a compreensão de como fatos diversos - físicos, biológicos, demográficos, econômicos e sociais - se expressam em combinações distintas e complexas e põem em evidência a importância das condições geográficas sobre o ser humano. Com efeito, na interrelação constante do homem com o meio geográfico em que vive - como agente e como resultante - é essencial que cada indivíduo esteja apto a compreendê-lo e a sobrepujá-lo conscientemente, o que é impossível sem o conhecimento da Geografia. Igualmente dentro da perspectiva de "aldeia global" em que se transformou o mundo contemporâneo, 
pela difusão, dos meios de comunicação de massa, é imperativo que este sentido de aproximação de distâncias entre os países, continentes e povos seja compreendido em suas verdadeiras dimensões e significado, o que somente poderá ser alcançado através do sentido da Ciência-geográfica. (Documenta, 1971, p. 194-195).

Um primeiro elemento presente neste "voto em separado" se relaciona à posição da Geografia no interior dos Estudos Sociais. Para alguns dos conselheiros, diferentemente do que foi institucionalizado pela Resolução no 8/71, era a Geografia que ocupava "posição primacial". Sem o conhecimento geográfico não haveria compreensão sobre a posição que o homem ocupa no meio social. Sua concepção clarificava os estudos históricos e sociológicos. Uma disposição bastante semelhante à defendida por Carvalho (1949), em "Didática das Ciências Sociais": a Geografia ocupa uma posição estratégica nas Ciências Sociais, pois a ela recorrem todas as outras Ciências. Mas não bastavam às nomenclaturas, já criticadas por Delgado de Carvalho (1940a) na primeira metade do século XX, era preciso entender as relações do homem com o meio e a "significação que tomam as várias formas de atividade humana." (p. 39). Mais ainda, em um contexto de globalização, com a diminuição das barreiras entre os países, a Geografia assumia uma importância ainda maior para a compreensão das relações entre os povos. Outra das indicações de Carvalho (1934b). Para ele, caberia a Geografia "revelar de modo objetivo a interdependência dos povos e das nações do globo.” (p. 11).

A organização curricular proposta pelo CFE foi objeto de sucessivas dúvidas e solicitações de esclarecimentos quanto ao lugar das disciplinas no currículo escolar. Por meio de associações, os geógrafos enviaram, conforme informa Martins (2000), uma série de telegramas, ofícios, pedidos de explicação e protestos ao Ministro da Educação, ao presidente da República e ao próprio CFE. A maioria das petições é datada de 1971 e de 1972 e defende a autonomia, ou individualização, da disciplina Geografia desde a escola de $1^{\circ}$ grau. Os pareceres oriundos destes ofícios, relatados em sua maioria por Terezinha Saraiva, mas também por Valnir Chagas e Paulo Nathanael de Souza ${ }^{240}$, nos ajudam a compreender melhor os aspectos difusos da doutrina do núcleo comum.

Na escrita do parecer $n^{\circ} 226 / 72$, Valnir Chagas (1972) argumentava que a Geografia matinha a sua importância no currículo escolar, mas que cogitar em

\footnotetext{
${ }^{240}$ Paulo Nathanael Pereira de Souza, paulista, nasceu em 25 de março de 1929. Graduado em Ciências Econômicas pela Universidade de Marília. Foi Secretário Municipal de Educação e Cultura de São Paulo (1971-1974), membro do Conselho Estadual de Educação de São Paulo e do CFE, tendo ocupado a sua presidência. Lecionou História na escola primária e secundária.
} 
disciplinas não era função do CFE. O postulado, presente tanto na lei $\mathrm{n}^{\circ}$ 5.692/71 quanto no parecer $n^{\circ} 853 / 71$, é o de um sistema descentralizado de ensino, com a distribuição das competências entre a União e os Estados, articulado por um conjunto de diretrizes nacionais. A concretização se daria na escola e através do trabalho do professor. Ao mesmo tempo em que se esperava certa homogeneidade, a partir de traços comuns, eram reconhecidas possíveis variáveis decorrentes da diversidade regional. Tal posição foi confirmada por Terezinha Saraiva (1975) no parecer $n^{\circ} 4.833 / 75$ : “Compete a cada Sistema de Ensino e a cada escola, dentro dos diversos sistemas, dar uma forma concreta, apropriada, definindo conteúdos, limites, períodos e carga horária.” (p. 84).

Enquanto as matérias (Estudos Sociais, Comunicação e Expressão e Ciências) foram estabelecidas pelo CFE, em esfera nacional, e a indicação da parte diversificada era responsabilidade dos Conselhos Estaduais de Educação, cabia à escola selecionar os conteúdos conforme as características da ambiência. O professor dosava este conhecimento, corporificado no currículo pleno, de acordo com o seu aluno. Por conseguinte, através do princípio da flexibilidade, o parecer $n^{\circ} 853 / 71$ permitia a "configuração própria do currículo de cada estabelecimento". (Saraiva, 1975, p. 78). As matérias eram o elemento comum, o tratamento dos "conteúdos específicos", entre eles a História e a Geografia, era encargo local. As formas distintas que poderiam assumir as matérias (atividades, áreas de estudo e disciplinas) dependiam de circunstâncias específicas (alunos, comunidade em que se situa e recursos humanos e materiais, entre outros). Isso foi um dos fatores que permitiram, por exemplo, com que a Congregação do Colégio Pedro II mantivesse a sua seriação tradicional, com a autonomia da História e da Geografia, rejeitando a implantação dos Estudos Sociais ${ }^{241}$.

Para além da dita justificativa psicológica, a implantação dos Estudos Sociais nos currículos escolares tinha uma justificativa nem um pouco pedagógica, que os conselheiros escamoteiam em seus pareceres. No parecer 977/72, Saraiva (1972a) indicava que um dos propósitos da lei $n^{\circ} 5.692 / 71$ era chegar ao "professor único polivalente", ou seja, um docente formado para ministrar diferentes disciplinas ou áreas de conhecimento. Desde a constituição do CFE, no início dos anos de 1960, uma das suas preocupações fundamentais era a

\footnotetext{
${ }^{241}$ Santos (2011) analisa outros fatores, como: os "padrões institucionais" do colégio.
} 
carência e a formação de professores. Com esse intuito foram criadas as licenciaturas curtas em 1964, o que pode ser considerado como um fator para a precarização da formação docente ao longo das décadas de 1970 e de 1980, já que um curso de três a quatro semestres habilitava ao ensino de até quatro disciplinas no caso da licenciatura curta em Estudos Sociais. Chagas (1993) afirmava que quanto maior fosse a especialização, maior seria o número de disciplinas e a carência de professores habilitados. Para ele, o currículo levava a carência.

Os currículos em execução até agora, de nítida inspiração intelectualista, tendiam cada vez mais a dividir o conhecimento em disciplinas muito específicas, já na própria escola primária, exigindo um número sempre maior de mestres cujos salários decresciam na mesma proporção e cuja "oferta", em termos de pessoal qualificado, não acompanhava o ritmo crescente da procura. (Chagas, 1993, p. 414).

A nova organização curricular proposta pelo CFE diminuiria a carência docente. Contudo, as justificativas "oficiais" apontadas pelos conselheiros em seus pareceres são, quase sempre, a questão pedagógica e a psicologia infantil:

É psicologicamente recomendado que o educando, na faixa etária dos 10-11 anos passe de um só professor, que o acompanhou nas primeiras séries do ensino de $1^{\circ}$ grau para, no máximo, 3 professores polivalentes que o acompanharão no final do ensino de $1^{\circ}$ grau, ministrando áreas de estudo, que integram as disciplinas ensinadas, anteriormente em compartimentos estanques, sem nenhum relacionamento, por professores diferentes, o que impedia a visão integralizante de conteúdos afins, chegando, finalmente, ao $2^{\circ}$ grau, em condições de ter professores por disciplina. (Saraiva, 1972b, p. 78).

Os conselheiros argumentavam que no antigo primário o aluno tinha um só professor, que lhe transmitia os conhecimentos relativos ao grau de ensino. Já no antigo ginasial passava-se de um para sete ou nove professores: "numa brusca sucessão de imagens, impressões e orientações, não raro contraditórias, que iam além da sua capacidade de discernimento. Os efeitos sobre a aprendizagem eram desastrosos." (Chagas, 1993, p. 414-415). Somava-se a isso o fato de que entre o primário e o ginásio existia o exame de admissão, uma vez que, eram graus de ensino distintos. Para os conselheiros, isso gerava uma dificuldade de adaptação do aluno. Na organização da escola de $1^{\circ}$ e $2^{\circ}$ graus, a área de estudo representava uma "passagem gradual", ou uma "suave transição" nas palavras de Valnir Chagas (1993), entre a generalização das atividades, ministradas por um único professor, e a especialização das disciplinas, lecionadas por professores diferentes para cada uma delas. A União Paulista dos Estudantes de Geografia encaminhou 
memorial ao Presidente da República questionando a diminuição do mercado de trabalho para os professores de Geografia. Em resposta, Terezinha Saraiva (1972b) advertia que o parecer n ${ }^{\circ}$ 853/71 "não impõe a exclusão da Geografia e da História nas últimas quatro séries do ensino de $1^{\circ}$ grau; apenas recomenda a sua aplicação sob a forma integrada de Estudos Sociais.” (p. 78).

Apesar de defenderem, nos diferentes pareceres em defesa do ensino de Estudos Sociais na escola de $1^{\mathrm{o}}$ grau, que o CFE não havia criado uma nova disciplina escolar, na prática, foi isso que se concretizou. A "interpenetração" dos conteúdos, salientada no parecer $n^{\circ}$ 853/71, virou uma simples fusão de disciplinas. Mesmo a área de estudo não previa a simples integração, já que os Estudos Sociais passavam a ser ministrados por um único professor. A partir de 1971, os Estudos Sociais se tornaram uma justaposição ou somatória de conteúdos, que não necessariamente levavam em consideração os métodos das diferentes disciplinas escolares, como a História. Nesse sentido, não há como deixar de concordar com Fonseca (2010, p. 36): uma "descaracterização e esvaziamento do ensino de História nas escolas de $1^{\circ}$ grau." Há uma diferença em relação ao que se estabeleceu nos Ginásios Vocacionais. Naquela experiência, os Estudos Sociais integravam conteúdos de disciplinas que se mantinham como campos autônomos e eram ministradas por professores especialistas com atuação coordenada. Os escritos de Delgado de Carvalho, entre 1930 e 1950, pelo menos em termos de escola secundária, também reconheciam a independência das disciplinas. Mesmo refletindo sobre os Estudos Sociais, os projetos apontavam a especificidade e a função de cada uma delas. A partir década de 1960, Delgado defende a coexistência dos Estudos Sociais com as disciplinas tradicionais.

$\mathrm{O}$ intelectual estava vivo e atuante durante a Reforma de Ensino de $1^{\circ}$ e $2^{\circ}$ graus. Contudo, apesar das semelhanças de argumentação, só há uma referência explícita a sua obra nos pareceres dos conselheiros, como observaremos mais adiante quando tratarmos da formação do professor da área de Estudos Sociais. Na década de 1950, conforme abordamos no capítulo anterior, o educador reviu a sua posição sobre o lugar dos Estudos Sociais no currículo da escola primária e secundária. Se na década de 1930, Delgado defendeu a sua inclusão na escola primária e secundária, na década de 1950, entende que o lugar da nova disciplina deveria se situar nos anos finais da escola secundária, devido ao grau de maturidade dos alunos. O CFE adotou uma posição inversa: os Estudos Sociais 
desde os primeiros anos de escolarização e as disciplinas específicas na escola de $2^{\circ}$ grau. Em 1975, após quatro anos de publicação do parecer n ${ }^{\circ} 853 / 71$, Delgado de Carvalho, nas entrelinhas, criticou a proposta. Pela sua importância, citaremos um fragmento já utilizado nesta tese. Na sua perspectiva era preciso:

[...] tratar os diferentes setores das Ciências Sociais como conjunto de influências recíprocas. Bem entendido, semelhante coquetel só pode ser oferecido aos estudantes dos últimos anos dos cursos secundários, isto é, depois de ter seguido, nos primeiros anos do curso ginasial os programas paralelos, mas separados das duas disciplinas básicas. (Carvalho, 1975b, p. 159).

Para Delgado de Carvalho, a História e a Geografia deveriam manter sua independência no currículo escolar do curso ginasial - incorporado pela lei $n^{\circ}$ $5.692 / 71$, juntamente ao antigo primário, a escola de $1^{\circ}$ grau - e no colegial, que passou a se chamar $2^{\circ}$ grau, poderiam ser ministrados os Estudos Sociais.

O educador propõe a realização de um "estudo social", isto é, a análise de "um conjunto de manifestações de circunstâncias humanas (Carvalho, 1968, p. 3). O objetivo é a apreciação das inter-relações de uma determinada época, a partir de três pontos de vista principais: geográfico, político e econômico. A sua abordagem, nesse momento, não excluí as outras disciplinas. Seriam duas aulas semanais para os Estudos Sociais, vinte aulas no ano letivo, dedicadas a um tema ou assunto que seria exposto e discutido por professores e alunos. Há o predomínio da disciplinarização em Delgado de Carvalho. Apesar de existirem várias possibilidades de "estudo social reunindo História, Geografia, Política, Economia", argumentava Carvalho (1968, p. 5, grifos do autor) que "em todos os temas, entretanto, sobressai sempre uma das disciplinas que fornece os fios principais do tema". Por exemplo: Se o tema fosse "Regime Parlamentar", tópico das Ciências Políticas seria enriquecido pela História e pela Economia.

Outro dos motivos para a crítica aos Estudos Sociais, além da já citada perda de autonomia das disciplinas escolares, relaciona-se à transferência da competência de elaboração dos currículos escolares e seus conteúdos do "especialista" para os "representantes dos órgãos públicos" (Martins, 2000, p. 98). A reforma foi imposta de cima para baixo e cabia aos professores e historiadores apenas a sua aceitação e implementação. No processo de constituição do sistema nacional de ensino e de centralização das definições curriculares, ocorridos nas décadas de 1930 e 1940, os professores do Colégio Pedro II e de universidades, eram chamados a definir sobre o que deveria ser ensinado nas escolas. Nesse 
contexto, ocorreu a atuação de Delgado de Carvalho nas definições de História presentes nas Reformas Campos e Capanema, e na concepção de Estudos Sociais presente na reforma anisiana do Distrito Federal. Os "órgãos públicos", como o CFE, estão "distantes dos centros de formação do profissional investigador da ciência, o especialista" e suas indicações não necessariamente deveriam passar pelo crivo dos especialistas nas diferentes áreas (Martins, 2000, p. 98). Basta lembrar que os principais articuladores do ensino de Estudos Sociais durante o regime militar, conselheiros Valnir Chagas, Terezinha Saraiva e Paulo Nathanael, não tinham formação específica em Ciências Sociais, História ou Geografia.

Todo o processo de revisão curricular ocorrido, a partir do início da década de 1970, deu-se em um momento de cerceamento das liberdades individuais e acadêmicas e durante expurgos processados nas universidades, a partir da perseguição a estudantes e da aposentadoria compulsória de inúmeros docentes incluindo aqueles preocupados com a renovação do ensino e da pesquisa em História no Brasil, como Emília Viotti da Costa (USP) e Maria Yedda Linhares (Universidade do Brasil). A orientação dada pelo CFE foi considerada pelos historiadores e geógrafos como um ataque às disciplinas de Ciências Humanas (Glezer, 1982) e os Estudos Sociais vistos unicamente como elemento de formação ideológica do regime ditatorial que se impunha aos brasileiros, conjugando arbitrariamente conteúdos pouco articulados entre si. Uma construção do sistema educacional, mas sem legitimidade científica (Martins, 2000). O depoimento de Déa Fenelon (1984, p. 11), ex-presidente da Anpuh é significativo:

Repressão quanto aos processos internos vividos pela comunidade universitária, silêncio quanto aos problemas concretos, e sigilo no trato das questões específicas das normas educacionais - esta foi a nossa vivência de trabalho nos últimos anos. $\mathrm{Na}$ verdade, durante todos esses anos, pareceres, decisões, portarias e decretos caíram sobre nossas cabeças, uns após os outros, como fatos já consumados, para que a eles nos ajustássemos ou nos adequássemos.

A obrigatoriedade dos Estudos Sociais na escola brasileira só foi possível em decorrência do autoritarismo que se implantou no Brasil a partir de 1964, em que os debates e as resistências mais amplos eram controlados e sufocados ${ }^{242}$, e do

\footnotetext{
${ }^{242}$ Cabe salientar que o currículo em ação é diferente do currículo escrito e nele há a reconstrução da norma pelo professor. Ao analisar o processo de constituição da licenciatura curta em Estudos Sociais da Faculdade de Formação de Professores de São Gonçalo, entre 1973 e 1987, entrevistamos os professores deste curso. Um deles, docente de Estudos de Problemas Brasileiros, destaca que utilizava os tempos desta disciplina para o ensino de História do Brasil, que tinha pouca ênfase no currículo. Era uma forma de resistência (Nascimento, 2012). De acordo com o
} 
dilatado poder decisório do CFE. Mesmo assim, como informa o depoimento de Fenelon (1984), não se deixou de questionar o modelo educacional vigente:

Na nossa área, por exemplo, queremos salientar que a existência de Estudos Sociais nos vários níveis de ensino, como resultado de interpretações e desdobramentos da legislação emanada do Conselho Federal de Educação, vem desde 1966, merecendo a atenção de profissionais no Campo das Ciências Humanas e Sociais, através de seguidas manifestações. Esses pronunciamentos, moções, ensaios ou estudos, seja de sociedades e associações científicas, seja de caráter individual, guardaram sempre uma tônica - o total repúdio a implantação daquilo que se considera ser uma verdadeira aberração da política educacional, ou seja, a progressiva fusão de disciplinas tais como a História e a Geografia, a Sociologia e a Filosofia em ESTUDOS SOCIAIS e suas seqüelas de OSPB e Educação Moral e Cívica. (Fenelon, 1984, p. 13).

Enquanto os geógrafos se articularam desde a publicação do parecer $n^{\circ}$ 853/71 contra os Estudos Sociais na escola brasileira, enviando uma série de questionamentos a autoridades políticas e ao CFE, os historiadores percorreram caminhos diferentes. Conforme aponta Martins (2000, p. 132), “o maior embate no que diz respeito à luta contra os Estudos Sociais expressava-se na formação do professor." A questão dos Estudos Sociais se restringia aos professores da escola primária e secundária e aos educadores que se dedicavam a pensar esses níveis de ensino, sem afetar, pelo menos diretamente, historiadores e geógrafos, ou aqueles que se dedicavam à pesquisa e lecionavam no ensino superior. Quanto a isso é significativo um trecho de um dos ofícios da Anpuh datado de 1980:

A implantação dos Estudos Sociais no passado, ao ensejo da reformulação do ensino de $1^{\circ}$ e $2^{\circ}$ graus, não logrou maiores conseqüências desde que os cursos de Geografia e História persistiram em sua vitalidade. No momento, entretanto, urge ação decisiva e esclarecedora de todos os canais de mobilização. (Glezer, 1982, p. 127, grifos nossos).

O momento, supracitado, era o de uma tentativa de extinção do curso superior de História. Os conflitos surgiram, em grande parte, quando as decisões do CFE, durante os governos militares, possibilitaram a criação de um curso superior de formação do professor de Estudos Sociais e exigiram a habilitação nesta matéria como condição ao ensino. A criação da licenciatura curta em Estudos Sociais, em 1964, antecedeu a lei $n^{\circ}$ 5.692/71, a Doutrina do Núcleo Comum e a obrigatoriedade dos Estudos Sociais. Contudo, esses documentos

relato de Neves (2014, p. 32) isso também ocorria na escola, como uma forma de contornar a diminuição da carga horária da disciplina História: “os professores de História, habitualmente, trabalhavam conceitos de conteúdos de História, independente da nomenclatura da atividade a seu encargo, fosse, propriamente, a disciplina História ou a área de Estudos Sociais, OSPB ou EMC." 
concederam novo sentido às licenciaturas curtas, respectivamente, ao oficializálas na legislação e ao criar disciplinas específicas na escola básica. A preocupação com a formação de professores era mais acentuada do que com a definição de conteúdos de Estudos Sociais, como abordaremos a partir da próxima seção.

\section{5 \\ O que ensinar em Estudos Sociais? Da ausência de um programa oficial à formulação de um "exemplo"}

Desde a publicação da LDBEN (1961), o CFE passou a indicar apenas a amplitude das disciplinas obrigatórias, cabendo aos Conselhos Estaduais, às escolas e aos próprios professores a elaboração dos programas de ensino. Diferentemente de Delgado de Carvalho, o Conselho não se preocupou tanto com a definição de conteúdos de Estudos Sociais, a elaboração de um programa e a prescrição de métodos de ensino. Não há nem mesmo uma definição mais aprofundada do que seriam os Estudos Sociais, o que gerou uma série de dúvidas tanto dos sistemas de ensino e das escolas quanto dos professores. Há, pelo menos, dois pareceres do CFE tratando das confusões geradas pela proposta de Valnir Chagas (1993). O primeiro deles é de autoria de Paulo Nathanael de Souza. Na escrita do parecer $n^{\circ} 1.471 / 72$ o conselheiro sintetizava a questão:

Exemplo disso é o que ocorre com os professores da área de Estudos Sociais, que, apesar dos muitos pareceres emitidos sobre a matéria, alguns magistrais, como os de $n .{ }^{\circ}$ s 853/71 e 977/72, relatados respectivamente por Valnir Chagas e Terezinha Saraiva, parece que, ainda em 1973, adentrarão o ano letivo com insegurança a respeito do que lhes compete realizar no exercício da docência. (Souza, 1972a, p. 269).

As incertezas e as inseguranças se relacionavam a três ordens de questões:

A matéria Estudos Sociais, no ensino de $1^{\circ}$ grau, deverá dar-se o tratamento de fusão ou de concentração de conteúdos? [...] O professor de Estudos Sociais deverá ser um, polivalente, para todo o curso, ou caberão vários, com habilitação específica nos vários ramos que compõem o campo de abrangência desta matéria? [...] Os livros didáticos deverão manter-se distintamente voltados para a História, a Geografia, a Organização Social e Política do Brasil e a Educação Moral e Cívica, ou terão que reduzir-se a um único manual que se intitule Curso de Estudos Sociais? (Souza, 1972a, p. 269).

Essa foi a primeira vez que a palavra fusão apareceu, de forma explícita, num parecer referente aos Estudos Sociais. Na realidade, Paulo Nathanael adverte 
que cabe à escola optar em seu planejamento, de acordo com suas condições e do melhor momento, entre a "fusão" ( $1^{\mathrm{a}}$ a $4^{\mathrm{a}}$ séries da escola de $1^{\mathrm{o}}$ grau) ou a "concentração de conteúdos" ( $5^{\mathrm{a}}$ a $8^{\mathrm{a}}$ séries da escola de $1^{\mathrm{o}}$ grau). Em ambas estão presentes o sentido de integração e o fim da compartimentação dos conteúdos. De um lado, "na fusão, obtêm-se a eliminação das linhas divisórias entre disciplinas afins, cujos conteúdos se interpenetram e se complementam, como se foram ingredientes a misturar-se numa receita de um bolo.” (Souza, 1972a, p. 269). O objetivo é a "globalidade" das noções estudadas. Por outro:

Na concentração, que implica na organização dos diversos conteúdos em torno de um centro, temos um esquema sistêmico que lembra o das gravidades planetárias. Diversos enfoques do mesmo campo de conhecimentos que se articulam pelas áreas cinzentas que os avizinham e fronterizam uns com os outros, para comporem o harmonioso painel, onde se conjugarão a História, a Geografia, a Organização Social e Política do Brasil e a Educação Moral e Cívica. (Souza, 1972a, p. 269270).

Quanto ao conteúdo que polarizaria os demais, mais uma vez, na concepção do conselheiro, caberia ao planejamento escolar, de acordo com os seus recursos humanos e técnicos, optar entre os constituintes dos Estudos Sociais. Ou seja, o CFE não se pronunciou sobre o que ensinar em Estudos Sociais. Não havia um consenso nem sobre o livro didático. Se se adotaria um só, intitulado Curso de Estudos Sociais, ou vários de acordo com cada um de seus componentes (História, Geografia, EMC e OSPB). Sobre o professor, Souza (1972b) reforçava aquilo que já tinha sido formulado por Terezinha Saraiva. Nas primeiras séries da escola de

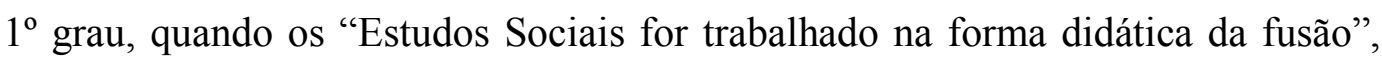
um só professor polivalente os lecionarão; nas séries finais, pode haver tanto o professor polivalente quanto uma equipe de docentes que, sob a coordenação de um deles, com uma programação integrada de Estudos Sociais, desenvolverá a cooperação dos aspectos geográficos, históricos, organizacionais e cívicos dos Estudos Sociais. Considerava o conselheiro, que esta seria a atitude mais prática enquanto os cursos de Estudos Sociais não formassem professores suficientes, nos termos de outro dos pareceres por ele relatado, o de $n^{\circ} 554 / 72$, e os sistemas de ensino não aperfeiçoassem os docentes em exercício. O parecer de Paulo Nathanael deve ter causado ainda mais dúvidas porque Terezinha Saraiva (1975, p. 76) foi levada a escrever mais um parecer diante da "necessidade sentida por educadores de todo o País, de documentos adicionais que lhes ajudassem na interpretação correta da doutrina curricular." 
O parecer $\mathrm{n}^{\circ} 4.833 / 75$, aprovado em dezembro de 1975 , em anexo ao seu texto, apresenta objetivos e conteúdos, além de possíveis atividades, que poderiam ser tratados pelas matérias, representando o que a conselheira classificava como “os mínimos desejáveis em cada matéria do núcleo comum” ministrada na escola de $1^{\text {o }}$ grau: Comunicação e Expressão, Ciências, Matemática e Estudos Sociais. Interessante observar que Ciências e Matemática são vistas como matérias independentes, diferentemente do que havia previsto Valnir Chagas no parecer $n^{\circ}$ 853/71. A formulação contou com contribuições de elementos da Secretaria de Educação e Cultura do Rio de Janeiro, onde Terezinha Saraiva atuava como Secretária, e do Conselho Estadual de Educação do Rio de Janeiro. Apesar da preocupação da conselheira em indicar que se tratavam apenas de "mera sugestão" ou uma "hipótese de trabalho", a abrangência das sugestões aponta uma tentativa de unificação da aplicação da doutrina do núcleo comum, algo que vai contra a própria ideia de flexibilização presente no parecer $n^{\circ} 853 / 71$. Segundo a autora:

É necessário enfatizar que esses conhecimentos relacionados, em anexo, não se apresentam sequenciados nem interligados, porque não configuram em nenhum momento um "programa". São apenas, alguns exemplos. Não devem ser confundidos com objetivos comportamentais nem com títulos para capítulos de eventuais manuais didáticos, como sucedeu no passado. (Saraiva, 1975, p. 85).

A fixação de objetivos era considerado como o primeiro passo para o planejamento do currículo. Na argumentação de Saraiva (1975) são eles que determinam os conteúdos a serem abordados e não o contrário. Foram indicados objetivos para todas as matérias. Os dos Estudos Sociais seriam:

Em Estudos Sociais, englobando Educação Moral e Cívica e OSPB:

- dispor-se ao ajustamento e à convivência cooperativa;

- identificar as diversidades das culturas e dos comportamentos dos povos e dos homens;

- assumir responsabilidade de cidadão mediante deveres básicos para com a Comunidade, o Estado e a Nação;

- respeitar e valorizar o Patrimônio Histórico e Cultural do País;

- utilizar princípios e procedimentos básicos das Ciências Sociais como instrumentos de interpretação da realidade;

- localizar e interpretar fatos sociais em um contexto espaço-temporal;

- analisar informações e utilizar instrumentos necessários à sua interpretação objetiva;

- tomar decisões objetiva e coerentemente;

- identificar os principais elementos da paisagem natural e cultural;

- avaliar sua conduta como indivíduo e membro de um grupo;

- reformular conceitos como instrumento de transformação da conduta;

- identificar o relacionamento entre mudanças culturais e experiências vividas; 
- propor soluções, após refletir criticamente sobre a realidade circundante, para problemas que se apresentem em seu meio físico e social;

- respeitar a pessoa humana, independentemente do credo político-filosófico, da religião, da raça, da condição econômica, da idade ou do sexo. (Saraiva, 1975, p. 89-90).

Os objetivos são abrangentes e não há indicação das séries em que deveriam ser versados. Apesar disso, trazem implícitos muitos dos elementos que estão presentes na concepção de ensino de Estudos Sociais desde a década de 1930, tais como: a preparação para a vida em sociedade, com a formação do cidadão conhecedor dos seus direitos e deveres. Mantinha-se a função principal dos Estudos Sociais na escola: habilitar o indivíduo a viver melhor. Cooperação, colaboração, reflexão, respeito às pessoas e instituições, responsabilidade e tolerância a quaisquer diversidades e pensamentos contrários são comportamentos a serem desenvolvidos pelos Estudos Sociais, na versão brasileira, desde a formulação do PCS (1934) pela equipe do Instituto de Pesquisas Educacionais do Distrito Federal, dirigido por Delgado de Carvalho na década de 1930.

Nos objetivos não transparecem o caráter doutrinário que adquiriram os Estudos Sociais, a EMC e a OSPB durante os anos da ditadura militar. Pelo contrário, conforme argumenta Martins (2000, p. 146), eles propunham "uma profunda capacidade transformadora do indivíduo" e pressupunham certa capacidade reflexiva e crítica. Aprender, como lembrava a obra de Anísio Teixeira (1968), é ganhar um modo de agir. A aprendizagem de conceitos, selecionados pelos professores, levaria à transformação de condutas. Dessa forma, a abordagem de Saraiva (1975), quanto aos objetivos dos Estudos Sociais, estava muito mais próxima de Delgado de Carvalho (1970) do que de Valnir Chagas (1993). Era preciso não apenas localizar, mas interpretar os fatos sociais. Só assim, após analisar as informações, com os instrumentos necessários, seria o aluno capaz de tomar decisões de forma objetiva e coerente. Sua postura não poderia ser passiva, já que o próprio objetivo do ensino de Estudos Sociais, formulado por Terezinha Saraiva (1975), requeria a apresentação de soluções para possíveis problemas presentes no meio físico e social em que se encontravam os alunos. Contudo, como atingir tais objetivos em uma sociedade governada por uma ditadura?

Nas propostas de Estudos Sociais, tanto a americana como a de Delgado de Carvalho, o respeito às instituições não significava ausência de críticas a elas. As apreciações sobre as suas funções levavam à melhoria. Para isso era essencial o 
estudo das Ciências Sociais na escola e isso Terezinha Saraiva (1975) reconhece ao apontar que os seus princípios e procedimentos fornecem os instrumentos para a interpretação da sociedade. Outra diferença central entre o que propôs a conselheira Terezinha Saraiva e a percepção de Delgado de Carvalho está no lugar das disciplinas componentes dos Estudos Sociais. Em Delgado cada um destes objetivos seria atribuído a um componente dos Estudos Sociais: História, Sociologia, Geografia. Em Terezinha Saraiva (1975) elas perdem totalmente o seu lugar. Isso fica claro nas sugestões de conhecimentos e atividades a serem trabalhadas na escola de $1^{\circ}$ grau. Apesar de afirmar em pareceres anteriores que os Estudos Sociais poderiam ser ministrados através das disciplinas tradicionais (História e Geografia) no $1^{\circ}$ grau, a sugestão de Saraiva (1975) funde os conhecimentos histórico-geográficos e outros (sociológicos, econômicos, etc.). Embora a autora não disponibilize os conhecimentos e atividades em forma de quadro, optamos por esse formato para facilitar a visualização da proposta. 


\begin{tabular}{|c|c|}
\hline Conhecimentos & Atividades \\
\hline $\begin{array}{l}\text { A Comunidade e a Sociedade } \\
\text { O indivíduo e a Sociedade } \\
\text { Conhecimentos e caracteres da sociedade em } \\
\text { que vive }\end{array}$ & $\begin{array}{l}\text { Pesquisar ocupações exercidas pelos membros } \\
\text { da comunidade. } \\
\text { Discutir para avaliar o trabalho cooperativo } \\
\text { como meio para atingir o bem-estar do grupo, } \\
\text { da família e da comunidade. }\end{array}$ \\
\hline $\begin{array}{l}\text { O Estado e a Nação } \\
\text { Evolução do Estado Brasileiro }\end{array}$ & $\begin{array}{l}\text { Observar, através de mapa político, as unidades } \\
\text { federadas que formam a Nação Brasileira. } \\
\text { Montar organograma sobre a função dos } 3 \\
\text { poderes mostrando as inter-relações entre eles. }\end{array}$ \\
\hline $\begin{array}{l}\text { Fatos da História do Brasil; Conhecimento dos } \\
\text { vultos que ajudaram a construir a nossa } \\
\text { História }\end{array}$ & $\begin{array}{l}\text { Construir uma linha de tempo para identificar } \\
\text { os principais fatos da História Brasileira. }\end{array}$ \\
\hline O crescimento demográfico & $\begin{array}{l}\text { Observar, através de gráficos, a distribuição } \\
\text { populacional. }\end{array}$ \\
\hline Os meios de comunicação de massa & $\begin{array}{l}\text { Distinguir e identificar os meios de } \\
\text { comunicação que atingem o seu Território. }\end{array}$ \\
\hline $\begin{array}{l}\text { O trabalho e o direito social. As Instituições de } \\
\text { Previdência Social }\end{array}$ & $\begin{array}{l}\text { Observar que a divisão de trabalho é uma } \\
\text { forma de cooperação social. } \\
\text { Pesquisar para concluir que existem encargos } \\
\text { sociais para o empregado e empregador. }\end{array}$ \\
\hline Os símbolos nacionais - conhecimento e uso & $\begin{array}{l}\text { Pesquisar sobre o uso dos símbolos nacionais } \\
\text { para conhecer seu significado e importância. }\end{array}$ \\
\hline A vida cultural brasileira & $\begin{array}{l}\text { Ler e interpretar textos que expressem } \\
\text { contribuições à vida cultural. }\end{array}$ \\
\hline Folclore & $\begin{array}{l}\text { Promover palestras sob orientação do professor } \\
\text { a respeito do Folclore Nacional, que envolvam } \\
\text { a Comunidade. } \\
\text { Visitar organizações e exposições culturais } \\
\text { (artesanatos, feiras, etc.). }\end{array}$ \\
\hline Fatos da História do Brasil & $\begin{array}{l}\text { Elaborar linha de tempo que situe os fatos e sua } \\
\text { importância no processo histórico. }\end{array}$ \\
\hline $\begin{array}{l}\text { Conhecimento dos vultos que ajudaram a } \\
\text { construir nossa História }\end{array}$ & $\begin{array}{l}\text { Elaborar quadros-murais relativos aos } \\
\text { diferentes vultos nacionais e seu papel na vida } \\
\text { político-social brasileira. }\end{array}$ \\
\hline
\end{tabular}

Quadro 16 - Conhecimentos e atividades indicadas para a matéria Estudos Sociais na escola de $1^{\circ}$ grau

Fonte: Parecer no 4.833/75 (Saraiva, 1975, p. 91-92).

Terezinha Saraiva (1975) argumenta que os conhecimentos e atividades apresentadas se relacionavam tanto ao objetivo geral das matérias, estabelecido pelo parecer $n^{\circ} 853 / 71$, quanto aos objetivos sugeridos em seu parecer. Contudo, os conhecimentos e atividades formulados por Saraiva (1975) são tradicionais e distantes dos objetivos acima expostos. Se os objetivos se aproximam do que defendeu Delgado de Carvalho, os conhecimentos apresentados no Quadro 16 estão em consonância com o parecer de Valnir Chagas e as diretrizes de ensino da ditadura militar. Os conhecimentos histórico-geográficos foram descaracterizados e diluídos no interior dos Estudos Sociais, formados por uma miscelânea de conteúdos pouco articulados entre si. Não há uma concepção de História ou de Geografia, embora possamos inferir que a História ensaiada por Saraiva (1975) é a 
política e baseada nos acontecimentos e grandes vultos brasileiros, elementos característicos, também, da EMC definida pelos militares. Um ensino de História criticado por Delgado de Carvalho desde a década de 1930, que não concede atenção ao econômico, ao cultural, ao social, ao intelectual. A ênfase na História do Brasil está presente desde o parecer n 853/71, mas Terezinha Saraiva (1975) excluiu do seu "exemplo" a experiência dos outros povos - elemento indicado tanto por Valnir Chagas (1993) quanto por Delgado de Carvalho (1970). A valorização dos "heróis nacionais" é tão importante na abordagem da conselheira que chega a aparecer várias vezes entre os conhecimentos citados.

A valorização e o respeito aos símbolos, incorporados ao ensino de Estudos Sociais, compõem a letra da lei $\mathrm{n}^{\mathrm{o}} 5.700$, de $1^{\mathrm{o}}$ de setembro de 1971, que "Dispõe sobre a forma e a apresentação dos Símbolos Nacionais e dá outras providências." $\mathrm{O}$ ato de hastear a bandeira e o canto do hino nacional no início das aulas fazem parte da formação de centenas de brasileiros que estudaram entre as décadas de 1970 e de 1990. A violação destes símbolos era considerada uma contravenção, passível de penalidades. O conteúdo da Geografia foi restrito a um tópico intitulado "crescimento demográfico", abandonando a Geografia Humana e a interação entre sociedade e espaço, elementos tão caros na abordagem de Delgado de Carvalho. Apesar de detalhar os conhecimentos, Terezinha Saraiva (1975) não aborda de que forma o seu ensino daria conta dos objetivos traçados.

Comparações com Delgado de Carvalho ajudam a compreender um pouco melhor os aspectos referentes à formação do aluno. Por exemplo: Saraiva (1975) inclui um tópico sobre os "meios de comunicação de massa", embora não especifique quais. Poderiam ser televisão, rádio, jornais de grande circulação. Esta era uma preocupação de Delgado de Carvalho (1970). Contudo, enquanto ele defendia que o aluno deve ser estimulado a possuir “juízo crítico”, através de uma escola que forneça elementos para que possa pensar e discutir, no parecer $n^{\circ}$ 4.833/75 cumpre apenas identificar quais são os meios de comunicação. Não há crítica. Diferentemente do que pregavam os objetivos, as atividades formuladas por Saraiva (1975) não possibilitavam muita ação e reflexão. A pesquisa não é entendida como possibilidade de descoberta e instrumento que possibilita ao aluno a capacidade de continuar sempre aprendendo, como defende a abordagem de Delgado de Carvalho, mas como uma confirmação de "resultados previamente definidos" (Martins, 2000, p. 150). Rompia-se com um fundamento central dos 
Estudos Sociais da primeira metade do século XX: a resolução de problemas como elemento formativo. Embora Terezinha Saraiva (1975) consiga formular os aspectos pedagógicos para a aplicação dos Estudos Sociais, demonstra pouco conhecimento das feições específicas dos seus componentes.

As especificidades dos conhecimentos históricos e geográficos não são objetos de preocupação da conselheira. Com isso, certamente, enfraquecia-se a formação do aluno. Ele não era levado a pensar historicamente ${ }^{243}$ e nem era movido a refletir sobre a sociedade e o seu lugar nela. Ao aluno não era incentivado o seu papel como possível agente de transformação e crítica do sistema vigente. Paralelamente a isso, havia forte resistência quanto ao esvaziamento da História e da Geografia nas escolas de $1^{\circ}$ e $2^{\circ}$ graus. Para o CFE, as falhas e a ausência de correta aplicação do que fora preconizado pelo parecer $n^{\circ}$ 853/71, e reafirmado por outros pareceres, não era consequência da falta de clareza da própria diretriz, mas culpa do professor, que não era adequadamente formado para lecionar os Estudos Sociais. Segundo Saraiva (1975, p. 81): “Antes acostumado aos rígidos 'programas de ensino', o professor vê-se agora com liberdade de planejar, ele próprio, o currículo pleno para seus alunos.” Essa deficiência era resultado da diversidade de formação de professores, com variadas modalidades de licenciatura e habilitações específicas, e do despreparo docente. A produção de Guias Curriculares, pelos diversos Estados, e a produção dos livros didáticos supririam, de certo modo, tais deficiências. Uma análise que exige outras pesquisas e ultrapassaria os limites desta tese. Contudo, a solução aventada pelo CFE foi a consolidação da licenciatura em Estudos Sociais, objeto de sua atenção ao longo dos anos de 1970. É a questão que tratamos a seguir.

\section{6}

\section{A formação do professor de Estudos Sociais: da licenciatura curta à proposta de extinção da licenciatura em História}

As licenciaturas curtas foram criadas como forma de suprir a carência de professores em determinadas regiões do país. Por isso, a indicação s/no de 1964 ,

\footnotetext{
${ }^{243}$ Entre outras coisas: Compreender o que é a História, suas características como uma disciplina com uma linguagem própria, métodos e conteúdos específicos. Compreender as relações entre o presente e o passado. Um ensino de História, segundo a concepção de Fonseca (2010, p. 43), "como possibilidade de reflexão."
} 
relatada por Newton Sucupira (1964), possibilitava a formação do professor polivalente, apto a lecionar as diferentes disciplinas do $1^{\circ}$ ciclo da escola média ${ }^{244}$. Sucupira (1966) sinalizava que, "sendo de mais modestas exigências" (p. 36), o ideal era que essas licenciaturas se instalassem no interior do país. Contudo, na prática, as licenciaturas curtas proliferaram nos grandes centros urbanos em um processo de mercantilização e expansão do ensino superior privado. Como destacamos em trabalho anterior, eram nessas regiões que as pessoas tinham mais condições para financiar os seus estudos e, consequentemente, o ingresso nas faculdades de formação de professores privadas (Nascimento, 2012). Por outro lado, de "solução emergencial" as licenciaturas curtas tornaram-se uma "solução definitiva" respaldada pela Reforma de Ensino Superior (1968) e pela Reforma de Ensino de $1^{\text {o e }} 2^{\circ}$ graus (1971). De acordo com Fonseca (2010, p. 26):

A implantação das licenciaturas curtas expressa a dimensão econômica da educação, encarada como investimento, geradora de mercadoria (conhecimentos) e mão-de-obra para o mercado [...] O papel dos cursos de licenciatura curta atendia à lógica deste mercado: habilitar um grande número de professores da forma mais viável economicamente: cursos rápidos e baratos exigindo poucos investimentos para a sua manutenção.

É preciso diferenciar as intenções da reforma, ou as intenções de Newton Sucupira (1964) na sua indicação, do que efetivamente ocorreu. Não entendemos que a proposta de licenciatura curta, tal como definida por Sucupira (1964), expresse uma dimensão econômica. Tentava-se resolver uma carência de professores que caracterizava o contexto brasileiro da década de 1960, principalmente no interior. Importante salientar que até meados da década de 1930 não existia um curso superior para a formação específica do professor da escola secundária, que no geral era autodidata ou egresso das Escolas Normais ou cursos de Direito e Medicina. Carvalho (1970) apontava esse problema. A expansão do ensino médio não foi acompanhada da expansão das Faculdades de Filosofia, responsáveis pela formação docente. A partir dessa constatação, o conselheiro

\footnotetext{
${ }^{244}$ Fonseca (2010, p. 26) argumenta que "no início do ano de 1969, amparado pelo Ato Institucional $\mathrm{n}^{\circ}$ 5, de dezembro de 1968 , o governo, através do decreto-lei $\mathrm{n}^{\circ} 547$, de 18 de abril de 1969, autoriza a organização e o funcionamento de cursos profissionais superiores de curta duração." Contudo, a interpretação é um erro, já que esse decreto não se refere à formação de professores, mas a outros cursos superiores e tecnólogos, pois as licenciaturas curtas foram criadas em 1964. Como já tivemos oportunidade de argumentar, mais do que uma intenção do Estado, que na compreensão de Fonseca (2010, p. 26), "revela ser desnecessária uma formação longa e sólida em determinadas áreas profissionais, quais sejam, as licenciaturas encarregadas de formar a mão de obra para a educação", era uma preocupação corrente no CFE desde a sua fundação em 1962, portanto antes do golpe militar. Cf. também: Nascimento (2012).
} 
ressaltou a necessidade de uma política de formação de professores que fornecesse resultados a curtíssimo prazo. É o que denominamos como política do mínimo por menos: mínimo de qualificação, pelo menor tempo possível (Nascimento, 2012).

Entretanto, a falta de atenção do CFE ao processo de autorização e funcionamento destes cursos favoreceu "à lógica do mercado", com a sua implantação em áreas em que efetivamente não havia carência de professores (Rio de Janeiro e São Paulo, sobretudo). Houve, sim, um descaso quanto à aplicação dos princípios definidos pelo próprio CFE (Fenelon, 1984). Não se limitou o professor polivalente às áreas com carência ${ }^{245}$. Posteriormente, os conselheiros passaram a defender essa modalidade de formação de professores como algo a ser ampliado. Em 1964, foram criadas três licenciaturas curtas: Letras, Ciências e Estudos Sociais. Inicialmente, a licenciatura curta em Estudos Sociais habilitaria ao ensino de História, Geografia e OSPB. As habilitações da nova licenciatura expressam a ausência de articulação entre a sua criação e os debates que a antecederam - sobre a não integração entre as disciplinas da escola secundária e dos cursos superiores de Ciências Sociais, como criticava Delgado. Sua criação não se tratou de uma questão pedagógica, mas eminentemente prática (formar o máximo de professores em pouco tempo). Não constava da lista de habilitações os Estudos Sociais, disciplina optativa do ciclo colegial a partir de 1962.

O currículo proposto para a licenciatura curta em Estudos Sociais, pelo parecer $n^{\circ}$ 106/66 escrito por Sucupira (1966), era simples e compreendia disciplinas relativas à História - seguindo a divisão cronológica tradicional: Antiga, Medieval, Moderna, Contemporânea e História do Brasil, com ênfase na organização política e social brasileira; à Geografia (Física, Humana e do Brasil); e, por fim, uma disciplina intitulada Fundamentos das Ciências Sociais, abordando os aspectos sociológicos e antropológicos da realidade social. Quanto ao ensino de História, o conselheiro incorporava a visão de que este não poderia se limitar aos aspectos políticos, abarcando a "evolução cultural dos povos e da humanidade". (Sucupira, 1966, p. 36). O curso tinha uma previsão 2.025 horasaula ou três anos letivos. Posteriormente, a resolução $\mathrm{n}^{\circ} 1 / 72$, de 8 de janeiro de 1972, relatada por Valnir Chagas, reduziu ainda mais o tempo da licenciatura

${ }^{245}$ À guisa de exemplificação: Na indicação $\mathrm{n}^{\circ}$ 22/73 Chagas (1976, p. 16) argumentava que "onde comprovadamente ocorra aquela maior oferta de meios, aos sistemas será lícito condicionar o exercício profissional dos licenciados a um preparo superior aos mínimos estabelecidos na lei [5.692/71] ou nos próprios pronunciamentos deste Conselho [...]." 
curta em Estudos Sociais: 1.200 horas de atividades, com a integralização a ser realizada no mínimo de um semestre e meio e no máximo de quatro semestres.

A lei $n^{\circ} 5.540 / 68$ indicou a possibilidade de diferentes modalidades de duração para os cursos de ensino superior. No entanto, foi a lei $n^{\circ} 5.692 / 71$ que estabeleceu as diversas modalidades de formação de professores, conforme as características culturais e econômicas de cada região do país e do nível de ensino em que fossem atuar. Previa-se, bem ao estilo de Valnir Chagas (1984), uma formação docente progressiva: do curso normal à licenciatura plena.

Art. 30. Exigir-se-á, como formação mínima para o exercício do magistério:

a) no ensino de $1^{\circ}$ grau, da $1^{\mathrm{a}}$ à $4^{\mathrm{a}}$ séries, habilitação específica de $2^{\circ}$ grau;

b) no ensino de $1^{\circ}$ grau, da $1^{a}$ à $8^{a}$ séries, habilitação específica de grau superior, ao nível de graduação, representada por licenciatura de $1^{\circ}$ grau obtida em curso de curta duração;

c) em todo o ensino de $1^{\circ}$ e $2^{\circ}$ graus, habilitação específica obtida em curso superior de graduação correspondente a licenciatura plena.

$\S 1^{\circ}$. Os professores a que se refere a letra a poderão lecionar na $5^{\mathrm{a}}$ e $6^{\mathrm{a}}$ séries do ensino de $1^{\circ}$ grau se a sua habilitação houver sido obtida em quatro séries ou, quando em três mediante estudos adicionais correspondentes a um ano letivo que incluirão, quando for o caso, formação pedagógica.

$\S 2^{\circ}$. Os professores a que se refere a letra $b$ poderão alcançar, no exercício do magistério, a $2^{\mathrm{a}}$ série do ensino de $2^{\circ}$ grau mediante estudos adicionais correspondentes no mínimo a um ano letivo. (Brasil, 1971a).

O modelo de formação docente se adaptava à realidade das matérias, distribuídas em atividades, áreas de estudo e disciplinas, ou seja, refletia o currículo que caberiam aos futuros professores desenvolverem no $1^{\circ}$ e $2^{\circ}$ graus e consolidava as grandes linhas de ação empreendidas pelo CFE na década de 1960. A ideia de Valnir Chagas (1984) era a de um magistério cujo nível de preparo crescesse constantemente. Os níveis indicados na lei $\mathrm{n}^{\circ}$ 5.692/71 seriam sempre os mínimos necessários à atuação, “aos sistemas de ensino cabe ajustar às suas peculiaridades e mesmo superar." (p. 310). A perspectiva era a da polivalência como uma categoria que se refere à formação do professor e ao exercício docente:

Com ela visa-se à organização de cursos ou ciclos de formação que abranjam amplos setores de conhecimento: de um lado, como resposta ao ensino integrado de "atividades" e "áreas de estudo" no $1^{\circ}$ grau; de outro, como abertura ainda tímida para a figura de um professor mais generalista capaz de situar-se na perspectiva do aluno, do Saber e, como insistentemente reclamava Whitehead, "da vida em todas as suas manifestações". (Chagas, 1984, p. 311).

A formação do professor generalista levou à reformulação da licenciatura em Estudos Sociais e à articulação com EMC. O decreto-lei no 869, de dezembro de 1969, ao instituir a obrigatoriedade da EMC na escola básica, indicou que a 
formação dos professores e orientadores dessa disciplina seria feita em nível universitário e que caberia ao CFE adotar as medidas necessárias para tal. O parecer $\mathrm{n}^{\circ}$ 554/72, de 8 de junho de 1972, relatado por Paulo Nathanael de Souza, e a resolução $\mathrm{n}^{\circ}$ 8/72, de 9 de agosto, formularam as diretrizes do "Currículo Mínimo para habilitação em Educação Moral e Cívica". O conselheiro advertia sobre a existência de duas possibilidades: considerar o Curso de Educação Moral e Cívica como uma licenciatura a parte, como ocorriam nos casos da História e da Geografia, ou considerá-lo como uma modalidade do Curso de Estudos Sociais, a partir da reformulação do parecer $n^{\circ} 106 / 66$. Optou-se pela segunda proposta. Primeiro, pela máxima imposta pelas políticas na ditadura militar: "a norma pela qual fica vedada a duplicação de meios para fins idênticos." (Souza, 1972b, p. 179). O princípio da economicidade. Segundo, porque o CFE entendia que a formação dos professores de EMC apresentava uma "área de estudos comum" com a formação dos professores de História, Geografia e OSPB, já que todas:

[...] essas licenciaturas, pertencentes, por assim dizer, a uma só família, visam conjuntamente, à formação de professores que irão manejar o mesmo instrumental didático, apenas com prismas e dosagens diversificados na linha de cada um, para a condução dos educandos do $1^{\circ}$ e $2^{\circ}$ graus ao exercício consciente da cidadania. (Souza, 1972b, p. 179).

O conselheiro argumentava que as licenciaturas plenas em disciplinas específicas eram limitadas, uma "idéia empobrecedora", e não forneciam uma "sistematização global" como os cursos polivalentes. Para ele, as licenciaturas curtas, surgidas a partir de indicação relatada por Sucupira (1964), eram “das mais ricas e frutuosas [experiências] de quantas se ensaiaram nos sistemas de ensino" (Souza, 1972b, p. 179). Desconsideravam-se as críticas e questionamentos que esta modalidade de formação docente já começava a sofrer e as especificidades das licenciaturas em História e Geografia, encaradas unicamente na sua função de "condução dos educandos do $1^{\circ}$ e $2^{\circ}$ graus ao exercício consciente da cidadania" (p. 179). Na sua formulação, Educação Moral e Cívica como uma habilitação do Curso de Estudos Sociais era a solução mais acertada, porque este curso envolvia aspectos filosóficos, históricos e geográficos numa perspectiva ampla e polivalente. Apesar disso, Paulo Nathanael nada mais fez do que seguir o esquema introduzido por Valnir Chagas. Na sua organização do núcleo comum, Chagas (1984) incluiu a EMC como um dos componentes dos Estudos Sociais. 
O parecer $n^{\circ} 554 / 72$ promoveu uma distinção entre a licenciatura curta e a licenciatura plena, para além da carga horária menor ou maior. Enquanto a primeira teria como função dotar "o professor de conteúdo suficiente e de técnicas apropriadas" através de uma formação generalizante, tendo em vista o ensino por áreas de estudo na escola de $1^{\circ}$ grau, a segunda visava ao "conhecimento amplo e aprofundado nas várias especializações e modalidades." (Souza, 1972b, p. 181). Há aí uma hierarquização na formação docente e uma clara distinção entre o professor e o pesquisador como projetos distintos. Na prática, o professor de $1^{\circ}$ grau, formado pela licenciatura curta, era entendido como simples vulgarizador do conhecimento e para isso bastavam o conhecimento de técnicas de ensino ${ }^{246}$. Para Souza (1972b), o lugar da pesquisa e formação do especialista era na licenciatura plena. Retomaremos esta questão mais adiante, em outro parecer do conselheiro.

A partir do parecer $\mathrm{n}^{\circ}$ 554/72, a licenciatura curta em Estudos Sociais, remodelada, passou a ter uma duração mínima de 1.200 horas-aula e habilitava o docente ao ensino de EMC, além das disciplinas já dispostas no parecer n 106/66. Somadas aos conteúdos de História, Geografia e Fundamentos de Ciências Sociais foram incorporadas ao currículo: Filosofia, Teoria Geral do Estado, OSPB, Estudos de Problemas Brasileiros (EPB) e Educação Física. Esta última tornou-se obrigatória no currículo de todos os graus de ensino através do decreto federal $\mathrm{n}^{\circ}$ 69.450, de $1^{\circ}$ de novembro de 1971. Eram facultadas a ampliação da duração do curso e o acréscimo de disciplinas, desde que aprovadas pelo CFE. Quanto à licenciatura plena em Estudos Sociais, Souza (1972b, p. 181-182) advertia que:

A licenciatura plena em Educação Moral e Cívica será obtida em habilitação específica que, dentro do contexto de Estudos Sociais, se desenvolverá paralelamente às de História, Geografia, Organização Social e Política do Brasil e outras, as quais não serão objeto de apreciação neste parecer.

Apesar de a habilitação ser em EMC, Souza (1972b) entendia que o ensino desta disciplina deveria ser articulado às outras, já que o curso comportava conhecimentos históricos, geográficos, filosóficos e sociológicos. Neste parecer, o conselheiro, incorporando posição de Valnir Chagas, já defendia que os Estudos Sociais fossem uma "habilitação geral" - que denomina o curso e lhe determina o campo - possibilitando habilitações específicas (EMC, OSPB, História,

\footnotetext{
${ }^{246}$ Era uma posição referendada em outros documentos produzidos pelo CFE. Newton Sucupira (1964, p. 111), ao defender a criação das licenciaturas curtas, argumentava que "o professor de ginasial não há de ser um especialista puro".
} 
Geografia, e assim por diante em todas as áreas do conhecimento) ${ }^{247}$. A licenciatura plena em Estudos Sociais passou a ter 2.200 horas-aula, distribuídas entre as matérias ${ }^{248}$ obrigatórias (básicas e complementares), matérias pedagógicas, de acordo com o parecer $n^{\circ} 672 / 69$, e matérias optativas.

\begin{tabular}{|l|l|l|}
\hline \multicolumn{1}{|c|}{ Matérias obrigatórias } & Matérias complementares & Matérias pedagógicas \\
\hline - Filosofia & & \\
- Geografia & & \\
- História & - História do Pensamento & - Psicologia da Educação \\
- Política & Político e das Doutrinas & (Adolescência e \\
- Sociologia & Sociais & Aprendizagem) \\
- Cultura Brasileira & - História e Filosofia das & - Didática \\
- Geopolítica do Brasil & Religiões & - Estrutura e Funcionamento \\
- Constituições Brasileiras & -Sociologia do & do Ensino \\
- Introdução à Economia & Desenvolvimento & - Prática de Ensino \\
-Estudos de Problemas & - Folclore & \\
Brasileiros & & \\
-Educação Física & & \\
\hline
\end{tabular}

Quadro 17 - Matérias do Curso de Estudos Sociais, habilitação em EMC Fonte: Parecer n ${ }^{\circ}$ 554/72 (Souza, 1972b).

O parecer de Paulo Nathanael de Souza é mais específico quanto àquilo que deveria ser ministrado pelas diferentes matérias do Curso de Estudos Sociais. Em História a ênfase deveria ser a Teoria da História e a História do Brasil em seus aspectos sociais, econômicos e políticos. Na Geografia havia o predomínio da Geografia Humana e Econômica, sobretudo do Brasil. Em Filosofia discutir-seiam os sistemas filosóficos sobre a Metafísica e Ética, em especial suas relações com a Religião. Na Sociologia, o destaque era para o estudo da realidade social. Em comum, todas as matérias valorizavam o Brasil como objeto. Apesar de embutidos num mesmo curso, não há uma discussão sobre como esses elementos se integrariam na prática. Delgado de Carvalho não pensou em uma licenciatura em Estudos Sociais, embora criticasse a ausência de integração entre os cursos de

\footnotetext{
${ }^{247}$ Segundo Valnir Chagas (1976, p. 20): "Um licenciado em Estudos Sociais com habilitação em Geografia, por exemplo, poderá simplesmente se dizer diplomado em Geografia, como antes, porque de fato o será; mas terá outras vantagens. Em pouco tempo, às vezes menos de um ano, facilmente se habilitará também em História, ou em Organização Social e Política do Brasil, ou em Educação Moral e Cívica - ou em todas essas disciplinas mediante sucessivas voltas à escola." $\mathrm{Na}$ prática o CFE defendia a licenciatura em Estudos Sociais como um núcleo comum para as outras licenciaturas plenas. Acreditava-se que isso ampliaria as possibilidades de emprego do professor. ${ }^{248}$ O termo matéria, aqui, é entendido na mesma definição formulada por Valnir Chagas (1984, 1993), como matéria-prima a ser desenvolvida em disciplinas.
} 
História, Geografia e Ciências Sociais. A proposta do CFE, tanto a formulada por Newton Sucupira quanto a indicada por Paulo Nathanael, realizou apenas uma justaposição de conteúdos de diferentes Ciências sob a rubrica de Estudos Sociais. Por isso, a principal crítica a essa licenciatura se relacionava ao empobrecimento da formação de professores de Ciências Humanas. Um curso tão abrangente não seria capaz de formar bons professores, com domínio de conteúdos e reflexivos.

Fonseca (2010, p. 27) apresenta alguns aspectos destas críticas:

Nestes cursos, começa a ser formada a nova geração de professores polivalentes, e neles o principal objetivo é a descaracterização das Ciências Humanas como campo de saberes autônomos, pois são transfiguradas e transmitidas como um mosaico de conhecimentos gerais e superficiais da realidade social.

Essa “descaracterização das Ciências Humanas” é, no nosso entendimento, mais uma consequência do que um objetivo premeditado seja do regime militar, seja dos conselheiros. Uma consequência porque a proposta do Curso de Estudos Sociais, entre 1966 e 1980, era generalista, abrangente e não tinha como foco a formação específica em História ou Geografia. Não haveria, pela carga horária, tempo hábil para o aprofundamento dos diferentes campos do conhecimento presentes no curso. Do mesmo modo, houve um processo de expansão desenfreado destas licenciaturas pouco atento tanto às questões científicas, concernentes a um curso superior, quanto às questões pedagógicas, necessárias ao exercício do magistério na escola de $1^{\circ}$ e $2^{\circ}$ graus. A instalação dos cursos de Estudos Sociais se deu, sobretudo, nas instituições privadas, com raras exceções, onde as condições de ensino eram precárias e inexistia a atividade de pesquisa. Isso não quer dizer que o CFE não tivesse a intenção de acabar com as licenciaturas plenas específicas, como a de História ou a de Geografia. Contudo, esse processo não pode ser encarado como mera "descaracterização das Ciências Humanas" porque não se limitava a elas, mas seguia a fórmula do parecer $n^{0}$ 853/71: reunião de áreas afins em torno de uma única matéria ou, nesse caso, curso superior. Valnir Chagas assim explicava seu projeto na indicação no 23/73:

[...] para o ensino de $1^{\circ}$ e $2^{\circ}$ graus como para os cursos superiores que lhe preparam os professores, os estudos gerais deverão compreender os campos de Ciências, Estudos Sociais e Comunicação e Expressão [...]. Daí resultariam, num esboço inicial, três cursos de alta densidade que se organizariam em correspondência com esses três campos, cada um deles culminando em habilitações específicas em nível de duração plena. (Chagas, 1976, p. 28). 
A natureza dos cursos superiores de formação docente era alterada no sentido de se adaptar à estrutura imposta para o ensino de $1^{\circ}$ e $2^{\circ}$ graus. Passando a compreender, basicamente, às três linhas de conhecimento presentes na definição do núcleo comum do $1^{\circ}$ e $2^{\circ}$ graus (parecer $n^{\circ} 853 / 71$ ). Os desenhos de Valnir Chagas para as licenciaturas visavam à fusão de cursos e disciplinas e não a integração, como ele tenta defender em seus escritos. Com isso, desconsideravam-se os objetos e metodologias específicos não apenas das diferentes Ciências Humanas, como das outras áreas - incluindo as Ciências Físicas e Naturais e as Linguagens, e as outras licenciaturas que não se enquadrassem no modelo formulado. Grosso modo, eliminavam-se os professores especialistas em favor dos professores polivalentes. Foram pensados cinco cursos, com 18 habilitações possíveis, conforme sintetizamos no quadro a seguir.

\begin{tabular}{|c|c|c|}
\hline Matéria ou campo & Licenciatura curta ou plena & Habilitações \\
\hline Ciências & Curso de Ciências & $\begin{array}{l}\text { Matemática } \\
\text { Física } \\
\text { Química } \\
\text { Biologia }\end{array}$ \\
\hline Estudos Sociais & Curso de Estudos Sociais & $\begin{array}{l}\text { História } \\
\text { Geografia } \\
\text { OSPB } \\
\text { EMC }\end{array}$ \\
\hline \multirow{3}{*}{ Comunicação e Expressão } & Curso de Letras & $\begin{array}{l}\text { Língua Portuguesa* } \\
\text { Língua Estrangeira Moderna* } \\
\text { Língua Clássica* }\end{array}$ \\
\hline & Curso de Educação Artística & $\begin{array}{l}\text { Música } \\
\text { Artes Plásticas } \\
\text { Desenho } \\
\text { Artes Cênicas }\end{array}$ \\
\hline & Curso de Educação Física & $\begin{array}{l}\text { Ginástica e Atletismo } \\
\text { Técnica Esportiva } \\
\text { Recreação }\end{array}$ \\
\hline
\end{tabular}

*Todas devendo abarcar os "necessários estudos literários" (Chagas, 1976, p. 32).

Quadro 18 - Licenciaturas de Educação Geral e suas habilitações Fonte: Chagas (1976).

De acordo com Valnir Chagas (1976), previa-se a coexistência com outras licenciaturas plenas que não fossem as polivalentes. Ele cita nominalmente as de Psicologia, Sociologia, Antropologia e Filosofia, o que indica a tendência de que os cursos de História e de Geografia teriam de se adaptar ao proposto pelas Indicações 22/73 e 23/73, ou seja, uma habilitação geral em Estudos Sociais e, posteriormente, a habilitação específica em História. Das licenciaturas indicadas no Quadro 18, foram regulamentadas apenas a de Educação Artística (resolução 
$n^{o}$ 23/73) e a de Ciências (resolução $n^{0}$ 30/74). O CFE determinou a obrigatoriedade de implantação do novo curso de Ciências até 1978. Contudo, foram diversas as resistências por parte de organismos como a Sociedade Brasileira para o Progresso da Ciência, o que acabou levando ao adiamento do prazo e a não efetivação da resolução $n^{\circ} 30 / 74$. A partir deste momento, houve uma unificação da luta contra as chamadas licenciaturas de Educação Geral e uma intensificação da oposição às políticas do CFE. Em 1976, por exemplo, a Universidade Federal de Minas Gerais, através de seus Conselhos, recusou-se a implantar o Curso de Estudos Sociais. Segundo Fenelon (1984, p. 18):

Em julho de 1976, em seu Congresso Anual a SBPC - Sociedade Brasileira para o Progresso da Ciência manifestou-se oficialmente contrária as licenciaturas em Educação Geral, nas várias áreas do conhecimento, solicitando também o fim da disciplina Estudos Sociais no $1^{\circ}$ e $2^{\circ}$ graus, o fim das licenciaturas curtas e plenas em Estudos Sociais e a participação das instituições universitárias, científicas e profissionais no processo de elaboração das políticas educacionais.

Apesar das resistências, o Ministério da Educação e o CFE ainda tentaram a imposição das licenciaturas em Estudos Sociais através da Portaria 790/76 e de uma proposta de parecer relatado por Paulo Nathanael de Souza, divulgado em 1980. A portaria $\mathrm{n}^{\mathrm{o}} 790 / 76$ sobre a concessão de registro aos professores, publicada em 22 de outubro de 1976, tornou obrigatória a formação em licenciatura em Estudos Sociais para o ensino desta área de estudo no $1^{\circ}$ grau. Os professores de História e Geografia ficariam habilitados a lecionar apenas no $2^{\circ}$ grau. A reação foi tamanha que o Ministério acabou recuando da sua aplicação e convocou o CFE a se manifestar, dando origem ao parecer $n^{0} 7.676 / 78$ relatado por Paulo Nathanel de Souza ${ }^{249}$. O documento reconhecia as críticas aos Estudos Sociais e a oposição à portaria 790/76, quando "a grita tornou-se de tal forma generalizada". (Souza, 1978, p. 28). Em sua resposta ao Aviso Ministerial, Paulo Nathanael já manifestava posição favorável à revisão do currículo mínimo do curso de formação de professores de Estudos Sociais, algo que demandaria estudos mais avançados e particularizados. Mais uma vez, o conselheiro parece querer se livrar da responsabilidade do CFE acerca da obrigatoriedade dos Estudos Sociais e argumenta que na legislação é utilizada a palavra

\footnotetext{
${ }^{249}$ Trata-se do Aviso Ministerial no 694 (Valorização da História e da Geografia no Ensino de $1^{\circ}$ grau) sobre "a necessidade de ser estudada maneira mais adequada para valorizar as disciplinas de História e Geografia, bem como melhormente ${ }^{\text {(sic) }}$ caracterizar a reunião de atividades docentes nessas áreas." (Souza, 1978, p. 28).
} 
"predominantemente". Ou seja, o parecer n ${ }^{\circ}$ 853/71 aponta que os Estudos Sociais deveriam ser tratados "predominantemente" como atividade ou área de estudo no $1^{\mathrm{o}}$ grau. Uma forma preferível, mas não exclusiva. Logo, poderiam ser abordados como disciplinas individuais, desde que os sistemas de ensino e escolas assim entendessem:

Nada impedirá, a não ser as próprias condições da escola, quando for o caso, que o currículo das séries finais, a partir da $5^{\mathrm{a}}$, do ensino de $1^{\circ}$ grau, trate a área de Estudos Sociais com a sua divisão nas disciplinas que a compõem, inclusive utilizando-se de professores específicos. (Souza, 1978, p. 29).

Contudo, em uma realidade de expansão do ensino privado, obviamente que as escolas optariam pelo ensino de Estudos Sociais enquanto uma área de estudo, ministrada por um único professor polivalente. Economizar-se-ia na contratação de professores de História e de Geografia. Além disso, o próprio conselheiro, já neste parecer, corrobora os Estudos Sociais como disciplina "que integra diferentes conteúdos" (Souza, 1978, p. 29) e é constituída pela fusão das disciplinas tradicionais. Note-se que isso não é uma intenção, ao menos visível, no parecer $n^{\circ} 853 / 71$ de autoria de Valnir Chagas, que nesse momento já não era mais membro do CFE. Nas suas conclusões, Paulo Nathanael atendeu algumas das reivindicações de historiadores e geógrafos e propôs mudanças na redação tanto do parecer $n^{\circ} 853 / 71$ quanto da portaria ministerial $n^{\circ} 790 / 76$. Quanto à primeira, na nova escrita, especificava que os Estudos Sociais poderiam ser ensinados como disciplinas específicas a partir da $5^{\mathrm{a}}$ série do $1^{\circ}$ grau e atribuídas a formados em História e Geografia. Por sua vez, a segunda deixava de excluir os licenciados em História e em Geografia do ensino de Estudos Sociais. Aparentemente era uma vitória, mas o propósito do CFE agora era o de afirmação dos Estudos Sociais não mais na escola básica, mas na formação de professores.

Em outubro de 1980, circulou nos meios acadêmicos um polêmico projeto do CFE, de autoria do conselheiro Paulo Nathanael de Souza ${ }^{250}$. Propunha-se um novo "Currículo Mínimo do Curso de Estudos Sociais", seguindo o "modelo

\footnotetext{
${ }^{250} \mathrm{O}$ parecer e as manifestações contrárias a ele foram disponibilizados em "Estudos Sociais: um problema contínuo", Noticiário publicado na "Revista Brasileira de História", organizado por Raquel Glezer (1982). Sobre isso nos informa a organizadora: "Considerando que assunto de tal magnitude deveria ficar documentado, a Profa. Dra. Alice Piffer Canabrava, presidente da Associação Nacional dos Professores Universitários de História no biênio 1979/1981, decidiu coletar e publicar os textos de repúdio ao projeto, excetuando notícias de jornais, artigos de associados já publicados em outros periódicos e cartas que lhe foram dirigidas pessoalmente, mas sem serem acompanhadas de manifestações institucionais." (p. 117-118). Referir-nos-emos aos documentos, os nomeando sempre que possível, mas a partir de Glezer (1982).
} 
chaguiano". A escrita do projeto é ambígua, já que o conselheiro promove uma crítica à licenciatura curta em Estudos Sociais, cuja organização foi estabelecida por ele próprio, e reflete o improviso com que foram formuladas as propostas de Estudos Sociais. Ao justificar o novo formato, argumentava que o parecer $\mathrm{n}^{\mathrm{o}}$ 554/72, de sua relatoria, era uma solução transitória, no qual se anunciava a intenção de "atrair para área de Estudos Sociais, as licenciaturas que permaneceram dela desvinculadas de História, Geografia e Ciências Sociais" (Glezer, 1982, p. 118). Lembrava que isso já havia sido realizado em outras áreas através de pareceres e resoluções "inovadoras da lavra do ex-conselheiro Valnir Chagas" (p. 118), embora silenciasse quanto à reação contrária a esta política e a não efetivação do Curso de Ciências organizado a partir da resolução no 30/74.

A principal falha das licenciaturas curtas estava em articular os diferentes conteúdos sob a sua rubrica, "permanecendo como uma espécie de colcha de retalhos descosida, onde entram elementos arbitrariamente conjugados da Sociologia, da História, da Geografia, da Economia, da Política e o que mais seja." (Glezer, 1982, p. 119, grifos nossos). Do mesmo modo, ela promovia uma "generalizada ignorância" não apenas em termos de conteúdos do conhecimento, mas também em relação aos métodos e técnicas de ensino necessárias ao ensino de atividades e áreas de estudo. A solução seria a eliminação da licenciatura curta como uma etapa obrigatória da licenciatura plena, mantendo-a como alternativa apenas para regiões realmente carentes de professores, e a criação de uma licenciatura plena em Estudos Sociais englobando diferentes habilitações:

O curso proposto será de Estudos Sociais, com as habilitações plenas de História, Geografia, Educação Moral e Cívica e Organização Social e Política do Brasil. No caso da História e da Geografia, que eram cursos avulsos (Resolução de 19/12/1962), teremos sua transformação em habilitações do curso unificado de Estudos Sociais. (Glezer, 1982, p. 121).

Este desenho não incluía uma habilitação em Ciências Sociais ou Sociologia. A explicação para tal foi elaborada a partir de uma citação a Delgado de Carvalho, a única a este autor presente nos pareceres sobre os Estudos Sociais produzidos pelo CFE entre 1971 e 1980. Com isso podemos afirmar que "Introdução metodológica aos Estudos Sociais", publicada em 1957, era uma obra conhecida dos conselheiros. Como apontamos, anteriormente, as semelhanças entre a argumentação de Delgado e os pareceres de Valnir Chagas e Terezinha Saraiva são inúmeras. O fragmento de Delgado de Carvalho utilizado, em 1980, é 
aquele em que o educador faz uma pequena distinção entre as Ciências Sociais, como investigação e pesquisa, e os Estudos Sociais como uma vulgarização para o ensino, embora em sua concretização também haja pesquisa. A partir daí Souza entende que "a formação de alguém em Ciências Sociais" deveria ser feita em curso próprio, “apartado do contexto de Estudos Sociais” (Glezer, 1982, p. 121), e de preferência em termos de um bacharelado e não licenciatura, já que as Ciências Sociais eram uma "especialização científica" e atribuição dos cientistas sociais. É uma interpretação errônea de Delgado porque em sua obra não se percebiam as Ciências Sociais apenas como a Sociologia, mas era definida como uma grande área que incluía também a História, a Geografia, a Economia, a Antropologia e a Ciência Política. A frase também é utilizada fora de seu contexto original.

Na década de 1980, já não era um consenso a separação entre o cientista e o professor, algo que estava dado no momento de escrita de "Introdução metodológica aos Estudos Sociais”, nos anos de 1950. Também começava a se deixar de enxergar o professor como um simples transmissor de conhecimentos produzidos por outros. Souza defendia que o estudo do homem era o elemento unificador das licenciaturas específicas em torno dos Estudos Sociais, já que este seria um objeto comum a todas elas. É a argumentação utilizada por Delgado de Carvalho para o ensino de Estudos Sociais, enquanto disciplina, na escola básica, mas o educador nunca apresentou tal proposta para a formação de professores ou criação de cursos superiores. O que Souza tencionava era reviver as escolas de formação profissional, apartadas da investigação científica, indo contra a legislação aprovada durante a própria ditadura militar. A lei $\mathrm{n}^{\mathrm{o}} 5.540 / 68$, de Reforma do Ensino Superior, abalizada pelo CFE, apontava em seu segundo artigo que a pesquisa e o ensino são atividades indissociáveis.

"Os Estudos Sociais novamente em questão", documento produzido pelos professores do Departamento de História da USP apontava essa questão:

É inacreditável que se defenda tão cruamente a ideia de ciências de primeira e segunda classe. Despreza-se o consenso que existe nas Universidades sobre a integração entre ensino e pesquisa e caminha-se no sentido oposto: busca-se estabelecer uma separação, por todos os modos anticientífica, entre o pesquisador, isolado em sua investigação acadêmica, e o professor, agora polivalente, destituído de uma visão mais aprofundada ou crítica da realidade em que vive. (Glezer, 1982, p. 135).

A enfática defesa da associação entre ensino e pesquisa na formação de professores, realizada pelos docentes do Departamento de História da USP, 
precisa ser relativizada, já que ficava muito mais em termos de projeto do que realização prática. Déa Fenelon (1983), membro de uma comissão que analisou os cursos de História na década de 1980, descreve um cenário pouco promissor, que decorria das políticas educacionais instituídas durante a ditadura militar pelo CFE e da estruturação dos próprios cursos. A professora da Universidade Estadual de Campinas argumentava que as licenciaturas em História estavam "simplesmente formando reprodutores de uma ciência já pronta e acabada, sem nenhum referencial teórico ou metodológico.” (Fenelon, 1983, p. 28). Somava-se a isso a distância entre as concepções de ensino de História ministradas pela universidade e a realidade de ensino. Fenelon (1983, p. 30) salientava que:

Grande parte de nossos alunos são formados em História, mas não capazes de elaborar uma problemática de pesquisa. Tiveram contatos mínimos com qualquer tipo de documentação e não aprenderam a trabalhar com ela, raramente frequientaram qualquer tipo de Arquivo ou foram em busca de outras fontes de investigação, aprendendo a questioná-las na forma como aparecem ou foram encobertas, no conteúdo do que dizem, na situação de testemunhos de que são origem. Isto não se faz, em verdade, porque a maioria dos professores muitas vezes jamais realizou este tipo de trabalho e tem sobre sua tarefa de ensino uma concepção que não difere da idéia do repassador de conhecimentos de informações.

A crítica às licenciaturas em Estudos Sociais forneceram importantes elementos para a percepção da necessidade de reformulações nas licenciaturas em História, que iniciassem o professor nos labores da pesquisa desde a graduação.

Mesmo fazendo uma distinção entre o professor e o pesquisador, Delgado de Carvalho (1970) acreditava - como salientamos no capítulo anterior - que o professor deveria ser um intérprete do seu tempo, tendo dele um conhecimento aprofundado. De certo modo, o professor era um investigador, um cientista social $^{251}$. Para Paulo Nathanael de Souza, pesquisador e professor eram atividades distintas. O novo Curso de Estudos Sociais manteria a sua carga horária, de 2.200 horas aulas, sendo composto por um conjunto de matérias básicas, comum a todas as habilitações, e as matérias específicas para cada habilitação, além das matérias

\footnotetext{
${ }^{251}$ Para Delgado de Carvalho, o professor não é apenas um transmissor de conhecimentos, mas um orientador, um formador. Em sua atividade cotidiana a pesquisa era uma tarefa essencial como elemento de formação dos alunos. Quanto a isso é significativo o parágrafo final de "Introdução metodológica aos Estudos Sociais": "Quando o magistério tiver descoberto um meio de levar os seus discentes a trabalhar, a pesquisar (embora modestamente), a coligir dados, a colher material, para construir o edifício de sua própria cultura; quando os elementos desta cultura não ficarem mais concentrados e mastigados em compêndios, mas forem estes apenas deixados à disposição dos educandos, para responderem a questões que lhes são feitas; quando o professor passar a ser essencialmente orientador, e guia, terá chegado o Crepúsculo da Preleção, da Exposição Oral e dos solilóquios que foram a glória do Passado.” (Carvalho, 1970, p. 297).
} 
obrigatórias (Educação Física e Estudos de Problemas Brasileiros) e das matérias pedagógicas. Os Estudos Sociais tornar-se-iam o núcleo comum ou ciclo básico das habilitações. A habilitação em História teria a seguinte estrutura ${ }^{252}$ :

1) Matérias básicas: Fundamentos das Ciências Sociais, Técnicas de Pesquisa Social, Antropologia Cultural e Sociologia.

2) Habilitação em História: Arqueologia e Pré-história, História Antiga, Moderna, Medieval e Contemporânea, História da América, História do Brasil, Historiografia Geral e do Brasil, Etnologia e Etnografia do Brasil.

3) Matérias Pedagógicas: Psicologia da Educação, Filosofia da Educação, Didática, Estrutura do Ensino de $1^{\circ}$ e $2^{\circ}$ graus, Legislação do Ensino de $1^{\circ}$ e $2^{\circ}$ graus, Prática do Ensino de $1^{\circ}$ e $2^{\circ}$ graus.

Não há indicação da carga horária dedicada a cada uma das matérias acima e nem a razão de Fundamentos das Ciências Sociais e Técnicas de Pesquisa Social constarem como disciplinas básicas e obrigatórias a todas as habilitações. As instituições de ensino poderiam acrescentar novas matérias e desdobrar as indicadas em disciplinas de acordo com os seus critérios. $\mathrm{O}$ aluno seria diplomado em Estudos Sociais, com habilitação específica em História. Em ofício enviado a todas suas seções regionais, a Associação Nacional dos Professores Universitários de História tentava organizar as críticas à proposta de Souza, reforçando que caberiam às instituições e à comunidade universitária decidirem sobre os conteúdos da formação profissional e que era preciso, portanto, reagir a todas as decisões que não ouvissem os formadores dos professores (Glezer, 1982). E, anos antes, geógrafos e historiadores já haviam optado por desmembrar os seus cursos.

Em Boletim Informativo do Núcleo da Anpuh - Seção São Paulo, de setembro de 1980, intitulado "Estudos Sociais: nova ofensiva", a diretoria regional admitia que após as vitórias de 1976, os historiadores se despreocuparam da questão dos Estudos Sociais. Logo, era necessária a retomada da resistência que, no entender da diretoria, já começava atrasada (Glezer, 1982). Tratava-se de:

[...] grave tentativa de destruir os campos de conhecimentos científicos, de interferir na universidade brasileira, a quem caberia decidir sobre a natureza de sua produção científica e sobre os profissionais que deve formar, e de transformar a área vital do ensino e da educação num aglomerado de elementos a serem "divulgados" entre os educandos. (Glezer, 1982, p. 129).

\footnotetext{
${ }^{252}$ Para cada uma das habilitações foram apresentadas um conjunto de matérias específicas, como o único aspecto que as diferenciava, já que todas seguiam as mesmas matérias básicas, pedagógicas e obrigatórias de acordo com a legislação (Educação Física e EPB).
} 
As inúmeras manifestações recolhidas por Glezer (1982) alertavam para o caráter arbitrário e antidemocrático da proposta, realizada sem consulta à comunidade universitária e científica nacional, como apontava um "Comunicado de Professores e Alunos da PUC-SP”. O projeto foi feito a revelia dos professores de História e dos historiadores, bem como de geógrafos e dos professores de Geografia. Aliás, as soluções aventadas apenas intensificavam os problemas gerados pelas políticas impostas pelo CFE e criticadas pelo próprio Paulo Nathanael. Permanecia, e mesmo se ampliava, a "colcha de retalhos" em que se transformou os conteúdos programáticos de Estudos Sociais. Os conteúdos continuariam sendo ministrados de forma superficial na formação docente, já que o tempo para a formação específica rivalizaria com o dedicado às outras matérias. E o mais grave: autorizava-se um professor que tivesse habilitação específica em OSPB ou em EMC a ministrar qualquer ou todos os conteúdos de Estudos Sociais no $1^{\circ}$ grau, quando estes fossem área de estudos ou disciplina. Na prática, era possível lecionar História e Geografia mesmo sem tê-las estudado na graduação. Nem se formaria um pesquisador, nem um professor habilitado.

Diante da forte oposição, o conselheiro Paulo Nathanael e o CFE foram obrigados a recuar e arquivar o projeto, alegando que se tratava apenas de um “estudo preliminar". A partir da década de 1980, intensificou-se a luta pela extinção das licenciaturas em Estudos Sociais e pela redistribuição da carga horária das disciplinas de OSPB e EMC entre as disciplinas de História e Geografia (Fenelon, 1984). Estava em curso um processo de abertura política. A extinção do Ato Institucional $\mathrm{n}^{\circ}$ 5, no final de 1978, possibilitou uma oportunidade maior de questionamento das políticas governamentais. A eleição de políticos oposicionistas em Estados importantes da federação, como São Paulo, Minas Gerais e Rio de Janeiro, levou ao processo de reformas curriculares estaduais e à discussão do ensino de História e da formação de professores, além do paulatino retorno da História e da Geografia como disciplinas autônomas. A força normativa do CFE começava a diminuir e os alicerces das suas reformas, como o ensino profissionalizante, foram revistos. Todavia, esse não foi o fim dos Estudos Sociais no Brasil. Com outro formato, eles permaneceram no currículo dos primeiros anos de escolarização até os anos de 1990. É um movimento que ainda precisa ser melhor examinado pelos pesquisadores brasileiros. 


\section{8 \\ Considerações finais}

Ao concluir o mestrado em História Social, em 2012, ponderávamos que era necessária uma investigação que aprofundasse as influências de John Dewey, Anísio Teixeira e Delgado de Carvalho sobre a compreensão de Valnir Chagas acerca dos Estudos Sociais. O período de leituras e pesquisas que antecedeu o ingresso no doutorado em Educação e, sobretudo, a revisão bibliográfica realizada a partir de 2015, distinguiu uma série de lacunas sobre os caminhos do ensino de Estudos Sociais no Brasil. Lugares comuns eram citados em vários trabalhos que não aprofundavam elementos importantes. $\mathrm{O}$ objetivo inicial para a pesquisa ampliara-se, não se tratando apenas de analisar os fundamentos da escrita de Valnir Chagas, em seu parecer $n^{\circ} 853 / 71$, o que já apresentava certo grau de complexidade e dificuldade, mas compreender de que forma a discussão sobre os Estudos Sociais chegou ao Brasil e como ela se transformou nos anos seguintes. Escolhas foram necessárias e as figuras principais (Carvalho e Chagas) mantidas, embora personagens secundários tenham aparecido no decorrer da pesquisa. Portanto, esta tese buscou investigar as continuidades e rupturas entre os projetos de Estudos Sociais defendidos por Delgado de Carvalho e Valnir Chagas.

A tese tornou-se ambiciosa, devido à larga temporalidade e a multiplicidade de autores e contextos a serem tratados, o que talvez possa gerar aberturas para críticas em relação ao seu tamanho, amplitude e passagens um pouco mais descritivas, mas a análise das fontes revelou informações sobre os Estudos Sociais pouco sopesadas pela historiografia educacional. Uma certeza, em meio a inúmeras dúvidas se firmou: os debates anteriores à ditadura militar eram muito mais ricos do que os ocorridos a partir de 1971. Não apenas por se processarem em uma temporalidade maior, mas por ocorrerem em um momento democrático da nossa história. Consideramos que o desenvolvimento proposto era necessário para assinalar possíveis olhares acerca da trajetória dos Estudos Sociais no Brasil, além de reforçar a necessidade de outras pesquisas. Por isso, privilegiamos as concepções de Estudos Sociais defendidas por Delgado de Carvalho, sem descurar das abordagens difundidas pelo CFE na década de 1970. 
As considerações finais desta tese podem ser articuladas em torno de quatro eixos principais: a influência americana, a pioneira experiência do Distrito Federal, os embates de Delgado de Carvalho pelos Estudos Sociais na escola secundária e as reformas educacionais organizadas pelo CFE. O ensino de Estudos Sociais, desde a inserção nos currículos brasileiros dos anos de 1930, representou uma forma de organização curricular diferente da consolidada com a criação do Colégio Pedro II no século XIX. A sua proposta se situava em um contexto de crítica ao caráter acadêmico dos programas, à excessiva especialização e ao distanciamento entre as questões debatidas pelas escolas e a vida dos alunos. Os críticos do modelo de escola secundária salientavam que esta se preocupava apenas com a formação acadêmica dos alunos, como um instrumento para ingresso no ensino superior, e argumentavam que era preciso que ela se abrisse a finalidades mais práticas, como a interpretação da realidade social.

As viagens pedagógicas e as leituras de intelectuais americanos forneceram aos educadores brasileiros os instrumentos para as reformas realizadas entre as décadas de 1920 e de 1930. A reorganização pedagógica e administrativa empreendida por Anísio Teixeira no Distrito Federal, entre 1931 e 1935, estava alicerçada nos preceitos defendidos por John Dewey, em obras como "A escola e a sociedade" e "Educação e democracia". Dewey e Teixeira defenderam o fim do divórcio entre a escola e a sociedade, a educação como vida e crescimento e uma mudança nos métodos de ensino. O ensino livresco e as "aulas-conferências" não formavam os jovens para a vivência numa sociedade em constante mudança. Buscava-se educar os alunos para a democracia. Para isso, era preciso ação, construção, reflexão e métodos que rompessem com a passividade. A capacidade de crítica é formada através da aquisição de instrumentos que possibilitem ao aluno continuar aprendendo e se desenvolvendo constantemente.

Dewey $(1959,2002)$ concedeu atenção especial ao ensino de História e Geografia, as quais, para ele, deveriam ser ministradas de forma integrada, pois suas análises se complementam. A História não poderia ficar restrita ao estudo do passado pelo passado e aos fatores políticos, sendo sua análise essencial para a compreensão dos problemas vividos no presente. A Associação Americana de História e a Associação Nacional de Educação dos Estados Unidos se apropriaram dos escritos de Dewey na sua demarcação de Estudos Sociais, como uma disciplina vinculada, prioritariamente, à realidade social e cuja função era a 
formação do cidadão capaz de compreender o mundo que o cerca. Os Estudos Sociais eram, portanto, responsáveis por tornar os educandos interessados pelas questões sociais e elementos ativos da sociedade, e seu ensino deveria se transmudar em habilidades, ideias e atitudes que levassem a uma vida melhor.

O relatório "The Social Studies in secondary education" (Dunn, 1916) primeiro a utilizar o termo "Estudos Sociais" - valoriza, sobretudo, a história americana e suas raízes europeias. No contínuo progresso chegava-se à democracia estadunidense. Divulgado nos anos da Primeira Grande Guerra, demarca o isolacionismo dos Estados Unidos e tem como preocupação central a harmonização dos imigrantes que ingressavam no país. Quase duas décadas depois, a "Investigation of the Social Studies in the schools" - organizada e patrocinada pela Associação Americana de História - consolidou os Estudos Sociais no currículo escolar daquele país. Beard (1932) e Krey et al. (1934) reafirmaram essa disciplina como uma construção pedagógica atenta às necessidades da escola e dos alunos. Reconheciam-se as articulações entre as Ciências Sociais, mas respeitavam-se as suas especificidades e contribuições acadêmicas. Criava-se, assim, uma disciplina escolar e não uma Ciência.

Editados após os horrores da Grande Guerra, os documentos da década de 1930 enfatizaram o ideal de solidariedade entre nações e a construção de hábitos de cooperação e respeito. $\mathrm{O}$ foco do programa americano mudou radicalmente e passou a incluir uma maior diversidade de análises e conteúdos, para além do binômio Estados Unidos e Inglaterra. É preciso salientar que o projeto de Estudos Sociais, tal como formulado por Beard (1932) e Krey et al. (1934), considera o pressuposto da liberdade de pesquisa e expressão como elemento básico do ensino-aprendizagem. Cabe à escola formar cidadãos capazes de questionarem e refletirem, sendo tais fundamentações apropriadas por Delgado de Carvalho em suas obras. Abordamos alguns aspectos dos debates nos Estados Unidos, com o objetivo de entender as interpretações brasileiras, porém muito ainda precisa ser pesquisado. Analisamos apenas a parte visível do iceberg. Cada comissão, cujas atividades de pesquisa e ação se efetivaram em mais de meio século, gerou inúmeros relatórios que podem e devem ser objetos de novas investigações.

Embora a proposta brasileira, aplicada no Distrito Federal durante a reforma anisiana da década de 1930, inspire-se em documentos estrangeiros, há um processo de apropriação que informa as leituras e concretizações. Os comitês 
norte-americanos não se preocuparam com prescrições detalhadas, algo que cada estado ou cidade deveria se ocupar, mas em indicar quadros referenciais de acordo com os quais os Estudos Sociais deveriam dialogar. As discussões foram realizadas por especialistas, principalmente historiadores, que não mantinham um diálogo mais profundo com a escola primária e secundária. O PCS (1934) foi produzido por professores generalistas, atuantes em um campo científico ainda em constituição, com formações e experiências variadas e uma estreita relação com a escola primária do Distrito Federal, e possui uma abordagem prática: há inúmeras indicações ou prescrições daquilo que se esperava do professor, dos conteúdos, dos métodos de ensino e sugestões de referências bibliográficas.

Se nos Estados Unidos os Estudos Sociais foram debatidos primeiramente no interior das associações científicas, no Brasil foi uma elaboração de intelectuais-educadores vinculados à administração pública do Distrito Federal. Os Estudos Sociais foram pensados no Brasil da década de 1930, como uma disciplina para a escola primária - formada a partir da fusão, sobretudo, de História, Geografia e Educação Cívica, algo que não fica claro na documentação norte-americana. É uma questão que a análise da organização escolar norteamericana pode ajudar a explicar. Beard (1932), historiador e, portanto, especialista em uma determinada área do conhecimento, não propôs o fim das disciplinas e não refletiu sobre a escola primária. Estariam Beard (1932) e seus colaboradores preconizando uma nova disciplina escolar ou uma área de estudos? Como os Estudos Sociais americanos se inseriram na prática cotidiana?

Anísio Teixeira, secretário de Educação do Distrito Federal, entendia que os programas deveriam se pautar na "organização psicológica das disciplinas escolares", com o conhecimento sendo ministrado segundo as fases do crescimento infantil. Nesse percurso, previa-se a integração de conteúdos nos primeiros anos de escolarização e disciplinas específicas na escola secundária, que seguiam as diretrizes da Reforma Campos (federal, 1931-1932), quando os alunos estariam mais maduros para a "organização lógica do conhecimento". Era uma perspectiva presente nas reformas distritais anteriores, como a realizada por Fernando de Azevedo (1927-1930). A novidade, da gestão anisiana, foi a criação de uma disciplina intitulada "Ciências Sociais".

O PCS (1934) foi escrito de acordo com a filosofia educacional de Dewey e Teixeira. Delgado de Carvalho defendeu a criação dos Estudos Sociais em 
decorrência das "conexões naturais" e "íntimas ligações" existentes entre História, Geografia, Sociologia, entre outras. Todas tinham como objeto o homem e suas relações. O seu ensino compartimentado contribuía pouco para a compreensão da complexidade da vida humana. Apesar disso, a História tem uma primazia entre os tópicos de ensino presentes no PCS (1934). Enquanto os programas da escola primária de então priorizavam a História Pátria, esse programa, movido por uma perspectiva pacifista, advogava o ensino de uma História da Civilização. Sua metodologia principal era a resolução de problemas e o método de projetos, sem abandonar os elementos tradicionais, como as longas listas de conhecimento que os alunos deveriam aprender na escola primária. Assim, apesar de criticar o uso excessivo das aulas expositivas, o programa não abandonou as pesadas cronologias. As professoras ficavam entre dois sistemas distintos: o método de projetos, exigindo a ação dos alunos, e os “mínimos a saber" que, certamente, impunham aulas expositivas para dar conta de sua amplidão.

Ambas as propostas (a americana e a brasileira) consideravam o professor mal treinado. Devido à ausência de pesquisas sobre o tema, entendíamos, durante o mestrado em História, que a primeira experiência de formação do professor de Estudos Sociais no Brasil ocorreu a partir da criação, pelo CFE, da licenciatura curta na década de 1960 (Nascimento, 2012). A pesquisa de doutorado possibilitou a oportunidade de corrigir essa interpretação falha. Os educadores brasileiros, diferentemente do que apontamos em nossa dissertação, propuseram um ensino de Estudos Sociais na escola primária, articulado à necessidade de formação do professor para este nível de ensino. Para isso foi criada uma matéria de Estudos Sociais na Escola de Professores do Instituto de Educação. Não se tratava de uma licenciatura, mas de uma intenção em habilitar a docente ao ensino das disciplinas que lecionaria na escola primária. O objetivo era estudá-las de acordo com os interesses da profissão e segundo as necessidades da escola. Nesse sentido, havia matérias de ensino sobre Ciências Naturais, Cálculo, Literatura Infantil, Leitura e Linguagem, Matemática e Estudos Sociais, em contraposição às metodologias e didáticas que não eram específicas. Uma experiência única em termos de Escola Normal - ou Instituto de Educação, na nomenclatura escolanovista - e cuja duração foi relativamente efêmera.

A organização do Instituto de Educação se efetuou de forma diferente do que se praticaria, posteriormente, na Universidade do Distrito Federal. Os 
professores do Instituto foram levados a conhecer, nos Estados Unidos, os seus intelectuais e teorias. Muitos desses docentes se tornaram referência do ensino na capital brasileira. Ignacia Guimarães e Maria dos Reis Campos foram personagens importantes no processo de institucionalização dos Estudos Sociais em nosso país, mas são desconhecidas. Próximas a Anísio Teixeira, atuaram, respectivamente, na organização do PCS (1934) e na elaboração de um Programa de Estudos Sociais no Instituto de Educação. São necessárias pesquisas que reconstituam a trajetória dessas duas mulheres, e tantas outras, presentes nos processos de reformas educacionais da década de 1930 e ofuscadas pela importância de nomes como o de Anísio Teixeira e o de Delgado de Carvalho. Apesar de interrompida no Distrito Federal, após a saída de Anísio Teixeira da Secretaria de Educação e os rumos da educação brasileira no contexto do Estado Novo, a discussão sobre os Estudos Sociais não se extinguiu no cenário educacional. Projetos foram desenvolvidos em outras regiões, como no Rio Grande do Sul (1939), porém, são experiências ainda pouco aprofundadas por pesquisas científicas.

Nos anos que antecederam ao golpe de 1964, o principal formulador e defensor dos Estudos Sociais nos currículos escolares da escola secundária foi o professor Delgado de Carvalho, que utilizava como argumentação, para organização da disciplina, a mesma adotada para a escola primária. Contudo, as ações desse educador foram diferentes em relação a este nível de ensino. Suas teorizações sobre as Ciências Sociais são caracterizadas por sua trajetória intelectual e atuação na constituição de diferentes campos disciplinares no Brasil. Com isso, apesar de defender uma nova disciplina, os Estudos Sociais, não raro, Delgado de Carvalho defendeu o fortalecimento das disciplinas tradicionais. O ideal, no seu entendimento, era que as disciplinas de Ciências Sociais fossem ensinadas em uma "unidade" denominada como Estudos Sociais. Enquanto isso não fosse possível, era preciso mudar os seus métodos na escola secundária, sendo esse um objeto de reflexão e de sua vida profissional durante quatro décadas.

As investigações sobre os Estudos Sociais reconhecem o papel de Delgado de Carvalho na conformação dessa disciplina, porém concedem uma primazia à leitura de "Introdução metodológica aos Estudos Sociais" (1957). A presente pesquisa mostrou, a partir da análise de outras obras - editadas entre 1930 e 1950 -, as continuidades e rupturas no pensamento do catedrático. A formulação dos programas do curso secundário era uma atribuição do Ministério da Educação. 
Não era possível, desta feita, a criação de uma disciplina, como Anísio Teixeira havia feito durante a reorganização da escola primária do Distrito Federal ${ }^{253}$. Utilizando-se de sua influência no campo disciplinar - como catedrático da Universidade do Brasil até a década de 1950 e membro de associações geográficas e históricas - Delgado de Carvalho apresentou em palestras, cursos, artigos e livros outras possibilidades de ensinar História e Geografia, sobretudo.

"Dissertação histórica", "estudo-dirigido" e excursões são exemplos de metodologias indicadas para a renovação do ensino das disciplinas ditas tradicionais. Somadas à pesquisa são atividades cuja função era desenvolver o espírito crítico e formar jovens capazes de observar, julgar e raciocinar. A atuação na produção de livros didáticos contribuiu para que Delgado de Carvalho pensasse a função de cada uma das disciplinas componentes dos Estudos Sociais ${ }^{254}$, o que gera uma pequena confusão quanto sua proposta. Se no PCS (1934) a História e a Geografia são conteúdos da disciplina Ciências Sociais, não fica claro, até a década de 1950, em relação à escola secundária, qual seria o lugar da História e da Geografia. Tal sentido só foi explícito em "Introdução metodológica aos Estudos Sociais". Enquanto História e Geografia seriam disciplinas autônomas no ciclo ginasial, cujo ensino deveria ser integrado através, por exemplo, de uma área de estudos, no colegial, tornavam-se conteúdos dos Estudos Sociais.

Na década de 1950, Carvalho compreende que a posição dos Estudos Sociais no currículo deveria ser nos anos finais da escola secundária, não na escola primária e não no ciclo ginasial. Essa é uma mudança significativa no seu pensamento, considerando-se que os Estudos Sociais foram introduzidos primeiramente nos currículos da escola primária. A inserção curricular da disciplina no curso secundário não significava a exclusão total de História e Geografia como disciplinas independentes. Em "Introdução metodológica aos Estudos Sociais", o educador apresenta uma proposta de programa que, como no PCS (1934), priorizava a História da Civilização. A função dos Estudos Sociais

\footnotetext{
253 Como salientamos logo no segundo capítulo desta tese, enquanto a escola secundária se constituiu a partir de disciplinas independentes, na escola primária as diferentes disciplinas eram diluídas. Até a década de 1930, era comum a História ser ensinada não como uma disciplina, mas como leitura instrutiva ou um conteúdo articulado a outros. Também não havia uma professora específica para o ensino de História ou Geografia, mas a normalista com uma formação geral.

${ }^{254}$ Cada componente tem uma função no interior dos Estudos Sociais (Cf. o sexto capítulo da tese). Isso é algo que distingue a interpretação de Delgado de Carvalho tanto das abordagens americanas quanto do que se institucionalizou a partir do parecer $\mathrm{n}^{\circ}$ 853/71.
} 
residiria no estímulo à compreensão das instituições do país e dos problemas sociais, políticos e econômicos que caracterizavam a sociedade brasileira.

Delgado de Carvalho, como argumentado ao longo da tese, embora tenha uma formação europeia, tomou como inspiração, para suas definições de Estudos Sociais, os documentos americanos e a filosofia educacional deweyana. Suas principais referências ao pensar o ensino de História são: John Dewey, em "Democracia e Educação", e Charles Beard. A despeito de ser um debate, já havia críticas aos Estudos Sociais na escola secundária. Defendemos que essas críticas não se relacionavam à opção de Carvalho por referências que estavam sendo questionadas naquele contexto histórico, como a escola progressiva, mas à ideia de supressão de disciplinas tradicionais do currículo escolar. Além disso, os historiadores, que refletiam sobre o ensino de História, argumentavam que as funções atribuídas por Delgado de Carvalho e outros intelectuais aos Estudos Sociais poderiam ser alcançadas pela História, desde que valorizada no currículo.

A publicação da LDBEN, em 1961, permitiu uma onda de experiências educacionais bem-sucedidas em que os Estudos Sociais foram repensados e incluídos nos currículos de instituições, como os Ginásios Vocacionais paulistas. Eram orientações indicativas, oriundas de um contexto democrático em que havia um estreito diálogo entre História e Geografia, como entes independentes na organização dos Estudos Sociais. O próprio CFE apontou esta última como disciplina optativa do ensino médio a partir de 1962. Entre os nossos objetivos, optamos por não aprofundar a discussão sobre esses movimentos já tratados por outros autores, mas salientamos a necessidade de se pesquisar tais propostas para além do eixo São Paulo-Minas Gerais. Como se aplicaram as diretrizes de 1961 em estados como Guanabara e Rio de Janeiro? Ocorreram experiências de Estudos Sociais nas escolas desses estados durante a década de 1960?

O golpe militar de 1964 suplantou as experiências realizadas nos anos anteriores, muitas consideradas como subversivas. Entre 1964 e 1971, contexto de gradativo fechamento político do país e constituição de aparelhos de repressão, como censura, tortura, perseguições e aposentadorias compulsórias, a ditadura impôs uma série de reformas educacionais viabilizadas pelo CFE e referendadas por importantes conselheiros. Entendemos que, ao mesmo tempo em que as reformas não podem ser compreendidas distanciadas do contexto autoritário instalado no país a partir de 1964, as suas leis não devem ser analisadas apenas no 
sentido de tentativa de imposição da conformação à ordem vigente, ou como intenção dos novos governantes em desestruturar a educação nacional, neste caso específico, o ensino de História efetivado nas escolas e universidades. Há uma concepção pedagógica que informa as intenções dos conselheiros e que estavam em debate no CFE desde a sua criação, em 1962. Em relação à lei no 5.692/71, de reforma de ensino de $1^{\circ}$ e $2^{\circ}$ graus, e ao parecer $n^{\circ} 853 / 71$, que delimitou a Doutrina do Núcleo Comum, o seu principal articulador foi Valnir Chagas.

Martins (2000) afirma que, mesmo alterando profundamente as estruturas educacionais brasileiras, a ditadura não desvirtuou o modus operandi do CFE conforme indicado pela LDBEN de 1961. Contudo, foi sob os anos em que os militares governaram o Brasil que o poder decisório desse órgão normativo atingiu a sua maior expressão. Os conselheiros legislaram sobre o funcionamento das escolas primárias à pós-graduação. Pelas características dos pareceres produzidos pelo CFE é rara a presença de referências mais explícitas sobre as suas influências pedagógicas. No entanto, podemos identificar a continuidade de debates que se processavam no cenário educacional brasileiro das décadas de 1950 e de 1960, além de fundamentos do pensamento anisiano e deweyeano em suas escritas. Ao estabelecer os Estudos Sociais, como um elemento curricular obrigatório na escola de $1^{\circ}$ grau, Valnir Chagas o fez como uma crítica à compartimentação do conhecimento. Uma abordagem próxima ao que defendia Delgado de Carvalho em suas obras, porém não restrita às Ciências Sociais e expandida para todo o currículo escolar.

A lei $n^{\circ} 5.692 / 71$ representou uma mudança organizacional na estrutura curricular da escola primária e secundária, a partir de disciplinas independentes, estabelecidas pelas Reformas Capanema da década de 1940, e no próprio sentido de Estudos Sociais. A referida lei e, especificamente, o parecer $n^{\circ} 853 / 71$ indicaram um modelo pautado em matérias, disciplinas, área de estudos e atividades. Foi uma alteração inédita no cenário educacional brasileiro. A partir de então, os Estudos Sociais tornaram-se uma matéria a ser desdobrada em diferentes peças. História e Geografia poderiam ser tanto uma disciplina escolar, nos anos finais da escola de $1^{\circ}$ grau e no $2^{\circ}$ grau, como um simples conteúdo a ser ministrado no interior de uma área de estudos. Diante disso, eliminaram-se as indefinições que cercavam a obra de Delgado de Carvalho sobre o lugar dos Estudos Sociais e das disciplinas. A proposta de Valnir Chagas não se preocupou 
com a função de História e Geografia - algo que Carvalho definia mesmo quando se tratavam de conteúdos - no currículo, já que a função principal delimitada era a de Estudos Sociais. Se antes a sua função, em Delgado de Carvalho, se relacionava à formação de cidadãos críticos, com o parecer $n^{\circ} 853 / 51$ se limitava ao ajustamento ao meio social e convivência com o sistema político vigente.

Em "Introdução metodológica aos Estudos Sociais", Carvalho (1970) argumenta que os Estudos Sociais não poderiam se prestar a nenhuma forma de doutrinação. A sua tarefa era, justamente, possibilitar os instrumentos que permitem a observação, discussão e compreensão. O sentido adotado a partir de 1971 promoveu a alteração dos componentes principais dos Estudos Sociais. Foram incluídos EMC e OSPB no lugar de Antropologia, Sociologia, Economia e Política, presentes na abordagem de Delgado de Carvalho (1970). A EMC foi uma imposição dos militares no poder; a OSPB foi criada pelo próprio CFE, ainda no período democrático, mas alterada em seus objetivos principais. A diminuição da carga horária de História e Geografia foi alvo de protestos, sobretudo dos geógrafos, desde a sua prescrição em 1971. Do mesmo modo, os sistemas de ensino e professores não souberam como aplicar as novas diretrizes. Desde 1961, o CFE indicava apenas as matérias obrigatórias, abstendo-se de orientações metodológicas ${ }^{255}$. Contudo, os conselheiros foram obrigados a se manifestar.

A principal autora de pareceres sobre os Estudos Sociais foi a conselheira Terezinha Saraiva - mais uma mulher importante no processo de organização educacional brasileira, obscurecida pelos nomes mais famosos do CFE (Anísio Teixeira, Newton Sucupira e Valnir Chagas). Ela tomou para si a defesa dos Estudos Sociais, mesmo após o fim do mandato do conselheiro Valnir Chagas. Foi dela a única proposta de programa apresentada pelo conselho. Embora Saraiva (1975) inove em termos de objetivos, ela indica conteúdos tradicionais e criticados pelos professores especialistas, como por exemplo, a História manter uma abordagem vinculada ao político e aos grandes vultos e heróis nacionais, elementos criticados por Delgado de Carvalho, mas valorizados pela ditadura

\footnotetext{
${ }^{255}$ Como salientamos no sétimo capítulo, a LDBEN apostava na flexibilidade e maior liberdade para estados, escolas e professores. Competia a cada sistema de ensino e escolas, a confecção dos programas de ensino. Uma possibilidade de pesquisa se relaciona à apropriação realizada pelos estados, como Rio de Janeiro e Guanabara, a partir da leitura do parecer $\mathrm{n}^{\circ}$ 853/71. Cabe aprofundar a investigação dos manuais didáticos de Estudos Sociais surgidos nos anos de 1970 e 1980, e mesmo os adotados, ainda, na década de 1990.
} 
militar implantada em 1964. A preocupação maior do CFE não era com a proposição de conteúdos, mas com a formação do professor.

Inicialmente, a licenciatura em Estudos Sociais foi criada sem uma intenção pedagógica claramente definida, isto é, a indicação que autorizou o seu funcionamento não apresentou uma justificativa pedagógica ou associação com debates em torno da criação de uma disciplina de Estudos Sociais no currículo da escola brasileira. Visava, tão somente, diminuir a carência de professores. Contudo, as reformas impostas pela ditadura militar tornaram a licenciatura curta uma regra e as institucionalizaram na legislação. Por isso, não entendemos a licenciatura curta em Estudos Sociais como uma simples “descaracterização das Ciências Humanas", já que o modelo foi adotado para todas as áreas do conhecimento, incluindo as Ciências Naturais e Matemática. Valnir Chagas criou as chamadas "licenciaturas de Educação Geral", formadas pelas grandes linhas do núcleo comum (Estudos Sociais, Ciências e Comunicação e Expressão) e suas habilitações. Havia nisso uma descaracterização consequente, já que o conselheiro, em sua formulação, desconsiderava as especificidades de cada uma das Ciências e unia disciplinas importantes, como História e Geografia, com elementos desnecessários do currículo, como EMC e OSPB.

O projeto de formação de professores de Valnir Chagas foi amplamente criticado pela comunidade científica e universitária nacional, mas teve um defensor e continuador no CFE, Paulo Nathanael de Souza, que idealizou e definiu, em uma série de pareceres, a formação do professor de Estudos Sociais. Apesar da experiência desenvolvida pelo Instituto de Educação do Distrito Federal dos anos de 1930, Delgado de Carvalho não formulou um projeto de formação de professores de Estudos Sociais para a escola secundária. Trata-se de uma criação do CFE, distanciada dos projetos de formação e universidade, defendidos pela comunidade acadêmica. A intenção de Valnir Chagas e Paulo Nathanael era pôr fim às licenciaturas específicas, fossem elas de História ou Matemática. Os conselheiros distinguiam pesquisa e ensino, algo que academia começava a romper. A reação dos historiadores, muito mais organizada do que em relação às mudanças processadas na escola, foi imediata e o projeto arquivado. A proposta de Estudos Sociais e de formação de professores, concebida por Chagas, só foi possível em contexto de autoritarismo e controle. Tudo foi pensado sem ouvir os docentes e sem considerar as suas condições de trabalho e estudo. 
Da constituição pela via das "conexões naturaes", os Estudos Sociais tornaram-se mera justaposição de conteúdos, justificados por uma pretensa integração do conhecimento e realizada pela política educacional de uma ditadura. Contudo, os Estudos Sociais não se limitaram à ditadura militar. Esperamos ter conseguido, através das análises realizadas nos capítulos anteriores, estimular outras interpretações sobre a sua trajetória de ensino no Brasil. 


\section{Referências bibliográficas}

\section{Fontes primárias}

\section{Manuscritos e fontes consultadas em acervos pessoais}

BAGLEY, W. C. et al. Bases do preparo de programmas. Tradução realizada pelo Departamento de Educação do Distrito Federal, s/d. Arquivo Anísio Teixeira, CPDOC/FGV, AT pi I.E. 1932.00.00.

CARVALHO, D. Rascunho de carta. Rio de Janeiro, 27 jan. 1975. Coleção Delgado de Carvalho, lata 13, pasta 6, item 8: Discursos e Recortes de Jornal. Rio de Janeiro: Instituto Histórico e Geográfico Brasileiro, 1975a.

Notas sôbre Programas de Estudos Sociais, out. 1969. Coleção Delgado de Carvalho, lata 11, pasta 3: Ensino de Estudos Sociais. Rio de Janeiro: Instituto Histórico e Geográfico Brasileiro, 1969.

Notas sôbre Estudos Sociais. Rio de Janeiro, abr. 1968. Coleção Delgado de Carvalho, lata 11, pasta 3: Ensino de Estudos Sociais. Rio de Janeiro: Instituto Histórico e Geográfico Brasileiro, 1968.

Carta de Carlos Miguel Delgado de Carvalho a Luís Vergara. Encaminhando "Relatório sobre o ensino de sociologia", onde é proposto um enfoque distinto do previsto pelo programa oficial de ensino desta disciplina. Em anexo carta de Getúlio Vargas a Vergara comentando as propostas do relatório e o programa oficial de ensino de sociologia. Rio de Janeiro, 22 jun. 1938. Arquivo Luiz Vergara, CPDOC/FGV, LV c 1938.06.22.

A integração das matérias de Ciências Sociais. Rio de Janeiro, s/d. Coleção Delgado de Carvalho, lata 1: Sociologia. Rio de Janeiro: Instituto Histórico e Geográfico Brasileiro, s/d.

Geografia Física e Geografia Humana. Rio de Janeiro, s/d. Coleção Delgado de Carvalho, lata 11, pasta 1: Programas de aulas: geografia humana e geografia física; estudos sociais. Rio de Janeiro: Instituto Histórico e Geográfico Brasileiro, s/d.

Instruções para o preparo de dissertações, com base em tópicos previamente escolhidos. Rio de Janeiro, s/d. Coleção Delgado de Carvalho, lata 12, pasta 1: Ensino de Educação. Rio de Janeiro: Instituto Histórico e Geográfico Brasileiro, s/d.

CONGREGAÇÃO DA FACULDADE NACIONAL DE FILOSOFIA. Parecer. Rio de Janeiro, 19 ago. 1955. Coleção Delgado de Carvalho, lata 12, pasta 2: Homenagens e prêmios. Rio de Janeiro: Instituto Histórico e Geográfico Brasileiro, 1955. 
DISTRITO FEDERAL. Decreto $\mathbf{n}^{\mathbf{0}} \mathbf{7 . 7 1 8}$, de 5 de fevereiro de 1944. Reorganização do ensino primário. Folheto, Distrito Federal. Arquivo Gustavo Capanema, CPDOC/FGV, GC 494f.

TEIXEIRA, A. As idéias básicas de John Dewey e o Método de Projetos. Rio de Janeiro, s/d. Arquivo Anísio Teixeira, CPDOC/FGV, AT pi Teixeira, A. 1956.1964.00.00.2.

Carta para Valnir Chagas (Prefácio p/ o livro de R. Walmir Chagas). Rio de Janeiro, 29 jan. 1957. Arquivo Anísio Teixeira, CPDOC/FGV, AT pi Teixeira, A. 1957.01.29, $10 \mathrm{f}$.

Carta ao pai Deocleciano Pires Teixeira, Bahia, 18 nov. 1927. Disponível em: <http://www.bvanisioteixeira.ufba.br/index.html>. Acesso em: 15 jun. 2017.

Anotações de viagem à Europa, Lisboa, 16 nov. 1925. 56 f. Disponível em: <http://www.bvanisioteixeira.ufba.br/artigos/viagemEuropa.html>. Acesso em: 25 jun. 2017.

Impressos (livros, artigos e revistas educacionais)

ARQUIVOS DO INSTITUTO DE EDUCAÇÃO. Distrito Federal, v. 1, n. 1, jun. 1934.

. Distrito Federal, v. 1, n. 2, jun. 1936.

Distrito Federal, v. 1, n. 3, mar. 1937.

Distrito Federal, v. 2, n. 1, dez. 1945.

AZEVEDO, F. A escola nova e a reforma: introducção aos programmas de escolas primarias. Boletim de Educação Pública, Distrito Federal, ano 1, n. 1, p. 7-23, jan./mar. 1930.

BEARD, C. A. A charter for the Social Sciences in the schools. New York: American Historical Association/Charles Scribner's Sons, 1932.

BUREAU OF EDUCATION (Department of the Interior US). Preliminary statement by chairmen of committees of the Commission of the National Education Association on the Reorganization of Secondary Education. Washington: Government Printing Office, 1913. (Bulletin nº 41).

The teaching of community civics. Washington: Government Printing Office, 1915. (Bulletin $n^{\circ} 23$ ).

Cardinal principies of secondary education. Washington: Government Printing Office, 1918. (Bulletin $n^{\circ} 35$ ). 
CAMPOS, M. R. Methodo de projectos. Schola, Rio de Janeiro, anno I, n. 6, p. 179-182, jul. 1930.

Escola moderna: conceitos e práticas. Rio de Janeiro: Graphico Fernandes \& Rohe, 1932.

Execução de um "projeto". Arquivos do Instituto de Educação, Rio de Janeiro, v. 1, n, 2, p. 223-231, jun. 1936.

Programa de Estudos Sociais. Arquivos do Instituto de Educação, Rio de Janeiro, v. 1, n. 3, p.329-332, mar. 1937.

CARVALHO, C. D. Apresentação. In: DEPARTAMENTO DE EDUCAÇÃO DO DISTRITO FEDERAL. Programa de Ciências Sociais: escola elementar, $1^{\circ}$ volume $\left(1^{\circ}, 2^{\circ}\right.$ e $3^{\circ}$ anos). Edição preliminar. São Paulo/Rio de Janeiro: Companhia Editora Nacional, 1934a. (Programas e Guias de Ensino, Série C, n. 4). p. 11-23.

Apresentação. In: DEPARTAMENTO DE EDUCAÇÃO DO DISTRITO FEDERAL. Programa de Ciências Sociais: escola elementar, $2^{\circ}$ volume $\left(4^{\circ}\right.$ e $5^{\circ}$ anos). Edição preliminar. São Paulo/Rio de Janeiro: Companhia Editora Nacional, 1934b. (Programas e Guias de Ensino, Série C, n. 4A). p. 9-12.

. Sociologia e educação. Rio de Janeiro: Editora Guanabara, 1934c.

. Dissertação, em aula. Arquivos do Instituto de Educação, Rio de Janeiro, v. 1, n. 1, p. 105-108, jun. 1934d.

Geographia Humana, Política e Econômica. 2. ed. São Paulo, Companhia Editora Nacional, 1935.

Programa de Sociologia Educacional. Arquivos do Instituto de Educação, Rio de Janeiro, v. 1, n. 3, p. 307-308, mar. 1937.

As Ciências Sociais na escola secundária. In: PEIXOTO, A. (Org.). Um grande problema nacional: estudos sobre ensino secundário. Rio de Janeiro: Irmãos Pongetti editores, 1940a. p. 25-52. $1940 \mathrm{~b}$.

Sociologia educacional. 2. ed. São Paulo: Companhia Editora Nacional,

Evolução da Geografia Humana. Revista Brasileira de Geografia. Rio de Janeiro, vol. 3, n. 2, p. 422-431, abr./jun. 1941.

Didática das Ciências Sociais. Belo Horizonte: Imprensa Oficial, 1949.

Os Estudos Sociais no curso secundário. Revista Brasileira de Estudos Pedagógicos, Rio de Janeiro, v. 20, n. 52, p. 54-60, out./dez. 1953. 
CARVALHO, C. D. Elementos de Sociologia Educacional e fundamentos sociológicos da educação: para uso das escolas normais do Brasil (segundo o Programa do Instituto de Educação da Capital Federal). 2. ed. São Paulo: Companhia Editora Nacional, 1956.

Organização Social e Política Brasileira. Rio de Janeiro: MEC, 1963.

Agir, 1970.

Introdução metodológica aos Estudos Sociais. 2. ed. Rio de Janeiro:

Meio século de atividades. Revista do Instituto Histórico e Geográfico

Brasileiro, Rio de Janeiro, n. 292, p. 201-206, jul./set. 1971.

Discurso do sócio benemérito Carlos Delgado de Carvalho ao receber em São Paulo o prêmio Boilesen. Revista do Instituto Histórico e Geográfico Brasileiro, Rio de Janeiro, n. 309, p. 158-162, out./dez. 1975b.

CHAGAS, V. Formação do magistério: novo sistema. São Paulo: Atlas, 1976.

O ensino de $1^{\circ}$ e $2^{\circ}$ graus: antes, agora e depois. 4. ed. São Paulo: Saraiva, [1978] 1984.

Núcleo comum para os currículos de ensino de $1^{\circ}$ e $2^{\circ}$ graus. Revista Brasileira de Estudos Pedagógicos, Brasília, v. 74, n. 177, p. 385-423, maio/ago. [1971] 1993.

DUNN, A. W. The Social Studies in secondary education. Washington: Government Printing Office, 1916.

FONSECA, J. B.; GASMAN, L. Guia metodológico Cadernos MEC: Estudos Sociais 1. Brasília: Fundação Nacional de Material Escolar (Fename), 1969.

GUIMARÃES, I. F. Introducção ao programma de Educação e Saude. Revista do Ensino, Belo Horizonte, ano 9, n. 116 e 117, p. 113-144, jul./ago. 1935.

Introdução ao programa. In: DEPARTAMENTO DE EDUCAÇÃO DO DISTRITO FEDERAL. Programa de Ciências Sociais. Escola elementar, $1^{\circ}$ volume $\left(1^{\circ}, 2^{\circ}\right.$ e $3^{o}$ anos). Edição preliminar. São Paulo/Rio de Janeiro: Companhia Editora Nacional, 1934a. (Programas e Guias de Ensino, Série C, n. 4). p. 25-26.

Introdução. In: DEPARTAMENTO DE EDUCAÇÃO DO DISTRITO FEDERAL. Programa de Ciências Sociais. Escola elementar, $2^{\circ}$ volume $\left(4^{\circ}\right.$ e $5^{\circ}$ anos). Edição preliminar. São Paulo/Rio de Janeiro: Companhia Editora Nacional, 1934b. (Programas e Guias de Ensino, Série C, n. 4A). p. 17-26.

LACOMBE, L. J. Cinco semanas nos Estados Unidos. Schola, Rio de Janeiro, anno I, n. 3, p. 90-96, mar. 1930a.

jul. 1930b.

A “Junior High School”. Schola, Rio de Janeiro, anno I, n. 6, p.183-187, 
LOURENÇO FILHO, M. B. A Escola de Professores do Instituto de Educação. Arquivos do Instituto de Educação, Distrito Federal, v. 1, n. 1, p. 15-26, jun. 1934.

Pesquiza sobre programa mínimo. Boletim de Educação Pública, Distrito Federal, v. 5, n. 3 e 4, p. 275-297, jul./dez. 1935.

A formação do professorado primário. Arquivos do Instituto de Educação, Distrito Federal, v. 1, n. 3, p. 283-293, mar. 1937.

KREY, A. C. Preface. In: BEARD, C. A. A charter for the Social Sciences in the schools. New York: American Historical Association/Charles Scribner's Sons, 1932. p. V-XII.

(Org.). Investigation of the Social Studies in the schools: conclusions and recommendations of the commission. New York: American Historical Association/Charles Scribner's Sons, 1934.

MACEDO, J. M. Lições de História do Brasil para uso dos alunos do Imperial Colégio Pedro II. Rio de Janeiro: Tipografia Imparcial, 1861.

Lições de Historia do Brasil para uso das escolas de instrucção primaria. rev. actual. Rio de Janeiro: Livraria Garnier, 1907.

PROGRAMA de Ciências Sociais. Escola elementar, $1^{\circ}$ volume $\left(1^{\circ}, 2^{\circ}\right.$ e $3^{\circ}$ anos $)$ Edição preliminar. São Paulo/Rio de Janeiro: Companhia Editora Nacional, 1934a. (Programas e Guias de Ensino, Série C, n. 4). p. 11-23.

Escola elementar, $2^{\circ}$ volume $\left(4^{\circ}\right.$ e $5^{\circ}$ anos). Edição preliminar. São Paulo/Rio de Janeiro: Companhia Editora Nacional, 1934b. (Programas e Guias de Ensino, Série C, n. 4A). p. 9-12.

PROGRAMA de Filosofia da Educação, Arquivos do Instituto de Educação, Distrito Federal, v. 1, n. 3, p. 312-315, mar. 1937.

RENAUlT, A. Prefácio. In: CARVAlHO, D. Didática das Ciências Sociais. Belo Horizonte: Imprensa Oficial, 1949. p. 9-14.

TEIXEIRA, A. Apresentação. In: DISTRITO FEDERAL. Programa de Linguágem. Rio de Janeiro: Companhia Editora Nacional, 1933. p. 8-13.

O Systema Escolar do Rio de Janeiro (DF): relatorio de um anno de administração. Separata de: Boletim de Educação Publica, Distrito Federal, anno II, n. 3 e 4, p. 307-370, 1932. 


\section{Jornais e revistas}

ARRUDA, Julieta. Procurando solucionar o problema educacional do Brasil. Rapida palestra com a professora d. Julieta Arruda sobre o curso de férias no Instituto de E. I. de Nova York. Correio da Manhã, quinta-feira, 27 mar. 1930. Rio de Janeiro, anno XXIX, n. 10.813, p. 5. Arquivado na Hemeroteca Digital da Biblioteca Nacional.

CARVALHO, D. Ampliando os horizontes da nossa cultura: a Associação Brasileira de Educação está cogitando de enviar anualmente 10 professores brasileiros para visitar as universidades americanas - diz-nos em entrevista, o professor Delgado de Carvalho. Jornal do Brasil, Rio de Janeiro, 5 jul. 1929. Arquivado na Hemeroteca Digital da Biblioteca Nacional.

CORREIO da Manhã. Procurando solucionar o problema educacional do Brasil. Rapida palestra com a professora d. Julieta Arruda sobre o curso de férias no Instituto de E. I. de Nova York. Rio de Janeiro, anno XXIX, n. 10.813, 27 mar. 1930. p. 5. Arquivado na Hemeroteca Digital da Biblioteca Nacional.

DIARIO Carioca. Intercambio entre Brasil e Estados Unidos. Rio de Janeiro, anno II, n. 432, 18 dez. 1929. p. 2. Arquivado na Hemeroteca Digital da Biblioteca Nacional.

DIARIO da Noite. Os novos methodos de ensino americano no Brasil: de volta dos Estados Unidos falam ao "Diario da Noite" as professoras Maria R. Campos e Consuelo Pinheiro. Rio de Janeiro, anno II, n. avulso, 11 mar. 1930a. p. 5. Arquivado na Hemeroteca Digital da Biblioteca Nacional.

Os novos methodos americanos no Brasil: fixando as impressões das professoras Laura Lacombe e Julieta Arruda. Rio de Janeiro, anno II, n. avulso, 12 mar. 1930b. p. 1 (Capa), p. 3. Arquivado na Hemeroteca Digital da Biblioteca Nacional.

DIARIO de Noticias. Recepcionados na Escola Estados Unidos e no Itamaraty, os professores norte-americanos. Rio de Janeiro, anno X, 10 ago. 1939. p. 4. Arquivado na Hemeroteca Digital da Biblioteca Nacional.

FONSECA, G. Cartas de Nova York. Correio da Manhã, Rio de Janeiro, Anno XXXIV, n.12.132, p. 1 e 11, sexta-feira, 15 jun. 1934. Arquivado na Hemeroteca Digital da Biblioteca Nacional.

LACOMBE, L. J. A pedagogia nos Estados Unidos. A Ordem, Rio de Janeiro, 11 mar. 1930.

LEÃO, M. Departamento de Educação do Distrito Federal. Programa de Ciências Sociais. Rio de Janeiro: Companhia Editora Nacional, 1934. Jornal do Brasil, ano XLIV, n. 146, p. 8, quinta-feira, 21 jun. 1934. Arquivado na Hemeroteca Digital da Biblioteca Nacional. 
O PAIZ. Intercambio intellectual com os Estados Unidos, anno XLV, $\mathrm{n}$. 16.334, 10 jul. 1929. p. 8. Arquivado na Hemeroteca Digital da Biblioteca Nacional.

REVISTA DE HISTÓRIA. Noticiário, São Paulo, v. 55, n. 110, p. 633-635, 1977.

REVISTA DO GÁS. Um prêmio rende homenagem à fidelidade e a constância. São Paulo, ano V, v. 29, p. 29-34, jun. 1975.

\section{Legislação}

BRASIL. Lei de 15 de outubro de 1827. Manda crear escolas de primeiras letras em todas as cidades, vilas e lugares mais populosos do Império. In: COLEÇÃO de Leis do Império do Brasil, Rio de Janeiro, Município Neutro da Corte, 1827. Disponível em: <http://www2.camara.leg.br/legin/fed/lei_sn/1824-1899/lei38398-15-outubro-1827-566692-publicacaooriginal-90222-pl.html> Acesso em: 14 jan. 2018.

Decreto de 2 de dezembro de 1837. Convertendo o Seminnrio de S. Joaquim em collegio de instrucção secundaria, com a denominação de Collegio de Pedro Il, c outras disposições. In: COLEÇÃO de Leis do Império do Brasil, Rio de Janeiro, Município Neutro da Corte, 1837. Disponível em: <http://www.cp2.g12.br/images/comunicacao/2015/historia_cp2/colleccao_leis_1 837_parte2.66-68.pdf >. Acesso em: 14 jan. 2018.

Decreto ${ }^{\circ}$ 1.331-A, de 17 de fevereiro de 1854. Approva o Regulamento para a reforma do ensino primario e secundario do Municipio da Côrte. In: COLEÇÃO de Leis do Império do Brasil, Rio de Janeiro, Município Neutro da Corte, 1854. Disponível em: <http://www2.camara.leg.br/legin/fed/decret/18241899/decreto-1331-a-17-fevereiro-1854-590146-publicacaooriginal-115292pe.html>. Acesso em: 14 jan. 2018.

Decreto $\mathrm{n}^{\circ} 7.247$, de 19 de abril de 1879 . Reforma o ensino primario e secundario no municipio da Côrte e o superior em todo o Imperio. In: COLEÇÃO de Leis do Império do Brasil, Rio de Janeiro, Município Neutro da Corte, 1879. Disponível em: <http://www2.camara.leg.br/legin/fed/decret/1824-1899/decreto7247-19-abril-1879-547933-publicacaooriginal-62862-pe.html>. Acesso em: 14 jan. 2018.

Decreto $n^{\circ}$ 981, de 8 de novembro de 1890. Approva o Regulamento da Instrucção Primaria e Secundaria do Districto Federal. In: COLEÇÃO de Leis do Brasil, Rio de Janeiro, DF, 1890. Disponível em: <http://www2.camara.leg.br/legin/fed/decret/1824-1899/decreto-981-8novembro-1890-515376-publicacaooriginal-1-pe.html>. Acesso em: 14 jan. 2018. 
BRASIL. Lei $\mathrm{n}^{\circ} 23$, de 30 de outubro de 1891. Reorganiza os serviços da Administração Federal. In: COLEÇÃO de Leis do Brasil, Rio de Janeiro, DF, 1891. Disponível em: <http://www2.camara.leg.br/legin/fed/lei/1824-1899/lei-2330-outubro-1891-507888-publicacaooriginal-1-pl.html>. Acesso em: 21 jan. 2019.

Decreto n ${ }^{\circ} 19.890$, de 18 de abril de 1931. Dispõe sobre a organização do ensino secundário. Diário Oficial [da] República Federativa do Brasil, Poder Executivo, Rio de Janeiro, DF, $1^{\circ}$ maio. 1931. p. 6.945.

Decreto $\mathrm{n}^{\circ} 19.852$, de 11 de abril de 1931. Dispõe sobre a organização da Universidade do Rio de Janeiro. Diário Oficial [da] República Federativa do Brasil, Poder Executivo, Rio de Janeiro, DF, 11 abr. 1931. p. 9.219 (Republicação).

Ministério da Educação. Lei no 4.244, de 9 de abril de 1942. Lei orgânica do ensino secundário. Diário Oficial [da] República Federativa do Brasil, Poder Executivo, Rio de Janeiro, DF, 10 abr. 1942. Seção 1, p. 5798.

Ministério da Educação. Lei no 4.024, de 20 de dezembro de 1961. Fixa as Diretrizes e Bases da Educação Nacional. Diário Oficial [da] República Federativa do Brasil, Poder Executivo, Brasília, DF, 27 dez. 1961. Seção 1, p. 11429.

Ministério da Educação. Lei no 5.540 , de 28 de novembro de 1968. Fixa normas de organização e funcionamento do ensino superior e sua articulação com a escola média, e dá outras providências. Diário Oficial [da] República Federativa do Brasil, Poder Executivo, Brasília, DF, 29 nov. 1968. Seção 1, p. 10369.

Presidência da República. Decreto-lei no 869, de 12 de setembro de 1969. Dispõe sobre a inclusão da Educação Moral e Cívica como disciplina obrigatória, nas escolas de todos os graus e modalidades, dos sistemas de ensino no País, e dá outras providências. Diário Oficial [da] República Federativa do Brasil, Poder Executivo, Brasília, DF, 15 set. 1969. Seção 1, p. 7769.

Ministério da Educação. Lei $n^{0}$ 5.692, de 11 de agosto de 1971. Fixa Diretrizes e Bases para o ensino de $1^{\circ}$ e $2^{\circ}$ graus, e dá outras providências. Diário Oficial [da] República Federativa do Brasil, Poder Executivo, Brasília, DF, 12 ago. 1971a. Seção 1, p. 6377.

Ministério da Casa Civil. Subchefia para Assuntos Jurídicos. Lei $\mathrm{n}^{\circ}$ 5.700 , de $1^{\circ}$ de setembro de 1971 . Dispõe sobre a forma e a apresentação dos Símbolos Nacionais, e dá outras providências. Diário Oficial [da] República Federativa do Brasil, Poder Executivo, Brasília, DF, 2 set. 1971b. Seção 1 Suplemento, p. 1.

Portaria 790/76. Dispõe sobre o registro de professores e especialistas de educação no MEC. In: MINISTÉRIO DA EDUCAÇÃO E CULTURA (MEC). Legislação Brasileira do Ensino de $2^{\circ}$ grau. Brasília: DEM, 1978. (Coletânea dos Atos Federais). 
BRASIL. Ministério da Educação. Lei no 9.394, de 20 de dezembro de 1996. Estabelece as diretrizes e bases da educação nacional. Diário Oficial [da] República Federativa do Brasil, Poder Executivo, Brasília, DF, 23 dez. 1996. Seção 1, p. 27833.

Ministério da Educação. Secretaria de Educação Média e Tecnológica. Parâmetros Curriculares Nacionais (Ensino Médio): Parte IV - Ciências Humanas e Suas Tecnologias. Brasília, 2000.

Comum Curricular. Brasília, 2015. Disponível em: $<$ http://basenacionalcomum.mec.gov.br/documentos/BNCC-

APRESENTACAO.pdf>. Acesso em: 14 jun. 2016.

RIO GRANDE DO SUL. Decreto $n^{\circ}$ 8.020, de 29 de novembro de 1939. Aprova o programa mínimo a ser adotado nas escolas primárias do Estado. Disponível em: <https://repositorio.ufsc.br/handle/123456789/122105>. Acesso em: 7 jan. 2019.

\section{Conselho Federal de Educação (Revista Documenta)}

CHAGAS, V. Parecer $n^{\circ}$ 226, de 7 de março de 1972. Instituto Brasileiro de Geografia e Estatística. Inclusão da Geografia, "como disciplina individualizada", do Núcleo Comum. Documenta, Brasília, n. 136, p. 115, mar. 1972.

DOCUMENTA. Normas para o ensino médio. Brasília, n. 1, p. 14-19, mar. 1962a.

Amplitude e desenvolvimento das matérias obrigatórias. Brasília, $\mathrm{n}$. 8, p. 35-43, out. 1962 b.

Sobre o ensino da Educação Moral e Cívica em estabelecimentos de ensino médio. Brasília, n. 26, p. 15-21, jun. 1964.

"Voto em separado" ao parecer $n^{0} 853 / 71$, de autoria do conselheiro Valnir Chagas: núcleo comum para os currículos do ensino de 1 e $2^{\circ}$ graus. Brasília, n. 132, p. 194-195, nov. 1971.

PADIN, C. Parecer $\mathrm{n}^{\circ}$ 131, aprovado em 30 de julho de 1962. Disciplinas e práticas educativas. Documenta, Brasília, n. 7, p. 42-43, set. 1962.

SARAIVA, T. Parecer $\mathrm{n}^{\circ}$ 977, aprovado em 14 de setembro de 1972. Associação Brasileira de Professores de Geologia (ABPG). Estudos sobre a disciplina Geografia face à lei no 5.692. Documenta, Brasília, n. 142, p. 192-195, set. 1972a.

Parecer $n^{\circ}$ 803, aprovado em 8 de agosto de 1972. União Paulista dos Estudantes de Geografia (Memorial). Documenta, Brasília, n. 141, p. 77-80, ago. 1972b. 
SARAIVA, T. Parecer $n^{\circ}$ 251, aprovado em 8 de março de 1972. Associação dos Geográfos Brasileiros. O ensino de Geografia e História em Estudos Sociais. Documenta, Brasília, n. 136, p. 159-161, mar. 1972c.

Parecer $\mathrm{n}^{\circ}$ 234, aprovado em 8 de março de 1972. Associação dos Geógrafos Profissionais. A Geografia no currículo de $1^{\circ}$ e $2^{\circ}$ graus. Documenta, Brasília, n. 136, p. 123-124, mar. 1972d.

Parecer $n^{\circ} 4.833$, aprovado em 3 de dezembro de 1975. Núcleo Comum e organização curricular, a nível de $1^{\circ}$ grau. Documenta, Brasília, n. 181, p. 76-96, dez. 1975 .

SOUZA, P. N. P. Parecer $\mathrm{n}^{\circ}$ 1.471, aprovado em 13 de dezembro de 1972. Estudos Sociais no ensino de $1^{\circ}$ grau. Documenta, Brasília, n. 145, p. 269-271, dez. 1972a.

Parecer $n^{\circ}$ 554, aprovado em 8 de junho de 1972. Currículo mínimo para a habilitação em Educação Moral e Cívica. Documenta, Brasília, n. 139, p. 178184, jun. 1972b.

Parecer $\mathrm{n}^{\mathrm{o}}$ 7.676, aprovado em 14 de dezembro de 1978. Aviso Ministerial n ${ }^{\circ} 694$ - Valorização da História e da Geografia no ensino de $1^{\circ}$ grau. Documenta, Brasília, n. 217, p. 28-31, dez. 1978.

SUCUPIRA, N. A nova disciplina "Organização Social e Política Brasileira". Documenta, Brasília, n. 3, p. 99-101, maio 1962.

Indicação s/no , aprovada em 9 de outubro de 1964. Sobre exame de suficiência e formação do professor polivalente para o ciclo ginasial. Documenta, Brasília, n. 31, p. 107-111, nov. 1964.

. Parecer $n^{\circ} 106$, aprovado em 4 de fevereiro de 1966. Currículo mínimo de Licenciatura em Estudos Sociais. Documenta, Brasília, n. 46, p. 36-38 fev. 1966.

\section{Fontes secundárias}

ANDRADE, V. L. C. de Q. Historiadores do IHGB/Catedráticos do CPII. Revista do Instituto Histórico e Geográfico Brasileiro, Rio de Janeiro, ano 168, n. 434, p. 219-231, jan./mar. 2007.

Delgado de Carvalho e a opção pela educação brasileira. In: MENEZES, L. M.; TRONCOSO, H. C.; MORA, R. (Org.). Intelectuais na América Latina: pensamento, contextos e instituições - dos processos de independência à globalização. Rio de Janeiro: UERJ/Labimi, 2014. p. 411-422.

ANGELINI, A. L. Defesa da tese apresentada ao doutoramento na cadeira de Didática Geral e Especial da Faculdade de Filosofia, Ciências e Letras da Universidade de São Paulo pela licenciada Amélia Americano Franco Domingues de Castro. Revista de História, São Paulo, v. 3, n. 7, p. 242- 249, 1951. 
ARANHA, P. M. Geografia como profissão: campo, auto-representação e historiografia (1934-1955). Rio de Janeiro, 2017. 282 f. Tese (Doutorado em História Social) - Instituto de História, Universidade Federal do Rio de Janeiro, Rio de Janeiro, 2017.

ARAÚJO, J. C. As concepções pedagógicas na história da educação brasileira: demarcações conceituais e algumas demarcações. In: LOMBARDI, J. C.; SAVIANI, D. (Org.). Navegando pela história da educação brasileira: 20 anos de Histedbr. Campinas: Autores Associados, 2009. p. 191-222.

ARENDT, H. A crise na Educação. In: ARENDT, H. Entre o passado e o futuro. 8. ed. São Paulo: Perspectiva, 2016. p. 221-247.

ARRUDA, J. J. de A. A crise do capitalismo liberal. In: REIS FILHO, D.; FERREIRA, J.; ZENHA, C. (Org.). O século XX: o tempo das crises revoluções, fascismos e guerras. Rio de Janeiro: Civilização Brasileira, 2000. p. 11-34.

AZEVEDO, F. A reconstrução educacional do Brasil: Manifesto dos Pioneiros da Educação Nova. In: MAGALDI, A. M; GONDRA, José G. (Org.). A reorganização do campo educacional no Brasil: manifestações, manifestos e manifestantes. Rio de Janeiro: 7Letras, [1932] 2003. p. 125-146.

Manifesto dos Educadores Mais uma vez convocados. In: MAGALDI, A. M; GONDRA, José G. (Org.). A reorganização do campo educacional no Brasil: manifestações, manifestos e manifestantes. Rio de Janeiro: 7Letras, [1959] 2003. p. 157-177.

AZEVEDO, M. O lugar da história nos manuais brasileiros destinados à formação de professores de estudos sociais. 2014. 97 f. Dissertação (Mestrado em Educação) - Universidade Federal de Sergipe, São Cristovão, 2014.

BALZAN, N. Estudos Sociais: opiniões e atitudes de ex-alunos. Cadernos de Pesquisa, São Paulo: Fundação Carlos Chagas, n. 22, p. 31-70, 1977.

BARBOSA, A. M. T. B. O Teachers College e sua influência na modernização da educação no Brasil. Revista GEARTE, Porto Alegre, v. 1, n. 1, p. 7-30, abr. 2014.

2015.

John Dewey e o ensino da Arte no Brasil. 8. ed. São Paulo: Cortez,

BITTENCOURT, C. Pátria, civilização e trabalho: o ensino de História nas escolas paulistas (1917-1939). São Paulo: Edições Loyola, 1990.

(Org.). O saber histórico na sala de aula. São Paulo: Contexto, 1997.

Propostas curriculares de História: continuidades e transformações. In:

BARRETO, E. S. de S. Os currículos do ensino fundamental para escolas brasileiras. São Paulo: Fundação Carlos Chagas, 2000. p. 128-161. 
BITTENCOURT, C. Disciplinas escolares: história e pesquisa. In: OLIVEIRA, M.; RANZI, S. (Org.). História das disciplinas escolares: contribuições para o debate. Bragança Paulista: Edusf, 2003. p. 9-38.

Ensino de História: fundamentos e métodos. São Paulo: Cortez, 2004.

Abordagens históricas sobre a História escolar. Educação e Realidade, Porto Alegre, v. 36, n. 1, p. 83-104, jan./abr. 2011.

BLOCH, M. Apologia da História. Rio de Janeiro: Jorge Zahar Ed., 2001.

BOMENY, H. Os intelectuais da educação. Rio de Janeiro: Jorge Zahar Ed., 2001.

BOURDIEU, P. O campo científico. In: ORTIZ, Renato (Org.). Pierre Bourdieu: Sociologia. São Paulo: Ática, 1983. p. 122- 155.

BRANDÃO, C. R. O que é educação? 33. ed. São Paulo: Brasiliense, 1995.

BROOKS, R. C. Book Reviews and notices. The American Political Science Review, E.U.A, v. 28, n. 5, p. 955-957, out. 1934.

BRUTER, A. Um exemplo de pesquisa sobre a história de uma disciplina escolar: a história ensinada no século XVII. História da Educação, Pelotas, n. 18, p. 7-21, set. 2005.

BUFFA, E.; NOSELLA, P. Educação negada: introdução ao estudo da educação brasileira. São Paulo: Cortez, 1991.

BURKE, P. A Escola dos Annales (1929-1989): a revolução francesa da historiografia. Editora Unesp, 1997.

CABRINI, C. et al. (Org.). O ensino de História: revisão urgente. São Paulo, Brasiliense, 1986.

CAIMI, F. E. Conversas e controvérsias: o ensino de História no Brasil (19801998). Passo Fundo: UPF, 2001.

CAMPOS, R. R. de. Análise crítica da obra de Vidal de La Blache e de sua influência no ensino de Geografia no Brasil. 2014. 436 f. Relatório (PósDoutorado em Educação) - Faculdade de Educação, Universidade Estadual de Campinas, Campinas, 2014.

CANABRAVA, A. P. (Org.). Anais do IX Simpósio Nacional da Associação dos Professores Universitários de História: o homem e a técnica. São Paulo: Anpuh, 1979.

A Associação Nacional dos Professores Universitários de História.

Revista Brasileira de História, São Paulo, v. 1, n. 1, p. 1-11, 1981. 
CARDOSO, C.; VAINFAS, R. História e análise de textos. In: CARDOSO, C.; VAINFAS, R. (Org.). Domínios da História: ensaios de teoria e metodologia. Rio de Janeiro: Elsevier, 1997. p. 375-399.

CARDOSO, S. de F. "Viajar é ser autor de muitas histórias": experiências de formação e narrativas educacionais de professores brasileiros em viagem aos Estados Unidos (1929-1935). 2015. 229 f. Tese (Doutorado em Educação) Faculdade de Educação, Universidade de São Paulo, São Paulo, 2015.

CARVALHO, D. Anísio, vulcão de idéias. In: AZEVEDO, F. (Org.). Anísio Teixeira: pensamento e educação. Rio de Janeiro: Civilização Brasileira, 1960, p. 219-227.

CASTRO, A. D. de. Alguns problemas no ensino da História. Revista de História, São Paulo, v. 11, n. 24, p. 257-266, out./dez. 1955.

CASTRO, T. de. Carlos Delgado de Carvalho. In: SANTOS, M. A. M. Geografia e Geopolítica: a contribuição de Delgado de Carvalho e Therezinha de Castro. Rio de Janeiro: IBGE, 2009. p. 21-37.

CERRI, L. F. Uma proposta de mapa do tempo para artesãos de mapas do tempo: história do ensino de História e didática da História. In: MONTEIRO, A. M.; GASPAREllo, A.; MAGAlHÃES, M. (Org.). Ensino de História: sujeitos, saberes e práticas. Rio de Janeiro: MauadDX, 2007. p. 59-72.

CERTEAU, M. de. A escrita da História. Rio de Janeiro: Forense Universitária, 1982.

CHARTIER, R. A História Cultural: entre práticas e representações. Lisboa: Difel, 1990.

Textos, impressão, leituras. In: HUNT, L. (Org.). A Nova História Cultural. São Paulo: Martins Fontes, 2001. p. 211-238.

CHAVES, M. W. A afinidade eletiva entre Anísio Teixeira e John Dewey. Revista Brasileira de Educação, São Paulo, n. 11, p. 86-98, maio/ago. 1999.

CHERVEL, A. História das disciplinas escolares: reflexões sobre um campo de pesquisa. Teoria \& Educação, Porto Alegre, n. 2, p. 177-229, 1990.

CHEVALLARD, Y. La transposicion didactica: del saber sabio al saber enseñado. Buenos Aires: Aique Grupo Editor, 1991.

CHIOZZINI, D. Os ginásios vocacionais: a construção da história de uma experiência educacional transformadora e o ensino de Estudos Sociais. In: FÓRUNS CONTEMPORÂNEOS DE ENSINO DE HISTÓRIA NO BRASIL, Campinas, 2008. p. 1-14.

CLARK, J. S. O desenvolvimento da educação cívica nos EUA, 1880-1930: Continuidade e/ou mudança. Cadernos de História da Educação, Uberlândia, v. 15, n. 1, p. 40-107, jan./abr. 2016. 
CONTI, J. B. Os Estudos Sociais: último combate do Prof. Eurípedes. In: SOUZA, A. C. M. (Org.). In memoriam de Eurípedes Simões de Paula. São Paulo: FFLCH/USP, 1983. p. 395-400.

A Reforma Educacional de 1971 e a situação da História no ensino de $1^{\circ}$ e $2^{\circ}$ graus no Estado de São Paulo. In: SIMPÓSIO NACIONAL DA ASSOCIAÇÃO DOS PROFESSORES UNIVERSITÁRIOS DE HISTÓRIA, 9, 1977, Florianópolis. Anais [...], São Paulo: Anpuh-SP, 1979. p. 879-884.

COSTA, A. L.; OLIVEIRA, M. D. de. O ensino de História como objeto de pesquisa no Brasil: no aniversário de 50 anos de uma área de pesquisa, notícias do que virá. Saeculum, João Pessoa, n. 16, p. 147-160, jan./jun. 2007.

COSTA, E. V. Os objetivos do ensino da História no curso secundário. Revista de História, São Paulo, v. 14, n. 29, p. 117-120, 1957.

Sugestões para a melhoria do ensino da História no curso secundário.

Revista de Pedagogia, São Paulo, v. 6, n. 11, 1960.

O problema da motivação no ensino de História. Revista de Pedagogia, São Paulo, v. 9, n. 9, p. 25-33, 1963.

COSTA, P. C. A voz do mestre: trajetória intelectual de Carlos Delgado de Carvalho. 2007. 157 f. Dissertação (Mestrado em Educação) - Universidade do Estado do Rio de Janeiro, Rio de Janeiro, 2007.

COSTA, R. P. A produção acadêmica sobre História do ensino de História no Brasil da última década. In: CONGRESSO BRASILEIRO DE HISTÓRIA DA EDUCAÇÃO, 8, 2015, Maringá. Anais [...]. Maringá: SBHE, 2015. p. 1-14.

CUNHA, C. Valnir Chagas: ideias e práticas pedagógicas. In: GARCIA, W.E. (Org.). Educadores do século XXI. Brasília: Plano Editora, 2002. p. 325-371.

CURY, C. E. Desafios da pesquisa com cultura escolar na documentação da Parahyba Oitocentista. In: VIDAL, D.; SCHWARTZ, C. (Org.). História das culturas escolares no Brasil. Vitória: Edufes, 2010. p. 37-58.

CUSINATO, Renato. A formação do professor da área de Estudos Sociais. 1987. 233 f. Tese (Doutorado em Educação) - Faculdade de Educação, Universidade Estadual de Campinas, Campinas, 1987.

DEWEY, J. Moral principles in education. New York: Houghton Mifflin Company, 1909.

; DEWEY, E. Schools of to-morrow. New York: E. P. Dutton \& Company, 1915.

Democracia e educação. 3. ed. Rio de Janeiro: Companhia Editora Nacional, 1959. 
DEWEY, J. A concepção democrática da educação. In: EDMAN, I. (Org.). John Dewey: sua contribuição para a tradição americana. Rio de Janeiro: Editora Fundo de Cultura, 1960a. p. 160-165.

A democracia como ideal moral. In: EDMAN, I. (Org.). John Dewey: sua contribuição para a tradição americana. Rio de Janeiro: Editora Fundo de Cultura, 1960b. p. 327-335.

. Vida e educação. 9. ed. São Paulo: Melhoramentos, 1979.

Experiência e educação. 2. ed. Petrópolis/RJ: Vozes, 1998.

A escola e a sociedade \& A criança e o currículo. Lisboa: Relógio D’Água Editores, 2002.

DIAS, M. de F. S.; CERRI, L. F. História do ensino de História e História da América. In: FÓRUNS CONTEMPORÂNEOS DE ENSINO DE HISTÓRIA NO BRASIL, Campinas, 1997. p. 113-115.

DIEHL, A. A. Apresentação. In: CAIMI, F. E. Conversas e controvérsias: o ensino de História no Brasil (1980-1998). Passo Fundo: Editora Universitária UFP, 2001. p. 13-14.

DOSSE, F. A História em migalhas: dos Annales à Noda História. Bauru: EDUSC, 2003.

EDMAN, I. John Dewey: sua contribuição para a tradição americana. Rio de Janeiro: Editora Fundo de Cultura, 1960. p. 15-31.

FALLACE, T. John Dewey's influence on the origins of the social studies: an analysis of the historiography and new interpretation. Review of Educational Research, v. 79, n. 2, p. 601-624, jun. 2009.

FARIA FILHO, L. M de. A legislação escolar como fonte para a História da Educação: uma tentativa de interpretação. In: FARIA FILHO, L. M de (Org.). Educação, modernidade e civilização: fontes e perspectivas de análises para a História da Educação oitocentista. Belo Horizonte: Autêntica, 1998. p. 89-125.

FENELON, D. A formação do profissional de História e a realidade do ensino. Cadernos Cedes, Campinas, n. 8, p. 24-31, 1983.

A questão de Estudos Sociais. In: ZAMBONI, E. (Org.). A prática do ensino de história. São Paulo: Vozes/Cedes, 1984. p. 11-22.

FERNANDES, A. T. Estudos Sociais no contexto da história brasileira nas primeiras décadas do século XX. In: ENCONTRO REGIONAL DE HISTÓRIA, 19, 2008, São Paulo. Anais [...]. São Paulo: Anpuh/SP, 2008. p. 1-12.

FERNÁNDEZ, R. C. Sociogénesis de una disciplina escolar: la historia. Versão online. Barcelona: Pomares-Corredor, 2009. Disponível em: <https://goo.gl/R6DWDr〉. Acesso em: 26 nov. 2017. 
FERREIRA, M de. M. A História como ofício: a constituição de um campo disciplinar. Rio de Janeiro: Editora FGV, 2013.

FILGUEIRAS, J. M. A Educação Moral e Cívica e sua produção didática: 1969-1993. 2006. 225 f. Dissertação (Mestrado em Educação: História, Política e Sociedade) - Pontifícia Universidade Católica de São Paulo, São Paulo, 2006.

FONSECA, S. G. Ensino de História: diversificação de abordagens. Revista Brasileira de História, São Paulo, v. 9, n. 19, p. 197-208, set. 1989/fev. 1990.

Ser professor no Brasil: história oral de vida. 3. edição. Campinas: Papirus, 2006.

Caminhos da História ensinada. 11. ed. Campinas: Papirus, 2010.

FONSECA, S.; GATTI JÚNIOR, D. (Org.). Perspectivas do ensino de História: ensino, cidadania e consciência histórica. Uberlândia: EDUFU, 2011.

FRANÇA, A. S. Propostas curriculares para o ensino de estudos sociais: circulação e apropriações de representações de ensino de história e de aperfeiçoamento de professores (Espírito Santo, 1956-1976). Vitória, 2013. 294 f. Tese (Doutorado em Educação) - Centro de Educação, Universidade Federal do Espírito Santo, 2013.

FREITAS, I. História para crianças nos currículos de Estudos Sociais nos Estados Unidos da América (2002/2010). Publicado online em 15 abr. 2011. Disponível em: 〈https://goo.gl/vmiQup>. Acesso em: 23 out. 2017.

Pensar historicamente em John Dewey? Publicado online 6 out. 2014. Disponível em: <https://goo.gl/aVu5Xm>. Acesso em: 23 out. 2017.

GASPARELlO, A. M. Construtores de identidades: a pedagogia da nação nos livros didáticos da escola secundária brasileira. São Paulo: Iglu, 2004.

Encontros de saberes: as disciplinas escolares, o historiador da educação e o professor. In: MONTEIRO, A. M.; GASPARELLO, A.; MAGALHÃES, M. (Org.). Ensino de História: sujeitos, saberes e práticas. Rio de Janeiro; MauadX/Faperj, 2007. p. 73-89.

Uma pedagogia histórica: caminhos para uma história da disciplina escolar. Educação e Realidade, Porto Alegre, v. 36, n. 1, p. 105-125, jan./abr. 2011.

Delgado de Carvalho: livros didáticos e práticas instituintes no ensino de História e Ciências Sociais. In: CÂMARA, S. (Org.). Pesquisas em História da Educação e da Infância: conexões entre ciência e história. Rio de Janeiro: Quartet, 2014. p. 379-404.

Delgado de Carvalho: intervenção e projeto social na constituição de uma disciplina escolar. In: GASPARELLO, A. M.; VILLELA, H. de O. S. (Org.). Educação na história: intelectuais, saberes e ações instituintes. Rio de Janeiro: MauadX, 2016. p. 57-71. 
GAUDENZI, J. de C.; S. Estudos Sociais na escola primária. 2. ed. Rio de Janeiro: MEC (Programa de Emergência), 1964.

GERMANO, J. W. Estado Militar e Educação no Brasil. 5. ed. São Paulo: Cortez, 2011.

GLEZER, R. História e Estudos Sociais: um estudo comparativo dos guias metodológicos do MEC. In: SIMPÓSIO NACIONAL DA ASSOCIAÇÃO DOS PROFESSORES UNIVERSITÁRIOS DE HISTÓRIA, 9, 1977, Florianópolis. Anais [...]. São Paulo: Anpuh/SP, 1979. p. 863-878.

Estudos Sociais: um problema contínuo. Revista Brasileira de História, São Paulo, v. 2, n. 3, p. 117-149, mar./1982.

Eurípedes Simões de Paula: uma bibliografia. In: SOUZA, A. C. M. (Org.). In memoriam de Eurípedes Simões de Paula. São Paulo: FFLCH/USP, 1983. p. 661-706.

GLEZER, R. Olhando o passado e desenhando o futuro. In: GLEZER, R (Org.). Do passado para o futuro: edição comemorativa dos 50 anos de Anpuh. São Paulo: Contexto, 2011. p. 9-11.

GÓES FILHO, J. F. O ensino secundário nos Estados Unidos. In: PEIXOTO, A. (Org.). Um grande problema nacional: estudos sobre o ensino secundario. Rio de Janeiro: Irmãos Pongetti Editores, 1940. p. 219-255.

GONDRA, J. G.; MIGNOT, A. C. A descoberta da América. In: TEIXEIRA, A. Aspectos americanos de educação \& Anotações de viagem aos Estados Unidos em 1927. Rio de Janeiro: Editora UFRJ, 2006. p. 9-24.

GOODSON, I. Currículo: teoria e história. 10. ed. Petrópolis: Vozes, 2008.

GUIMARÃES, M. L. S. Nação e civilização nos trópicos: o Instituto Histórico e Geográfico Brasileiro e o Projeto de uma História Nacional. Estudos Históricos, Rio de Janeiro, n. 1, p. 5-27, 1988.

HARRISON, R.; JONES, A.; LAMBERT, P. A primazia da história política. In: LAMBERT, P.; SCHOFIELD, P. (Org.). História: introdução ao ensino e à prática. Porto Alegre: Penso, 2011. p. 56-74.

HOFLING, E. M. A concepção de cidadania veiculada em livros didáticos de Estudos Sociais do primeiro grau. 1981. 260 f. Dissertação (Mestrado em Educação) - Universidade Estadual de Campinas, Campinas, 1981.

HOLLANDA, G. de. Um quarto de século de programas e compêndios de História para o ensino secundário brasileiro (1931-1956). Rio de Janeiro: Inep/Ministério da Educação, 1957.

JULIA, D. Disciplinas escolares: objetivos, ensino e apropriação. In: LOPES, A. C.; MACEDO, E. (Org.). Disciplinas e integração curricular: história e políticas. Rio de Janeiro: DP\&A, 2002. p. 37-71. 
JULIA, D. A cultura escolar como objeto histórico. Revista Brasileira de História da Educação, Campinas, n. 1, p. 9-44, 2001.

LEITE, J. L. Intelectuais e professores pensando a paz no período entreguerras. In: LEITE, J. L.; ALVES, C. (Org.). Intelectuais e História da Educação no Brasil: poder, cultura e políticas. Vitória: Edufes, 2011. p. 303-331.

LEITE, M. M. O ensino de História no primário e no ginásio. São Paulo: Cultrix, 1969.

LEME, D. M. P. de C. et al. O ensino de estudos sociais no primeiro grau. São Paulo: Atual, 1986.

LEMME, P. Memórias de um educador: vida de família, formação profissional, opção política. 2. ed. Brasília: Inep, 2004.

LIMA E FONSECA, T. N. de. História da Educação e História Cultural. In: VEIGA, C. G.; LIMA E FONSECA, T. N. (Org.). História e historiografia da educação no Brasil. Belo Horizonte: Autêntica, 2008. p. 49-75.

História e ensino de História. 3. ed. Belo Horizonte: Autêntica, 2011.

LOPES, S. C. Oficina de mestres: história, memória e silêncio sobre a Escola de Professores do Instituto de Educação do Rio de Janeiro (1932-1939). Rio de Janeiro: DP\&A/Faperj, 2006.

LOURENÇO, E. O ensino de Estudos Sociais/História em São Paulo: década de 1970. In: SIMPÓSIO NACIONAL DE HISTÓRIA, 25, 2009, Fortaleza. Anais [...]. Fortaleza: Anpuh, 2009, p. 1-8.

LOURENÇO FILHO, M. B. Prefácio. In: DEWEY, J. Vida e educação. 9. ed. São Paulo: Melhoramentos, 1979.

MAGALDI, A. M; GONDRA, José G. (Org.). A reorganização do campo educacional no Brasil: manifestações, manifestos e manifestantes. Rio de Janeiro: 7Letras, 2003.

MARTINS, M. C. A História prescrita e disciplinada nos currículos escolares: quem legitima estes saberes? 2000. 263 f. Tese (Doutorado em Educação) Faculdade de Educação, Universidade Estadual de Campinas, Campinas, 2000.

MATTOS, S. R. Brasil em lições: a História do ensino de História no Brasil através dos manuais de Joaquim Manuel de Macedo. 1993. 162 f. Dissertação (Mestrado em Educação) - Fundação Getúlio Vargas, Rio de Janeiro, 1993.

Lições de Macedo. Uma pedagogia do súdito-cidadão no Império do Brasil. In: MATTOS, I. R. de. Histórias do ensino de História no Brasil: Rio de Janeiro, 1998. p. 31-44.

MENDONÇA, A. W. Anísio Teixeira e a Universidade de Educação. Rio de Janeiro: EdUERJ, 2002. 
MENDONÇA, A. W. et al. Pragmatismo e desenvolvimentismo no pensamento educacional brasileiro dos anos de 1950/1960. Revista Brasileira de Educação, São Paulo, v. 11, n. 31, p. 96-113, jan./abr. 2006.

MESQUITA, I. M. Entrevista com Doutora Déa Ribeiro Fenelon. Cadernos do CEOM, Chapecó, ano 21, n. 29, p. 283-308, dez. 2008.

; ZAMBONI, E. A formação de professores na trajetória histórica da Associação Nacional de História (Anpuh). In: FONSECA, S.; ZAMBONI, E. (Org.). Espaços de formação do professor de História. Campinas: Papirus, 2008. p. 130-162.

MICHAELIS, J. U. Estudos Sociais pra crianças numa democracia. Porto Alegre: Editora Globo, 1963.

MIGNOT, A. C.; GONDRA, J. G. Viagens de educadores e circulação de modelos pedagógicos. In: Viagens pedagógicas. São Paulo:

Cortez, 2007. p. 7-14.

MONTEIRO, A. M. Professores de História: entre saberes e práticas. Rio de Janeiro: Mauad X, 2007.

; GASPAREllo, A.; MAGAlHÃES, M. (Org.). Ensino de História: sujeitos, saberes e práticas. Rio de Janeiro: Mauad X/Faperj, 2007.

MUNAKATA, K. Dois manuais de História para professores: histórias de sua produção. Educação e Pesquisa, São Paulo, v. 30, n. 3, p. 513-529, set./dez. 2004.

NADAI, E. Estudos Sociais no $1^{\text {o }}$ grau. Revista em Aberto, Brasília, v. 7, n. 37, p. 1-16, jan./mar. 1988.

O ensino de História no Brasil: trajetória e perspectiva. Revista Brasileira de História, São Paulo, v. 13, n 25/26, p. 143-65, set. 1992/ago. 1993.

; BITTENCOURT, C. Repensando a noção de tempo histórico no ensino. In: PINSK, J. O ensino de História e a criação do fato. 14. ed. São Paulo: Contexto, 2012. p. 93-120.

NAGLE, J. Educação e sociedade na Primeira República. Rio de Janeiro: Fundação Nacional de Material Escolar, 1974.

NASCIMENTO, T. R. Licenciatura curta em Estudos Sociais no Brasil: sua trajetória na Faculdade de Formação de Professores de São Gonçalo-RJ (19731987). 2012. 236 f. Dissertação (Mestrado em História Social) - Faculdade de Formação de Professores, Universidade do Estado do Rio de Janeiro, São Gonçalo, 2012.

O ensino de História e Estudos Sociais em John Dewey e Delgado de Carvalho. História e Cultura, Franca, v. 4, n. 2, p. 212-236, set./dez. 2015. 
NELSON, M. R. The Social Contexts of the Committee on Social Studies Report of 1916. In: MURRY, N. R. (Org.). The Social Studies in secondary education: a reprint of the seminal 1916 report with annotations and commentaries. Washington: ERIC, 1994. p. 71-92.

NEVES, J. O ensino de História nos 50 anos do Golpe Militar: Estudos Sociais sob a ditadura. In: SCHMIDT, M. A.; ABUD, K. (Org.). 50 anos da Ditadura Militar: capítulos sobre o ensino de História no Brasil. Curitiba: W\&A Editores, 2014. p. 13-40.

NIKITIUK, S. M. L. (Org.). Repensando o ensino de história. São Paulo: Cortez, 1996.

NÓVOA, A. História da educação: percursos de uma disciplina. Análise Psicológica, Lisboa, n. 4, p. 417-434, 1996.

Carta a um jovem historiador da educação. Historia y Memoria de la Educación, La Laguna, n. 1, p. 23-34, 2015.

NUNES, A. A. O ensino de História em Faculdades de Estudos Sociais. In: SIMPÓSIO NACIONAL DA ASSOCIAÇÃO DOS PROFESSORES UNIVERSITÁRIOS DE HISTÓRIA, 9, 1977, Florianópolis. Anais [...], São Paulo: Anpuh-SP, 1979. p. 967-994.

NUNES, C. Anísio Teixeira: a poesia da ação. Bragança Paulista: Edusf, 2000a. O "velho" e "bom" ensino secundário: momentos decisivos. Revista Brasileira de Educação, Rio de Janeiro, n. 14, p. 35-60, maio/ago. 2000b.

Anísio Teixeira na América (1927-1929): democracia, diversidade cultural e políticas públicas de educação. In: MIGNOT, A. C.; GONDRA, J. G. (Org.). Viagens pedagógicas. São Paulo: Cortez, 2007, p. 143-162.

Anísio Teixeira. Recife: Editora Massangana, 2010.

Modernidade pedagógica e política educacional: a gestão de Anísio Teixeira na Secretaria Municipal de Educação da cidade do Rio de Janeiro (1931 1935). In: MIGUEL, M. E. B.; VIDAL, D; ARAÚJO, J. C. de S. (Org.). Reformas educacionais: as manifestações da Escola Nova no Brasil (1920 a 1946). Uberlândia: EDUFU, 2011, p. 291-313.

OLIVEIRA, M. A. A. Educação e cidadania: uma contribuição ao ensino de Estudos Sociais. 1993. 223 p. Dissertação (Mestrado em Educação) - Instituto de Estudos Avançados em Educação, Fundação Getúlio Vargas, Rio de Janeiro, 1993.

OLIVEIRA, M. A. T. de. Os estudos históricos sobre o currículo e as disciplinas escolares: das preocupações com as práticas escolares para o mundo da pesquisa acadêmica. Pensar a Educação em Revista, Curitiba/Belo Horizonte, v. 3, n. 1, p. 3-41, jan./mar. 2017. 
OLIVEIRA, M. M. D. Ensino de história: (des)caminhos na construção de um objeto de pesquisa. SILVA, C. B.; ZAMBONI, E. (Org.). Ensino de História, memórias e culturas. Curitiba: CRV, 2013. p. 229-244.

ORIÁ, R. O Brasil contado às crianças: Viriato Corrêa e a literatura escolar brasileira (1934-1961). São Paulo: Annablume, 2011.

PAIVA, O. da C.; MOURA, S. Hospedaria de imigrantes de São Paulo. São Paulo: Paz e Terra, 2008.

PASSOS, J. A História e a Reforma do Ensino Médio no Estado de São Paulo. In: SIMPÓSIO NACIONAL DA ASSOCIAÇÃO DOS PROFESSORES UNIVERSITÁRIOS DE HISTÓRIA, 5, 1969, Campinas. Anais [...]. São Paulo: Anpuh-SP, 1971. p. 547-570.

PAULA, E. S. Relatório da realização do IX Simpósio da Associação Nacional dos Professores Universitários de História (Florianópolis. 17-23 de julho de 1977). In: SIMPÓSIO NACIONAL DA ASSOCIAÇÃO DOS PROFESSORES UNIVERSITÁRIOS DE HISTÓRIA, 9, 1977, Florianópolis. Anais [...]. São Paulo: Anpuh-SP, 1979, p. 33-37.

PEIXOTO, A. (Org.). Um grande problema nacional: estudos sobre o ensino secundario. Rio de Janeiro: Irmãos Pongetti Editores, 1940. p. 219-255.

PERES, E. A Escola Ativa na visão de Adolphe Ferrière: elementos para compreender a Escola Nova no Brasil. In: STEPHANOU, M.; BASTOS, M. H. C. (Org.). Histórias e memórias da educação no Brasil: século XX. Petrópolis: Vozes, 2005. p. 114-128.

PINSK, J. O ensino de História e a criação do fato. São Paulo: Contexto, 1988.

PINTO, A. G. T. Valnir Chagas. Recife: Editora Massangana, 2010.

PINTO, K. P. Por uma nova cultura pedagógica: prática de ensino como eixo da formação de professores primários do Instituto de Educação do Rio de Janeiro (1932-1937). 2006. 390 f. Tese (Doutorado em Educação: História, Política, Sociedade) - Pontifícia Universidade Católica de São Paulo, São Paulo, 2006.

PORTZ, John. Federalismo e a política de educação nos Estados Unidos: a distribuição de autoridade e responsabilidade entre os níveis do governo. Disponível em: <https://goo.gl/yRFYzm >. Acesso em: 12 nov. 2017.

PRADO, E. M. A disciplina História nos anos da ditadura militar. Jundiaí: Paco Editorial, 2014.

PRESTON, Ralph C. Ensinando Estudos Sociais na escola primária. Rio de Janeiro: Fundo de Cultura, 1965.

PROST, A. Doze lições sobre a História. 2. ed. Belo Horizonte: Autêntica, 2012. 
REIS FILHO, D. A. Ditadura e Sociedade: as reconstruções da memória. In: REIS FILHO, D. A.; RIDENTI, M.; MOTTA, R. P. S. (Org.). O golpe militar e a ditadura militar: 40 anos depois (1964-2004). Bauru/SP: EDUSC, 2004. p. 2952 .

REVEL, J. Microanálise e construção do social. In: (Org.). Jogos de escalas: a experiência da microanálise. Rio de Janeiro: FGV, 1998. p. 15-38.

REZNIK, L. Tecendo o amanhã: a História do Brasil no ensino secundário Programas e Livros Didáticos (1931-1945). 1992. 300 f. Dissertação (Mestrado em História) - Universidade Federal Fluminense, Niterói, 1992.

ROMANELLI, O. de O. História da Educação no Brasil (1930/1973). 32. ed. Petrópolis: Vozes, 2007.

SANTOS, B. B. M. O currículo da disciplina escolar história no Colégio Pedro II: a década de 1970 - entre a tradição acadêmica e a tradição pedagógica; a história e os estudos sociais. Rio de Janeiro: MauadX/Faperj, 2011.

SANTOS, B. B. M.; ANDRADE, V. L. C. de Q. Colégio Pedro II: polo cultural da cidade do Rio de Janeiro - a trajetória de seus uniformes escolares na memória coletiva da cidade. Rio de Janeiro: Mauad, 2016.

; NASCIMENTO, T. R. O ensino de Estudos Sociais no Brasil: da intenção à obrigatoriedade (1930-1970). História e Perspectivas, Uberlândia, v. 28, n. 53, p. 145-178, jul./dez. 2015.

83, fev. 2013.

A ciência do currículo. Revista de História, Rio de Janeiro, n. 89, p. 80-

SANTOS, L. L. de C. P. História das disciplinas escolares: outras perspectivas de análise. Educação e Realidade, Porto Alegre, v. 20, n. 2, p. 60-68, jul./dez. 1995.

SARAIVA, T. Caminhos trilhados: reflexões e fazeres. Rio de Janeiro: Editora e Livraria Espaço do Saber, 2004.

SARMENTO, C. E. O Rio de Janeiro na era Pedro Ernesto. Rio de Janeiro: Editora FGV, 2001.

SAVIANI, D. História das ideias pedagógicas no Brasil. 4. ed. Campinas: Autores Associados, 2013.

O legado educacional do Regime Militar. Cadernos Cedes, Campinas, v. 28, n. 76, p. 291-312, set./dez. 2008.

SAXE, D. W. On the alleged demise of social studies the eclectic curriculum in times of standardization- a historical sketch. International Journal of Social Education, v. 18 n. 2, p. 93-102, 2004.

SCHMIDT, M. A. M. dos S. História do ensino de História no Brasil: uma proposta de periodização. Revista História da Educação, Porto Alegre, v. 16, n. 37, p. 73-91, maio/ago. 2012. p. 73-91. 
SCHMIDT, M. A. M. dos S.; ABUD, K. (Org.). 50 anos da Ditadura Militar: capítulos sobre o ensino de História no Brasil. Curitiba: W\&A Editores, 2014.

O porquê dos Estudos Sociais: implicações histórico-sociais, políticas e sociais. In: SCHMIDT, M. A.; ABUD, K. (Org.). 50 anos da Ditadura Militar: capítulos sobre o ensino de História no Brasil. Curitiba: W\&A Editores, 2014. p. 175-190.

SCHRIEWER, J. Sistema mundial y redes de interrelación: la internacionalización de la educación y el papel de la investigación comparada. In: CARUSO, Marcelo; TENORTH, Heinz-Elmar (Comp.). Internacionalización: políticas educativas y reflexión pedagógica en un medio global. Buenos Aires: Granica, 2011. p. 41-105.

SHIROMA, E.; MORAES, M. C.; EVAnGELISTA, O. Política educacional. Rio de Janeiro: DP\&A, 2000.

SILVA, C. B.; ZAMBONI, E. (Org.). Ensino de História, memórias e culturas. Curitiba: CRV, 2013.

SILVA, T. T. Apresentação. In: GOODSON, Ivor. Currículo: teoria e história. 10. ed. Petrópolis: Vozes, 2008.

SMITH, B. A.; PALMER, J.; CORREIA, S. T. Social Studies and the Birth of NCSS: 1783-1921. Publicado em 1995. Disponível em: 〈https://goo.gl/R5cZTL〉. Acesso em: 17 out. 2017.

SOARES, J. da C.; COSTA, P. C. da.; NASCIMENTO, T. R. Carlos Delgado de Carvalho: um professor secundário em defesa da especialização (1920-1950). In: CONGRESSO BRASILEIRO DE HISTÓRIA DA EDUCAÇÃO (CBHE), 9, 2017, João Pessoa. Anais [...]. João Pessoa: [s.:n.], 2017, p. 4538-4555.

TARDIF, M. Saberes docentes e formação profissional. Petrópolis: Vozes, 2002.

TEIXEIRA, A. Pequena introdução à Filosofia da Educação: A Escola Progressiva ou a transformação da escola. 5. ed. São Paulo: Companhia Editora Nacional, 1968.

A pedagogia de Dewey. In: DEWEY, J. Vida e educação. 9. ed. São Paulo: Melhoramentos, 1979. p. 13-41.

Educação para a democracia: introdução à administração educacional. 2. ed. Rio de Janeiro: Editora UFRJ, 1997.

Aspectos americanos de educação \& Anotações de viagem aos Estados Unidos em 1927. Rio de Janeiro: Editora UFRJ, 2006.

Escolas de educação. In: TEIXEIRA, A. Educação e universidade. 2. ed. Rio de Janeiro: Editora UFRJ, 2010. p. 43-75. 
URBAN, W. J. A Associação Nacional de Educação dos Estados Unidos da América. História da Educação, Porto Alegre, v. 20, n. 48, p. 121-138, jan./jun. 2016.

VALE, N. G. Delgado de Carvalho e o ensino de História: livros didáticos em tempos de reformas educacionais (1931-1946). 2011. 200 f. Dissertação (Mestrado em História Social) - Universidade Federal do Rio de Janeiro, Rio de Janeiro, 2011.

VEIGA, C. G. História política e História da Educação. In: VEIGA, C. G.; LIMA E FONSECA, T. N. (Org.). História e historiografia da educação no Brasil. Belo Horizonte: Autêntica, 2008. p. 13-47.

; LIMA E FONSECA, T. N. (Org.). História e historiografia da educação no Brasil. Belo Horizonte: Autêntica, 2008.

VIDAL, D. O exercício disciplinado do olhar: livros, leituras e práticas de formação docente no Instituto de Educação do Distrito Federal. Bragança Paulista: Editora da Universidade São Francisco, 2001.

VIDAL, D.; SCHWARTZ, C. Sobre cultura escolar e história da educação: questões para debate. In: VIDAL, D.; SCHWARTZ, C. (Org.). História das culturas escolares no Brasil. Vitória: Edufes, 2010. p. 13-35.

WESTBROOK, R. John Dewey (1859-1952). In: ROMÃO, J. E; RODRIGUES, V. L. (Org.). John Dewey. Recife: Editora Massangana, 2010. p. 11-32.

XAVIER, L. A reforma do ensino no Distrito Federal (1930-1935): experimentalismo e liberalismo em Anísio Teixeira. Cadernos de História da Educação, Uberlândia, n. 6, p. 145-159, jan./dez. 2007.

. Matrizes interpretativas da História da Educação no Brasil republicano. In: XAVIER, L.; TAMBARA, E.; PINHEIRO, A. C. F. (Org.). História da educação no Brasil: matrizes interpretativas, abordagens e fontes predominantes na primeira década do século XXI. Vitória: Edufes, 2011. p. 17-43.

ZAMBONI, E. (Org.). A prática do ensino de história. São Paulo: Vozes/Cedes, 1984. p. 11-22.

Panorama das pesquisas no ensino de História. Saeculum: Revista de História, João Pessoa, n. 6/ 7, p. 105-117, dez. 2000/jan. 2001.

Encontros nacionais de pesquisadores de história: perspectivas. In: ARIAS NETO, J. M. Dez anos de pesquisas em Ensino de História. Londrina: AtritoArt, 2005, p. 37-49.

Tese formatada e revisada por Mirna Juliana.

(mirnarevisora@gmail.com) 


\section{Anexos}

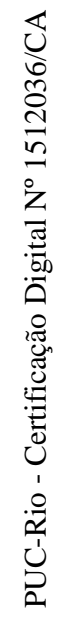




\section{Anexo A}

\section{Programas Mínimos de História, Geografia e Educação político-social extraídos do "Programa de Ciências Sociais" (1934b, p. 95-97)}

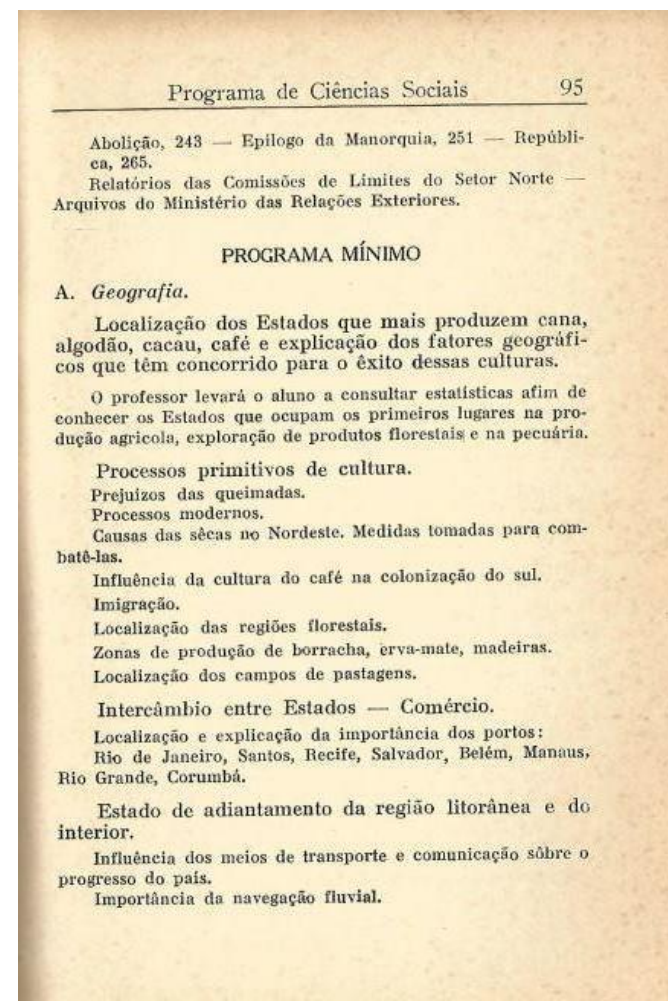

Rio Amazonas, S. Francisco, Paraná-Paraguai, TocantinsAraguaia, Itapicurú, Parnaiba.

Explicaçẩo da abertura e localizaçăo das estradas.

Estradas das boiadas, de Bain a Piaui.

Estrada dos bandeirantes do Rio de Janeiro a Minas Gerais.

Uniāo e Indústria

Estrada de Ferro Central do Brasil.

E. F. Noroeste

E. F. S, Pauto-Rio Grande.

Fstrado de rodegem Rio-S. Paulo.

Localizaçăo do Distrito Federal, Território do Acre e das

capítais dos Estados.

Paises limitrofe

Localizaçăo

B. História,

HISTORIA DAS CULTURAS COLONIZADORAS

Cana de açúcar.

Café.

Café.

As grandes fazendas - vida

Colonização amazônica.

Indústria extrativa da borracha.

Colonização do Paraná.

Madeira e mate.

Colonização do Sul

Criação de gado.

Estradas de ferro que seguiram os caminhos traçados pe

Núcleos de

\section{Programa de Ciências Sociais}

\section{7}

Histórico do telégrafo no Brasil — Capanema.

Os meios de comunicação e o desenvolvimento do

Influência da abolição da escravidão no desenvol. vimento econômico do Brasil.

Brasil Império.

D. Pedro I - D. Pedro II

Vida na Côrte.

Brasil República.

Açũo dos grandes vultos.

Deodoro. - Benjamin Constant.

Vultos eminentes do Brasil:

Barão de Mauá - Visconde do Rio Branco - Barão do Rio Branco - Rui Barbosa - Osvaldo Cruz - Pereira Passos . Paulo de Frontin - Saturnino de Brito - Indiear outros no-

C. Educação politico-social.

Contribuịşāo do africano para o đesenvolvimento econômido Brasil.

Influência indigena e africana sôbre usos e costumes do povo.

Necessidade e vantagens da educação popular.

Influência social da aristocracia rurà

Vantagens da independência politica de um povo.

Dependência e interdependèneia dos povos.

Formas de governo - monarquia e repúbliea.

Pecessidade de saneamento.

grandes vultos que contri-

Respeito e reconhecin pais

Respeito e reconhecimento aos estrangeiros que têm con- 


\section{Anexo B \\ Programa de Estudos Sociais (Curso Colegial) \\ Extraído de: Delgado de Carvalho (1970, p. 210-214)}

\section{$1^{\text {a }}$ série}

Unidade I: As influências climáticas

1. Elementos formadores do clima - Classificação dos Climas.

2. O clima e as sociedades humanas. Aclimação.

3. Os tipos étnicos - medidas antropométricas.

Unidade II: $\mathrm{O}$ meio físico

1. O homem e a montanha; o homem e o rio; o homem e o mar.

2. Formação e fixação dos grupos - família, tribo, classes.

3. A vida nas regiões polares, nas regiões temperadas e nas regiões tropicais (habitat, alimentação, gêneros de vida).

4. Migrações e colonização.

Unidade III: A cultura social

1. Os fatores sociais: linguagem, arte, ciência e moral - A noção de progresso.

2. Os contatos culturais: concorrência e conflito. Acomodação, assimilação e integração - Aculturação.

3. Áreas culturais e difusão cultural.

4. Controle social e educação - desajustamentos.

Unidade IV: A organização econômica

1. Fatores de produção: natureza, trabalho, capital.

2. Fundamentos e origens da propriedade.

3. Distribuição das riquezas - Os impostos.

Unidade V: As estruturas políticas

1. Distribuição geográfica das línguas e das religiões.

2. Conceitos de espaço e de posição - O Estado.

3. Origens e elementos do Estado - território, povo, governo, nação - As fronteiras do Estado - Formação das Cidades.

Unidade VI: A evolução política

1. Os Impérios da Antiguidade em seu quadro geográfico.

2. As cidades - os Estados da Grécia e de Roma - O Império Romano e as invasões - Os árabes.

3. O Estado feudal e a vida econômica da Idade Média - A formação das monarquias ocidentais.

4. Os Estados Modernos - o descobrimento e a expansão comercial - o regime colonial.

5. Os regimes políticos: absolutismo, democracia, totalitarismo.

Unidade VII: O Estado brasileiro

1. A ocupação efetiva, a expansão e a fixação das fronteiras.

2. Regime político, econômico e social da era colonial.

3. O Brasil Império - Constituição - Regência $-2^{\circ}$ Reinado. Parlamentarismo e Partidos - Revoltas Políticas - A diplomacia no Império.

\section{$2^{\mathrm{a}}$ série}

Unidade I: A Revolução Espiritual

1. Invenções e descobrimentos: o Renascimento artístico, científico e literário - a Itália.

2. A Reforma e as lutas religiosas na Europa. 
3. As idéias econômicas: exclusivismo e mercantilismo.

Unidade II: A Revolução Política

1. O Antigo Regime e a Europa do século XVIII.

2. A Revolução Francesa e a fase napoleônica.

3. Restauração e reação política - As colônias.

Unidade III: A Revolução Industrial

1. Novas condições da produção: inventos mecânicos.

2. A industrialização da Grã-Bretanha.

3. A burguesia e o capitalismo - Urbanização.

Unidade IV: O Estado e a ordem econômica

1. As teorias econômicas no princípio do século XIX.

2. Socialismo, sindicalismo, comunismo.

3. Intervenção do Estado: salário, seguros, previdência; as leis sociais.

4. A circulação das riquezas: proteção e livre câmbio.

5. Condições geográficas das comunicações e transportes.

6. A vida econômica internacional.

Unidade V: Atividade agrícola e industrial

1. Condições sociológicas da vida rural e urbana.

2. As principais culturas alimentares; criação.

3. As plantas industriais; explorações minerais.

4. A grande indústria moderna - seus centros.

5. Feições atuais da economia mundial.

Unidade VI: A economia brasileira

1. A libertação econômica - a abolição.

2. A evolução política, social e econômica do Império. O Brasil em 1889.

Unidade VII: O Brasil atual

1. Federação e República - as Constituições.

2. A produção agrícola e suas crises.

3. Os contingentes imigrados - a colonização.

4. A industrialização e a política comercial.

5. O aproveitamento econômico - transportes.

6. A política exterior da República.

\section{$3^{a}$ série}

Unidade I: Os Estados Unidos da América do Norte.

Unidade II: A República Argentina e o Prata.

Unidade III: A Comunidade das Nações Britânicas.

Unidade IV: As Repúblicas Soviéticas.

Unidade V: A Alemanha e os problemas da Europa Central.

Unidade VI: A Franca e a África Ocidental.

Unidade VII: A Península Ibérica.

Unidade VIII: A Itália e o Oriente Médio.

Unidade IX: O Extremo Oriente (Japão e China). A África.

(Em cada unidade serão estudados sucessivamente: 1 - o meio físico e os habitantes; 2 as regiões naturais e os recursos econômicos; 3 - a evolução política de 1815 a 1940; 4 os principais problemas econômicos e sociais da atualidade). 